Agata Brajerska-Mazur/

Edyta Chlebowska (eds)

\title{
On Cyprian Norwid. Studies and Essays
}

\section{Vol. 1: Syntheses}

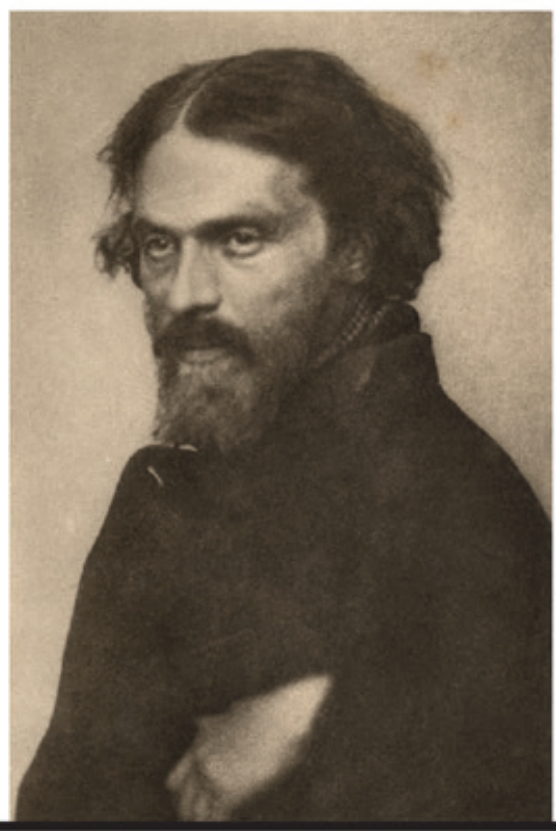


Agata Brajerska-Mazur/

Edyta Chlebowska (eds)

\section{On Cyprian Norwid. Studies and Essays}

The book is the first volume of an extensive four-volume monograph devoted to the work of Cyprian Norwid (1821-1883), one of the most outstanding Polish authors. The impact of Norwid's oeuvre does not fade, as he addresses fundamental and timeless issues, such as the moral and spiritual condition of man or his place in the world and history and seeks to answer universal questions. The book contains an extensive selection of contributions which represent different approaches to the poet's work. They cover various areas of research, including interpretation, thematology, genology, and editing.

\section{The Editors}

Agata Brajerska-Mazur is a researcher on translation and works of Cyprian Norwid and Adjunct Professor in the Institute of Applied Linguistics at the Maria Curie University of Lublin, where she teaches translation and introduces the method of katena, as devised in her doctoral dissertation. She collaborated with Danuta Borhardt on translations of Norwid's poems and published a book on English translation of Wislawa Szymborska's poems.

Edyta Chlebowska is an art historian and works in the Institute for the Study of Cyprian Norwid's Literature at the John Paul II Catholic University of Lublin. She has authored articles and books about the artistic creativity of Norwid and the relationship between artistic and literary creation. She is working on catalogue raisonné of the works of Cyprian Norwid. 
On Cyprian Norwid. Studies and Essays 


\section{POLISH STUDIES \\ TRANSDISCIPLINARY PERSPECTIVES}

Edited by Krzysztof Zajas / Jarosław Fazan

VOLUME 23 
Agata Brajerska-Mazur, Edyta Chlebowska

\section{On Cyprian Norwid. Studies and Essays \\ Vol. 1: Syntheses}




\section{Bibliographic Information published by the Deutsche Nationalbibliothek}

The Deutsche Nationalbibliothek lists this publication in the Deutsche Nationalbibliografie; detailed bibliographic data is available in the internet at http://dnb.d-nb.de.

The Publication is funded by Ministry of Science and Higher Education of the Republic of Poland as a part of the National Programme for the Development of the Humanities. This publication reflects the views only of the authors, and the

Ministry cannot be held responsible for any use which may be made of the information contained therein.

\section{NATIONAL PROGRAMME \\ FOR THE DEVELOPMENT OF HUMANITIES}

Cover image: Portrait of Cyprian Norwid (heliogravure copy of photography).

Printed by CPI books GmbH, Leck

ISSN 2191-3293

ISBN 978-3-631-78278-1 (Print)

E-ISBN 978-3-631-78479-2 (E-PDF)

E-ISBN 978-3-631-78480-8 (EPUB)

E-ISBN 978-3-631-78481-5 (MOBI)

DOI $10.3726 / \mathrm{b} 15402$

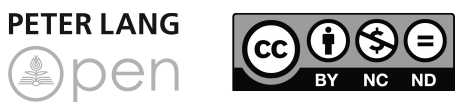

Open Access: This work is licensed under a Creative Commons Attribution Non Commercial No Derivatives 4.0

unported license. To view a copy of this license, visit

https://creativecommons.org/licenses/by-nc-nd/4.0/

(c) Agata Brajerska-Mazur, Edyta

Chlebowska, 2019

Peter Lang - Berlin · Bern · Bruxelles · New York ·

Oxford $\cdot$ Warszawa $\cdot$ Wien

This publication has been peer reviewed.

www.peterlang.com 


\section{Contents}

Introduction

Agata Brajerska-Mazur

Translated by Aleksandra Niemirycz

A Starry Diamond

Edyta Chlebowska

Translated by Aleksandra Niemirycz

From the History of Norwidian Research

Edyta Chlebowska

Translated by Aleksandra Niemirycz

Editor's Notes

Zenon Przesmycki

Translated by Grzegorz Czemiel

From Notes and Documents on Cyprian Norwid

Kazimierz Wyka

Translated by Rafat Augustyn

Norwid's Old Age

Wacław Borowy

Translated by Agnieszka Gernand

Norwid the Poet

Jerzy Sienkiewicz

Translated by Rafat Augustyn

Norwid the Painter

Wacław Borowy

Translated by Grzegorz Czemiel

Leading Motifs in Norwid's Poetry

Irena Stawińska

Translated by Agnieszka Gernand

Norwid's Producing Hand 
Jan Błoński

Translated by Grzegorz Czemiel

Norwid among the Great-Grandchildren

Stawomir Świontek

Translated by Agnieszka Gernand

Norwid's Theatre of the World

Juliusz Wiktor Gomulicki

Translated by Monika Lutostanski

Introduction to Cyprian Norwid’s "Pisma Wszystkie"

Elżbieta Feliksiak

Translated by Agnieszka Gernand

The World of Norwid's Thought

Michał Głowiński

Translated by Agnieszka Gernand

Norwid's Poem-Parables

Stefan Sawicki

Translated by Rafał Augustyn

On Norwid's Poetic Semantics 375

Edward Kasperski

Translated by Rafat Augustyn

The Problem of Questions in Norwid's Work

Danuta Zamącińska

Translated by Grzegorz Czemiel

Discovering Norwid's Poetry

Michat Głowiński

Translated by Agnieszka Gernand

Norwid's Obscure Allegories 465

Rev. Antoni Dunajski

Translated by Rafat Augustyn

Norwid and Theological Tradition 
Jadwiga Puzynina

Translated by Rafat Augustyn

Norwid's Concept of the "Whole"

Stefan Sawicki

Translated by Rafał Augustyn

Publishing Guidelines for Cyprian Norwid's Dzieła Wszystkie

Zdzisław Łapiński

Translated by Grzegorz Czemiel

A Poet of the Senses

Illustrations

Text Sources 567

Index of Names 569

Index of Titles of Literary Works and Artworks of Cyprian Norwid 581 

Introduction 



\section{Agata Brajerska-Mazur}

\section{A Starry Diamond}

Cyprian Norwid (1821-1883) was described by the following words in an obituary notice written by Józef Tokarzewicz in 1884:

There lived in Paris... a Polish writer little known in his own country, an artist known even less, a strange poet, a hieroglyph-stylist, whose every poem has to be read syllable by syllable ten times over... His ideas, despite his profound learning and detailed familiarity with the achievements of contemporary knowledge, move in a diametrically opposite direction to that of the modern philosophical current.

But he was not a dilettante, and certainly not a visionary, a mystic, or a lunatic... He knew how to uncover in every thing such a relation of it to other things that it would become so original as to appear almost unrecognizable...

He carried his soul around with him as if it were some kind of numismatic rarity, unknown to anyone, unwanted, useless. Of less than middle height, lean, though shapely, with intelligent eyes... he had in his manner the assurance and suavity of someone who had been in good society, and in his thoughts and words the roughness of ore burning with an inner fire. He resembled a stone salvaged from some marvellous edifice, which somewhere, sometime had burnt down completely. ${ }^{1}$

Tokarzewicz gives a very accurate characterisation of the poet: unknown, obscure, moving in an opposite direction to fashionable trends in art and philosophy. His description is also appropriate, because in the eyes of his contemporaries Norwid was indeed strange, obscure, ill-understood and rejected.

This exceptional Romantic poet, novelist, playwright, sculptor, painter, engraver and draftsman was born in 1821. Orphaned in his early childhood, he was raised by his grandmother Hilaria Zdziechowska, née Sobieska. ${ }^{2}$ Norwid spent his youth studying painting but in 1840 he made his poetic debut on the pages of Warsaw newspapers. As a result, he enjoyed a brief spell of fame and recognition. Unfortunately, it soon ended in rejection and bitterness because it became clear that his works had little to do with the poetry of the second generation of Polish Romantics and his views did not fit the programs of emigré

1 English translation by Bogdan Czaykowski, "The Poet as 'Christian Socrates," in: Cyprian Kamil Norwid, Selected Poems, transl. by Adam Czerniawski (London: Anvil Press, 2004), p. 7.

2 Norwid was very proud of his noble origin; despite impoverishment, he often boasted of his close relations to the family of King John III Sobieski. 
political parties, ${ }^{3}$ nor did they have much in common with the manifestoes of Polish Positivism. They were too difficult, too precursory to be understood by the readers of that time. As one of the poet's critics stated - he was an "underappreciated genius [...] born one hundred years too soon." ${ }^{4}$

Norwid died in poverty and oblivion in France, in Saint Casimir's Poorhouse for impoverished Polish war veterans and orphans, which was run by nuns. He was first buried at Ivry, and then moved to a mass grave in the Polish cemetery at Montmorency.

A hundred and thirty-five years after Norwid's death nobody accuses him of "obscure speech,"5 "negligent form"6 or "tormenting, distorting sounds without thinking"7 or vows "not to toil over his words like over the Talmud." The "future grandsons" consider the structural complexities of Norwid's works and the depth of thought contained therein to be an advantage rather than a fault. "Future: the Eternal Editor" replaced the verdict that Norwid's texts follow "a pattern of fluffy nothingness where the absurdity of thought matches the absurdity of

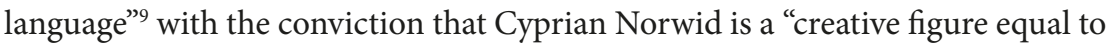
the trinity of the greatest romantic poets" 10 and that "poring over the hieroglyphs of his art is rewarding work which generously pays off." 11

Norwid's genius surpassed his epoch by over hundred years, so it is no wonder that his contemporaries did not understand him. He is better understood and appreciated by later generations, though they, too, maintain the opinion that

3 Because of censorship and the invaders' oppression (Poland was then under colonial partition), many Polish intellectuals, Norwid among them, lived and worked abroad, particularly in France where in the hope of regaining independence they created societies and parties.

4 All the quotations documented in footnotes 4-11 originate from: "Wybór głosów o twórczości pisarskiej Cypriana Norwida. 1840-1918," in: Cyprian Norwid, Pisma wybrane, ed. J. W. Gomulicki (Warszawa: PIW, 1983), Vol. I, p. 94-139 (further shortened as PW) and the bibliographic information is given in the following order: the full name of the author of the quoted opinion, year of pronouncement and page in PW. This commentary was made by Aleksander Jełowicki, 1853, PW, p. 107.

5 Zygmunt Krasiński, 1849, PW, p. 101.

6 Jan Koźmian, 1850, PW, p. 102.

7 Andrzej Edward Koźmian, 1851, PW, p. 105.

8 Władysław Bentkowski, 1849, PW, p. 101.

9 Julian Klaczko, 1858, PW, p. 109.

10 Stefan Żeromski, 1915, PW, p. 138.

11 Kazimierz Bereżyński, 1911, PW, p. 136. 
Norwid is a difficult writer. ${ }^{12}$ Difficult, because he requires his readers' cooperation in deciphering the multitude of meanings contained in single words, phrases and complete literary texts. Difficult, because in creating multi-level layers of meanings he resorts, inter alia, to wordplay, going back to the words' sources, reinterpreting concepts, introducing tensions between them, seeking out polysemy, using the techniques of silence and understatement, creating new meanings, stratifying synonyms, applying paradox, semantic contrast, parable, allegory, symbol or concept. ${ }^{13}$ Difficult, because he dismantles the structural constraints governing specific literary forms and experiments with rhythm and rhyme. Difficult, because the construction of his verses (which are subordinated to meanings, but purposefully strange and liberated from the rules of traditional metrics ${ }^{14}$ ) always serves the thoughts they express. Difficult, because the utilitarianism of his poetry, its moral service to "incarnating goodness and illuminating truths" is manifested in all aspects of his writings - "the prosaicised meter of verse, the absence of conventional caesura, the monostich of autonomous meaning, even the series of full stops signifying understatement." ${ }^{15}$ Difficult,

12 Cf. Tadeusz Sinko, "Poeta trudny," Kurier Literacko-Naukowy, 1933, No. 21, pp. I-II; Wacław Borowy, Norwid poeta, in: Pamięci Cypriana Norwida. Muzeum Narodowe w Warszawie (w 125 rocznicę urodzin artysty) (Warszawa: Muzeum Narodowe, 1946), pp. 32-49; Jan Błoński, “Norwid wśród prawnuków," Twórczość, 1967, No. 5, p. 68; Józef Bujnowski, “Glasgow, 21-22 stycznia 1984," Studia Norwidiana, 1985-1986, 3-4, p. 299; Kazimierz Wyka, Pochwała niejasności Norwida, in: Studia, artykuły, recenzje (Kraków: Wydawnictwo Literackie, 1989), p. 193; Trudny Norwid, ed. Piotr Chlebowski (Lublin: TN KUL, 2013).

13 The semantic techniques applied by Norwid were discussed, among others, by: Ignacy Fik, Uwagi nad językiem Cypriana Norwida (Kraków: Druk W. L. Anczyca i Spółki, 1930); Błoński, "Norwid wśród prawnuków," pp. 67-94; Zbigniew Łapiński, Norwid (Kraków: Znak, 1971), pp. 9-49; Stefan Sawicki, Z zagadnień semantyki poetyckiej Norwida, in: Sawicki, Norwida walka z forma (Warszawa: PIW, 1986), pp. 29-71.

14 Maria Grzędzielska, "Wiersz Norwida w okresie Vade-mecum,"Annales Universitatis Mariae Curie Skłodowska, 1960, vol. XV, No. 5, pp. 113-145; Aleksandra OkopieńSławińska, Wiersz nieregularny i wolny Mickiewicza, Słowackiego i Norwida, in: Z przemian wiersza polskiego. Antologia, ed. R. Lubas (Kraków: Wydawnictwo Naukowe WSP, 1972), pp. 5-22; Lubas, "Jak formy osobowe grają w teatrze mowy," in: Tekst i fabuła, ed. Cz. Niedzielski, J. Sławiński (Wrocław: Zakład Narodowy im. Ossolińskich, 1979), pp. 9-32; Teresa Kostkiewiczowa, Oda w poezji polskiej. Dzieje gatunku (Wrocław: Zakład Narodowy im. Ossolińskich, 1996), pp. 257-270; Lucylla Pszczołowska, Wiersz polski. Zarys historyczny_(Wrocław: Zakład Narodowy im. Ossolińskich, 1997), pp. 195-270, 305-327.

15 Juliusz Wiktor Gomulicki, Uwagi o poezji Cypriana Norwida, PW, Vol. I, p. 42. 
because original - in language, style and thought, at least a century ahead of his time. Finally, difficult, because he has no counterpart in all of Romantic European literature.

Today Norwid is described as "a Christian sage,"16 "a poet of conscience"17 or "a poet of dialogue." ${ }^{18} \mathrm{He}$ is called a philosopher and a "poet-thinker," ${ }^{19}$ an ironist, ${ }^{20} \mathrm{a}$ romanticist, ${ }^{21}$ a moralist ${ }^{22}$ and an "ironic moralist." ${ }^{23}$

In his works one can see not only "a reflection of architecture," "a reflection of sculpture" and "the tenderness of light" ${ }^{24}$, but also his "producing hand." ${ }^{25}$ Such categories as "picturesqueness" 26 or "musicality" 27 are used to describe some

16 Alina Merdas, Łuk przymierza. Biblia w poezji Norwida (Lublin: RW KUL, 1983); Antoni Dunajski, Chrześcijańska interpretacja dziejów w pismach Cypriana Norwida (Lublin: RW KUL, 1985); Dunajski, Teologiczne czytanie Norwida (Pelplin: "Bernardinum," 1996); Dunajski, SŁOWO stało się SIŁĄ. Zarys Norwidowej teologii słowa (Pelplin: "Bernardinum," 1996); Stefan Sawicki, Wartość - sacrum Norwid (Lublin: RW KUL, 1994), pp. 241-254; Norwid a chrześcijaństwo, ed. J. Fert and P. Chlebowski (Lublin: TN KUL, 2002); Czaykowski, “The Poet as 'Christian Socrates," pp. 7-19.

17 Józef F. Fert, Poeta sumienia. Rzecz o twórczości Norwida (Lublin: TN KUL 1993).

18 Józef F. Fert, Norwid - poeta dialogu (Wrocław: Zakład Narodowy im. Ossolińskich, 1982).

19 Borowy, "Norwid poeta," p. 40; PW, Vol. I, p. 5-47; Elżbieta Wolicka, “Przymierza tuk - o sztuce w pismach Cypriana Norwida," in: Norwid a chrześcijaństwo, pp. 67-75.

20 Błoński, Norwid wśród prawnuków, pp. 67-94.

21 Zofia Stefanowska, Strona romantyków. Studia o Norwidzie (Lublin: TN KUL, 1993).

22 Borowy, “Norwid poeta," p. 40; Sawicki, Wartość, pp. 241-254; PW, Vol. 1, pp. 5-47.

23 Arent van Nieukerken, "Norwid europejski," Studia Norwidiana, 1993, Vol. 11, pp. 3-30.

24 Titles of individual articles by Kazimierz Wyka in: Wyka, Cyprian Norwid. Studia, artykuty, recenzje (Kraków: Wydawnictwo Literackie, 1989).

25 Irena Sławińska, Reżyserska ręka Norwida (Kraków: Wydawnictwo Literackie, 1971). The researcher makes a reference to the book by Richard Flatter, Shakespeare's Producing Hand (New York: W.W. Norton \& Co., 1948).

26 This feature of Norwid's work was commented on, among others, by: Teodor F. Domaradzki, Cyprian Kamil Norwid - piewca kultury chrześcijańskiej (Londyn Montreal: 1983), p. 22; Fik, Uwagi, p. 7, 12, 47; Zofia Szmydtowa, "O motywacji i wartościowaniu w poezji," Poezja, 1971, No. 9, pgs. 41, 44; Dariusz Pniewski, Między obrazem a stowem. Studia o poglądach estetycznych i twórczości Literackiej Norwida (Lublin: TN KUL, 2005).

27 Cf. Cezary Jellenta, "Idee muzyczne Norwida," Muzyka, 1925, No. 4-5, p. 142 passim.; Tadeusz Filip, Cypriana Norwida Fortepian Szopena (Kraków: Księgarnia i Wydawnictwo M. Kot, 1949), pp. 229-282; Tadeusz Makowiecki, Fortepian Szopena, 
of the poet's works, and Norwid himself is called a magician, ${ }^{28}$ for being able to combine several kinds of art in a single literary work: literature, graphics, painting, music, architecture and sculpture. His Polish and European identities are also topics of discussion. ${ }^{29}$

However, Norwid is first and foremost a poet of contradiction, in whose works two extremes meet and converge as far as his style of writing and attitude towards faith, tradition and culture are concerned. Norwid is able to be both orthodox in his views on Christian faith, ${ }^{30}$ and very bold and revolutionary when it comes to the truths commonly adopted by the Catholic Church of his time. ${ }^{31}$ In his way

in: K. Górski, T. Makowiecki, I. Sławińska, O Norwidziepięć studiów (Toruń: Księgarnia Naukowa T. Szczęsny i S-ka, 1949), pp. 126-129; Julian Krzyżanowski, Polish Romantic Literature (London: Unwin, 1930), pp. 291-292; Władysław Stróżewski, "Doskonałe - wypełnienie. O Fortepianie Szopena Cypriana Norwida," Pamiętnik Literacki, 1979, Vol. 4, pp. 68-72; Wyka, Cyprian Norwid. Studia, pp. 67-88; Mieczysław Tomaszewski, "Muzyka a literatura," in: Stownik literatury polskiej XIX wieku, ed. J. Bachórz i A. Kowalczykowa (Wrocław-Warszawa-Kraków: Ossolineum, 1991), p. 585; M. J. Kowalczyk, "O inspirującej roli muzyki w utworze poetyckim Cypriana Kamila Norwida Fortepian Szopena," Język Polski w Szkole Średniej, 1993/1994, No. 2 (30), pp. 74-83; Teresa Kostkiewiczowa, Oda w poezji polskiej. Dzieje gatunku (Wrocław: Ossolineum, 1996), p. 266; Władysław Stróżewski, C. Norwid o muzyce (Kraków: Wydawnictwo Literackie, 1997), pp. 76-78; Jadwiga Puzynina, Barbara Subko, "O francuskich przekładach Fortepianu Szopena," Studia Norwidiana, 19971998, No. 15-16, pp. 151-152; Agata Brajerska-Mazur, O angielskich ttumaczeniach utworów Norwida (Lublin: TN KUL, 2002), pp. 148-194.

28 Kazimierz Wyka, Cyprian Norwid. Poeta i sztukmistrz (Kraków: PAU, 1948). Cf. Poeta i sztukmistrz, ed. P. Chlebowski (Lublin: TN KUL, 2007); Edyta Chlebowska, Norwid sztukmistrz nieznany (Lublin: TN KUL, 2013).

29 Juliusz W. Gomulicki, “Sprawa Norwida," Życie Literackie, 1961, No. 40, p. 8; Stanisław Grochowiak, "Ktoś, co sobie idzie," Kultura, 1966, No. 38, p. 2; Mieczysław Jastrun, Pamiętnik artysty (Warszawa: PIW, 1956), p. 40; Kazimierz Wyka, "Prezentacja Norwida," Polityka, 1969, No. 10, p. 7.

30 Cf. Jacek Leociak, "Strzaskana całość. Norwid o Żydach," in: "Całość" w twórczości Norwida, ed. J. Puzynina and E. Teleżyńska (Warszawa: Wydział Polonistyki UW, 1992), p. 121; Ryszard Zajączkowski, "Głos prawdy i sumienie." Kościót w pismach Cypriana Norwida (Wrocław: Leopoldinum, 1998); Alina Merdas, "Dochodzić - trud," czyli o problemach badań nad chrześcijaństwem Norwida, in: Norwid a chrześcijaństwo, pgs. 105, 111.

31 Krzysztof Baliński, "Norwidowska krytyka negatywnych zjawisk w Kościele," Poznańskie Studia Polonistyczne. Seria Literacka IV, Vol. XXIV, 1997, pp. 179-191; Anna Kadyjewska, Tomasz Korpysz, Jadwiga Puzynina, Chrześcijaństwo w pismach Norwida (Warszawa: UW, 2000); Merdas, "Dochodzić- trud," p. 113; Tomasz Korpysz, 
of writing - he is at the same time an innovative author, delighting readers with his open and modern style and an author implementing archaic, complicated or even abstruse syntax. From the numerous opinions on Norwid's style, it is worth mentioning the two most extreme, expressed by Mieczysław Jastrun ${ }^{32}$ and Julian Przyboś, respectively. The former was impressed by the openness of Norwid's style as early as in 1947, praising its commonness, discursivity, irony, paradoxicality and ambiguity. The latter defined it as unintelligible, opaque, stubborn, difficult and "picking constant fights with the colloquial, living, everyday word." ${ }^{33}$

When it comes to literary tradition, it seems that Norwid's creative work "was fuelled by the main currents of Western thought, but at the same time drew from native tradition as its main source; it was rooted in the past, but remained an everlasting inspiration for contemporary innovation." ${ }^{34}$ Therefore, Norwid continues to be perceived as an old-fashioned poet, stuck not so much in Romanticism as in the even earlier epochs (especially with regard to his syntactical allusions to Old Polish ${ }^{35}$ ), as well as a progressive author - in the manner of writing and thought expression that exceeded his time by at least an epoch. The English language translators of his works are faced with a dilemma: which poetry style, which literary convention they should choose, to convey both the romantic roots and the pioneering spirit of the Polish poet:

How can a translator verify Norwid's genius? Norwid is a 19th-century poet as well as a precursory author. How then can one introduce the work of a poet, who is simultaneously grounded in 19th-century traditions and who at the same time shatters them?... How to convey then to the English-language reader [...] that the poet he is reading is not only expressing the consciousness of the second half of the 19th century, but also proclaiming the poetry of the 20 th century? ${ }^{36}$

"Chrześcijanin w pismach Norwida," in: Norwid a chrześcijaństwo, pp. 371-402; Ryszard Zajączkowski, "Kościół - naród - ludzkość," in: Norwid a chrześcijaństwo, pp. 139-160.

32 Mieczysław Jastrun, "Norwid - poeta nieznany," Kuźnica, 1947, No. 21 and other articles collected in the volume Gwiaździsty diament (Warszawa: PIW, 1971).

33 Julian Przyboś, "Próba Norwida," in: Nowe studia o Norwidzie, ed. J. W. Gomulicki, J. Z. Jakubowski, (Warszawa: PWN, 1961), p. 76.

34 Stanisław Barańczak, Tablica z Macondo (Londyn: Aneks Publishers, 1991), p. 93.

35 Cf. Teresa Skubalanka, Mickiewicz, Słowacki, Norwid. Studia nad jezykiem i stylem (Lublin: UMCS, 1997).

36 Czaykowski, “The Poet as 'Christian Socrates,'” p. 11. 
Should it be the style of Gerard Manley Hopkins, oftentimes compared to Norwid by critics, ${ }^{37}$ or perhaps that of a contemporary English poet?

One should show Norwid's originality; but how to demonstrate it without sounding ridiculous and eccentric? In brief, the answer is not to come off like some second-rate Hopkins, Browning or Clough, like an Emily Dickinson imitation, or like yet another mediocre Victorian-era artisan. What a challenge! Who can tackle it! ${ }^{38}$

The question asked by Norwid's translator, Adam Czerniawski, was answered by Bogdan Czaykowski, who wrote:

[...] the translator who endeavours to adequately translate Norwid into the English language should make the effort not only to avoid turning Norwid into a second-rate version of the mentioned poets, but he also, in an ideal world, should exhibit the craftsmanship of these poets, and not only theirs, but also that of Ezra Pound in his poem Hugh Selvyn Mauberley, or of Auden, as well as Carlyle and Eliot. Obviously, this requirement is so ambitious it is hardly feasible. But the translator should at least have an erudite command of stanzas, rhythm and rhyme, even imperfect or assonant rhyme. ${ }^{39}$

Similarities between Norwid's works and those of other English language poets - Walt Whitman, Edgar Allan Poe, William Morris or the Pre-Raphaelites ${ }^{40}$

37 Jerzy Peterkiewicz, "Introducing Norwid," Slavonic Review, 1948/1949, vol. 27, pp. 244-246; J. Zielińska, Norwid i Hopkins (London: Oficyna Poetów i Malarzy, 1966); Adam Czerniawski, "A Flawed Master," Introduction in: Polish Poetry Supplement No. 7, “Oficyna Poetów," No. 2 (29), London, May 1973, p. 5; Stanisław Barańczak, "Nieśmiertelny diament: o poezji Hopkinsa," in: Gerard M. Hopkins, Wybór poezji, ed. and transl. Barańczak (Kraków: Znak, 1981); Czerniawski, George MacLennan, "Norwid: Time for Discovery," Modern Poetry in Translation. New Series, Summer 1994, No. 5, p. 77; Barańczak, "Nieśmiertelny diament (i jego polscy szlifierze)," in: Barańczak, Ocalone w tlumaczeniu (Poznań: a5, 1994), pp. 93-110; Aleksandra Kędzierska, Poetics of Truth and Darkness: Gerard Marley Hopkins and Polish Poet, Cyprian Kamil Norwid gerardmanleyhopkins.org/lectures_2003/norwid.html; Kędzierska, "Norwid and Hopkins," PASE Papers in Literature, Language and Culture, ed. Grażyna Bystydzieńska, Emma Harris, Paddy Lyons (Warszawa: UW, 2005), pp. 166-171. Czaykowski is of a different opinion (Norwid is a very different poet from Hopkins) presented in "The Poet as 'Christian Socrates', " p. 11.

38 Cyprian Kamil Norwid, Poezje/Poems, trans. Adam Czerniawski(Kraków: Wydawnictwo Literackie, 1986), p. 127.

39 Bogdan Czaykowski, “Angielska próba Norwida," Kultura (Paryż), 1987, Vol. VI, No. 477, pp. 103-104.

40 Borowy, "Norwid poeta," p. 32; Juliusz Wiktor Gomulicki, Wstęp, in: Cyprian Norwid, Vade-mecum (Lublin: Krajowa Agencja Wydawnicza, 1984), p. 12; Peterkiewicz, 
have also been found. The Polish poet has also been compared to the French Symbolists. George Hyde has written of him:

For the English reader, he is like the French Symbolists, and shares Baudelaire's fascination with paradox and the dialectic. [...] His almost paranoid view of language as a dense system of "correspondences" from which we are necessarily excluded (but by which we are judged) again echoes Baudelaire and Mallarmé. [...] He is simultaneously a political poet steeped in the history of a specific moment, and one of those powerful practitioners of the genre of "silence" (or a hermeticism bordering on silence) that the "new" Poland [...] will have to reassess. ${ }^{41}$

However, it is Hopkins that Norwid has been most frequently and most extensively compared to - especially in the novel hallmarks of his writings, such as the way of depicting the world, the use of different semantic techniques and the originality of language.

Both authors were versatile, specially gifted with artistic abilities. Norwid sculpted, painted and drew. ${ }^{42}$ Hopkins was exceptionally skilled in pencil sketching.

They were both profoundly religious, and the Christian faith shaped their life and art. In Norwid's creative work his thoughts (even those about man, society, politics or art) always referenced the Catholic faith and its principles. As an example, one can point to the idea of Polishness and Polish national art in "Fortepian Szopena" ["Chopin’s Grand Piano"]. As Władysław Stróżewski ${ }^{43}$ claims, when Norwid wrote about "Polska - przemienionych kołodziejów!," [Poland - of wheelwrights transfigured into kings!] he meant not so much a transformed idyllic Poland of the old Piast dynasty as the source of national art,

Introducing, pp. 245-247; Danuta Zamojska-Hutchins, "Form and Substance of Norwid's Poetry," The Polish Review, 1983, Vol. 28, No. 4, p. 33.

41 George Hyde, Cyprian Kamil Norwid: 'Yesterday - and - I,' in: Adam Czerniawski, The Mature Laurel (Bridgend: Seren Books, 1991), p. 91.

42 Jolanta Polanowska, "Cyprian Norwid," dictionary entry in: Słownik artystów polskich i obcych w Polsce działających (zmarłych przed 1966 r.). Malarze. Rzeźbiarze. Graficy, Vol. VI, ed. K. Mikocka-Rachubowa, M. Biernacka (Warszawa: Instytut Sztuki Polskiej Akademii Nauk, 1998), pp. 135-150; Aleksandra Melbechowska-Luty, Sztukmistrz. Twórczość artystyczna i myśli o sztuce Cypriana Norwida (Warszawa: Neriton, 2001); Norwid. Znaki na papierze. Utwory literackie, akwarele, grafiki, rysunki i szkice, ed. P. Chlebowski, E. Chlebowska (Olszanica: Bosz, 2008); Edyta Chlebowska, Cyprian Norwid. Katalog prac plastycznych, Vol. I. Prace w albumach 1 (Lublin: TN KUL, 2014); Vol. II. Prace w albumach 2 (Lublin: TN KUL, 2017).

43 Stróżewski, C. Norwid o..., pp. 69-75. 
but the transfigured - that is, deified by Christian values - Poland since the dawn of its history:

IV

$[\ldots]$

A w tym, coś grał: taka była prostota

Doskonałości Peryklejskiéj,

Jakby starożytna która Cnota,

W dom modrzewiowy wiejski

Wchodząc, rzekła do siebie:

"Odrodziłam się w Niebie

I stały mi się arfą - wrota,

Wstęgą - ścieżka...

Hostię - przez blade widzę zboże...

Emanuel już mieszka

Na Taborze!"

$\mathrm{V}$

I była w tym Polska, od zenitu

Wszechdoskonałości Dziejów

Wzięta, tęczą zachwytu - -

Polska - przemienionych kołodziejów!

Taż sama, zgoła,

Złoto-pszczoła!...

(Poznał-ci-że bym ją - na krańcach bytu!...)

(PWsz II, 144-145)

$[[\ldots]$

In what you played, was the simplicity

Of Periclean perfection,

As if some Virtue of Antiquity

Entering a larch-wood country manor -

Said to herself:

"I was reborn in Heaven:

Its gates became - my harp,

Its path - my ribbon...

The Host - through the pale wheat I see...

And Emmanuel already dwells

On Mount Tabor!"

$\mathrm{V}$

And in this was Poland - from its zenith

Through Ages' all-perfection,

Captured in songs of rapture

- That Poland - of wheelwrights transfigured into kings! 
The very same - indeed

A golden-bee...

(Recognize it I would, at the limits of existence!...) $]^{44}$

Unlike Hopkins, Norwid was neither priest nor monk, although after a Resurrectionist Priest retreat in April 1852 he did seek admission to their community ${ }^{45}$ After a rather firm rejection ${ }^{46}$ he nevertheless continued to be a faithful believer. Like Hopkins, he was a poet of contradiction, torn between two opposite extremes in the perception of reality: he saw the harmony and beauty of Creation, noticing at the same time the disharmony, paradoxes and contradictions associated with human life. For both authors the person of Jesus Christ was "an omnipresent link between the world of divine harmony and human suffering." ${ }^{47}$

Both Norwid and Hopkins were innovative in the domain of wordplay, and poetic structure, language and imagery. They both broke the poetic conventions of their epoch, they both stood up against "wielkoludy" [giants] (Hopkins called them "giants of stardom"). In the first poem of the Vade-mecum cycle Norwid wrote: "Dlatego od was... - o! laury - nie wziąłem/Listka jednego, ni ząbeczka w liściu" (PWsz II, 15) [That is why from you...o! laurels, I took/No single leaf, nor its tiniest tooth] ${ }^{48}$ Hopkins admitted in one of his letters that "[t]he effect of studying masterpieces is to make me admire and do otherwise." ${ }^{\text {" }}$ Both of the poets felt the need to transform the apparatus of poetry; both of them pulled, twisted and stretched rhyme and meter and offered verse based upon tormented syntax and inelegant vocabulary. One of their affinities with each other is also the way they confronted or even affronted their readers with new shapes, rhythms and sounds. Both could say that their "poetry errs on the side of oddness." 50 The verse of both "is less to be read than heard [...] it is oratorical." ${ }^{11}$ Thus both authors, as precursors of modern poetry breaking 19th-century literary

44 English translation by Danuta Borchardt in collaboration with Agata Brajerska-Mazur, in: Cyprian Norwid, Poems (New York: Archipelago Books, 2011), p. 71-73.

45 Cf. Zofia Trojanowiczowa, Zofia Dambek, Kalendarz życia i twórczości Cypriana Norwida 1821-1860, Vol. I, (Poznań: UAM, 2007), pp. 492-495.

46 Trojanowiczowa, Dambek, Kalendarz, p. 494.

47 Barańczak, Nieśmiertelny diament: o poezji, p. 17.

48 English translation by Borchardt, p. 15.

49 Letter from September 25, 1888, in: Gerard Manley Hopkins, Poems and Prose, ed. W. H. Gardner (Harmondsworth: Penguin Books, 1986), p. 210.

50 Letter from November 6, 1887, in: Letters of Gerard Manley Hopkins to Robert Bridges, ed. C.C. Abbott (London: Oxford University Press, 1935), p. 66.

51 Letter from August 21, 1877, in: Letters to Bridges, p. 46. 
conventions, were rejected and criticized by publishers and readers. Therefore, their works were published very rarely. ${ }^{52}$

Norwid was even more frequently than Hopkins accused of "whimsicality," "obscurity" or even "darkness" of speech. In 1849, Władysław Bentkowski described the Polish poet's poems as having: "a mannerized obscurity of thoughts, images and expressions which [...] by no means are in my taste." ${ }^{53}$ In 1851, Lucjan Siemieński said the following about Promethidion: "The simplest things, the most common ones, are contorted into the whimsical scrawl of platitudes and words. [...] another Champollion would need to be born to decipher these hieroglyphs, if it is even worth being born for something so small." 54 And in 1865, Marceli Motty asked regarding "Fortepian Szopena:" "what is the point of this persistent effort to create vague logogriphs and to twist all the limbs of sentences, this intentional violation of any rhythm and harmony, all grammatical constructs, proper forms and meanings of words, even the most elementary punctuation?" 55

No wonder both these ill-understood poets spent most of their time abroad and died in foreign lands. Living away from his friends and family in England, Hopkins referred to his stint in Ireland as "being at a third remove." ${ }^{56}$ Norwid suffered from poverty and oblivion in emigration. He died on the 23rd of May 1883 in Paris at Saint Casimir's Poorhouse, where Polish veterans sought shelter.

Both poets only came to be appreciated posthumously. Norwid's discoverer and eulogizer was Zenon Przesmycki (Miriam), who published a first edition of his novella "Ad leones!" in Chimera in 1901, along with an article poignantly titled: "The Fate of Geniuses."

The discoverer of Hopkins' poetry was Robert Bridges, who published his late friend's poems in 1918. He began the volume:

the triumphal march of the poetry of Hopkins, who is today considered simultaneously one of the most profound religious poets, one of the greatest masters of language and

52 Cf. Gomulicki, “Mała kronika życia i twórczości Norwida,” PW, Vol. I, pp. 48-93; Cyprian Norwid, Pisma Wszystkie, ed. J. Gomulicki, Vol. 11, (Warszawa: PIW, 1976), pp. 201-225, 279-288; http://www.kul.pl/bibliografia-podmiotowa-cypriananorwida,art_78927.html.

53 PW, p. 101.

54 PW, p. 102.

55 PW, p. 112.

56 Gerard Manley Hopkins, Poems and Prose, ed. W. H. Gardner (Harmondsworth: Penguin Books, 1986), p. XXVII. 
innovators of poetic technique, and finally - a precursor [...], who exerted a vital influence on the development of modern English-language poetry. ${ }^{57}$

For this reason, Hopkins' works became the subject of lectures and discussions, and the author himself gained the readership and fame he had never dreamt of. Norwid, in turn, exerted a significant influence on the development of modern Polish poetry and has been one of the very few writers in the world whose language is described in specialist dictionaries and whose works and thoughts have been and continue to be studied by a succession of distinguished researchers, ${ }^{58}$ supported since the eighties of the 20th century by different research institutions such as: Ośrodek Badań nad Twórczością Cypriana Norwida (KUL) [Institute for the Study of Cyprian Norwid's Literature (The John Paul II Catholic University of Lublin)], Pracownia Słownika Jezzkka Cypriana Norwida (UW) [Cyprian Norwid Language Dictionary Division (University of Warsaw)], Pracownia Kalendarza Życia i Twórczości Norwida (UAM) [Chronology of the Life and Work of Cyprian Norwid Division (Adam Mickiewicz University)].

The truth was the main focus of the two poets. They both considered art a tool through which they could reach the truth, transmit it and teach it. Hopkins, convinced that the world reflects divine harmony, preached the beauty of Creation. It is for a good reason that he is considered "one of the most satisfying of the so called 'nature-poets." 59 The depth of his poems' religiousness is derived not only from his praise of the greatness of God and the harmony of his world, but also from his descriptions of the tragedy of human existence. ${ }^{60}$ Norwid, however, took up a much broader range of topics. He wrote about the problems of his contemporary world: politics, history, tradition, labour, freedom, slavery and social problems (like the emancipation of women). Juliusz Wiktor Gomulicki called this trend in poetry "the poetry of man" or "the poetry of human matter." 61

57 Barańczak, Nieśmiertelny diament: o poezji, p. 6.

58 Among others: Jan Błoński, Wacław Borowy, Józef Fert, Michał Głowiński, Juliusz Wiktor Gomulicki, Mieczysław Inglot, Mieczysław Jastrun, Zdzisław Łapiński, Tadeusz Makowiecki, Jadwiga Puzynina, Stefan Sawicki, Irena Sławińska, Zofia Stefanowska, Zofia Szmydtowa, Zofia Trojanowiczowa, Jacek Trznadel, Kazimierz Wyka, Zbigniew Zaniewicki, Maciej Żurowski.

59 W.H. Gardner, Introduction, in: Hopkins, Poems and Prose, p. XIII.

60 Cf. David A. Downes, Gerard Manley Hopkins: A Study of his Ignatian Spirit (New York: Bookman Associates, 1959); Alan Heuser, The Shaping Vision of Gerard Manley Hopkins ( London: Oxford University Press, 1958); John Pick, Gerard Manley Hopkins, Priest and Poet (London: Oxford University Press, 1933); John Pick, A Hopkins Reader (London: Oxford University Press, 1953).

61 Gomulicki, Uwagi, PW, Vol. 1, pp. 21-22. 
Both "Knights of Truth" ${ }^{2}$ required the appropriate tools to convey their views. They both reached for similar measures of expression, because the precise definition of things and phenomena was essential for them.

"The poet needs only the victory of the truth" - Norwid proclaimed in 1860, paraphrasing the words of the Gospel. [...] The subject of his poetry [...] was therefore the Truth, $[\ldots]$ in all its shapes and situations: philosophical and religious, social and psychological, aesthetic and scientific. This $[\ldots]$ specific attitude towards the truth [...] was closely connected to Norwid's concept of the "word" realizing itself in "deed" and he required from such a word the solemnity appropriate to its tasks. ${ }^{63}$

Hopkins wanted to illustrate his theory of "inscape" - to see and name in everything all that makes it exactly what it is. The language of his poems had to be characterized by aspirations of specificity and uniqueness of description.

For Norwid, as he wrote in "Ogólniki" ["Generalities"], it was also essential to "Odpowiednie dać rzeczy - słowo!” (PWsz II, 13) [name each matter by its rightful - word!]. ${ }^{64}$ So, his language is:

rich and very original, both because of the vocabulary, abundant in archaisms and neologisms, in rare special terms and in words which at that time were perceived as vulgar and anti-poetic ("stool," "carrion" etc.), and because of its original syntax. ${ }^{65}$

Beside the precision and originality of the language, the intricacy of poetic structures, syntax and graphic layout also appeared in Norwid's works. The poet relied on obscurity, because in his opinion: "[p]rawda obejmuje życie, jest więc niejasna, bo obejmuje rzecz ciemną" (PWsz VI, 449-450) "[t]ruth embraces life and is therefore obscure, because it embraces a dark thing."

In Hopkins' poetry, the expression of the tragic, the reflection of paradoxes

and anxieties of human existence is everything that could be labelled by dissonance dissonance which is not only phonic, but also grammatical, syntactic, semantic. [...] The unique rhythm of his verses[...] the so-called Sprung Rhythm played a similar role. ${ }^{66}$

For Norwid the dissonance of an otherwise harmonious world was above all the imperfection of man. He expressed "incompleteness," "lack" or "shortage," for example, using silence or bizarre punctuation. Wanting to reveal the truth about "the world's shattered wholeness," he:

62 The term by Kędzierska, gerardmanleyhopkins.org/lectures_2003/norwid.html.

63 Gomulicki, Uwagi, PW, Vol. 1, p. 45.

64 English translation by Borchardt, p. 13.

65 Gomulicki, Uwagi, PW, Vol. 1, p. 43.

66 Barańczak, Nieśmiertelny diament (i jego...), p. 100. 
carefully elaborated and consistently used his own individual system of signs and tricks, by means of which he signalled and adequately distributed dynamic tensions throughout the text. [...] All those measures specifically brought out from Norwid's text [...] something very peculiar, which could be called his original "score," and which brought the reader closer to the author's intentions and made it possible for him to read the texts in a dynamic way, enabling penetration into the more profound layer of their content. ${ }^{67}$

Looking carefully at Hopkins' and Norwid's original "scores," one may also spot differences in the way they expressed their ideas. Norwid surpassed Hopkins in the use of irony, understatement, silence and graphic solutions, while Hopkins was unparalleled (even by Norwid) in creating neologisms. The distinction between the two poets was also based on different emphases on the main topics of their works: Hopkins dealt with God, nature and man, while Norwid: with God, man and all that is human - history and man's work. Besides, the Polish author expressed his thoughts not only through poetry and letters. He also wrote dramas, novellas, verse letters and longer narrative poems which sometimes took the form of philosophical treatises.

Norwid's most important epic poems include Promethidion, Quidam and Rzecz o wolności słowa [On the Freedom of Speech]. In 1865-66 he created his most beautiful cycle of poems. Titled Vade-mecum, the collection contains a number of masterpieces, including "Bema pamięci żałobny-rapsod" ["A Funeral Rhapsody in Memory of General Bem"] and "Fortepian Chopina" ["Chopin's Grand Piano"]. Norwid was also a master of the 19th-century novella. His outstanding novellas include Czarne Kwiaty [Black Flowers], Białe Kwiaty [White Flowers], "Ad leones!", Bransoletka [Bracelet], Cywilizacja [Civilization] and Stygmat [Stigma]. He also authored numerous plays. The best known among them include Za kulisami [Backstage], Zwolon, Kleopatra i Cezar [Cleopatra and Caesar] and Pierścień Wielkiej-Damy [The Noble Lady's Ring].

Both posthumously discovered and appreciated poets have gained their welldeserved tribute and fame from posterity. More than a hundred years after their death, they both have been symbolically buried in places of national cult status. On the 15th of December 1975 Hopkins was honoured with a commemorative plaque in the Poets' Corner at Westminster Abbey; and on the 24th of December 2001 an urn containing soil from the mass grave at the Montmorency cemetery where Norwid was once buried was placed in the Great Polish Poets' Crypt at the Wawel castle, near the reliquaries of Adam Mickiewicz and Juliusz Słowacki.

67 Gomulicki, Uwagi, PW, Vol. 1, p. 42. 
Comparing the life and works of Norwid to the biography and writings of Hopkins and other precursors of modern literature, although it serves mainly the purpose of helping English language readers understand the personality and works of the Polish poet, also shows the extent to which he is in line with European literary tradition. One can clearly see that Kazimierz Wyka was correct in writing that "none of the great emigré poets were as deeply rooted in the surrounding European intellectual and artistic tradition as Norwid." ${ }^{68}$

At the same time Norwid is all too Polish, and in his Polishness very foreign and thus challenging to understand for representatives of other cultures. He is hard for them to understand also on account of his uniqueness and singularity.

In fact, apart from similarities to the mentioned writers, Norwid is so unique and so idiosyncratic that he should remain himself in translations: obscure, eccentric, a bit of a visionary but at the same time very down to earth, on one hand deeply rooted in tradition but on the other establishing new trends in poetry. The challenge is enormous. ${ }^{69}$

Bogdan Czaykowski put the matter this way:

Norwid's poetry, whatever the analogies with other poets, is sui generis. And so was Norwid himself, a wholly idiosyncratic person, who cultivated idiosyncrasy not because he wanted to, but because it was thrust upon him by his marginalization and highly individual perspective. And it was precisely this perspective, questioning and reverent at the same time, that lay at the bottom of his ironic mode, in fact, of his poetics. ${ }^{70}$

No wonder that Stanisław Grochowiak worried

whether Europe will give back what is duly owned to him? One should have no illusions. Permeated with passion for Universalism, Norwid wrote in a language so intensely Polish that it was indeed strange in its etymological quest. Yet it is not only a difficulty of translation. Decades have passed, and it will take several more before we ourselves will be able to understand the greatness of his genius. And maybe then - thanks to our efforts, always insufficient in this measure - Norwid's name and thought will become, at least to a certain degree, the property of European culture. ${ }^{71}$

The editors of the following volumes of Norwidianum do believe that the English translations of these extensive and thorough works of research on Norwid will

68 Wyka, "Prezentacja Norwida," p. 7.

69 Agata Brajerska-Mazur, "Strange Poet," The Sarmatian Review, 2013, No. 1, Vol. XXXIII, p. 1727. The first three paragraphs of this introduction also come from this article, p. 1723.

70 Czaykowski, “The Poet as 'Christian Socrates," p. 18.

71 Grochowiak, "Ktoś, co sobie idzie," p. 2. 
significantly contribute to making his name and thought the property of not only European, but world culture. And maybe then, next to Hopkins' "immortal diamond" Norwid's own "gwiaździsty dyjament" [starry diamond] of well-deserved international fame will sparkle in that same sky, and an affirmative answer will be given to the question asked by the poet himself in his poem "W pamiętniku" ["In an Album"]:

Co raz to z ciebie, jako z drzazgi smolnéj,

Wokoło lecą szmaty zapalone;

Gorejąc, nie wiesz, czy? stawasz się wolny,

Czy to, co twoje, ma być zatracone?

16

Czy popiół tylko zostanie i zamęt,

Co idzie w przepaść $\mathrm{z}$ burzą? - czy zostanie

Na dnie popiołu gwiaździsty dyjament,

Wiekuistego zwycięstwa zaranie!...

(DW VI, 17)

[As from a torch dipped in pitch, now and again

Flaming rags fly from you in all directions:

As you burn, you do not know: Will you be freed?

Or will all that is yours be destroyed?

Will only the ashes remain and the confusion,

Which the storm blows into the abyss? - Or will there remain

Beneath the ashes, a starry diamond,

The dawn of eternal victory!... $]^{72}$

72 Passage translated by Ludwik Krzyżanowski and Gerard T. Kapolka, “The Polish Review," 1983, Vol. 28, No. 4, p. 7. 


\section{Edyta Chlebowska \\ From the History of Norwidian Research}

The claim that textual criticism and the art of editing constitute the basis of research on the works of Cyprian Norwid may seem trivial and not entirely revelational, considering the fact that the process of getting acquainted and re-acquainted with the creative profile of every writer, poet or, in broader terms, cultural creator has its origins in the act of accumulating and determining the content of his oeuvre. However, a careful look at the history of Norwidian editing allows us to notice that the long-lasting process of searching for and publishing Norwid's scattered literary legacy, teeming with interesting discoveries and sudden "plot twists" - if we recognize the symbolic epitome of this movement to be the publication of the complete critical, fully scientific edition of his work - is still ongoing. ${ }^{1}$ In the history of scholarly Norwidian editing, we are able to point to three most important moments, the first two being closely related to the activities of the eminent publishers of Norwid's literature: Zenon Przesmycki (pen name Miriam) and Juliusz Wiktor Gomulicki. The former one, called the "discoverer," or "reviver" of the author of Vade-mecum, or even "the father of Norwidology," undertook, with assistance of a group of several dozen people, the search for Norwid's dispersed writings and works of fine art on a large scale. In the beginning, he was publishing the Norwidiana in Chimera, a magazine he edited, but as early as in 1911 he began work on an exclusive edition of Norwid's Pisma zebrane [Collected Works] (from the planned 8 volumes, only 5 were actually printed, and the last volume F, printed in incomplete form, appeared in bookstores only in 1946). The suspension of this ambitious publication did not mean that Miriam gave up his editing activity in the field of Norwidology; in subsequent years the editor published many individual pieces, three volumes of inedita and a poetical anthology, and in the years 1937-1939 in response to the allegations that he had purposely withheld the publication of the poet's collected literature - the edition of Wszystkie pisma Cypriana Norwida

1 The editorial history of Norwid's posthumous papers has been tracked in detail by Marek Buś, who is the author, among others, of: Składanie pieśni. $Z$ dziejów edytorstwa twórczości Cypriana Norwida (Kraków: Wydawnictwo Naukowe WSP, 1997) and Norwidyści: Miriam - Cywiński - Borowy - Makowiecki - Wyka; Konteksty (Kraków: Wydawnictwo Naukowe Akademii Pedagogicznej, 2008). 
po dziś w całości lub fragmentach odszukane [Cyprian Norwid's Collected Works Found in Fragments or in their Entirety]. ${ }^{2}$ Alongside the publishing initiatives Miriam ran on a large scale, the book market was additionally reinforced by the Norwidiana published by other editors, such as Roman Zrębowicz, Bolesław Erzepki and Stanisław Cywiński. The dubiously famed single-volume edition of the poet's Dzieła [Works] edited by Tadeusz Pini, advertised as the first complete edition of Norwid's writings, should also be mentioned. Incomplete and full of mistakes, and moreover, preceded by the publisher's inferior foreword, this publication ignited vivacious criticism, on top of a public opinion already concerned with Miriam and Pini's dispute over the poet's posthumous copyrights, which received wide press coverage.

After World War II, the challenge of publishing "the whole" of Norwid was taken up by Juliusz Wiktor Gomulicki, who, having published two volumes of poetry within the framework of Dzieła zebrane [Collected Works] (Warsaw 1966) and the five-volume edition of Pisma wybrane [Selected Writings] (Warsaw 1968), ${ }^{3}$ published 11 volumes of Pisma wszystkie [Collected Writings] between the years 1971-1976, finally giving Polish culture "the entirety" of Norwid's works. The advantage of being an "entirety" did not mean the end of editorial efforts in this case, because Gomulicki's scholarly edition, intended for the general public was - and this is rarely mentioned - plagued by many shortcomings, mainly, but not only, on account of an overzealous attempt to modernize and unify the text's typographic form; it was at an intermediate, rather than a final, stage of textual arrangement. The first critical edition of Norwid's Dzieła wszystkie [The Complete Works] was only initiated in recent years, by a team of researchers headed by chief editor Stefan Sawicki, under the auspices of Ośrodek Badań nad Twórczością Cypriana Norwida [Institute for the Study of Cyprian Norwid's Literature] at the John Paul II Catholic University of Lublin. As of now, 7 of

2 Before the outbreak of the war Przesmycki managed to publish six out of the nine planned volumes, however, only four were put out for sale (Dramaty, Vols. III and IV and Listy, Vols. VIII and IX), two subsequent ones were only printed (Proza epicka, Vol. V and Pisma o sztuce i literaturze, Vol. VI). The entire stock of volume VII (Pisma filozoficzne, społeczne i inne) was consumed by fire at the printing house before wirestitching. Basing on the one complete copy saved from burning, the volume was published in 1957 in London by Miriam's secretary Zbigniew Zaniewicki, under a different title: Pisma polityczne i filozoficzne.

3 Two subsequent editions of Pisma wybrane were published in 1980 and 1983. 
the planned 17 volumes, each supplied with a critical apparatus and explanatory notes, have been published. ${ }^{4}$

A crucial argument for the particular importance of editorial achievements in the history of research on the literature of the author of Promethidion is the remarkable trend among his most important publishers, of furnishing their editions with rich critical and commentary apparatuses. The first editions, especially the one Zenon Przesmycki started in 1911 - Norwid's Pisma zebrane [The Collected Works] (not finalized by the publisher) - set a very high bar. The texts published in Pisma zebrane were supplemented with extensive commentaries providing substantial information on the texts' genesis, descriptions of the sources (original manuscripts, copies, first editions) which constituted their textual basis, as well as broad biographical and historico-literary explanations. ${ }^{5}$ It is impossible not to mention the aesthetic values of this edition, the tasteful graphic design, the carefulness and elegance of the typography and the richness of the "Artistic Addenda" ["Dodatki artystyczne"], consisting of reproductions of Norwid's works of fine art. In the context of Przesmycki's critical approach to the interpretation of Norwid's texts, from among the later editions attributed to the editor, his Poezje wybrane [Selected Poems] from 1932 deserves special attention. The publisher's notes included in this edition constitute, as, Marek Buś, a researcher studying the editorial history of Norwid's posthumous work, stressed, the only edition of Miriam's Norwidian work which is "characterized by entirety, completeness." Moreover, if the editor's selection of poetry represented Norwid's creative profile, the commentary reflected Miriam's vision of "Ad leones!"s author's output. ${ }^{6}$ In spite of the prevalent opinion among critics and literary researchers that Przesmycki was "stuck in a 'Young Poland' era mindset" (the unfairness of which was already indicated by Wacław Borowy, who emphasized

4 C. Norwid, Dzieła wszystkie: Vol. III: Poematy I, ed. Stefan Sawicki, Adam Cedro (Lublin: TN KUL, 2009); Vol. IV: Poematy II, ed. Stefan Sawicki, Piotr Chlebowski (Lublin: TN KUL, 2011); Vol. V: Dramaty I, ed. Julian Maślanka (Lublin: TN KUL, 2015); Vol. VI: Dramaty II, ed. Julian Maślanka (Lublin: TN KUL, 2014); Vol. VII: Proza I, ed. Rościsław Skręt (Lublin: TN KUL 2007); Vol. X: Listy I, ed. Jadwiga Rudnicka (Lublin: TN KUL, 2008); Vol. XI: Listy II, ed. Jadwiga Rudnicka (Lublin: TN KUL 2016).

5 Zenon Przesmycki, "Przypisy wydawcy," in: C. Norwid, Pisma zebrane, published by Z. Przesmycki. Vols. A, C, E (Warszawa-Kraków: Nakład Jakóba Mortkowicza, 1911) [in reality 1912-1914], Vol. F (Warszawa-Kraków: Nakład Jakóba Mortkowicza, 1911) [in reality 1946].

6 Marek Buś, Zenon Przesmycki jako czytelnik Norwida, in: by the same author: Norwidyści, p. 37. 
the editor's "incredible diversity of points of view"), his synthetic yet not simplistic annotations to Poezje wybrane evidence a "wise reading of the poet," not through the passive contemplation or application of some predefined methods or styles of interpretation, but through an active dialogue with the text. This attitude stemmed from an awareness of the multi-layered and complex nature of the literary work, and guided Miriam towards an analysis which combined text parsing [dismantling] with contextual interpretation. Following Przesmycki's example, other pre-war editors of Norwid's writings also paid great attention to their commentaries, placing the emphasis either on synthetic prefaces and epilogues, or on the notes and explanations accompanying the published texts; just to mention the Wybór poezji [Selected Poems] edited by Stanisław Cywiński (1924) and the first individual publication of Promethidion, considered the most renowned work penned by Norwid, which was undertaken by Roman Zrębowicz (1922). The pinnacle of this trend, several decades after the mentioned editions, was J. W. Gomulicki's commentary to the volume of poems which in and of itself filled several hundred pages of the second volume of Dzieta zebrane (1966), while the significant limitation of the critical apparatus in Pisma wszystkie was the result "not so much of the editor's guidelines, but rather of a circumstantially forced resignation."

Along with the sharp increase in the number of editorial publications, which occurred before 1939, the current of literary history studies began to expand in association with the development of literary research in Poland, as well as the prevalence of subsequent research methods and attitudes. A characteristic trait of the interwar editorial efforts on Norwid's literature was the markedly strong tendency to modernize, saturating researchers' texts with the tone of "criticality" and determining the accents of valuation from a contemporary perspective. As a result of that - as Buś noticed - "the cases of denying any significant and lasting value to the interwar phase of the poet's reception are pretty common. This is connected to the suggestion that the image of the reception of Norwid's literature at that time was subordinated to "legend-making [legendary]" criteria rather than to those assertive, historico-literary, ones, and that it was a reflection of a "false awareness" presenting a mythologized and "imaginary" Norwid". The extent to which Buśs criticism of this judgement is unfair and one-sided is clearly demonstrated by the fact that quite a few studies from

7 Wacław Borowy, O Norwidzie. Rozprawy i notatki, ed. Zofia Stefanowska (Warszawa: PIW, 1960), p. 145.

8 Buś, Składanie pieśni, p. 243.

9 Buś, Składanie pieśni, p. 243. 
that time have been permanently adopted by research tradition, and constitute a significant reference point for successive generations of scholars. Here we should at least mention Wacław Borowy's insightful remarks, Zofia Szmydtowa's solid analyses, Tadeusz Makowiecki's interpretations, the books by Ignacy Fik and Władysław Arcimowicz, and the problem studies by Kazimierz Wyka and Stefan Kołaczkowski. ${ }^{10}$

The literary research and critical discussions on the originality and greatness of Norwid's works undertaken during the interwar period, as well as the attempts to establish the poet's position on Poland's cultural map, which naturally accompanied the stage of the collection of his works and determination of their final shape, were discontinued after 1945. Although Norwidology, with a very few and insignificant exceptions, was spared from Marxist influence, this discipline did not take on any specific research direction for a relatively long time - which was inevitable in the years dominated by "the only acceptable" perception of Norwid's works as "reactionary" and "obscurantist." ${ }^{11}$ In this situation,

10 Cf. Kazimierz Wyka, Norwidiana (the series of bibliographical settings provided with the valuable comments of the scholar, published in Pamiętnik Literacki, 1924/25; Vol. 1 (1930); Vol. 4 (1936); Vol. 1-4 (1937); Zofia Szmydtowa, "Norwid jako tłumacz Homera," in: Prace Komisji do Badań nad Historia Literatury i Oświaty, Vol. III (Warszawa: Wyd. Towarzystwo Naukowe Warszawskie, Wydział I, 1929), pp. 99-115, same author, "Platon w twórczości Norwida," in: Prace historycznoliterackie. Ksiega zbiorowa ku czci Ignacego Chrzanowskiego, (Kraków: Skł. Gł. w Kasie im. Mianowskiego, 1936, p. 365-385), same author: O misteriach Cypriana Norwida (Warszawa: Wydawn. Kasy im. Mianowskiego, 1932); Tadeusz Makowiecki, "Norwid wobec Powstania Styczniowego," Pamiętnik Literacki, 1929, p. 564-581, same author, "Młodzieńcze poglądy Norwida na sztukę," "Pamiętnik Literacki” 1927, p. 24-85, same author, "Stygmat ruin w twórczości Norwida," Droga 1933, No. 11, p. 1144-1149; Ignacy Fik, Uwagi nad językiem Cypriana Norwida (Kraków: Druk W.L. Anczyca i Spółki, 1930); Władysław Arcimowicz, Cyprian Kamil Norwid na tle swego konfliktu z krytyka (Wilno: Koło Polonistów Sł. U.S.B., 1935); Stefan Kołaczkowski, "Ironia Norwida," Droga, 1933, No. 11, pp. 993-1025; Kazimierz Wyka, "Starość Norwida," Droga, 1933, No. 11.

11 Efforts to read Norwid's texts in a "modern" way were undertaken rather on the grounds of literary criticism and publicism, whose main task became the struggle for a new shape of literature, among others through profiling a canon of the cultural tradition suitable for "the challenges of contemporaneity." An extensive report of the "operation" carried out by the communist cultural life ideologists on Norwid's literature, which they attempted to "cut out" in accordance with Marxist instructions, is given by Przemysław Dakowicz in his book: "Lecz ty spomnisz, wnuku..." Recepcja Norwida w latach 1939-1956. Rzecz o ludziach, ksiażkach i historii (Warszawa: Instytut Badań Literackich PAN, 2011). 
structuralism became the principal methodological reference point for post-war research on Norwid; humanities studies around the world were experiencing dynamic developments between 1930-1960, but these significantly delayed their appearance in Poland on account of wartime turmoil and the subsequent Marxist terror. The expansion of structuralism resulted in the development of the theory of literature and especially that of poetics, and also led to the establishment of interpretation as the method allowing for the most profound comprehension of Norwid's writings. ${ }^{12}$ The privileged position of the studies and analyses devoted to individual texts of Vade-mecum's author, which mostly took lyrical poetry and dramas into consideration, but sometimes also artistic prose (mainly novellas), poems or epistolography, yielded an abundance of extensive publications of an almost exclusively interpretative nature. ${ }^{13}$

The special status of interpretation is also - after collecting Norwid's writings and discussing his position on the map of Polish culture - the next step towards more profound knowledge of the poet's works through the more thorough understanding of his texts. Researchers' papers raise many polemics and discussions around the interpretation of Vade-mecum's author's writings. "There

12 The abundance of interpretations has been accounted for in bibliographical analyses elaborated on by the Cyprian Norwid Literature Research Department at KUL: Bibliografia interpretacji wierszy Cypriana Norwida, eds. Adam Cedro, Piotr Chlebowski, Józef Fert with the cooperation of Marek Buś and Jacek Leociak (Lublin: Magraf, 2001); Bibliografia interpretacji poematów Cypriana Norwida, ed. Włodzimierz Toruń with the cooperation of Marek Buś, Piotr Chlebowski, Jan Gotfryd (Lublin-Rome: Cedro i Synowie, 2007); Łukasz Niewczas, Bibliografia prozy artystycznej Cypriana Norwida (Lublin: Cedro i Synowie, 2011); Piotr Chlebowski, Bibliografia interpretacji dramatów Cypriana Norwida (Lublin: Cedro i Synowie, 2011).

13 Cypriana Norwida kształt prawdy i miłości. Analizy i interpretacje, ed. Stanisław Makowski (Warszawa: WSiP, 1986); Cyprian Kamil Norwid. Interpretacje i konteksty, ed. Piotr Żbikowski (Rzeszów: Wydawnictwo WSP, 1986); Czemu i jak czytamy Norwida, ed. Jolanta Chojak, Elżbieta Teleżyńska (Warszawa: Wydawnictwo UW, 1991); Czytając Norwida. Materiały z konferencji poświęconej interpretacji utworów Cypriana Norwida zorganizowanej przez Katedrę Filologii Polskiej Wyższej Szkoły Pedagogicznej w Słupsku, ed. Sławomir Rzepczyński (Słupsk: Wyższa Szkoła Pedagogiczna, 1995); Norwidowskie fraszki (?), ed. Jacek Leociak (Warszawa: Wydawnictwo Energeia, 1996); Liryka Cypriana Norwida, ed.

Piotr Chlebowski, Włodzimierz Toruń (Lublin: TN KUL, 2003); Rozjaśnianie ciemności. Studia i szkice o Norwidzie, eds. Jacek Brzozowski, Barbara Stelmaszczyk (Kraków: Universitas, 2004); Jedno dzieło - wiele interpretacji. Rozważania nad "Wielkimi słowami" Cypriana Norwida, ed. Dariusz Pniewski (Toruń: Wydawnictwo Naukowe UMK, 2012). 
is growing talk - emphasizes Anna Kozłowska, the author of a study devoted to these problems - that it is necessary for reciters, translators, and scenarists to think Norwid through." Most of the linguists interested in Norwid's literature set the understanding of his work as their fundamental goal. ${ }^{14}$ Critical reflection on the element of interpretation present in Norwidological research inevitably turns our attention to the radical discrepancies or even misunderstandings taking place on different levels of the analysed texts' organization, many of which can be easily found in the published testimonies to the reading of Norwid. Kozłowska gives examples of interpretative controversies characteristic of the discipline, and proceeds to indicate the factors at the root cause of the observed divergencies. In this respect, she ascribes a special role to the general differences in outlook on the essence of interpretation, allowing the distinction of a few main ways to "read Norwid," based on the differentiation of goals set by the interpreters. ${ }^{15}$ Depending on whether the researcher is attempting to get at the communicative intentions of the author, is trying to grasp the text's meaning from the reader's perspective, or else, is searching for the elements that would render it possible to place the piece of writing in some context (biographical, historical, ideological, or more broadly cultural), individual interpretations extract diametrically opposed meanings from Norwid's literature.

The analytical approach sometimes bore the fruit of studies leading to the formulation of categories and units of a higher order, like a genre, which was evidenced, for example, by Irena Sławińska’s classic monograph O komediach

14 Anna Kozłowska, Co to znaczy "czytać Norwida"? in: Jak czytać Norwida? Postawy badawcze, metody, weryfikacje, ed. Bernadetta Kuczera-Chachulska and Joanna Trzcionka (Warszawa: Wydawnictwo UKSW, 2008), p. 24. The problems of semantics in the work of Norwid's poetry reciter were dealt with by Wojciech Siemion (Lekcja czytania. Norwid, Warszawa: Muzeum Literatury im. Adama Mickiewicza, 2001), and an attempt to set a best strategy for Norwidian texts' translation was undertaken by: Agata Brajerska-Mazur, O angielskich tłumaczeniach utworów Norwida, Lublin: TN KUL, 2002). See also the article by Jadwiga Puzynina, Język - interpretacja - przekład. Na materiale "Vade-mecum" tlumaczonego na język niemiecki przez Rolfa Fiegutha, Studia Norwidiana, Vol. 11 (1993), pp. 31-51. The important role ascribed to interpretation by linguists, especially those from the circle of the Cyprian Norwid Language Dictionary Division at the University of Warsaw, has been accounted for by the bibliographical setting prepared by Tomasz Korpysz, with references to many interpretative texts (Tomasz Korpysz, "Bibliografia prac Zespołu Pracowni Słownika Języka Cypriana Norwida (w 20-lecie Pracowni)," Studia Norwidiana, Vol. 20-21 (2002-2003), pp. 319-336).

15 Kozłowska, Co to znaczy “czytać Norwida”?, pp. 27-33. 
Norwida [On Norwid's Comedies]. ${ }^{16}$ Studies devoted to the issues of Norwidian poetics, usually developed in a structuralist spirit, were especially popular in the literary subject matter of the 1960s and 1970s, but have also been continued in more recent years. It is worth indicating the studies in this current that dealt with the problems of genre, style, composition and types of articulation undertaken by authors such as: Michał Głowiński, Mieczysław Inglot, Marian Maciejewski and Stefan Sawicki. ${ }^{17}$

Ideological considerations in Promethidion's author's oeuvre constituted an important trend in post-war Norwidology: within its framework there were attempts to recognize Norwid as a thinker, philosopher, theologist, poet of culture, poet of history etc. Among the researchers exploring the mentioned areas it is especially important to mention Zofia Stefanowska, Elżbieta Feliksiak and Reverend Antoni Dunajski. ${ }^{18}$ Those investigations saw different research trends; beside structuralism, hermeneutical studies were especially noticeable. The book Czytanie Norwida. Próby [Reading Norwid. Essays] (Warsaw 1978) by Jacek Trznadel or Dwie twarze losu. Nietzsche-Norwid [The Two Faces of Fate. NietzscheNorwid] by Ewa Bieńkowska can be taken as examples of critical analyses in which the thesis closely linked with the hermeneutical circle - that interpretation strongly depends on pre-understanding - was clearly expressed. However, the hermeneutical vision more frequently led Norwid scholars to publications focused on the communication of the theory of literary work, concerning problems associated with the reception and the recipient. This is why so many research papers concentrated on the communication forms and dialogue in Norwid's oeuvre, like for example, Michał Głowiński’s Norwidowska druga osoba [Norwidian Second Person] ${ }^{19}$ or Józef Fert's Norwid poeta dialogu [Norwid as a Poet of

16 Lublin 1953.

17 Michał Głowiński, Intertekstualność, groteska, parabola. Szkice ogólne i interpretacje (Kraków: Universitas, 2000), pp. 244-351; Mieczysław Inglot, Wyobraźnia poetycka Norwida (Warszawa: PWN, 1988), Marian Maciejewski, Spojrzenie "w górę" i "wokoło" (Norwid - Malczewski), in: same author, Poetyka - gatunek - obraz. W kregu poezji romantycznej (Wrocław: Zakład Narodowy im. Ossolińskich, 1977), pp. 136-164; Stefan Sawicki, Norwida walka $z$ forma (Warszawa: PIW, 1986).

18 Zofia Stefanowska, Strona romantyków, Elżbieta Feliksiak, Norwidowski świat myśli: Norwid i Vico; Ukryta struktura "Vade-mecum" and other studies collected in the book by Feliksiak, Poezja i myśl. Studia i szkice o Norwidzie (Lublin: TN KUL, 2001); Antoni Dunajski, Chrześcijańska interpretacja dziejów w pismach Cypriana Norwida (Lublin: TN KUL, 1985).

19 Roczniki Humanistyczne, Vol. 19, 1971, No. 1, pp. 127-133. 
Dialogue $],{ }^{20}$ appeared in the 1970s and 1980s.

Norwidology - beginning with the 1990s - did not lack the application of postmodern methodologies, although they did not succeed in dominating other currents, despite having strongly resonated with the literature of the subject matter. In this respect one should first and foremost mention the book, widely talked about in its time, by Wiesław Rzońca Norwid - poeta pisma. Próba dekonstrukcji dzieła [Norwid - the Poet of Script. An Attempted Deconstruction of Literary Works]. ${ }^{21}$ The study was not lacking in provocative and peremptory statements aimed, above all, at Norwidology (or, to be exact: Norwidologists). However, the author's revelations do not withstand critical pressure when confronted with historical material. This is because in case of Quidam's author, his incoherence, incompleteness, fragmentation of style and thought had been written about since the very beginning, even during his lifetime - critics accused him of "obscurity," "intricacy," "muddled style." Such opinions about Norwid were written not only by Józef Ignacy Kraszewski, but also by Zygmunt Krasiński, and even Teofil Lenartowicz. ${ }^{22}$ From the group of researchers who conducted their analyses using different methodologies connected with broadly-understood modernism, we should mention Michał Kuziak and his study Poststrukturalizm $i$ Norwid. Wstęp do wstępu [Poststructuralism and Norwid. An Introduction to the Introduction ${ }^{23}$ or the article Norwid - zmagania $z$ podmiotowościa. Epifanie poetyckie autora "Vade-mecum" [Norwid. The Struggle with Subjectivity. Poetical Epiphanies of the Author of "Vade-mecum"]. ${ }^{24}$ This group of texts should include the book by Rzońca: Premodernizm Norwida [Norwid's Pre-modernism], ${ }^{25}$ as well as the book Mallarmé - Norwid ${ }^{26}$ by Piotr Śniedziewski. The latter one is an example of seizing the achievements of comparative literature in Norwidology, and the comparison of both poets is carried out mainly on the plane of language

20 Wrocław: Zakład Narodowy im. Ossolińskich, p. 170.

21 Warszawa: Semper, 1995, p. 205.

22 It is characteristic that Rzońca's deconstructional attempt was criticized by the researchers commonly considered to be supporters of Derrida's views. See for example: Piotr Markowski, "Pochwała subiektywizmu," Europa, No. 45 (2005), supplement to Fakt, p. 13.

23 In: Jak czytać Norwida, pp. 181-194.

24 Pamiętnik Literacki, No. 4 (2015), pp. 5-25.

25 Premodernizm Norwida - na tle symbolizmu literackiego drugiej połowy XIX wieku (Warszawa: Wydział Polonistyki Uniwersytetu Warszawskiego, 2014).

26 Mallarmé - Norwid. Milczenie i poetycki modernizm we Francji oraz w Polsce (Poznań: Wydawnictwo Naukowe UAM, 2008), p. 354. 
and aesthetics as well as the poetics/rhetoric of silence, not touching upon the sphere of ideas. In recent years - especially among the younger generation of researchers - there has been a significant increase of interest in comparative readings of Norwidian literature, either pointing out its similarities to analogous literary and intellectual phenomena or confronting it with phenomena on the complete opposite end of the spectrum..$^{27}$ It suffices to mention the books by Ewangelina Skalińska (juxtaposing Norwid's works with Dostoyevsky) ${ }^{28}$ by Eliza Kącka (describing Norwid's reception by Stanisław Brzozowski) ${ }^{29}$ or by Karol Samsel (constructing a comparison between Norwid and Joseph Conrad). ${ }^{30}$ These studies significantly and extensively contributed to the development of the present current of Norwid research, devoted to different forms of intertextual investigations into the writings of the author of Vade-mecum ${ }^{31}$ such as the

27 Agata Brajerska-Mazur, "Los geniuszów, czyli niezwykle paralelizmy w życiu i twórczości Gerarda Manleya Hopkinsa i Cypriana Kamila Norwida," in: Symbol w dziele Norwida, ed. Wiesław Rzońca (Warszawa: UW, 2011), p. 299-310; Ewangelina Skalińska, Norwid - Dostojewski. Zbliżenia i rekonstrukcje (Warszawa: Wydawnictwo UKSW, 2014); Karol Samsel, Norwid - Conrad: epika w perspektywie modernizmu (Warszawa: Wydawnictwo Naukowe Semper, 2015); Norwid notre contemporain, ed. Maria Delaperière (Paris: Institut détudes slaves, 2015); Arent van Nieukerken, "Norwid, Heine, Gautier i początki modernizmu," Litteraria Copernicana, No. 2(16) (2015), pp. 115-130; Agata Brajerska-Mazur, "Norwid - Hopkins: Listy," in: Norwid: listy, listy ..., ed. Łukasz Niewczas (Lublin: Wydawnictwo KUL, 2017), pp. 389-405.

28 Skalińska, Norwid - Dostojewski, p. 482.

29 Eliza Kącka, Stanisław Brzozowski wobec Cypriana Norwida (Warszawa: Wydział Polonistyki Uniwersytetu Warszawskiego, 2012), p. 204.

30 Samsel, Norwid - Conrad, p. 348.

31 A comparative reading of Norwidian poetry was also proposed by: Rolf Fieguth, Poesie in kritischer Phase. Cyprian Norwids Gedichtzyklus Vade-mecum (1866), in: Cyprian Norwid, Vade-mecum 1866. Polnisch-deutsch. Herausgegeben, eingeleitet und übersetzt von Rolf Fieguth. Mit einem Vorwort von Hans-Robert Jauß (München: Fink, 1981), pp. 22-67; Rolf Fieguth, "Vade-mecum Cypriana Norwida w kontekście Victora Hugo i Charlesa Baudelaire'a," in: Strona Norwida. Studia i szkice ofiarowane profesorowi Stefanowi Sawickiemu, eds. Piotr Chlebowski, Włodzimierz Toruń, Elżbieta Żwirkowska, Edyta Chlebowska (Lublin: TN KUL, 2008), pp. 139-154; Ilona Woronow, Romantyczna idea korespondencji sztuk. Stendhal, Hoffman, Baudelaire, Norwid (Kraków: Wydawnictwo UJ, 2008); Magadalena Siwiec, "Komparatystyka przełomu. Norwid i Baudelaire," in: Komparatystyka dzisiaj, Vol. 2, ed. Edward Kasperski and Ewa Szczęsna (Warszawa: Wydawnictwo Elipsa, 2011), pp. 213-231; Katarzyna Trzeciak, "Rzeźba i ruina jako metafory formy artystycznej u Gautiera i Norwida," Ruch Literacki Vol. LV, 2014, No. 6, pp. 589-601. 
publications of Maciej Żurowski, ${ }^{32}$ Zofia Szmydtowa ${ }^{33}$ or Edward Kasperski, to name a few. ${ }^{34}$ Quite a lot has also been written on the reception of Norwid in contemporary Polish poetry. ${ }^{35}$

Despite the significant expansiveness and research proficiency, none of the aforementioned research currents or methods (structuralism, hermeneutics, postmodernism, comparative literature etc.) found solid ground in Norwidology; and none of them succeeded in permanently dominating the area of research on the poet's oeuvre. Structuralism - analysing literary work from the perspective of a superimposed order - was unable to impose its representation of the world on the poet's highly individualized texts, it never managed to confine it to any system. For example, very few Norwidological works were written about Norwidian literary genetics at a time when this topic practically dominated the literary research scene. The books and articles of eminent Norwidologists, like Irena Sławińska, Stefan Sawicki, Zdzisław Łapiński or Zofia Stefanowska prove the natural resistance of Norwid's literary material to any systemic approach. The freedom (optionality) of associations drawn from the poet's texts - characteristically hermeneutic - was very quickly compromised on philological grounds. Deconstruction was also discredited rather quickly, although its appeal was undeniable; its anti-rationalism could not hold up to the pressure exerted by works emphasizing the need for objective cognition, rationalism and concentration on reality. However, the art of analysis and interpretation proved to be a stable factor in Norwid research. From the very beginning, studies of this

32 See for example: "Norwid i Gautier," in: Nowe studia o Norwidzie, ed. Juliusz W. Gomulicki, Jan Z. Jakubowski (Warszawa: PWN, 1961), p. 167-190.

33 See for example: "Norwid wobec włoskiego odrodzenia," in: Nowe studia, p. 125-165.

34 Three works, especially, should be mentioned: Norwid - Kierkegaard. Paralela komparatystyczna; Terapia czy utopia? Norwid - Kierkegaard: komparatystyka estetyczna $I$ and $O$ estetyce obowiązku i o Moralności. Norwid - Kierkegaard: komparatystyka etyczna II. All published in the book by the same author: Tropami Norwida. Studiainterpretacje - paralele, ed. Żaneta Nalewajk (Warszawa: UW, 2018), pp. 305-349.

35 Kazimierz Świegocki, Norwid i poeci Powstania Warszawskiego (Warszawa: PAX, 2007), Małgorzata Rygielska, Przyboś czyta Norwida (Katowice: UŚ, 2012); Teresa Skubalanka, "Norwid a poezja współczesna. Szkic stylistyczny," Colloquia Litteraria, Vol. 3, 2008, No. 1-2, pp. 171-191; Przemysław Dakowicz, "Lecz ty spomnisz, wnuku...;"Recepcja Norwida w latach 1939-1956. Rzecz o ludziach, książkach i historii (Warszawa: PAN, 2011); Anita Jarzyna, "Pójście za Norwidem" (w polskiej poezji współczesnej) (Lublin: TN KUL, 2013). 
type were somewhat dominant in the field of research related to the works of Promethidion's author: they appeared in practically all of the mentioned methodologies and currents.

The katena method, ${ }^{36}$ devised and used by Agata Brajerska-Mazur to both evaluate and/or create faithful translations of literary masterpieces, was also hermeneutic and interpretational in nature. She assumed that translators of Norwid's polysemic works should offer target readers precisely as many interpretations of a source text as it had in the original. ${ }^{37}$ The method sums up the general knowledge of all the interpreters of an analyzed text, enables critics to evaluate the quality of various translations of Norwid's works and helps their readers discover and understand the specific character of his literary achievements.

In the conclusion of this brief review it is worth noting that in recent years (from the turn of the 20th century) the research on Norwid was to a great extent organized into three large-scale projects: lexicographical, biographical and editorial. Their execution was tied to the activities of three research centres established in the 1980s: Pracownia Słownika Języka Cypriana Norwida [Cyprian Norwid Language Dictionary Division] at the University of Warsaw headed by professor Jadwiga Puzynina, Pracownia Kalendarza Życia i Twórczości Cypriana Norwida [Chronology of the Life and Work of Cyprian Norwid Division] headed by professor Zofia Trojanowicz at the Adam Mickiewicz University in Poznań and Ośrodek Badań nad Twórczością Cypriana Norwida [Institute for the Study of Cyprian Norwid's Literature] active at the John Paul II Catholic University of Lublin under the auspices of professor Stefan Sawicki. Only the last of the mentioned centres continues to function on the map of

36 "Katena" is derived from the Latin word meaning "chain," and is linked to Bibliology. Thus the term means "collections of excerpts from the writings of Biblical commentators, especially the Fathers of the Church, strung together like links of a chain and in this way exhibiting a continuous and connected interpretation of Scripture." In the katena method used in translation studies commentaries on a literary text made by renowned scholars are collected to identify the text's most significant features that must not be lost in translation.

37 Cf. Agata Brajerska-Mazur, O angielskich tłumaczeniach utworów Norwida (Lublin: TN KUL, 2002), "Katena and Translation of Literary Masterpieces," Babel, Vol. 51, 2005, pp. 16-30, "O przekładzie na język angielski wierszy Norwida Śmierć, Do zeszłej..., Finis," Pamiętnik Literacki, XCVII, booklet 4 (2006), pp. 229-237, “Ten Commandments for the Translation of the Works of Cyprian Norwid (and what came from them, or, on the translations of Danuta Borchardt)," The Polish Review, Vol. LIII, No. 4 (2008), pp. 495-540. 
Polish humanities studies, the former ones concluded their activities upon achieving their research goals.

The studies carried out by Professor Puzynina's team - through books, articles, subsequent volumes of Seria słownikowych zeszytów tematycznych [The Series of Lexicographical Thematic Notebooks] ${ }^{38}$ - introduced the issue of Norwid's language to the realm of Norwidology on a large scale, and, above all, made the development of the Online Dictionary of Cyprian Norwid's Language ${ }^{39}$ possible. The Poznan team, tackling the difficult matter - full of gaps, inaccuracies and myths - of the poet's biography, finalized its efforts in the three-volume Kalendarz życia i twórczości Cypriana Norwida [Calendar of Cyprian Norwid's Life and Works $]^{40}$ published in 2007. The Lublin Centre, whose beginnings were associated with the establishment of the annual publication Studia Norwidiana, ${ }^{41}$ organizes thematic research conferences - Colloquia Norwidiana - cyclically, every two years, bringing together the scholars specializing in the poet's works from many research centres in the country and abroad, ${ }^{42}$ publishes the editorial

38 Five volumes have been published: Słownictwo etyczne Cypriana Norwida, part I: Prawda, fałsz, kłamstwo, ed. Jadwiga Puzynina (Warszawa: Wydawnictwo UW, 1993); Elżbieta Teleżyńska, Nazwy barw w twórczości Cypriana Norwida (Warszawa: Wydawnictwo UW, 1994); Słownictwo estetyczne Cypriana Norwida, ed. Jolanta Chojak (Warszawa: Wydawnictwo UW, 1994); Tomasz Korpysz, Jadwiga Puzynina, Wolność i niewola w pismach Cypriana Norwida (Warszawa: Wydawnictwo UW, 1998); Anna Kadyjewska, Tomasz Korpysz, Jadwiga Puzynina, Chrześcijaństwo w pismach Cypriana Norwida (Warszawa: Wydawnictwo UW, 2000).

39 http://www.slownikjezykanorwida.uw.edu.pl/ (accessed 20.07.2018).

40 Zofia Trojanowiczowa, Zofia Dambek, with the cooperation of Jolanta Czarnomorska, Kalendarż̇ycia itwórczości Cypriana Norwida, Vol.I: 1821-1860 (Poznań: Wydawnictwo Poznańskie, 2007); Zofia Trojanowiczowa, Elżbieta Lijewska, with the cooperation of Małgorzata Pluta, Kalendarz życia i twórczości Cypriana Norwida, Vol. II: 1861-1883 (Poznań: Wydawnictwo Poznańskie, 2007); Zofia Trojanowiczowa, Zofia Dambek, Iwona Grzeszczak, Kalendarz życia i twórczości Cypriana Norwida, Vol. III: Aneks. Bibliografia. Indeksy (Poznań: Wydawnictwo Poznańskie, 2007).

41 Studia Norwidiana is the only scholarly magazine devoted to the literature of a single writer. As of 2018, 36 volumes of Studia Norwidiana have been published, and they are also available in the online version: http://czasopisma.tnkul.pl/index.php/sn/issue/ archive (accessed 20.07.2018), volumes 34-38 are also being successively published in the English language and are available under the same link.

42 As of now 16 editions have been carried out, out of which two were held abroad. 
series Studia i monografie [Studies and Monographs], ${ }_{43}^{43}$ and most importantly, organizes and coordinates the critical edition of Dzieła wszystkie [The Complete Works] which has already been mentioned, as well as the scholarly catalogue of Norwid's works of fine art. ${ }^{44}$

43 As of 2018, 29 monographs within the series have been published, either by one author or collective ones, devoted to different aspects of Norwid's literature (the full list of titles is presented on the Centre's website: http://www.kul.pl/studia-i-monografie,art_21674. html - accessed 20.07.2018).

44 From the seven planned volumes, as of now three have been published: Edyta Chlebowska, Cyprian Norwid. Katalog prac plastycznych, Vol. 1, Prace $w$ albumach 1 (Lublin: TN KUL, 2014); Vol. 2, Prace w albumach 2 (Lublin: TN KUL, 2017); Vol. 3 , Prace w albumach 3. Prace luźne 1 (Lublin: TN KUL, 2019). 


\section{Edyta Chlebowska}

\section{Editor's Notes}

The articles collected in this publication comprise the four-volume monograph devoted to Cyprian Norwid's oeuvre. They present a panorama of scholarly Norwidological thought in Poland, starting with the turn of the 19th century all the way up until today. The approaching 200th anniversary of the poet's birth in 2021 constitutes an exceptional occasion and favourable circumstance for taking on such an initiative. The edition contains a comprehensive selection of original Polish articles, previously published in renowned literary research magazines and monographs; articles of unquestionable scholarly value, representing the most important currents and aspects of studies forming a synthesis of Norwidological achievements.

In publishing a monograph devoted to the works of Cyprian Norwid in the English language, we hope that this field of research, which is such an important element of Polish humanities studies, will be able to join international scholarly circulation. Studies on the oeuvre of Vade-mecum's creator have attracted successive generations of researchers for more than a century, among whom we may find literary historians, linguists, cultural historians and fine art historians, as well as historians of ideas, theologians and researchers on translation. The revival of research activity has also long been accompanied by an unusually strong and lively current of Norwidian literature's reception in contemporary Polish culture and literature. This status quo stems above all from the specificity of the poet's works, which remain extremely relevant even today, and have not become - as is the case with the works of many 19th-century writers, even the most outstanding ones - solely the domain of historical research. In his writings, Norwid touches upon fundamental and timeless issues, concentrates on the moral and spiritual condition of man, reflects on man's position in the world and in history, and attempts to answer the current, and at the same time universal, questions. The monograph presented here is the result of a profound conviction that the work and thought of one of the greatest authors of Polish culture, his literary, journalistic texts as well as his works of fine art, should resonate more loudly on the European and global humanities' map. Relatively extensive fragments of Norwid's literary legacy have finally been translated into the English language (this refers, among others, to the anthologies published in recent years: Cyprian Norwid, Selected Poems, translated by Adam Czerniawski [London: Anvil 
Press, 2011] and Cyprian Norwid, Poems, translated by Danuta Borchardt in collaboration with Agata Brajerska-Mazur [New York: Archipelago Books, 2011]), therefore it is time to let a foreign audience get acquainted with the panorama of scholarly Norwidological thought.

Scholarly reflection on the life and works of Norwid, one of the greatest figures of Polish culture, started - as has been mentioned before - with the activities of Zenon Przesmycki, the first editor of the disseminated and for the most part previously unpublished writings of the poet, who was also a careful reader and versatile researcher. Przesmycki's name opens the list of the dozens of other authors represented in this selection, from among which we should distinguish recognized authorities such as: Wacław Borowy, Konrad Górski, Michał Głowiński, Zofia Stefanowska, Stefan Sawicki, Irena Sławińska, Jadwiga Puzynina, Zdzisław Łapiński, Zofia Trojanowiczowa, Władysław Stróżewski and Teresa Skubalanka.

The basic key for the selection of articles in this publication is their scholarly value and representative nature from the point of view of the discipline's development. Therefore, both the classical studies which laid the foundations for Norwidology and have maintained their topicality until the present day, as well as more recent articles, sometimes even those written over the span of the last decade, setting new directions for scholarly investigations, penetrating unknown or insufficiently explored territories, have been included.

An effort was taken to make the publication cover the widest possible range of themes which will help researchers and the general public abroad become acquainted with and better understand Norwid's oeuvre, paying close attention to the problems which are dear to European sensitivities and tradition. Taking into account the specificity of the discipline and the general context and convention, the collected material has been divided into four parts contained in their respective volumes. They cover the following spheres of problems, with each volume titled accordingly: Syntezy [Syntheses], Aspekty [Aspects], Interpretacje [Interpretations] and Konteksty [Contexts]. Conscious of the immense diversity of articles, covering even within a single volume - an extremely broad range of issues, methodologies and research approaches, a decision was made to abstain from any further thematic divisions, since it could unnecessarily obfuscate the discipline's picture, and to opt for a chronological arrangement of each section which would follow the stages of development of the scholarly reflection on the works of the author of Vade-mecum.

\section{Vol. 1. Syntheses}

The history of critical scholarly editing has played an extremely important role in shaping Norwidology studies - therefore, texts written by the three 
great publishers of Norwid's posthumous writings: Zenon Przesmycki, Juliusz Wiktor Gomulicki and Stefan Sawicki, could not possibly have been omitted from the planned publication. Besides those, the first volume also contains a selection of texts constituting some successful attempts to present a comprehensive analysis of Norwid's writings, exploring different research areas including poetics, thematical criticism and literary genetics.

\section{Vol. 2. Aspects}

This volume contains a selection of articles referring to a broad range of issues, covering both isolated areas of Norwid's output and aspect-based analyses of the poet's creative profile. The published studies concern the artistic theory and practice of Promethidion's author, exploring the world of his thoughts and views. In addition to the articles written by literary historians, the volume also contains studies by linguists, fine art historians, theologians and translators. Texts concerning the intricacies of Norwid's biography have also been included here.

\section{Vol. 3. Interpretations}

This volume gathers articles of an analytical and interpretational nature devoted to a selection of Norwid's works. In selecting the texts, an effort was made to represent all the literary genres, and broader areas of the poet's creative activity (including his works of fine art). Careful consideration has been given to classic interpretations of Norwid's most important texts, including: "Fortepian Szopena," Czarne kwiaty, Promethidion, Quidam, "Bema pamięci żałobny-rapsod;" writings providing the most comprehensive insight into the poet's literary genius.

Vol. 4. Contexts

This volume, in turn, covers articles devoted to the analysis of selected sources and inspirations lying at the foundations of Norwid's creative work, as well as comparative texts, tracing signs of the unity of thoughts and views linking Norwid to the leading authors of the epoch, both domestically and abroad. An effort was therefore undertaken to outline the profile of this poet and artist whose creative work remained deeply rooted in West European tradition and contemporaneity, but at the same time was characterized by a tremendous openness and receptiveness to cultural differences and diversity.

The articles collected in this publication were written over a span of more than a century. Many of them were published at a time when neither the complete edition of the poet's Pisma wszystkie edited by Gomulicki nor the 7 out of 18 volumes critically edited by Sawicki had been published yet. Up until the 1970s, researchers were using many different editions. If this historical status quo were to be upheld, 
we would be dealing with a sort of chaos with regard to the textual criticism. Given this situation, the decision was made, for the sake of the contemporary reader's (and especially the foreign reader's) convenience, to allow for a bibliographical anachronism, in compliance with the binding rules of scholarly critical editing adopted by Norwidology. And so, all the quotations have been adjusted wherever it was possible - to be based on the critical edition of Dzieła wszystkie prepared by the team led by Stefan Sawicki: Cyprian Norwid, Dzieła wszystkie, Vol. III: Poematy 1, ed. Stefan Sawicki, Adam Cedro (Lublin: TN KUL, 2009); Vol. IV: Poematy 2, eds. Stefan Sawicki, Piotr Chlebowski (Lublin: TN KUL, 2011); Vol. V: Dramaty 1, ed. Julian Maślanka (Lublin: TN KUL, 2015); Vol. VI: Dramaty 2, ed. Julian Maślanka (Lublin: TN KUL, 2014); Vol. VII: Proza 1, ed. Rościsław Skręt (Lublin: TN KUL, 2007); Vol. X: Listy 1: 1839-1854, ed. Jadwiga Rudnicka (Lublin: TN KUL, 2008); Vol. XI: Listy 2: 1855-1861, ed. Jadwiga Rudnicka (Lublin: TN KUL, 2016) (hereinafter referred to as DW, a Roman numeral indicating the volume, and an Arabic one - the page). In other cases Norwid's texts have been cited according to: Cyprian Norwid, Pisma wszystkie, zebrał, tekst ustalił, wstępem i uwagami krytycznymi opatrzył J.W. Gomulicki [Juliusz Wiktor Gomulicki collected, determined the texts and provided the introduction and critical comments], Vols. I-XI (Warszawa: PIW, 1971-1976) (hereinafter referred to as PWsz, a Roman numeral indicating the volume, an Arabic one the page). This decision, motivated by the present editorial status of Norwid's literature, involves discrepancies in the graphic conventions used; particularly in the case of Norwidian emphases, which in PWsz were rendered in the form of so-called spaced out print while in DW - with the use of italics.

We have to remember the changes in the scholarly findings concerning facts, for example those connected with the poet's biography or genesis of his literary works as well as Norwidian documents (letters, poems, notes etc.), both those which have surfaced since Zenon Przesmycki's times, and those whose handwritten originals were lost (for example during World War II). ${ }^{1}$ It compelled the editors of this monograph to introduce the appropriate commentaries and footnotes. Moreover, the bibliographic records and notes have been unified

1 In 1940 the German occupational authorities gathered manuscripts and other special collections from different Warsaw libraries in the building of the Library of the Krasiński Estate, where they endured the Warsaw Uprising in 1944 with no losses. However, in October of that year, after the capitulation of the Home Army and evacuation of the city's civilian population, the collections were destroyed by the Germans within the planned burnings which were one of the elements of the plan to annihilate Poland's capital (85\% of the city fell to ruin). 
in order to produce a synthetic entirety with a coherent and logical message. And, concerning those of Norwid's texts cited in the articles, beside the original (Polish) version, the philological English translations have also been given, their boundaries clearly marked by square brackets. Sometimes the existing translations of Norwid's poems into the English language were quoted, and in such cases the source of the translation has been indicated in a footnote. Additionally, each volume has been provided with indexes of the names and titles of Norwid's texts. It was also considered appropriate to list the sources of the printed texts. 



\title{
Zenon Przesmycki \\ From Notes and Documents on Cyprian Norwid
}

\begin{abstract}
This collection of notes and documents was attached to the first posthumous edition of selected works by Cyprian Norwid, which were published by Zenon Przesmycki in 1904 in a special volume of literary and artistic magazine Chimera titled "Pamięci C. Norwida" ["In Memory of C. Norwid"], a forerunner of a planned edition of the poet's collected writings. The editor gives an account of the contemporary state knowledge, which was the fruit of several years of extensive quests for the poet's legacy scattered among a variety of sources. The text contains a list of known portraits and self-portraits of Norwid, a bibliography of his writings published in the form of compact prints during his lifetime, a brief description of Norwid's artistic work, and the first comprehensive outline of the poet's biography.
\end{abstract}

Keywords: Cyprian Norwid, biography, bibliography, iconography, portrait

This commemorative volume ${ }^{1}$ contains only works by Cyprian Norwid representing his achievements in both literature and visual art. In presenting this volume we wanted above all to allow the voice of this great artist to be heard in all its virtuosity - a voice that had been for so long consigned to the deep silence of neglect. To achieve this goal, we did not hesitate to expand this volume, which was originally conceived as a double issue but now has the length of a quarterly set. When this project exceeded the scope of three issues, we decided to postpone the inclusion of a general introduction, wishing to publish this in a later issue rather than omit any of the selected works. Finally, when choosing the material from among Norwid's miscellaneous writings, giving priority to items that previously remained only in manuscript form, we did not hesitate to reprint some previously published works that are of particular prominence. Having seen the light of day, they passed by like bright meteors, astonishing and confusing readers rather than taking root in their memory. In this category we find, first of all, the bizarre Promethidion - a prophetic gospel of art written over fifty years ago (Paris, 1851), which nevertheless remains fresh, proving its immortality not just to us but certainly to future generations. Those of its passages made available to us we decided to place at the very beginning of the present volume. The second

1 Chimera, 1904, vol. VIII, no. 22-24 (Pamięci C. Norwida). 
long poem, entitled Pompeja [Pompeii], also previously published (see: Pokłosie, zbieranka literacka na korzyść sierot, second year, Leszno: E. Günther, 1853), had probably been forgotten not only by the reading public but also by the poet himself since he did not include this fabulous visionary work in either the 1863 volume of his collected poems (Leipzig: Brockhaus, 1863), or the later, second cycle entitled Vade-mecum (1865). We wish to thank Adolf Sternschuss of Kraków for bringing our attention to this and for copying the poem.

With the exception of the above two reprints, all the works contained in this volume are published for the first time from manuscripts obtained - thanks to a great deal of time and effort - from owners dispersed all around the world. These are by no means fonds de tiroirs, or leftovers whose importance would lie only in the fact of not having been published before, but rather a small selection (the other manuscripts could fill several more extensive volumes!) from a wide range of inspired, first-class works that Norwid created in the second half of his life and was (shamefully!) unable to publish. In fact, he never really had publishers in Poland at all. Perhaps with the exception of several editions brought out by M. Wolff in St. Petersburg, and by Brockhaus in Leipzig, all his other works were self-published or published with the help of close friends. However, later on, when he was roaming the streets of Paris, neither could he afford to self-publish, nor could he rely on his friends, who were also becoming poorer and poorer. More and more manuscripts would lie neglected around his house. After his death, many of them were dispersed, some lost forever without trace. Even the magnificent and Orphistic Rzecz o wolności słowa [On the Freedom of Speech] which A. Giller praised elatedly, declaring that "like others, we have also failed to properly acknowledge the talent of Mr. Norwid" - could not find a willing publisher, despite its enthusiastic reception in the magazines Czas and Dziennik Poznański. Had it not been for savings that were meticulously made by a group of foresighted, appreciative friends (S. Goszczyński, L. Nabielak, Z. Węgierska and B. Zaleski), the work would probably never have seen the light of day. This good fortune was not shared, after all, by many other poems, including the bizarre, profound masterpiece Milczenie [Silence]. In 1882, one year before his death, Norwid wrote to T. Lenartowicz with understandable bitterness: "Pracuję troszkę nad poematem w pięciu pieśniach [...] - ale polscy edytorowie są do niczego!" (PWsz X, 178) ["I am working a little on this longer poem in five cantos [...], but the Polish publishers are useless!"] As a result of Norwid's deeply painful relationship with publishers, he was condemned, as it were, to silence during his lifetime. To remind the wider public about him today is, as far as most of his works are concerned, to reveal them for the first time. Such revelations certainly include: Kleopatra [Cleopatra], despite its unfinished state and familiarity 
with Krakus and Wanda; the deeply symbolic short story Stygmat [Stigma], which may surprise even those who have read his three other stories published in Chimera; the entire astonishing cycle of lyrical and satirical poems, from the pipe organ-like introductory psalm to the concluding light epigrams, which may surprise those who still believe that Norwid is a difficult, obscure and harsh poet; a true gem for translators and admirers of classicism in the form of numerous aspects of draft translations from the Odyssey, which are so thoroughly Homeric in spirit, so intuitive in their style by comparison with Siemieński's grotesquely unbalanced rendering; the revelation of a new, unanticipated aspect of Norwid in "Filozofia wojny" ["The Philosophy of War"], matching the intellectual heights of a Hoene-Wroński; and finally, a revelation of the poet's soul - showing his mind and spirit at the turning point nel mezzo del cammin della vita - in the private and candid correspondence with Maria Trębicka.

Originals of these works come from many sources. Manuscripts of Kleopatra $i$ Cezar, Stygmat and all works from the Vade-mecum cycle (undated) form part of the magnificent (though incomplete) archive left by Norwid which has been donated to us by W. Gasztowt. Some shorter works to which dates can be assigned ("Lapidaria," "Powiedz im" ["Tell them"] and a translation from Buonarroti) were found among Norwid's letters and drawings, kindly given to us by E. Geniusz of Port Said. Two others - "Mój psalm" ["My Psalm"] and "Fraszka" ["A Bagatelle"] were chosen from among mementoes kept by Seweryna Duchińska, the existence of which was brought to our attention by D. Sliwicki. The manuscript of translations from the Odyssey we owe to the late Adam Pług, who sent it to us via W. Nawrocki. The French war treatise - the manuscript of which contains the dedication, made in pencil, "To Józef Reitzenhaim I offer this excerpt from an opus from the time of the last war" - was licensed to us, through the friendly mediation of Artur Górski of the archive of J. Reitzenheim, presently in the possession of Duchess Maria Adamowa Lubomirska of Miżyniec. Letters to Maria Trębicka, which she herself donated to the Jagiellonian Library, were copied and prepared for publication by S. Kossowski. Later, after proofreading, they were kindly collated by Adolf Sternschuss.

It was far more challenging to comprehensively present Norwid's achievements in visual arts. Finished works have been dispersed - through donation or sale in larger and smaller private collections, some of which may be difficult to access. Some works are simply difficult to trace, having changed owners several times. Neither was it possible, therefore, to present the entirety of the artist's output, nor even to select the best and most characteristic works to be reproduced in this volume. We had to be content with studies and sketches. They are certainly outstanding and inspire curiosity, but it remains doubtful whether they adequately 
reflect Norwid's unique talent. We have selected them in such a way as to display the broad extent of his inspiration and the range of techniques applied. The only types of work we have chosen not to include here are etchings and sculptures. This is because Chimera has already featured a fabulous collotype reproduction of the etching "Le Musicien inutile" (Fig. 1) in one of its previous issues, while the only work of sculpture we were able to locate - a bronze plaque of Z. Krasiński was presented earlier by W. Strzembosz in Tygodnik Ilustrowany (No. 34, 1904), which made it unnecessary to show it again.

The work that begins this volume - "Chrystus i Barabasz" ["Christ and Barabbas"] (Fig. 2) - is a reproduction of a pen-and-ink drawing from the Kraków collection of Adolf Sternschuss. It is probably the first finished preparatory drawing for a larger work under the same title, which J.I. Kraszewski saw in 1858 in Norwid's Paris studio, pronouncing it to be "a forceful attempt to achieve unique expression and originality" (Kartki z podróży. 1858-1864, vol. 2, Warszawa, 1874, p. 316). Upon closer inspection the expression is indeed unusual, but in a positive way, emanating an almost Leonardian sense of mystery. In fact, the depth of expression and the ability to reveal the entire soul in the figure's facial expression and movement are the striking characteristics of Norwid's style. This is also exemplified in two sketches from the so-called Norwid file at the Rapperswil Museum. The first, an oil with the kind of boldness, energy and breadth that renders it similar to contemporary painting, presents a woman immobilized by some sudden surge of feeling. The second, a watercolour of exquisite colouring, reveals depths of the simple yet mysterious soul of a child that are matched today only by a Dębicki or Wyspiański. One more work of this kind, depicting a small child, done in pencil, was selected from the archive donated to us by Gasztowtt. Two more coloured pen-and-ink works were chosen from this collection: a deeply sad (though not ostentatiously so) male figure with his eyes fixed (spiritually) on the faraway, tormented homeland, and an unknown sketch of Z. Krasiński's head, which appears to be a preparatory drawing for a sculpture, but seems more interesting, in many respects, than the above-mentioned bronze plaque. A completely separate category is formed within Norwid's oeuvre by excellent caricatures as well as satirical and humorous drawings. They do not stoop to sheer buffoonery but rather bring out a certain characteristic of a figure or scene, exaggerating some of their fundamental features. In this category we present two perfect hand-made sketches in pencil ("Zebranie emigracyjne" ["Emigre meeting"] (Fig. 3) and "Sąsiedzi w Zakładzie Św. Kazimierza w Paryżu” ["Neighbours at the CEuvre de Saint-Casimir in Paris"]) (Fig. 4) chosen from among over twenty works belonging to E. Geniusz of Port Said, as well as a pen-and-ink sketch "Chemin du progrès," (Fig. 5) kindly given 
to us by W. Gomulicki. Finally, the tailpiece ("Złoty kubek" ["A Golden Mug"]) (Fig. 6) was reconstructed from the cover designed by Norwid, for Lirenka by T. Lenartowicz, published by J.K. Żupański (Poznań, 1855).

\section{Norwid's Iconography}

We wanted very much to complete this double commemorative issue celebrating Norwid's literary and artistic achievements with several portraits of him made at various times. At first, this seemed impossible. In his own autobiography from 1872 (cf. Wiadomości numizmatyczno-archeologiczne, Kraków, 1897, No. 4, p. 355), he himself insisted that "there are no photographs, portraits, plaster statues in Poland showing the external appearance of this person - allegedly, there are several caricatures." On the other hand, E. Geniusz of Port Said - who knew Norwid personally during the last fifteen or twenty years of his life and sent us a beautiful written portrait of the artist ${ }^{2}$ - argues with full conviction that there is in fact no existing likeness of the poet, other than one sketch made by P. Szyndler while Norwid was sleeping, because he would decline any offers from painters, saying "I'd rather not have a portrait..." As it turns out, however, Norwid must have meant that there is no widely available image of this kind in Poland, either in magazines or in galleries. He would not include self-portraits or photographs meant for private use. Moreover, it seems that he did agree to sit for certain painters. While searching further we discovered traces of a whole range of images. The list of these - ordered more or less chronologically - can serve as the first modest step towards a future, more comprehensive iconography of the poet.

1. The oldest works would consist of "several caricatures" mentioned in his autobiography, which we have been unable to locate. According to Norwid, they were created in Poland, so it should be assumed that they date from the years 1839-1844, i.e. after his debut and before he left the country.

2 "I know three different faces of Norwid. In conversation he is the most exquisite citizen of the world, even if he was somewhat scruffy towards the end of his life. A brilliant conversationalist, he was brimming with good humour. When lost in thought, he had the impressive appearance of an intellectual, his head veiled in deep thought and beauty. I once ran into him on the street and could hardly recognize him. He was walking quickly, as if he was rushing to join Derwid's choir, only without his harp. His beard was blowing in the wind, his eyes fixated on infinity or on himself - he did not notice anybody. I don't know where he was going or why. I never saw him like that either before or afterwards" (letter dated 24 August 1904). 
2. A pencil self-portrait, undoubtedly from the same period, is found in an album belonging to Łucja Rautenstrauch née Giedrojć. It shows a man in his early twenties. We saw a copy, drawn in pencil by Wacław Wejtke, in the archive of W. Gomulicki. The drawing itself shows only the bust and measures $7 \mathrm{~cm} \mathrm{x} 6 \mathrm{~cm}$.

3. A letter to M. Trębicka, dated 21 February 1854 (DW X, 485), mentions an unsent daguerreotype showing the poet. It is unknown whether the addressee received it later.

4. We suspect that a later copy ${ }^{3}$ could be the first photograph of Norwid we have obtained, taken in the Hamaret studio, in rue Louis le Grand 30 (Paris), and kindly donated to us by Anna Norwid, widow of the poet's brother Ludwik. Our supposition is based on the type of photograph and the age of the man in the picture (he cannot be older than 32 or 33, which would confirm the date suggested by the reference in the letter). This formal portrait shows the poet's full figure, sitting on a chair at a table, sideways, with his head turned threequarters towards the viewer, in a very natural pose, wearing casual white clothes, his right hand on the table, his left on the leg, his legs crossed. His facial expression is extremely subtle, full of gravity, goodness and featuring a slight hint of irony. We do not reproduce this portrait here because the photograph has faded and the final effect would not be very noteworthy. In any case, the etching by F. Siedlecki contained here (Fig. 7) is largely based on this image and perfectly captures the characteristics of Norwid's head.

5. In a letter to M. Trębicka dated 18 July 1856 (sent from Paris), we find the following remark: “Ktoś z artystów, zgorszony fotografem, robić zaczyna tu mój portret, to przeszlę go - ale nie lubię już tych wszystkich cieniów" ["some artist who was present, appalled by the photographer, began to take my portrait, so I could send it later, but I do not like all these shadows"] (DW XI, 80). We have been unable to verify whether this portrait was finished or who was making it.

6. Norwid's file in Rapperswil contains, as we have discovered, a photograph of the poet, aged 37-40, which leads us to conclude that - despite certain coincidences - it is not the one referred to in the letters listed here in note 2 . It was no doubt taken during the period 1858-1860.

7. In 1857 J.I. Kraszewski noted in his Catalogue d'une collection iconographique polonaise (Dresden, 1865) a second self-portrait of the poet: "Dessin sur

3 We cannot be certain whether it is this copy or some other photograph that is mentioned in letters to M. Trębicka dated 8 April 1856 (DW XI, 54), 18 July 1856 (DW XI, $79,80)$ and in an undated letter $(1856, \mathrm{DW}$ XI, 107). The last mention would suggest that the reference was to a different, unknown image. 
papier bleu, rehaussé de blanc. (C. Norwid ipse ipsum 1857). $8^{\circ}$. Il représent l'artiste sur une carte de l'Europe, appuyé sur une porte-crayon, et des chiens qui aboyent après lui." (Fig. 8)

The archive of W. Gomulicki, kindly donated to us, contains the following images reproduced in this volume:

8. A pen-and-ink sketch of 1877 (Fig. 9).

9. "Norwid śpiący" ["Norwid asleep"] - a sketch in oil by P. Szyndler of 1879 (Fig. 10).

10. A pen-and-ink self-portrait created, it seems, towards the end of Norwid's life, i.e. during the period 1880-1883 (Fig. 11).

11. Around 1880 P. Szyndler must have finally overcome Norwid's dislike for "shadows" on portraits, creating a large, very interesting image of him in oil, which was displayed along with "Norwid śpiący" in the last years of the 19th century in the Salon Artystyczny in Nowy Swiat. However, since Norwid was relatively unknown at that time, the author of the portrait could not find a buyer for the picture, which remains to this day in the artist's studio.

The only posthumous portraits worthy of mention are:

12. A subtle, very distinctive watercolour by F. Siedlecki, reproduced here (Fig. 7).

13. A woodcut - made, it seems, after the above watercolour - by J. Łoskoczyński, published in Tygodnik Ilustrowany (1904, No. 20, p. 388).

Finally, there are two images based on this photograph, which we received from Anna Norwid:

14 and 15. Two miniature drawings featured in both the "Wielka [Great] Encyklopedia" and "Orgelbrand's Encyclopedia," mere stencils.

\section{A Bibliography of Norwid's works}

At this stage it is impossible to prepare a complete bibliography of works by Cyprian Norwid. This is mainly because many of them remain in manuscript form. Many of them have been traced in incomplete form only and many others remain dispersed around the world, unrecorded. Some - including manuscripts of well-known works, admired and noted by experts ${ }^{4}-$ may

4 Let us just mention a "kind of journal" kept on board a ship taken by the poet to America, containing "interwoven writings and sketches," which makes it interesting 
even have been lost forever. In one letter that is in our possession Norwid complains that during his many long wanderings, often in unfavourable conditions, many of his works were irretrievably lost. Anna Norwid brought it to our attention that there is an entire trunk of papers which - by an unfortunate coincidence - ended up in Brussels, in the hands of an indifferent foreigner. Who knows, perhaps these papers were turned into shopping bags. And how many manuscripts, distributed by the author to people who would never fully appreciate them, may come to light in the future? Considering the example of Filozofia wojny, an amazing yet hitherto completely unknown work, it seems likely that many surprises are in store for us. Let us hope that this book will promote interest in the great writer Norwid and lead to many more such discoveries!

Not only manuscript works but even those published in magazines remain impossible to catalogue. The lack of tables of contents and incomplete holdings of annual volumes of magazines in libraries make any such attempts very difficult. We have undertaken this task thanks to the kind cooperation of A. Sternschuss and L. Wellisch. After sifting through many compendium volumes and periodicals (Biblioteka Warszawska, Przegląd Warszawski, Przeglad naukowy, Piśmiennictwo krajowe, Pokłosie leszn.-poznańskie, Przegląd Poznański, the monthly supplement to Czas krakowski, Pismo zbiorowe bendlikońskie, Orędownik naukowy, J.I. Kraszewski's Atheneum and many others which we have pored over fruitlessly), we are now in possession of several dozen works by Norwid that have not yet been published in book form. Many more are likely to be discovered eventually. Norwid himself wrote to M. Trębicka in 1857 (DW XI, 226) that he had been disseminating his works in all Polish journals! Until this project is completed we do not find it necessary to publicly announce the results. In any case, the present volume could not include them.

Meanwhile, therefore, we offer a first bibliography of individual works by Norwid, in book form and offprints, compiled in accordance with the latest conventions. It comprises fifteen titles:

from the perspective of both literature and visual arts. "This book of memories," stated J.I. Kraszewski after seeing the journal in 1858 at Norwid's home in Paris, "is immensely interesting. [...] Perhaps in his entire legacy [...] this collection of drawings created on board ship is of the greatest value" (Kartki $z$ podrózy. 1858-1864, vol. 2, Warszawa: Nakładem Gustawa Sennewalda, 1874, pp. 316-317). 


\section{8}

1. - WIGILIA [CHRISTMAS EVE] | (Legenda dla przyjaciół [Legend for Friends]). | [motto].

Unbound, without cover and title page. - Large $8^{\circ}\left(21 \times 15^{1 / 2} \mathrm{~cm}\right)$. Pages: 1-3, 4 (empty). - Without month and year. - At the bottom of the third page: "in L. Martinet's printing house, at 30 Jacob street" [PARIS]. Ibid., below the last line: "written in Rome, 1848, summer" - and signed: CYPRYAN KAMIL NORWID. - Printed in frames. Over the title a vignette showing three flying angels. - Rhymed lyrical poem in four parts. Karol Estreicher, Bibliografia polska XIX stulecia, part. I, vol. III, Kraków: Akademia Umiejętności, 1876, p. $244^{5}$.

2. - JESZCZE SŁOWO [A WORD MORE] | (czyniącym pokój przypisane [ascribed to those promoting peace]). | [double motto].

Unbound, without cover and title page. Large $8^{\circ}\left(21 \times 15 \frac{1}{2} \mathrm{~cm}\right)$. Pages: 1-3, 4 (empty). - Without month and year - At the bottom of the third page: "in L. Martinet's printing house, at 30 Jacob street" [PARIS]. Ibid., below the last line: "written in Rome, 1848, summer" - and signed: CYPRYAN KAMIL NORWID. - Printed in frames. Over the title a vignette showing a praying child. - Rhymed lyrical poem in three parts. Estr. III, 244 and VI, 517.

\section{9}

3. - PIEŚNI SPOŁECZNEJ [SOCIAL SONG] | cztery stron [in four pages]. | Napisat [Written by] | CYPRYAN KAMIL NORWID. | 1848. | [line] | Poznań, | Druk i nakład [Printed by] W. Stefańskiego w Bazarze. | 1849.

(Shortened title on the cover: P. | Sp. | czt. str. | Poznań | 1849.) Large $8^{\circ}(25 \mathrm{x}$ $151 / 2 \mathrm{~cm}$ ). Pages: 6 (faux-titre, title page and motto), 1-17 and 18 (empty). A lyrical and didactic long poem, rhymed, in four parts (I. Równość, wolność, braterstwo [Equality, Liberty, Fraternity]; II. Niewola [Enslavement]; III. Własność [Property]; IV. Rzecz pospolita [Res publica]). - Estr. III, 244.

1851

4. - ZWOLON [ZWOLON]. | (Monologia [Monologue]) | przez [by]| C.K. NORWIDA. | [line] | Poznań. | Drukowano i w komisie u [Printed and sold at] W. Stefańskiego. | 1851.

5 Hereinafter referred to as Estr., the Roman numeral rewers to the volume, the Arabic numeral to the page. (editors' note) 
$8^{\circ}(23 \times 14 \mathrm{~cm})$. Pages: 8 (faux-titre, title page, dedication to "Brother Ksawery," double motto), 1-52 (1 -Do czytelnika [To the Reader] [in prose]; 3 - the same double motto again; 5-51 - the text of the work; 52 -Objaśnienia [Notes]). - Dramatic poem, rhymed, comprising a lyrical "Wstęp" ["Introduction"] and eleven scenes (Ogród na wałach [Garden on the embankment], Rynek na przedmieściu [Market in the suburbs], Inna część placu przed kościołem [Another part of the square in front of the church], Dolne zamku pokoje [Lower chambers of the castle], Rynek na przedmieściu [Market in the suburbs], $W$ glębi zamku dziedziniec [Courtyard deep in the castle], Noc w podziemiach [Night in the vault], Górne zamku pokoje [Upper chambers of the castle], Na wieży zamkowej [At the castle tower], Wnętrze domu miejskiego [Inside a city house], Na placu głównym [On the main square]). Estr. III, 244.

5. - PROMETHIDION | [line] | Rzecz [Treatise] | w dwóch dialogach z epilogiem [in two dialogues with an epilogue]. | Przez [by] | AUTORA PIEŚNI SPOEECZNEJ CZTERECH STRON [THE AUHTOR OF SOCIAL SONG IN FOUR PAGES]. | [motto] | [line] | Nakładem autora [Published by the author]. - Cena franków 3 [Price: 3 francs]. | [line] | Paris. | W drukarni L. Martinet [In L. Martinet printing house], | przy ulicy Mignon, 2 [at 2 Mignon street] | 1851.

$8^{\circ}$ (23 x $\left.14 \mathrm{~cm}\right)$. Pages: $1-56$ (1 - title page; 3 - dedication [rhymed verse]; 5-6 -Wstęp [Introduction] [rhymed verse]; 7-8 -Do czytelnika [To the Reader] [in prose]; in three parts; 9-27 -BOGUMIE. Dialog, w którym jest rzecz o sztuce i stanowisku sztuki. Jako forma. [BOGUMIt. Dialogue on art and the position of art. As form.] [rhymed verse]; 29-43 -WIESŁAW. Dialog, w którym jest rzecz o prawdzie, jej promieniach i duchu. Jako treść. [WIESŁAW. Dialogue on truth, its radiance and spirit. As content.] [rhymed verse]; 45-56 -EPILOG [EPILOGUE] [in prose] in twenty parts). - Note on the last page: Written on the Christmas Eve of 1851. CYPRYAN KAMIL NORWID. - Estr. III, 244.

\section{8}

6. - O SZTUCE [ON ART] | (dla polaków) [for Poles] | napisat [written by] | CYPRIAN-KAMIL NORWID | [motto] | [between two lines:] | Nakładem autora [Published by the author]. | Paris | w drukarni L. Martinet [In L. Martinet printing house], | przy ulicy Mignon, 2 [at 2 Mignon Street] | 1858.

(Shortened title on the cover: O SZTUCE | CYPRIAN NORWID.) - $12^{\circ}(18$ $1 / 2 \times 11 \mathrm{~cm}$ ). Pages: 1 -24 (1 - title page; 2 - contents; 3 - dedication [in verse]; 
5-24 - text). - A prose discussion in five chapters. - Estr. III, 244. - Second edition in 1863 (see item no. 12).

7. - NA ZGON [ON THE DEATH] | Ś.P. JANA GAJEWSKIEGO [OF THE LATE JAN GAJEWSKI] | polityczno-polskiego emigranta [a political Polish émigré] | inżyniera francuskiego [French engineer] | zabitego explozya machiny parowej $w$ Manchester [killed by an exploded steam engine in Manchester] | July 1858.

Unbound, without cover and title page. $8^{\circ}\left(22 \times 13^{1 / 2} \mathrm{~cm}\right)$. Pages: 4 . Without year. On the last page, in the middle, between lines: Paris. In L. Martinet printing house, at 2 Mignon Street. On the third page: written in Paris, July 1858. CYPRIAN KAMIL NORWID. - Lyrical poem in six stanzas. - Estr. III, 244.

\section{9}

8. - Skarbczyk [Treasure Trove] | poezyi polskiej [of Polish Poetry]. | Tom XI [Volume 11]. | Część II [Part 2]. | POEZYE [POEMS BY] | Konstantego Gaszyńskiego | CYPRYANA NORWIDA | i [and]| Antoniego Czajkowskiego. | [publisher's monogram] | St. Petersburg. | Printed by B. M. Wolff. | 1859.

$24^{\circ}(14 \times 9 \mathrm{~cm})$. Pages: 94-112. Poezye |CYPRJANA NORWIDA. - Zawartość [Contents]: Wieczór w pustkach [An Evening in Wilderness], Wspomnienie wioski [Memory of a Village], Skowronek [Skylark], Pożegnanie [Farewell], Pióro [Quill]. - Estr. IV, 248.

9. - AUTO-DA-FÉ. | Komedya w jednym akcie [A comedy in one act]. | [line] | SZCZĘSNA | powieść [a novel]. | CYPRJANA NORWIDA. | [publisher's monogram] [St. Petersburg. | Printed by Bolesław Maurycy Wolff. | [line] 1859.

$8^{\circ}\left(201 \frac{1}{2} \times 14 \mathrm{~cm}\right)$. Pages: 4 (1 - title; 2 - censorship; 3 - dedication), 1-31 (1-7-AUTO-DA-FÉ, komedya w jednym akcie i jednejscenie [a comedy in one act and scene]; 9-12-Wstęp, czyli przed-pieśń [Introduction, or pre-song] (DO LUTNI [TO THE LUTE]); 13-31 -SZCZĘSNA. Powieść [SZCZĘSNA. Novel]), last page empty. -Auto-da-Fé - rhymed verse; Do lutni and four cantos of Szczęsna (Tło [Background], Szczęsna, Spotkanie [Meeting], Listy [Letters]) in sestets. - Estr. III, 244.

10. - GARSTKA PIASKU [A HANDFUL OF SAND]. | Legenda [Legend]. | Przez [By] | CYPRYANA N. | [motto] | [line] | Paris | In L. Martinet printing house | at 2 Mignon Street. | 1859.

$8^{\circ}\left(21 \frac{1}{2} \times 13 \frac{1}{2} \mathrm{~cm}\right)$. Pages: $1-15$ ( 1 - title; 3 - dedication; $5-15$ - text), 16 (empty). - Estr. VI, 547. - Second edition in 1863 (see item no. 12). 
1861

11. - O [ON]| JULIUSZU SŁOWACKIM [JULIUSZ SŁOWACKI] | w sześciu publicznych posiedzeniach [in six public meetings] | (z dodatkiem rozbioru Balladyny) [with an analysis of Balladyna] | 1860 | CYPRIAN KAMIL NORWID | [motto] | [line] | Paris | In L. Martinet printing house | at 2 Mignon Street. | 1861.

(Shortened title on the cover: O. J. SŁOWACKIM | Cyprian Norwid.) $-12^{\circ}$ (18 1/2 x $11 \mathrm{~cm}$ ). Pages: 4 (1 - title; 3-4 - contents), 1-90 (1-80 - O Juliuszu Słowackim lekcyj sześć [Six lectures on Juliusz Słowacki]; 81-90 -Do M... S... [To M... S...] | O BALLADYNIE [ON BALLADYNA] | (Dodatek) [Addendum]). - Discussion in prose - Estr. III. 244.

\section{3}

12. - POEZYE [POEMS] | CYPRIANA NORWIDA. | [line] | First collected edition. | [publisher's logo] | Lipsk: | F. A. Brockhaus. | [line] | 1863.

(On the cover: Biblioteka Pisarzy Polskich [Polish Writers Library]. | Volume twenty-one. | POEZYE | CYPRIANA NORWIDA | etc. as on the title page). Small $8^{\circ}\left(19 \times 12^{1 / 2} \mathrm{~cm}\right)$. Pages: 2 (empty), I-VI (I - faux-titre: Bibliotek Pisarzy Polskich. | Volume XXI; III - title page; V-VI - Contents) and 1-292. The collection includes: four prose works: (OSztuce [reprinted with minor additions], Garstka Piasku [reprinted], Bransloteka [Bracelet], Cywilizacya [Civilization]; a verse drama, rhymed, in ten scenes, titled Krakus, książe nieznany [Krakus, an Unknown Prince]; longer epic and lyrical poems (Próby [Attempts], Pięć zarysów [Five Sketches] [I. Rzeczywistość [Reality], II. Pisarstwo [Writing], III. Ruiny [Ruins], IV. Burza [Storm], V. Lilie [Lilies]], Rozmowa umartych [Dialogue of the Dead], Dwa męczeństwa [Two Martyrdoms], Epimenides, Człowiek [Human], Quidam, Polka [Polishwoman]); lyrical and occasional poems (Bezimmienni [The Nameless], Malarz z konieczności [A Painter out of Necessity], Wielkość [Greatness], Na zapytanie czemu w konfederatce odpowiedz' [Response to the Question: Why Wear a Four-pointed Confederate Cap?], Do panny Józefy z Korczewa [To Miss Józefa de Korczew], Do Emira Abd el Kadera w Damaszku [To Emir Abd el Kader in Damascus], John Brown, Do władcy Rzymu [To the Ruler of Rome], Żydowie polscy 1861 [Polish Jews 1861]; and a paraphrase of Horace's ode to the miser (II, 18). - Estr. III, 244.

\section{4}

13. - NIEWOLA [ENSLAVEMENT] | i [and] | FULMINANT | 1849-1863 | Dwa rapsody [Two Rhapsodies] | przez [by] | CYPRJANA NORWIDA. | [publisher's logo] | Lipsk: | F. A. Brockhaus. | [line] | 1864. 
Small $8^{\circ}\left(19 \times 12 \frac{1}{2} \mathrm{~cm}\right)$. Pages: I-VI (I - title; III-V -Do czytelnika [To the Reader] [written "in Paris, 1848"] and Ostrzeżenie [A Warning] [written in 1863], both in prose) and 1-36 (1 - motto; 3-4 - prologue; 5-18 - three cantos of Niewola; 19-20 - epilogue | PLATO and ARCHITA; 21-23 notes; 25-33 - fourteen passages of FULMINANT; 34-36 -MODLITWA MOJŻESZA [MOSES'S PRAYER] translated from the Hebrew and the Vulgate [Psalm LXXXIX]). - Estr. III, 244.

\section{7}

14. - SURSUM CORDA | [line] | 17 October 1867.

Unbound, without cover. $-32^{\circ}\left(101 \frac{1}{2} \times 7 \mathrm{~cm}\right)$. Pages: 4 ( 1 - title; 2 - motto; 3 - ENCYKLIKA OBLĘŻONEGO [ENCYCLICAL OF THE BESIEGED]. | (Oda.) [Ode]; 4 - empty). Signed on the third page: CYPRYJAN NORWID. Ibid., under the line: Paris, dr. Rouge et comp. du Four-St-Germain, 43. [Ode to Pius IX]. - NOT MENTIONED BY ESTREICHER. - Reprinted in full in Bolesławita's RACHUNKI [ACCOUNTS] in 1867 (year two, part two, Poznań 1868, pp. 80-81). Also mentioned in that same book on p. 271.

\section{9}

\section{5. - CYPRYANA NORWIDA | Rzecz [On the] | O WOLNOŚCI SŁOWA} [FREEDOM OF SPEECH] I wygłoszona przez autora [delivered by the author] | na jednym z odczytów publicznych, urządzonych [during one of the public readings organized by] | przez komitet stowarzyszenia pomocy naukowej w Paryżu [the committee formed by the association of scientific support in Paris] | dnia 13 maja 1869 roku [on 13 May 1869] |[motto] |[line] | Paris | Księgarnia Luksemburska | 16 de Tournon street | [line] | 1869. $16^{\circ}$ (18 x $14 \mathrm{~cm}$ ). Pages: 1-96 (1 -faux-titre; 2 - Druarnia [sic] braci Rouge, Dunon i Fresné [Brothers Rouge, Dunon and Fresné printing house] $\mid 43 \mathrm{du}$ Four-Saint-Germain; 3 - title page; 5-9 - WSTEP [sic] [INTRODUCTION], in seven parts, written in prose; 10-96 - the text in fourteen cantos [in verse]). - Lyrico-philosophical poem. - Estr. III, 244.

\section{Norwid's Artistic Work}

Norwid's body of art works is not likely to be fully catalogued in the near future. So far, the best guide in this sphere has been the list of sculptures, oil paintings, preparatory drawings, watercolours, drawings, sketches and etchings published by the author himself in the 1872 autobiography (Wiadomości numizmatycznoarcheologiczne, Kraków, 1897, No. 4, pp. 356-357). However, this list is extremely 
sporadic and general. Almost everything we have been able to find in our search (which encompassed retrospective exhibitions in Lviv [1894; cf. the catalogue prepared by J. Bołoz-Antoniewicz, pp. $234-235^{6}$ ] and in Warsaw [1898], the National Museum's collection, the Czartoryski collection in Kraków, the Rapperswil Museum collection, the archive donated to us by W. Gasztowt, the collections of the Zachęta Fine Art Society in Warsaw and Towarzystwo Przyjaciól Nauki [the Society of Friends of Learning] in Poznań, the private collections of E. Geniusz, W. Gomulicki and A. Sternschuss, reproductions published in Tygodnik Ilustrowany and Wędrowiec etc.) was mentioned or described in greater detail in Rachunki (issues from the years 1866, 1867 and 1868), Kartki z podróży (second volume), and in the catalogue "d'une collection iconographique polonaise" by J.I. Kraszewski, in Sto lat dziejów malarstwa w Polsce by J. Mycielski, $\mathrm{PhD}$, and finally in articles by Marrené-Morzkowska and Cybulski-Łada. None of these works, let us repeat, are mentioned in the above-mentioned autobiography. Nor does it mention the "beautiful Mass book, decorated with beautiful watercolours," dedicated to W. Łubieński, or a book of drawings (also a gift to Łubieński), both of which were recently shown by Counsellor F. Chłapowski in a paper he delivered to the Towarzystwo Przyjaciół Nauki [Society of Friends of Learning] in Poznań. Moreover, the autobiography omits to mention another album which - according to Count Engeström - used to belong to Count Adam Plater and contained "from 300 to 400 drawings" (cf. "Kurier Poznański",1904, No. 285). One may therefore anticipate that many unexpected items, in many cases true gems, may yet come to light, from the least expected sources, in many years to come.

Norwid's watercolours, we find, are the most difficult to catalogue comprehensively. Judging by those we have had the opportunity to view, it is possible to conclude that works of this type may be the greatest in his entire oeuvre, perhaps even the richest. "[...] maluję głównie akwarelą" ["I mostly paint in watercolours,"] wrote Norwid to T. Lenartowicz in 1882, "bo o wiele wieków od olejnego starsza i większą game obejmuje" ["because this technique is many centuries older than oil painting and covers a broader range"] (PWsz X, 179). On another occasion (in 1883), while discussing one watercolour, "malenieczka rzecz, jak garść fiołków" ["tiny as a bunch of violets,"] in a letter to F.H. Duchiński, Norwid remarked:

6 Katalog wystawy sztuki polskiej od roku 1764-1886. Wydał Dr Jan Bołoz Antoniewicz Profesor Uniwersytetu. Z 75 ilustracjami (Lwów: Dyrekcja Powszechnej Wystawy Krajowej, 1894), pp. 234-235. (editors' note) 
miałem był zarozumiałość powiedzieć kilku artystom GŁośno, że chcę tam doprowadzić akwarelę, gdzie jeszcze nie była, to jest, aby po równi i więcej niż olejne wyrażać mogła wszystko. Czyli nie żeby były 'sujets d’aquarellle', ale ażeby nią swobodnie myśleć można było. Otóż to w tym kierunku jest robione! (PWsz X, 197)

[I had the audacity to declare to several artists that I wished to take the watercolour technique to new heights, that is to say make it as expressive as oil paintings, or even more so. The goal would be to go beyond 'sujets d'aquarelle' and make watercolours capable of addressing any subject. This is my aim!

Norwid must have painted large numbers of watercolours, more than one could imagine, because he supported himself by selling them, especially in the second half of his life. As a result of this, however, they became dispersed, through art dealers, among foreign collectors in Europe and America (cf. letter to M. Trębicka, DW X, 456). Some of them may perhaps never be traced.

It would perhaps be possible to list hundreds of Norwid's pen-and-ink or sepia drawings, often lavishly thickened with gouache or enhanced with watercolours, as well as pen-and-ink, charcoal or pencil sketches. Because these works would often serve as gifts or keepsakes offered to those who were closest to the artist, it seems more likely that their catalogue could be somehow completed. So far, we have managed to record over a hundred of them through investigations focusing primarily on literary works.

Norwid painted least of all in oils. However, although his autobiography mentions only four, it appears that there were several dozens of them.

We know little about Norwid's sculptures, although he studied in Florence under Luigi Pampaloni. He modelled in clay, as is confirmed by his only known sculpture - the plaque of Z. Krasiński. In one of his letters to M. Trębicka he mentions woodcarving: "rzeźbiłem właśnie krucyfiks z bukszpanu w czasie, kiedy list mie doszedł" (DW X, 488) ["I was just carving a crucifix from boxwood when your letter arrived”]. Sometimes he would creatively combine sculpture with painting. "Above the bed," writes J.I. Kraszewski, describing his Paris studio,

there hung a white cross, without a figure of Christ but with very meticulously rendered marks of blood in places where his hands and legs were impaled and where his wounded head would lie. I have never seen a crucifix like that in my whole life. It made a greater impression on me than the most magnificent Christ figure" (Kartki z podróży, Warszawa, 1874, p. 316).

There must have been more sculptures, but no trace of them remains.

In the sphere of graphic arts, Norwid practised primarily copperplate engraving and etching, with only several lithographs created in Paris. He left only a small number of such works, and he would make very few copies from 
the original plates. Apparently, the only surviving works of this kind are: "Le musicien inutile" (Fig. 1) in the Czartoryski Museum in Kraków, and "the dead man rising from the grave" mentioned by J.I. Kraszewski (Catalogue d'une collection iconographique polonaise, Dresden 1865).

Was Norwid a designer? We have not come across any evidence of this, but his views on art - expressed in Promethidion and in the essay "O sztuce (dla Polaków)" ["On art (for Poles)"] - suggest that he was. In a letter of 1876 to J.B. Wagner he wonders why Western art is alive and organic, rather than becoming a mere matter of fashion or something for amateurish cliques. In answer to this question, he formulates a clear-cut conviction: "This stems from the fact that a healthy organ needs to be firmly rooted in two dimensions: craftsmanship and morality" (from papers donated by E. Geniusz). A hint of how Norwid turned theory into practice is contained in a letter to M. Trębicka dated 22 February 1854 , in which he describes his tiny room in New York with an attic window:

wnętrze sam sobie wymalowałem i opasałem bareliefem en-grisaille, przedstawującym różne sceny ze starożytnej i nowożytnej historii - dodałem także medaliony mężów wielkich, ale podług znajomych i przyjaciół - August Cieszkowski jak Sokrates, kto inny jak Plato, kto inny jak Aleksander, kto inny jak Safo. (DW X, 486)

[I painted the interior myself and decorated it all around with a bas-relief en grisaille depicting various scenes from ancient and modern history - adding plaques of great men in the likeness of my friends - August Cieszkowski as Socrates and others as Plato, Alexander or Sappho.].

More examples of this kind could probably be found from his Parisian period.

W. Gomulicki once suggested in a letter to me that perhaps the entirety of Norwid's drawings ought to be reproduced and published. Recently, Count Engeström proposed, after hearing the paper by F. Chłapowski, the preparation of a similar publication dedicated to W. Lubieński, and the publication of a Plater Album, if it could be found. We would make so bold as to modify these two projects and propose the publication of a comprehensive catalogue of Norwid's art works, featuring many reproductions of the best of them, representing all forms of visual arts. This idea, however, would be the most difficult to realize. Nevertheless, if owners of Norwid's works were willing to grant experts access to them, the matter could be settled more easily and quickly than one might initially suppose.

\section{Norwid's Biography}

Materials for a biography of Norwid still remain to be collected. There are three autobiographical sketches produced by the poet at the request of editors 
of compendia. The first was published in 1867 in the eleventh edition of Brockhaus's Conversations-Lexicon (volume 10, p. 898), but it was apparently deleted in subsequent editions. The second sketch, more concise though almost identical in content, can be found in Grand Dictionnaire Universel du XIX siècle by P. Larousse (Paris, 1874, vol. 11, p. 1100). The third, which takes into account Norwid's artistic output, was sent in 1872 to A. Zaleski and W. Bartynowski, who intended to publish a form of biographical dictionary of Polish artists. It awaited publication for twenty-five years and finally saw the light of day in 1897 in Kraków’s Wiadomości numizmatyczno-archeologiczne (No. 4, pp. 354-358).

Since these biographical notes were made hastily and with limited scope in mind, they are incomplete and merely show dates rather than indicating their purpose. Even in respect of the dates they are not without errors, as we have ascertained in a number of cases. That is why they do not even offer a complete outline of Norwid's life and can only serve as a starting point or a loose catalogue of hints that need to be verified, co-ordinated and supplemented with further research. One of the first steps would be to determine the actual date of his birth. All three biographical notes unanimously indicate the year 1824 (Wiadomości numizmatyczno-archeologiczne: "when Noel Byron was dying in Greece"), while Brockhaus provides even more exact details: “im April." It was in fact the year and month of Byron's death. Bearing in mind Norwid's utter and deeply motivated adoration of the English "Archistrategos" - or "the Socrates of poets" - we may surmise that the thought of a certain mystical coincidence of these two events (Byron's death and Norwid's birth) fascinated him to such an extent that he actually came to believe in it absolutely. With the passage of time and the blurring of memory, this false date of birth became fixed and was uncritically accepted by all Polish encyclopaedias and histories of literature or art, which would sometimes even commit errors of their own (e.g. Orgelbrand's Encyclopaedia gives the year 1825). Doubts about this date were first expressed by F. Chłapowski in the paper mentioned above.

In Norwid's archive generously donated to us by W. Gasztowtt and repeatedly mentioned here, we have found a bundle of the poet's private documents, including: (1) a hand-painted parchment entitled "Excerptt (sic) Genealogij Starożytnego Domu Urodzonych Norwidów” [“An Excerpt from the Genealogy of the Historical Norwid Family"], issued in 1811 to the requisitioning authority on the basis of the registers of the genealogical lineage commission for the gentry

7 Cf. the entire first two lectures On Juliusz Stowacki (PWsz VI, especially pp. 415 \& 419-422). 
operating in the Minsk province; (2) a hand-written note confirming the status of Jan Norwid (the poet's father) as a third-degree member of "de l'Aigle Blanc," one of the twenty-three masonic lodges subordinate to the Grand Lodge Astrée à l'O in St. Petersburg; (3) the poet's original certificate of confirmation, conferring on him the name of "Kamil", issued by Cardinal Franzoni in Rome in 1845 ("patrinus fuit Illumus D. Carolus Comes Krasiński”); and finally (4) the poet's birth certificate, which confirms his authentic date of birth as 24 September 1821, along with a French translation of this document, drawn up probably for use abroad, though not officially verified. This birth certificate, made out on the official form and bearing both watermarks and an official stamp, is quoted below in full:

Warsaw Governorate (7.5 kopeck revenue stamp) District of Stanisławów ${ }^{8}$ Extract from the Register of Births of Dąbrówka Parish Church.

No. 86, Sheet 19, Village of Głuchy. On this 1st day of October in the year 1821 at ten o'clock in the morning, there appeared in person before me, Father Jan Kanty Matliński, parish priest of Dąbrówka, civil registrar in the Dąbrówka parish, District of Stanisławów, Province of Mazovia, the Most Honourable Jan Norwid, aged thirty seven, Knight of the Order of Malta, Lord of Laskowo Głuchy, there resident, who presented a male infant born on the twenty fourth day of last month at eight oclock in the evening in Laskowo Głuchy, in his own house, known as number one, and declared that this was the child of himself and his wife, the Most Honourable Ludwika Zdzieborska, aged twenty two, and he expressed their wish to name him Cypryan Xawery Gierard Walenty. The above declaration having been made and the said child having been presented to the Most Honourable Cypryan Szukiewicz, aged forty one, President of the Court of Appeals in Grodno, resident in Warsaw, and Xawery Dybowski, aged fifty, Marshal of the District of Węgrów and Lord of Dębinki and Ceranów Estates, resident in Dębinki, this Certificate was read out to the parties present and signed by me, by the father of the child and by two witnesses, viz Jan Norwid, Cypryan Szukiewicz, Xawery Dybowski, Father Jan Kanty Matliński, Parish priest of Dąbrówka.

Certified to be a true copy of the relevant entry in the Register of the Church in Dąbrówka on 29 April 1846 by

Father Fr. Zanaszewski assistant curate of Dąbrówka Parish Church

[place for the seal]

Such documents, confirming dates and rectifying facts as well as others (including correspondence, confessions and recollections) which fill in blanks in the bare outline of events, putting flesh on the bones and revealing what was behind certain actions and even identifying their spiritual motivation, helping to understand the poet's emotional and intellectual development, are absolutely necessary. An abundance of such data is a prerequisite for any

8 Today, District of Radzymin. 
attempt to approach a biography of Norwid. Nobody has taken this up until recently. Nobody has even collected and utilized the numerous hints, allusions and details about the poet's life dispersed among his works. Tales of Norwid's involvement in Warsaw's bohemian community have been repeated ad nauseam $^{9}$, whereas it is no exaggeration to say that the rest of his life was rather neglected - those mature years which were extremely eventful and creative, full of intense passion and spiritual endeavour; he travelled widely, meeting great minds of the day. All this was often reduced to the terse remark that "he later visited Italy and then settled in Paris, where he died in poverty." Nothing helped to arouse greater interest or inspire broader investigations, though many efforts were made: Z. Sarnecki tried to remind the public about Norwid in the Warsaw Echo; in one of Kraków's reviews, J. Barański published important passages from Norwid's letters to General Skrzynecki regarding the Towiański sect; finally, generally favourable obituaries were published after his death, though they were mostly feeble and vacuous. It was only recently that some activity began in this area. Posthumous tributes began to be published here and there. Letters and poems began to resurface. In this area special mention is due to Adam Pług, Wiktor Gomulicki and Bogusław Kraszewski, though these were still isolated, fragmentary contributions, incapable of significantly contributing to contemporary Norwid studies, given the state of currently available information about his life.

The first major publication capable of initiating new developments in this area is the collection of letters to Maria Trębicka from the years 1845-1857, contained in the present volume ${ }^{10}$. Naturally, we do not claim that they could serve as a basis for drawing a detailed picture of this significant period in Norwid's life. There are still vast lacunae - missing periods in between letters, sometimes extending to several months or even several years. Some facts of great significance we know about from elsewhere are frequently omitted altogether, e.g. his political imprisonment in Berlin and later transportation to the French border, which was the beginning of the artist's wanderings abroad (he never returned to Poland). There is not a word in his letters about this, apart from general allusions to his états d'âme. Similarly, the break between letters no. 16 and 17 (dated June 1847 and April 1848, respectively) - both sent from Italy, as if there had been

9 Despite the denials of Wacław Szymanowski in Norwid's obituary (Tygodnik Ilustrowany, 1883, p. 364), which are corroborated by passages from letters written by an eyewitness - T. Lenartowicz - recently published by Kazimierz Witte (Tygodnik Ilustrowany, 1904, p. 526).

10 Chimera, 1904, vol. VIII, no. 22-24 (Pamięci C. Norwida), pp. 317-416. 
no break in the continuity of his stay there - leaves not the slightest hint of the undoubtedly significant events and meetings during his time in Brussels. Norwid attended a city hall meeting on 29 November 1847, during which he "lectured his compatriots" on the "concept of the middle," which he later expressed in poetic terms in Promethidion (DW IV, 125, footnote). Nor is there any mention of the events of 1848 in Rome, where he met with Mickiewicz, or of the apostolic letter sent to Norwid by Pius IX (mentioned elsewhere). All of these events must have deeply affected the young man, who was just entering maturity and was certainly eager and enthusiastic. Generally speaking, the entire correspondence - either out of easily understandable considerations, or because the addressee was female, (therefore prioritizing questions related to art, creativity and mainly emotional matters) - completely disregards Norwid's social and political activities (with which he was particularly preoccupied in this period). However, in the first part it clearly reveals his emotional oversensitivity, and in the second part - the frequent, most intimate of breakdowns and spiritual outpourings.

From the perspective of the principal goals of biography - "um das Dämonische zu packen," as Franz Servaes put it in his splendid essay on the life of Goethe - it is this fundamental character of the letters to Maria Trębicka that lends them such prominence. Besides, they provide us with a plethora of detail, entirely new facts, corrections based purely on dates ${ }^{11}$ as well as hints and allusions to people close to the poet - individuals who might have been in possession of even more important documents.

On the basis of materials familiar to us today, which we have been able to acquire either in print or manuscript form (both originals and copies), we briefly summarize here at least some essential components of a biography of Norwid, and enumerate possible further sources of documents that so far remain undiscovered. We do so in the hope that those in possession of such papers will either publish them or kindly contact the present author.

Of Norwid's childhood and school years, Brockhaus's biography tells us only that "after the premature death of his parents, he was raised in Warsaw by his grandmother, Hilaria Sobieska." Materials shedding light on these years are likely to be in the possession of close or distant heirs of the Sobieski, Norwid and Dybowski families. Perhaps some could be found in school archives. When Norwid, aged 20, debuted as a poet, his more intense relationships should not

11 For example with regard to his stay in America, which began - according to the first two biographical notes - in the year 1849, whereas the first words of letter (DW X, 455) categorically confirm that the poet was still in Europe on 14 November 1852. 
be sought in the well-known Warsaw bohemian milieu, but within a smaller circle of close friends - Włodzimierz and Leon Łubieński, Władysław Wężyk, Henryk Podchorski, T. Lenartowicz and A. Czajkowski; also among artists, in particular Jan Klemens Minasowicz and Tadeusz Brodowski, and in the homes of Łucja Rautenstrauch née Gedrojć, Nina Łuszczewska and Mrs. Dziekońska, the general's wife whom Norwid recalls so frequently and with such affection (perhaps she was even portrayed in the short story Stygmat). The archive of Włodzimierz Łubieński, who was Norwid's best friend until his death in 1849 , is now believed to be in the possession of $\mathrm{F}$. Chłapowski, whose recent paper delivered to the Towarzystwo Przyjaciół Nauki [Society of Friends of Learning] in Poznań testifies to his deep interest in the author of Pieśni społecznej cztery stron [Social Song in Four Pages] and gives us hope that these supposedly very rich materials will be either published or kindly made available to scholars. Many letters could be probably found among papers left by T. Lenartowicz, because their correspondence - despite great differences in their perception of the artist's tasks (cf. listy do M. Trębickiej, DW XI, 105, 118-120, and excerpts from letters by T. Lenartowicz in Tygodnik Ilustrowany, 1904, p. 526) - continued, with some breaks, for their entire lifetimes.

The names of Władysław Wężyk and Antoni Czajkowski are related to the journey around Poland undertaken by Norwid in 1842. The former, an already experienced "pilgrim" (he travelled to the East and the Holy Land), accompanied the young poet on this journey, while the latter wrote a passionate ode ${ }^{12}$ in response to the "marvellous poem"13 presented by Norwid immediately after their return at a gathering organized by Count L. Łubieński. ${ }^{14}$ This first peregrination must have made an incredible impression on the city-hating young poet, who longed for "the countryside and the sky"15; apart from the beauty of nature, he must have been deeply struck by folk tales, historical relics, architectural monuments, ancient monastic libraries, all those "bones sticking out of the earth" ("Wspomnienie wioski" ["Memory of a Village"]). He must have returned with masses of notes, sketches ${ }^{16}$, memories, conclusions and

12 Monthly supplement to Słowo, vol. 1. St. Petersburg, 1859. J. Ohryzko, p. 143. This is the poem that annoyed K. Gaszyński and L. Siemieński.

13 Unfortunately, it remains unknown to us.

14 Monthly supplement to Słowo, vol. 1. St. Petersburg, 1859. J. Ohryzko, p. 143, footnote.

15 Cf. "Wspomnienie wioski" (1840) and "Pożegnanie" ["Farewell”] (1842).

16 In the Czartoryski Museum in Kraków we saw an interesting pencil drawing depicting some sculptures from a church in Wiślica, probably taken from a notebook Norwid kept during this journey. 
premonitions, because later on, many years later, echoes of these encounters and emotions kept re-appearing in almost all Norwid's works, confirming their diversity and vividness. One does not readily lose touch with companions on travels such as these; we therefore assume that papers left by Władysław Wężyk must include a substantial collection of letters from Norwid, perhaps even some drawings, and quite probably that lost "marvellous poem." At that point, Norwid probably began to establish a deeper, more cordial relationship with Antoni Czajkowski, given their shared views on the role of the poet. This seems to be confirmed by the magnificent "Pióro" ["My Quill Pen"], which Norwid wrote in Czajkowski's book of reminiscences and published, with a motto from Byron's Beppo, in Biblioteka Warszawska (1842, vol. 2, p. 177; cf. also Wolff's Skarbczyk poezji polskiej). It was J. K. Minasowicz who - as Norwid states in his 1872 autobiography - taught him "the rudiments of art." The poet remained warmly attached to him until the end of his life, recalling that he had "an immensely broad mind and considerable talent" and that he was "an unusual artist and an excellent man, who was considered half-mad in Poland's capital." ${ }^{17}$ This means that they must have enjoyed a healthy relationship. Perhaps it was on Minasowicz's advice that Norwid, shortly after completing his Polish trip, left to visit Germany. ${ }^{18}$ Certainly, he would share his impressions with this friend, especially - it seems - those regarding artistic matters. Similarly, he must have reported back to Tadeusz Brodowski, his peer (b. 1821) and - as he claims in Promethidion (DW IV, 139) - someone he valued highly and loved as a brotherin-art. Both of them would also be Norwid's pen friends during his art studies in Italy in 1844 . This information could be useful to owners of manuscripts left by both artists.

The date 1843 is also related to another document whose location remains unknown: the intriguing "collaboration with Polish political magazines," which Brockhaus calls in his biography "the beginning (?) of a literary career." It remains uncertain what magazines these were (whether published in Warsaw or Poznań)

17 This praise is confirmed by E. Rastawiecki, according to whom J. K. Minasowicz was a highly educated man, a lover of both art and literature, owner of "a collection of paintings representing various schools" and a "considerable library" (Słownik malarzy polskich tudzież obcych $w$ Polsce osiadłych lub czasowo $w$ niej przebywajacych, vol. 3, Warszawa, 1857, p. 330).

18 The date and place (Nuremberg) provided under the poem "Adam Krafft" (PWsz I, 59-60) indicate that on 20 October 1842 the poet was already abroad, while the first two autobiographies claim that he left Poland only in 1843. 
and what form this collaboration took. Our guess would be that this is either foreign correspondence regarding artistic matters (the kind he exchanged later, in 1845, in "O rzeźbiarzach florenckich dziś żyjących" ["Florentine Sculptors Living Today"]; PWsz VI, 361-368), or essays of the kind that the poet refers to, without being too specific, in Promethidion ("Epilogue," part VIII; DW IV, 136).

In the second half of 1845, Norwid abandoned his studies and interrupted his Italian journey to come to Berlin, where - as F. Chłapowski tells us - "he established many relationships with the Polish ex-patriates living there." It is difficult to ascertain exactly who these people were at first and then subsequently, after he was transported to the French border, later travelling to Paris, Brussels and Rome. We can assume that he met August Cieszkowski in Berlin. The mention of Cieszkowski in the letter from America quoted above invites the conclusion that their relationship became closer and more permanent, although there is no trace of this in any known correspondence. Norwid's letters to M. Trębicka from Berlin also mention Edmund Chojecki, H. Moraczewski, Adam Potocki and the musician Rożniecki. In Brussels, where he moved primarily in political circles, the poet became acquainted with General Skrzynecki, with whom he was later on intimate terms. Apart from the above mentioned passages from his correspondence about the Towiański sect, the close character of this relationship is confirmed by the following excerpt we found in Norwid's papers contained in the collection donated by W. Gasztowtt: "I wish you good health. Please remember me in your prayers and write to me some time and please write as much as you can. God bless you - Skrzynecki."

In 1848, Norwid met Adam Mickiewicz for the first time, in Rome, and on that occasion drew an intriguing silhouette, which was published in Tygodnik Ilustrowany by L. Meyet. Interesting and important recollections, revealing a good deal about Norwid's views at the time, could perhaps be found in the archives of Mickiewicz's fourteen "volunteers," among whom was the above-mentioned G. Rożniecki. While visiting Rome, the young poet must have also met Zygmunt Krasiński, with whom he became good friends. Their correspondence, which continued for many years, concluding with the latter's 1859 preface to Norwid's long poem Quidam, would be a literary document of immense value. Unfortunately, as I have learned, none of Norwid's letters survived, while all letters from Zygmunt, which Norwid supposedly sent him back in a fit of exasperation, remain with his family. We have no doubt that Count Adam Krasiński, who has contributed so greatly to the unearthing of many unknown works by his grandfather, will soon release these valuable materials.

The Paris years of 1849-1852 are among the busiest in Norwid's life. He would call on all Polish expatriates living there at the time, regularly visiting Duchess Marcelina Czartoryska, and maintained close, cordial relations with 
Chopin and Słowacki. ${ }^{19}$ He may even have become acquainted - through August Cieszkowski - with Hoene Wroński, who isolated himself from his compatriots. ${ }^{20}$ Simultaneously, it was a time when Norwid was rapidly maturing as an artist and poet. It was then that he conceived the magnificent and prophetic idea of national architecture, which he summarized in a letter to the sculptor Henryk Dmochowski ${ }^{21}$ about the Polish okos or ogive. In the same period, several of his works were beginning to take their final shape, including Wanda ${ }^{22}$ (i.e. its second revision of 1851), Pięć zarysów obyczajowych [Five moral sketches], Zwolon and Promethidion. Out of the rather vague artistic unrest in Rome - which bred "Wigilia" ["Christmas Eve"], "Jeszcze słowo" ["A Word More"] and Pieśń społeczna - there emerged a clear, self-confident artistic consciousness capable of expressing the deepest thoughts in clear and lucid forms. It has been brought to our attention that biographical materials relating to this period could be found mainly in the archive of Duchess Marcelina Czartoryska. Apart from "a copious collection of drawings" by Norwid - which are certainly part of her archive (as mentioned by Dr Jerzy Mycielski ${ }^{23}$ ), a collection which could have originated only in that period - it is bound to contain both letters and manuscripts, in fact a whole range of documents that could help us avoid coming to hasty conclusions on the basis of other materials. Some traces of these years could be also found in papers left by General Władysław Zamoyski, August Cieszkowski and Walenty Pomian Zakrzewski with whom Norwid appears to have frequently corresponded at the time.

This lively and prolific period concluded towards the end of 1852 , or at the beginning of 1853, when Norwid suddenly left for America, "bez pożegnania jednej poczciwej ręki" ["without taking his leave of a single person"] and "napoleona jednego w złocie w kieszeń biorąc na 62-dniową podróż morską" ["having only one Napoleon coin in his pocket for the entire 62-day voyage"]

19 Cf. Czarne kwiaty [Black Flowers], DW VII, 41-57.

20 This is confirmed by a watercolour portrait of the philosopher, certainly made from a live model, whose original was first owned by Dr T. Żebrawski, then by W. Bartynowski, and a reproduction of which was published by Wiadomości numizmatycznoarcheologiczne (1897, No. 4, p. 355) as a "sample" of Norwid's talent.

21 Said to have been published in its entirety "in a Poznań daily," but we do not know which one. A summary featuring extensive excerpts was found in the literary supplement to Czas (folio - 1 December 1849, No. 4, p. 3).

22 DW V, 131-163.

23 Sto lat dziejów malarstwa w Polsce [A hundred years of history of painting in Poland] (Kraków, 1897), p. 629. 
(letter to M. Trębicka dated 8 April 1856, DW XI, 53). The reasons for this escape were various. On the one hand, he was a heartbroken lover; two versions of this story exist. On the other, there was a series of other disappointments, which have taken away everything from the poet "począwszy od pełności serca/Aż do ziarn piasku pod stopami" ["beginning with the integrity of his heart, and ending with the grains of sand under his feet."] ("Pierwszy list, co mnie doszedł z Europy" ["The first letter I received from Europe"], PWsz I, 219). We have no further details about this, but the state of his heart - "pękło jak organ zepsuty" ["broken like a damaged organ"] - is painfully depicted in the relevant letters to M. Trębicka. This is certainly confirmed by his rapid departure, his intention never to come back $^{24}$ and, finally, even the way he decided to travel - on some shabby sailing ship, if not as a member of the ship's crew then as one of the least privileged passengers. As he recalls, "twarda to i prawie głodna podróż dwumiesięczna przeszło była" ["it was a harsh and hungry two-month journey"] ${ }^{25}$; "liny okrętu ciągnąłem wiele razy tą samą ręką, kórą te słowa piszę, i topora nią niemniej tykałem" ["I tugged at the ship's ropes many times with the hand I now use to write these words, and I also worked hard with an axe"]. ${ }^{26}$ However, despite being heartbroken and impoverished, or perhaps rather as a result of emotions aroused by both these circumstances, the ocean passage became a memorable experience for the poet. Traces of this, dispersed among many works (including some of the last one ${ }^{27}$ ), make it a matter of great regret that the diary he kept on board, seen by Kraszewski, remains undiscovered.

As far as we know, his stay in America, which lasted a year and a half, was limited strictly to the city of New York. Fleeing from "the ruins of his own self," he lived the life of an outcast, initially taking up hard, physical work (with an axe) in order to support himself..$^{28}$ Apparently, he found employment at the World's

24 “[...] dla zabawki nie szuka się grobu/Na półokręgu przeciwległym grobu” [“one does not seek a grave on the other side of the globe just for fun"]; "[...] żałuję tylko, że być może,/Iż nawet grobu mieć nie będę/Tak jak prosiłem o to mych przyjaciól” [“I just regret that perhaps I will not even have the kind of grave I asked for from my friends"] ("Pierwszy list, co mnie doszedł z Europy" ["The first letter I received from Europe"], PWsz I, 217-218).

25 Białe kwiaty (DW VII, 70).

26 Letter to $Ł$. Rautenstrauch from 1859 (DW XI, 376).

27 Czarne kwiaty [Black Flowers], Białe kwiaty [White Flowers], Cywilizacja [Civilization] and even "Boga-Rodzica" ["Mother of God"] (1873).

28 As related in the above mentioned letter of 1859 to Eucja Rautenstrauch. See also letter to M. Trębicka dated 20 October 1853 (DW X, 468-469). 
Fair. ${ }^{29}$ Later on, he would live by selling his drawings and watercolours. ${ }^{30}$ We may assume that, while staying in this foreign land, in a society whose values were entirely opposed to his own ${ }^{31}$, he received help and support from the sculptor Henryk Dmochowski (known there by the name of H.D. Saunders), to whom he had addressed his letter on okos, mentioned above, four years previously. Norwid himself mentions Rev. Lubomirski, who lived in Brooklyn, as a person "Wiele [...] chwil przyjemnych i przyjacielskich usług" ["to whom I owe many pleasant moments and kind favours,"] as he put it towards the end of Biate kwiaty (DW VII, 72). Certainly, he was in contact with other Poles living in New York, but these contacts must have soon ended in disillusionment, causing him to cut short his stay in America. A whole series of mentions in the opening passage of letter to M. Trębicka dated May 1854 (DW X, 492) allows us to guess what was essentially involved. However, specific information about these matters may be found in the archives of the above mentioned H. Dmochowski and Rev. Lubomirski, perhaps even in Norwid's correspondence with his closest relatives in Europe (his family, W.P. Zakrzewski and friends from Paris). At the end of June 1854 the poet was seen on the steamship Pacific bound for Liverpool. ${ }^{32}$

Having landed in Great Britain, he stayed in London for some time - as is confirmed in Białe kwiaty - where he lived as "Artysta, też i ludowego pierwiastku czciciel" ["an artist and admirer of folk culture"] as well as a rather impoverished man, "w najuboższym prawie domku najuboższej miasta części” ["in the poorest house in the poorest district"] (DW VII, 69). We have no idea how long he stayed there, nor how he spent the next year and a half. ${ }^{33}$ At the beginning of 1856 he was back in Paris. ${ }^{34}$ The only thing that drew him to this city, from which he had fled "nie żeby szukać Ameryki, ale ażeby nie być tam..." ["not to seek America but simply so as not to be there,"] was perhaps the hope that old contacts and

29 See: biographies by Brockhaus and Larousse, and Wiadomości numizmatycznoarcheologiczne, the latter mentioning initials signed by Norwid on World's Fair documentation.

30 Letter to M. Trębicka from 1853 (DW X, 456).

31 Letter to M. Trębicka dated 20 October 1853 (DW X, 468).

32 Among the "keepsakes" donated to us by W. Gasztowtt we found a cabin slip with the poet's name: "No. 1865. New York and Liverpool United States Mail Steamship Company. Steamship Pacific. New York to Liverpool voyage No. 28. Intended to sail June 24 Y. 54. Received from Cyprian Norwid ... Dollars for Cabin passage for this voyage" (italics denote details filled in on the slip).

33 Perhaps he visited Crete during that time, as is deduced by some on the basis of Epimenides.

34 Letter to M. Trębicka dated 8 April 1856 (DW XI, 54). 
acquaintances would enable him to avoid compromises and apply his skills in order to find suitable employment or a place to stay. Then he would leave the city that was filled with painful memories. At first he could delude himself that this hope might be realized. After returning from across the ocean, he was received very cordially and did not lack promises; sometimes he even obtained real support. On 15th September he wrote to M. Trębicka (DW XI, 121):

Robiłem po raz pierwszy do Florencji, co mie ucieszyło, bo z tamtej Akademii wyszedłem, będę robił do południowej Francji, robiłem do Rzymu i do Konstantynopola. Może kiedyś u schyłku życia będę miał jaką robotę do kościoła jakiego nawet i w Polsce!...

[I worked for Florence for the first time, which I enjoyed, because I studied at the art academy there; I will work for southern France and I have worked for Rome and Istanbul. Perhaps towards the end of my life I will even receive some commission from a church in Poland!...]

In another, earlier letter (dated 18th July 1856, DW XI, 80) he shares his thoughts about being hopeful and disillusioned about his peregrinations:

Miałem w przeszłym miesiącu wyjechać do Bieguna-północnego, [...] w świcie Jego Cesarzewiczowskiej Mości Księcia Napoleona Bonaparte jako rysownik tej scientyficznej ekspedycji - ale zmniejszono świtę I książę raczył żałować, iż mnie odmówić musiał [...] Że mi znowu coś proponują stałego w Rzymie, naturalnie, że mogę byc zmuszony tam się udać.

[I was to leave last month for the North Pole [...] in the retinue of His Majesty Napoleon Bonaparte as a draughtsman in a scientific expedition. However, the retinue was scaled down and he was sorry to have let me down [...] Since I am again being offered a permanent position in Rome I will perhaps be forced to accept and go there ...]

Judging by these words, one could assume that the Eternal City on the Tiber did not tempt him too much at the time. Later on, the thought of finding refuge there became fascinating as it grew on him that Paris is a city where

artysta, kiedy [...] upadnie w niedostatek, zdarzy mu się w najlepszym razie najokropniejsza rzecz-protekcja,[niespożytkującczłowiekawedługświętościjego, alewszystko tylkowedług tych a tych czasowych kierunków i widoków ${ }^{35}$ ] albo robota tak zręcznie podana, iż może nie odgadnać od razu jej następstw praktyczno-dramatyczno-sentymentalno-drewnianych. ${ }^{36}$ [an artist who becomes impoverished can count, in the best scenario, on protection ["which does not utilize what is best in one but rather puts one at the mercy of passing trends and fashions"], or a job so skilfully presented that one does not immediately see its practical, dramatic, sentimental and hollow consequences.

35 Letter to M. Trębicka dated May 1854 (DW X, 492).

36 Letter to M. Trębicka dated October 1856 (DW XI, 130). 
That is why in 1876, towards the end of his life, we see him setting out for Rome for the fifth time. ${ }^{37}$ Unfortunately, this plan was thwarted, just as in the past. This time, however, he had actually already sent his luggage to Italy and it was only thanks to his friend (A[ntoni] Z[aleski]?) - who was in Florence at the time that he managed to have it returned to Paris free of customs duties. Still, it cost over a hundred francs, which he had to pay himself (despite his poverty!).

Thus, despite his intense, repeated efforts and hopes of leaving Paris, he spent the entire second half of his life there, which lasted for over a quarter of a century (1856-1883). In these years his talent reached the heights of its maturity. He remained resolute and spiritually strong despite the ever worsening material conditions, working hard and prolifically, both in literature and visual arts, until his death. Lack of specific data prevents us speaking in any detail about his output in the sphere of plastic arts. However, it must have been huge, as is testified several times by J.I. Kraszewski (in Kartki z podróży andvarious volumes of Rachunki) and especially by Norwid's own autobiography of 1872 . Most works he lists there were created in these years, though we now know, thanks to various data randomly coming to light, that this list needs to be supplemented with a whole series of works forgotten by their author or produced later, e.g. church paintings "made for Florence or Constantinople"38; a great oil painting of St. Stanislaus (1874) for (presumably) Euvre de Saint Casimir ${ }^{39}$; a large etching mentioned by Kraszewski ${ }^{40}$ and depicting the Resurrection (1857) (Fig. 12); and finally, a large number of watercolours, to which he devoted himself increasingly towards the end of his life, and which were only occasionally a source of income.

As far as literary works are concerned, their number is astonishing, even if we disregard a whole series of writings of which we do not even know the titles, as well as smaller or occasional pieces. There was hardly a single year during which he would fail to publish a first-class work. During the years 1856-1859 he worked on the "great abyss" entitled Quidam. Additionally, in the year 1856 he wrote Czarne kwiaty; in 1857 - the long poem Człowiek [A Human], and Białe Kwiaty; in 1858 - the well-known essay O sztuce; in 1859 - the Anhellilike Garstka piasku [A Handful of Dust], and the wonderful "List do Walentego Pomiana Z." [“A Letter to Walenty Pomian Z."] (Chimera I, pp. 185-193). During

37 Letter to L. Nabielak from February 1877 (PWsz X, 94).

38 We assume that the "Work for Rome" was the "small preparatory drawing" mentioned in the autobiography, depicting St. Basil and St. Macrina.

39 Letters of gratitude from T. Mikułowska, sister of mercy, are contained in the collection donated by W. Gasztowtt.

40 Catalogue d'une collection iconographique polonaise (Dresden, 1865). 
the years 1860-1866 he worked on the shimmering Vade-mecum cycle, full of various gems. In 1860 he prepared the wonderful lectures O Juliuszu Stowackim [On Juliusz Słowacki]; in 1861 - the deep vision Cywilizacja; in the years 1862-1864the first revision of Aktor [The Actor]; in 1863 - Fulminant; in 1865 - "Tancerka" ["The Dancer"], "W dzienniku warszawskim"41 and the wonderful masterpiece "Fortepian Szopena" ["Chopin's Grand Piano"]. The years 1866-1869 were occupied with work on the bizarre dramatic fantasy Za kulisami [Backstage], while he was simultaneously composing, during the years $1868-1869$, the colossal, truly Hesiodic rhapsody $O$ wolności słowa. In 1870 Norwid was reading the Odyssey, perhaps in order to keep his mind off the harsh reality, and translating passages from it. The year 1871 is marked by the unexpected Filozofia wojny. The years 1872-1873 were occupied with work on the "Boga-Rodzica" study (PWsz VI, 495-528), which is the only (in the deepest sense) aesthetic analysis of its poetic beauty. At about the same time, Norwid became a member of the Societé de Philologie, to which he submitted, in 1873 and 1878, a series of essays and memoranda, the most interesting of which would probably be Mémoire sur la glossolalie. ${ }^{42}$ In 1876 Norwid sent Z. Sarnecki, who founded the Echo magazine in Warsaw, several works, supposedly including the essay "O typach literackich" ["Literary Types"]. ${ }^{43}$ Probably between the years 1872 and 1875 he wrote the first act of Kleopatra i Cezar, the second act in 1875-1878; the third, unfinished act was started in 1878 . That same year he began an unknown work entitled "Msza Święta" ["Holy Mass"]. ${ }^{44}$ The period 1878-1881 is, we presume, the time of the composition of three prose works: “Ad leones!” (DW VII, 201-215), Tajemnica lorda Singleworth [Lord Singleworth's Secret] (DW VII, 217-233) and Ostatnia z bajek [The Last of the Fables] (DW VII, 235-250) as well as an unfinished revision of Aktor. Milczenie (PWsz VI, 221-248) was written - as confirmed by the letter to T. Lenartowicz quoted above, in 1882. Stygmat was completed in the poet's last months, in 1883 . The period preceding his death is also the time of the composition of two works grandly conceived but unfortunately unfinished: the

41 Mention of both poems (previously unknown to us) is found in the letter from Marian [Professor Sokołowski]. “Tancerka prześliczna” [“The Beautiful Dancer”] was discovered in the archive donated by W. Gasztowtt.

42 Letters from $\mathrm{H}$. de Charencey, president or founder of the society, are contained in the archive donated by W. Gasztowtt.

43 Letters from Z. Sarnecki are contained in the archive donated by W. Gasztowtt.

44 In a letter from B. Zaleski (in Gasztowtt's archive), dated 22 January 1878, we read: "I hasten to tell you that I have received the manuscript of Msza święta. I will read it carefully - why would I disrespect it?" 
comic-epic long poems A Dorio ad Phrygium and Emil na Gozdawiu [Emil in Gozdawie]. ${ }^{45}$ This long period of inspired creativity must seem astonishing if one takes into account that it was also a time of ever less successful attempts to find publishers for his literary works and buyers for his art works. ${ }^{46}$ Manuscripts destined never to see the light of day kept amassing and news would come from Poland of disrespectful comments about him. ${ }^{47}$ It was also a time when he was subjected to ridiculous accusations and arrogant charges by certain Polish émigrés. ${ }^{48}$ Pitiful stories about him would be circulated, as well as rumours about the "weird and capricious activities de ce pauvre Ciprien." Finally, it was a time when he was becoming increasingly poverty-stricken, a situation further aggravated by Norwid's readiness to come to the help of others in need.

The first Parisian years had been considerably better. In 1856 Norwid had enough work and hopes of better times in the future. He even had at his disposal a pleasant studio, which he describes in a letter to M. Trębicka (DW XI, 92), although by 1858 Kraszewski found him in a "poky little room" (Kartki $z$ podróży, p. 316). In that year he failed to complete lectures on art as he had intended ${ }^{49}$ and instead he financed the publishing of an essay with his own money. ${ }^{50}$

45 Contained in the archive donated by W. Gasztowtt.

46 Letter to M. Trębicka from 1856 (DW XI, 118).

47 “Z literatury wiem przypadkiem (bo, co o mnie piszą, nie czytuję), wiem, że ś.p. Senator i Kaszt[ela]n Fr[anciszek] Wężyk wyśmiewa mię w swych dziełach, stawiąc obok Odysei Homera mój pamflet, pisany, kiedy miałem lat około dwudziestu, i który otrzymał owoce swoje. Tudzież hist[oria] lit[eratu]ry dla użytku gimnazjów zniesławia także imię moje i pisma, aby przyszłe pokolenia oświecić. Zatrzymuję się nad zdaniami Senatu i Pedagogii -Senatus populusque - iż te cenić godzi się pierwej." ["I know from literature (I do not read what they write directly about me) that the late senator and castellan F. Wężyk mocks me in his works, comparing The Odyssey to a pamphlet of mine written when I was twenty, and which had already borne its fruit. Also, a history of literature written for the middle school disrespects my name and writing in order to enlighten future generations. I shall only quote the Senate and the People: "Senatus populusque" (it is better to respect these two)"] (a letter to T. Lenartowicz of 1882; PWsz X, 179).

48 A letter to M. Trębicka of 1856 (DW XI, 106). There were also crude replies, accusations, demands - written and spoken - after the lectures on Słowacki, which made the poet aware that he might have been preaching to an audience more deaf than stones. Even friends would occasionally torment him, advising him to be more "practical" and stop avoiding patronage, as well as reprimanding him for excessive "self love" (in letters to M. Trębicka, DW X, 79, 91, 186 and elsewhere).

49 A letter from J. Klaczko, dated 26 January 1858, in W. Gasztowtt's archive.

50 A letter to J.B. Wagner of 1876, in E. Geniusz's archive. 
Despite all the above, in the period immediately following his return he was warmly received by friends, who tried to bring him to the attention of the Polish public, find publishers for his works, or even raise money for self-publishing. In 1859, B.M. Wolff, a bookseller of St. Petersburg, published Norwid's juvenilia in Skarbczyk, and bought the long poem Szczesna from someone authorized by the poet for 200 francs. ${ }^{51}$ In 1861, M[arian] S[okołowski], Seweryn G[oszczyński?] and someone else [Zofia Węgierska?] copied the lectures on Słowacki, while other friends argued that "they should sponsor their publishing." 52 Brockhaus, who was favourably disposed towards Norwid, undertook in 1862 to edit not only Krakus (as proposed by the author) but an entire volume of collected works, amounting to 15-20 sheets. He offered the poet the standard fee of 500 francs established for authors in the Biblioteka Pisarzy Polskich [Library of Polish Writers] series. ${ }^{53}$ W.P. Zakrzewski, A. Zaleski and others actively advocated the publication of this book. Thanks to the efforts of Count Edward Łubieński and the support of Henryk Korwin Prendowski, the long poem Niewola [Enslavement] was published in 1862. Norwid had apparently sent it too late to ensure its inclusion in the previous volume. However, this meant he was able to complement it with freshly written stanzas of Fulminant. ${ }^{54}$ At the same time, a limited collection of Norwid's poems was published in the Kraków magazine Czas (1856 and 1857), in Biblioteka Warszawska (1862), and in Pokłosie (Leszno-Poznań, 1853-1862), while in 1861 and 1862 Tygodnik Ilustrowany published his satirical drawings. In that period, the artist himself published several of his drawings as lithographic prints - "Echo ruin," "Scherzo" and "Solo," (Fig. 13) but the press in Poland and abroad ignored them. ${ }^{55}$ At a time when Norwid had already published such masterpieces as Quidam or the lectures on Słowacki, the opinion (of uncertain origin) that "he raised great hopes but did not live up to them" ${ }^{\text {"6 }}$ was still current.

51 A copy of the original contract, signed by Wolff, is in W. Gasztowtt's archive.

52 O Juliuszu Słowackim (Psz VI, 465).

53 Letters from Brockhaus dated 5 February, 5 April and 19 December 1862, in Gasztowtt's archive.

54 A letter from Brockhaus, dated 23 February 1863, in Gasztowtt's archive.

55 We have not been able to find a single substantial or broader discussion of these publications (or the previous Promethidion and Zwolon) in contemporary publications. The first serious work on Promethidion was St. Malczart's "Norwida poglądy na sztukę narodową" ["Norwid's Views on National Art”] (Tygodnik Słowa Polskiego, 1902, No. 6-9).

56 This claim was first quoted in Przeglad Naukowy (Warszawa, 1843, II, p. 406) from an article by Schierer on Polish poetry published in a German magazine. This claim 
Although these editions were not very helpful in enhancing the poet's material position, they nevertheless did raise his spirits when he saw that people were reading them, and that they were not hidden away in manuscript form. This meant that even if his generation were to forget about these writings, perhaps future ones would rediscover them.

However, worse times were to come. Attempts to publish Vade-mecum were in vain. "There was nothing I could do," wrote Kraszewski to Norwid on 5 June 1866. ${ }^{57}$ "I have a dispute with Brockhaus, which perhaps will end up in court. I am truly sorry - as God is my witness - that I cannot help you. Perhaps you could write to Żupański - perhaps you will have some luck with him. I would gladly help and will certainly do so if I can in the future." Henryk Merzbach from Brussels also declined his request, advising him to wait until the bronze cannons stop firing.$^{58}$ Norwid did wait, presumably without losing hope, because he kept expanding the cycle by adding new poems. In 1869 it featured - as is clear from the table of contents - an unknown work entitled "Relacja" ["An Account"] and the fantasy $\mathrm{Za}$ kulisami. In the last few years, he also intended to include $A$ Dorio ad Phrygium in this book, as is suggested by a note added beneath the title. Unfortunately, all these hopes turned out to be illusory. Vade-mecum remained in manuscript and it has reached us today only in fragments. That was the beginning of a series of failures, the continuation of which could not be halted in any way. Not even after the acceptance of his etching "Sybilla" by Arsène Houssaye's renowned review l'Ariste (1868), the publication of the masterpiece "Fortepian Chopina" in Bendlikon's Pisma zbiorowe (1865), the indescribable elation of the audience after the lectures $O$ wolności słowa (1869), Agaton Giller's resounding review of this rhapsody, or the publishing of the poem itself thanks to efforts made by closest friends, who were themselves not very wealthy. In the last fifteen years of his life, the poet was increasingly shrouded in silence, falling into oblivion. All attempts to find publishers or secure some work, either as a lecturer or commentator on current artistic life, were fruitless. Sales of drawings and watercolours made by the lone artist, who did not seek to advertise himself at the Parisian vanity fair, were increasingly sluggish. Every day his material situation worsened. In 1877 the poet found himself obliged to seek shelter at St. Casimir's. In these last years he was still writing and drawing, proving his spirit to be truly

is ridiculous because Norwid was 22 in 1843, which is much too early to speak of any failed hopes. Nevertheless, the label stuck, to a large extent thanks to Kraszewski.

57 Letter from Gasztowtt's archive.

58 Letter dated 23 June 1866, from Gasztowtt's archive. 
invincible! He continued to produce beautiful first-class works until his passing away on 28 May 1883, when liberating death took him.

I porwan jest ku złotym na niebie plejadom,

Gdzie wolność... ${ }^{59}$

[And he was taken to heaven's golden pleiades,

Where freedom ....]

By now we have a good deal of information about this period, which was so painful both in material and in spiritual terms. Most pointers were naturally obtained from Norwid's personal archive (so frequently mentioned here), especially letters addressed to the poet as well as his interesting memoirs. Thanks to the kind cooperation of the librarian at the Rapperswil Museum, W. Karczewski ${ }^{60}$, we were able to collect a whole series of Norwid's letters, many of major importance, from the so-called Norwid file (archive no. 215[I]) and from the papers left by L. Chodźko, Ludwik Nabielak, Seweryn Goszczyński and Ludwik Dygat. Extremely valuable letters and manuscripts were found in the archives of E. Geniusz, W. Gomulicki and S. Duchińska, who were the first private individuals to share their Norwidiana with us, for which we are very grateful. Finally, thanks to the kindness of Count Krasiński we have been able to learn about the correspondence between Norwid and Z. Krasiński, as well as to access copies of Norwid's interesting letters and works from the last period, which were found in papers left by Count A. Potocki. These materials, in turn, introduce us to the poet's inner circle, allowing us to establish where further biographical materials could be found. We have reliable indications that various documents (letters, memoirs, manuscripts of unknown works, or copies of incomplete works) should be held at the following locations: the Czartoryski family archive; the archives of August Cieszkowski, Kazimierz Gawroński, Wojciech Grzymała, Rev. A. Jełowicki, Count Kleczkowski, J.I. Kraszewski, Count A. Tabasz-Krosnowski, X. Marceli Lubomirski, L. Niedźwiecki, Delfina Potocka, Count S. Potocki, Maria Sadowska (pseudonym "Zbigniew”), Zofia Węgierska, W. Wielogłowski, A. Zaleski, Gen. Władysław Zamoyski, and - among the living - in the possession of Deotyma, J. Klaczko, Chamberlain C. Lachnicki and Professor M. Sokołowski. Time will tell

59 "Autor-nieznany" (poem by Norwid, 1856), from the archive of S. Duchińska (PWsz I, 251-252).

60 We also recall, with gratitude, the hospitality of the museum's honourable custodian W. de Rosenwerth Rożycki, who helped us to search through the artist's works and photograph them. 
whether these documents can be found or have been irretrievably lost. However, time is also ticking away and such research can no longer be postponed.

The body of Cyprian Norwid was initially laid to rest in a Polish grave at the Montparnasse cemetery (allée Lenoir, 17 division), but six years later, in 1889, it was removed to Montmorency. The process of transferring the body was attended by only two people, Anna and Aleksander Dybowski. "None of the invited people came," we read in a letter from Anna Dybowska to E. Geniusz dated 22 February 1889. Not even death could break the spell of silence. Little wonder. The empty, bland obituaries, navigating carefully between general praise and groundless reservations, published in 1883 (Czas, No. 120; Tygodnik Ilustrowany, p. 364; Kłosy, p. 399; Kurier Warszawski, No. 131-b; Wędrowiec, p. 399; Biblioteka Warszawska, III, p. 164) only intensified and justified the general indifference towards the poet. Historians of Polish literature and art - who knew even less than the authors of these obituaries, but were nevertheless more self-confident by dint of their university positions - ultimately buried the great artist under a pile of platitudes about "mysterious thoughts and impenetrable raptures" or under ridiculous fabricated fantasies about "demagogueries," "imitating Słowacki" (!) and... symbolism. But the future shall serve here as the "eternal reviser."

Con altra voce omai ritornerà poeta when - without intermediaries - Norwid shall speak to us from his future Collected Works, to which the present volume can serve only as a humble introduction.

\section{Bibliography}

Bolesławita B. [Kraszewski, Józef Ignacy]. Rachunki z roku 1866. Poznań: Jan Konstanty Żupański, 1867.

Bolesławita B. [Kraszewski, Józef Ignacy]. Rachunki z roku 1867. Poznań: Jan Konstanty Żupański, 1868.

Bolesławita B. [Kraszewski, Józef Ignacy]. Rachunki z roku 1868. Poznań: Jan Konstanty Żupański, 1869.

Chimera 1904, Vol. VIII, No. 22-24 (Pamięci C. Norwida).

Kraszewski, Józef Ignacy. Catalogue d'une collection iconographique polonaise.

Dresden: Hellmuth Henkler, 1865.

Kraszewski, Józef Ignacy. Kartki z podróży. 1858-1864. Vol. 1: Kraków, Wiedeń,

Triest, Wenecja, Padwa, Mediolan, Genua, Piza, Florencja, Rzym. Warszawa: Gustaw Sennewald, 1866.

Kraszewski, Józef Ignacy. Kartki z podróży. 1858-1864. Vol. 2: Włochy, Neapol, Francja, Belgia, Niemcy. Warszawa: Józef Unger, 1874. 
Lenartowicz, Teofil. Lirenka. Poznań: Jan Konstanty Żupański, 1855.

Malczart, St. [Malewski, Zygmunt Stanisław]. "Norwida poglądy na sztukę narodową", Tygodnik Stowa Polskiego, 1902, No. 6, p. 2-4; No. 7, p. 3-5; No. 8, p. 2-4; No. 9, p. 3-5.

Mycielski, Jerzy. Sto lat dziejów malarstwa w Polsce 1760-1860. Z okazji wystawy retrospektywnej malarstwa polskiego we Lwowie. Kraków: Druk. "Czasu” Fr. Kluczyńskiego, 1897.

Pokłosie, zbieranka literacka na korzyść sierot. Rok drugi:1853.Leszno: Ernest Günther, 1853.

Rastawiecki, Edward. Słownik malarzów polskich tudzież obcych w Polsce osiadłych lub czasowo w niej przebywajacych. T. III. Warszawa: Drukarnia S. Olgerbranda, 1857.

Skarbczyk poezji polskiej. T. XI. Część II. Poezje Konstantego Gaszyńskiego, Cypriana Norwida i Antoniego Czajkowskiego. St. Petersburg: B. M. Wolff, 1859.

Witte, Kazimierz. „Cyganeria Warszawska i Teofil Lenartowicz,” Tygodnik Ilustrowany, 1904, No. 27, p. 526.

Strzembosz, Władysław. "Nieznany medalion Krasińskiego," Tygodnik Ilustrowany, 1904, No. 34, p. 653.

Kopera, Feliks. "Nieznana autobiografia Cypriana Norwida," Wiadomości numizmatyczno-archeologiczne (Kraków), 1897, No. 4, p. 354-358. 



\title{
Kazimierz Wyka \\ Norwid's Old Age
}

\begin{abstract}
The author points to the importance of the category of old age in the biography and work of Cyprian Norwid. The category itself appears in three different variants. The first one, real old age, refers directly to the tragic fate of the poet, which culminated in the last few years he spent abandoned in the St. Casimir poorhouse. The second old age is expressed in Norwid's noble-minded, though painful, view of the fate of man in the spirit of Christian humility and love, while the third old age is identified with the maturity of artistic intentions and mastery of form, which the author describes as classical maturity. This old age, which finds its fullest expression in Cleopatra and "Ad leones!", combines humility with deep pride and faith in the enduring value of art.
\end{abstract}

Keywords: Cyprian Norwid, old age, late oeuvre, biography, artistic prose

Norwid's old age is strange and threefold. To write about it today is most fitting, as it is closest to the anniversary of the day we are so eagerly awaiting. Compared to the old age of all the other greats this one is the strangest, reclusive, but the one evoking the greatest astonishment and admiration today. It is an old age embodying absolute freedom, absolute indeterminism of art, its own life, which from the distant perspective of time overcomes the ostensibly true, apparently real life accessible to others. In considering this triad of Norwid's old age, one longs to ask "Ach, któryż jestem żywy" [Ah, which one am I alive].

The first old age - is his real old age. Norwid's youthful years had passed, as had his later years of great conscious wandering - not always as a pilgrim with his cane, but let us not impose on him an image reserved for others. Of course, in his wandering we can see a longing for the land, "gdzie kruszynę chleba/Podnoszą z ziemi przez uszanowanie" (PWsz I, 223) [where they pick a breadcrumb up from the floor as a sign of respect], but apart from that, we have a distinctive expression from a letter to Maria Trębicka, written in 1846 when it seemed he would have to return to the country:

Cały mój artyzm zakończony, nie [będę] miał muzeum, akademii i szkoły w estetycznym znaczeniu tego słowa. Przychodzi chwila rozstrojenia kierunku, jaki wziąłem. (DW X, 79)

All my artistry is finished, I will not have a museum, academy and school in the aesthetic sense of the word. There comes a moment of dismantling the direction that I took. 
The extent to which this wandering, this change of environments was instructive for Norwid's art can be best seen in his old age, when the art he creates is conceived of such varying temporal and local elements, drawn from his own memories.

His years of worldly experience and years of great love for a grand lady had passed. The time of frenzied national hopes had gone by, memorable and important years had passed - for instance, how many changes in France, to which he was most faithful, occurred between 1848 and 1877, when Norwid would have to seek shelter in St. Casimir poorhouse.

That is the first old age. Norwid - a reclusive, deaf eccentric reeking of the tobacco and alcohol to which he has no aversion. He is becoming poorer and increasingly abandoned. It is unspeakably embarrassing that in a series of letters from different periods of time, in which he sought - albeit in vain - to publish one of his works, there is the recurring sentence: "miałem ja już edytora Niemca [Brockhaus - K. W.], co 500 franków mi płacił...” [I already had a German editor who was about to pay me 500 francs...] A whole 500 francs! The shocking letter from 1875 in which he applied for a loan - this is the first old age, which was finally laid to rest under the same tombstone as a dozen others.

This is the old age that astonished Norwid's researchers, and which aroused an understandable sense of terrible injustice towards this man, a sense of immeasurable loss in that this sacred life was wearing away, burning out in poverty, in the loneliness of "paryski bruk" [the Parisian street]. His own words reveal a bitter truth: "ja jestem z ciemnością dni, [...] bólem organu-serca i bólem moralnym serca." (PWsz X, 113) [I am with the darkness of days, [...] the organic pain of the heart and the moral pain of the heart...].

Is it necessary to endure it in silence? Against the backdrop of this old age we can fully understand the rapture when the modest pages of silly little notebooks, torn by blind hands, revealed the most precious jewels of Polish artistry; when they were persistently and carefully extracted by untiring eyes and fingers from under the layer of oblivion and neglect - like a precious insect preserved in a transparent coat of amber.

However, this time of initial astonishment and embarrassment also passed and we are no longer concerned with this aspect of Norwid's old age. Not this one, although certainly the most touching - but also the most external, not dependent upon him, but upon bad fortune. Nonetheless, there is also a second and third dimension to Norwid's old age.

Because he was lonely and abandoned, the virtues of humility and simplicity all the more purely blossomed in this incredibly believing soul. The former passionate protests against "serio fałszywemu" [false seriousness], against the fatal 
restraint of humanity by time frames, the frames of the irreversible past, the oppressive physical surroundings were seemingly appeased. And if they were present, they took the most crystalline form, disconcerting in scope of thought, as in Stygmat [Stigma]. But on the surface of his artistic work its basis always emerged: a humble love of everything, a gentle manifestation of the simplicity of feelings, and a most Christian tendency to embrace the whole of creation with love. This was by virtue Norwid's attitude towards man, who - no matter how great and unique among all creatures - has to carry Christ's cross with pride and the highest glory, yet remains only a number in the sequence of creatures made by the same Creator. Ostatnia $z$ bajek [The Last of the Fables], written in Franciscan spirit, marks this surge in love for the whole world, this resistance to the imperialism of man towards his inferior brothers. It is a pity that this work was not mentioned in the recent discussion in Wiadomości Literackie [Literary News] on the attitude of integral pacifism towards animals.

This resistance to the violence of man did not result in severe irony towards him. A certain insight into human fate, which is understanding and ready to forgive, though painful, can be found in the following words: “...dziecię potrzeb, nędzy i szaleństwa, nagie, bezbronne, głodne - syn zakopciałych [...] drzew... [...] przepisujący tą właśnie nędzą swoją prawa bytom!" (DW VII, 247) [... a child of need, misery and madness, naked, helpless, hungry - son of burnt [...] trees... [...] attributing this very misery of his to the laws of beings!]. We are dealing with the same tone of metaphysical astonishment and humility developed in the darkness of the worlds used by Blaise Pascal to question this particular, and not any other, fate of man, and his place in existence.

In this old age, Norwid's subtle gentleness is bound with humility, rarely hiding under the shell of irony. The tones of the mentioned past start to calm down. An understanding smile appears over man's inevitable smallness; a certain lyricism - fleeting, but not sentimental, because it is too diligent - begins to shroud the former years, colouring the treasured memories collected in the time of wandering and salon life. This is why Norwid's wandering becomes so instructive, as Norwid assuredly and often draws on its achievements. Calm understanding tells us it had its point, the profound artistic benefit that is manifesting itself now.

This growing clarity of memories gives rise to their numerous cameos in Norwid's late works. Among them is the little masterpiece of humour and meticulous memory lightened with friendly irony - the image of Venice in Tajemnica lorda Singelworth [Lord Singelworth's Secret]. But this smile-saturated friendliness is not enough for Norwid. As in Ostatnia $z$ bajek humility ended with a metaphysical question, here memory would turn into a sudden historiosophic outline 
of the city, which "przeżyło idyllę, dramę, nadużyło tragedii i komedii i które jako znudzona już wszystkim wielka dama pozostało piękne i czarowne" (DW VII, 224) [survived the idyll, drama, abused both tragedy and comedy, and which, as a grand lady bored with everything, remained beautiful and charming].

The memory of the Polish countryside recurs to the poet - the poet who was far from submissive sentimentalism towards the familiar. Reminders of the Polish landscape from his youthful wanderings reappear to Norwid a few times. The action of Assunta is set on Italian soil, but every now and then one wonders if it is not Czerna near Kraków, as Miriam does, or Kalwaria Zebrzydowska, as Życzyński believes. In Emil na Gozdawiu [Emil in Gozdawie] a few poems suffice for the author to suggestively evoke the tranquillity of the Polish countryside. But more importantly, these memories are intertwined with the said increase in humility and simplicity. It is in the historical novella Stygmat [Stigma], which finishes with the most beautiful poetic projection of the Polish landscape in Norwid's writings, with the geese and funny gooseherd girl, that this very gooseherd makes the poet take up the quill "którego i używanie, i użytek obmierzili byli mi literaci" (DW VII, 199) [whose use and employment had been completely spoiled by the literati]. The scope of the originally given memories of the countryside is already exceeded here, similarly to how it was done with Venice, or previously with the attitude towards animals.

However, Norwid takes things even further. The praise for the Polish countryside in A Dorio ad Phrygium reaches an astonishingly high and one of a kind level of "Fortepian Szopena" ["Chopin's Grand Piano"]:

O! wsi biała w atłasie kwiatów jabłoni

I w źwierciadłach księżyca,

Jako oblubienica

Na ustroni...

Przeszłość twa - zawsze wczora!

Przyszłość - ręką dosiężna,

U ciebie zawsze - pora!

Tyś wczasów księżna... (DW III, 382)

Oh! The country white in the satin of apple blossoms

And in the mirrors of the moon,

Like a bride

On the retreat...

Your past - always yesterday!

Your future - a reaching hand,

For you, always - it's time!

You are the duchess of the holiday... 
Lastly, the same Norwid, who with reference to salon life of the past used to write in a tone which can be found in "Nerwy" ["Nerves"] or "Marionetki" [“Marionettes"]:

Zapomniećludzi, a bywać u osób,

- Krawat mieć ślicznie zapięty!... (PWsz I, 346)

Forget people, call on persons, wear,

A neatly fastened tie!... ${ }^{1}$

now musters a composed, anecdotal-ironic tone in the first pages of Stygmat [Stigma]. A dissonance drawing on a past riddled with anxiety and quandary dissonance moderated with an appropriate footnote - is visible in the poem "Czemu" ["Why"]; but that already belongs to the past.

And thus, Norwid is surrounded on all sides by incoming waves of wisdom, wonderful reverie over the past - reverie which, however, does not shed tears over the inevitability of evanescence, does not give rise to protest or dilemma, but only bears the necessity of commemorating the past in unchanging, everlasting artistry. Art more and more becomes that which bestows eternity upon human affairs. Norwid's whole poetry could be described with the words used by the poet himself in relation to his life:

[...] śnię i czuję, jak się tom historii

Z-marmurza... (PWsz I, 335)

[...] I dream and sense that the history's tome

Turns marble-hard...2

Norwid's poetry was always about immortalizing, especially when it comes to the poet's personal life or acquaintances. That is why there are so many lost diaries, so many raw descriptions, so many portraits of newly met people, scattered portraits, preserved on scraps of paper (a marvellous profile of Horace Delaroche written on the invitation to his funeral!), this is why Czarne kwiaty [Black Flowers] came about so early (1856).

Now, in the solitude of the poorhouse, old age demanded a review of life achievements, since only the art of writing was to present future generations with his experiences and reflections - this attitude of undisturbed commemoration, calm commemoration painting a linear, unambiguous and clear picture

1 English translation by Adam Czerniawski in: Cyprian Norwid, Selected Poems (London: Anvil Press, 2004), p. 44.

2 English translation by Danuta Borchardt in collaboration with Agata Brajerska-Mazur in: Cyprian Norwid, Poems (New York: Archipelago Books, 2011), p. 117. 
is characteristic of Norwid's later artistic work. And perhaps for this reason the previously less venerated prose and novella now make way for unquestionable works of art. Maybe this is why he goes beyond the indecisiveness of Bransoletka [Bracelet] or Cywilizacja [Civilisation], without falling into memoir writing of the noblest sense, but only the memoir writing typical of Czarne kwiaty, and produces an excellent blend of a faithful experience and a deeper free interpretation of this experience through artistry. Maybe Norwid felt that prose was better suited to describing things which conscientious loyalty to one's own experiences called for preserving in an as much as possible unaltered form but that, at the same time, forcibly reconstructed the emotional attitudes with which the poet perceived them.

The accumulating stores of tranquillity and humility also demanded the same composure and subtlety in the artistic interpretation of his own memories and reflections, from which resulted the poet's attitude towards man and the world at that time. Prose proved to be better for this purpose, as well. A poem, even if it always - as in Norwid's case - was (in Horzyca's words) "the most silent song," even if "the logic of prayer and silence" was always its key, a poem intrinsically stresses emotions and tips the scale in their favour. Prose, by contrast, can just be an account of events, it does not have to impose any emotional charge on the reader, and though Norwid did that, he only ever suggested a tone, never enforced it, in anticipation of such dangers. Without linking itself to a direct emotional conclusion, postulated by the poem, prose can simultaneously accommodate more concrete material. Norwid's numerous artistic mistakes resulted from the fact that he had a surplus of this material, in particular thinking material. Making this material available in the form of a poem was unsuccessful, because it lacked the necessary emotional extensions. The effect was rhymed prose, as in Rzecz o wolności stowa [On the Freedom of Speech], which reworked in the form of Ostatnia $z$ bajek could have been the masterpiece of free, fanciful use of prose.

And this is the third variety of Norwid's old age, the old age which is equivalent to the maturity of artistic intentions in terms of their control over the form, the levelling of previous disparities between Norwid's artistic intentions and achievements. If a lack of this dissonance and the control of the word are to be called classical, then this would be Norwid's classical maturity. I have the impression that this third old age, to the best of its understanding, is Norwid's most precious old age.

The first old age - his overwhelmingly sad life? Indeed. But we are dealing with an artist - it is only the framework of more important things. It may be heartbreaking, but we should turn our attention towards these more important 
things; after all, the artist only concerned himself with these. The second old age - grasping for the late sun of the inner layers of the soul: yes, it is important to note, this is intertwined with the third old age, but it is only through it, i.e. the calmness, depth and maturity of the third old age that it reaches the expression we can observe today.

In this third old age, which is closer to the poet's dreadful fortune, the most important thing is the excellent sense of his indispensability, his significance in the face of the approaching "korektorka wieczna" [eternal editor], which gave Norwid's pen no rest. This feeling always accompanied him. Already convinced that he was entirely correct, in his "List do Walentego Pomiana Z." ["Letter to Walenty Pomian Z."] (1859) he appealed from the unstable present to the future. But now comes something more interesting. There is no appeal. There are no direct appeals to the tribunal of omni-justice. His only grand appeal is that - he silently writes - there are more and more draft papers, notebooks, diaries, papers which nobody would accept, nobody would publish, but which are deeply self-contained, any torn page of which would be more valuable than the books held by "złote paznokcie" [golden fingernails]. This must have been the proudest maturity, some real classicism. When Koźmian polishes the poems in his narrative Ziemianstwo [Landed Gentry] and publishes them as late as in 1838, he has - all things considered - a similar sense of art's self-reliance. When Flaubert thinks that one should never rush a work of art, it is never too late for one when he writes: “...se dépêcher, c'est le moment, il est temps, place prise, se poser, hors la loi, sont pour moi un vocabulaire vide de sens"3 - Norwid could be repeating him.

However, how do humility and internal tranquillity transition into this mature pride? There is surely no disagreement, unless if instead of this pride, we saw an impatient claim of his own worth, impatient attempts to impose himself. But humility and deep pride are entirely in accord with one another, pride cannot force itself, it must be solitary, intended to be content with itself. Because, as the excellent saying by Dąbrowska goes, this pride is "poczucie tajemnicy i ważności własnego istnienia" [a sense of mystery and importance of one’s own existence], while humility is "skromnością wobec ludzi, a hołdem wobec wspaniałości i grozy bytu" [modesty towards people and a tribute to the magnificence and terror of being].

3 G. Flaubert, Oeuvres completes, v. 13, Correspondance. 1850-1859, Paris: Club de l'Honnête Homme, 1974-1976, p. 203. 
That would be all for the life-like aspect of this third old age. From a purely artistic perspective it is most fully expressed in two works: Kleopatra [Cleopatra] and "Ad leones!". We should not be offended by the fact that Kleopatra is unfinished. In its fragmentary nature it is just as classical and whole as would be the Belvedere Torso deprived of its arms, neck and head. We should also not be offended by the fact that despite being called so by the poet it is not a tragic play. Norwid's static nature, his complete lack of the sense of action, the lack of time in his artistic perspective made it impossible for him to create a real drama. Hopefully, the anticipated work Pierścień Wielkiej-Damy [The Noble Lady's Ring] would dispel this claim... More importantly, excessive allegory, some stubborn supervision - since everything had its own hidden, sometimes allegorical, sometimes parabolical sense - disturbed the line, did not allow the drama's characters to have their own life, liberated from the omnipotent and omniscient writer.

However, Kleopatra did not compensate for the first shortcomings. It was not burdened by any dramatic plot. It is also not a tragedy, just as Jan Kochanowski's Odprawa postów greckich [The Dismissal of the Greek Envoys] is not one. But alternatively, Norwid's non-dramatic artistry becomes so clear here, his excessive allegory is largely reduced! Finally, the sense of historiosophy, the ideological basis of historical movements started to run parallel to his ability to incorporate it into concrete historical facts. When we read about the juxtaposition of two imperfect powers, Egypt and Rome, which both have to fall in light of the prophecy of Christianity, the artistic dialectics of this juxtaposition amazes with its very justness and sociological subtlety. This dialectic is so compact and perfect, although only reflectively, and not dramatically compact, that one could doubt whether Norwid would have been able to impose upon it a convincing synthesis of the insufficiency of these powers, even if the torso of Kleopatra was complete and finished.

Norwid, in the sociological sense, requires us to think of the most important comparisons in Polish art in this respect, for instance, of the juxtaposition with the most outstanding historical novel in Polish literature - Faraon [Pharaoh] by Bolesław Prus. There is no space here for a more detailed discussion of their affinity. Of course, it is not based on the common background, or Egypt - this is not important. What is important is that Prus wrote the only Polish historical novel, the historicity of which serves only as the material which makes it possible to show, in an as detailed as possible and dispassionate way, because it is emancipated from the splinters of the present, an important social schema or equation. His aim was to show social tectonics, the scale and difficulty of ruling, to show the conflict between mighty tradition and ineluctable progress - the most difficult battle, because it is fought with thousands of sentient pawns on the living body of the state. There is some tragedy in the battle of these two powers, 
which makes Faraon perpetually relevant, which elevates this particular, because presented by one example, fight between young Ramses and the priesthood to a symbol of the constant course of history.

This same general human, sociological view found in Prus's novel determines the mature importance of Kleopatra. Although Norwid is interested in other problems, he shows the same ability to predict their significance. Those problems for Norwid are the problem of historical tradition and work, the problem of the certain barbarity and wildness with which new historical values are born. On the one hand, we have Egypt - the nation whose life was enslaved and put in a static deathbed state by its tradition and excessive history, and on the other hand, there is Rome - the magnificent nouveau riche of history, bending itself according to time and circumstance without any harm to itself, vigilant against matters requiring immediate action, trusting in raw power, not traditional, true in the past, but today insignificant. The scope of this antithesis is that we go far beyond what was constrained by historical finiteness. Every now and then some Nietzscheanism peeks through; Caesar, the best of the Romans, impersonates this pride of man's solitude, which matches the level of tragedy in Faraon:

[...] To źle jest być więcej niż pierwszym!

Lub nie myśleć, że pierwszym trzeba być w czymśkolwiek. (DW VI, 293)

It is wrong to be more than the first!

Or not to think that one has to be the first in anything.

Yet another motif in Kleopatra should be highlighted with respect to Norwid's attitude to art in the examined period. This classical faith in the power of art, which saved him, was not a resignation only for art's sake. When everything was disappointing, only art was left! With a longing unrest Psymach twice utters: "Kiedyż! będę mógł zniknąć w dziele moim..." (DW VI, 378) [when! will I be able to disappear into my work...]. But disappearing does not mean melting in it together with the smallness of life, this is not saving oneself through art:

Powiadają, że dzieła mają nas uwieczniać:

Nie to wszelako czyni je drogimi. One,

Gdyby nasz przewlekały żywot z nędzą jego,

Ze zazdrościami ludzi, $\mathrm{z}$ odbytych walk trudem,

Zaiste, że cenniejsze byłyby, im wiotsze!...(DW VI, 386)

They say that the works should immortalize us:

However, this is not what makes them valuable. They,

If they experienced our life along with its misery,

With the jealousies of people, with the hardship of battles fought,

Indeed, the more fragile they were, the more valuable they would be!... 
Thus for Norwid, especially now, art means conferring eternity upon human things. But this alone does not suffice. Art is not there to protect us, to give us all the shape of beauty or for us to take shelter in it. Art is there to record and immortalize what is the best. Only then is it worthy of lasting.

The problem of art and its attitude towards life is also the topic of "Ad leones!", which is Norwid's most mature novella, the one with the least number of problems that are not blended with the formal assumption itself. In both Tajemnica lorda Singleworth and Stygmat [Stigma] there is certain gap which does not allow one to fully give oneself over to the artistic experience. Between the lord's balloon and further consequences in the form of an attack on the spiritual impurity of the civilised savages, as well as between the history of failed love and the referencing theory of historical stigmata there is a certain unjustified leap, a certain lack of proportion. We find nothing like that in "Ad leones!". The change of the sculpture and the poet's ideological commentary are generally in accord, which does not mean that we should not treat this final commentary as an integral part of the work, i.e. something that we must approach, examine and not take Norwid's commenting word for it.

In believing only the poet's commentary, we will have yet another attack on civilizational trafficking, on the venality of bad art. Believing in Norwid's words we impoverish this much richer (than he wanted to impose) content of "Ad leones!". In the sculptor's attitude, silent, not lending himself to anything, agreeing to what people's stupidity is doing to his work, we find an interesting manifestation of Norwid's attitude towards understanding his art, and generally of his attitude of art towards the world.

First things first. The sculptor, in voluntarily altering his work under the influence of other persons, expresses Norwid's characteristic irony of perfect superiority. This is the irony of a man who is so convinced of his correctness, of being misunderstood, that he feels all attempts at stooping to persuade and convert others would only humiliate him. The intellectual disparity is too vast for him to accomplish it. There is nothing left then but to armour oneself with the irony of feigned agreement: do as you wish - we shall see what you will do. Or else, as in a letter to Zaleski, there is an evangelical reply to the strange criticisms of Promethidion: “Tyś powiedział" [Thou have said], and nothing more.

Through its ostensible agreement, this irony takes the opponent to absurd levels, it lets him go too far so that the stance of perfect superiority will appear to end in victory. Through his apparent concessions to the ever new and increasingly stupid ideas of the gathered "experts," the sculptor renders them absurd. For instance, if he only listened to them until the moment the cross turns into the key, it would be impossible to demonstrate their worthlessness and stupidity 
through the use of ironic agreement. It is only thanks to absolute passivity, being adamant until the most utilitarian ideas of the American man that it is possible to expose them through staticity. And here, from a group of Christians thrown to the lions, we came to banking-allegorical "Capitalisation." The grand irony of this passage outclasses those who led to it - not the one who agreed while hiding his superiority. However, if, following Norwid, or more explicitly, following Miriam, we recognised "Ad leones!" as a satire on artistic trafficking, we would most unjustly deliver a blow to the excellent ironic sculptor.

In Norwid's artistic work there are many examples of such irony - one was quoted here - and on their basis we may interpret "Ad leones!" in this way. And again, it is important to note that it is for the first time in this novella that this irony found its most classical expression, perfectly camouflaged, as befits any great irony.

On the other hand, "Ad leones!" is a general symbol of the relationship between art and life. There is something of this symbol in the title itself and in the course of the event being told. It is not only the first Christians from the group in the sculpture that are thrown to the lions - it is the artist thrown to the lions of the world; the fate of a piece of art is a fate of incomprehension, immaturity of the world towards it. There is a complaint that cannot be hidden behind strict irony, there is a pathetic truth that nothing in the world may stay in the state of "dziewicze natchnienie" [pure inspiration]. Even art, which is supposed to protect the most valuable part of our humanity against time. It is not a rebellious protest, which at the same time is an attack, but some inevitable pain, sorrow quenched with a manly sense of necessity, and because of that more memorable and poignant than protests. Finally, it is also concordant with the poet's spiritual tendencies which were indicated as his second old age. This interplay of irony and gentleness of memories (Rome), dominating complaint and masterful narrative of the novella constitutes its irresistible charm.

And if we once again take a look now, remembering Kleopatra and "Ad leones!" in particular, at Norwid's classical third old age, we should be able to better underline its new features: the utter liveliness of its late work. It would not impress us that he had a proud sense of his indispensability, that he did not stop writing without real support - this would be a fate similar to that of Aleksander Fredro, who pretending to have broken his pen was writing for himself, and certainly for the posterity, hiding it in his drawer, but he did not impress us with this literary ascetism, because in no case did his works match the comedies written before 1835 .

And as for Norwid, we must conclude that his sense of self, which compelled him to write, is entirely on par with our evaluation of him. And this parallelism 
is the most important, since as we search Polish literature over for an analogy to Norwid's late work, we can find no one that could be juxtaposed with him. In no other author would the last novella-Stygmat [Stigma] - bind together the course of historical reflection, or would the last poem - "Słowianin" ["The Slav"] - seal the stone fate of the poet with such great irony. This recluse, abandoned alive, remains a recluse posthumously, but a glorious recluse of the living work until his last twitch of the pen. 


\title{
Wacław Borowy
}

\section{Norwid the Poet}

\begin{abstract}
The article provides a synthetic description of Norwid's poetic work preceded by a discussion against a number of erroneous or contradictory judgements put forth in art criticism, originating both from critical attitudes and the antinomies of Norwid's poetry itself. The essential feature of this work is the inseparable connection between artistic and ethical values, as reflected by the key role attached to the category of truth, which structures his poetic oeuvre. One of the most important means of expressing the complex truth about the world and man is Norwid's characteristic irony, which appears in various shades: from cordial humour, through wise leniency, to bitterness and sarcasm. The author also looks at the "darkness" of Norwid's speech, exposing the positive aspects of the difficulties that can be seen in the poetic work. It is in the reader's cooperation where he sees the greatest chance of overcoming these difficulties.
\end{abstract}

Keywords: Cyprian Norwid, poetry, semantics, irony, truth in literature

\section{1}

His contemporaries did not understand him. But in the generation of "grandchildren," after his poetry was so wonderfully discovered by Miriam, understanding it was not any easier. He was first viewed as a great precursor of various later poets (Maeterlinck, J.P. Jacobsen, Wyspiański, etc.). Later came more historical comparisons: with western writers slightly before him or contemporary to him (Edgar Poe, Baudelaire, Carlyle, "disappointed" realists and Parnassians from France, Villiers de l'Isle-Adam, some symbolists). Who was he in Polish literature? According to some, just one more Romantic disdainer of the human "marketplace;" according to others, quite the opposite: a socially aware poet. Some wished to see him as a "fourth bard" alongside the main trio of Polish Romantic bards; some saw him as a positivist who chose his own and somewhat strange paths. In some circles he was admired as a poet of "mystic" depths; elsewhere, he was valued as an "authentist" who wrote poems in a language befitting prose. And that is not all. After the period of captivation and rapture came another wave of criticism, nearly as sharp as it was back when Norwid was alive. The allegations of "darkness" returned. One critic even wrote that Norwid was a poet only for "puzzle lovers." At the same time, analysing the poet's conflict with his contemporaries, level-headed 
researchers began to discover that Norwid was not quite without fault there, demanding too great of an effort from a defeat-stricken society. Finally, the time came that Norwid was presented as a purely historical phenomenon, nearly without any vital significance, and "of no further use" to the future development of Polish culture.

Naturally, the most extreme of those judgements come from people who have no feel for poetry. But even those who have a sense of it, admit the poetic power of only some of Norwid's works. They claim that his "mystery plays," stage "monology" and attempts at historical tragedy were unsuccessful. They say that his larger works are in general mainly unfinished artistic pieces. And such opinions cannot entirely be contradicted.

Yet let us think what the treasury of poetry would have been without "Fortepian Szopena," "Bema pamięci żałobny-rapsod," "Pieśń od ziemi naszej," "Moja piosnka," "Amen," "W Weronie," "Rozebrana" ["Chopin's Grand Piano," "A Funeral Rhapsody in Memory of General Bem," "A Song from our Land," "My Song," "Amen," "In Verona," "Disrobed"], to name just a few examples. Let us imagine for a moment that some cataclysm wiped those works out of print, writing and memories. What a huge loss that would be! Open any recent anthology of Polish poetry and see just how much space is taken up by Norwid's poems.

It is true that this poet, constantly discussed, considered - and rightly so - as a difficult artist, with an immensely individual style, did acquire quite extensive readership circles. Some of his poems - like "Czemu, Cieniu, odjeżdżasz," "Do kraju tego, gdzie kruszynę chleba...," "Tam gdzie ostatnia świeci szubienica” ["Why are you leaving, Shadow," "To that country where a morsel of bread...," "Where the last gallow glows"] - may today be considered as well-known as the best-known works of Mickiewicz. What is more, it is likely Norwid has become the most quoted Polish poet. His words are found in the titles of poetry volumes as well as in the headings of "militant" magazines; his verses are used to perfectly describe certain phenomena in the spiritual life of an individual or society both by the followers and the opponents of his views. Some of his expressions, e.g. about the future being the "Korektorka-wieczna" [Eternal-editor], about beauty being "kształt miłości" [the shape of love], about the globe which is still not quite "przepalony [...] sumieniem" [burnt through [...] with conscience] have nearly become colloquial. Thus, in Norwid's works there are most definitely parts which are not only intelligible, but which can even be found popular. And as Vico had realised back in the 18th century, this feature accompanies every true poetic sublimity (although it is, naturally, not a guarantee thereof). 


\section{2}

The antinomy of difficulty and intelligibility is not the only one found in Norwid. It is striking how many contradictory opinions on his poetry can be found in the studies it concerns, including the most enthusiastic ones. For some, he is deeply traditionalist in essence; for others, a wise glorifier of modernity. For some, he is an arch-national poet; for others, an arch-cosmopolitan one. Some see prophetic pathos as his natural element, others subtle humour and multi-faced irony. Some find his works to denounce life - bah, to even praise death; others see him as the eulogist of heroic, yet unfaltering hope. A few other opinions of a similarly contradictory nature have already been mentioned above.

Most of those contradictions have their source in the one-sided approach of critics who are unwilling to consider the possibility that antinomies may exist in poetry itself, and that they may also find their solutions in that same poetry. Such is Norwid's writing, and his words from the ironic-doleful "elegy" "Na zgon Poezji" ["On the Death of Poetry"] (1877) can be taken as a strong reference thereof

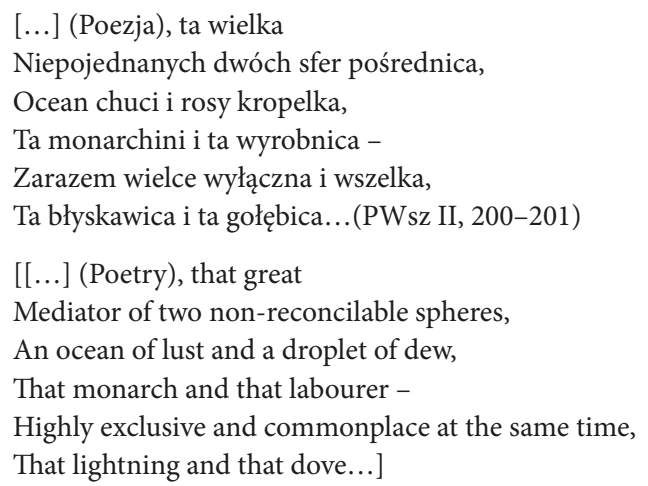

There seems to be antinomy in Norwid's very approach to the tasks of poetry, and of art in general. The speech of Promethidion, ground-breaking in so many respects, can seem archaic in other regards. One may wonder if the phrase that beauty is meant to "zachwycać do pracy" [enrapture into work] and the formula: "Pieśń a praktyczność jedno" [Song and practicality are one and the same] are not just particular expressions of utilitarianism. Some critics believe and assert that Norwid required poetry to have "some didactic minimum." Yet it was not so. Norwid did write didactic works, also in verse, but he distinguished them from poetry proper. Promethidion's words should be taken to have a double meaning: stating the inevitable connection between art and "craft" (technique), 
and as a postulate of its organic connection with the whole of man's spiritual life, that "cało-żywot wieczny i czasowy" [eternal and temporary whole-life], to quote another of the poet's phrases. Words about art being "najwyższe z rzemiosł apostoła" [the highest of an apostle's crafts] and about "najniższa modlitwa anioła" [the lowest prayer of an angel] express the same thing: the distinctiveness of art's domain in spiritual life, as well as its connection to other areas of that life. ${ }^{1}$

Hence Norwid's disdain for all the words "co jak liście lecą" [which fall like leaves], for all the flowers and poetic frills whose sole ambition to be liked, or to astonish. In the early poem "Pismo" ["Writing"] (1841) he said of the written word that "cud wcielonego ducha - to" [it is the miracle of a spirit incarnate], that it is the traditional Christmas wafer which "łamać się trzeba" (PWsz I, 35) [has to be shared]. Multiple declarations from all the other, later periods of his work prove that his attitude towards the word never changed, but in fact only grew stronger. Perhaps the clearest statement proving his attitude towards poetry can be found in the poem "Czy podam się o amnestię?" ["Shall I Request an Amnesty?"] (1855):

I każdy wiersz ten miałem w mojej dłoni,

Jak okrętową linę w czasie burzy.

[And I held each of those poems in my hand,

Like a ship's rope during a storm.]

\section{3}

But perhaps the allegation of intellectualism in Norwid's poetry is true? He did say in Promethidion that he saw art "nie jak zabawkę ani jak naukę" [not as a toy, and not as education], yet one of the most common words in his poetry is Truth. It is a motif-word and a holy-word. The saying Morituri te salutant, Veritas appears several times as a motto, providing more than clear proof of how significant the word is, and what emotional hue it has.

1 Norwid uses the word "art" not only in the sense of artistic creation (which is the only meaning considered in this paper), but also in the sense of an intuitive element (as often happens in colloquial speech). Hence he speaks of "art" in medicine, science, even in the sphere of moral progress. This is the sense found e.g. in the brochure $O$ sztuce (dla Polaków) [On Art (For Poles)] (1861). With that in mind, the border areas mentioned by him are also understandable, e.g. the one in "Psalmów-psalm" ["Psalm of Psalms"], where you read of the "struna" [cord] "co zamyka pieśń, a rzeczywistość odmyka" [which closes the song, and opens reality]. 
Norwid keeps the arrows of sharpest sarcasm for those "poezyje" [poetries] which he defines in the poem "Cacka" ["Pretty Things"]:

Są one dla prawd... czym w oknach sztory,

Na których wstrzymują się promienie,

Wyświecając płótno malowane,

$\mathrm{Z}$ malakitowemi krajobrazy,

Ze źródłami ametystowemi,

Pasterkami owianymi w gazy...

Z ziemią tą... co - nie dotknęła ziemi! (PWsz II, 131)

[Those are for truths... what for windows are the curtains,

On which sunrays stop,

And illuminate a painted canvas,

With malachite landscapes,

Amethyst springs,

Veiled shepherdesses...

With land... which - never touched the earth!]

Any illusory "consolations" are foreign to Norwid. Why write lulling "tales?" To write "Że wszystko toczy się, jak kute koła,/Że wszystko pięknie" (PWsz I, 398) [That everything turns like iron-bound wheels,/That everything is fine] would be to sanctify spiritual wretchedness: Vanitas vanitatis. It is better to see even the worst human wretchedness, "Ale bez kłamstwa - ale w prawdzie nagiej [...] Bez dekoracji cnót, wiary, mądrości” (PWsz I, 218) [But without lies - but in its bare truth [...] Without the decorations of virtues, faith, wisdom], as he presents the matter in a letter from America written in 1853, in loftily grave verse. Even cynicism is better than a lie; hence Norwid quite often defends cynics, and Diogenes is one of the most warmly treated figures in his works.

In his most effusive poem, Norwid writes of his longing for people "co mają tak za tak - nie za nie -/Bez światło-cienia" (PWsz I, 224) [who take yes for a yes - no for a no / - Without shadows]. And the main goal of poetry is, in his view, to express truth: "Odpowiednie dać rzeczy - słowo!" [To name each matter by its rightful - word!] ${ }^{2}$ - as he said in the poem "Ogólniki"["Generalities"], serving as an "introduction" to perhaps the best of Norwid's works, the collection Vade-mecum.

Truth it is, then. But in what sense? After all, a poet employs opinions which are clearly untrue, fantasies, metaphors, etc. In that respect, Norwid is no different than other poets. One could even point out the fact that he uses traditional

2 English translation by Danuta Borchardt in collaboration with Agata Brajerska-Mazur, in: Cyprian Norwid, Poems (New York: Archipelago Books, 2011), p. 13. 
"poetic" fictions more frequently than many other 19th-century poets: various "harps," "lyres," "cords," etc., and so, everything that he himself considers (in the poem "Do Nikodema Biernackiego" ["To Nikodem Biernacki"]) "kłamstwo sztuki" [the lie of art]. The above is true, but that conscious "lie" of artistic means actually allows him to show the truth. The poet advises the artists walking among the resplendent views of the world: "Co kłamać wolno, to lepiej skłam od nich" [What you can lie about, lie about better than they do], and that way "kła mstwo zdradzisz kłamstwem sztuki” (PWsz I, 268) [you shall betray a lie with the lie of art].

The spirit of that "lie of art" is imagination - a great power, but also quite dangerous. Numerous of Norwid's works present its insanities, the ease with which it goes astray. Take an example from the poem "W albumie" ["In an Album"]:

Bah!...

Wyobraźnio!... pani Penelopo,

Znam cię - i lekką jak pomykasz stopą

Po spopielonych sercach twych amantów...

Znam cię - i wachlarz twój przerozmaity,

I giest - i słodkich zapiewy dyszkantów,

I moc - i prawdę twą - i - jestem syty...(PWsz I, 154-155)

[Ah well!...

Oh imagination!... Lady Penelope,

I know you - as when your nimble foot

Skips over your suitors' ashen hearts...

I know you - and your mottled fan,

Your gesture - the sweet descants' chant,

Your power - and truth - and - I rest content. $]^{3}$

In Norwid's epic and dramatic works, there are few external conflicts, and if they appear, they are of no major consequence. Their action consists mainly in that some truth is explained and established therein, or that someone (like the protagonist of Quidam) dies in the search for the truth. Norwid's most expressive poems are committed to revealing the "beautiful" falsehoods or illusions and showing the austere (and noble in its austerity) truth beyond them. Monumental examples would include "Tęcza" ["Rainbow"] or "W Weronie" ["In Verona"]. Charming is the story of star-tears shed by the sky onto the graves of unhappy lovers, and charming is the story of a rainbow reconciling feuding houses, but

3 English translation by Adam Czerniawski, Cyprian Kamil Norwid, Selected Poems (London: Anvil Press, 2004), p. 33. 
the truth is that the feuding houses fell into ruin, and the falling stars are merely stones. Poems like "Narcyz," "Bogowie i człowiek," "Święty-pokój” ["Narcissus," "Gods and Man," "Blessed Peace"] (to name just the best-known examples) similarly expose the truth behind illusions.

It happens at times that Norwid provides examples deriving even from scientific truths. This is observed e.g. in the poem "Ogólniki," where the poetic meditation focuses on the roundness of the earth. Those works in particular raised the issue of intellectualism among critics. But the statement: "Ziemia - jest krągła" (PWsz II, 13) [“The earth - is round"] is a symbol of many truths which seem sufficient " $\mathrm{z}$ wiosną życia" (PWsz II, 13) [in the spring of life] - just like its completion ("U biegunów - spłaszczona - nieco..., PWsz II, 13 [Somewhat - flattened - at the poles]) is a symbol of the precision and clarifications which become necessary "skoro puchy kwiatów zlecą" [when the down of flowers has fallen] and "Nawalne gdy przeminą deszcze" (PWsz II, 161) [when the rainstorms have passed]. Those metaphors alone, the tone in which they are introduced, clearly indicate that the matter is not about strictly cognitive truths, but the ones that have an immense emotional echo, such as may even invoke acts of will. Norwid did not propose the common Romantic juxtaposition of head versus heart. He even directly attacked it (e.g. in one of the digressions in Assunta). He sees inspiration which draws only from negation as naïve. Why should emotion not permeate thought? Why should a thought always be cold? The poet "w górę patrzy... nie tylko wokoło" (DW III, 354) [looks up... not just around]:

Znać się mnie nie dość - ja się nadto cierpię, (DW III, 354)

['Tis not enough for me to know myself - I also suffer too greatly,]

This is why Norwid's truths roar like thunder and, at the same time, wipe the sweat of deadly toil from the brow, like Veronica's veils. This is why Norwid's heart throbs with a strong pulse for so many things which can be defined... by abstract nouns.

\section{4}

In the feuilleton Z pamiętnika [From the Diary], speaking of one of George Sand's works, Norwid states ironically that "jednego pięknego dnia, gdy spyta kto na Północy o najnowszą paryską modę, odpowiedzą mu: 'Ostatnia obowiązująca moda jest prostota i prawda... " (PWsz VI, 375-376) [one fine day, when someone in the North asks about the latest Parisian fa sh i on, they will reply: 'The most current fashion is simplicity and truth... ']. He goes on to add: "A gdzież wtedy sklep formuł i gdzie miara prawdy a prostoty" (PWsz VI, 376) [So where 
is the shop of formulas and where are the measures of truth and simplicity]. In his eyes, truth is not necessarily always obvious, and it is not enough for simplicity to be described as simple. Their significance must be measured, they must be placed in some "store." Those who lectured the poet, could not or wished not to understand that; according to his own words (from "List do Walentego Pomiana Z." ["Letter to Walenty Pomian Z."]): "ile? rzeczą jest poczciwą/Różę zwać różą, tudzież pokrzywę pokrzywą" (PWsz II, 153) [how? Right/To call a rose, a rose, to call a nettle, a nettle]. Therein lies one of the major reasons for his tragic "misconnection" with his own era. Yet even this century has not necessarily always found the right measures or the right place. The fact that Norwid was not only a poet, but also a moralist philosopher, does not make the task any easier.

Naturally, one may stop e.g. at the first two lines of "Do zeszłej... (na grobowym głazie)" [“To the Deceased... (On a Tombstone)"]:

Sieni tej drzwi otworem poza sobą

Zostaw - - wzlećmy już daléj!... (PWsz II, 120)

[Leave the door of the vestibule open

Behind you - - let us fly up higher!...]

and, on superficial reading, interpret that exaltation in the face of the mystery of death as a yearning for the grave. Yet a stanza from another poem ("Śmierć" ["Death"]) is no less characteristic of Norwid:

Skoro usłyszysz, jak czerw gałąź wierci, Piosenkę zanuć, lub zadzwoń w tymbały;

Nie myśl, że formy gdzieś podojrzewały;

Nie myśl - o śmierci. (PWsz II, 116)

[When you hear a worm bore a bough,

Hum a song or strike timbals;

Don't think of forms ripened elsewhere;

Don't think - of death. $]^{4}$

Those are the two poles of Norwid's poetic truth. You need to know both to obtain the right "measurement."

It is easy to make a mistake without a "measure." Work is the duty of man, and a condition of his dignity; but Mak-Yks, a protagonist of Pierścień WielkiejDamy [The Noble Lady's Ring], states bitterly and not without the author's clear approval that:

W Babilonie, za Ezechiela dni,

4 English translation by Borchardt, Cyprian Norwid, Poems, p. 57. 


\author{
Najmniej czynnym, zaiste, ten bywał, \\ Kto z załamanymi nie stał dłońmi (DW VI, 121) \\ [In Babylon, in days of Ezekiel, \\ Sometimes the least active one was in fact \\ The one who did not stand with idle hands]
}

The "lie" of art gains dignity in that it is a tool of sincerity. Yet there is sincerity "która prawdę kryje" (PWsz I, 288) [which hides the truth], according to Deotymie odpowiedź [In response to Deotyma]. Details have great meaning - and it is quite "łatwo prawdę przetrącać wachlarzem" (DW III, 343) [easy to break the truth with a fan], as the ironic Assunta states - but there is nothing that Norwid flogs with the whip of satire more than life filled with trifles, gossip literature demonstrating "trinkets" and serving to merely satisfy empty curiosity.

It is thus with all antinomies in Norwid's poetry: between eternally-living history and stifling "non-history," between optimism and pessimism, between the nation and panhuman ideals, between the holy rights of individuals and social duty, between tradition and progress, between spontaneity of art and the irrevocable rigour of composition etc. Those antinomies, striking on the surface but essentially resolving themselves, hold the truth of Norwid's poetic world.

How to express that truth, with its many contradictions and many hues? That question raises the key issue which any reader and critic of Norwid's poetry faces. Of course, when considering the issue, one cannot overlook the influence of contemporary times, and that of closer or more distant tradition. Their elements are discernible and have been indicated above. Malczewski, Zaleski, Mickiewicz, Słowacki, Krasiński - are among the closer ones. Trembecki, Krasicki, Kochanowski, Górnicki - from the more distant past. They are all the masters from whom Norwid's style took plenty. His works were influenced by the ancient classics, as well as by some great modern poets from western Europe. Some influences of contemporary European foreign countries could be felt, as the poet happened to have spent most of his life abroad. Yet the shape of Norwid's expressive means was mainly decided by his own poetic individuality.

A complex truth (and as it has been stated here, Norwid reveals even simple truths to be complex in reality) cannot always be stated simply. Hence, alongside the expressions which "otwierają nam serce" [open our hearts], according to one of Promethidion's characters, "Jak ktoś do domu wchodzący własnego" (DW IV, 99) [like one entering his own home], there are numerous indirectly expressive phrasings, almost veiled. Hence the irony, so immensely typical of Norwid. Its hues are countless: from smiling cordiality, through wise leniency, helpless awareness, mitigated sadness, all the way to boundless bitterness and the sneer 
of sarcasm. Passages from one hue to another are often elusive, and the borderline between truth and illusion (which stands at the heart of irony) nearly nondiscernible. The same motif appears in various emotional colours. Let us take as an example the pseudo-ceremonialism, with which Norwid often treats everyday or minor matters and things. In the fragment of Wesele [Wedding] starting with the words "Początki tego, co dziś balem się nazywa,/Różne sąa" (DW IV, 34) [The beginnings of what is now called a ball,/Vary], wry mockery shines through its humour. The exclamation in "W pracowni Guyskiego" ["In Guyski’s Studio"]: "O jakie głębokie/Są w trefieniu warkoczy sprawy historyczne!” (PWsz II, 194) [Oh how deep/Are the historical matters contained in plaiting hair!] only broadens with a smile the sense of archaeological reflection stated in all seriousness. What a mixture of tenderness, delicate playfulness and bitter melancholy can be found the poems from the fragmentary epic poem Ziemia [Earth]:

Non é maggior dolore, jak wrócić wspomnieniem

Do pewnych herbat, tudzież ciast i konwersacji,

Prawdziwie wielkim dobrze zaprawnych natchnieniem,

Do szkolnych dni, bukietów z róż i do wakacji. (DW III, 56)

[Non é maggior dolore, than to return through memory

To certain teas, cakes and conversations,

Well spiced with truly great inspiration,

To school days, rose bouquets and summer holidays.]

Assunta sees the similar digression of a sophisticated conversation, in which the most important sentence is often interrupted "Aromatycznej pojawem herbaty" (DW IV, 343) [By the appearance of aromatic tea]; lightly started, it ends in the chord of sarcastic dolour. Many more such examples could be cited, similar in image, yet with completely different emotional foundations.

It may be surprising to find so much irony with a poet who often spoke in pure great pathos, like in "Bema pamięci żałobny-rapsod," "Żydowie polscy," "Modlitwa," the poem "Do Emira Abd el Kadera," or "Do obywatela Johna Brown" ["A Funeral Rhapsody in Memory of General Bem," "Polish Jews," "Prayer," "To Emir Abd el Kader," "To Citizen John Brown"]. But his pathos is frequently interwoven with irony, to indicate only the ending of "Fortepian Szopena" or the closure of the poem "Smutną zaśpiewam pieśń" [“A Sad Song I Will Sing”] (1853), unfathomable in its pain, with words describing the "kokieteria ziemi" [coquetry of the earth]. Elsewhere, as can also be seen in some of the previous examples, irony is connected with humour. In this combination it sometimes has a double layer, the upper one critically looking down at the lower one. Its incarnations may be so diverse and so complex in their subtle richness that a reader can take 
as much from them as he (or she) can afford, to quote one critic. With Norwid, irony is truly "bytu cieniem" [a shadow of being], according to the words of a poem concerning this very topic. It cannot be understood by someone who has no sense of irony. It did happen that even eminent critics fell victim to that, if only in seeking it out where it did not exist. For instance, it is difficult to agree with one who sees some ironic equation of God with nothingness in the poem "Do zeszłej" - "Tam gdzie jest Nikt i jest Osobą" (PWsz II, 120) [There, where is No-body, and is a Person." There is enough proof that Norwid's religious faith was not - ironic. Here (just like in the similar words from the poem "Dookoła ziemi naszej" ["Around Our Land"]: "I znajdziesz tego, który nie istnieje" (PWsz I, 126) [And you will find the one who does not exist]), one has to keep in mind literary tradition, which differentiated the existence of the Creator from the existence of the creations with a paradoxical combination of words.

Undoubtedly, Norwid's irony is one among various difficulties in accessing his poetry.

\section{5}

Norwid's expression presents one more difficulty. The truth, posited as ideal, requires precision and conciseness. And thus any wild expansion of imagination is foreign to Norwid's poetry. Its particular character may be revealed by comparing e.g. "Fortepian Szopena" to Słowacki’s "Uspokojenie" ["Reassurance"]. The latter dazzles the reader like a virtuoso performance of a series of variations on one topic. One could imagine more of them, but would not be offended to have it recited in an abridged version. "Fortepian Szopena" cannot be shortened, and no one can imagine it being lengthened. Norwid's descriptions, always suggestive, are never detailed. They are usually limited to a few sketched lines ("Był tam i wojak, bosym podparty dzirytem,/Z ręką chorą, na resztce perskiej zwisłą szaty" ${ }^{5}$ [There was also a soldier, leaning on an unshod javelin,/with a bad arm, dangling on the remnants of a Persian robe]: such is the full image of a man from the Roman crowd in "Dwa męczeństwa" ["Two Martyrdoms"]). If a longer description is offered, it usually serves as more than just a description. Let us take the poem "Do słynnej tancerki rosyjskiej, nieznanej zakonnicy" ["To a Famous Russian Dancer, an Unknown Nun"] as an example. One would be hard pressed

5 C. Norwid. Pisma zebrane. Pisma wierszem. Volume A. Part two. (WarszawaKraków: Jakub Mortkowicz, 1911) p. 495 (quoted here according to the edition Borowy used, on account of the emendations changing the sense of the fragment, implemented in PWsz) [ed.] 
to find another such description of dance in world poetry. But notice that the comparison which ends the description ceases to either compare or describe, and becomes an expression of the poem's major "truth:"

Patrz, patrz! wybiegła jak jaskółka skoro,

Nad śliskie woskiem teatru jezioro,

I trzyma stopę na powietrzu bladem,

Pewna, że niebios nie poplami śladem,

Schylając kibić, jakby miała zbierać

Rosę lub kwiatom łzy sercem ocierać.

Płynniej i słodziej tylko ciekną fale,

Tylko różańców zlatują opale,

Grawitujące do Miłości-środka,

Co zwie się Chrystus - i każdą z nich spotka. (PWsz I, 393)

[Look, Look! she ran out swiftly like a swallow,

On the lake slippery with theatrical wax,

And holds her foot in pale air,

Certain she will not stain the skies with a trace,

Bending over as if she were to gather

Dew, or wipe flowers' tears off with her heart.

Only waves flow more fluent and sweet,

Only opals of rosaries fly in swifter,

Gravitating to the centre-of-love,

Called Christ - who will meet each of them.]

And it is always so with Norwid. The scenic background, the atmosphere of the moment are presented in greatly refreshing images, great vividness and colour (just to mention the "heliotropy szarego obłoku" [heliotropes of a grey cloud] from Assunta, the moon from "Vendôme," peeping out from behind the clouds "Jako atłasu brzeg z zamkniętej trumny" (PWsz I, 112) [like a fringe of satin from a closed coffin], or the conversation in Wędrowny sztukmistrz [Wandering Magician] compared to a jug of blue glass, "rozpływający się" [melting] in the lake), yet the function of those images is only auxiliary. The main goal is to capture matters concerning the deeper aspects of human life, or more extensive periods of history. Those domains are vast and to a large extent - we can generally agree - unclear. Hence, with general conciseness, things are left unsaid, not fully said, or words are given unusual meanings, derived from their etymology.

That is precisely the "darkness" which Norwid was frequently accused of. $\mathrm{He}$ refuted that accusation many times, as well. His explanations are of twofold. One is objective in nature: the poet wrenches the truth from that darkness; it is no wonder it retains some of the darkness. To over-clarify it would be to falsify it. 
Those who demand absolute light "nie znają ironii zrządzeń" [know not the irony of events]: "kto nazbyt odkrył, pewno gdzieś zasłoni" [who uncovers too much, will likely cover something elsewhere]. One of the critics aptly noted that in that explanation, Norwid treats words not "expressionistically" but "realistically," i.e. as something real, consisting of the same elements as the reality it expresses.

The other explanation is subjective in character: not all truths are fit to be shouted out loud. Norwid ironically addresses this topic in the poem "Szczęsna," especially, in speaking of the dark expressions used by one "co matki śmierć donosi komu" (DW III, 65) [who informs someone of their mother's death].

It is certain that there is no intentional darkness with Norwid, as happens with various Mallarméists and their followers, who used it as an "artistic effect." With Norwid it is really, in accordance with both the explanations he offers, only the inevitable difficulty of expression. In his view, the reader can and should overcome that difficulty with kind cooperation. He considered complaints of illegibility an expression of laziness.

Are those words justified, and do they fully explain why Norwid's contemporaries drew away from him? They undoubtedly took little time to refuse to "współutrudzać się" [co-labour] with him. He did not accept compromise. Consternation towards such works as Pieśni społecznej cztery stron [Social Song in Four Pages], or "Jeszcze słowo" [A Word More] is understandable and even shared today. Unfortunately, those were his earliest isolated publications, which decided on the readers' attitude. And that audience did not include anyone who would have liked to revise that early attitude, or simply distinguish it, like the poet himself did (“Ja wiem - że z pieśni mej odleci wiele," (DW IV, 177) [I know - that much will fly way from my song] he said in Salem).

Truly everyone, who has read through Norwid's works in good will, knows the experience of a work which seemed either fully or partially not quite clear, which upon deeper reading and gaining a better sense of the poet's style and imaginary world, became fully illuminated. Also familiar would be the experience of a "very simple" work revealing, after a while, new perspectives, at first indiscernable and unexpected. It ought to be added that even in Norwid's "darkest" works, even those with the least fortunate composition, there are always fragments of great poetic expression. Such fragments are found also in those of his writings which were simply meant to be treaties in verse (e.g. Rzecz o wolności słowa [On the Freedom of Speech]). In a large part of Promethidion the didactics is winged with poetry, like in Virgil's Georgics.

But the misconceptions do not end here. They say that Norwid has many "prose-isms" - not just in his didactic writings, but also in those with clearly poetic intentions. What are we to make of this? True, it happens at times that 
in his striving for perfection, Norwid's verbal expression may be so filtered, so drained of anything that bears the slightest similarity to a "crafted" ornament, to conventional sweetness, to a superficial technical aid, that the sentences left could with little or no change find their place also in colloquial prose. "Nie oglądają się ludzie zadziwieni,/Lecz, jak stali pierw, stoją" (PWsz I, 360); "I niekoniecznie atletą pułkownik;/Prędzej kaleka" (PWsz I, 369) [People do not turn around in surprise,/They stand as they stood before; And the colonel is not necessarily an athlete;/Rather the invalid]. Such sentences are found on numerous pages of the poet's works. They were probably what critics had in mind when they wrote of the "asceticism" of Norwid's words. But one must look at their context to see the true artistic purpose behind that asceticism. First and foremost, one must test his ear. Listen to the rhythms pulsating within them.

Norwid's poetry (just like any other poetry) cannot be judged in isolation from its phonic side. The melic element is intrinsically joint therein with what only in critical simplifications is distinguished as content. The poet himself reminds the reader many times that the "lyre" (sound, or melody) cannot be treated as something separate. According to the words of the poem "Liryka i druk" ["Poetry and Print”], the lyre is "jako żywemu orłu pióro:/Aż z krwią, nierozłączona!” (PWsz II, 24) [like a feather of a living eagle:/Inseparable unless blood is drawn!]. Even the rhythms of true poetry "w środku są, nie w końcach wierszy" [are in the middle, not at the ends of poems]. How paradoxical that seems! But then it is given truth and depth through the comparison: "Jak i gwiazdy nie tam są gdzie świécą" (PWsz II, 114) [like stars which are not where they shine]. This is how Norwid treats what others often call the "versification technique."

One ought to realise just how extensive the scale of Norwid's "lyre" is. From the lulling melodiousness of "Moja piosnka I" and "Moja piosnka II" up to the unbelievable, indescribable rhythmics of Pierścień Wielkiej-Damy, A Dorio ad Phrygium, or the letter "Do Bronisława Z." ["To Bronisław Z."]. That letter alone (1879) would suffice to prove the range Norwid was able to cover with one rhythm: from restrained historical pathos ("Wiek tu który? Który rok? Niedola która?" [Which century is it? Which year? And which misery?]) all the way up to a quiet confidentiality of kindly, slightly ironic dreams of the future:

Zniknie i przepełznie obfitość rozmaita,

Skarby i siły przewieją, ogóły całe zadrżą,

Z rzeczy świata tego zostaną tylko dwie,

Dwie tylko: poezja i dobroć... i więcej nic...(PWsz II, 238)

[Varieties of opulence will crawl away and vanish,

Treasures and powers blow away, whole communities shake, 
Of the things of this world only two will remain,

Two only: poetry and goodness... and nothing else... $]^{6}$

That is the poet.

And the critics? "Zadaniem krytyki," [The task of criticism] Norwid wrote in a letter to J.B. Wagner from 1881, "jest wszystko postawić na właściwym miejscu i otworzyć okno - pozostawiając resztę światłu i czasowi - nic więcej!" (PWsz VI, 538) [is to put everything in its rightful place and open the window - leaving the rest to light and time - nothing more!].

6 English translation by Czerniawski, Selected Poems, p. 92. 



\title{
Jerzy Sienkiewicz
}

\section{Norwid the Painter}

\begin{abstract}
The article provides a concise description of Norwid's creative persona as a visual artist, based on a collection of several hundred works presented at the monographic exhibition organized by the National Museum in Warsaw on the 125th anniversary of the poet's birthday. The author focuses mainly on the analysis of drawings, the largest part of Norwid's visual art heritage, tracing the stylistic changes that they went through over the years and indicating their thematic scope. He also draws attention to the poorly understood sculptural and graphic activity of the author of Solo and stresses the dominant role of watercolours in Norwid's late works. Finally, he tries to situate the artist on the map of 19th century artistic phenomena and currents.
\end{abstract}

Keywords: Cyprian Norwid, art, drawing, watercolours, sculpture, graphics

Do we know, and have we ever known Norwid - the painter?

We know from many sources and his own statements that from his earliest youth he treated fine art as the main objective in his life. In his epistolary confessions from different places and times, we can find expression of his ambition and worry, his pride, but also the sorrow and bitterness which he felt at his contemporary compatriotsnot recognising and not appreciating this area of his artistry.

He only took part in exhibitions in Poland occasionally (in Kraków in 1855 and 1856, and in Warsaw in 1877 and 1879). Word of similar exhibitions organised in France rarely reached the press. Only sometimes did a graphic copy cross the border (however, the sole well-known instance of this is the sad episode when the tsarist censorship sequestered all the copies of the lithography "Solo"). Norwid's illustrations for Polish publishers were almost anonymous. A few of his drawings in woodcut reproductions were published in Tygodnik Illustrowany [The Illustrated Weekly], but this happened by complete accident. Krasiński's medallion (Fig. 15) was not popularised at that time, while the architectural guidelines and drawings for the town of Krzeszowice were of a private nature. Indeed, many of Norwid's drawings, sketches and watercolours were acquired by Poles travelling to Rome, Florence or Paris, they were added to the albums of his friends and female acquaintances, but these works remained in their personal or family collections, accessible only to a limited circle of people. Few works were purchased for Poland. 
Similarly, news of Norwid's work abroad and the recognition he received in the foreign artistic world, different critical opinions, including biting remarks, rumours and false news, only seldom reached the country, and at random. And although there were some interesting opinions full of his praise, such as those of Z. Sarnecki and even J. I. Kraszewski, ultimately, the Polish equivalent of a 19th-century Vasari, a distinguished and well-known art collector Baron Edward Rastawiecki - made only the following mention of Norwid in his Słownik rytowników [Dictionary of Engravers] published in 1886: "A living poet, working somewhat with sculpture, lithography and engraving. He produced a few etchings." In a comment, he rectified the incorrect information "living," but provided the wrong date of his death - mid-January 1882 !

Discovering Norwid, bringing his works back to life and to society, is always associated with the name Miriam. It is not surprising, since Miriam's service is considerable and obvious. Miriam is also the first person to uncover the veil hiding Norwid's output in the area of fine art for future generations. Chimera, Pisma zebrane [The Collected Works] featured rich reproductions of different sketches, drawings, watercolours, oil paintings and engravings, as well as exhaustive information on these and other works by Norwid. Both the thematic (determined for editorial reasons, such as, primarily, the illustration of Norwid's biography or supplementation of written works) and formal scope of this area of Norwid's work was then revealed on a scale that caused a certain concern and chaos; its variety was so greatly surprising and the indicated number of works was huge. Norwid's profile as a visual artist could not yet be clearly characterised at that time. Previous and more recent characterisations were not helpful, while the most contradictory opinions and beliefs about him were based on, among others, less available sources or individual works that were owned by private persons.

Sometimes he was even regarded as a genius, proceeding with the power of a precursor of new ideas and forms. But often he was regarded only as a dilettante, amateur, and to be more precise, an amateur talentless writer with a passion for drawing. In addition, it could often be observed that people were unable to take a stance on his phenomenon. Often, they would shyly avoid commenting on the poet's drawings and paintings, this area of his artistic work was silently omitted or pushed into the background out of fear that it might lead to possible clashes and dissonance in presenting the role of his main material - the written word.

This dissonance was not opposed by Cypriana Norwida Antologia artystyczna [Cyprian Norwid's Artistic Anthology] published by Miriam in 1933 in Grafika [Graphic Arts] and as a separate print. Sixty-three reproductions (of which only nine had been published before) considerably enriched the dossier of Norwid's 
works made available to the global audience. Also undoubtedly, in accordance with the publisher's intention, Antologia [Anthology] was partially opposed to excessively one-sided and hasty characterisations and assessments of Norwid's entire artistic work. However, it must be stated that its material was also, unfortunately, not systematised; it showed, in a broad framework, new surprises and highlighted formal issues which were previously only outlined based on small examples.

Let us juxtapose the so-called Leonardo sketches (e.g. Fig. 15) - which were already well-known at that time, and which in Antologia were supplemented with new items, were overcharacterised - with delicate drawings and watercolours presenting as if incidentally observed figures and contemporary life phenomena: "Dama w jasnej sukni" ["Lady in a Light Dress"], "Dama w płaszczu i kapeluszu z szerokim rondem" [Lady in a Coat and Broad Brim Hat], "Tancerka" [Female Dancer] (Fig. 16) (Antologia, p. 14 and 26). Whereas in the first group we deal with what is almost a caricature drawing, the second group is characterised by the subtlety of artistic means used, similar to the subtlety found in the art of the painter of the life of the Second French Empire - Constantine Guys, whom Norwid did not try to imitate, however. Thus we have a wide range that cannot be captured in the schema of a hasty definition.

In this way, unexpected problems demanding solutions arose on the ever broadening territory of Norwid's fine art works. It can be said we were waiting for the completion of the edition of the poet's writings initiated and conducted with all perseverance by Miriam. Bearing in mind the commentaries published in Chimera on Norwid's activity in the area of fine art, and the descriptions of artistic supplements contained in Pisma zebrane, we felt justified in waiting for the materials of Norwid's extra-literary works that were meticulously both collected and catalogued by Miriam, materials that were expected to help shed light on many pressing questions.

However, the blow of the war reached us also in this domain, although to a certain extent it was parried. Miriam died. The part of his work which was about to be finished, both in manuscript and printed form, perished. However, the great legacy of the entire life of the collector of Norwid's works, which was in danger of obliteration and destruction, was saved. Beside the documentation of thoughts and emotions expressed through words, an important place in this legacy was occupied by sketches, drawings and watercolours, which were also the expression of these thoughts and emotions.

The rescue of Miriam's collection gains all the greater significance, considering we incurred very severe losses in this area. For instance, the lesser known parts of Norwid's legacy kept in the Przeździecki and Krasiński family libraries 
in Warsaw burnt in two phases of World War Two - one part in September 1939 while the city was besieged, and the rest during and after the uprising in September 1944. Other private collections (belonging to W. Horzyca, J. W. Gomulicki, J. Pomorski, Zb. Zaniewicki) shared similar fate, and even not everything from the collections of the National Museum survived - among others, the large watercolour from Sucha "Zdjęcie z krzyża" ["The descent from the Cross"] (Fig. 17), which was deposited there, went missing. We do not know the fate of the collections from the region of Greater Poland, among others, the albums containing several hundred drawings and a cycle of illustrative watercolours which had once been exhibited in Poznan. Perhaps we must accept they were destroyed, just as some of Norwid's works in the Polish Library in Paris were squandered by Germans (except for two albums lent to Warsaw before the outbreak of the war, which by a strange but fortunate twist of fate survived in spite of the post-insurrectionist ravages).

For this reason, Miriam's collection was the foundation of the exhibition organised in the National Museum commemorating the 125th anniversary of Norwid's birth (which is now housed in the National Library), supplemented with the two above-mentioned Parisian albums and the rescued Warsaw collections kept in the National Museum, the Zachęta National Gallery of Art, Warsaw University Library, and E. Kokoszka's and Al. Hryniewicz's collections. Thanks to the borrowed exhibits from the public collections in Kraków: the Jagiellonian Library, the National Museum, the Czartoryski Museum, it was possible to present a deeper systematic review of Norwid's works in the area of fine art, they helped re-address the "problem" of this output from a new perspective.

Despite its richness, the exhibit material has some noticeable shortcomings. Sculpture is represented by the single medallion of Z. Krasiński (Fig. 14), oil painting - by three randomly purchased paintings; it is thus difficult to elaborate on both branches. But also among the numerous drawings and watercolours we will not find many larger compositions and illustrative drawings, which were known even from Pisma zebrane [Collected Writings] and Antologia artystyczna [Artistic Anthology]. By strange coincidence, we will also not find the frequently reproduced, characteristic "Leonardo" types (e.g. Fig. 15). Nonetheless, the abundance of the material is so great that it fills many gaps in our previous knowledge of Norwid's works, and despite this fact it will certainly introduce some order in this complicated area of knowledge about him, at least in determining the research direction.

Thus, more than anything it is finally possible to address the problem of dating individual works and, by extension, capturing the historic timeline of stylistic differences which started to appear in Norwid's fine art output over the years. 
It is probably not necessary to provide proof of the significance of this seemingly formal issue. Not only does dating introduce order, it often allows for posing questions, and eliminates the various intruders introduced to Norwid's legacy. It is not so much out of ill will, but a lack of knowledge and clarity about a coincidental fact that sometimes something found its way into a common set of various files, albums and papers along with Norwid's unquestionable, long-untouched works.

But the chronological examination of Norwid's works also - in accordance with the guidelines - allows us to grasp the very complicated structure of the artist in a most simple way.

Let us consider the pencil drawings from 1838, drawings pertaining to trivial themes (Fat Thursday, hunting, drunkards - Fig. 18, a travelling theatre) grouped into some sets on individual sheets with the almost greeting card layout characteristic of the epoch. Norwid was then 17, he quite skilfully showed off the knowledge he acquired in Warsaw, among others, from A. Kokular or Jan Klemens Minasowicz. It is difficult to see any particular influence of these teachers in these works; their trace can more easily be found in later small portraits. Zoilus (Fig. 19) - a satire on the criticism from 1841 - has the specific characteristics of a drawing prepared - if not repeated - for reproduction in woodcut. It should be considered from this perspective.

The difference between the Warsaw works and those made abroad a few years later is very striking. A different contour line (usually in pen drawings), sharper, often made as if with a woodcarving flair - clearly highlights the outline of the presented objects and figures, shading and deepening them with thick hatching. These formal features, especially strongly emphasised in the curiously ambiguous - characteristic of the Romantic trends at that time - collection Awantury arabskie [Arabic adventures] (Fig. 20, 1848-1849) - admittedly predispose most of the drawings from the 1850s-1860s to be reproduced graphically, principally as watercolours or copperplate engravings. They speak a common language to such a degree that, for instance, a composition on the theme from the epilogue of Irydion (1851, Fig. 21), if it were to be presented only in reproduction, could be taken without any hesitation for a chalcography. At the same time, the contour-like presentation of some figures from those years, their statue-like solemnity - a Jew striding in long robes (1849), the prophet Isaiah (1851, Fig. 22) - their strong, artistic separation from the background and space with a line that was characterised above or with a sharp cut - makes us see those drawings as a sort of transposition of a monumental, noble, solemn sculpture, which was foreign to Classicistic imitations. 
In that period, we will look for painterliness in rather smaller, often accidental sketches and notes; the exception here is the only, unexpected altar composition "Złożenie do Grobu" ["The Entombment"], drawn in Berlin in 1846 under the influence of Overbeck's and his "Nazarethian" companions' ideology which Norwid had previously learned in Rome. Among those, in particular when it comes to portrait figures and caricatures, there are many instances of an as if affected and mnemotechnic tendency to simpler drawing in one direction - to the left. The equal treatment of the latter drawings with other works came to be the source of regarding Norwid as a dilettante artist.

The analysis of the material displayed in the exhibition allows us to speculate that without disrespecting the small sketch, assigning a note or completed composition alongside it, in this first period of his artistic work abroad, Norwid nonetheless, with greater or lesser awareness preferred drawing in its graphic and sculpted form, well-thought-out and matured in the atmosphere of independent self-instruction, assisted by the guidelines provided by self-selected teachers and models of great European art that was learned directly in retrospect.

It is not until the 1870s that Norwid's watercolour becomes competitive and merges with the old direction of his artistic path.

Norwid's watercolour was advertised and - to use Norwid's term - completed in the transparently glazed colouring of delicate copies of the figures of saints from catacombs or early Italian frescos, but mainly in ink-toned sketch projections that recorded the notes of impressions. They read and reflect - in a strangely suggestive and synthetic manner - the beauty of folded robes in an antique sculpture, its noble or solemn gesture. Through them, Norwid - the artist and the poet - opened the distant world of the great past to himself.

These note-sketches, usually collected in albums with a programme-like content structure, are awaiting special study.

Let us return, however, to the unfinished thread and, having put aside the contribution of watercolours to Norwid's artistic output for later discussion, follow the track of Norwid - the draughtsman. In the 1870s, the artist's drawing line is subject to certain change, becoming more and more distinct. Formerly very puritan, often sharp - now it is becoming softer and smoother, it idealises the drawn shape with its outline, and sometimes (as in the profile of a young woman) its contour tries to express an almost unearthly purity. Only when Norwid returns to characteristic types and caricatures (e.g. the drawing from 1844 "Plotki u wodopoju" ["Rumours at the waterhole"], Fig. 23), does he take up the former sharpness in carving the curvature of a grimace and the expression of eyes, sometimes complemented by a telling arm or hand gesture; at the same time, he pulls with nervous, short strokes and highlights strong shadow 
contrasts. Undoubtedly, it was aptly recognised as a Leonardesque passion for the realistic-characteristic shaping of the vision of live man, the face of whom, as in the mirror, reflects the truth. The truth is often brutal, decoded from the wrinkles and expression of the psyche, of the exposed character. The inscriptions that comply with this: Pilate, Nero (Fig. 24), Barabbas... The artist imposes the presentation of the dull, the criminal, the anxiety-stricken etc. even more strongly than the inscriptions.

Similarly, in compositions, such as in the sketch of an author talking to the personification of Literature or Knowledge (1870) or in the rough sea waves with Christ's boat (1876), Norwid does not forget about the advantages of the sharp drawing line which he has been using for such a long time. He still uses it - irrespective of the time - in other select cases as well. However, starting with 1870 Norwid uses an increasingly smooth and soft line, more of a painting stroke than a graphic line, even when he resorts to his particularly favourite form of that time - caricature.

His drawing is not as analytic as it was in the past, it is more synthetic, it resigns from depicting details, but as if it were a shortcut, it makes a quick, admittedly contour-like projection of the figure, highlighting its characteristic or specific features, which evoke a definitive attitude in the viewer towards the figure - laughter, contempt, sarcasm or irony.

These four periods distinguished as a result of a stylistic analysis of drawings, and not clearly delimited by dates, have a common link arising from the artist's humanistic attitude. In this broad timeframe, man is their primary theme: man facing problems of life and death, ethics and religion, man marked by the stigma of history. We can notice this stigma in the dignity of the ancient husband, in the reverie of the biblical prophet, in the solemnity of the Renaissance wise man and artist, as well as in the ordinary hardship and rest that is common to both the contemporary passer-by and the wanderer of the past.

Of course, this attitude of Norwid is manifested not only in his drawings, but in his entire work. Nevertheless, we can observe the effects of this attitude more clearly in the drawing - perhaps owing to the precision of the line and stroke this is the procession of the heroes of the subjects he addressed, overstylised with a great impression of the epochs to which they belong.

In the late 1860s drawing, which so far has dominated Norwid's artistic output, though still constituting the "quantitative" majority, starts to increasingly giving way to watercolour, which is more and more clearly pushing its way to the foreground.

The intermediary here was coloured and toned drawing, which Norwid used not only for the purposes of his scientific notes sui generis, but also in sketches 
(their small, but artistically very interesting group was discussed in previous remarks), further in smaller and larger studies, and in compositional projects. Two women playing with a child (Fig. 25), a mother cuddling an infant - these two beautiful sketches, deriving from the Renaissance representations of motherly love; compositional variants on death walking towards an old man standing next to a child (Fig. 26) - again they speak in this tone of deep humanity which has already been mentioned.

Watercolours in grey tones are used by the painter before and after 1860 for profoundly serious religious compositions based on the Holy Scripture that are archaic in their form, i.e. reflecting the specific pathos of grouping, gestures and movements found in religious paintings by Rubens. Norwid kept many drawing studies and copies of those paintings, which particularly testify to his zealous following of Christ's crucifixion. He must have been captivated by the suggestive truth of the reconstruction of this great Christian act by the Flemish master.

The colourful watercolour expressed Norwid's creative fantasy, making it his most favourite medium of illustration in the last years of his life - for instance, in visually incredible scenes resembling the Renaissance dramas - and, above all, the means to capture the world of children and women, the world separated from reality by its own specific mood. In this watercolour technique the artist was supported by the smoothness of colours filling the contours of figures and objects.

However, it is not only in his watercolour paintings (how interesting when compared with Wojtkiewicz's works!), but also in small coloured sketches that Norwid directs his attention to woman. With reference to the Milan school, he studies the expression of the womanly smile in the outline of the nose and eyes, he tries to decipher female facial expression, and finally gives an impression of the love between woman and child and her heroism (Fig. 27). His humanism is expressed here in a most sincere and general human way. In Polish painting at that time, Teofil Kwiatkowski was perhaps the only of Norwid's comrades, who addressed this female theme in his art with equal subtlety.

Norwid - the painter and the draughtsman, thus emerging from the framework of the exhibition, has not had the last word yet.

He was a sculptor. Unfortunately, we know only one of his works in this area the medallion dedicated to Zygmunt Krasiński (Fig. 14). However, sculpture similarly to the word that shaped his thought and image - could also quite often be felt in his drawing.

This drawing frequently led us to engraving, because they are related. This is testified by the line of the drawing, as if cut with a burin, also testified by the contrast of light and shadow in toned drawings - after all, it is the favourite language 
of watercolour. But a reproduction from the plate that circulated around the world in many copies was associated with publicité, whereas a drawing could stay in a file, in hiding, or in the materials for one's own studies; besides, often it was more improvised than worked out. "Prawdziwych szkiców robić nie można umyślnie: one się same narzucają..." (PWsz VII, 428) ["Real sketches cannot be made on purpose - they impose themselves..."] - stated Norwid in the album given to T. Jełowicki. Meanwhile, engraving had to be "made." Conceptions or impressions had to be digested and encapsulated in the composition, since the author was as responsible for its distribution, as he was for the printed word, all the more so because he used the language available to all people here.

There are few examples of Norwid's engraving works (e.g. Figs. 1, 6, 12-14). Each newly found work expands our perception of this modest, but important part of his artistic work. Watercolour sometimes combined with a dry needle and a roulette takes first place here. Here Norwid is faithful to himself - original, not searching for effects, but a sincere and serious expression that calls for concentration. And one more remark. Also in this domain, as was the case with drawing and watercolour - despite some features common to all his artistic work, he aspires to autonomy and it must be said he reached it. This already says a lot.

Towards the end of these reflections, being fully aware of how inexhaustible they are and how many problems had to be omitted, one would want to go back to the point of departure and answer the question: Have we already gotten to know Norwid?

His artistic output is clearly outlined, it is unique, governed by its own rules of life and stylistic expression. It is not obscured by the variety of sketches, drawings, studies, paintings, prints and small notes. The last ones especially, from albums, notebooks and diaries, can most easily obscure the real view if their reading is approached in the wrong way and one forgets that they were left behind by a man who had broad interests, Norwid - the artist, the poet, the erudite, the philosopher and the researcher - it should be added here, an insightful researcher, a researcher who in wanting to learn the past epoch or the individual character of a past artist as it were becomes this person, copies them, follows another person's footsteps to reach someone else's truth and repeats that truth, retaining for precision someone else's language. This can sometimes explain the strange incommensurability of the style and level of his two drawings coming from the same period. This is because - we shall repeat again - many of Norwid's drawings are only a copy or note from someone else's document, not his own interpretation or the reaction of his artistic sensitivity.

However, these numerous sketches, drawings, watercolours by Norwid, usually small in forms - as he himself called them "karteczki i złamki" ["little sheets 
and fragments"] - were also the source of the widely-held opinion that his fine artistry should be recognised as amateurish-dilettantish graphomania rather than painting. This opinion may be shared by a disoriented and prejudiced viewer, but also by someone who - with the help of "mędrca szkiełko" [the sage's glass] - is used to evaluating a work of art solely by its dimension and finish. In such cases, the viewer will miss not only Norwid, but also the essence of Piotr Michałowski's art, for whom study and sketch are actually the only complete forms of expression, despite his own ambitions and permanent plans to paint big and "finished" compositions.

Of course, one cannot juxtapose the two artists with such extremely different temperaments and using such different forms, but one cannot ignore the fact that both had been neglected for far too long.

The delayed induction of Michałowski into our cultural and artistic output takes its toll on us even today. His paintings that go beyond the definition of "Romanticism" perfectly broaden the concept of Polish Romanticism and enrich it with thoroughly European, but simultaneously individual features.

Similarly, although on a scale that is incommensurate with Michałowski's work, Norwid's fine artistry breaks with infamous Polish parochialism and particularism. This is revealed in the artist's attitude as described above and in those formal issues, which - although in these more or less inconspicuous toned drawings, quick and telling lines of caricature, in engravings and watercolour attempts - arise from a deep feeling of the separate properties of the language of fine art as compared to the other domains of artistic creativity.

Cała plastyki tajemnica/Tylko w tym jednym jest,/Że duch - jak błyskawica,/A chce go ująć gest. (PWsz II, 223)

[The whole mystery of fine art lies only in that the spirit - is like lightning - and gesture wants to capture it.]

This succinctly formulated credo strongly expresses and characterises Norwid. This is complemented by Norwid's confession about his own works:

Prawdziwych szkiców robić nie można umyślnie: one się same narzucają. Odpycha się je piórem lub ołówkiem i zostaje ślad, notatka, szkic. Są to dlatego zazwyczaj karteczki i złamki, które (here for the addressees he emphasises with sharp sarcasm:przecież) żadnej rzeczowej wartości nie mają. Aucune valeur efféctive! Atoli żaden fotograf nie zastąpi nigdy prawdziwego szkicu. (PWsz VII, 428)

[Real sketches cannot be made on purpose - they impose themselves. They are pushed away by a pen or pencil, and leave a trace, note, sketch. This is why they are usually little sheets or fragments, which (here for the addressees he emphasises with sharp sarcasm: after all) have no material value. Aucune valeur effective! Be that as it may, no photographer can ever replace a real sketch.] 
We should realise that Norwid writes this in 1874, when art is dominated by naturalism, which is so closely related to photography as an aid and supervisor of the painter's point of view! He writes and reflects that entirely in his fine art. And since he does not always manage to cope with the arising difficulties, sometimes excessively trusting his memory, his works often show that he lacked a sufficient study of nature. Otherwise, the same memory - keenly repeating the observed expression, movement and gesture - overcomes this lack of study with its directness of expression.

This is also noticeable in the colouring, where Norwid gives chiaroscuro the dominant role in the structure of a composition. In this way, by achieving high contrast, he is close to the Romantic artists to whom he is also related through his ideological attitude towards works of art.

Therefore, we would sooner find similar accents to Norwid's artistic work (toute proportion gardée) in the art of Delacroix, Daumier or Guys than in the painting of academic traditionalists. But still, it is quite characteristic that even though Norwid appreciated Delaroche, he did not succumb to his influence or imitate him, even in the most appropriate branch in this case - illustration. Norwid did not reach for his store full of equipment, armour and costumes properly selected for the depicted scenes. He did not follow the path of naturalism, which in many different ways was being introduced also in Poland, which in the historical painting of the late 19th century - countering Delaroche's theatricality - simultaneously submitted to his suggestion - the model dressed in authentic attire characteristic of the epoch which he was supposed to represent. Norwid based his historicism - as it has already been indicated above - primarily on the study of the face of an old man juxtaposed with his contemporary. And on this path - through the world of ancient culture, Christ's era and the time of the Renaissance - he searched for an eternal man in order to - in accordance with the words in Promethidion - ask him and "dziejów o spowiedź piękności” (DW IV, 106) ["history for a confession of beauty"].

Although Norwid's fine art touches mostly upon Romanticism, it is not entirely contained within its limits and does not enter the beaten or cleared paths of different trends which at that time were remodelling French painting and then were to spread to entire Europe. Being hostile to some trends, such as Courbet's realism, Norwid seems not to notice some others - such as impressionism, but at the same time he does not allow for his inclusion in naturalism, which was foreign to him. He stands alone. 



\title{
Wacław Borowy
}

\section{Leading Motifs in Norwid's Poetry}

\begin{abstract}
The author emphasizes the importance of historical themes in Norwid's work, expressed both in the significant number of works devoted to great contemporary and outstanding figures in the past and civilizational changes as well as in the ability to picture the cultural backdrop and render historical atmosphere. At the same time, he draws attention to the poet's predilection for embedding modest figures, minor events and objects with important meanings, which makes it possible to call Norwid a "poet of history" as well as a "poet of atoms." It is between the atom and the cosmos, which mark the boundaries of Norwid's work, where the main field of his poetic attention extends: the kingdom of man.
\end{abstract}

Keywords: Cyprian Norwid, poetry, motif, history, humanism

\section{I}

Arguably, one can sense the whirlwind of history pervading the entire poetry of Cyprian Kamil Norwid. Besides the word truth, history itself - including related concepts - is one of the most frequently recurring motifs in his work; indeed, these are poetically the most highly charged. Anyone familiar with Norwid's oeuvre will readily recall lines such as: " $\mathrm{Z}$ wysokości dziejów patrzę/Na rzecz ludzką" ["From the vantage point of history I observe human affairs"] ("To rzecz ludzka," PWsz I, 63 [“It is a Human Matter”]), “Dzieje - jak szczenna na zlężeniu lwica" ["History like a pregnant lioness in labour"] ("Do władcy Rzymu" ["To the Ruler of Rome"]), "Czujesz dzieje, jak idą, niby stary na wieży zegar" ["You can feel history passing as upon an old clock tower"] ("Do Bronisława Z." [“To Bronislaw Z"]), "wielka historii zniewaga" ["the grand insult of history"] (“O sztuce dla Polaków. Dedykacja” [“On Art for Poles. A Dedication”]), "potopy historii" ["deluges of history"] (Promethidion [Promethidion]), "dziejów praca" ["the labour of history"] ("Czasy" ["Times"]), "dziejów zaciąg" ["the conscription of history"] ("Bohater" ["Hero"]), "historii oklask" ["the applause of history"] ("Polka" ["A Polish Woman"]), "zmarmurzający się tom historii" ["the book of history solidifying in marble"] ("Wczora-i-ja" ["Yesterday-and-I"]), "msza dziejów" ["the holy mass of history"] (“Co robić?" ["What to Do?”]). These expressions appear in the context of various emotions, and are often delivered with great solemnity, e.g. in the poem on Dembiński, who stands in a place where "czujny dziejów styl - nikomu nie uwłóczy" ["the vigilant style of history affronts -no-one's dignity"], or in the poem "Sariusz" ["Sarius"], which ends with 
the words: "A wiatr, od Azji, szczeka:/Historia żyje!" ["And a wind from Asia rustles and barks: History is alive!"]. Sometimes, however, these remarks provoke "philosophical" laughter, as in "Laur dojrzały" ["Mature Laurel"]: "A co? w życiu było skrzydłami,/Nieraz w dziejach jest ledwo piętą" ["What was wings in life could be a mere heel in history"], or in the bitter lines from "Eposnasza" ["Our Epic"]:
A śmiech? - to potem w dziejach - to potomni
Niech się uśmieją, że my tacy mali,
A oni szczęśni tacy i ogromni, (PWsz I, 159-160)
[And laughter? - that comes later in history - these are future generations Let them laugh at our smallness,
Feeling so happy and enormous,]

Many outstanding lyrics by Norwid are dedicated to some of his great contemporaries - Pius IX, Markos Botsaris, Emir Abd el Kader, John Brown, Adam Mickiewicz, Fryderyk Chopin, Józef Bem, Adam Czartoryski, Henryk Dembiński, Władysław Zamoyski and Andrzej Zamoyski. Norwid’s works also contain echoes of many contemporary political movements and events, from the Spring of Nations to the Franco-Prussian War. Contemporary events form the core subject-matter of the following poems: "Psalm wigilii" ["Christmas Eve Psalm"], "Amen," "Socjalizm" ["Socialism”], "Do władcy Rzymu” ["To the Ruler of Rome"], "Pieśń od ziemi naszej" ["A Song from our Land”], "Odpowiedź do Włoch" ["A Response to Italy"], "Czy podam się o amnestię?" ["Shall I Request an Amnesty?"], "John Brown," "Wczora-i-ja," ["Yesterday-and-I”], "Improwizacja na zapytanie o wieści z Warszawy" ["Improvisation on the Request for News from Warsaw”], “Żydowie polscy. 1861” [“Polish Jews. 1861”], “Na zapytanie: Czemu w konfederatce? Odpowiedź" ["Response to the Question: Why wear a Fourpointed Confederate Cap?"], "Święty-pokój” ["Blessed Peace”], "Syberie” [“The Two Siberias"], "Tymczasem" ["Meanwhile"], "Pamięci Alberta Szeligi [...]” ["In Memory of Albert Szeliga [...]”], "Fortepian Szopena" ["Chopin’s Grand Piano"], "Dedykacja” ["A Dedication”], "Encyklika-Oblężonego. (Oda)" ["The Encyclical of the Besieged. (Ode)"], "Do spółczesnych. (Oda)" ["To My Contemporaries. (Ode)"], "Jeszcze Francja nie zginęła!" [“France Has Not Yet Perished!"], "Co robić?" and "Rozebrana" ["Disrobed"]. This list includes only the most outstanding works. There are also numerous poems dedicated to major historical figures from the past or at least mentioning them briefly or alluding to their existence in some way. In Norwid's works we meet figures such as Moses, Homer, Socrates, Plato, Spartacus, Caesar, Cicero, Saint Paul, Marcus Aurelius, Columbus, Adam Krafft, Raphael, Michelangelo, Tadeusz Kościuszko and Napoleon. Some of them make 
more than a single appearance. Most of Norwid's longer poems are historical in character - the sole long poem Quidam, and dramas including Krakus, Wanda, the lost Patkul, Tyrtej [Tyrtaeus] and Kleopatra i Cezar [Cleopatra and Caesar].

When it comes to expressing emotions relating to specific historical events, Norwid's expressivity is invariably acute and incisive. Let us consider, for example, several poems from the Salem cycle, written in 1852:

Apokalipskie spięły się rumaki,

A od narodu lecą do narodu

Spłoszonym stadem legendy i znaki...(DW IV, 185)

[Steeds of Apocalypse are spurred on,

From nation to nation fly

Legends and signs, like a drove running scared...]

These lines express the atmosphere of the years following the frustration of hopes raised by the Spring of Nations. This is how he had described his native country of Poland, just a short time previously, in the poem Pieśń od ziemi naszej [A Song from Our Land]:

Więc mamże nie czuć, jaką na wulkanie

Stałem się wyspą, gdzie łez winobranie

I czarnej krwi?... (PWsz I, 124)

[Am I not to feel what kind of island

On a volcano I have become, in a harvest of tears

And black blood?...]

These are the words of a poet frequently criticised for his abstract style. At the same time, however, Norwid offers evocative images depicting transformations of mores, and he renders historical detail exquisitely. Consider the introduction to his long poem Emil na Gozdawiu [Emil in Gozdawie]:

To nie czas twardych w żelazie Mieczników,

Zamczysk, sterczących nad sioła i chaty,

Chrzęstów chorągwi, sprawowania szyków;

To nie Epoka Lechickiej Krucjaty -

Wstrzymano hordy wschodnich najezdników!...

Ludy i ludzkość w nowe cele mierzą,

Zamki maleją do wpół rozebrane;

Pałace na nich z udawaną wieżą,

Wały się w parków zamieniają ścianę,

Śród których sarny niepłoszone leżą. (DW III, 361)

[It is not the time of steel-hardy Swordmakers,

Castles towering over hamlets and cottages, 


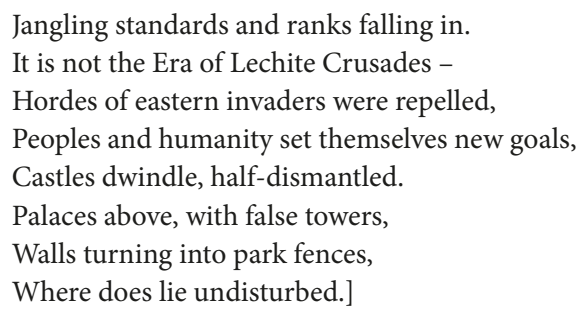

Numerous examples of this kind could be quoted. Clearly, such background images evoking a historical atmosphere cannot be regarded as merely ornamental in Norwid's works. It is characteristic of this poet that even while discussing great historical figures he does not focus his creativity on their individual dramatic situations alone. All his works embrace broader masses, greater social forces, and general trends in civilization. His drama Kleopatra i Cezar has been compared to Shakespeare's Antony and Cleopatra. It has been pointed out that whereas the latter is a drama of several great personalities caught up in historical events, Norwid depicts above all the impact of tradition, mores, beliefs and political and social interests on the masses as well as on great individuals. In Quidam, every character represents some cultural feature of the period. What we encounter in this work is primarily mass movements, the actions of individuals being merely secondary. Similarly in Tyrtej. The legend of Wanda was given a different interpretation by Norwid, who fused her personal story with the transition from paganism to Christianity. Characters like Rytygier, Skald, the Jew (and many others) give voice to the various cultural developments taking place in their epoch, as do the characters in Quidam. Rakuz and Krakus - protagonists in Norwid's second mythological drama - are not merely discrete individuals but also representatives of two different types of culture. The same is true of those works by Norwid which are set in his own time. Emotions are universal, but all conflictual situations are conditioned by the morality prevalent in a given epoch. This applies to Noc tysiaczna druga [The Thousandth and Second Night], Miłość-czysta [...] [Pure Love...], Pierścień Wielkiej-Damy [The Noble Lady's Ring], Za kulisami [Backstage], and all short lyrical and epic works written in verse or in prose. Even Norwid's definitions of tragedy and comedy are telling in this respect. In a commentary to Krakus, he argues that tragedy consists in "uwidomienie fatalności historycznej, albo socjalnej, narodowi albo wiekowi jakowemu wyłącznie właściwej" (DW V, 167) ["presenting the specific historical or social fate of a given nation or epoch"]. In the introduction to Pierścien Wielkiej-Damy, he defines haute comédie as a work in which "cywilizacyjnacałość-społeczna, jakoby ogólnego sumienia zwrotem, pogląda na się" (DW VI, 
110) ["an entire civilised society turns its conscience on itself and observes itself in the mirror"]. The buffo comedy, Norwid continues, is different only in that one social class is observing another. The point here is not to assess the validity of these definitions but simply to highlight the emphasis he places on historical factors.

Generally speaking, every detail of Norwid's poetry involves a sense of encumbrance with the past, confirming that "przeszłość - jest to dziś, tylko cokolwiek daléj" ["the past is in fact today, only a little further away"] (as we read in the poem "Przeszłość" ["The Past"] from the Vade-mecum cycle, PWsz II, 18), that "za odległe gdzieś rzeczy -/Dziś włosienie kaleczy" ["we are suffering today for things from the past"] (in "Wigilia" ["Christmas Eve"] DW IV, 11), and that those who bewail the present day are actually, like Absalom, hanging by their hair from the hands of those "co z dawna umarly" ["who died long ago"] (as declared in the poem "Wielkie słowa" ["Big Words"] PWsz I, 113). One could quote many similarly expressive poems by Norwid, in which emotion is centred around the same unceasing awareness of the long, unbroken chain of relationships linking all human affairs throughout history.

Even the most personal feelings, those that so often lead many other poets to alienate individuals from society, bringing them closer to nature, do not lack historical accompaniment in Norwid's works. This is true not only of friendship but also of love. Consider, for example, the love story told in Assunta (canto IV, stanzas 7-8):

Nad Eufratem byłem z nią, gdzie piaski, Jedyne drzewko w gruzach Babilonu I u Piramid na rozłodze płaskiéj,

W Nazaret, równym dziewiczemu łonu, Krytemu biało, w zieleniuchne paski W Grecji, fijołki rwąc u Partenonu, Gdzie w marmurowe wargi Ideału Pszczoła brzęcząca zachodzi pomału... O zachodzącym słońcu nadtybrowym Byłem z nią w rudych, wieczystych ruinach; W Giulietty mieście - pierwej w Apeninach, I nad Dunajem smętno-Owidowym; Bywałem w wiekach razem i w godzinach Żywej historii czarem Sybillowym Gdzie Scyta klacze doi - kędy Geci Ciskają kręgle, naiwni jak dzieci... (DW III, 350)

[I was with her at the sandy shores of the Euphrates, A lone tree on the ruins of Babylon - 
And at the Pyramids, on a flat plain, In Nazareth, equal to a virgin's womb, Covered in white, with bold green stripes In Greece, picking violets at the Parthenon, Where the marble lips of the Ideal

Are slowly scaled by a buzzing bee...

At sunset, on the shores of the Tiber, I was with her in the russet, eternal ruins; In the city of Juliet, earlier in the Apennines, And over the Danube, sulking like Ovid; I used to visit the centuries and hours Of history come alive with Sybille's spell Where Scythians milk mares, and Goths Hurl skittles, naïve as children...]

Norwid's local preferences also always feature some historical accents. His Warsaw, for example, is monumentalized - epitomized on the one hand in the form of a parish church, "patrycjalne" ["patricians"] houses, "Zygmuntowy w chmurze miecz" ["Sigismund's sword in the clouds"] and Cossack regiments pounding along the streets (in "Fortepian Szopena"), and on the other - in the strange emblem of the siren, and a rare concept - cobblestones that do not shine with blood and tears. This is not the Warsaw of vistas and moods - it is a city of great history.

However, historical relations are never treated by Norwid as deterministic. The significance of human will is never expunged from them. In his poetry, people are burdened with the heritage of the past, which is both good and bad. The human task would consist in acknowledging this legacy and managing it. History does not involve passive subordination to the inevitable consequences of events from long ago, but rather the experience of the great drama common to individuals and entire nations, indeed all civilizations. French Parnassian poets - Norwid's contemporaries - would often praise history as a spectacle worthy of our contemplation. This view was also shared by the Russian poet Fyodor Tyutchev, in whose poem "Cicero" we read: "Fortunate is he who came into this world/At fateful times!/Summoned by the beneficent gods/To partake of their feasts./Witness to their exalted spectacles,/Party to their inner councils,/ An earthly yet celestial dweller,/He drank from their cup of immortality!"1 Poems exemplifying such a contemplative approach to history seem unthinkable in Norwid's case. Whenever he praises a hero, it is in order to express solidarity

1 Translation by Patrick Corness. 
with the idea of his deed, and to suggest to the reader the inevitable consequence of apotheosis, calling "Dalej - dalej" ["On-on-"], as in the ending of the poem "Bema pamięci żałobny-rapsod" ["A Funeral Rhapsody in Memory of General Bem"]. "Zaiste - być aktorem trza i być w Teatrze" ["Indeed - one needs to be an actor and to be on the stage"], as Rzecz o wolności stowa [On the Freedom of Speech] argues (canto II). This is why Norwid wrote a dithyramb in praise of John Brown, the heroic founder of the Black American liberation movement, and paid poetic homage to Emir Abd el Kader, the chivalrous Muslim who came to the defence of people representing a different religion and a different nationality. This is also why he dedicated a funeral rhapsody to Bem, who would "chase with spears" after "many ideas" in the name of Humanity. Further, Norwid reveres Czartoryski for his untiring work for the nation. The same applies to all the historical heroes he writes about - these figures always display greatness not only in terms of courage or the scale of their achievements, but also in terms of the certitude shown in their actions. The greatness of Emir Abd el Kader consists - in the eyes of the poet - in the fact that he "konia swego dosiadł w czas" ["mounted his horse at the right moment"]. Bem's deeds are symbolized - for the very same reason - by his "rumak" ["steed"]. Therefore, it seems that this "steed" could be still spurred on with a spear, "jak starą ostrogą" ["as if with an old spur"] after the hero's death. Even Saint Paul is portrayed as a rider on an open field, bent over on horseback, in a column of light ("Salem"). In the same poem, his vision of future heroes also takes an equestrian form: "Rycerz raz jeszcze płaszcz oblecze nowy,/ Narodów wiele Miłością obejmie" (DW IV, 185) ["The knight shall once more don a new cape,/And embrace many a nation with love"].

These last words are an outstanding example of Norwid's approach to history. In the world of his poetry we are always reminded that history has its "conscience" ("Czasy"), i.e. that "dziejów mądre są ekwacje" ["historical equations have their wisdom"] ("Salem"), or that history "pozornie są za męt,/Gdy w gruncie są: siła i ładność szeroka" ["only seems to be cha otic,/whereas it is in fact strong and sweepingly beautiful"] (“Żydowie polscy. 1861"). Perhaps this is why humankind is destined to square accounts with history. This is what the sand in the hourglass whispers to the narrator of the short story Garstka piasku [A Handful of Dust]: "Wiedz, że to przez tradycję wyróżniony jest majestat człowieka od zwierząt polnych, a ten, co od sumienia historii się oderwał, dziczeje na wyspie

2 Norwid's poetry and the "universally human philosophical lyricism" of Tyutchev (and of several other poets of the nineteenth century) are also compared (though for other reasons) by K.W. Zawodziński in "Uroczystości Norwidowe," Myśl Wspótczesna, 7/8 (1947), p. 149. 
oddalonej i powoli w zwierzę zamienia się" (DW VII, 98) ["Know this: it is tradition that separates the majesty of humans from wild animals, while those who detach themselves from the conscience of history run wild on a distant island and slowly turn into animals"]. ${ }^{3}$

This concept of history allows us to put people of deeds and artists on a par. The greatness of Chopin did not lie in the fact that in his art he expressed not merely Polishness, but a specific kind of Polishness - "Polskę - przemienionych kołodziejów!" ["The Poland of wheelwrights transformed into kings!”], additionally conceived in the perspective of history's "wszechdoskonałość" ["universal perfection"]. The greatness of Mickiewicz lies not only in his mastery of words, but also in the fact that as a master of words he cast "perłowych tęczę ziarn" ["a rainbow of pearly seeds"] of "Miłość i Wiara" ["Love and Faith"] ("Salem"); as he was departing from this Earth, "Kochajmy się wyrzekłszy przy zgonie" ["He would say on his deathbed: let us love each other"]. Norwid was even willing to consider Byron's struggle for the liberation of Greece as a greater achievement than his literary output ("Rozmowa umarłych" ["Dialogue of the Dead"]) (juxtaposing in this case two domains that cannot really be compared).

Thus, Norwid displays - to an exceptional degree - a poetic sense of history. This may appear to stand in contradiction to his complaints about the "historylessness" of his own epoch. Anyone who has read him a little more widely would readily recall lines about the "nominalna" ["nominal"] era (in A Dorio ad Phrygium) or other, similar poems that abound in his oeuvre, beginning with the early epistolary poem "Do mego brata Ludwika" ["To my Brother Ludwig"]:

I w doczesności się pijanej gubię,

Nie śmiejąc wiekiem nazwać - i osądzić,

Że taki ogrom czasu można - błądzić. (PWsz I, 71)

[I am lost in this drunken earthly life,

Not daring to call it an age - and judge

That one can go round in circles so long.]

This attitude of protest against one's own age is the origin of a plethora of Norwid's poetic invectives as well as the source of numerous sarcastic poems and satirical elements that abound in his works. This protest is also the source of another type of poem, expressing the pain of historical anticipation, a subject that Norwid

3 There is an excellent treatment of this topic by Mieczysław Jastrun in the introduction to Norwid's Poezyje wybrane (Warsaw, 1947): "He [Norwid] has a vivid sense of the historicity contained in every moment" (p. x); "the historical moment is of interest to Norwid only insofar as it takes on the form of a moral truth" (p. xi). 
mastered in his writing. This is at the root of the entire lyrical meaning of a poem like "Wczora-i-ja" ["Yesterday-and-I"]; one needs to cover one's face with a coffin lid, waiting for the "book of history to be set in marble." In another poem ("Tymczasem") he writes: "Lecz moje dni - to odwłoki,/lata moje - czekanie" (PWsz II, 41) ["But my days are all a postponement, and my years an awaiting"]. One's entire personal life seems like an intermission in the theatre of history. The dramatic character of historical waiting is one of the most original themes in Norwid's poetry.

This specific dramatic nature of his works is linked to a new, special kind of heroism. The knight of "new arms" is not necessarily the one who engages in physical combat - he could be "the one who waits," as is declared half-jokingly in a poem which actually has deep meaning: "Na zapytanie, czemu w konfederatce, odpowiedź." At the same time, "słodycz chrześcijańska" ["Christian sweetness"], which accompanies valour, "wspól-zwycięża duchem" ["co-triumphs in spirit"].

However, it is never the case that a sense of being alienated from one's epoch or opposing its goals leads Norwid to despair, or to doubt the meaning of history. The generally gloomy poem "Do mego brata Ludwika" (1844) concludes, after all, with the shaking off of pessimism ("A jednak ziemi kląć nie będę wcześnie" ["But I shall not curse Earth too soon"]), while the later poem "Salem" compares the "historyless" period with the time of a gospel parable in which the lord leaves his house to be managed by an inept servant; a day will come when he will return and demand to see the accounts. This theme recurs, with a different image, in the long poem A Dorio ad Phrygium:

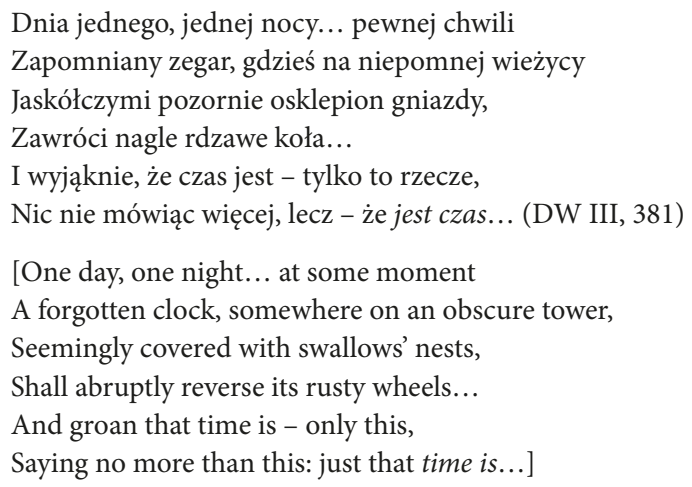

Therefore, despite his own complaints and protests, Norwid's poetic world is permeated with a certainty that there truly are no historyless periods. The ahistorical character of certain epochs is illusory. Even in a time that appears to be purely "nominal," history does in fact speak again and again (as he puts it, "odpomina" ["as 
a reminder of itself"]): a Jew is standing in front of a cottage "jak starożytny obelisk" ["like an ancient obelisk"], old armour is ploughed up once in a while from the earth, or a portrait falls off the wall. All of this is included in historical accounting. The nominal, therefore, has lesser significance than that which is essential, even though it may seem - in its everyday character - to remain beyond the reach of history. What does it matter that Poland is partitioned and invisible in the 19th century (as in one of Norwid's strangest late poems entitled "Rozebrana" ["Disrobed"]), if the rivers Vistula, Warta and Nida do not cease to flow, "oracz wywleka pług" ["the ploughman is out in the field”], and "dzieci o rannej godzinie/Gdzieś do szkó idą" ["children are going to school/s o me where in the morning"]?

The life of history is manifested in everything, including ruins, which constitute one of the recurring motifs in Norwid's poetry ("To rzecz ludzka" ["It is a Human Matter"], "W Weronie" ["In Verona"], "Mogił starych budowa" ["A Construction of Old Graves"], "Modlitwa" ["A Prayer"], "Marmur-biały" ["White Marble"], Pompeja [Pompei], "Ruiny" ["Ruins"], Quidam and others). One of the more distinctive features of his poetry is revealed upon comparing Norwid's poems about ruins to similar works by other poets. One example that suggests itself is Goethe's "Der Wanderer," which was popularized by Mickiewicz's translation into Polish as "Podróżny." This poem praises Nature, guiding a swallow to choose its nesting place among cornices made by a master sculptor, and suggesting to humans how to place "nikczemne domy" ["humble cots"] among the "glorious relics" of past ages, and thus to "używać życia na grobie" ["enjoy life amid tombs"]. ${ }^{4}$ Another poem about ruins that comes to mind while reading Norwid is the lyric "An Italian Villa" by his contemporary Tyutchev, which features ruins that are majestic in their emptiness and calmness, gradually and silently becoming one with their natural surroundings. A group of tourists enters the courtyard and something like a shiver makes the ruins quiver. "What is this?" the poet asks, "Is this caused by some bad life, which has crossed the secret threshold along with us, bringing its raging fever?" When Norwid speaks of ruins, his attitude is the exact opposite of that assumed by Goethe and Tyutchev. He considers ruins to be primarily an expressive document of history, a testimony to the human creative will. Consider the concluding image from Rzecz o wolności słowa ["On the Freedom of Speech"] (part XIV) - that of Palmyra's columns:

\footnotetext{
- Z dala - z dala - nim stopa ma dotknęła piasku,

Zawołałem sam: „Tadmur!...” - przy księżyca blasku

Kolumn tysiąca więcej widząc, których chóry
}

4 Trans. Edgar Alfred Bowring, with modifications. 
Szły tam i owdzie kiedyś w myśl architektury,

Co gdzieś albo istnieje, lub stała się siłą

Myśli ludzkiej, i widzi w niczym, jak coś było. (DW IV, 271)

[- From afar - from afar - before my feet touched the sand,

I cried out "Tadmur!..." - in the moonlight

I saw a thousand more columns, where choirs

Used to go back and forth obeying an architecture

That either still exists somewhere or has become the strength

Of human thought - and sees that something was in nothing.]

It is the same with ruins of national life as with ruins of buildings. Though the country's freedom may be destroyed, public opinion remains alive. Even though this may sound like a banal cliché, public opinion is in fact powerful, posing a threat to all tyrants, violators of laws, and traitors. Norwid never shied away from using so-called prosaic words. Of course, he invested many of them with poetic meanings. However, he could also write - as in the second part of Promethidion an apostrophe beginning in the following way:

Opinio! ojczyzn ojczyzno - twe siły

Są z głosu ludu... (DW IV, 123)

[Opinion! the homeland of homelands - your strength

Comes from the voice of the people...]

He goes on to demonstrate that the significance of this voice consists in the fact that it is only a voice. Like the voices of prophets, it is unarmed and has no material backing. No deceptions, yet it has great power:

To strach! - - milczycie teraz - strach to wielki:

Ten głos, przez potów, krwi i łez kropelki

Ociekający w sumienia naczynie

Pod narodami, jak w mistyczną skrzynię, (DW IV, 123)

['Tis fear! - — You are silent now - the fear is great,

This voice, dripping through sweat, blood and tears

Into the vessel of conscience

Placed under nations, as if into a mystical chest,]

Therefore, what appears to be a lack of history in fact turns out to be merely a variant of it.

\section{II}

In Norwid's poetic universe, just as there are no historyless periods, there are no meaningless people or matters. Almost all of his works open broad historical 
perspectives, although great historical figures do not necessarily have to remain in the foreground all the time. The poet speaks about this himself in "Do Walentego Pomiana Z." [“To Walenty Pomian Z."]:

- Owszem więc, mój bohater - i jeden, i drugi -
Wielkich nie czynią rzeczy, to zaś ich spotyka,
Co ludzi miernych albo małoznaczne sługi. (PWsz II, 154)
[- Certainly then, my heroes - this one or that -
Do not accomplish great things but experience
The same things as mediocre people or lesser servants.]

These lines relate primarily to the so-called homo quidam - the nameless person who moves like a shadow across the pages of the great historical poem. However, they also bear significance in relation to other works by Norwid. His most vivid work for the stage -Pierścień Wielkiej-Damy [The Noble Lady's Ring] - features a rather "insignificant" protagonist: Mak-Yks. The short story Stygmat [Stigma] offers a view of history's great expanse but its starting point is a rather trifling and ordinary matter. Even when Norwid introduces great historical figures onto the stage in his works, they are not always involved with the main plot. Kleopatra $i$ Cezar contains neither grand military scenes nor intense diplomatic negotiations. Indeed, they do take place in the background, but the poet focuses our attention on matters much closer to mundane aspects of the era. This is even more palpable in works set in his own time. In the background of the epic poem A Dorio ad Phrygium we witness the funeral of a Gypsy woman; in Emil na Gozdawiu - the suffering of an old wet-nurse who has been long forgotten. The stories told in his long poems such as Szczesna, Wesele [Wedding] or the longer Assunta could be summarized in just several sentences without employing any elevated expressions, while those narrated in Norwid's many shorter lyrical poems often encapsulate some minor, ordinary event.

However, such events are typically depicted in a way that completely alters the conventional scale of greatness. A colonel may not be athletic but an inconspicuous cripple. Heroes do not necessarily have to be mighty warriors - in fact they are often more like the humble factory technician Jan Gajewski, who died in a boiler explosion. It is not only the mother who elicits warm attachment but also the wet-nurse. Hence, "mapa życia" ["the map of life"] - so unlike standard maps of the Earth - would have "góry i pustynie" ["mountains and deserts"], as we read in A Dorio ad Phrygium, "Przeniosłyby się w krótkie jedne mgnienie oka,/A ocean przepadłby, gdzie ledwo łza płynie" (DW III, 389) ["compressed into the blinking of an eye,/and the ocean collapsed into a single teardrop"]. 
There are no neutral events. Life-changing developments are unveiled everywhere. Everything accumulates somewhere in order to tip the scales at some point. Already in his early poems Norwid clearly expresses this conviction, for example in gnomic form, in the poem "Do mego brata Ludwika":

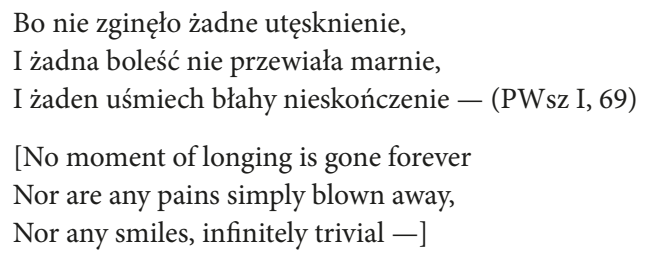

There are many more occasions on which Norwid voices this conviction. The poem ["Do Stanisławy Hornowskiej"] [“To Stanisława Hornowska”] (1857) contains a passage sounding like a continuation of the one quoted above:

I żadna łza, i żadna myśl, i chwila, i rok

Nie przeszły, nie przepadły, ale idą wiecznie, (PWsz I, 266)

[No tear, no thought, no moment, no year

Is gone or lost, but they all march eternally...]

This perspective - afforded, as it were, by Norwid's poetic microscope dissolves the boundary between the unique and the ordinary. As it turns out, "nadzwyczajnego wiele jest u zwykłych" ["the extraordinary abounds in the ordinary"] ("Do mego brata Ludwika"). A plethora of "mistyczne rzeczy i nieodgadnione" ["things mystical and inscrutable"] is manifested in the mundane ("W tej powszedniości”) [“In this mundaneness"].

Indeed, in Norwid's poetry even clear water proves to be wondrous, despite the fact that it can be easily forgotten in the context of the riches of which modernity boasts. However, when a fire breaks out, water becomes more valuable than anything else:

O! wodo czysta... bardzo zapomnieli ciebie,

Służebnej, cichej, prostej, szczególnie ubogiéj,

W której jest błękit niebios, i która jest w niebie. (PWsz I, 277)

[O clear water! You are quite forgotten,

Ancillary, silent, simple, particularly poor,

Wherein is the blue of the skies, as it is in heaven.]

Water is praised differently in the long poem Assunta (accompanied by a glass, just as it appears along with the bucket in "A Toast"):

Wody nie piłem na życiu tak czystej

Ni łza mi kiedy obiła się skorzej

O szklanki gminnej kryształ przezroczysty [...] (DW III, 328) 
[Never in my life have I drunk water so pure,

Nor has my tear ever fallen more eagerly

On the translucent crystal of an ordinary glass...]

Highly expressive also are Norwid's descriptions and similes evoking images of dust, sand or cobblestones. The following example from Assunta (I) is just one of many:

Jak w bruku kamień, stopą coraz inną

Deptany ciągle w ulicy grodowéj,

Niehistoryczny i bez-napisowy,

Wytarte czoło ma, choć twarz niewinną,

Tak - z dniami bywa, lubo nie powinno!...(DW III, 323)

[Like a cobblestone continuously trodden

By different feet on a capital's street,

Unhistorical and inscriptionless,

Its forehead is worn out, though its face is innocent:

The same happens for days, though it should not!...]

A different role is assigned to cobblestones in Quidam (XI). Let us also recall the lyrically charged stones from Warsaw's cobbled streets ("Dedykacja" ["A Dedication"]), "na którym krew i łza nie świecą" ["on which blood and tears do not shine"]. Further, consider the significance of a handful of sand from the said prose poem, or "pyły z posadzki podniesione nogą" ["dust from the floor, stirred up by the feet"] in "Sława" ["Fame"], which have something of "zwłoki człowieka" ["a human corpse"] about them. ${ }^{5}$

Norwid's poetry also demonstrates, on numerous occasions, the impact that minor events and matters can have on people's lives: words spoken too softly or too loudly, interrupting a conversation to take a sip of tea, a fan, a bracelet, or a cap lined with lambskin. One of his frequently recurring themes is that of flowers

5 This tendency in Norwid's writing is also connected with his mode of writing about art, which he frequently employs in his numerous remarks on the subject. He would convey artistic impressions through images related to particular techniques used by artists or craftsmen. When discussing visual arts, Norwid often uses images of a chisel, brush, paint etc. Addressing an excellent violinist (N. Biernacki), he speaks mainly of the wood used to make the instrument, as well as the strings and the horsehair on a bow. The poem about Poland's great composer is significantly entitled "Fortepian Szopena." Even Norwid's two early works on the art of writing carry the technical titles "Pismo" and "Pióro" ["Writing" and "My Quill Pen", respectively], and feature many technical images. This group of themes is closely analysed by Kazimierz Wyka in the book Cyprian Norwid. Poeta i sztukmistrz (1948). 
thrown or sent without commentary. One such flower is the chief memory of the protagonist in Noc tysiączna druga, so striking and tormenting:

Kwiat zerwany w czasie przejażdżki do Amalfi - widzę jeszcze lekką jej rękę pochyloną z konia ku skale... te kwiaty tam czepiają się po obu stronach drogi na ścianach wąwozu... przez ręce przewodnika, który szedł przy jej koniu, otrzymałem kwiat ten... różowy był wtedy... w nieskalanej czystości atłasu swego...

Dziś - zżółkł... oblata z liści, które koroną jego były... i staje się podobnym do pająka, co wysnuł już z piersi przędzę całą ... wszystko się zatrzymuje... osycha... i ginie... a nie wraca... (DW V, 108)

[A flower plucked during a trip to Amalf - I can still see her light hand extended from the horse's saddle towards the rock below... these flowers cling to the valley's walls on both sides of the road... from the hands of a guide who walked by her horse I received this flower... it was pink then... in the purity of its satin...

Today it is yellowed... its leaves are fallen, no longer its crown... and so it becomes like a spider that has drawn all the thread from its chest... all stops... and withers... and does not return...]

"Kwiatek nadesłany w liście" ["a flower sent in a letter"] appears later in the poem Szczesna in a dramatic and ironic light. In the poem "Człowiek" ["A Human"], the author considers the possibilities of the protagonist, and poses questions that have apparently been answered, e.g.: "Czy gdzie z niekrewnych najbliższe ci łono/Jaśminne pąki otrząśnie na ciebie” (PWsz I, 272) ["Is there a place where the dearest bosom that is not related by blood shall shake jasmine buds down on you?"]. Further on, Norwid writes about "dziewice piękne i bardzo rzewliwe" ["beautiful, wistful virgins"], who can "kabalistyczne rzucać w twarz stokrocie" ["throw cabbalistic daisies in your face"]. The nameless Epirote - the protagonist of Quidam - relates the story of a laurel leaf thrown by the philosopher Artemidorus, which was "rozchwytywany" ["snapped up"] by his disciples, and he recalls his own memory (in "Zwitek pierwszy" ["the first scroll”): “Tak niegdyś z polnym postąpiłem kwiatkiem” ["I did so once with a flower of the field"]. In A Dorio ad Phrygium this theme emerges as a leading example in a series of unforgettable similes that remain without reference:

Jak gdy kto ciśnie w oczy człowiekowi

Garścią fiołków i nic mu nie powié... (DW III, 379)

[Just as one throws a bunch of violets

In someone's face without saying a word...]

In this respect, Norwid is certainly the heir of 18th- and 19th-century realism, which he adopted, developing the conviction that details are both characteristic and of crucial importance - a belief introduced by Laurence Sterne. This 
Irish writer himself clearly demonstrated how apparently random reactions or words, even gestures, can have a deeper psychological, moral or social meaning. Capitalizing on Sterne's breakthrough, later writers created an entirely new current in literature, whose representatives include Norwid's contemporary Honoré de Balzac. Even though the Polish poet was fairly hostile to the kind of prose that was written in his own time, often speaking of it in caustic terms, he did in fact share certain tenets with the realist programme. He assimilated them quite early on. All his juvenilia feature themes that originate in the sphere of the simplest and most ordinary of phenomena and matters. His similes and metaphors also usually rely on this sphere. There are common plants and birds, even "zrachowane jaja, kiedy idą w kosze" ["eggs counted as they land in baskets"] and a quill used for a smallpox vaccination. Thoughts are compared to "najemne draby" ["hired bruisers"] who demand payment, and writing to a bird's wing used to sweep up rubbish. Even the most fantastic poem written by the young Norwid - "Wieczór w pustkach" ["An Evening in the Wilderness"] is a fantastic conversation between two ordinary, real objects. The only personified abstraction that appears in it is "Cisza" ["Silence"] (the choice also being quite significant). Already at this stage the poet was aware that all "chwilowe bańki" ["momentary bubbles"] have meaning, and that "każde głupstwo działa, każda mądrość działa" (PWsz I, 42) ["all foolishness has an effect, all wisdom has an effect"] ("Dumanie [II]" ["Meditation II"]). Many aspects of this belief are indebted to the direction taken by Sterne in his literary works. It is of lesser importance whether he learned this from the master himself or from the works of his countless imitators writing at the beginning of the 19th century, e.g. Xavier de Maistre, Washington Irving, Moritz August von Thümmel, Alexander Bestuzhev (pseud. Marlinsky) - his works were translated into Polish when Norwid was young - or even Józef Ignacy Kraszewski, whose early tales are clearly derived from Sterne.

However, the philosophy of characteristic detail, which did not go beyond the psychological or social domain among novelists, was taken by Norwid to a cosmic level and invested with tremendous power of emotion through its elevation to the sphere of religion. These factors also finally explain Norwid's sarcasm, exhibited in relation to people who imagine that "nieśmiertelność jest komą niedzielną,/Co siedm dni prozę by przerwać bezczelną" (PWsz I 290) ["immortality is like a Sunday comma,/interrupting the prose of life every seven days"] ("Sława" ["Fame"]). Moreover, these factors elucidate the claim by "Psalmówpsalm" ["The Psalm of Psalms"] that "i dziś cudy są, byleś się poznał na cudzie" (DW IV, 78) ["even today there are miracles as long as you can recognize them"] or the even more shocking statement that "nie ma grobów... oprócz w sercu lub 
w sumieniu" (PWsz I, 266) ["there are no graves... other than those in the heart or conscience"] ([“Do Stanisławy Hornowskiej”]).

There are no graves, because nothing really dies, neither in the spiritual nor in the material world. Consider the following lines from "Sława" ["Fame"]:

...onej ćmy zielonej atom,

Co wleciał oknem, ledwo dostrzeżony,

I, dyjamentom i we włosach kwiatom

Szepcąc coś, znika... myślicież?... «stracony!...» (PWsz I, 289)

[...that atom of a green moth

That flew in through the window, barely noticed,

Whispering something just before disappearing

To the diamonds and flowers in one's hair... do you think it's lost?]

The poetic quality attributed here to the word "atom" is highly characteristic of Norwid. There are many examples to confirm this. In the youthful poem "Do mega brata Ludwika" ["To my Brother Ludwig"] people are referred to as "atomów władcy" ["masters of atoms"], while thought is likened to "atom boski" ["a divine atom"]. In Pompeja we learn about "ścisłych atomów marmury" ["the close-knit atoms of marble"]. In Pierścień Wielkiej-Damy, Szeliga speaks of "atom fatalizmu" "the atom of fatalism" (Act II, Scene 3), while Maria Harrys admits that she might have had "jakiś błahy atom" ["a certain trivial atom"] of feeling for him (II, 6). In a poem of 1873, enormous flowers were "Śród dzbanów ziemi zielonym atomem" ["a green atom among the vases of earth"] (["Na ofiarowane sobie kwiaty"] ["On flowers dedicated to oneself"]). In Quidam, the Epirote mentions "rozgłośne systemy atomów" (XIII) ["resounding systems of atoms"], while Artemidorus's disciples argue that he is "wolny jak atomy" (V) ["free as atoms"].

Yet another aspect of atoms is revealed in that passage from "Do Walentego Pomiana Z." where Norwid opposes Mickiewicz's Konrad:

Bo jam nie deptał wszystkich mędrców i proroków,

Ale mię huśtał wicher, ssałem u obłoków

I czułem prochów atom na twarzy upadłéj. (PWsz II, 270)

[I have not trampled on all wise men and prophets,

But the wind was rocking me, and I sucked at clouds, Feeling an atom of dust on the face of the fallen.]

This is no longer a hyperbole of smallness, or a symbol of freedom as was the case in the above examples. It is rather an expression of an entire movement in the development of civilization, deeply sensed by the poet.

"Azali Netwonowe jabłko/Prawd nie pouczyło znamienitych?" (PWsz I, 240) ["Alas, has not the Newtonian apple/taught us profound truths?" Norwid 
asks in one of his testamentary works, namely the resigned yet loftily cheerful letter "Do Bronisława Z" (1879). ${ }^{6}$ Indeed, great truths may sometimes arise from details - and these great truths can do quite well without lengthy commentary. Sometimes two words suffice, "i pono to zwie się: «Epoka»./Słów dwa, a z których jest potem treść ciągła -/Jak te, nieliczne: «Ziemia jest okrąła»" (DW III, 349) ["and this is supposedly called an Epoch/two words which make complete sense/like the succinct: Earth is a sphere" (Assunta, IV, stanza 4). In such a world, calling humans "the masters of atoms" ("Do mego brata Ludwika") or "the Jehovah of dust" ("Modlitwa") is not a trivial title.

Thus, just as he is a poet of history, Norwid is also a poet of atoms. He deserves this appellation because whenever he speaks of atoms, we are reminded of their cosmic function. Just like "atom" ["atoms"], "proch" ["dust"] and "pyłek" ["specks"], he often employs themes such as "kula świata" ["the globe"], the planet, interstellar space, "wiatr, co obejma glob i Boga chwali" ["the wind that embraces the spheres and praises God"] etc. In his poems, Norwid characteristically fuses these two sequences of themes. When conjoined, minor phenomena and minor matters acquire greater gravity, while immense ones are scaled down, ultimately reducing the distance between the two: "Na mchu jeśli w odludnym przylegniesz parowie,/Planeta Ci się zaraz pod Twe małe skronie/Zbiega, i czujesz globu kulę za wezgłowie" (PWsz II, 157) ["If you lay your head on the moss in a secluded ravine,/a planet will soon form beneath your temples,/and you will feel a sphere as your headrest" ("Do Walentego Pomiana Z."); "Świat tak się mały stał nam - że pod stopy/Czuliśmy obrót globu” (DW III, 350) [“The world had shrunk so much that under our feet/we felt the turning of the globe"] (Assunta, IV, stanza 9).

In Assunta the combination of cosmic contrasts appears several times in representations of love. Having related his first meeting with Assunta, the narrator adds "Dwoje nas było w ogrodzie na świecie" ["There were two of us in the garden, in the world"] (II, stanza 9). Later, when Assunta sheds a teardrop on leaves of ivy and departs, the narrator speaks similarly about the feelings this evokes: "I tylko ten liść ze łzą i ja byłem/Na świecie całym, jak wielki i błogi" (DW III, 337) ["There was only this leaf with a tear on it, and me/in the entire world, vast and blissful"] (II, stanza 17).

6 The same theme appears in a different role in the second part of Za kulisami, where Omegitt says: "When a child sees an apple falling, it reaches out its hands towards the fruit, as if it were looking for the mother's breast. However, the same event told Newton something entirely different, taking his mind elsewhere...". 
A sense of cosmic expanse conditions in this case appreciation of the value of smaller things or fleeting moments. This truth is expressed by Norwid, in a manner typical of Sterne, in Pierścień Wielkiej-Damy [The Noble Lady's Ring] (Act I, Scene 6):

Zaiste! tylko podróżnik umie

Podróżować i we własnych stronach -

Monumenta odkrywać, lub czynić

Nieznane dla innych spostrzeżenia. [...]

- Rzeczy, obok których bliscy co dnia

Opierają swe rubaszne łokcie,

Uderzają wzrok mój - budzą mój słuch.

Podróżuję wciąż i wciąż... jak w Syrii! (DW VI, 140)

[Indeed! only a traveller can/journey also in his own land/discovering monuments or making/observations previously unheard of. [...]/Things that those close to me rest/ their rough elbows on every day/strike my eyes and awaken my hearing.../I am continuously journeying... as in Syria!]

The extent to which these convictions are characteristic of Norwid is confirmed, among other things, by their vivid stylization in the poem concluding the essay "Krytycy i artyści" ["Critics and Artists"] (1849), which presents a vision of future art - "świątynia przymierza" ["a temple of covenant”]:

A sklepień sieć gwiazdami nieba się przezłoci,

A każda z gwiazd poziomej odpowie stokroci. (PWsz VI, 597)

[And the web of vaults will be gilded by the stars in the heavens, And every star will reflect the profusion on Earth below.]

This is certainly one of the uniquely original voices in Norwid's poetry. Sometimes, he lends it a humorous or satirical tone, as in "Marionetki" ["Marionettes"], "Malarz z konieczności” ["A Painter out of Necessity”], [“Co? jej powiedzieć...”] ["What Shall I Tell Her?"] and other similar "epigrams" in which the poet dons the mask of a worldly man and, as if playing this role, begins complaining: "Jak się nie nudzić? gdy oto nad globem/Milion gwiazd cichych się świeci” (PWsz I, 345) ["How can one not be bored when all over the globe/a million silent stars are shining"]. He also attempts to initiate a salon conversation "o rytmie sił,/ Które sprawują planet korowody" (PWsz I, 316) ["about the rhythm of forces/ that commands the procession of the planets"], or about the fact that "poryroku... nie tylko/Są zamarzaniem i tajeniem wody" (PWsz II, 190) ["the seasons of the year... are about more than/just the freezing and melting of water"], only to be met with the anxiety of those who are only interested in a well-tied tie or in the latest creations of fashionable tailors and hairdressers. 
More often, however, this voice acquires a tone of solemnity. This is the case when the poet addresses Pope Pius IX: "To Ty, na globie Sam!" (PWsz II, 179) ["It is you, alone on the globe!"] and when he pays homage to the abolitionist ("Do obywatela Johna Brown" ["To Citizen John Brown"]), who was supposed to kick away the gallows stool, and along with it the entire "spodlona planeta" ["debased planet"]. This also happens when Norwid speaks - in the poem "Do zeszłej" ["To the Deceased"] - about the Saviour's feet, which are "gwoźdźmi przebite" ["pierced with nails"] and "uciekają z planety" ["fleeing from the planet"], or when he says, while contemplating the map of Europe, that he would like to "Znać stopy Zbawiciela swobodniej oparte" ["see our Saviour's feet more comfortably placed"].

\section{III}

The atom and the cosmos mark the boundaries of Norwid's poetic world. Between the two there lies the area which remains in his focus: the realm of a man.

In the poem "Autor nieznany" ["Author Unknown"], Norwid is naturally referring to himself when he introduces the poet who began to "człeka śpiewać powinność i cele" ["serenade the duty and goals of a man"], thus displeasing the audience. Such a perverse choice of words gives the impression of someone like Jacques Delille or some other moralizer writing in verse. Usually, however, the word "human" appears in Norwid's works in contexts that are highly emotionally charged (although this emotion is restrained, both here and in all other poems). Besides "truth," "history," "globe" and "atom" it is one of the notable expressions in his repertoire. Recalling the benevolence of Lenartowicz, which he enjoyed for many years, Norwid expresses his gratitude to this man in a poem of 1856 in the following way:

\footnotetext{
Niechże Cię miłość-Boża za to czeka,

Nie, żeś pamiętał mnie, lecz że - człowieka. (PWsz I, 239)

[May God's love be your reward for this,

That you remembered not me but a man.]
}

The protagonist of Szczesna ends his last letter, written on the verge of despair, in the following way: "Dwa słowa tylko: pomne... kocham... człeka" (DW III, 77) ["Two words only: I remember... I love... a man"]. Furthermore, the poet uses satire and irony to talk about an archaeological expedition in "Epimenides," where the team examines an excavated grave, takes measurements, examines inscriptions, pots, broken nails and remnants of laurels, forgetting nothing, "nic - - [...] oprócz człowieka" (DW III. 90) [“nothing - - -except humanness 
itself']. One historical figure particularly revered by Norwid is Saint Paul, who was bound like an animal by some pagans, and called a god by others; nevertheless, he persevered in his humanness, abiding "przy wierze,/Że człekiem był" (DW I, 121) ["by the faith,/that he was a man"] ("Dwa męczeństwa" ["Two Martyrdoms"]). To be human is no trifle. It is - as Caesar says in the second act of the drama Kleopatra i Cezar - "zacnośc" ["a privilege"]:

To w dyjademie przejść się pod jarzmem - to więcej

Niżli dość... (DW VI, 328)

[Wearing a diadem while passing under the yoke is more Than enough...]

The "privilege" is something the poet aspires to above all in his poems. In "Odpowiedź" ["A Response"] to the letter from Deotyma (1858), he compares himself to other poets and says, in words that would become widely popularized later: "kto inny ma laur i nadzieję,/Ja - jeden zaszczyt: być człekiem" (PWsz I, 323) ["Let others have laurels and hopes,/For me there is/one honour only: being human"]. In the conclusion of his fundamental lyrical and gnomic Vade-mecum cycle, Norwid contemplates - in poem No. XCVII entitled "Finis" - what signature to assign to the entire work and decides to use the word "śmiertelnik" ["a mortal"].

It is therefore not his main ambition to be an individual quite unlike any others. On the contrary, he wishes to express humanness in its broadest sense.

When Norwid discusses humanness, he often uses language that approximates to Horatian universals, although he deploys a different emotional intensity, as in the poem "Królestwo" ["Kingdom"] (Vade-mecum, XLI):

Nie niewola ni wolność są w stanie

Uszczęśliwić cię... nie! - tyś osobą:

Udziałem twym - więcej!... panowanie

Nad wszystkim na świecie, i nad sobą. (PWsz II, 64)

[Neither captivity nor freedom are able

To make you happy... no! - you are a person:

Your share is - greater!... mastery

Over all that is in the world, and over yourself.]

Many of Norwid's poems, especially those from the Vade-mecum cycle, can be considered as illustrating different aspects of that paradox of universality "Pielgrzym” ["Pilgrim”], "Sfinks" [“The Sphinx”], “Czułość" [“Tenderness"], "Narcyz" ["Narcissus"], "Nerwy" ["Nerves"], "Fatum" ["Fate"], "Harmonia" ["Harmony"], "Święty-pokój" and many others. Again and again he describes situations in which humanness is subjected to a test probing its internal strength. 
Almost all his poems dedicated to poetry or art in general are only part of a larger cyclical poem on humanness. Let us recall for example "Próby" ["Attempts"], where following the ironic blessing of "malinowe" ["raspberry"] or "kalinowe" ["viburnum"] songs, the poem pointedly praises human song as the only one that is actually alive:

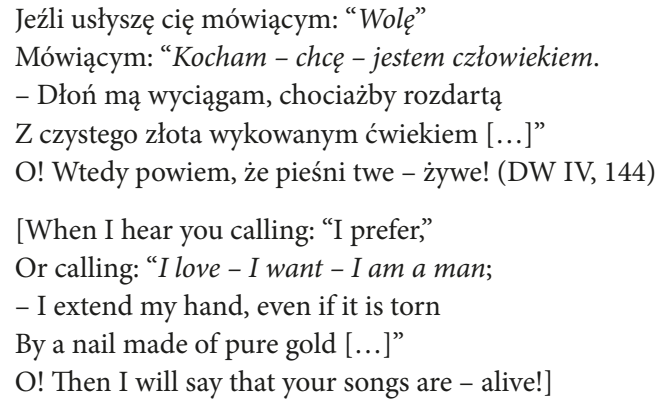

The very epithets assigned to beauty in Promethidion - "kształt miłości" ["the form of love"] or "profil prawdy i miłości" ["the profile of truth and love"] - are of great eloquence.

Another common error made with regard to Norwid is to compare him to the great poets of nature, e.g. Afanasy Fet (which has led some to despair over the Polish poet and praise the Russian one), because it would involve seeking in Norwid's work something which he himself deliberately rejected.

It is not that he had no sense of the beauty of nature or that he was incapable of expressing it. It suffices to recall images of village life from A Dorio ad Phrygium, along with songs of "pijany słodyczą kwiatów bąk" ["bumblebees intoxicated with the sweetness of flowers"], "Pieśń pijana, z kielicha niesiona w kielich" (DW III, 375) ["intoxicated songs, carried from cup to cup"]. These phrases would not disgrace any poem by Fet or Keats. Consider also images of nature from Quidam, e.g. as in the beginning of part XI: "Przez bramę miasta, przez winnic kwadraty,/ Furtki owiane $\mathrm{w}$ roślin aromaty,/Którym bluszcz służy jak zwiewna zasłona" (DW III, 169) ["through city gates, through vineyard squares,/gates shrouded in aromas of plants,/where ivy serves as an airy curtain/guard flowers not planted with human hands"], or the sixth part of the poem "Do L.K." ["To L.K."] dedicated to that "pieśni [...] nieustannej/co każdą wiosnę lutnię swą strojącej" (PWsz I, 357) ["the eternal song [...] which/tuning its lute every spring"], the song which "Naturę śpiącą w długie rzęsy trąca,/Zielonych włosów jej podejma sploty” (PWsz I, 357) [“touches sleeping nature's long eyelashes,/lifting her green braids"]. It is a magnificent song in praise of nature. However, Norwid sings a different song - the song of "obóz ludzkości" ["the human camp"] (as he puts it 
in "Próby"). He turns to the muse "bezwidnego filarem kościoła/Na safirowym utwierdzeniu stoi" (DW IV, 143) ["standing on the sapphire foundation of/the invisible pillar of a church"]. ${ }^{7}$

Bearing some aspects of this question in mind, Kazimierz Wyka wrote in his article "Norwid nieobecny" ["The Absent Norwid"] for the weekly Odrodzenie (1945, no. 19) that Norwid's "natural poetic world" is nothing other than "the objective world of culture." This observation is probably more apt than any comparisons to Fet and Tyutchev. It is accurate insofar as many of Norwid's main themes originate in the world of objective culture, from which he often derives his metaphors and the comparisons used to describe natural phenomena. Already in his juvenilia we find examples such as "łoże chmurnego obłoku" ["the bed of an overcast cloud"] ("Sieroty" [“Orphans"]) and "listek atłasowy" ["a satin leaf”] by a poppy head ("Marzenie" ["A Dream"]); a village lies "jak flet, co w sobie liczne pieśni tłumi" ["like a flute that contains many songs"] ("Wspomnienie wioski" ["Memory of a Village"]); a skylark "zawikłany" ["entangled"] in "tkaniny" ["the fabric"] of mist ("Skowronek" ["Skylark"]); the moon is writing on doors and ceiling beams "białym miękkim promieniem" ["with its white, soft rays"], as if it were a priest writing with "święcona kreda" ["blessed chalk"] on the day of Epiphany ("Wieczór w pustkach"); in the same poem, the moon also pulls a cloud over herself, "jak gdyby rękawem/Łzy ocieral" ["as if wiping away a tear/with its sleeve"] etc. Norwid's later poems also contain many such images. In "Próby", trees "od ziemi jak kolumny rosną" ["grow from the earth like columns"], while in the sky "miękkich gałęzi obręcze/Podobne mają do harf" (DW IV, 141) ["soft hoops of branches/resemble harps"]. In the poem "Do L.K.", nature is to cover its waist in emerald turf as if with a dress, while little birds flying above her form a natural diadem. In Quidam (XVI), the moon would "w przysionek otwarty/ Szerokie składał promienie, jak karty/Księgi, z głęboką uwagą czytanej” (DW III, 215) ["lay its broad beams/in the open vestibule/like pages of a carefully read book"] etc. Even more frequent are similes and metaphors linking human affairs to the objective world of culture. Two poems from Assunta could serve as examples - No. I and No. IV. In the former, the narrator recounts a story about a sweeping monk, saying: "Przed Lessueura tym stałem obrazem" ["I was standing before Lesueur's painting"]; in the latter, as he presents the beauty of his beloved,

7 As Mieczysław Jastrun writes in the book mentioned above, "it is said that Norwid is primarily a thinker or philosopher. That is inaccurate. Norwid is first of all an artist, albeit one to whom the most interesting material is thought, reflection, and the cultural experience of humanity" (p. xii). These words are extremely apt. 
in the words: "Patrzyłem jako Fidias na Dyjanę" ["I was observing her as if I were Phidias regarding Diana"] (the statue of Diana, of course).

Such is the breadth of humanness in Norwid's poetry. It triumphs, on many occasions, over nature. This is even clearer in relation to human affairs. Even in representations of love, the human towers over the lover. When the poet discusses unrequited love (which is most often the case), we hear less about the unfortunate lack of reciprocity and more about sins against humanness - false emotions, coldness of soul, and lack of respect for human dignity. Examples of this are found in "Trylog" ["Trialogue"], Szczesna, Noc tysiączna druga, Miłośćczysta and Pierścień Wielkiej-Damy. Recall the superficial marriage projects in Assunta, involving lies, cynicism, calculation, disregard for humanness and brutality... instances of harmonious love are rare. Moreover, such relationships are either destined to be tragically broken up (as in Wanda, Kleopatra i Cezar, and most probably in the incomplete Tyrtej), or to end as the result of an early death (Assunta).

In Norwid, humanness dominates even over happy love. Mickiewicz once wrote: “My love! What are we talking for?" In Norwid's erotic world such words are unimaginable, even in jest. Indicating yet another link to Balzac, Norwid considers dialogue to be the crucial component of any relationship between a man and a woman, even if it occurs in silence, as is paradoxically the case in Assunta. That is why the dramatic nature of love is expressed in Norwid's poetry through conversations that are out of tune. Particular poetic expression is found in those poems where he presents the paradoxical attitude of a person who is enabled by such dialogue to both see things in a critical light and to indulge in fascination. This happens, for example, in the poem "Malarz z konieczności":

\footnotetext{
Siądźże - i włosy swe grzebieniem zbierz,

Gdy ja - przylegnę na progu;

I będę, jak do feodalnych wież,

Śpiewał: nieznanej i Bogu. (PWsz I, 317)

[Sit down - gather your hair with a comb,

While I sit at the doorstep

And sing, as if to feudal towers,

To an unknown woman and to God.]
}

This is also what happens to Szeliga in much of Pierścień Wielkiej-Damy. A similar situation is also depicted by Norwid in the poem "Co jej powiedzieć?" and in others. This is also the message conveyed in most poems where this "poet of humanness" features as a poet of salons, social life and flirtation. This attitude lies at the origin of some of his most acute characterological poems, as in the case of 
poem L from Vade-mecum, where he talks about those close ones who "znają Cię, jak się litery/Zna - pókiś ku nim zwrócony.../I póki twarzą w twarz przestajesz z niemi/Zaś - ani chwilę już potem" (PWsz II, 76) ["know you only like letters of the alphabet/that one knows as long as one is turned towards them.../recognized only when one is facing them/but, a second later, no more"]. Elsewhere, Norwid talks about certain "people" - in the words of Szeliga from Pierścień WielkiejDamy (Act III, Scene 1) - who cause us, when we depart from them, "Ziemia nam przestaje być okrągłą,/Niesłychanie płaszczy się a płaszczy.../Słońce ma ckliwy blask i mosiężny.../Zieloność jest jak na bilardzie/Sukno czyste, równe i porządne" (DW VI, 206) ["to feel as if the Earth had ceased to be round,/unbelievably flattening out, flattening out,/the brassy sun shines mawkishly.../greenness is like a pool-table/the cloth clear, even and neat"]. Hence the advice given to the artist in the "Sonnet" to Marceli Guyski (1871), which is to represent women in such a way as to depict men's illusions also. A woman ought to be "sobą i ową, jak Ty poglądałeś na nię./Nieustannym zjawiskiem! Ona i nie ona” (PWsz II, 205) ["herself and as you saw her:/a perpetual phenomenon! her and not her!"].

These are the numerous and diverse aspects of humanness in Norwid's work. This deeper current in his poetry is also associated with the ironic words of A Dorio ad Phrygium about reserving the term "human" to denote someone dependent and inferior. In Norwid's poetic world a guilty verdict is also pronounced with regard to the kind of civilization in which the sense of humanness is restricted in such a way as to incorporate only the area of one's homeland, making all peoples seem - each to themselves - "nad wszystkie pierwsze" ["better than others"] ("Vanitas," Vade-mecum, XXXIV). Norwid's biography contained in Brockhaus's encyclopaedia - inspired by the writer himself - rightly states that "pierwsze poruszenie ducha jego jest jako Człowieka, drugie jako Polaka" ["one draws one's first breath as a human being, and only the second breath as a Pole"]. He dedicated many poems to his home country, touching upon its heroic feats, its broad achievements as a civilization, its suffering, and evidence of its dignity; however, he would invariably regard Poles primarily as human beings, considering matters concerning Poland to be part of Humanity at large.

What does Norwid's poetry have to say about the fate of Humanity and its hopes? $\mathrm{He}$ is far from what we broadly call optimistic. One of his poems begins with the words "Smutną zaśpiewam pieśń" ["A sad song will I sing"], which could serve as a motto for many of his poems, which do not prophesy sweetness and light. Consider the significant passage from "W pamiętniku L.A." ["In the Album of L.A."] (1844):

Przyszłości wieczna! Na niewiecznym polu

Do ułomnego śmiejąc się człowieka, 
Tylko mu jeden cel otwierasz - bolu...

I tylko jednę prawdę - że jej czeka... (PWsz I, 75)

[Eternal future! On a transient field

Smiling to an imperfectman,

You mention only one goal - pain...

And only one truth - that it is expected...]

Norwid's lyricism is fundamentally sad. The tone of that sadness is conveyed by the frequently used word "sieroctwo" ["orphanhood"]. However, his poetry is not depressing; indeed, it is never despairing. There is in it a deep-seated stern stoicism, Catholic faith and the hope derived from it. The most painful conclusions are transformed in his works into noble resignation or a prayer-like ascension of the spirit.

“...Ludzie kiedy mię mylili,/Było mi zawsze tym rzeźwiej do Boga,/I rozpiórzały się ramiona moje;/Patrzyłem w zawrót gwiazd, w wieczne spokoje” (PWsz I, 257) [“...When people misunderstood me,/I was all the more eager to turn to God,/and I would spread my arms like wings;/gazing up at the whirling stars, into eternal peace"]. These words come from the above-mentioned epistolary elegy sent from America to Maria Trębicka ([“Do Marii Trębickiej”] [“To Maria Trębicka”]). Consider also a passage from a much later poem "Do L.K.” (1861):

"Gdzie nie ma oaz, oazą ostrogi,

A wiatr gdzie palmy poruszyć nie może,

Bo palmy nie ma, tam, oczy zawróciwszy

Do gwiazd, wystarczy raz zawołać: «Boże!» -

I wiedzieć, że jest w niebie step szczęśliwszy..."

(PWsz I, 357)

["Where there are no oases, or they seem like fortresses, and the wind does not stir any palm, because there are none, you just need to turn eyes towards the stars and call out once "God!"

to know that a happier steppe lies in the heavens"]. ${ }^{8}$

These are Norwid's responses to the raw truth of life. A similar message is conveyed by poems such as "Teofilowi” ["To Teofil”], "Człowiek" [“A Human”],

8 Norwid's religiosity has been examined a good deal, but often inaccurately. One groundless claim is that he was a mystic. See: Wacław Borowy, "Norwid w typie A+M," Przeglad Wspótczesny 1936, No. 10, pp. 113-118. Many apt remarks are contained in T. Makowiecki's "Norwid myśliciel" from the collection Pamięci Cypriana Norwida (Muzeum Narodowe w Warszawie, 1946). 
"Tęcza" ["Rainbow"] and many others. God is present above the world and even his wrath makes the human orphan recall his "najbliższy" ["closest"], "sąsiad" ["neighbour"] and "ojciec ojców" ["father of fathers"].

This attitude is also linked to a vision of laborious, universal duty. Few arrive at the great feast in "górny sklep" ["the upper room"] like the prophet Elijah: on a chariot of fire. So one is forced to forge the axle of one's own cart by oneself, as in one of the more characteristic images in the poem "Do mego brata Ludwika." Elsewhere - in the poem "W pamiętniku L.A." - we encounter the image of a cross that a man needs to hew for himself before they "w ręce go umarłe złożą" ["place it in his dead hands"]. This does not mean that death should be the only human goal - those critics who ascribed such a view to Norwid are deeply mistaken. It would be difficult to find two bodies of works as dissimilar as Norwid's poems and Novalis's death-praising Hymns to the Night. Norwid actually contemplated composing the fourth part of the Divine Comedy, which was supposed to be entitled "Earth." He even wrote some lines meant to be incorporated into it:

Prócz ciemnych piekieł, czyśca pół-ciemności

I blasku niebios - ach, ziemia jest jeszcze... (DW III, 53)

[Beyond Helląs darkness, the half-light of Purgatory And the bright Heavens - O! There is still Earth...]

There is Earth - the place where human beings must fulfil their duties. Death itself does not - by any means - involve a settling of accounts, because it can be either grand or miserable (Norwid offers a poetic contemplation on this subject in the poem "Bohater"). It can shock by its suggestion of shattering but it can also take the form of something complementary, lofty yet cheerful, as in the case of the death of Józef Z., "oficer Wielkiej Armii" ["an officer in the Great Army"], who concluded his life " $\mathrm{z}$ tym królewskim wczasem i pogodą,/Z jakimi kapłan zamyka Hostię w ołtarzu" (PWsz II, 149) ["with the same royal peace and cheerfulness/with which the priest hides the Host in the altar" ("Na zgon śp. Józefa Z." ["On the Death of the Late Józef Z."]).

In this way, the human being-atom who creates history overcomes death, which - as we read in the poem "Śmierć" ["Death"] from Vade-mecum (LXXXII) "tyka" ["touches"] only "sytuacyj" ["situations"] but not "osób" ["individuals"]. "Fatum" ["fate"] of humans consists only in the necessity to confront misfortune. Thus, when it arrives (as in the poem "Fatum" from Vade-mecum [XXX]), it just waits to see "czy człowiek zboczy" ["if the human will turn away"]":

9 Cyprian Kamil Norwid, "Fatum and W Weronie," translated by Patrick Corness, The Sarmatian Review, no. 1, vol. XXXIII (2013), p. 1728. 
Lecz on odejrzał mu, jak gdy artysta

Mierzy swojego kształt modelu;

I spostrzegło, że on patrzy - co? skorzysta

Na swym nieprzyjacielu:

I zachwiało się całą postaci wagą

- - I nie ma go! (PWsz II, 49)

[Instead the stare was fair returned As artists size up subjects top to toe Aware the human had discerned What gain he'd draw from such a foe It shuddered to its very core - - And it's no more!]

Thus, anguish disappears, ceasing to be anguish. ${ }^{10}$ (At the same time, it might be the only occasion on which Norwid embraces aestheticism!)

Having adopted such a stance on life, Cleopatra - one of Norwid's protagonists argues that "miłość zupełna jest zawsze/Szczęsną!... dlatego, że jest!" ["complete love is always happy!... simply because it exists! (Kleopatra i Cezar, Act II, Scene 3, DW VI, 330)]. This attitude also allows one to discover in life the cheerful joy described in Norwid's bizarre epistolary poem that recounts, among other things, play in the orphanage. The account combines melancholy with joy as bitterness turns into cheerfulness, and irony becomes kind-hearted. Children are seizing oranges from a basket; they are still too large for their small hands:

Szczęście - widzisz, mój drogi! - jest - i Ojczyzna - i Ludzkość

(Z pomarańcz bierz dowód... azali Newtonowe jabłko

Prawd nie pouczyło znamienitych?...) - jest i potęga istna sztuki

Żywej wtedy, gdy bliskie umie idealnym znamienować. (PWsz II, 240)

[Happiness - you see, my dear! - is both Homeland and Humanity

(Take oranges as proof... Has not the Newtonian apple

Taught us profound truths?...) - art can be powerful too,

Coming alive when it can show familiar things as ideals.]

In this short passage written in hexameter, which sounds straightforward yet extraordinary, Norwid perhaps captured the essential truth of his poetry and of the worldview he expressed in it. Zenon Przesmycki (Miriam) - a noted expert on Norwid, deserving of our appreciation despite his stylistic mannerisms rightly argued that Norwid displays "a spiritual homogeneity [...] which

10 A subtle analysis of this poem is offered by Stefan Szuman in the book O kunszcie i istocie poezji lirycznej (1948), pp. 113-120. 
becomes constantly more intense in the bravery of its tone, finally reaching [...] the immense $[\ldots]$ natural solemnity of a man to whom 'the entire firmament is a neighbourhood." In this lies the greatness of Norwid's poetry. ${ }^{11}$

\section{Bibliography}

Borowy, Wacław. "Norwid w typie A+M.” Przegląd Współczesny, 1936, No. 10, pp. 113-118.

Makowiecki Tadeusz. "Norwid myśliciel." W: Pamięci Cypriana Norwida. Warszawa: Muzeum Narodowe w Warszawie, 1946, pp. 50-60.

Pamięci Cypriana Norwida. Warszawa: Muzeum Narodowe w Warszawie, 1946.

Szuman, Stefan. O kunszcie i istocie poezji lirycznej. Warszawa: Poligrafika,1948.

Wyka, Kazimierz. Cyprian Norwid. Poeta i sztukmistrz. Kraków: Polska Akademia Umiejętności, 1948.

Zawodziński, Wiktor Karol. “Uroczystości Norwidowe." Myśl Współczesna, 1947, z. 7/8, p. 149.

11 The present article is based on a paper delivered on 1 October 1947 at the Kraków branch of the Adam Mickiewicz Literary Society. Further issues pertaining to criticism of Norwid's works are discussed in an article entitled "Norwid poeta" published in the collection Pamięci Cypriana Norwida (Muzeum Narodowe w Warszawie, 1946). 



\title{
Irena Sławińska
}

\section{Norwid's Producing Hand}

\begin{abstract}
The article is devoted to the problems of stage play, including dramatic language in Norwid's plays and reflection. The following three issues are analysed in detail: stage silence, the use of a human group on stage, and a "real live woman" as an actor. The author draws attention to the theatricalisation of silence in Norwid's dramas, its transposition on stage and its means of expression. Later, using a few examples, she proceeds to characterize his collective scenes, emphasizing the individuality and specificity of the functions of particular groups of characters and pointing to the changes taking place in this respect in the poet's work to arrive at a discussion of the verbal construction of these scenes. Finally, she discusses Norwid's appeal for a significant and not decorative or episodic participation of female figures in drama.
\end{abstract}

Keywords: Cyprian Norwid, drama, stage play, actor, silence, woman

The title of this essay is inspired by a British researcher, Richard Flatter. In 1948, his book Shakespeare's Producing Hand caused much stir among his Shakespearean colleagues. The book's subject was defined in more detail in the subtitle: A Study of His Marks of Expression to Be Found in the First Folio. The author analysed the graphic shape of the lines, line divisions, the use of colons, pauses and any metric disturbances. All those "mistakes" Shakespeare made were once corrected. Flatter proved that each deviation from the norm was introduced purposefully, to express Shakespeare's "directing" or "producing" intention.

While the title is borrowed from Flatter, the domain of discussion is different here. It is not the "signs of expression" which are the focus, but records of consistent care for the acting, for the right theatrical presentation of the drama - by the actor. It is worth recalling Norwid's reflections on actors and the role ascribed to them by the poet. There are numerous statements directly concerning that matter; they are found in letters, aesthetic treaties (Białe kwiaty [White Flowers]) and poetic texts (Aktor [Actor]). Similar statements allow some generalisations to be made, which may then be verified in dramas. That intention will also direct the process here - from Norwid's direct reflections on acting, to his directing instructions hidden in the dramas.

On the other hand, the discussion of Norwid's direct statements on acting does not exclude matters of a more general nature, which concern common principles of aesthetics, and thus also relate to the theatre. Those principles (e.g. the law of the parable, the "white flower" law in art) will thus be recalled, as well. 
It is well known how much Norwid valued the theatre, that "atrium spraw niebieskich" [atrium of heavenly things], and what social role he ascribed to it. When speaking of distinguishing Power (Potestas) from the obsession of sensual rule (Dominatio), he says: "W normalnym stanie rzeczy służy ku temu najlepiej prowadzony teatr [...]" (PWsz VII, 137) [In a normal state of affairs, the purpose is served by the best organised Theatre]. In the reflections contained in O sztuce (dla Polaków) [On Art (for Poles)], he takes a scene from Hamlet to illustrate the thesis that the lie of the theatre expresses the truth of life in the most profound manner.

Norwid constantly relates both the birth and the essence of theatre to acting and the actor's presence. This thought is already crystallised clearly in the essay Widowiska w ogóle uważane [Spectacles in General] (1852), where you read that fraternities, companies have become "nowe źródło tragedii i dramy chrześcijańskiej" [a new source of Christian tragedy and drama] and "komedii posada" (PWsz VI, 392) [seat of comedy]. Also appearing repeatedly is the formula of the poet as the first actor, the Protagonist, in relation to the beginnings of tragedy in Greece, but also in relation to Calderon. This tradition - Norwid indicates - also includes Schiller: "w Dreźnie dawał posiedzenia aktorom współczesnych sztuk swoich [...]" (PWsz VI, 391) [in Dresden, he held meetings with the actors of his modern plays].

Norwid also boldly calls for social nobilitation of the acting profession - from the comedy-drama Aktor to his last letters. In Aktor, Jerzy posits arguments against superstitions; in 1882, Norwid states without further argumentation: "Chciałbym wiedzieć, która Radziwiłłówna etc... ma to, co Helena Modrzejewska [...] Cóż ich życie przy jej życiu!" (PWsz X, 161) ${ }^{1}$ [I would like to know which Radziwiłł daughter etc... has what Helena Modrzejewska does... what is their life compared to hers!] The name of Rachel is recalled in an extended simile defining Chopin's "apoteotyczna skończoność gestów" [apotheotic completeness of gestures] (Czarne kwiaty [Black Flowers]). The most discerning formulation of the actor is found in the story of Rachel and her dream, O sztuce (dla Polaków). The story ends with the following generalisation: "Każdy a ktor, wchodząc do celi kameduły, przed podobnym klęcznikiem powiedzieć sobie może z onym głosem tajemnym: «Tu - koniec twój».” (PWsz VI, 343) [Each actor, entering the cell of the Camaldolese, facing similar kneelers may say to himself in that mysterious voice: «Here is - your end»]. Entering the order of "potęgi wyższej życia" [a

1 List do Konstancji Górskiej z września 1881 [Letter to Konstancja Górska, September 1881]. 
higher power of life], art "kona sobie a najjaśniejszym-tajemnicom wiary objawionej jako uwidomiające ciało, postać i forma posługuje." (PWsz VI, 343) [dies unto itself and serves the brightest-mysteries of the revealed faith as the substantiating body, shape and form].

The law of the parable definitely belongs to the basic principles of Norwid's aesthetics. He speaks so often of "parabolising" events or "parabolising" monologue. It is never about a static condition, but a living process including both life and works of art; hence the "parabolising" verb in gerund. It seems that Norwid's constant gesturing towards the accumulation of higher and more general semantic layers is also an important indicator for the actor. Particularly worth remembering are fragments concerning the analysis of a small gesture or glance. A letter from the time of the Franco-Prussian war contains a record of such an observation from a street corner. On reading an announcement of MacMahon's defeat, a passer-by turned his eyes away, and his look "zdało mi się przebłyskiem od wysokości niebios popod antypodów biegun przelatującym jako grom” $\left(\mathrm{PWsz}\right.$ IX, 476) ${ }^{2}$ [seemed to me a flash flying like thunder from the heavenly heights unto the pole of the antipodes]. This further brings to mind the analysed "spojrzenie ku niebu" [gaze unto heaven] added to Assunta. Such comments make one more sensitive and prepared to properly recognise "Norwid's producing hand" in dramas.

It is a similar case with the aesthetics of silence, as explained in an essay of the same title (Milczenie), in Białe kwiaty, and elsewhere. In fact, Norwid relates it expressis verbis to the drama, emphasising the importance of silence "w dramatyzowaniu" [in dramatizing], silence which becomes as fundamental an element of the dramatic structure as " $w$ obrocie planety niedotkliwa i niewidzialna planety $o s^{\prime 3}$ [the axis of a planet, intangible and invisible in the planet's rotation]. Already at the time of Białe kwiaty, Norwid explains the lack of European drama by the loss of "pojęcie dramatyczne ciszy i jej natur" [the dramatic concept of silence and its nature]. He returns to that thesis in Rzeczo wolności słowa [On the Freedom of Speech]:

Dlatego z wielu figur wymowy na scenie

Najsilniejszą! - przestanek... głosu zawieszenie...

I cisza stąd daleko jest szerszą w swej gamie

Od gromu, który cały horyzont połamie - (DW IV, 227)

2 List do Augusta Cieszkowskiego, 1 marca 1871 [To August Cieszkowski, 1st March 1871].

3 Białe kwiaty, DW VII, 62. 
[That is why from among the many figures of speech, on stage

The strongest is pause - suspension of voice.

As silence is far broader in range

Than thunder breaking the whole horizon.]

To express on stage "natura cichości rozmaitych" [the nature of various silences] is, of course, the actor's task. After all, "bezmowne chwile dramy" [the drama's speechless moments] are entrusted to actors. Those speechless moments are employed not only by the theatre, but also by painting and sculpture. Biate kwiaty starts with an interpretation of a relief where "wszystkie osoby słuchają $\mathrm{i}$ pytają razem, i odpowiadają razem... milcząc...” (DW VII, 61) [everyone listens, and asks together, and responds together... in silence...].

As it is known, the theory in white flowers explains not only the tenor of stage silence, but also the oftentimes powerful impact of "bezkolorowe słowa" [colourless words], the simplest, most colloquial ones which gain immense pathos only in the context of the whole situation (the background). Formulas concerning pathos and aimed quite clearly against bad Romantic tradition, against "vociferation" are sometimes directed straight at the actors by Norwid. He also refers several times to Hamlet and to the lesson given by the Danish prince to actors in Elsinore.

The poet opposes the pathos of tragedy, pathos of "krew wyraźna i czerwona" [clear red blood], to "nagie wielkie serio" [the great bare seriousness] which expresses pure commonness, the very "ciąg i rozwój" [continuation and development], and it is thus also a colourless flower in nature. There are no serious elements in tragedy, in comedy, or in "rozrywkowe gadki" [entertaining talk]. You attain true seriousness with thought and conscience: it is the characteristic element of drama (or haute comédie) - moral issues, shown in the commonness of everyday life. The analysis of that seriousness concerns stage acting, as well: it calls for restraint, discretion, simplicity, calmness.

The concept of simplicity and naturalness is always polarised in Norwid's aesthetics and reveals its positive and negative pole. There is coarse naturalness, vulgar, compulsive, representing lack of style and lack of artistic discipline and mature, refined naturalness, which is a bonus for diligence in art, i.e. style. Norwid circles around that issue at the time of Czarne kwiaty and Białe kwiaty, and thus at a time when his aesthetics was forming its final shape. The reference to acting cannot be helped.

So far, a matter of keen interest to the poet has been omitted: the matter of wygłos (projection), i.e. the loud declamation of a text. How deeply Norwid cared for that projection is proved by the introductions to his dramas (Pierścień Wielkiej-Damy [The Noble Lady's Ring], Kleopatra [Cleopatra]) and reflections in Rzecz o wolności słowa. 
Norwid already notes in Białe kwiaty, to illustrate his thesis of colourless words, that the final meaning of a word is only decided (in live speech) through a set of phonic factors, through intonation. He quotes the anecdote of a London guest who welcomed the poet with a pompous: "rodaku!" [My countryman!] “... ale przycisk taki był na literze pierwszej [...] światło przytem mdłe i postawa, i laska gruba uczyniły razem, iż zdało mi się nie rodaku, ale rrrobaku! usłyszeć" (DW VII, 69) [... but there was such stress on that first letter [...] and the dim light and the stance, and the thick cane all together made me hear not countryman, but worrm!]. Later, the poet stated outright that "prozy nie ma wcale" [there is no prose at all]:

I jakże by być mogła!... skoro są periody?,

Dwukropki? - komy? - pauzy -? -

...to jest brulion $O d y$,

Nie napisanej wierszem... proza jest nazwiskiem,

Które - jak zechcę? - głosu odmienię przyciskiem...

(Rzecz o wolności słowa; DW IV,)

[And how could it be!... if there are periods?

Colons? -commas? - pauses -? -

...this is an Ode's draft

Not written in verse... prose is a surname,

Which - if I want? - I will change with modulation of the voice...]

True, Norwid's terminology in this matter is clearly amateur: wygłos, litera, przycisk [projection, letter, accentuation]. Yet the poet persists in seeking the right words to make his intentions as thoroughly precise as possible. He creates new words, defines old ones, carries French terms over to Polish. Norwid's vocabulary always caused his critics much trouble, e.g. the famous krementy [from crément], repeated twice in the introductions to his tragedies (DW VI, 245). The poet vastly broadened the meaning of that French borrowing; if you were to judge based on those two statements, in Norwid's use it meant not only escalation, rising intonation, but also a whole set of phonic factors, active in every line, and most of all - the rhythmic pattern of the poem. Hence an authoritative thesis: "Czytanie głośne - wygłaszanie rymu, zależy pogłównie i stanowczo na umiejętnym czytaniu krementów - kto krementu czytać nie umie, ten wcale nie umie czytać wiersza" (Wstęp do "Kleopatry" [Introduction to "Cleopatra"]; DW VI, 245) ${ }^{4}$ [Reading aloud - enunciating rhyme, depend solely and emphatically

4 Wanda Achremowiczowa attempted to interpret the word in her study "Rola obrzędowości w Kleopatrze Norwida," Roczniki Humanistyczne KUL, IV, Vol. 1 (1953). In the note on p. 224, the author translates krement as intonation. 
on the skilled reading of krementy - he who cannot read a krement, cannot read a poem at all]. The same thesis is repeated in the two introductions in similar words and analogous context; in both cases, it is accompanied by the particularly significant mention of a krement in a rhyme-free poem, a blank one, which "rytmuje [się] na całą swą długość" [is rhythmic throughout].

Norwid's sensitivity to punctuation is well known. Using unique punctuation signs deviating from the general norm, plus graphic emphasis, he aims to single out particular words or whole expressions. Wstęp do "Pierścienia" [Introduction to the "Great Dame's Ring"] reveals the true addressee of those signals: the dramatic artist. After all, the text of the drama was sent to the Kraków competition committee together with the introduction in the hopes of being admitted to the theatre, and thus making its way directly into the hands of the actors.

Norwid's reflections on theatre and stage acting include two more issues: dramatic language and "kobieta żywa" [a real live woman]. The relation of those two matters to acting is perhaps not explicitly stated, but is still certain. In Wstęp do "Pierścienia," Norwid calls for the subtle shading of language, aware of the difficulties brought about by "wykwintny dialog potoczny" [refined common-day dialogue]. That is it: the colloquial, realistic language of everyday conversation, which must find its own style in the theatre.

Norwid attaches an even greater significance to the "a real live woman" in theatre; her absence causes Polish drama to stop in its development. Hence it is (like Polish literature as a whole) "w monologu cały" [all in the monologue], hence there is no dialogue, no clash or cooperation of different elements - the male and the female. In his lectures O Juliuszu Stowackim [On Juliusz Słowacki], the poet attempts to awaken his countrymen's awareness of the consequences thereof for the dramatic structure and for the very language. Norwid defines the wealth of Słowacki’s language as languages "wszystkie wieków, czasów, społeczeństw, typów i płci” (PWsz VI, 459) [of all ages, times, societies, types and genders]. No precedent or contemporary of Słowacki managed to achieve that; each of them spoke with the language "jednej płci" [of one gender] only - male (Mickiewicz, Krasiński, Żmichowska) or folk-female (Lenartowicz). True drama must use the languages of both genders, as only that differentiation gives the basis for significant dialogue. Another difficult task for an actor.

It is easy to notice how Norwid consequently realises the ideal of a language thus viewed in his own works of the mature period: it is enough to contrast the manners of speech (lexis, syntax) of Cleopatra and Caesar. It seems that on account of the lack of "female" language which he noticed, Norwid gives more care to shaping the theatrical roles of female protagonists in his dramas. There is a crowd of "real live women" in his theatre! Maria and Magdalena, Durejkowa, 
Marta and Julia, Lia, Eginea and Dorilla, Nicka and Olimpia, countess Palmyra, Cleopatra, Eroe... Early mysteries and dramas, written before Norwid's great overseas voyage, ought to be omitted here as they do not contain "real live women" yet.

Finally, let us note one more signal of the poet's theatrical eye: it concerns great human gatherings, which the poet sees as choirs or processions, théories. The coincidental but solemn rituality of the crowd in the street, guests in the living room or at a ball is described in Listy [Letters] and the poet's other writings. The word choir, so frequent and significant in Norwid's poetry, deserves a separate semantic study. Yet here, a closer analysis of those complex matters needs to be waived in favour of just a general acknowledgement of their existence.

Norwid as a poet of the theatre covers many elements of stage acting in his reflections and imagination. It is not possible to include all of them in this essay. The records of stage gestures have already been the subject of deeper analysis. From among analysis-worthy issues, only three will be discussed here: 1 . the organisation of stage silence; 2 . the use of a human group on stage; 3 . "the real live woman" as a role. The material will be taken both from the side text and from the dialogues themselves, where stage directions are implied. Examples will mainly come from Norwid's later, mature works, i.e. the period when the poet's "producing hand" had already gained unerring efficiency.

\section{1}

Silence becomes the topic of Norwid's work as early as in his youthful poetry. Later, it does not disappear - quite the contrary; at a later period it comes back more insistently even in the first dramas (Zwolon, Wanda, Krakus). "Coming back" is in itself a very general and imprecise term. The poet introduces a "silent protagonist" in each of those dramas. The silence of Zwolon, Wanda or Krakus spawns from their contemplative life, from their careful contemplation of Truth. It is their weapon and strength proper; it makes them capable of sacrifices and ultimate victory. At the same time, "muteness" separates them from people, makes them orphans.

In his first dramatic attempts, although already sensitive to the issue of silence on stage and as an aesthetic value, Norwid cannot express it other than in commentaries. There he tries to differentiate types of silence (“... ale jest nocna cisza $i$ dzienna,/Jest dno mająca i jest bezdenna" [ ... but there is the silence of night and day,/There is one which has a bottom and there is a bottomless one]) and seeks suitable names for various kinds of silence and speech. The motif is surrounded by synonyms and neologisms: milczenie, niemota, zniemowlenie, niemczyzna 
[silence, muteness, retreating into muteness, mute-being] (Wanda), and next to that: różno-głosy monolog, tłum-pustek, ciszy-wrzawa samotniczej [multivoicemonologue, crowd-emptiness, hubbub of solitary silence] (Zwolon). Those last formulas deserve closer attention: the paradoxical combinations speak of loneliness in a crowd, of such a loss of human contact that a conversation becomes a multi-voice monologue, of a hubbub which communicates nothing. Those terms are useful in understanding Zwolon as well as Za kulisami [Backstage].

Starting with the masquerade scenes, the poet reveals a never before seen skill: silence is theatricalised here, transposed onto the stage and its means of expression. Concern for the semantic hues of stage silence endures - and with a quite new force.

In Norwid's theatre, silence becomes a gauge of culture; it defines and differentiates culture. It happens so mainly in the two historical tragedies (Tyrtej [Tyrtaeus] and Kleopatra), both of them contrasting two cultures: the living and creative one versus the dead and infertile one. The poet adds the motif of silence to each of them; it is polarised, showing its positive and its negative pole. The calm silence of the Athenian choir or Caesar's restraint express mature reason (and power); the laconic conciseness of Sparta, limited to slogans ("zginąć albo zwyciężyć" [to die or to win]), become "przestankiem mowy człowieczej" [a pause in human speech]. Daim (Spartiate) thus defines himself: "Niewolnikiem będąc, o! obywatele, nauczony jestem zwłaszcza trwać i milczeć” (Tyrtej) [Being a slave, oh! citizens, I have in particular been taught to abide and stay silent]. So silence can be the fruit of free thought ("widnokrąg myśli człowieka zaokrąglony jest milczeniem" [the horizon of human thought is rounded up by silence]) or the symptom of a civilisation ruled by "nagi ukaz" [bare order].

How to demonstrate those two poles in a theatre? Obviously, it is the actor's role. But Norwid provides ample aid and instructions: he clearly specifies the gestures and stage movement of the Athenian choir, which "rozmawia ustawnie z prawdy rytmem" [speaks constantly with the rhythm of truth]. He also signals to the actor the lie in the very steps of Daim, the "Spartiata prawy" [righteous Spartiate], when after some light-hearted skips he approaches "krokami kapłańskimi” [in priestly steps].

Norwid returns to the issues of crowd-emptiness and hubbub of solitary silence in Za kulisami. The motif is first given in the versed overture ( $W$ pamiętniku [ In an Album]):

A ten systemat sprężyn, bez ich celu, Jakby tragedia bez słów i aktorów, Jak wielu nudów i rozpaczy wielu Muzyka, gwałtem szukająca chorów: (DW VI, 16-17) 
[And that system of springs, with no aim,

Like a tragedy without words and actors,

Like the music of many boredoms and despairs,

Desperately looking for choirs:]

A bold and strange idea: a tragedy without words and actors. In masquerade scenes, stage movement alone, dancing, music, fragments of conversations, "nieobmyślony rytm w pochodzie" [non-deliberate rhythm in the procession], props, theatrical place are to present that tragedy without words and actors and show Omegitt's "samotnicza cisza" [silence of solitude] against the noise of the ball.

A still different tune belongs to the silence of the suddenly emptied ballroom at dawn - in no way empty (emotionally) or colourless. Extremely meaningful is the waxed floor covered with magic writing, read by Mandolin in the beautiful poem: "Na posadzkę zapustnej sceny..." ["Alone on the Floor"].

It is not the only time that the poet makes his characters step back to let the theatrical place speak. The same often happens in Kleopatra. Yet the audience is usually to experience that silence through some medium - through a character's perception. Thus as a final instance, Norwid refers to the actor again, who is to provide subtle interpretation. It is the actor who is to find such a scale of means of expression within himself or herself as to conjure up the symphony of a night in Egypt, composed of "szelesty drobne" [small rustles]; the grave dead silence of a mummy; the lovers' silence joining Cleopatra and Caesar; as well as the "głuche - magnetyczne" [hollow - magnetic] silence, which will finally separate Szeliga and the Countess (Grand Dame's Ring).

Certain dramatic functions imposed by the poet on drama's speechless moments have already been mentioned. Those moments largely contribute to the unmasking of culture in the great synthetic image of the historic epoch, which exists in two versions - literal and metaphorical. But that is only one function and perhaps not the most important one.

The main objective of stage silence is related to an individual, to revealing his fate and his interior, as well as the more general moral laws directing him (or her). Man's truth is revealed in silence, when lies are silent and the head's inclination or a hand's gesture speak (because the gesture "nie kłamie" [does not lie]). In silence, the moral awakening of countess Harrys takes place. In silence, one speaks with the rhythm of Truth and discovers oneself. Silence "ukróca czas" [shortens time], quickens changes, tears off masks. This is experienced both by Magdalena and Maria (Pierścień); both by Cleopatra and Caesar.

Stage silence does not have to entail the utter "suppression" of conversations or a character's disappearance from the stage. It may be part of only one character - and 
thus heavily impact the theatrical reality. Such heaviness is found in Cleopatra's silence - maintained with maximum effort and ready to spill into madness - at the moment when blind Szechera speaks of Caesar's death. Perhaps even stronger is Julia Murcja's silence in Stodycz [Sweetness] when she is absent from the stage but present in the thoughts of Jove's high priest. That silence - a sign of the fearless, victorious attitude of the imprisoned Christian girl - is actually the protagonist proper of the tragedy, and the antagonist of Veletrius. It is that silence he fights most ferociously and loses irrevocably, since Julia Murcja's death stretches her silence eternally.

Let us also remember the formula from Białe kwiaty: "tędy drama $w$ rzeźbę przechodzi" (DW VII, 63) [here, drama turns into sculpture]. It is not a general prescription and it has to be applied to Norwid's drama carefully. Yet it may be referred to when analysing the theatrical functions of silence: Cleopatra's or Kordelia's silent passage across the stage, described in detail and experienced by other characters, are definitely meant to be sculpture-like. But it is possible to interpret in the same manner the apparent extras from the ballroom or even servants, especially as the prologue supports such an interpretation: "milczy jak pomnik, będąc sam pomnikiem" [he is silent like a monument, being a monument himself] (W pamiętniku).

Various terms have been used here: silence, muteness, speechless moments of drama - following the poet's own terminology. These are not complete synonyms; silence as muteness (milczenie) implies the presence of a human, silence as absence of sound (cisza) does not require such presence. As has been indicated above, speechless moments accompany a human on stage. Some theatrical functions can be added thereto: concealment, understatement and pause in conversation. This essay will not involve a detailed analysis of those, but only mention their presence. It is known that Norwid attached much importance both to concealment and "przestanki" [pauses]; substantial proof can be found both in his treaties and in his dramatic texts alone. It is astounding, what differentiated - and sometimes fantastic! - punctuation he uses; how many dashes single, double, triple - to indicate pauses within a sentence. Constant thought is given to the precise marking of a pause: hence cut or dotted lines, graphic pauses (light) in writing, ellipses. Yet Miriam, the editor, did not pay full respect to Norwid's intentions in that area ${ }^{5}$, hence neither Pisma zebrane nor Wszystkie pisma can be relied on. To analyse the pause - and related issues - in detail, one ought to wait for an even more meticulous edition. ${ }^{6}$

5 Cf. W. Achremowiczowa, "Nad autografem i tekstem Kleopatry Norwida," Pamiętnik Literacki, Vol. XLIX (1958), Vol. 2, pp. 531-554.

6 Wojciech Górny attempted an analysis of the issues, cf. "Jedna $\mathrm{z}$ zagadek niezrozumiałości," Tygodnik Powszechny, XII (1958), No. 27 (493), pp. 4-5. 
Yet the dramas' texts provide enough material to confirm the extent of the silent stage's contribution, an unarticulated, distant buzz of voices, or the silence of one character in Norwid's theatre - including minor or longer moments of silence and pauses. The connection of those scenes to the exposure of gesture, stage movement, music ( $Z a$ kulisami), the very theatrical place, and finally the word which is to attract particular attention, is also obvious. All those theatrical intentions are, however, directed with concern for the sematic shading of each moment of silence on stage, to clearly convey a person's experience or opinion on culture, to "parabolise" that silence according to the poet's thought. "Piękna trudność" [beautiful difficulty] and a beautiful lesson for an actor.

\section{2}

Another issue which has not been subject to deeper analysis is the operating of human groups on stage. In all works of a bigger format (from Zwolon to Kleopatra) Norwid includes collective scenes. The groups of people bear various names: chór, tłum, kilku młodych ludzi, służba, grono gości [choir, crowd, several young people, servants, group of guests] etc. Of course, that is largely determined by the situation: there will be a different group of people as Cleopatra's audience, a different one filling ballrooms, and yet a different found in the living room of countess Harrys. Anyway, it may be stated that Norwid chooses situations which justify the presence of such groups - either socially (ball, party) or only conventionally (the choir in the Tyrtej tragedy). Each of those groups has its own collective individuality and its own unique function in the given drama. Let us look - exempli grata - at just a few scenes of the kind from various periods of the poet's work.

"Street scenes" in Zwolon require a numerous crowd. They appear at random in that "wcale emigrancki" [quite emigrant] drama which is to show crowdemptiness. Crowds of people are always present in the market square. Yet Norwid orders those crowds and arranges them symmetrically in sections - like in a tableau vivant. "Kobiety i dziatwa kończą obraz" [women and children end the image], he adds in the side text. The crowd is so unanimous in their reactions that it responds as a choir; only after a moment, three choirs form and converse with each other, as well as supplement one another in the call for revenge ("zemsta, zemsta na wroga" [revenge, revenge against the enemy]).

The same large, open scene appears in Wanda and in Krakus, but the human gatherings are used differently. In both mystery plays, taken deep into the legendary past, the nation understands its rulers (Wanda and Krakus), sympathises with them and takes part in making them offerings. The poet groups the people 
into as many as 7 choirs, joined by common work and offerings (choir of shepherds, farmers...). The ceremonial procession of choirs passes rhythmically before Wanda's tent. Finally, Norwid arranges them symmetrically in two open half-circles, with the Vistula River visible through the gap between them. Again a tableau vivant. Ancient tradition brings in coryphaei - choir leaders. Also, hexameter stresses the solemn nature of the procession.

Despite some differentiation, the manners of introducing human gatherings and their function can be summarised in a few principles. What strikes the reader most is the unity and unanimity of each sub-group, whether it be treated as a choir or crowd, the symmetrical nature of the arrangements, freezing in a tableau vivant. This is a convention still commonly used in Romantic theatre.

All those principles and patterns are broken in later works. You cannot find them in masquerade scenes, in Tyrtej, in Ring, in Kleopatra. Norwid mainly abandons the use of great crowds on an open stage - the Romantic solution of a stage resembling an arena - in favour of an architectonically confined stage closed off with a backdrop, a stage that would likely be quite deep. He also stops using tableau vivants; on the other hand, he enriches the functions and the theatrical perspective of human gatherings as concerns stage movement and word structure.

An area of particularly interesting experiments in that domain are the ball scenes in Za kulisami. The ballroom sees a constantly dancing or walking procession, usually named "crowd" by the poet. The term ttum masek [crowd of masks] returns several times, sometimes turning into the more precise chór Fiołków [choir of Violets] or Domina [Dominoes]. The theatrical problem - in Norwid's view - is to subject those groups to some compositional principles while avoiding the stiff symmetry of earlier works. That principle is movement - flowing, likely parallel to the footlights, but changeable. The pace of the passers-by changes (from a smooth procession to a group running from the Critic-mask). Sometimes the poet calls the masks to the front of the stage, sometimes he makes them go back and clear the front of the stage to articulate the dialogue of selected characters. The movement of the masks should also follow the principle of rhythm, ruled by the ritual of the masquerade, the orchestra, and the music of some individual bards. The rule of music in this drama is definitely of great significance. It was already indicated in the essay Za kulisami "Tyrteja", but it was not shown in detail there.

7 T. Makowiecki and I. Sławińska, "Za kulisami Tyrteja," in: K. Górski, T. Makowiecki, I. Sławińska, O Norwidzie pięć studiów (Toruń: Księgarnia Naukowa T. Szczęsny i S-ka, 1949). 
Definitely, the text of the drama indicates the poet's clear intention: "pośpieszność toku i ciaggu" [the pace of the metre and continuity] should create "nie obmyślony rytm w pochodzie" [non-deliberate rhythm in the procession].

Another novelty in Norwid's mature dramas is the great differentiation and individualisation within the gatherings. Masquerade scenes are usually dominated by mask and costume (Feuilleton, Fiołki, Diogenes, Domina) as well as - or perhaps mainly - function. Even greater individualisation is upheld in Kleopatra, although it appears in a different historic and cultural context. In both those dramas, collective scenes are created through cooperation, harmonisation of colourful individuals with each their own representative opinion (Za kulisami) or even own experiences (Kleopatra). In Norwid's highest theatrical achievement, Kleopatra, there are no extras, no supernumeraries: what rich and singular life is given to the Knight, Szechera, Her! It is no coincidence that Norwid provides those characters with proper names. A proper name is a sign of personalisation, it expresses their individual personality.

And finally one more theatrical problem, definitely immensely important for Norwid: the word structure of collective scenes. It is worth taking a closer look at the history of the choir in the poet's drama and the changes it undergoes. The choir already appears in Wanda and lasts until Kleopatra. Since the very beginning, Norwid is aware of two benefits of the choir: 1. visual - a group of people as part of the "theatrical visuals," connected with joint stage movement, gesture, often with the same costume or prop; and 2. aural - joint recitation or song. A choir thus understood appears still in Tyrtej, stylised à la grecque, forming a triptych (two half-choirs and an epod), which introduces not only an element of dialogue, but quite a vocal variety, certainly not indifferent to the poet. In Kleopatra, the choir appears only in a single episode, one with a special motivation at that (royal wedding). It is in that case an element of a largely impressive insertion in the word structure of the whole. Here the whole procession is also divided into two choirs (female and male), linked by the Epod, and the song of the choirs is distinguished by rhythm, saturation with metaphors, and a wealth of inner choruses.

Besides choir arrangements, Norwid often uses choir recitation in collective scenes. This happens also in the last dramas - in Pierścień, Za kulisami, Kleopatra. In the masquerade, the choir of Violets provokes Omegitt; chor biegnacych [the choir of runners] (masks) debates with the Critic. That is naturally determined by the semantic regard - the poet is not looking for a realistic motivation behind such choral performances. Similarly, the guests in Ring praise the taste of the Lady Countess and her party in a unisono, and the tragic groups of Romans and Egyptians forming two choirs in Kleopatra join as one choir in the final performance. 
However, the word structure of collective scenes is determined by the principle of individual voices - at least in the last period of Norwid's work. In the "żywota maskarada" [masquerade of life], where you are clearly in the land of poetic metaphor, the passing masks add what may seem like random comments to the dialogues (Astrologist, Diogenes) or ask questions in passing, to which Omegitt replies. The whole scene - central to the drama - consists of those brief dialogues, justified with the passing crowd of guests and randomness of meetings. Some statements are straightforwardly concise, declarative monologues (Pole foreign official; local Poet).

There are far more collective scenes in Kleopatra, and they vary in character. In act I, servants supervised by courtiers set the table: the dialogue is situational at first, and then turns into a discussion of Egyptian tradition. Later dialogues of Cleopatra's court or Caesar's retinue - which start off from a specific situation, have a similar purpose: to present the Egyptian or Roman culture or confront the two. The characters (e.g. Eukast, Kondor) and their statements then become necessary to saturate the work with historic flesh, oriental colour, to create the visual background, and foremostly the cultural background for Cleopatra and Caesar, who feel strangulated by that "mumii odór" [stench of a mummy]. Characters who seem secondary advance to major positions: the bearers of the chief themes of the work. Hence the conversation topics, the choice of words, as well as their projection are to present the Egyptian or Roman culture. It seems that Norwid strives to melt that huge topic into the most theatrical situation possible - not tragic, but everyday. A bold and probably quite successful attempt of that is the dice playing scene, where the information about the number of points scored is interspersed with news of Rome and the fate of the triumvirs:

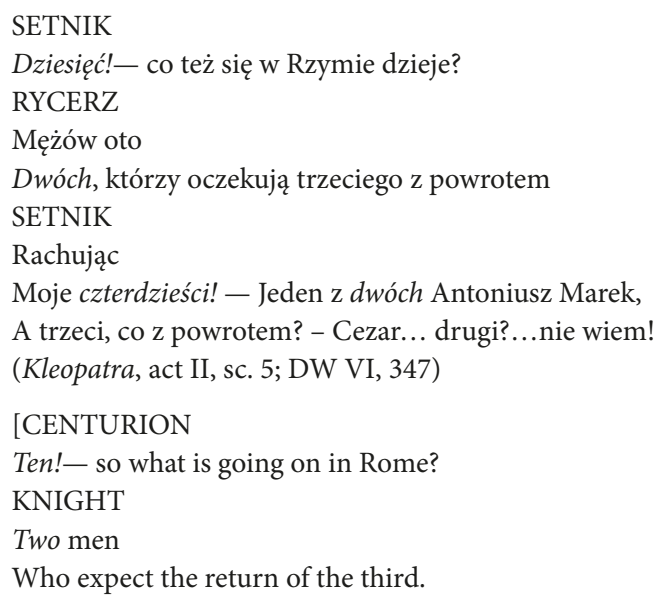




\section{CENTURION}

Counting

Forty for me! - One of the two is Anthony Marcus,

The returning third is? - Caesar... The second?... I don't know!]

The scene is interpolated - and enriched - with the passage of "foreground" characters (like Cleopatra), who play episodic roles in that scene. The ability to thus switch proportions is a significant achievement of Norwid's late theatre.

Despite exposing some of the characters, despite the presence in each drama of people who are easily identified as protagonists, it may be said that Norwid's theatre has nothing in common with the theatre of stars. In its development, it draws ever closer to the ideal of "poetic justice," which gives each character their own, complex, mysterious existence. Like every dramatist, Norwid must fight the danger of breaking the rules imposed by the compactness and unity of drama. He frequently creates that own existence, own figure and own speaking voice - in the mature period of his work - using just a few gestures and just a few words.

\section{3}

A dramatic character as an actor's role - this is a very difficult issue and one that has not been discussed much. Some methodological inspiration may be found in three books by Descotes (cited elsewhere) ${ }^{8}$ on the roles in Corneille's, Racine's and Molière's theatre. The books are filled for the most part with the stage history of such characters as Phèdre or Bérénice. The variety of actors' interpretations of the same role becomes a significant argument in favour of its richness.

The same method could not be applied to Norwid yet, for the simple reason that the stage history of his dramas is short and provides little material for analysis. At most, it may be said that his characters did well on stage.

A different approach must be taken: to focus on the characters themselves, and only the female ones, referring to Norwid's explicitly defined programme creating a real live woman. It is clear (from the context in which it appears) that the description poses aesthetic postulates. The postulates are difficult to define positively - it is easier to do so with negatives, by indicating fragments where Norwid scoffs at Aldona or Zosia from Mickiewicz's works. A real live woman should not be a mere "large profile," a pattern, noble but dead, an ideal without its own life (everyday life), inconcrete. In Polish literature, women are

8 I. Sławińska, “Teoria dramatu za Zachodzie (1945-1960)," part 2, Pamiętnik Literacki (LIII) 1962, Vol. 1, pp. 283-309. 
merely “... przegrywki w antraktach opery poza ich udziałem dziejącej się" (DW VII, 62) [... small insertions in the intermissions of an opera happening beyond their participation]. That is an obvious appeal for a significant and not decorative or episodic participation of a complete woman in a drama.

Let us look at Norwid's women, relying on the creative programme of the poet himself: completeness - departure from a pattern, a profile; richness of character; true participation in the drama; introducing female language. The description of the characters, social representativeness, semantic functions etc. will not be included here. ${ }^{9}$ This analysis will refer mainly to the characters from the poet's last period of work: countess Harrys, Durejkowa, Magdalena, Cleopatra. Those characters are playing roles of the greatest richness and interest.

Richness covers various senses of the word, even in the sense of external, visual concretisation. The poet does not define the outer features of the characters directly (height, hair colour - although countess Harrys's blue eyes are mentioned) - but he records their gestures, sometimes in great detail, the manner in which they pass across the stage, Palmyra's "ruszenie dziwnie tajemnicze" [strangely mysterious movement], Cleopatra's "stąpanie lekkie, drobne niby liści szelest" [light, dainty step, like the rustle of leaves]. Those are usually recorded not in the side text, but in the reactions of other figures, especially men. The general instruction, but binding as an element of the role is thus a woman's physical charm, the ability to fascinate (today, one would say: sex appeal).

This register of the purely female charms of Maria Harrys, Cleopatra or Palmyra, or even Magdalena, must include the childish, naïve craftiness, the constant readiness for small lies, simple cheats which are to hide their earthly feelings. Whenever Cleopatra betrays her feelings towards Caesar, she immediately - and loudly! - orders presents to be sent to her husband-brother. And she betrays herself constantly: not with words, but with gestures (which do not lie). Acting those moments out in full must be an ultra-rewarding role for an actress.

Richness of character also means a great extent of features and capabilities: in those great dramas, childish lies coexist with "kula refleksji głębokiej" [a sphere of deep reflection], keen intelligence, perspicacity, not wanting even in such severely judged and generally negative women as Lia or Palmyra. The great amplitude also covers the distance from thoughtless cruelty to the capability of life sacrifice (Countess Harrys). A formidable but interesting challenge for an actress who must demonstrate moral trauma - and the awakening of the Countess.

9 Cf. I. Sławińska, O komediach Norwida, (Lublin 1953). 
Such paradoxes are not found in any other character, even Cleopatra, who is a figure of the subtlest hues of female jealousy, anger, caprice, coquetry. Both those prime female characters are developed through events and conversations; the poet aims for gradual theatrical revelation of their charms, weaknesses and the charisma which conquers the people around them.

Richness of a role also consists in the great scale of emotions the character experiences on stage. The author gave most generously to Cleopatra: her love for Caesar is born on stage, the queen parts with him on stage, then she receives the devastating news of his death, then comes the game with Anthony, the growing repulsion towards mummies, the whole court ceremonial, finally hatred towards Rome. Also countess Harrys experiences - on stage - many emotions she was never expecting: humiliation, jealousy, finally the discovery of her own cruelty and the other's suffering.

The great amplitude of abilities and experiences, violent, paradoxical combinations and contrasts make those women a mystery or a riddle. It is easy to classify Lia or Palmyra, but countess Harrys and especially Cleopatra escape categorisation. Endless possibilities of the most varying acting interpretations open up - shifting the emphasis towards one or the other pole of their personalities. Despite the whole richness of the characters - or perhaps on account of it - there remains some incompleteness in their definition, some poetic concealment, resulting from seeing a one-and-only, unique mystery in every person. It may be surmised that this is an integral layer of every great role...

Is it only today's specific perspective which makes those characters appear so very stylish to a contemporary audience - and so modern at the same time? They were most likely already felt to be stylish by the poet. Norwid has the ability to look from a distance at high society manners and their civilizational child, the grand dame. That stylishness includes social convention, very strict, although apparently natural - and requires the actress to adhere to the rigours of 19th-century social liturgy with great ease and grace. (There have been examples on stage of what unfamiliarity with that style can lead to!) That style is fostered by the costume, "fałd szaty" [robe folds], props (a fan), the whole set design provided by the poet, lustrous floors, chandeliers... For the very reason that the "salon" is a co-actor, not just a visual background, it is impossible to think of a production which would waive that partner e.g. in favour of an arena scene. A young woman in a sports jumper would obviously not be countess Harrys or Palmyra, born of the 19th century.

A stylish role - that is true. But one might ask, are not the Klaras and Anielas stylish, as well? The characters created by Fredro, Korzeniowski, Bałucki? You clearly feel that Norwid's grand dames are different - modern. They lack the 
endearing sweetness of the others. They are sharp, aggressive, sometimes cruel sometimes cynical, and despite all their hypocrisy - they are self-aware. And that level of awareness makes Norwid's grand dames as roles lack any old-fashionedness, any associations with an old couch!

What is the emploi that Norwid envisioned in his theatre? Did he think in such categories at all? Let us try to match Norwid's women with the recurring terms of theatrical criticism in late 19th century: l'ingénue; tragic heroine; belle in a comedy of manners, modern manners heroine (end of century), lyrical artist. The list is obviously quite incomplete, but compiled with a comedy of manners in mind. Do any of those emplois fit Norwid's grand dame? Likely not. Her emploi treated ironically by the poet - is the very role of a grand dame on the stage of life, a role viewed by her and her environment from a theatrical perspective, as a social mask. Anyway, that mature and aware woman (usually a widow) is far from l'ingénues, far from the traditional belles of Polish comedy in the 19th century; she is much closer to Musset's dames.

The grand dame is not the only interesting role in Norwid's theatre. She is accompanied by a dame de compagnie, a confidante, socially equal by all appearances, but actually with a far lower standing, sometimes highly individual and interesting (Magdalena, Marta in Palmyra). A characteristic emploi is very rare: perhaps Nicka, definitely the temperamental, "tongue-showing" Durejkowa, venerable wife of the judge, and a poet. Actually, characteristic roles are one of a kind, like the old prophetess Szechera, the old Countess from Aktor, or Salome. All three old women are very interesting and have the gift of a particularly keen outlook on the world, and in Szechera's case, literally a prophetic one. That uncommon development of intuitive cognitive powers seems to be a prize for focus, for maturity allowing contemplation (as Norwid understood beautiful aging), for leaving aside worldly ambitions and endeavours. Those old women may be viewed as the most beautiful and perhaps even most interesting of Norwid's creations, although their uniformity deprives them of the broad scale of theatrical possibilities typical of the grand dames.

On various occasions, numerous instructions given by Norwid to the future performers of his creations have been mentioned. Studies also indicate the great assistance of imagery in that respect - for the theatrical concretisation of the character. ${ }^{10}$ It seems that the performers of female roles should consider it with particular attention.

10 I. Sławińska, "Metafora w dramacie," Zeszyty Naukowe KUL, 1963, Vol. 3, pp. 25-36. 
Several dramas by Norwid have a female name in their title or at least a clear female reference: Wanda, Pierścień Wielkiej-Damy, Kleopatra; perhaps Palmyra's name was to represent comedy. Could it not indicate a theatre of one star, a recital of one actress? Above, the thesis has already been provided that in Norwid's mature theatre there are no insignificant roles, that less exposed characters are also given their own life and often an important function. The ability to show some characters not just against others, but through those others, through their experiences and reactions, additionally confirms the principle of collectivity. Before you get to see countess Harrys, you learn about her more through the emotions than through the words of three characters: Mak Yks, Szeliga and Salome. The first grand dame in Norwid's theatre, Klaudia, never appears on stage: she is presented only through her own letter (cut in two, so that new information about Klaudia is revealed later) and the strong emotions of Roger, revealed in the ironic interpretation of the letter, in the commentary. In Kleopatra, you meet not just the title heroine, but also some less exposed characters through the experiences of others (e.g. the love of Ganimedion and Melmeja - through Cleopatra's jealousy). Eginea and Dorilla also have an "equal start", as do, similarly Magdalena with Countess Harrys.

To summarise the above:

The ironic image of a grand dame, highly diversified as well, is an extremely rich and interesting role. Norwid was, however, able to go beyond that emploi in many of his female characters: in Cleopatra, in many women accompanying their dames. He knew how to turn the traditional confidante into a real live woman with her own temperament and personality. He sketched servant figures carefully: all of them have some emotion to experience, not just lines to say. Female characters are often additionally enriched with the intentional allusiveness of their names: biblical (Marta, Maria, Magdalena), literary (Julia, Lia), even topographic (Palmyra - a beautiful ruin). They are further enhanced by poetic imagery, finally by the language of the drama. The attempt to create a female language - at various social levels, too - a language equipped with a powerful emotional undercurrent, becomes a very significant consideration when interpreting a role. The language is "rozległy w swej gamie" [extensive in its scale] - full of finessed barbs (Magdalena, Maria, Cleopatra), innocent lies, skilful parries, veiled confessions and provocations (Magdalena), but also poetic expressions ("Człowiek jest niemowlę niewysłowionych rzeczy" [Man is the infant of ineffable things]). A separate study is needed to delve into those charms in detail. They do not lose their brilliance even when compared to the most famous female roles of the time - from LaDame aux Camélias (1852) to Madame Sans-Gêne (1893). 
This essay touches upon just a few matters related to the issue of stage acting as seen by Norwid. All of them concern actors and their creative contribution to a theatrical work. The poet entrusts the actors with speechless moments of drama, the composition of collective scenes, and finally the creation of a real live woman. Many issues have not been considered here - they have either been already discussed (like gestures) ${ }^{11}$ or are still too difficult to present in an analysis (intonation, vocal delivery of the text). The whole theory of acting, explained in Aktor, has not been considered at all. What was able to be included here were brief mentions. All those matters ought to be considered in the future in order to present Norwid's theatre in all its richness, so much its own, and so new. That new richness is visible in the context of the theatre contemporary to the poet.

\section{Bibliography}

Achremowiczowa, Wanda. "Rola obrzędowości w 'Kleopatrze' Norwida." Roczniki Humanistyczne KUL, IV: 1953, Vol. 1, pp. 209-235.

Archemowiczowa, Wanda. "Nad autografem i tekstem 'Kleopatry' Norwida." Pamiętnik Literacki, XLIX: 1958, Vol. 2, pp. 531-554.

Górny, Wojciech. "Jedna z zagadek niezrozumiałości." Tygodnik Powszechny, XII: 1958, Vol. 27 (493), pp. 4-5.

Makowiecki Tadeusz, Sławińska Irena. "Za kulisami Tyrteja." W: Konrad Górski, Tadeusz Makowiecki, Irena Sławińska. Pięć studiów o Norwidzie. Toruń: Księgarnia Naukowa T. Szczęsny i S-ka, 1949, pp. 33-64.

Sławińska, Irena. “'Ciąg scenicznych gestów’ w teatrze Norwida.” W: Sceniczny gest poety. Zbiór studiów o dramacie. Kraków: Wydawnictwo Literackie, 1960, pp. 35-90.

Sławińska, Irena. "Metafora w dramacie." Zeszyty Naukowe KUL, 1963, Vol. 3, pp. 25-36.

Sławińska, Irena. O komediach Norwida. Lublin: Towarzystwo Naukowe KUL, 1953.

Sławińska, Irena. “Teoria dramatu na Zachodzie (1945-1960).” Część 2. Pamiętnik Literacki, LIII: 1962, Vol. 1, pp. 283-309.

11 Cf. I. Sławińska, “Ciąg scenicznych gestów w teatrze Norwida," in: Sceniczny gest poety (Kraków 1960). 


\title{
Jan Błoński
}

\section{Norwid among the Great-Grandchildren}

\begin{abstract}
The article describes Norwid's oeuvre in the context of a significant increase in the interest in his work among the great-grandchildren generation, preceded by a juxtaposition of a number of erroneous and harmful opinions and incomplete readings of his work, demanding clarifications and additions, based on a literature review of the subject. In Norwid's lyrics, analysed in connection with the main aspects of his emigration fate, the author sees above all an ideal of the poet, whose vocation is to read signs scattered across reality by Providence. This vocation becomes a source of Norwid's attitude to history, truth and Christianity, expressed throughout his poetic work. His poetry is also discussed in terms of three distinct techniques used by the poet: irony, silence and revaluation, which, in the author's opinion, provide the strongest testimony of Norwid's poetic individuality.
\end{abstract}

Keywords: Cyprian Norwid, poetry, Christianity, irony, silence

\section{I}

Norwid's posthumous triumph - one achieved not among the grandchildren but the great-grandchildren - constitutes one of the greatest mysteries indeed, not only in literary terms but in cultural terms as well. It needs to be solved, even if only provisionally and without much grace, at least for our own benefit and understanding, if not for Norwid himself, who could and did write, in his farewell to Maria Trębicka: "Proszę się za mnie nie modlić, ale za powodzenie prawdy w społeczeństwie" (DW XI, 175) ["Please do not pray for me, but for the prevailing of truth in society"]. After all, it does not seem that Norwid would appeal to his contemporaries, at least at first glance. A principled essentialist and Christian, he also seems at odds with the 20th century. Goodness, beauty and truth were always on his lips, but these days they are badmouthed even by jokers, not just rebels. Nevertheless, we are witnessing a revaluation of Polish literary tradition. Perhaps Norwid and Kochanowski have not replaced the great Romantics, but they have at least become the equals of Mickiewicz and Słowacki. Only the school curricula remain anachronistic, as seems fitting. There is talk of bringing school closer to life, meanwhile children are needlessly required to read literary magazines and interpret the latest works, which will soon fall into oblivion anyway. At the same time there is great disregard for that which we perceive to be topical, contemporary and creative in our tradition and spiritual achievement. It is yet another misunderstanding that would certainly amuse 
Norwid, who was quite used to them, or would at least bring out that lofty and bitter smile of his, which we recognize in so many of his poems.

In fact, since the moment of Norwid's posthumous rediscovery, he has been the subject of just as many misunderstandings as when he was alive, although they now often carry nuances of appreciation or even enthusiasm. As Jastrun rightly observed, Norwid's very recognition was paradoxical because Miriam did not really have a lot in common with him. Thus, the latter's sensibility appears all the more worthy of credit, especially his ability to figure out and understand others, unlocking the secrets of their souls. Many works on Norwid exist and the field of "Norwid studies" seems to constitute a rich body of knowledge. Nowhere else, however, do we encounter similar proportions of bias, weirdness, spiritual factionalism, as well as the embedding of one's own thoughts into those of others and a plain lack of understanding. "What the Masurian spirit can achieve in the culture of social spirit and political thought is proven by Roman Dmowski, who embodies the purest Masurian type: a true large-scale genius. Norwid could spread his wings equally wide, but there was just something peculiar about him!"1 According to this account, Norwid was a bit like Dmowski, only a slightly worse version; plus, his family came from Żmudź [Samogitia], as we know. "Norwid, a literal pensioner of emigré Polish aristocracy, was a typical representative of the lower middle class within the Polish intellectual elite of the 19th century." ${ }^{2}$ Let me just add, in a slightly wicked tone, that a much greater poet formulated an analogous and not much more informed thesis after the war: "Along with Wyspiański, Norwid is becoming a figure whose work ought to be taken up by the State in order to expand the nation's knowledge of itself." ${ }^{3}$ This is how one columnist associated with the Sanation - guided by instinctual care for the state (and considering himself to have the spirit of Szymon Gajowiec) - tried to acquaint the Polish public with Norwid. But enough is enough - after all, Norwid scholarship has a serious side too.

Still, concrete studies of Norwid are, almost as a rule, fragmentary. Though some of his diligent researchers spent as much as much as half of their lives examining his works, they wrote about him with great anxiety, which stemmed precisely from their conscientiousness. This is firstly because factual knowledge about Norwid began to take shape only recently, culminating in the works by J.W. Gomulicki. Though sparking a lot of controversy and provoking

1 Zygmunt Wasilewski, Norwid (Warszawa: Skł. gł. w administracji "Myśli Narodowej," 1935), p. 59.

2 Marian Piechal, O Norwidzie (Warszawa: Rój, 1937), p. 139.

3 Kazimierz Kosiński, “Cypriana Norwida 'sen Prometowy'”, Droga, No. 11 (1939). 
discussion, they are impressive and broad enough to be of help to the general public, proving infinitely useful to complete amateurs. Secondly, Norwid is indeed obscure and difficult, making him easier to misread than other writers, even if the university curriculum's cruelty is unmatched. Consequently, many of those who could have really made Norwid more approachable and lucid circled around some of his great themes, endlessly adapting and preparing, or focusing on matters that are certainly important but also undoubtedly marginal. Anyway, Norwid only gradually revealed himself to us, as if illuminated by the rays of a rising sun. Certainly, Kridl did not lack goodwill when he limited the poet's worth to his lyrical pieces, and not even all of them, but rather rare and scarce ones. This does not seem to hold ground now because the process of discovery is a never-ending one. Thanks to poets, scholars and even incidental readers, we have witnessed a blossoming of new sentences, phrases as well as thoughts of exquisite beauty and uncommon wisdom. Ultimately, nothing is irrelevant in Norwid's oeuvre - all of its components illuminate one another, though naturally not everything is of equal value. As I can perfectly understand myself, he can get on one's nerves, even today. His poetry and thought were torn from himself by the most intense effort and against the backdrop of the worst indifference. Such spiritual toil can leave nasty scars. However, the scope of harsh judgments and valuations does not seem to have narrowed down in decades... Certainly, personal discoveries about Norwid will continue to be made for a long time. They could certainly be hastened by livelier research. Perhaps it would be firstly advisable to recall, or broaden the distribution, of those critical works (however brief!) that capture Norwid in more general terms without becoming less serious, and bring him closer to readers in plain language. After all, Borowy and Jastrun, Kołaczkowski and Makowiecki, as well as others, were able to read Norwid simply and deeply, the depth an outcome of that very simplicity.

As early as in the 1930s Borowy noted that Norwid is the most often quoted Polish poet. This tendency has only intensified. However, my guess would be that Norwid's power over contemporary poetry has roots deeper than in the accuracy of loosely quoted observations, in lightning bolts of poetic wisdom. Nor does it originate in the system of thought he created for himself (if it can in fact be called a system). Rather, it rests outside the system, simultaneously within it and beyond it, in some element of it, or in its foundation. It is difficult to isolate this factor because that which is most topical in Norwid permeates, as it were, the entirety of his writings, thus being everywhere and nowhere at the same time. At the same time, attempts to systematize or rationalize his views are among the most risky exercises, making it very easy to turn them 
into something banal or bizarre if we were to avoid explaining particularities by referring to wholes. It is easiest to notice - or frame and describe - some fragments of Norwid's. There are plenty of examples. This was perceived by the most sensitive of his readers - the poets. Jastrun made the reservation that "Norwid is primarily an artist, but an artist for whom the most interesting material is thought, reflection, and the cultural experience of humanity." 4 This is correct, but thought cannot be mere material, unless you are a spiritual adventurer travelling through philosophical reflections, which Norwid certainly was not. Thus, as Jastrun logically concluded, being a poet whose work is permeated by Norwid's, not just in terms of style and imagery, "Norwid's truth is marked by deep contradictions and denials." This claim is where thought needs to pause, uncertain. How to derive certainty from contradictions and denials? How to develop the kind of spiritual fortitude achieved by Norwid? I am recalling the opinions of a reliable and passionate reader to bring attention to the difficulties inherent in contact with Norwid's writings. What is problematic here is most likely the ambiguity of concepts such as system, contradiction or truth. A contradiction within one system does not exclude consistency within another. The system itself can be more of a perspective or method rather than the universal key and final explication of whatever exists. It is only by making multiple reservations that a poetic "consistent grasp" of the world can be transferred into the conceptual, philosophical domain, because the unity ascribed by the artist to his or her work can develop only on an unconscious level without reaching the surface of conceptualization, or doing so only partially. In such cases, reading resembles the study of icebergs whose tips are all that rise above sea level. Moreover, the very configuration of contradictions as long as they feature regularity or some kind of rhythm - can often turn out, upon closer inspection, to constitute a formula of consistency. Today we know about many such methodological complications and shall discover even more in the future. So, bring it on, my fellow philologists! Do not waste your youth or old age on Kaczkowski and Opaliński, Bohomolec and Bałucki! In Norwid we have our own Stephane Mallarmé, a mystery and a labyrinth, the subject of endless speculation and a tangle of innumerable complexities. What interpretational delights await us!

4 Mieczysław Jastrun, preface to: Cyprian Kamil Norwid, Poezje (Warszawa: PIW, 1956), p. 12.

5 Mieczysław Jastrun, preface to Poezje, p. 9. 


\section{II}

These, however, could be preceded by or supplemented with some humble readings, which aim to give testimony to a meeting with Norwid, to undo a mere strap of the statue's sandal. It would be a meditation that does not shy away from starting with the obvious and experiencing it once more. It would include Norwid's solitude and exile - things that have become platitudinous. But what were they back then? Ineffable solitude - the kind that grasps at whatever comes along: razor, woman, friend, event, idea - only to learn that a razor is a razor, or that this woman or that friend cannot be relied on. Norwid's deafness has - like many aspects of his life - a symbolic sense. It is not a sign of oversensitivity, for he retained an unusually open mind, but one of disconnection. Norwid was like the point where all solitudes meet, or - to put it more precisely - a point where contradictory forces could be applied, cancelling each other out and creating a ruthless vacuum around the poet: the kind that, I would venture to say, is familiar only to madness. Norwid was predestined for exile, rejection and emigration, including internal emigration from everywhere, to which he was sentenced by the fault - if we can speak of "fault" - of the Romantics... Finally, he was exiled from love, deprived of the simplest - or rather the most accessible test and confirmation of one's worth. On account of its humility and discretion, Norwid's eroticism belongs to one of the most impenetrable of its kind, though today some would rudely say it was "censored." He captured it himself in the contrasting figures of a "pagan" and "Christian" woman -a present and absent one, an alter ego and companion on the one hand, and a salon-based or sexual object on the other. Still, this juxtaposition can be viewed in historical terms: the Romantic lovers of Mickiewicz or Słowacki - Maryla or the ethereal angel from "W Szwajcarii" ["In Switzerland"], an outdated model whose provenance is well known - had to come down to earth and inhabit mortal flesh, sharing table and bed, which Norwid explained in a clear yet discrete and respectful way to Maria Trębicka. Behind every woman met in poetry or real life there seems to loom a shadow larger than her, which is to become embodied: her forerunner or calling. Proof of this is scattered everywhere, often in places where eroticism would be least expected:

Męża jeżeli posąg wywiodłeś z kamienia

Tak, jak on jest, niech wiekom późniejszym zostanie,

Lecz kobieta - zarazem kobietą-spojrzenia,

Sobą i ową, jak Ty poglądałeś na nię.

Nieustannym zjawiskiem! Ona i nie ona,

Jako palm okolica stała na pustyni, 
Ale w nieistniejące lądy obwiniona,

(“Sonet do Marcelego Guyskiego" [“Sonnet for Marceli Guyski”] PWsz I, 205; emphasis added)

[If you procured the mans statue from stone

Let him remain the way he is for centuries to come,

But the woman - she is also a looked-at woman,

Herself, and the way in which you saw her.

A perpetual sight to behold! Herself and not herself,

Like a row of palms in the desert,

But wrapped in non-existant lands.]

Is it a theory of sculpture? A flash of self-knowledge (or of love)? Both. It is easy to note that Norwid's women are inherently dualistic. They often appear in pairs - in poems or other works like Za kulisami [Backstage] and Assunta - and can be dualistic themselves, like an ideal requiring supplemental reality, or a real being which Norwid attempts to idealize, usually without success. This opposition is explicated in "Beatrix," where we read:

Bo byłem smutny - a kto przyszedł do mnie?

Nie ty - o pani!

Gdy krew i ogień, i fala koło mnie

Wrzały z otchłani...

[...]

Anim gazowy oberwał ci welon,

By otrzeć skronie,

Choć nie duch jestem, ale jestem wcielon,

Pomny o zgonie...

Dlatego znam cię, Realności - wdowo!

(PWsz I, 314-315)

[For when I was sad - who came to visit me?

Not you - my lady!

When the blood and fire, and waves around me

Roared from the abyss...

$[\ldots]$

I did not tear down your gauze veil,

To wipe my temples,

Though I am no ghost, but an embodiment,

Conscious of mortality...

This is how I know you, widow of Reality!]

Not to mention "Polka" ["Polishwoman"], where - not by accident! - true beauty does not have a physical profile or character, but only a moral one: 
Ale włos, jakiej ma barwy? - zapomniałem.

Ale oko? - nie wiem, doprawdy, czy modre;

Jeśli to gdzie pisałem,

To odszukam i podrę! -

(PWsz I, 361)

[And what colour was her hair? - I forgot.

And her eyes? - I do not know, really, if they were deep blue;

If I ever made a note,

I shall find it and tear it to pieces! - - ]

The motto - "sunt verba et voces" - expresses a similar truth. Also consider the astonishing descriptive technique of zooming-in, to which Jastrun drew his admiring attention:

Jak gdy akacją z wolna zakołysze,

By woń, podobna jutrzennemu ranu,

Z kwiaty białymi - na białe klawisze

Otworzonego padła fortepianu...

(A Dorio ad Phrygium, DW III, 379)

[Like when one slowly sways the acacia tree,

So that its scent, reminiscent of the dawn,

Falls with white leaves on the white keyboard

Of the open grand piano...]

This technique derives, psychologically speaking, from the dualism of women figures in Norwid. Unembodied perfection cannot be characterized directly, but only through allusion and comparison. The relatively late Assunta (1870) drives the argument home, bringing the development of Norwid's eroticism to a conclusion. The heroin is mute, acting as the alter ego of a deaf man! Dumbness - or the impossibility of earthly communication - is transformed into a symbol of higher communion, into a necessarily incomplete presence of the ideal in reality, a presence that the poet is nevertheless able to discern. Thus, Norwid resolved the erotic theme by identifying it with a religious one: after all, the word "assunta" means "to look to the heavens." What is left is the "flatness of the earth":

Pamięć dnia, odkąd jej nie oglądałem:

Tylko cyprysów ciemność - woń lewkonii - -

I płaskość ziemi... gdzie samotny stałem.

W słońcu bezczelne półśmiechy ironii...

Triumfujące nad mym ideałem.

(DW III, 351-352)

[The memory of the day, since I last saw her:

Only the darkness of cypress trees - the scent of gillyflowers 
And the flatness of the earth... upon which I stood alone.

In the sun, impudent half-smiles of irony...

Triumphed over my ideal.]

However, we arrive at a final reconciliation:

I w górę patrzę... nie tylko wokoło:

[...]

Pomnąc, że gdzie są bezmowne-cierpienia,

Są wniebogłosy... bo są - przemilczenia...

(DW III, 353)

[I look up... not just around:

[...]

Acknowledging that where there is mute-suffering,

There are also rising voices... because there are - things left unsaid...]

However, I may have gone too far. Exiled from love by his own idea of love, which splits, as it were, every woman in two and requires their "supplementation" perhaps this is how we should understand, on an erotic basis, Norwid's eternal reservation, the disagreement and demands, which exiled him from reality. This rhythm recurs everywhere in his works! Was he exiled from Romanticism by his own understanding of poetry's Romantic calling? Naturally, this is a matter too well known to be considered here. I shall only limit myself to a quotation from a particularly popular poem, because I believe everything is in plain sight in his most widely known works. It is simply necessary to place them alongside one another and allow them to illuminate each other:

Nie wziąłem od was nic, o! wielkoludy,

Prócz dróg zarosłych w piołun, mech i szalej,

Prócz ziemi, klątwą spalonej, i nudy...

("Klaskaniem mając obrzękłe prawice," PWsz II, 15) [“Their Hands Swollen from Clapping”]

[I took nothing from you, o! giants,

Except for roads overrun with wormwood, lichen, and cowbane,

Except for earth scorched with curses and tedium... $]^{6}$

Exiled from Polish history, both close and distant, Norwid was also exiled from Poland itself, both literally and metaphorically, but perhaps more in the latter sense! I would even go on to say that he was exiled from his homeland by his

6 English translation by Danuta Borchardt in collaboration with Agata Brajerska-Mazur, in: Cyprian Norwid, Poems (New York: Archipelago Books, 2011), p. 15. 
own high notion of homeland. It is true that the police issued warrants, when later - especially when he was older - they could have been bypassed or altogether annulled. However, why would Norwid want to return to Poland? We should never stop reiterating that the real tragedy of Polish emigré literature was precisely the fact that this emigration was deliberate. The existing quasi-Poland was simply worse than exile - for creativity, for spiritual development, and for itself. All of the greats had their moment when they could return to Poland but none of them chose to do so because they all felt that this would result in the capitulation and failure of their ambitions. National dignity and Polish honour, which compelled them to throw the Tsar's amnesty in his face, were indeed running strong, but there was also the conviction that the Poland of their times meant spiritual death:

Ojczyzna moja nie stąd wstawa czołem;

Ja ciałem zza Eufratu,

A duchem sponad Chaosu się wziąłem:

Czynsz płacę światu.

(“Moja ojczyzna," PWsz I, 336; [“My Country”])

[My country has not risen here;

My body antedates the Flood,

My spirit soats over Chaos:

I pay rent to the world. $]^{7}$

Nogą odepchnąłem ten brzeg, co pokornie

Zgiął się pod moim obcasem -

I skrzypiał mi on, że jest męczeńskim, wytwornie

(Ale przeklinał mnie basem!).

Och, wy! - którzy śpiewacie krwawo i pożarnie

Kiedyż... zrozumiecie sąd?

Żyć wy radzi w dziejach, lecz żaden nie wie,

że cali urośliście w krwi - ulewie,

Czyści i matematyczni, jak błąd!

(“Do spółczesnych,” PWsz I, 182; [“To my Contemporaries”])

[I pushed away this shore, which humbly

Bent under my heel -

And it creaked to me that it is elegantly martyr-like

(But cursed me hoarsely!).

7 English translation by Adam Czerniawski in: Cyprian Kamil Norwid, Selected Poems, (London: Anvill Press, 2004) p. 41. 
O, you! - who sing bloody and fiery

When... will you understand the judgement?

You are glad to live in history, but none of you know

that you have grown up in blood - torrents of it,

Pure and mathematical, like an error!]

They are mistaken precisely because they grew up in torrents of blood - not the other way around, as the Romantics thought, associating the experience of martyrdom with the power to discover truth. In this we are reminded of Baczyński, who, thinking of Norwid wrote: "miłość - cóż zrodzi - nienawiść, struny łez" ["love - what will it bring - hatred, strings of tears"]. A terrible poem that proves how bold Norwid was when he shoved it in the faces of his contemporaries. Maybe it is for the better that they did not understand it? You want to live in history, but you do not understand it, because in this country "książka każda przychodzi za późno" ["every book arrives too late"]. Norwid was more insightful than these "giants" in that he was able to name the reason for which he chose the pitiful fate of an impoverished Parisian bohemian. For him, the actual Poland was a country lacking historical awareness, perhaps even lacking history itself. Certainly, history never stops, even if it goes by unnoticed; however, it is only by properly acknowledging history that we can consciously shape it (yet another point of contact between Norwid and Brzozowski). At the same time, "the countryside" - in general, regardless of geographical coordinates, though especially in Poland - has yet to develop an awareness of time:

Przeszłość twa - zawsze wczora!

Przyszłość - ręką dosiężna,

U ciebie zawsze - pora!

Tyś wczasów księżna...

(A Dorio ad Phrygium, DW III, 382)

[Your past - always yesterday!

Your future - a reaching hand,

For you, always - it's time!

You are the duchess of the holiday...]

I cannot understand how and why these lines were interpreted to be nostalgic praise. ${ }^{8}$ Naturally, they are emotionally ambiguous, at least initially:

O! wsi biała w atłasie kwiatów jabłoni (DW III, 381)

[Oh! The country white in the satin of apple blossoms]

8 Cf. the interpretation provided by J.W. Gomulicki in: C. Norwid, Dzieła zebrane, ed. J.W. Gomulicki, vol. 2: Wiersze, (Warszawa: PIW, 1966), pp. 771-772. 
But nostalgia is merely a starting point, and one that needs to be overcome. Everything that follows shall be articulated through anti-phrases - everything will be cruel mockery, just like the peculiar image of a heifer towards whom the herdsman turns his cows, not the other way around as it usually happens and as common sense dictates! Anyway,

[...] świat to osobny zda się,

Coś, jak Fortunne-Wyspy starożytne,

Dziejów mające wdzięk - nie trud i ciąg.

(DW III, 383)

[The world seems peculiar,

Like the Fortunate-Isles of antiquity,

Having history's charm - not its hardship and persistence.]

If we read in search of meaning, not just scanning the words, the ending of the autonomous version of "Wieś" ["Village"] has to have an ironic sense (even without $A$ Dorio ad Phrygium):

Ach!... czy nie ma już miejsca na świecie

Dla Niewinności?

I kiedyż?... zapomną o Powiecie

Plagi ludzkości!

(PWsz II, 36)

$[\mathrm{Oh} ! \ldots$ is there no place left in this world

For Innocence?

And when?...will they forget about our village,

These plagues of humankind?]

Of course, the plagues of humanity will never forget about our village. To think so would be as immature - Norwid says (or thinks) - as a child chasing mushrooms and berries, which he demonstrates through the preceding images. It is this child that Norwid wishes to overcome in himself and others. Moreover, the meaning of the autonomous poem does not differ from the meaning that shouts at us, as it were, from A Dorio ad Phrygium. It is not only the "toleration of serfdom relations" that constitutes the accusation Norwid addresses to the "village" - more essential, much deeper and vital, is the illusion that one can set him- or herself free from history. The mockery of the famous phrase "To swoi, to kółko domowe, to nasi" ["This is us, this is our homey circle, these are our very own"] is also the mockery of the Polish nobility's cultural sociability and the beliefs that boil down to nationalist limitations: 
Gród zaś ojczysty, że - najpierwszym w świecie,

A w grodzie jeszcze, że nad geniusz wszelki -

Sąsiad, z którym się wypienia butelki.

(“Początek broszury politycznej," PWsz II, 98; ["Beginning of a Political Pamphlet"])

[The homeland is the first in the world,

And in this land, over and above all genius -

Is the neighbour with whom one empties the bottle.]

In Norwid, all of this is linked, it seems, with the attitude that Poland is a parochial province, which found itself outside historical consciousness and cannot live otherwise than among false measures and childish notions.

Only, as is well known, Norwid did not feel any better about Paris or London. He was too much of a Pole and a Christian to consider 19th-century Europe to be something other than a capitalist apocalypse. In a shocking poem addressed to exiles, he says:

Wrócicież kiedy? - i którzy? i jacy? -

Z śmiertelnych prób,

W drugą Syberię: pieniędzy i pracy,

Gdzie wolnym - grób!

(“Syberie," PWsz II, 58; [“The Two Siberias”])

[Will you return one day? - Who will? Looking how? -

From deadly ordeals,

To second Siberia of money and work,

Grave of the free! $]^{9}$

Perhaps the most focused and thorough account is found in "Larwa" ["Larva"]:

Na śliskim bruku w Londynie,

W mgle, podksiężycowej, białéj,

Niejedna postać cię minie,

Lecz ty ją wspomnisz, struchlały.

$[\ldots]$

Rzekłbyś, że to Biblii księga

Zataczająca się w błocie,

[...]

Takiej-to podobna jędzy

Ludzkość, co płacze dziś i drwi;

9 English translation by Michael J. Mikoś in: Michael J. Mikoś, Polish Romantic Literature. An Anthology, (Bloomington: Slavica, 2002), p. 137. 
- Jak historia?... wie tylko: „krwi!...”

Jak społeczność?... - tylko: „pienięd zy!...”

(PWsz II, 30-31)

[On London's slippery London pavement,

In fog, sub-lunar, white -

Many a figure will pass by,

You'll remember her, terrified.

[...]

You'd say, that book is the Bible

Rolling thus in slime,

[...]

Such is Mankind - a witchlike crud

That weeps today and finds things funny;

- Its history?... knows only "blood!..."

Its institutions?... - only: “money!...”] ${ }^{10}$

All of these are well-known matters - I am only so bold as to put them in a certain order. The world that Norwid witnesses in the West is only seemingly real and historical. However, the Bible - read: man - is reeling in the mud of an industrial and capitalist "system sprężyn, bez ich celów" ["system of springs, without purpose"], where we see the unfolding of "tragedia bez słów i aktorów" ["a tragedy without words and actors"] ("W Pamiętniku," ["In an Album"], which is insightfully commented on by Gomulicki). In other words, the village (or Poland) represents tradition and virtue without history, while the West is all history without virtue and purpose, because only finality lends some dignity to human efforts. The bundle of themes that frequently recur in Norwid's works triviality, pretence, salon, the Event-idol (“événement-bóg” ["god-événement”]), uselessness, fear of machinery and automatism, replication of thoughts - or the entire set of issues he kept returning to, are all linked with the image of a civilization that the poet grasped, understanding its good and bad aspects better than his Romantic predecessors. Therefore, Norwid became exiled from it as well, emigrating from it, if not physically then spiritually. He relentlessly emphasized that he knew why he did so, and that he penetrated its mechanisms through experiences that were equally personal and ruthless.

Thus, he was nowhere. Should I recall the declaration that is both statement and programme, or at least a starting point for a programme born of complete exile? "The generation born in a void, between the past and the future, which

10 English translation by Borchardt in: Poems, p. 29. 
is not connected with anything - and what is to become of it?... an angel that passes, a phantom that flies, an effeminate nothing... a martyr... Hamlet?" Norwid's entire oeuvre briefly answers: no.

\section{III}

However, for that "no" to truly resound, it has to turn into a "yes." How to rid it of the pure negativity, in which Norwid-the-exile seemingly came to live? How to instil it with value? The diagnosis he formulated with regard to himself and his generation was indeed overwhelming. It can be understood in literary terms as something existing between Romanticism and Positivism. However, it can also be viewed in social categories as located between the nation of the nobility and the nation of the bourgeoisie, or geographically as placed between Poland and Europe. The epoch in which "więcej/Rozłamań - niźli Dokończeń” ["there are more/Breaches than Completions"] did not deserve to be called an epoch, but still, it was one. Similarly, his generation was probably unworthy of being called a generation, just like that ancient one, which

[...] w wilię chrześcijańskiej prawdy objawienia,

Między zachodem greckiej i żydowskiej wiedzy,

Dziko rośnie i ginie jak zioło na miedzy,

(“Do Walentego Pomiana Z.,” PWsz II, 155; [“To Walenty Pomian Z.”])

[on the eve of the Christian revelation of truth,

Between the dusk of Greek and Jewish wisdom,

Rises wildly and dies like herbs on a balk.]

Nevertheless, that generation did exist. Like the "nadkompletowy aktor" ["extra actor"] - a term Norwid used to refer to not only his own failures with the literary public - that generation demanded a role to play. The sense of exile (and also of want, randomness and a lack of fulfilment), found expression - as far as I can say - in Norwid's life too, as he was perpetually discontent and unable to brush aside any trivialities. If then, for whatever reason, this sense of exile seemed important to him, it must have developed relatively early, maybe even sparking the creative crisis from which he suffered mid-century. It even inspired some of Norwid's greatest works, ultimately pushing him away from his contemporaries, at the same time securing both "korektorka wieczna" ["the eternal editor"] and the future's judgement.

Norwid resembles a man who answers every question by saying "yes, but..." or "no, but..." and whose truth can never be fully rooted in reality. To put it more precisely - despite the curse, for the rose to be a rose, and to have "yes for yes, and no for no" - Norwid never sees reality unambiguously. Reservation 
is his homeland - the aforementioned "but." What are the origins of this? It may have roots in the simultaneous experiencing of love and sparring with history. In both areas we can discern a similar obsession with "niedowcielenie" ["underincarnation"] and "dopełnienie" ["completion"], which are so characteristic of Norwid. This obsession is terribly dangerous and usually even paralysing. A mind that cannot find support or a starting point to reality - whether it is personal (love) or social (history) - usually encloses itself in vain negation, flees into mirages, or masochistically turns against itself. However, Norwid's genius and spiritual fortitude (moral resistance conditions intellectual vigilance in similar contexts) revealed themselves to the fullest extent when he derived an attitude, a system even, from negation, from solitude and absolute emigration, or - in a word - from the obsession with expressing opposition and making reservations. Norwid's great poetry began when it grew darker and weirder with the introduction of capital letters, spaced-out lettering, syntactical ellipses, silences and pseudo-etymologies (though the last ought to be considered not as a peculiarity or the product of a derailed mind, but as a specific mode of poetic creativity; similarly, Mallarmé scholars elaborate at length on theories of fashion or elements of English grammar in the poet's French). These were all signs that Norwid found, though without yet clarifying it to himself, a formula for poetry as a second language, and at the same time (as is easier to begin with) identified its proper calling or function as the reading of reality's secondary meaning (according to him it was of course the first and only). This could be said in a simple and banal way, remembering only the depth with which Norwid experienced and ruminated the function of poetry and the discovery of the world. It is as if he suddenly became convinced that the love he held was not true love, while the history that carried him along was not true history, and that everything in which his generation was stuck - "between the past and the future, which is not connected" - was a mere illusion. Certainly, the scales falling from his eyes in a sort of revolution or revelation, reaching deeper than intellectual formulas and transforming the very mode of his existence in the world, was not a onetime ecstatic experience (as some of the others had had), but a continuous and relatively slow process. In the eyes of an exile the world became so alien that it seemed unreal. Readers are encouraged to pursue this path by the obsessive recurrence of the word "truth," which does not designate a system, not even a Christian one, although it sometimes coincides with it. Norwid's "truth" is rather a way of seeing, a secondary model of sight and understanding. First, it regards history, as can be easily established:

Aż oto, że dzieje pozornie są zamęt,

Gdy w gruncie są: siła i ładność szeroka! - 
Aż oto, że dzieje są jako testament,

Którego cherubin dogląda $\mathrm{z}$ wysoka -

(“Żydowie polscy," PWsz I, 340; [“Polish Jews"])

[Until suddenly, history only seems to be cha otic,

Whereas it is in fact broadly strong and beautiful! -

Until suddenly, it becomes a testament,

Watched over by a cherub from on high -]

History is not what it seems to the Romantics or the scientists, Poles or Parisians, socialists or cynics. It is a cypher meant to be decoded by the poet Norwid - although he knows that his reading will be imperfect. In comparison to Romanticism it is somewhat like the Copernican Revolution: the Romantic ideal of bard and prophet, which Mickiewicz or Słowacki wished to attain, or of the prophesying poet inspired by the Holy Spirit to lead the people, who trust in his words, is replaced by the ideal of a poet whose proper calling is to read the signs dispersed by Providence throughout reality (naturally, not only the historical one). Norwid's obsessive truth involves both the signs themselves (invisible to the masses - hence the specific aristocratism) and, perhaps even more so, the ability to discern and interpret them. In this sense, poetry does not only reach the truth but also - more importantly - it is the truth because it boils down to the exercising of this ability. Poetic perspective is thus entirely reversed. It is not the revolution in Paris, Lisbon, or God knows where, that proves to be crucial, but rather the one started by Emir Abd el Kader in Damascus. After all, revolution is illusory, an accident, still a function of the past, while the deeds of Emir are a sign of spiritual growth, which is decisive about the development of humanity and the ethical ecumenism of the future. Similarly, as has been long observed, true importance lies not in a salon conversation but in the matter that cannot penetrate it because it is silenced with illusion. What matters is a detail:

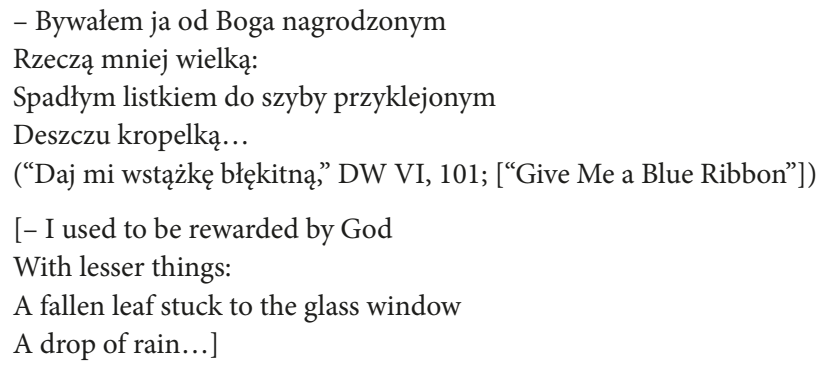

This is Norwid: a poet for whom the leaf is more important than the love ribbon, because the former was sent by God and is therefore truly meaningful. It contains a hidden meaning - one that only the poet can and must read as the specialist in 
cracking the code of existence. Perhaps he is less a bard and more like a flamen who reads from the entrails of sacrificed animals, from the changes in weather, from the cosmos, deciphering signs of the future and maybe the present too, because from a certain distance our world's temporal sequence may dissolve. A flamen does not lead anyone to battle, nor is he a host to some sage demon. He is not a saint even though he does save. He is the one who knows but does not profit from his reading of the book of light.

Exiled from reality - reality understood in the way that Norwid's contemporaries preferred, i.e. as deprived of any meaning to the poet, and limited to "chaos" - Norwid, by changing his perspective, regains in a certain way the entirety of reality (once more I need to point out that I present the maturation process, whose seeds emerge in his early poetry, as a "crisis" only for the sake of clarity). Gestures and figures of being rejected, pushed away or, in the most dramatic instance, "kicked away," appear very often in Norwid's works:

Więc, niźli ziemi szukać poczniesz piętą,

By precz odkopnąć planetę spodloną -

(“Do obywatela Johna Brown,” PWsz I, 302; [“To Citizen John Brown”])

[Thus, ere you seek the ground with your heel,

To kick the disgraced planet aside -$]^{11}$

Nogą odepchnąłem ten brzeg, co pokornie

Zgiął się pod moim obcasem;

(“Do spółczesnych,” PWsz II, 182; [“To my Contemporaries”])

[With my foot I pushed away the shore, which meekly

Bent under my heel; ]

- Tam - stopy dwie, gwoźdźmi przebite,

Uciekające z planety...

(“Do zeszłej," PWsz II, 120; [“To a Deceased”])

[- There - two feet, pierced by nails,

Fleeing -from the planet... $]^{12}$

As is clear, these elements typically appear in moral or religious contexts: "My kingdom is not of this world." However, expressions of grabbing, or - more precisely - rescuing and reclaiming, are equally common and strong. Norwid believes, or wishes to believe, that whatever exists is useful: it is only necessary to discover this higher "use." The entire human world should rise from the dead.

11 English translation by Borchardt in: Poems, p. 113.

12 English translation by Borchardt in: Poems, p. 59. 
Twenty-three-year-old Norwid was able to clearly articulate this conviction as early as in 1844, in Florence:

Bo nie zginęło żadne utęsknienie,

I żadna boleść nie przewiała marnie,

I żaden uśmiech błahy nieskończenie -

Jest taki anioł, co skrzydłami garnie

I śmiech, i boleść, i to niedotkliwe

Człowieka chaos bierze w dłoń, jak żywe.

A droga taka jest na wieżę życia,

Że wiele szczeblów idzie coraz wiotszych,

Jaśniejszych coraz, przezroczystych, złotszych,

Jak różne sny są, różne serca bicia;

A który szczebel dłonią witasz chciwie

I obłokowe czujesz w nim widziadło -

Nogami zdepczesz, stojąc na łuczywie,

Bo już ci skrzepło, w rzecz się ścięło - zbladło.

To rzeczy dola - wielem widział rzeczy...

("Do mego brata Ludwika," PWsz I, 69; [“To My Brother Ludwig"];

emphasis added)

[Because no longing was lost,

and no pain was blown away in vain,

And no infinitely trivial smile -

There is an angel that gathers with its wings

Both laughter and pain, and that intangible

Takes man's chaos in hand, as if it were alive.

And there is a road up the tower of life,

That has many rungs, which are ever more fragile

And lighter, almost transparent, more golden,

Like different dreams, different heartbeats;

And the rung you greedily clutch at

Sensing in it a cloudy mirage -

You will stomp down with your foot, standing on a torch,

Because it has already solidified into matter, and paled.

This is the fate of things - of which I have seen many...]

This is a fascinating passage. It contains both the aforementioned will to conserve, read and regain the entirety of reality, framed in Christian terms, and the images of ladder and ascension, undoubtedly constituting a symbol of creative freedom. Marvellous are these rungs of cognition, which "solidify" into matter, or - to use today's language - become reified. However, the full intrinsic meaning of things 
has not fully revealed itself to young Norwid: he does not trust them anymore, but does not yet know why or how he shall reach out beyond them... He is nevertheless certain, as he paradoxically argues in the long poem, that "i na tej ziemi [...] znajdzie się kilka rzeczy wielkich" (PWsz I, 71) ["even on this earth [...] one can find certain great things"], namely - everything... Indeed, if the world has aim and meaning, it has to have them as a whole. Totality is the guarantee of truth - nothing is useless to humanity. Twenty years later, in Za kulisami, Norwid recorded a conversation between a spy, Domino and Omegitt, clearly the poet's porte-parole:

DOMINO

A zaś moc prawdy skąd idzie?

OMEGITT

Pochodzi z jej Całości... a przeto stąd, że prawda jest Idea powodująca nieustannie równe sobie świadectwo...

(DW VI, 92)

[DOMINO

Where does the power of Truth come from?

OMEGITT

It comes from its Wholeness... hence from the fact that Truth is an Idea, one ceaselessly producing a testimony equal to itself...]

Omegitt's statement refers to several motifs of Norwid's thought, including the power of truth derived from its wholeness, since, to put it theologically, reality as a whole was expiated. Truth, "resounds everywhere but does not leave its designated place, telling the mortal individual 'you are' and saying that you are because you have embraced both the everywhere and the here." Thus, individuals identify themselves and the world in reference to the entirety of the divine plan. Finally, truth produces "a testimony equal to itself" and is thus not a system but a mode of existence - a lifestyle rather than philosophy. It constitutes a profession of faith in the attainable unity of man and God:

Tam - milion rzęs, choć jedną łzą pokryte;

Kroć serc, łkających: „Gdzie Ty?”

(“Do zeszłej," PWsz II, 120)

[There - a million eyelashes, though under one tear;

Myriad hearts, sobbing: "Where are Thou?"] $]^{13}$

This is the kind of unity that one achieves through spiritual work and - in Norwid's case - through poetic insight. It has a fundamental meaning for his poetics because it allows him to regain the world he entirely negated at first.

13 English translation by Borchardt in: Poems, p. 59. 
In short, like many deeply religious people, Norwid approaches the world through God, not the other way round. For what is revealed in the course of deciphering reality? What does the poet attain through his insight? The Divine Plan, the real history of humanity, the one God intended to be inaccessible. The only caveat is - and this marks Norwid's originality - that this plan is not a system, or rather that it cannot be formulated as a system. Only towards the end of his life will Norwid give in to the temptation of developing his own historiosophy, arguing that history has its phases: "legend" (the vision of God outweighing man's self-knowledge), "epic" (the discovery of man by man), "history" (the determination of mankind's historicity) and so on. Surely, this "historiosophy" does not have much to do with Hegel, or even some watered-down or transformed variant of the philosopher's thought. I do not know if anyone has drawn attention to this argument's formality - which I consider crucial - namely the fact that it is expressed in literary terms. The phases of history are in fact literary genres! Indeed, from Norwid's perspective - that of a poet reading reality - the boundaries between the course of history and that of creative development, or self-knowledge, are blurred. Therefore, Norwid's "historiosophy" can be understood as a systematization of literature's cognitive functions, which gradually develop into a study of being...

It is true that Norwid does not rely on any previously established system. Hence the difficulty reducing his thoughts to any particular philosophy; hence the "contradictions" noted by his most faithful readers. Out of the building blocks Norwid seems to have scattered, one can assemble many different constructions. His numerous poetic apologues always have - as has been noted long ago - a similar objective: they refer to truth as the ultimate foundation. As Brzozowski impatiently noted: "He writes that truth can be the only foundation - we all know that. But what is the foundation of truth?" Catechism and Revelation are the kind of poetry, he concluded, that can only convert the already converted. Well, not really... or not entirely. Norwid's truth is always open, for which there are several reasons. Firstly, the "true" plan of reality - the one in God's sight - remains impossible for man to grasp in its entirety. Secondly, the variable of man's freedom gives the truth - as witnessed on Earth - a tinge of unpredictability demanding ever new and vigilant study.

Thus, to Norwid Christianity is not an ideology but a mystery - one that exists objectively and is, plainly speaking, God. What God has revealed exists beyond doubt, but it can never be fully grasped. It follows that man's ultimate goal, according to Norwid - as Makowiecki simply and accurately put it - is "rising from the dead, ceasing to be [...] a passive pawn in the game of fate, but rather 
becoming an aware [...] and 'liberated' co-creator of reality." ${ }^{14}$ What counts for God is man's effort, not the result he already well knows insofar as He constitutes it himself. Man's truth, or the one accessible to him, is contained in the motion of gradually arriving at it. Hence the meaning Norwid ascribes to intention:

$\mathrm{Z}$ intencji rodzi się wielki uczynek -

Ty! - będąc czynu-człowiekiem -

Gardzisz intencją? - uwielb pojedynek

I głoś: żeś na równi z wiekiem!

(“Coś," PWsz II, 69; [“Something”])

[Grand deed is born of intention -

You! - being a man-of-action -

Do you spurn intention? - praise the duel

And proclaim that you are level with the era!

It is likely not just the complaint about the obsession with duels that determines the meaning of this mysterious apologue. As is known, the intention behind the deed that provoked the duel was often disregarded or ignored by virulent duellists. Thus:

Mniejsza - czy senat pobłądził? czy rynek?

Bo czyjakolwiek bądź wina,

Najlepszym sędzią - zawsze pojedynek:

(“Coś," PWsz II, 69; [“Something”])

[It does not matter if the senate erred, or the market

Whoever is at fault,

The best judge is always the duel]

Ethics which do not take into consideration the intentions behind actions shall ultimately become a morality of chance and ill will, as is demonstrated by recalling "lichy Mandarynek" ["some poor Mandarin"] and by the poem's conclusion, which is naturally ironic.

The emphasis on the importance of intention is only one side of Norwid's morality. The poet must have meditated extensively on Christ's words: "I am the way and the truth and the life." So, truth is life, a way, an attitude - not a system, an ideology, or a complete rationalization. After all, ideas neither embody nor expiate reality. This is how I propose to interpret "Idee i prawda" ["Ideas and Truth"], especially the conclusion:

14 Tadeusz Makowiecki, “Promethidion,” in: K. Górski, T. Makowiecki, I. Sławińska, O Norwidzie pięć studiów (Toruń: Księgarnia Naukowa T. Szczęsny i S-ka, 1949), p. 18. 
Bo w górze - grób jest Ideom człowieka,

W dole-grób ciału;

I nieraz szczytne wczorajszego wieka

Dziś - tycze kału...

*

Prawda się razem dochodzi i czeka!

(PWsz II, 66)

[For upon those heights -lies the grave of man's Ideas,

Down in these depths - his body's tomb;

And often what's lofty yesteryear

Today - touches excreta...

*

Truth, one both reaches it and waits! $]^{15}$

Norwid juxtaposes ideas with truth; the former even border on being a caricature of the latter. Up there, where man illegally forced his way - "człek - gardzi byty" ["man - scorns beings"] - "światy są zera" ["worlds are zeroes"] and reality becomes ignored, not "zwolona” ["freely cooperating with God's will”]. Ideas are merely historical - what was noble yesterday can sink in the mud today. Truth needs to be both waited for, insofar as it is a (partially) revealed Mystery, and perfected because "approaching" it constitutes man's highest ideal. The content of truth cannot be fully accessed, while the content of ideas can be deceiving. However, the process of reading reality in the light of God's recommendations contains in itself the entire dignity of moral life. In short, Norwid does not trace the rising self-consciousness of the Idea in reality, but rather the development of human understanding, or the process of testifying to the Mystery (that is why he gives such importance to opinion, seeing vox populi as vox Dei, because it embodies and preserves God's truth, once it has been comprehended). Mystery and History are the two poles of Norwid's thought. As he put it himself:

W tej powszedniości, o! jakże tu wiele

Mistycznych rzeczy i nieodgadnionych,

Maleńkich, jako światełka w kościele

[...]

Ale to, że jest duchom i popiołom

Zwyczajną rzeczą - innym skryj to lepiéj

I nie mów (bliskim chyba przyjaciołom),

[...]

Gdzie jednomyślność tylko jest godziwa.

[...]

15 English translation by Borchardt in: Poems, p. 47. 
Ta zaś nie tam jest, ani tam być może,

Gdzie będą ciała dwa o jednej duszy,

Lecz gdzie dwie dusze o tej samej porze.

(“W tej powszedniości..., PWsz II, 255; [“In This Ordinariness...”])

[In this daily life, o!, how many

Mystical and unfathomable things there are,

Miniscule like lights in the church

[...]

But better conceal the fact that

it is an ordinary thing to spirits and ashes

And not a word (except to close friends),

[...]

Where only unanimity is fair.

[...]

Which is not there, and cannot be there,

Where there will be two bodies with one soul,

But where two souls coincide.]

This lyric poem is addressed to Trębicka, but Norwid had the same thoughts for women that he had for himself. The unanimity in recognizing the "small" mystical things depends on the historical moment, while truth is available to all and is the achievement of humanity as a whole, though he means creative humanity - one that is simultaneously faithful to the Gospel.

Norwid's understanding of "the church" is particularly broad: he equates it with humanity insofar as it is enlivened by a sense of the workers' duty and hunger for the ideal, even if imperfectly defined. Thus, Norwid's praise of Spartacus, Byron, Bem, Brown, Abd el Kader - a pagan rebel, an atheist, a heretic, a Muslim - is not as inconsistent as Jastrun suggests. Though it is for various and often surprising reasons, all of them were baptised by the poet's hands: "Niech łzy sieroty, łzy kaleki,/Zabłysną Tobie, jakby chrzest." (PWsz I, 326); ["Let the tears of orphans and cripples/Shine for you like baptism"] ("Do Emira Abd el Kadera w Damaszku" ["To Emir Abd el Kader in Damascus"]). Such a broad understanding of the church, outside of which salvation is impossible, may seem risky, but it is rooted in a strong theological tradition. Norwid's Christianity is - if I may put it in such paradoxical terms - institutionalized only in mystical terms. If man dies outside the church, as in the epigram about Michelet, God is also outside the church because He is inside the suffering man. If man sacrifices himself for a goal that - though it may be named differently - meets, even imperfectly, the criteria of virtue or love, that man is a Christian by blood or desire. At the same time, the viciousness of attacks on ostensible Christians, on Puritanism, or on "the Papists of St. Petersburg and Vienna" was unparalleled: 
O! katolicy szanowni... ta wasza

O Chrystusową potęgę obawa

To jeszcze resztki wnętrzności Judasza,

Co się po świecie rozwlekły jak lawa -

To Piotrowego odłamek pałasza,

Co przed zaparciem sięz pochew dostawa!

Gdybyście wiarę mieli, to już dawno

Widzielibyście, że glob jest Kościołem,

Który ma oną bazylikę sławną

Piotrową - niby ołtarzem i stołem...

Ale wam trzeba Kościół w ołtarz wcisnąć

I zamknąć - i straż postawić przy grobie,

Żeby za prędko nie mógł Bóg wybłysnąć...

(“Fraszka [III]," PWsz I, 170; [“Epigram [III]”])

[O! esteemed Catholics... your

Fear for Christ's mightiness

Is a remnant of Judas's insides,

Which spilled over the world like lava -

It is a shard of Peter's broadsword,

Drawn from its sheath before renouncement!

If you had faith, you would long

Know that the entire globe is a Church,

Which has the famous basilica

Of Peter's like an altar and a table...

But you need to squeeze the Church into an altar

And close it - and place guards at the tomb,

So that God does not shine out too soon...]

This brings to mind Dostoevsky's Grand Inquisitor... It sometimes happens that the court of conscience brings man - above and beyond the ostensible church to the mystical church:

Albo zapytaj siebie, ale w chwili

Gdy pod stopami glob ci się zakręci,

I cudza w tobie waga się przesili,

I w swojej staniesz mierze, bez pamięci:

Zapytaj - -

(PWsz I, 170)

[Or ask yourself, but in the moment

When the globe will spin under your feet,

And some foreign weight will tilt you,

And you will stand as you are, without memory:

Ask - -] 
Norwid had a truly incredible intuition of how Christianity would develop in the future. This also basically confirms his relevance as a thinker during his own period, which needs to be clearly stated regardless whether some might dislike it, while others - ones specifically destined to clarify and interpret this aspect of his genius - may be compelled to take up more detailed studies. Truth as a process of testifying, not as a dogmatic system that serves merely as a crutch; a church that is ecumenical and not confessional, one expiating the entirety of humanity and responsible for all people, not just the "chosen" ones who - averting their eyes from blood - sing in the Bethlehem stable; belief in Mystery, ceaselessly embodied in action, though not the kind that is worldly and seeks historical success as its goal; morality that is unlike a codex or a set of rules, but more like an openness to the otherness of fellow man and his secrets; and finally, man as a moral measure and a task to be realized - these are the components of Norwid's Christianity, as far as I glean from his work. I implore you, however, not to turn the poet belatedly - as is the Polish custom - into yet another prophet. Norwid did not invent 20th-century Christianity. He just felt rather bad in the 19th century, much like Christianity as a whole. Desiring to save the values he was deeply devoted to, he moved - like many did - in the right direction: forward. The future confirmed his premonitions, which were nevertheless only hunches - consistent from the perspective of individual life, they would have been illegible in social terms had it not been for more recent developments within Christian thought, because they were so entangled in concepts, ideas, superstitions even, that were so characteristic of the epoch Norwid loathed so much.

\section{IV}

Norwid's aesthetics is the subject that has probably been studied the most closely. It is also related to the two poles between which it oscillates: the ideal and the human, the divine and the crafted. After all,

Patrz, gdzie doszła Florencja Ideału drogą,

I czy byłaby doszła bez szkoły swej cudów?...

A dziś nosi słoneczny dyjadem na głowie,

Który jej zwiastowali Michał-Aniołowie.

Bo zaprawdę ci powiem: że narodów losy,

I koleje ludzkości, i świat, i niebiosy,

I słońce, i gwiazd chóry, i rdzeń minerału, I duch!...

...i wszystko - bierze żywot z Ideału.

(“W pracowni Guyskiego," PWsz II, 194; [“In Guyski’s Studio”]) 
[Look where Florence arrived by following Ideal,

Would it achieve this without its school of miracles?...

Today it wears a solar diadem on its head,

Which was foretold by Michelangeloes.

For indeed I tell you: the fates of nations, Humanity's history, the world, the heavens, The Sun, the choirs of stars, mineral cores, And spirit!...

... and everything - is enlivened by the Ideal.]

In other words, beauty is the shape of love, if - as Makowski strongly emphasized - Norwid saw "love among people [...] only as a reflection, the shadow of divine, eternal love." 16 The seemingly platonic terms have, in this context, a clearly Christian meaning. At the same time, "beauty incites man to work, to realize love in reality, to rise from the dead." ${ }^{17}$ Thus, it acts as the proverbial (and slightly tedious, we have to admit) flag atop man's tower of work. Just like his morality, Norwid's aesthetics demands the act of faith. Jastrun was the most recent critic to remind us of this: "Norwid is saved - let me emphasize this - by his faith in [...] humanity's divine origin and destiny." ${ }^{18}$ The profession of faith in the ideal character of art is somewhat grounded in the moralistically utilitarian side of Norwid's aesthetics, which naturally abounds in original, pioneering observations that have been analysed on numerous occasions.

Norwid's poetics, on the other hand, can be derived not so much from his aesthetics (though this is also possible and necessary) as directly from his views on man and the poetic, metaphysical attitude I wanted to present in the way that I, as an ordinary reader, see it. However, the idea of poetry as a study of existence needs to be clarified. Certainly, Norwid's search for "mystical things" in the ordinary "was rooted in his belief - which he shared with many excellent poets of European Romanticism (Novalis, Lamartine, Hugo, Saint-Beuve, Nerval, and others) - that the invisible world keeps peeking out from the visible one that surrounds us, and that every being, even the tiniest, and every event, even the most trivial, represents an eternal symbol, hides away a parable." 19 We need to constantly remind ourselves of the Romantic origins of Norwid's poetry and thought. However, the Romantic faith that Gomulicki rightly recalls could be

16 Tadeusz Makowiecki, Promethidion, p. 18.

17 Tadeusz Makowiecki, Promethidion, p. 18.

18 Mieczysław Jastrun, “Gwiaździsty diament,” Poezja, No. 1 (1967), pp. 3-12.

19 Cf. the remarks made by J.W. Gomulicki (C. Norwid, Dzieła zebrane, vol. 2: Wiersze, pp. 499-500); quotation after Gomulicki. 
understood in many ways. Norwid indeed saw it differently than the Romantics. There is a difference between believing that we are surrounded by invisible entities, as in the case of Nerval or Novalis, and believing that there is a hidden symbolism of things, which harks back to various Orphic and esoteric systems, which were widespread among the Romantics and especially the symbolists. It is also a different matter to seek out the secret meaning of events and reveal God's plan as inscribed in our reality by engaging in humble interpretation that knows its limitations, aware that every insight is merely a rung in its ladder. The fundamental differences between the three beliefs or positions are certainly beyond the scope of Gomulicki's commentary. Nevertheless, each of them establishes a different philosophy and a different poetics. The first instructs to search for mystical solutions, sometimes turning poetry into an account of hallucinations. As has often been sensibly underlined, Norwid was not a mystic (unless we take this term in the broadest sense to denote a general rapport with the divine, and thus practically any religious faith; however, I stick here to the narrower meaning, which is the only useful one). The second, blossoming in symbolism, often leads to the superimposing of semantic "systems" derived from the poet's psyche and imagination, onto external reality, ultimately culminating - as in the glorious example of Mallarmé - in a remodelling of reality's structure. ${ }^{20}$ Norwid, however, was not a symbolist. He thought that Mystery resides beyond the world, the world which is "merely" History. The interpretation he preferred and encouraged focused on the moral meaning God's love imposed on reality, which is read by man through his faith and work. Ultimately then, it is only the third position that best suits Norwid, although - as is often the case - he used misleading images and terms, which invariably bring to mind their predecessors. There is plenty of evidence of this. Let us quote the same passage as J.W. Gomulicki:

Lecz mnie ci więcej drożsi, co w rzeczach potocznych

Trzeźwi będąc, są przecież w wieczne zachwyceni,

Treść niewidzialną z onych zgadując widocznych.

(“Ruiny," DW IV, 163; [“Ruins”])

[But I hold more dearly those who, being sober In ordinary things, are enthralled with the eternal, Guessing invisible meanings from the visible ones.]

and the well-known expression:

20 Cf. Jean-Pierre Richard, L'Univers imaginaire de Mallarmé (Paris: Editions du Seuil, 1961). 


\section{[...] jest i potęga istna sztuki}

Żywej wtedy, gdy bliskie umie idealnym znamienować.

(“Do Bronisława Z.," PWsz II, 240; [,To Bronisław Z."])

[there is also a true power of art,

Which is alive when ordinary things can be suggested by ideal ones.]

Thus, the Romantic intuitions, beliefs and dreams among which he grew up were transformed by Norwid and given new meanings, quite removed from Romantic notions. His poetic devices can simply be regarded as forms of truth-seeking, all the while bearing in mind that seeking is the most important aspect... The popular poem about Earth - a globe despite being "slightly flattened at the poles" can be also summarized in a similar strain. Regardless of all its rhetorical beauty, the formula expressing the charms and aims of poetry:

Odpowiednie dać rzeczy - słowo!

(“Ogólniki," PWsz II, 13; [“Generalities”])

[To name each matter by its rightful - word!]

remains - perhaps purposefully - banal... It is, after all, the classical definition of truth as adequatio rei et intellectus, but applied to poetry. It is probably more important for Norwid that truth is not obvious. The Earth is slightly flattened at the poles but man must grow up and mature in order to notice.

Three devices in particular need to be discussed in this context: irony, silence and one I like to call "revaluation." Irony was penetratingly studied by Kołaczkowski, who argues that it constitutes the highest form of objectivity. Norwid would stop at statements, without drawing any conclusions. The sense of irony hides in the overlooked symbol - one that the poet remains silent about because "an ironist, if he wants to triumph, must become the same kind of victim as the tragic hero." ${ }^{21}$ It is the last statement especially which seems profound to me because it sheds a lot of new light on Norwid's relation to his own fate and failure. Norwid saw himself as the privileged object of irony, or strictly speaking - his own fate would somehow bring out the irony inherent in people and things. After all, he regarded himself as a victim of his age, an "extra actor," a misunderstood thinker, a lamb sacrificed on the altar of irony...

Norwid's irony does not have a lot in common with that of Baudelaire. The latter's irony rests with the poet himself - he admits to being both knife and wound, the nihilistic "no" and suffering caused by his negation of Christian

21 Stefan Kołaczkowski, "Ironia Norwida," in: Dwa studia. Fredro. Norwid (Warszawa: F. Wyszyński, 1934), p. 52. 
dreams and aspirations. His is the irony of a dandy - a dandy both real and metaphysical - neither of which Baudelaire could ever cease to be. The same word uttered in the same epoch can mean entirely different things depending on the context and structure in which it appears. Gomulicki sometimes strays from this principle in his commentaries, which are otherwise extremely valuable. Norwid himself distinguished between the irony of events (time) and the irony of actions. I hope I am not mistaken in putting them back together, if only because events stem from actions. Coming back to the position I am attempting to grasp and define: if the study of being, history, or life depends on extracting a moral truth, divine plan, or secret meaning, then it necessarily leaves debris, like the slag left over after smelting ore. The awareness that this residue exists, or that even - to the undiscerning eye and mind, not sharpened by faith - there is more of it than anything else: this is Norwid's irony. It indeed manifests in events, which is obvious, and in actions, even the most virtuous ones, because people, artists for example, are never able to completely achieve their goals, not to mention the fact that their goals may be imperfect in the first place... Sculptors know the irony of their material, which is stubborn and places its own needs before ideals. This is why wisdom never allows us to forget irony:

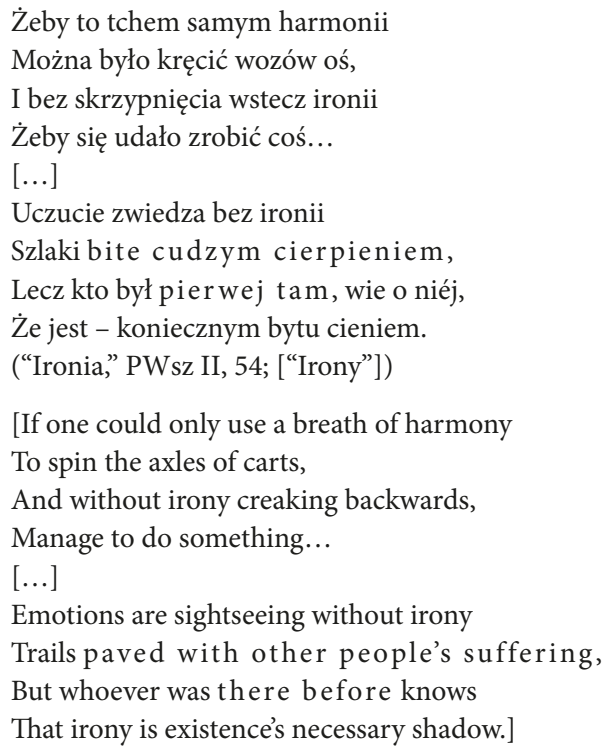

Irony creaks backwards. It is essential to being, an inseparable part of it. It is not only the consciousness of resistance, gravity and the past, but also the sense of the uselessness and waste of existence: 
Jakby wcielonej ciągle puls Ironii:

Słysząc, wiesz naprzód i wiesz ostatecznie,

Że z godzin żadna siebie nie dogoni!

Że nie wydzwoni siebie, dzwoniąc wiecznie!

(“W pamiętniku” [“In an Album”])

[The pulse if Irony, as if incarnated:

Listening, you know beforehand and ultimately,

That none of the hours shall catch up to themselves!

That they shall not outring themselves, but ring eternally!]

Ultimately then, irony is an awareness of either difficulty or failure in the struggle for "resurrection" and "active participation in God's plan" - the opposite of a life that is "zwolon" ["freely cooperating with God's will"]. This is aptly demonstrated in the following stanzas:

A ten systemat sprężyn, bez ich celu, Jakby tragedia bez słów i aktorów, Jak wielu nudów i rozpaczy wielu Muzyka, gwałtem szukająca chórów;

Raz wraz porywa spazmem za wnętrzności, Jak nie zwykłego do morza człowieka; Tylko - nie spazmem nudy, lecz wściekłości, Który, sam nie wiesz, skąd? i po co? wścieka.

(DW VI, 17)

[And this system of springs, without purpose, Like a tragedy without words and actors, Like a music of much boredom and despair Desperately looking for a choir;

Again and again it spasmodically grabs your insides Dragging down like the sea drowning one who cannot swim;

Only not - with a spasm of boredom, but one of rage,

Without knowing why? or for what? it rages.]

Laying this out in modern terms, the disappearance of values causes frustration, which in turn leads to aggression... From this perspective, Norwid is relevant. However, the "necessary shadow of being," of history or action, is finally overcome by Norwid, who keeps the wise man in mind. In Baudelaire, on the other hand, irony is internal: a sign of superiority, an aristocratic awareness of nothingness, a brutal force which is sometimes praised and sometimes loathed but always constitutes the originality of the dandy and poet.

In Norwid's poetry, irony is virtually considered a property of existence that expresses itself through irony as a literary device. I fail to explain whether this 
was supposed to be what distinguishes the two kinds of irony: that of time, and that of action, because Norwid tended to immediately translate his intellectual discoveries into literary terms, and sometimes vice-versa. There is a mystery here - one inherent to Norwid's very way of thinking, e.g. his aforementioned historiosophic literary terminology. Irzykowski shed some light on this, explaining that sometimes "Norwid treats words not 'expressionistically' but 'realistically', i.e. as something real and consisting of the same elements as the reality it expresses."22 Would it be the case that the forms words take - such as epic, irony, etc. - are simultaneously forms or characteristics of reality? If not in Norwid's conscious philosophy then at least in his poetic subconscious, which demands, as it were, such associations and terms. Whatever the case, irony in a poem can be as difficult to read as it is in real life. The complexity involved in interpreting Norwid, especially in attributing to him views that are constructed from elements found in his thought and work, stems mainly from the omnipresence of irony, as Borowy accordingly recognized. Even specialists have occasionally failed to recognize in which cases Norwid was speaking from the heart and when he was "quoting" - derisively or ironically - the opinions of his spiritual opponents, or those of his feelings and beliefs that he finally managed to overcome. It is a vicious circle since the actual meaning can only be determined by the entirety of Norwid's thought and poetry, which has not yet been fully reconstructed, not even provisionally. Gomulicki is right in promoting interpretations "from the bottom" - as it were - by empirically summarizing partial explanations, especially biographical ones. ${ }^{23}$ However, we also lack interpreters bold enough to dare verify more general working hypotheses. The history of Polish literature is afraid of Norwid, which the poet himself would

22 Karol Irzykowski, "Inter augures. Słaba odpowiedź opuszczonego zrozumialca," Wiadomości Literackie, No. 50 (1924). Quoted after: Wacław Borowy, O Norwidzie (Warszawa: PIW, 1960), p. 21.

23 With all due respect for J.W. Gomulicki's precision, it is possible, however, to oppose the prioritization of biographical interpretations. In the poem "Do Bronisława Z." Gomulicki discerns Norwid's complaint about the conditions at St. Casimir's, and the indication that "the power of art [...] allows him [Norwid] to idealize things that are close to him yet sometimes entirely trivial" (C. Norwid, Dzieła zebrane, vol. 2: Wiersze, p. 954 \& 949). Naturally, such an allusion, though very discrete, can be identified in the poem. The work as a whole, however, touches upon other matters, which are of a somewhat greater gravity. It seems to me that Norwid would not agree with such an understanding of "idealization" or "power of art." I would say that this is not the key to the poem and that Borowy came closer to deciphering it. 
consider ironic. Finally, in Norwid's works irony gave rise to a multitude of lyrical characters, who were thus given a voice: various "singers" and conversation partners, as well as embodied attitudes, truths, or psychological qualities. Thus, it gave many poems a dramatic touch. Essentially, drawing conclusions (or reaching the truth) often occurs not by means of confronting views, but through the ironic presentation of false or imperfect ideas.

Norwid's silences are easier to approach. This device is also derived from metaphysics. Jastrun agrees with Makowiecki that the theory of silence boils down to a conviction of the necessary continuity of both poetic speech and existence itself. Every sentence (act, event) speaks for itself and is at the same time similar to some of the previous ones, heralding or implying further ones. It is thus a result, a structure and a virtuality. The possibilities and virtualities that have been silenced should be revealed and developed by the poet. The poet? Everyone, that is. "Man's task is to grasp that which is left silent in the last sentence, act, or historical fact, and to articulate it, moving one link further up along the chain of truth." ${ }^{4}$ In his views on "understatement," Norwid combines the task of reading reality in moral terms with his convictions of progress and the desire to attain or at least approach wholeness - a strong tendency he has. This being the case, why would he so frequently skip over conclusions in his poems, leaving the readers to resolve sequences of thoughts and images - charades, as some would maliciously comment - on their own? Why would he disguise solutions with symbols, or even more often - hide them within the relationships between contradictory statements or equally false claims? A truth that has been left silent should - it seems - be shouted from the rooftops. Some argue that conclusions are more emphatic when omitted - a device of great subtlety and convincing aesthetic value. One could also suppose that understatement as a poetic device is analogous to a situation in which the truth remains unarticulated in real life. In this light, it could be the effect of mimetic meticulousness, fancifully conceived. Still, it seems that the key to this is much simpler. Norwid's poetic argumentations are clearly based on Socratic tradition, in which the truth remains unarticulated so that the readers can fill it in for it themselves.

Norwid's obscurity does not consist only in "an inevitable difficulty in expression"25 - it often seems to mimic the difficulty in attaining the truth, a difficulty that is deliberately made part of the poem and thus demonstrated in it.

24 Tadeusz Makowiecki, "Norwid myśliciel," in: Pamięci Cypriana Norwida (Warszawa: Muzeum Narodowe, 1949), p. 54.

25 Wacław Borowy, O Norwidzie, p. 22. 
After all, as I have already mentioned, the process of progressing towards truth is equally important to the moment of arriving at it. Thus, the "joint struggle" with the reader acquires both intellectual and moral dignity. Borowy wrote that "in Norwid we do not have intentional obscurity, as is the case with those like Mallarmé and his followers; he does not use obscurity as an 'artistic effect.' "'26 Though it may seem like a compliment, it is not. It compels me to argue, perhaps erroneously, that Norwid sometimes does use obscurity as an artistic effect, but one that has a proper moral foundation (though not always, of course!). The times when Norwid had to be defended against accusations of incomprehensibility are long behind us. There are already some who would even say he is too lucid... Just like Bieńkowski, I am certain that this opinion will gain more supporters in the future (I can understand what he - a great poet who knows his art well - means by that, i.e. that the question of Norwid's obscurity is outdated). Characteristically, though, Norwid would not renounce his obscurity, demanding only - angrily - that we trust him and make the effort to understand:

Wiary trzeba - nie dość skry i popiołu...

Wiarę dałeś?... patrz, patrz, jak płonie!...

(“Ciemność," PWsz II, 26; [“Obscurity"])

[Grant it faith, not just sparks and ash -

With your faith... see how it glows! $]^{27}$

The truth that readers arrive at on their own has greater value than the one served on a platter. Truth needs to be embodied in life. Therefore, the difficulty in understanding becomes a figure of embodying ideas in oneself and in reality. As Norwid put it himself in the aforementioned poem, purposefully emphasizing the second line,

On skarży się na ciemność mej mowy -

Czy choć świecę raz zapalił sam?!

Sługa mu ją wnosił pokojowy

(Wielość przyczyn tak ukryto nam).

(PWsz II, 165)

[He complains my speech is dark -

Has he ever lit the taper?

That reminded his servant's task

(The many reasons hid from us). $]^{28}$

26 Wacław Borowy, O Norwidzie, p. 22.

27 English translation by Adam Czerniawski in: Selected Poems, p. 60.

28 English translation by Czerniawski in: Selected Poems, p. 60. 
The gnomic conciseness of this stanza in almost unparalleled in world poetry! The technique of silence should therefore not be separated from the question of obscurity as an artistic effect (by all means not a vain and empty one - vanity is characteristic of unjustified obscurity, like the insuperable difficulty of expression, not uncommon in Norwid) for it has a certain Socratic and moral value, compatible with the poet's thought as a whole.

Finally, we can move on to "revaluation." What do I mean by this term one that Norwid neither knew nor used? Borowy aptly noted that "Norwid's most articulate lyrics are devoted to the exposition of 'beautiful' falsehoods or illusions, indicating the truth that exists besides them - one that is raw and therefore solemn." ${ }^{29}$ Borowy would support this by quoting the poem "W Weronie" [“In Verona"]:

Że to nie łzy są, ale że kamienie,

I - że nikt na nie nie czeka!

(PWsz II, 22)

[That was no tear but a rock

Awaited by none! $]^{30}$

It has been also known since a long time that Norwid liked to reveal meaning and beauty through details, minor elements that are often disregarded and remain unnoticed:

...O, jakie głębokie

Są w trefieniu warkoczy sprawy historyczne.

(“W pracowni Guyskiego," PWsz II, 194; [“In Guyski’s Studio”])

[...O, how deep

Are the historical matters contained in plaiting hair.]

This device seems all the more important because it stemmed directly from Norwid's poetics, namely his attitude towards his poetry's material, reality. His imagination typically worked along a scale of values. In his poetry we constantly observe the elevation and degradation of concepts, opinions, judgments and prejudices. This is not just "a crystallization of general concepts" - as Kridl put $\mathrm{it}^{31}$ - but their specification and redefinition. Beauty does indeed appear to be of interest in the search for truth... One needs to remember, however, that in the course of his work on intellectual and cultural poetic material Norwid returns

29 Wacław Borowy, O Norwidzie, pp. 13-14.

30 English translation by Czerniawski in: Selected Poems, p. 59.

31 Manfred Kridl, “O lirykach Norwida,” Droga, No. 11 (1933). 
to the readers more than he took from tradition. Truth emerges from his poems enriched. How does he do it? Usually, he achieves this by "building a chain," i.e. revealing the various links between one specific truth and many others. Norwid most often takes, as his starting point, certain general notions: reason and emotion, tradition and progress, the past and the future, nation, work, piety, tenderness... The "subject" of the poem is practically unimportant to him because, in essence, the wise man should redefine all the concepts and place them in a real-life context, juxtaposing them with other, related ones or their opposites: a conclusion would result from their situation and confrontation. To put it differently, the most frequently employed poetic device in Norwid's mature works is probably the redefinition of the concept by revealing its antinomies, especially contextual ones. There are heaps of examples, both among the better and the worse poems, the latter being the case when the device is clearly visible, making the lyric an apologue. "Addio!" offers a redefinition of two concepts by means of demonstrating their inadequacy:

1.

„Jeśli ty mnie szukasz - Prawda woła -

To z namiętnościami czasowemi

Węzeł swój roztargnij, synu ziemi!

Bo nie dojrzysz i cieniu swego zgoła...”

2 .

Silna na to zakrzyknie Popularność:

„Chodź! z namiętnościami czasowemi

Złącz się, opieszały synu ziemi.

Ja? nazywam cię czynność, Prawda?... - marność!”

3.

Bądźcież zdrowe, obiedwie - do widzenia!

Mnie wołają sny na mech cmentarny;

Ani widzieć chcę tej Prawdy marnéj,

Ni tej Popularności, bez sumienia.

(PWsz II, 23)

['If you are looking for me,' Truth calls,

'Then temporal passions

Must be abandoned, o son of earth!

Because you will not even notice your own shadow...'

Popularity, which is strong, calls back:

'Come! join in the temporal passions

O my sluggish son of earth.

Me? I am called action, Truth?... - is futile!' 
Goodbye, you two - farewell!

Dreams summon me to the cemetery moss;

I wish to see neither this futile Truth,

Nor this conscienceless Popularity.]

The opposition is simple, the poem's construction is based on parallels, while the conclusion is negative. A much richer example is provided by "Saturnalia" ["Saturnalia"], "Sieroctwo" ["Orphanhood"], or "Królestwo" ["Kingdom"]:

Na probierczy kamień dość przeszłości;

Było jej dość, by sprawdzić, co? boli -

Więc nie słuchaj, co dziś o wolności

Mówią - co dziś mówią o niewoli.

(PWsz II, 63)

[Enough history for the touchstone;

Enough history to verify - what? hurts -

So do not listen to what they say today

About freedom - those who talk about bondage.]

The next two stanzas of "Królestwo" demonstrate the inadequacy of both concepts with situational examples (of Nero, and of the cattle). Could it be that the truth lies somewhere in the middle?

Lecz ten $\mathrm{z}$ wszystkich nieudolny lekarz, Kto, nie wiedząc, z chorób leczyć którą?

Pomięsza dwie - nie mędrzec! - aptekarz!

- Prawda? - nie jest przeciwieństw miksturą...

(PWsz II, 63-64)

[But among doctors this one is incapable

Who, knowing not which disease to cure?

Mixes both - no sage! - a pharmacist!

- Truth? - is not a concoction of contrasts...]

Truth should not be sought in the middle, but elsewhere. Right before our eyes a new concept is born, a new quality:

Nie niewola ni wolność są w stanie

Uszczęśliwić cię... nie! - tyś osobą:

Udziałem twym - więcej! - panowanie

Nad wszystkim na świecie, i nad sobą.

(PWsz II, 64)

[Neither bondage nor freedom are capable

Of making you happy... no! - you are a person: 
Your share is - more! - to rule

Over everything in this world, and yourself.]

In fact, Norwid reaches absolute perfection in terms of the old technique of developing logical narratives, which was preferred by classicist poetry, and in Poland especially cherished by Kochanowski. Norwid is his most obvious disciple in this respect, which gives his poetry a tone and flavour that are contrary to all appearance - traditionalist. This sort of technique is rather unique for the 19th century as it goes against current of the times, returning to the source where wisdom and beauty spurt forth, mixing, and testifying to the deeply held belief that they truly condition one another. In writing his poems, Kochanowski, too, did not stop teaching us how to think. Norwid's lyricism is no less didactic, though his didacticism is lyrical. However, the truth that he didactically conveys is not ready-made, but rather contained in the very process of discovering the mystery, while his method does not rely on lecturing ex cathedra but on leading the readers to their own conclusions Socratically.

Naturally, I have provided only the simplest examples of the revaluation technique. It clashes ideas against one other, revealing their inadequacy or explicating them through situational analogies:

1.

Mistyk? jest błędnym - pewno!

Więc i mistycyzm nie istnieje?

Tylko jest próżnią rzewną,

Snem - nim roz-dnieje!...

2.

Góral? na Alpów szczycie

Jeżeli się zabłąka w chmurę -

Czy wątpi o jej bycie

$* * * * * *$

Błądząc - po wtóre?

(“Mistycyzm," PWsz II, 46 [“Mysticism”])

[A mystic? he's lost - of course!

Is there no mystic way?

It's a melancholy void,

A dream - till break of day!...

Does a highlander?

Lost on a clouded peak

Doubt the Alp is there 
When lost - again? $]^{32}$

Moreover, this technique operates by comparing images and placing concepts in new sequences of analogies or relations:

Czułość - bywa jak pełny wojen krzyk,

I jak szemrzących źródeł prąd,

I jako wtór pogrzebny...

I jak plecionka długa z włosów blond,

Na której wdowiec nosić zwykł

Zegarek srebrny - -

(“Czułość, PWsz II, 85; [“Tenderness”])

[Tenderness - is oft like a war-drenched cry,

And like wellsprings' murmuring whirl,

And like a burial lament...

*

And like a braided long blond curl,

Upon which the widower is wont to wear

His silver watch --$]^{33}$

Thus, Norwid would demolish concepts and opinions, revealing contradictions or, especially, exposing the inadequacy or incompleteness of meanings ("brak" ["lack"], "rozłamanie" ["brokenness," "breach"]). This tendency also corresponds with its opposite, which may be even stronger, i.e. the reinforcing and consolidating of concepts by tying them together and complementing one with another. It is as if Norwid were convinced that true things are the ones that can be tied to a larger whole, made into a sequence, "complemented" - ones that do not close down but rather open further intellectual perspectives. Consider the following stanzas from "Do panny Józefy z Korczewa" ["To Mademoisselle Josephine de Korczew”]:

Pani bo jesteś z takiego klasztoru,

Gdzie ścianę z ścianą

Gdy połączano, to cięcie toporu

Za zbrodnię miano.

[...]

A łuki z skrzydeł są serafinowych,

W węzły związanych;

32 English translation by Czerniawski in: Selected Poems, p. 66.

33 English translation by Borchardt in: Poems, p. 53. 
I stoją lecąc, lub czekają nowych,

Światu nie znanych.

(PWsz I, 354)

[Lady, you are from the kind of cloister

Whose walls were put together

In times when the chop of an axe

Was considered a crime.

[...]

And arches are made from seraphim wings,

Tied in knots;

And stand flying, or waiting for the new,

Unknown to this world.]

These stanzas can be understood as the unconscious confession of an internal intellectual dream - one of a consistency that would simultaneously be open. The frequent imagery of chains, knots, arcades, as well as the construction metaphors and architectural comparisons reveal the obsession with relations and continuity, which was first described by Makowiecki as "the recognition of an organic continuity being the main characteristic of all matters or things that are alive, healthy, and have a future." ${ }^{34}$ Norwid implements his redefinitions in order to reveal the interrelations between arts, between work and its material, the national and the universal, the folkloric and the worldwide, tradition and future etc. The one who was exiled from everywhere became the one who wished to join everything together, see everything in proper measure, i.e. as embedded within the chain of truth. This ambition makes sense on an intellectual level, but it would be worth investigating from an artistic perspective, in the process of constructing poems. Moreover, it would be worthwhile to trace its origins, and not just the psychological ones, which stick out because they are clearly rooted in Norwid's exile - a challenge that history placed before him, and which he heroically accepted. At this point we observe the convergence (through obsessiveness) of Norwid's two major concerns: the historic and the religious. How to position oneself beyond the antinomy of progress and conservatism? How to live in one's era, rebelling against it? How to live both in mortal life and the eternal one, simultaneously in History and in Mystery? In other words, how to be a Christian?

34 Tadeusz Makowiecki, Promethidion, p. 20. 


\section{V}

The role of poetry is to decipher the code and simultaneously connect the links of the chain, while the poet is both a "flamen" (for lack of a better term) and a worker of words insofar as he forges the chain's links. He recognizes God's love for what exists - the divine element of truth - and at the same time crowns the edifice raised by humanity in joint effort. Luckily or not, contemporary poetry, at least as a whole, does not have such ambitions, or the kind of confidence displayed by Norwid despite his humility. So where does his strange relevance come from? In my mind it has a threefold character. As Jastrun beautifully put it, Norwid's historical concerns, his fear of history and the accompanying stubborn duty to partake in history, have passionate yet anxious echoes among many contemporaries whose fate taught them that, on the one hand, there is no way to evade history, but on the other - one should not see the divine in it. Not one but scores of writers (and readers...) feel the same way today, i.e. as exiles from history, ones absently existing in an alien epoch, which - to paraphrase Norwid - frets and rages like Nero. Like Norwid, they all know, however, that it would be a sign of weakness, or even baseness, to "go back to sleep." As a result, they are looking for indications, patterns, or at least examples in the solutions that the poet came up with. Norwid's solution was creative and Christian - in this rests the second aspect of his relevance. There is little use now for the Christianity of Henryk Sienkiewicz's Quo Vadis or Rodzina Połanieckich [Children of the Soil], but that of Norwid resonates also with those people to whom religion (if not religiosity) seems distant. Finally, there is the relevance of Norwid as a poet in the eyes of poets. Even before the war his influence could be felt everywhere, sometimes excessively. Norwid certainly had an impact on the symbolists and the "catastrophists," Jastrun, Czechowicz, also Miłosz, though to a lesser extent. His mark is clearly discernible in wartime poetry, especially in Baczyński. Later, his influence became strangely dispersed, affecting poets from Herbert to Grochowiak, the latter having assimilated him in the most original way, in terms of letter rather than spirit (which is by no means an accusation!). The affinity with symbolism is the easiest one to demonstrate, starting, for instance, with an observation made by Kołoniecki: "symbolism, as we know, favoured multi-layered poetry, in which concepts (not the best word, let us rather say: constructs) have many dimensions. This would entail the need to apply twofold or even threefold interpretations." ${ }^{35}$ Similarly with Norwid; this simple and correct remark could also be expanded to include analogies with, or intuitions

35 Roman Kołoniecki, “Mit rzeczy czarnoleskiej,” Droga, No. 11 (1933). 
of technique, attitude and understanding of poetry. It also seems permissible to risk a more general hypothesis.

Contemporary poetry, perhaps even contemporary literature in general, seems to be often convinced, not necessarily in a conscious manner, that the poet's speech and the reality of the world intersect, that poetry does not "reflect" the world but - as it were - continually creates it. Poetry would thus dissolve the boundary between the microcosm of the poem, novel or drama, and the macrocosm to which the poetic lines, story plots or dramatic images refer. Hence the ambiguity of the poem (if we were to limit ourselves to this form) and the plethora of its possible meanings - not just intellectual but also understood as structures of significance, even when formed unconsciously, or semi-consciously. Naturally, this conviction is not identical to Norwid's concept of poetry as the study of hidden truth. However, it has many parallels with Norwid's position, ones contained in Norwid's mutual relationship between "myśl rozszyfrowująca" ["deciphering thought"] and "chaos życia" ["life's chaos"], between poetic speech and the given reality of contemporary times. Just like Norwid would impose truth on an epoch he considered undeserving of this term - though he himself would probably call it "recognizing" this truth - so now poetic words create (possibly, "recognize") structures of significance and impose them on the chaos of external reality, which presents itself only to the eyes of poets, in this sense becoming dependent on them. This may be a mere analogy, but do we not use analogies in order to communicate with the past?

Ultimately, both Norwid and our contemporaries give absolute precedence to the question of language, which eternally determines and creates meanings. At the same time, language creates human beings - ones who are aware, or are in the process of resurrection, as Norwid put it. He touches upon this in one of his last poems:
Jak Słowianin, gdy brak mu naśladować kogo,
Duma w szerokim polu czekając na siebie -
(“Słowianin,” PWsz II, 254; [“The Slav"])
[Just as a Slav, lacking anyone to emulate,
Ponders, in vast pastures, and his own self awaits - $]^{36}$

However, he himself was that Slav who - though exiled from Poland and his epoch - found himself in the end and perhaps, along with himself, found many of us.

36 English translation by Borchardt in: Poems, p. 135. 


\section{Postscript}

I am one of those Zoilus-like complainers who demanded that J.W. Gomulicki publish Norwid's works sooner. As a result, he derides and curses me (though without pointing fingers) in the preface. C'est de bonne guerre -I got what I wanted. Gomulicki admits that the ghastly edition prepared by Tadeusz Pini gave Miriam the right push. If my complaints contributed, even a little bit, to the creation of an atmosphere of need and demand, I would rest content. All the more so since Dzieła zebrane [Collected works] is a beautiful edition! I would just like to mention that I have never doubted the knowledge and competence of J.W. Gomulicki. If this is how he received my grumblings, I shall gladly apologise. I just thought - and still think - that perfect is the enemy of good. In order to make Norwid accessible to average readers, among whom I count myself, and not just the specialists, it would be more useful to begin with a simple edition (even if incomplete) because such post-war editions of his lyricism failed to meet expectations. Now it is all over. The first volumes of Dzieła zebrane certainly have their deficiencies, but I am not in the position to discuss them. There can be no doubt, however, that their merits outweigh any fallacies, constituting - along with his biography - a qualitative breakthrough in making Norwid available to the wider public. We owe the most heartfelt gratitude to this advancement.

\section{Bibliography}

Borowy, Wacław. O Norwidzie. Rozprawy i notatki. Wydanie opracowała Zofia Stefanowska. Warszawa: PIW, 1960.

Irzykowski, Karol. “'Inter augures.' Słaba odpowiedź osaczonego zrozumialca.” Wiadomości Literackie, 1924, No. 50, p. 1.

Jastrun, Mieczysław. “Wstęp.” W: Cyprian Kamil Norwid. Poezje. T. I.

Warszawa: PIW, 1956, pp. 5-20.

Jastrun, Mieczysław. “Gwiaździsty diament.” Poezja, 1967, No. 1, pp. 3-12.

Kołaczkowski, Stefan. “Ironia Norwida.” W: Dwa studia. Fredro. Norwid.

Warszawa: Wydawnictwo "Droga," 1934, pp. 43-75.

Kołoniecki, Roman. "Mit Rzeczy Czarnoleskiej.” Droga, 1933, No. 11, pp. 1028-1051.

Kosiński, Kazimierz. “Cypriana Norwida 'sen Prometowy.” Droga, 1939, No.

11, pp. 960-977.

Kridl, Manfred. “O lirykach Norwida.” Droga, 1933, No. 11, pp. 1135-1143. 
Makowiecki, Tadeusz. "Promethdion.” W: Konrad Górski, Tadeusz Makowiecki, Irena Sławińska. Pięć studiów o Norwidzie. Toruń: Księgarnia Naukowa T. Szczęsny i S-ka, 1949, pp. 5-32.

Makowiecki, Tadeusz. "Norwid myśliciel." W: Pamięci Cypriana Norwida. Warszawa: Muzeum Narodowe, 1949, pp. 50-60.

Piechal, Marian. O Norwidzie. Warszawa: Rój, 1937.

Richard, Jean-Pierre. L'Univers imaginaire de Mallarmé. Paris: Editions du Seuil, 1961.

Wasylewski, Zygmunt. Norwid. Warszawa: Skł. gł. w administracji "Myśli Narodowej," 1935. 



\title{
Sławomir Świontek \\ Norwid's Theatre of the World ${ }^{1}$
}

\author{
Dlaczegóż wcale inaczej jest, niźli jest?... \\ (Za kulisami, $D W V I, 78$ ) \\ [Why is it quite different than it is?... \\ (Backstage)]
}

\begin{abstract}
The author recognizes the treatment of the world as theatre as the most important component of Norwid's thought. The specificity of Norwid's concept of theatrum mundi can be seen in his ambivalent attitude towards two basic visions: Dei theatrum mundi and hominis theatrum mundi. In the latter conception, the director is no longer a supernatural being - God. Instead, the function of the director is taken over by man, and the paradox - a somewhat tragic one - is the fact that man not only directs this theatrum but also appears on stage. Presenting reality in terms of theatre of appearances, falsehood, or even hypocrisy, Norwid comes close to the Renaissance worldview, according to which man should be blamed for this "small stage" being "inexpertly raised." At the same time, Norwid's vision is a call for an ideal, which would bring order to the stage. In this respect, it also comes close to the categories developed in Antiquity and the Middle Ages, referring to the same topics.
\end{abstract}

Keywords: Cyprian Norwid, drama, theatrum mundi, theatre

1

The theatrical awareness of Norwid as a drama writer has been the subject of several studies and papers. ${ }^{2}$ These studies both originated from an immanent analysis of the dramatic achievements of the author of Aktor [Actor], and referred to the poet's numerous theoretical and programmatic statements on the topic of drama and theatre, which proved his knowledge of the dramatist's craft and of the rules governing theatre. However, I would like to examine the matter of Norwid's theatrical awareness from a different point of view, expanding the

1 The paper is a fragment of a larger work.

2 E.g. I. Sławińska: “Ciąg scenicznych gestów’ w teatrze Norwida”, in: Sceniczny gest poety. Zbiór studiów o dramacie (Kraków: Wydawnictwo Literackie, 1960); "Reżyserska ręka Norwida," Przegląd Humanistyczny, No. 4 (1964); "O terminologii teatralnej Norwida," Pamiętnik Literacki, Vol. 4 (1968). 
scope of the term by relating it to certain elements of the poet's worldview which are constantly present in his reflections and reappear in numerous statements, letters and artistic works. This procedure will not so much concern the secrets of "Norwid's producing hand" as it will allow to explain the manner of seeing the world which was expressed throughout the writer's work, and in particular in his dramas. If one were to assume that it is a particular worldview which decides a playwright's given technique, then Norwid's theatrical awareness and, by extension, his dramatic and theatrical stylistics may acquire additional justification and motivation.

The manner of seeing the world presented in a dramatic work is determined not only by the theatrical convention of the given time in history, but also results from the specific attitude of the writer towards the real world. Creating the protagonists' interpersonal relations and communications, mutual influences and interactions (in a word - constructing dramatic action) are processes based on seeing the homology of those interactions with interpersonal relations in the real world. Constructing the drama's presented world and stage action depends thus on a particular "modelling" of human social behaviours. In this way, the manner in which the writer sees the world and reality determines the way in which that writer creates the world of artistic fiction, and further results in the determination of the scope of applied techniques and styles. In the case of a drama, this principle has a much more categorical effect than e.g. in poetry, if only for the fact that man is one of the elements which creates it.

It ought to be considered which elements of Norwid's worldview had the strongest impact on his awareness as a playwright. In other words, how his view on social, interpersonal relations, his interpretation of reality, the world, its history and modernity, treated as a macrocosm, determined the presentation of those issues in the categories of a dramatic microcosm on stage. The selective and combinatory nature of creating a stage reality in relation to the objective world does not exclude the principle of the homology of those two worlds. The concept of homology here covers very different manners of constructing the theatrical world: from construction based on contiguity, to creation built on the principle of substitution. Considering the intentions of the writer or "intentions" of a specific cultural trend, one may - allowing some simplification - say that it is either about creating the illusion of a "mirror-like" reflection of reality, or about creating something one might call a great metaphor. The borderline is fluid enough to make the above-mentioned concepts of macrocosm and microcosm lose their differential character, so that they can be used interchangeably: the theatrical world can take on the properties of a macrocosm in relation to the 
real world. That interchangeability is always based on the principle of homology between the two worlds.

While selecting certain elements of Norwid's worldview, one has to be aware of the accompanying risk. What is understood as the writer's worldview constitutes a certain system characterised by a specific level of its elements' cohesion, contradicted neither by their mutual opposition nor moments of their constant evolution throughout the writer's life, as documented in subsequent artistic works. At the same time, that system has particular relations with the worldview of literary trends contemporary to the writer, with the worldview of the era, or - to look at the issue more broadly - with the social awareness of the given time. It thus joins a more general system and becomes an element of its structure, co-constructing the larger system and often programming the direction of its evolution. Thus, making a selection such as the aforementioned requires full awareness of any and all such connections, relations and correspondences. The selection procedure should have its own additional motivation, which would determine the criteria to make the selection and the purpose of such an operation.

In this case, the choice concerns the elements of Norwid's awareness that are constantly present in his thought, appearing in his works very frequently, and thus valent elements of the poet's worldview system, which seems to provide additional justification for their distinction. At the same time, those elements maintain a connection with Norwid's philosophy and historiosophy, his aesthetics and poetics. Moreover, their existence and frequent appearance are related to the poet's unique place in the social life of the world contemporary to him, and to his attitude towards society and the world.

It is mainly about defining how Norwid's awareness as a playwright came about, what factors convinced the writer to present the world in his dramatic works in the specific manner he chose, as well as where his predilection to construct non-stage works into structural forms of a paradramatic nature came from (e.g. numerous poems shaped as dialogues).

It is symptomatic that the poet treats social reality and human life as drama. "Życie jest to smutny i piękny dramat [...]" (DW XI, 305) [Life is a sad and beautiful drama], Norwid writes in a letter to Konstancja Górska. In his lectures on Juliusz Słowacki, he elaborates on this thought, defining the dramatic vision of life as the one which best matches its essence, as the only authentic and nonfalsified manner of approaching reality:

Prawda obejmuje życie, jest więc niejasna, bo obejmuje rzecz ciemną [...]. Winszuję zaś tym, co życie jasno widzą; dla mnie jest ono sprawą pełną stron dramatycznych, 
a nie automatycznych, a więc i zawiłych, skoro zaś musiałbym od prawdy oddzielić życie, musiałbym zaraz podejrzewać, że ona jest fałszem, i dopuszczając tylko, że do niej wchodzi życie - dopuszczam, że jest prawdą. (PWsz VI, 449-450)

[Truth embraces life, and is therefore unclear, because it embraces an obscure thing. [...]. I congratulate those who see life as clear; for me, it is a matter full of dramatic sides, not automatic, and thus complicated, and if I were to separate life from truth, I would have to immediately suspect that truth to be false; and only assuming that life enters it - I assume it to be true.]

The contexts in which Norwid compares life to a drama allow to differentiate the meanings brought out by such a juxtaposition. Characterising them according to categories of stylistic means, one might say that it is about passing from a simile of life as drama to the use of the term "drama" as a metaphor or even symbol of life as such. The comparison does not really have an evaluative character; rather, it results from the poet's ambition to verbally express his own manner of seeing reality and people, who should use their actions and wills to join the course of events according to their place in the world and society. Here, Norwid refers to "drama" in the etymological sense of the term, which in Greek corresponded to such words as: action, impact, activity. The author of Milczenie [Silence] thus writes:

człowiek i spółcześnie zajmuje przecież także żywe miejsce w codziennej dramie doczesności, a na jej powołania odpowiadać i dopisywać onym jest obowiązany. (PWsz VI, 225-226)

[mind you, man takes a lively place in the everyday drama of worldliness even today, and is obliged to answer its calls and favour them.]

For man to answer that calling in the sad but also beautiful drama of life is at the same time, according to the poet, to ennoble man, who in that manner marks his existence not only in his own contemporary reality, but also in the history of the world, confirming the fact "jako bogatym jest dramatem życie tego lichego zlepka, który doczesny jest co chwila, a wieczny zawsze" (DW VII, 79) ["how rich a drama is the life of that pitiful cluster, earthly almost everymoment and forever eternal."] The drama which exists in reality sometimes turns into a tragedy which not everyone is able to face, as the poet ironically remarks:

Szczęśliwi, którzy przed każdym aktem tragedii pakują się i na czas jadą à n’importe où do wód. (PWsz X, 50)

[Happy are those who before each act of tragedy pack up and leave à n'importe où to the springs for a while.]

It is typical of Norwid that when he starts speaking of the reality contemporary to him, when comparing life to drama he very often replaces the latter term with 
the word "tragedy." As a matter of fact, "tragedy" also becomes a metaphor when he speaks of the history of the world, and more specifically: about man's struggle against the turning wheel of history. To quote two statements characteristic in that respect:

Dawno, jeszcze przed wystąpieniem Garibaldiego na scenę polityczną, uważałem, iż odwieczna tragedia grająca się pomiędzy wolą człowieka a historią ściera się gdzieś w powietrzu, i piorunnie się kędyś spotykają te potęgi. (PWsz VI, 82)

[Long ago, even before Garibaldi entered the political scene, I believed that the age-long tragedy playing out between the will of man and history clashes somewhere in the air, and that those powers meet someplace in thunder.]

Żyjemy w Epoce podobnej do piątego aktu tragedii przed nami zaczętej; rób co chcesz! rób co chcesz!... nie odmienisz następstw i losów-aktorów, i pędzących sił do naznaczonego im węzła dramatycznego... fatum...(PWsz IX, 280)

[We live in an Era similar to the fifth act of a tragedy which began before us; do as you like! do as you like!... you cannot change the consequences and actor-fates, and the forces rushing towards the dramatic plot set for them... fatum...]

The above-presented manner in which Norwid presents reality as "the drama of life" and "history's tragedy" results from the writer's specific attitude towards the world, and forms an element of his worldview as a system. Analysis of the poet's statements concerning that topic should be the starting point for discussing issues related to the techniques used by Norwid as a dramatist. His dramatic awareness concerning reality, life and history determines his drama and theatrerelated awareness. The famous statement from Aktor: "Tragedia jest w historii, a w życiu jest drama/Z komedią..." (DW V, 389) [Tragedy is in history, and in life there is drama/With comedy...], ties into defining those two kinds of awareness: on the one hand, it results from a sense of life's dramatic nature; on the other, it technically specifies the genealogical dramatic concepts for the genres, within which Norwid worked, anyway.

Norwid's presentation of reality as drama contains multiple semantic hues, and often assigns the name "drama" to the life of a single individual - sometimes to a fragment of their life, or a single event. For instance, this type of "dramatic" character can be found in events which are elements of the storylines of his epic poems and artistic prose (e.g. Menego, scenes from Czarne kwiaty [Black Flowers] and Białe kwiaty [White Flowers]). Some of his lyrical poems also have the structure of dramatic miniatures, with clearly defined scenery, and dramatic action often presented in a dialogue (e.g. "Scherzo I" and "Scherzo II," "Spartakus," "Obyczaje," "Beatrix," "Malarz z konieczności," "Polka," "Sfinks," "Narcyz," "Fatum,, "Spowiedź," "Nerwy," “Ostatni despotyzm," "Krzyż i dziecko" ["Scherzo I" and "Scherzo II," "Spartacus," "Customs," "Beatrix," "A Painter out of 
Necessity," "Polishwoman," "Sphinx," "Narcissus," "Fate," "Confession," "Nerves," "The Last Despotism," "The Cross and a Child"]).

The fact that Norwid treated the life of an individual or the events therein as a "drama" has its consequences in how the author of Pierścien Wielkiej-Damy [The Noble Lady's Ring] constructed dramatic events in his own stage works, and through that, it may become the starting point for an analysis of the dramatic action's structure in those works. In Norwid's comedies, motifs of "dramat serca" [the heart's drama], the "passing-by" of man and woman, people and human attitudes not meeting, on account of "ironia zdarzeń" [the irony of events] are of particular significance. ${ }^{3}$ In Miłość-czysta u kapieli morskich [Pure-Love at Sea Baths], one of the protagonists addresses this topic:

Cóż za szczególne są w życiu zdarzenia -

Co to jest? na co to? skąd to powstaje?

Czy obraziłam go?... czy on mnie? czyli

Obraziliśmy jakiś życia-atom?...

Nieznanej wagi i treści!... cóż to jest?

[...]

O! nędzo - nędzo uwidzeń i marzeń!

[...]

- Byłożby prawdą, że w zbliżenia-dramie,

Ludzie, gdy ciałem i duchem nierówno

Ku sobie idą, nadbiega ta doba,

Która rachunek kroków takich pełni

I jako lichwiarz domaga się liczby?! (DW VI, 445)

[How particular are life events -

What is this? what for? how does it come about?

Did I offend him?... or he, me? did we

Offend some life-atom?...

Of unknown import and content!... what is this?

[...]

Oh! the misery - misery of illusions and dreams!

[...]

- Would that be the truth that in the drama of coming together,

When people go towards each other

Out of step in body and soul, there comes a day

Which keeps score of such steps

And demands the number like a pawnbroker?!]

3 See S. Świontek, "Paraboliczność struktury scenicznej 'Pierścienia Wielkiej Damy' C. Norwida," in: Dramat i teatr. Piąta konferencja teoretycznoliteracka w Świętej Katarzynie, ed. J. Trzynadlowski (Wrocław, 1967). 
Another leitmotif of Norwid's dramas is the conflict of a (creative) individual with society. That motif - quite typical of the Romantic worldview, as it were - along with the above-mentioned one, is the basis for constructing the events and dramatic action in the poet's three most important stage works: Pierścień Wielkiej-Damy, Za kulisami and Kleopatra [Cleopatra]. The problem of isolating a great individuality from the social group, of a creator surpassing the contemporary awareness stereotypes with his achievements, is related to Norwid's perception of the "irony of time." The drama arising from that conflict is expressed in extenso in the poem "Coś ty Atenom zrobil, Sokratesie..." ["What Have You Done to Athens, Socrates..."]

The writer's choice to operate with the two motifs discussed above is additionally motivated by Norwid's own biography, the personal history that shaped his individual worldview, and which started to function in the artistic construction of the world of his dramatic works in such a specific manner.

\section{2}

Norwid's juxtaposition of life and drama, as discussed so far, was rather a simile or a metaphor, intending to reflect the essence and character of life practically without any tendency to evaluate. What is more, Norwid's conception of reality appears to be quite similar, although this one has a clear valuating function. What is meant here is the treatment the world as theatre, ${ }^{4}$ Norwid's specific concept of theatrum mundi. The valuating function of this attitude is even visible in just the title of the poem "Marionetki" ["Marionettes"]: the term concerns people creating a society and subjecting it to its rules, rules which falsify their authentic humanity, forcing them to wear marionette masks and turning their lives into a game of appearances and illusions. The poem contains a well-known fragment with semantic emphasis on the adjectives "small" and "inexpert:"

Jak się nie nudzić na scenie tak małéj,

Tak niemistrzowsko zrobionéj,

Gdzie wszystkie wszystkich Ideały grały,

A teatr życiem płacony - (PWsz I, 345)

[How not to be bored on this small stage

So inexpertly raised,

Where everyone's Ideals are played,

And the theatre with life is paid -$]^{5}$

4 This issue was addressed by M. Jastrun in “Teatr podwójny," Twórczość, No. 9 (1970).

5 English translation by Danuta Borchardt in collaboration with Agata Brajerska-Mazur, Cyprian Norwid, Poems (New York: Archipelago Books, 2011), p. 121. 
The valuation is of an even more severe form in the poem "W pamiętniku" ["In an Album"], where the theatre-world is identified with hell - several times, at that:

Patrząc przed siebie z obłędu wyrazem, Wieki potrącać, jako grzyby w lesie,

Ludzi, Epoki!... mięszać wszystko razem -

Być tam i owdzie -w on czas, dziś i potem,

Jako się wyżej albo niżej rzekło;

A nie równiejszym wracać koło-wrotem,

A nie odpomnić, że zwiedziłem Piekło!...

[...]

Tam - uczuć nie ma, tylko ich sprężyny,

Zdające z siebie wzajemny rachunek,

Do nieużytej podobne machiny,

Puszczonej w obieg - przez pęd lub trafunek.

Tam -celów nie ma, lecz same rutyny

Pozardzewiałe - i nie ma tam wieków -

Dni - nocy - epok - tam tylko godziny

Biją, jak tępych utwierdzanie ćwieków.

$[\ldots]$

A ten systemat sprężyn, bez ich celu, Jakby tragedia bez słów i aktorów,

Jak wielu nudów i rozpaczy wielu

Muzyka, gwałtem szukająca chorów:

Raz wraz porywa spazmem za wnętrzności,

Jak niezwykłego do morza człowieka;

Tylko - nie spazmem nudy, lecz wściekłości,

Który, sam nie wiesz, skąd? i po co? wścieka, ${ }^{6}$

[...]

Lecz - prawić o tym i prawić na dowód,

Że byłem owdzie? - myśl sama udławia!

Jestem zmęczony... wolę jechać do wód -

Nie na wyjezdném o Piekle się mawia. (DW VI, 15-18)

[Look ahead with a mad look,

Jostle centuries like mushrooms in the forest,

6 The boredom with the "small stage of the world" from the previously quoted poem here becomes a protest, and the "fury" results from the awareness of the lack of power and uselessness of protest and rebellion. 
People, Epochs!... mix everything together -

$\mathrm{Be}$, here and there - that time, today and later,

As said above or below;

Come back in a non-lesser whirlwind,

Never forgetting I visited Hell!...

$[$.

There are no feelings, just their springs,

Providing mutual accounts of one another,

Similar to an unused machine

Activated by speed, or maybe by chance.

There are no goals, just mere routines

Corroded - and no centuries -

Days - nights - eras - there are only hours

Striking, as in fastening blunt nails.

[

And this system of springs, without purpose,

Like a tragedy without words and actors;

Like a music of much boredom and despair,

Desperately looking for a choir:

Again and again it spasmodically grabs your insides,

Dragging down like the sea drowning one who cannot swim;

Only not - with a spasm of boredom but one of rage,

Without knowing why? or for what? it rages.

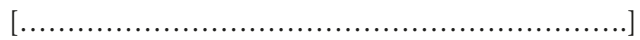

But - to talk of it and talk to prove

That I was there? the thought alone is stifling!

I am tired... I prefer to go to the springs.

Hell is not talked about on a trip.]

Seeing the world as theatre has a rich tradition in the history of human thought, and especially so in the history of theological and anthropological thought. It is not the purpose of this paper to reconstruct that tradition and place Norwid's worldview in its context, and it is even further from analysing the impact of that tradition on how the author of Vade-mecum viewed the world as theatre. That exceeds the capacity of this paper, or the ability of its author. This is also the result of incomplete data on those of Norwid's readings and studies which might have shaped his worldview in that respect.

Yet one ought to be aware that the concept of theatrum mundi dates back to the most ancient times of human thought, and throughout history one can see its constant evolution, richness of forms and diversity of interpretations. One 
would not be mistaken in stating that the concept appears in a more or less conscious way, in implications or in extenso expressions, in the theological-mythical awareness recorded both in ancient mythologies and in the Old Testament, and that it can be found today in J. Huizinga' Homo ludens (1938) or in the worldview system of the author of Le Phénomène humain (1955) - Teilhard de Chardin. Operating under the assumption that views of the world and reality as recorded in the history of drama and theatre are marked with a large dose of homology with visions of reality which are elements of worldview systems - the concept of the world as theatre can be found in the history of drama from Aeschylus to Jean Genet.

Although it is clearly a simplification of the matter, let us try to categorise the various historical formulations of the concept of theatrum mundi appearing as one of two types which underlie the said diversity. One of them, usually rooted in theological doctrines, viewed the world as a great stage of the spectacle directed by God, where people are actors directed by a force beyond them, a force which decided their fate and life in advance. In ancient tragedy, such force was usually gods' judgment, doom leading to the tragic termination of an individual's life. Some medieval doctrines understood that force as the Christian God, while the final fate of an individual did not necessarily have to be tragic or even pessimistic. Even death could be viewed as a kind of liberation, bringing one closer to God.

In ancient drama, the life of the actor-man, directed by fate, was tragic: it ended in a death which led to a realm of shadows, neither good nor bad; it ended in losing one value without gaining another. In a medieval morality play, mortal life was also tragic, but only on account of its wretchedness and insignificance; yet it was also an overture to authentic life, life after death, and the more tragic the overture, the happier the conclusion. Even mystery plays about Christ's Passion ended in resurrection, ascension and even redemption of the actor-humans' sins. That is why medieval theatre did not produce tragedies. In the concept of theatrum mundi at that time, the term "mundus" included not only man's life on earth, but also life after death; God-producer ruled over both. In that moment when the tragedy of Christ's fate as a man likely shows to the fullest, he calls to God the Father, seeing Him in that very function: "Abba, Father," he says, "everything is possible for you. Take this cup from me. Yet not what I will, but what you will."7 The motif of viewing the universe as a total theatre, played before God, to His glory and at His will, appears as early as in the Old Testament, where

7 The Gospel of Mark 14:36, New International Version. 
in a curious imaging, the thought returns in the Book of Proverbs. Eternal Wisdom, the source of Justice and Power, says there that before all creation, it played before God for His entertainment, and in the world of the earthly realm it amuses itself by playing with human children. ${ }^{8}$

The idea of man as a marionette animated by a greater force, and the world as a great stage where the existence of order or chaos depends on that greater force, also finds expression in platonic and neoplatonic philosophy. In Laws, Plato says that "man is made to be the plaything of God," "each of us living beings [...] a puppet of the Gods, either their plaything only, or created with a purpose;" those words "often quoted by others, took on a dark meaning in Luther's: All creatures are God's pupae and puppets [...]"10

A somewhat different vision of the medieval concept of theatrum mundi was presented by numerous treaties, popular in the late 16th and 17th centuries, written in the spirit of counterreformation, aspiring to become a universal description of the structure of the universe and its order as established and followed by the divine, and specifying the place and role of man in that "theatre," often viewed in the spirit of medieval mysticism and asceticism. ${ }^{11} \mathrm{~A}$ similar view on the history of the world and humanity could be found in some conceptions of mystics. A characteristic doctrine is the one by Sebastian Franck, which opposed both Lutheranism and the dogmatics of the Catholic Church. Promoting the "idea of a non-denominational and non-ecclesial Christianity,"12 he presented the history of humanity as

a theatre of the world, in which human life appeared as the internal conflict of truth and freedom versus falsehood and submission, Christ versus Adam. In this theatre of the world, according to Franck, the same old comedy continues to play out before God's eyes, with the powers of "Adam" rising and triumphing over the powers of "Christ," only to be then hurled down into catastrophe and misery. ${ }^{13}$

8 J. Huizinga, Homo ludens. Proeve eener bepaling van het spel-element der Cultuur (Amsterdam: Amsterdam University Press, 2008), p. 245. The text from the Book of Proverbs (8:30-31) is as follows (New International Version): "Then I was constantly at his side. I was filled with delight day after day, rejoicing always in his presence, rejoicing in his whole world and delighting in mankind."

9 Plato, Laws. Book I, transl. Benjamin Jowett. The Project Gutenberg EBook 2008.

10 Huizinga, Homo ludens, p. 245, footnote 1.

11 See B. Suchodolski, Narodziny nowożytnej filozofii człowieka (Warszawa: PWN, 1963), pp. 479-484.

12 L. Kołakowski, Świadomość religijna i więź kościelna. Studia nad chrześcijaństwem bezwyzaniowym XVII wieku (Warszawa: PWN, 1965), p. 107.

13 Suchodolski, Narodziny nowożytnej..., p. 465. 
Sebastian Franck was the one who drew conclusions, on the plane of theological thought, about the conceptions of the world and man formed by Renaissance humanists. His negation of the institutional Catholic Church which stopped being the "Church of Christ" and became a "Church of Adam," negation of the ceremony and liturgy in that Church which were merely masks as opposed to what they should authentically be - those views joined elements of the Renaissance worldview, which treated all social institutions, customs, habits and conventions as mere appearances which make this world the theatre, where man, subjected to all that, becomes an actor who falsifies his human authenticity, just playing a role imposed on him by the theatre of social life. And here one arrives at the second view of the conception of theatrum mundi, whose director is no longer the supernatural being - God. In this conception, that function is taken over by man, and the paradox - a somewhat tragic one - is the fact that man is both the director and the actor there.

The first of the theatrum mundi concepts described here, due to its character determinist in ancient times, and determinist-theological in the Middle Ages "absolved" man in a way, treating him as "the plaything of God." The other one introduced a volitional element and thus blamed man for the fact that the world was a theatre, and that metaphor here held a pejorative attitude towards reality, and was critical towards man, who created that reality.

The comparison of life to theatre in the second understanding did appear in antiquity, but it was then accompanied by the faith that man can make a "good" theatre out of life, that he may become its good director and be a good actor thereof. Lucius Seneca writes in his Epistolae: "Life is like a play: it's not the length, but the excellence of the acting that matters." 14

Some Renaissance views had connections with the first of the theatrum mundi concepts presented here, but man was not seen there as a powerless marionette. According to the hedonistic life views held by Renaissance people, man was an actor in the theatre of the world created by God, but it was the privilege of the man

that he does not receive a specific role, that he may be anything; the protean greatness of man lies in the very fact that he can be different than he is, he can impersonate lesser and greater beings. Human life is thus de-realised; it is reduced to theatrical dimensions, expresses the experiences of the courtly style and at the same time also Plotinian tradition where the variety of men and their fates was just a set of elements in the dramatic

14 Quotation after J. Ker, The Deaths of Seneca (Oxford and New York: Oxford University Press, 2009), p. 118. 
plot of the world, $[\ldots]$ the essence of man was that he could act out anything, $[\ldots]$ he feels best in his own "mask," meaning this character of his own which allows him to be a versatile actor. ${ }^{15}$

But that is only one side of the Renaissance theatrum mundi. That is still an interpretation in which humanists wished to relate their own vision of man to the ancient traditions they valued so highly. Yet at the same time, Erasmus of Rotterdam wrote his teasing Praise of Folly, where God stops being the director of the theatre of the world, that role being taken by human folly, which

in the garb of pride, of vanity, of vainglory, is the hidden spring of all that is considered high and great in this world. The state with its posts of honour, patriotism and national pride; the stateliness of ceremonies, the delusion of caste and nobility $[\ldots]^{16}$

In a word (of Erasmus) -

And what is all this life but a kind of comedy, wherein men walk up and down in one another's disguises and act their respective parts $[\ldots]$.

And elsewhere:

In a word, this folly is that that laid the foundation of cities; and by it, empire, authority, religion, policy, and public actions are preserved; neither is there anything in human life that is not a kind of pastime of folly. ${ }^{17}$

Here, the work of Erasmus is just one of many examples of the new concept of theatrum mundi, a concept that has a particular impact on later visions of the world which saw it in theatrical categories. Sophocles' King Oedipus sentences himself in the name of social and moral order, and his fate fulfils the prophecy of gods who guard that order at the same time. Dante describes his vision of the world as a universe in which God is the one who decides on the reward or punishment for an offense against the order. Yet the Divine Comedy is likely the last great work to present a theatre of the world ruled over by the Great Director - God.

Then come Cervantes and Shakespeare. The former presents the world described by Erasmus of Rotterdam. The protagonist of the Spanish writer is a man from beyond that world, from beyond the reality of appearances, masks and falsehood. He is foreign to the world and at the same time an enemy thereto,

15 Suchodolski, Narodziny nowożytnej..., p. 346.

16 J. Huizinga, Erasmus and the Age of Reformation (Princeton: Princeton University Press, 2014), p. 71.

17 Desiderus Erasmus, In Praise of Folly, transl. John Wilson (New York, 2010), pp. 22, 20-21. BN II, 81. 
because his attitude exposes its artificial and theatrical nature. He is someone thus described in the Praise of Folly:

If anyone seeing a player acting his part on a stage should go about to strip him of his disguise and show him to the people in his true native form, would he not, think you, not only spoil the whole design of the play, but deserve himself to be pelted off with stones as a phantastical fool and one out of his wits? [...] But to discover this were to spoil all [for] the spectators. ${ }^{18}$

Paradoxically, within the reality in which Don Quixote exists, he is the "false" character. His gestures are "theatrical," but only because they belong to a different "theatre." The proportions are changed following the change of the theatrum mundi concept together with a different social awareness.

The characters in Shakespeare's dramas are the actors of the new theatrum mundi. Yet their tragedy is not based - like with Cervantes - on a negating attitude towards the world in which they live. As actors, they consciously adopt the rules of behaviour imposed on them by stepping onto a stage. Subsequent kings from historic annals want to be the main protagonists. However, it is too late when they realise that the theatre they joined will destroy them, that by becoming "someone" they stop being "themselves," ${ }^{19}$ that by playing a specific role in the theatre of the world, they become part of a mechanism which will annihilate them.

And that was the main problem in the Shakespearean philosophy of man, the fundamental axis of his dramas. Man lives and is shaped by the social, human world, but that world - the only element of human existence - is the cruel destruction of that existence at the same time. Shakespeare showed that dramatic and contradictory truth in diverse variations and various modes. ${ }^{20}$

The great theatre of a world in which man wishes to be the director and the main actor plays out on the stage of The Globe. That theatre no longer has God as its director. Man is responsible for the tragedy of his own life, for the things which destroy him - history, social institutions, the masks he wears - are all his own doing.

The baroque theatre of the 17th century brings one more attempt to reintroduce God as the producer of the theatre of the world. Yet He ceases to be the metaphysical, invisible, objective force steering human marionettes from beyond the stage. He becomes one of the dramatis personae, active on the same plane as

18 Erasmus, In Praise of Folly, p. 22.

19 Suchodolski, Narodziny nowożytnej..., p. 506.

20 Suchodolski, Narodziny nowożytnej..., p. 519. 
other creators of the spectacle, with perhaps the one difference that he also fulfils the supervisory function of a producer. This applies especially to the works of Calderón de la Barca, in particular his autos sacramentales. The prologue of one of them, El Gran Teatro del Mundo, has an Author who orders the World to perform a spectacle. In the Spanish understanding of the term at that time, author means playwright here, director of the theatre, and director of the spectacle. Calderón's drama presents him wearing "a cloak woven of stars, and a crown of rays of light (the image of God the Creator from devotional images)." ${ }^{21}$ God is anthropologised here, $\mathrm{He}$ is one of the actors in the theatre. If he can still be recognised as the power from beyond the presented world, it is only because you can notice the actual author of the drama behind His face. Taking away God's metaphysical nature and humanising Him gives him a double role. He is an actor in this theatre of the world, and if He rises above that to be the creator, then he is the playwright. Prosper from Shakespeare's The Tempest comes to mind. The man-playwright starts to be the actual creator of the spectacle playing out on the stage of the theatre of the world.

The vision of a "world without God" finds its homological reflection in drama and theatre. The presentation of that world as a theatre is related to the new conception of theatrum mundi, where God is humanised, but man is not deified.

\section{3}

The names of Dante, Cervantes, Shakespeare or Calderón have not appeared here by coincidence. They are important here not only because the vision of the world contained in their works is in some way related to the various worldview concepts of theatrum mundi. They were also among the figures in the history of human culture and thought most highly valued by Norwid. This is proven by various statements of his about them, referring to their authority as artists and as people, numerous mottoes taken from their works and, finally, translations done by the poet. It is thus not surprising that the vision of the world contained in their writings had to have had a significant impact also on those elements of Norwid's worldview which made him view reality and world history in theatrical categories.

Norwid's treatment of the contemporary world as a great theatrum mundi resulted from his well-known critical judgement of the social reality of the 19th

21 Z. Karczewska-Markiewicz, Calderón de la Barca (Warszawa: Wiedza Powszechna, 1970), p. 324. See also A. del Rio, Historia de la literatura Española, Vol. 1 (New York: The Dryden Press, 1948), pp. 432-446. 
century, a reality in which insincerity, appearances and social masks falsified the authenticity of the human being and allowed it to fall into ruin, where

en changeant en public ce qui est intime on change en intime ce qui est public - alors au lieu du sentiment il y a le théâtre et au lieu de l'histoire le commérage. (PWsz VIII, 422 footnote)

[by changing into public that which is intimate, one changes into intimate that which is public-instead of feeling there is theatre, and instead of history there is gossip.]

In Norwid's thinking, there is a constant awareness that life presents an endless contradiction between falsehood and truth, appearances and authenticity, mask and true face, between conventionalised and institutionalised social reality and the internal life of a human individual. This awareness resulted in a sharper perspective on the conflict between society and the individual, a conflict which Norwid saw as the drama of human life played out on the stage of theatrum mundi.

It seems that the contradictions indicated above appeared as topics throughout Norwid's work, and found their most complete picture in his dramas and the unfinished poem A Dorio ad Phrygium, where the juxtaposition of the Dorian and Phrygian elements was to reflect those oppositions: the "Phrygian" categories related to the "nineteenth century which he hated,"22 and more specifically to the theatrical nature of that century. It is worth comparing a characteristic fragment of the poem with the fragment of Praise of Folly quoted above:

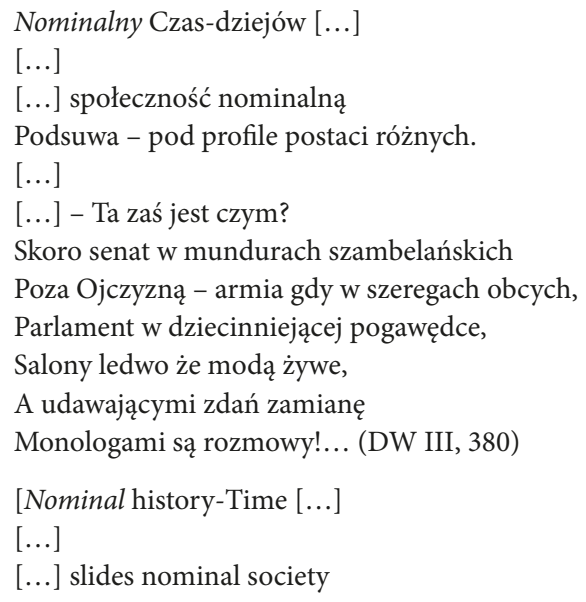

22 See Gomulicki's note to A Dorio ad Phrygium in C. Norwid, Pisma wybrane, selected and prep. by J. W. Gomulicki, Vol. 2 (Warszawa: PIW, 1968), p. 274. 
Under the profiles of various figures.

[...]

[...] - What is this society?

When the Senate in chamberlain uniforms

Is outside the Homeland, when the army stands in foreign ranks,

Parliament engages in increasingly childish chitchat,

Salons are sustained only by fashion,

And conversations are monologues

Pretending to be discourse!...]

Norwid's vision of the world as theatrum mundi encompassed more than his contemporary reality. It often extended to a vision of humankind's history. In the early period of his work, he already positioned himself as a viewer of the theatre of world's history, as he wrote in relation to seeing ancient monuments and ruins in Italy (“To rzecz ludzka!..." [“It is a Human Matter!...”]):

W pompejańskim aż teatrze,

Z wysokości dziejów patrzę

Na rzecz ludzką...

*

Jakie zlepki!!...(PWsz I, 63)

[In the Pompeian theatre

I look from the summit of history

Down on the human matter...

*

What random clusters!!...]

He realised that each epoch created its own masks, that "komedia czasów swe odmienia sceny" [the comedy of time changes its stages], and with those changes, man has to play different roles. In such a vision of reality as a theatre of the world and of history, Norwid shifts towards the second conception of theatrum mundi, the one shaped during the Renaissance, where man is the force behind creating and setting the theatrical mechanism in motion instead of God, and thus it is man who is to blame for the functioning of the said mechanism. Hence the critical assessment of reality, the world and history as contained in Norwid's vision of the world as a theatre. Below quoted is one more fragment (from Fulminant), where the poetic imagery is very close to Shakespeare's:

- Gładzi się jedno drugim i jest ślisko

Na scenie, która krwi wciąż pragnie nowej.

Śmiałżebyś orzec, że to koczowisko,

Nie zaś odwieczny zastęp Chrystusowy - 
Że serce ludzkie stawa się pomału

Czasów wahadłem, już nie wiecznym listem;

Kazuistyczne a bez Ideału,

Jak historyczno-polityczny system -

Że żołnierz jest już zakonnikiem-szału

W dnie ostateczną obwołane trąbą,

Gdy prozy-zbytek tłustej iść nie może,

A kłamstwa-demon spada hekatombą...

I to - nazywa się Historia?...Boże! - - (DW IV, 199-200)

[- One smooths out another and it is slippery

On the stage constantly thirsty for new blood;

Would you dare say this is a nomadic encampment,

And not Christ's eternal hosts;

That - the human heart slowly becomes

A pendulum of Times, not the eternal letter-

Casuistic and without an Ideal,

Like a historico-political system;

That the soldier has become a frenzy-monk

In the days announced by the final trumpets,

When the thick prose-opulence cannot walk,

And the lie-daemon hails down in a hecatomb...

And that - is called History?... Oh, God! - - ]

In that density of metaphors, we have the characterisation of those elements of reality which resulted in the pejorative view of the world as a theatre: comparing humanity to a nomadic encampment, the human heart to a pendulum of Time dependent on casuistic historical and political systems, a man to a soldier seized by a frenzy of destruction and subjected to a daemon of lies, and finally comparing the world and history to a stage constantly thirsty for new blood. Yet there is a baffling indication of opposition in the lines:

Would you dare say this is a nomadic encampment,

And not Christ's eternal hosts;

While diagnosing the world and history, Norwid seems to refer to some ideal possibility of order (the word "Ideal" in the fragment also functions within an opposition). That possibility casts a new perspective on the theatrum mundi. It is a vision of a theatre of the world subordinated to certain rules and principles resulting from the adoption of a specific idea, and the behaviour of man as an actor in that theatre, playing a specific role, must be in line with the order and that idea.

Norwid was known to be deeply religious. Was he shifting towards the vision of the world as directed by the highest power, while characterising reality as a 
theatre of falsehood, lies and hypocrisy? There is an ambivalence in Norwid's presentation. When characterising reality, he leans towards the Renaissance view of theatrum mundi; when stipulating his vision of the world, he refers to some extent to the vision of the world from antiquity or the Middle Ages.

After Shakespeare, the vision of the world as a theatrum mundi directed by God is simply not possible. Norwid is aware that it is man who directs and acts in the world. The poet's stipulation concerns the manner, and the order and idea on behalf of which the man will fulfil those functions. At this point, Norwid's concept of a "complete man" is born, and here the poet realises the human drama resulting from man's existence in a falsified theatrum mundi, the drama of someone whose philosophy or action is ahead of the social awareness in which they live. Norwid saw such people in history (Socrates, Columbus, Kościuszko), he noticed them among his contemporaries (Byron, Mickiewicz, John Brown). He wrote appreciatively about one of his contemporaries who did not want to wear any mask imposed on him by the theatre of the world:

To był człowiek! -

To był i książę - a reszta są lokaje poprzebierane i grające komedie - (PWsz IX, 191)

[He was a man! -

He was also a prince - and the rest are but butlers dressed in costumes and playing comedies -]

The life tragedy of Norwid's "complete man" consisted in the inability to adjust to the reality of the theatre of the world. The above stated ambivalence of presenting the world as theatrum mundi led to a new concept of man negating the existing reality with his attitude. His individuality lay in his "untimeliness" against the epoch in which he had to live and function: he came too late or too early, he belonged to a different spectacle, he played his role in a different "theatre." Don Quixote came too late, Socrates came too early. It is a similar case with Norwid's characters: Caesar and Cleopatra come too late, and Zwolon, Omegitt or Quidam come too early. Oftentimes, their ill-adjustment to reality makes them inactive, enforces the contemplative attitude of a thinker, resulting from their understanding that acting in the existing theatre of the world implies wearing a specific mask, and thus a negation of their own individuality, becoming "someone" instead of "themselves." Such an attitude aspires to impact - if not the contemporary, then future generations. Norwid counted himself among that group, too...

Są czasy w dziejach, kiedy kilka indywidualności skłamać może własnym życiem, iż życie jest. Te gdy zgasną... okazuje się, że to były indywidua... (PWsz X, 10) 
[There are times in history when a few individuals can lie with their own lives, that life exists. When those fade... it turns out they were individualities...]

In other words: they lie with the drama of their personal life, thus negating the false theatre of the world.

Here, Norwid's vision of life as drama joins the conception of the world as theatre. The drama of human life must be played on the stage of theatrum mundi. The conflict: individual - society, man - reality, becomes the grounds to build up the dramatic action of his theatre works. In that way, the elements of the poet's worldview in which he saw life as drama, and the world as theatre, begin to function on the plane of the artistic creation of the world presented in his works. Dramatic awareness implies dramaturgic awareness. Elements of the worldview system determine the specific artistic action of creating an artistic vision of the world using such technical and stylistic means as to give homology to the worldview.

The description of those means is related to the immanent analysis of the structure of Norwid's dramas. It seems that through such an analysis, which would also consider the poet's worldview that sees the world in theatrical categories, one can obtain additional justification for the technical drama devices he used, and mainly, a motivation for the "theatre-within-theatre" construction used by the playwright (the construction of Za kulisami, as well as - in its own way-Aktor).

Because of his vision of the world as theatrum mundi, when using the theatrewithin-theatre device, Norwid was building his vision of the world on the opposition of the two presented worlds. If reality was a certain theatrum mundi, then introducing a different theatre within such a vision of the world allowed him to make revelations: the vision was a critical diagnosis of reality, and the theatre within the theatre was a postulated vision. Norwid's description of "theatre within theatre" in Shakespeare's works (see O sztuce (dla Polaków) [On Art (for Poles)], PW 4, 365-366) allows for such interpretation. It results from Norwid's characteristic view of reality as the grand theatre of the world, while that characteristic nature of his view results from Norwid's ambivalent attitude towards the two concepts of theatrum mundi present in the history of human thought: Dei theatrum mundi and hominis theatrum mundi.

\section{Bibliography}

Jastrun, Mieczysław. “Teatr podwójny.” Twórczość, XXVI: 1970, No. 9, pp. 66-80. Karczewska-Markiewicz, Zofia. Calderon de la Barca. Warszawa: Wiedza Powszechna, 1970. 
Kołakowski, Leszek. Świadomość religijna i więź kościelna. Warszawa: PWN, 1965.

Rio, Angel del. Historia de la literatura Española. Vol. 1-2. New York: Dryden Press, 1948.

Sławińska, Irena. “'Ciąg scenicznych gestów’ w teatrze Norwida.” In: Sceniczny gest poety. Zbiór studiów o dramacie. Kraków: Wydawnictwo Literackie, 1960, pp. 35-90.

Sławińska, Irena. "Reżyserska ręka Norwida." Przegląd Humanistyczny, VIII: 1964, No. 4, pp. 19-32.

Sławińska, Irena. "O terminologii teatralnej Norwida: szkic problematyki badawczej.” Pamiętnik Literacki, LIX: 1968, No. 4, pp. 65-80.

Suchodolski, Bogdan. Narodziny nowożytnej filozofii człowieka. Warszawa: PWN, 1963.

Świontek, Sławomir. "Paraboliczność struktury scenicznej Pierścienia Wielkiej Damy C. Norwida." In: Dramat i teatr. Piąta konferencja teoretycznoliteracka w Świętej Katarzynie. Ed. Jan Trzynadlowski. Wrocław - Warszawa - Kraków: Zakład Narodowy im. Ossolińskich, 1967, pp. 45-59. 



\title{
Juliusz Wiktor Gomulicki
}

\section{Introduction to Cyprian Norwid's "Pisma Wszystkie"}

\author{
I \\ DOKTOR: Napisz nam książę - \\ WARIAT: ...Cóż? Niźli napiszę, \\ To pierwej powiem, co potem ustyszę: \\ Że drukujący mało jej rozumie, \\ Więc cała Polska, i wiek, i Epoka \\ Nie zrozumieją także!... \\ C. Norwid (PWsz II, 139) \\ DOCTOR: Write us a book - \\ MADMAN: ... Well? Before I write it \\ Let me first say, what I'll later hear: \\ That the publisher hardly understands it, \\ And so all of Poland, and the era, and the Epoch, \\ Won't understand it either!... \\ C. Norwid
}

\begin{abstract}
This text is the introduction to the complete eleven volumes of Pisma wszystkie (Collected Writings) of Cyprian Norwid published in 1971-1976. The author tracks the editorial history of Norwid's poetry. Norwid's closest friends hoped to publish his collected writings already during his life. The only realized collection was the edition of Norwid's 1862 Poezje (Lyrics) by Brockhouse publishing house in Leipzig as part of Biblioteka Pisarzy Polskich (Library of Polish Writers). Most people forgot about Norwid's person and art after his death until the memorable issue of the journal Chimera published by Zenon Przesmycki in 1904, when his art was "discovered." Before the Second World War, Przesmycki published different Norwid's works - separately or in collections of previously unpublished pieces but never succeeded in his hopes to print a complete gathering. This chapter meticulously enumerates the achievements of Norwid's editors: Stanisław Cywiński, Tadeusz Makowiecki, Zofia Szmydtowa, Roman Zrębowicz, Stanisław Pigoń, and others. Post-war editorial work was continued by Wacław Borowy, Franciszek German, Zofia Muszyńska, Jerzy W. Borejsza, and Jadwiga Rudnicka, but Gomulicki found many lost Norwid's texts himself. The first decade after the Second World War saw the completion of Przesmycki's diverse works, while the years after 1956 concentrated on debates and actions that directly led to the publication of Pisma wszystkie. This chapter scrupulously lists and describes all
\end{abstract}


the stages of this process, and it characterizes them according to relevant editorial discoveries. In a word, the text is an abbreviated history of Norwid's editing.

Keywords: Cyprian Norwid, editing, Pisma wszystkie, Zenon Przesmycki

1

The complete collected edition of the writings of Cyprian Norwid (1821-1883) a poet of the same rank as his greatest contemporaries Mickiewicz, Słowacki, Baudelaire, Heine or Whitman - is indeed unlike any other analogous publication, Polish or foreign, devoted to the works of a great 19th-century writer.

It is unlike the others not only because it is being published - after a few unsuccessful attempts - a whole eighty years after the poet's death, but above all because two-thirds of the works contained therein (not including his notebooks, letters, and other minutiae of a very personal nature) are posthumous works, extracted or abstracted from manuscripts only in this century. They are responsible for the wonderful rehabilitation of their author, a phenomenon with no equivalent in the history of world literature.

The paradoxical situation is most often explained by Norwid's pioneering spirit, as his innovative poetic practice was ahead of all his contemporaries, but also by the exceptional obtuseness of Polish critics at that time, who - unable to see beyond the most conventional forms of late Romantic literature - were in no state to understand, let alone appreciate, his sensational, albeit then controversial, poetry, persistently characterizing it as "obscure" or "incomprehensible."

This explanation is fundamentally correct, but one-sided, however, because it does not account for certain other reasons behind Norwid's tragedy. His innovative poetic form really was surprisingly different from the forms which the Polish literary public had been accustomed to by Pol, Zaleski, Lenartowicz, Ujejski, or Syrokomla, but he would have been able to accustom his readers to it - going back to the start to "organize" the whole national imagination, which was his dream - if not for the very important fact, that having displeased a few strong ideological opponents at a certain moment, he drew their attention precisely to this peculiar form. They singled it out and mocked it, and it then became the favourite target of their derision, which they widely disseminated, ultimately making normal literary activity impossible for Norwid.

For this exact reason, Polish poetry lost an enormous developmental opportunity: the chance to escape beyond the provincial barriers behind which it sought refuge following the deaths of Mickiewicz and Słowacki, and also the chance to catch up to, and maybe even surpass, the European poetry of that time. It would have become more universal (without losing its national qualities), 
would have drawn greater attention to "swoją część moralną i obowiązkową" [its moral and dutiful component] as well as intellectual fabric, and at the same time would have gained new possibilities of expression, thanks to the use of silence, understatement, allusion, dialectic composition and the other innovative poetic "techniques" that Norwid had developed and ever more fluently implemented.

\section{2}

Were the poets and critics contemporary to him, above all the poets and critics of the younger generation, really unable to understand and appreciate Norwid's innovativeness?

This question is answered by the history of how his youthful poetry was received by the Varsovian community. Its otherness and slightly unsettling originality were immediately discerned - which even led to a few interesting parody attempts (so typical, anyway, when new meets old) - but it ultimately enjoyed success, shaping, to a large extent, the later poetic works of many minor Varsovian poets. By 1841, Norwid was commonly considered in Warsaw to be the most outstanding poet of the young generation; in early 1842, the fact that his poetry had not yet been subject to a thorough critical debate aroused profound astonishment. When several months later he left Warsaw to go abroad, his journey was accompanied by poetic tributes from his older colleagues, one of whom called him "an Evangelist's bird," another one asserting with full conviction that "the dead or resurrected Poland will proclaim him - the poet of its insides... the son of its pains!..."

More importantly, this unanimous enthusiasm was diminished neither by Norwid's first "foreign" lyrics - in which his "new inspirations" had matured nor by that difficult and in places actually a little obscure, but also beautiful, poem "Do mego brata Ludwika" ["To My Brother Ludwig"], which, truth be told, evoked lively disputes among the younger readers of Norwid's poetry, but nevertheless made an unforgettable impression on them.

The Warsaw literary community, it must be added - so different from that of Cracow, and above all from Poznan, in this respect - readily favoured Norwid, and was perhaps the only one, that not only did not attack and deride his original creations, but which also made the first attempts to more fully characterize them (Sarnecki, Marrené, Niewiarowski).

Norwid's person and poetry were met with similar interest and clear preference in the first stage of his stint abroad (1842-1848). Ignacy Zaleski sang his praises in Florence, Ludwik Orpiszewski in Rome, Edmund Chojecki in Dresden, Włodzimierz Łubieński in Berlin, and Stanisław Egbert Koźmian in 
Poznań, informing the readers of Przeglad Poznański [The Poznań Review], that this "belletrist, critic, poet, sculptor, draftsman, and artist provides proof of his inexhaustible bounty and creativity every day," adding as a comment, that "one strengthens the other, kindles, and creates a balance, constitutes a certain indivisible whole."

The most interesting praise actually came from distant Belarus, by way of Antoni Czarkowski, who in April 1849 announced he was writing an article on Norwid's output, intending to show "that regarding [Norwid's] expression of the poetic word, which interprets a range of emotions, we will find nothing greater even in the poetries of the French, German and English..."

And not only! - some of Norwid's Warsaw lyrics - most likely those which appeared in Biblioteka Warszawska [The Warsaw Library] and in Przeglad Naukowy [The Scientific Review] - were already known to Słowacki, as well as to Krasiński, both of whom, independently of one another, recognized their undeniable originality. Słowacki even expressed, when speaking about these pieces (1849), that "Cyprian is like a spirit, from whom I can take nothing and to whom I can give nothing," and Krasiński also admitted (1847) that he considers him "a master in the external construct of a poem," but that oftentimes his interior contents "are insufficiently visible beneath their resonant and beautifully shaped outer layers." The following year, after he had met Norwid personally and addressed a beautiful poetic apostrophe to him, he ended this apostrophe with a prophetic announcement of his future triumph:

\footnotetext{
Nie odchodzisz na zniknięcie -

Snów Twych ujrzysz wżywotwzięcie -

Tyś nie śmierci łup!

Skrzydlnym jeszcze wzlecisz lotem,

Gdy z trupami ja pokotem

Leżeć będę, trup! -

[In departing you will not disappear -

You will see your dreams realized -

Death will not vanquish you!

You will yet soar in winged flight

While I in a heap of corpses

Will lie, dead! -]
}

\section{3}

Actually, the reputation Norwid had achieved in these nine years suddenly wavered upon his arrival in Paris (1849), where The People's Tribune had just 
been established, and where the poet, who was close friends with its first secretary, Edmund Chojecki, established closer ties with representatives of the international socio-political left wing. These included Aleksander Hercen and the students of Pierre-Joseph Proudhon (Chojecki's friend and collaborator) who usually met in the revolutionary Herwegh salon.

The first wind of this change was an article by Władysław Bentkowski, who greatly disliked Norwid's poem "Jeszcze słowo" ["A Word More"] (1848) - critical of the People's Spring and calling for the joint effort of "peacemakers" - which actually, instead of arguing with the poet about ideological themes (he himself was preparing to take part in the Hungarian campaign), pointed out the "ambiguous manner of thought, expressions, and images," highlighting that he does not want to have to toil over his words "like over the Talmud." His charges were relatively trifling, and Norwid immediately dispelled them with a poised polemical article, but it just so happened that Bentkowski's polemic was taken over shortly thereafter by Norwid's old friends and "masters," who were also prominent representatives of the conservative camp: Zygmunt Krasiński, who maintained correspondence with the poet and patronized him on ideological matters, and Jan Koźmian (the brother of Stanisław Egbert), who knew the poet from Berlin, where he had tried to subordinate him to his own goals and convictions.

Norwid provoked both of these authorities with his comments on sensitive social matters: Krasiński - through his relationships with the editors of The People's Tribune and left-wing activists, as well as his protest (or, according to Krasiński, "childish declamation") against the violations committed on the memorable day of June 13; Koźmian - with his chapter on "property" published in the poem Pieśni społecznej cztery stron [Social Song in Four Pages] (1849), and also his allegedly "too shy" upholding of "the banner of Christian truths" as well as his too careless tossing about of certain social slogans.

All of this was understandable and easily explained. After all, instead of clearly and plainly formulating their actual complaints, both antagonists, following Bentkowski's dangerous example, used the smokescreen of strictly formal allegations. Thus Krasiński, one of the "obscurest" Polish poets at that time, at that, tyrannically tormenting his native language himself, began to point out to the younger poet his alleged incomprehensibility and impute (in letters to their mutual friends) that he has an "obscure mind" and that "because of him the Polish language is reaching a final desocialization." Meanwhile Koźmian avoiding sharp and clear formulations - recited a whole rosary of his worst poetic sins to him: "complex speech," "tedious word play," "uncertain thought," "careless form," as well as "stubborn mannerism." 
The attacked poet, at that time suffering heavily from poverty, illness as well as emotional disappointment, responded to both of his critics, but differently to each one: to Koźmian - by violent epistolary protest, to Krasiński - by sending all of his letters back to him and cutting off all personal contact. These responses got Norwid into even more trouble with his adversaries, who incited their entire associated conservative literary community against him, seeking a convenient opportunity for an ultimate reckoning with him.

\section{4}

An opportunity like this presented itself in 1851, when Norwid's famous Promethidion was published in Paris. It was a true poetic oddity, by all measures deserving of a thorough and complete analysis, in which the literary public's attention could be drawn not only to its ideological contents and original aesthetic thought, but also to the beautiful lyrical passages found in both its dialogues.

This is what should have happened, but unfortunately did not. The review of, or more precisely: the execution of Promethidion was undertaken by Lucjan Siemieński, who was tied as closely to Krasiński's circle as he was to Koźmian's, and was more than aware of what was being said about Norwid in both circles at that time.

The "execution" itself was only a mere trifle: first, Siemieński mocked Promethidion's composition ("the chaos of pretentious humour"), the language ("the most drolly perverted words"), and the style ("clichéd scribbles"), and then he closed his argument with the following cruel and exceptionally unfair conclusion: "It is enough to read any passage, before giving up and telling yourself: another Champollion would need to be born to decipher these hieroglyphs, if it is even worth being born for something so small."

Siemieński's review brought, of course, great pleasure to Norwid's circle of antagonists. "Oh child, petulant child! - a satisfied Krasiński wrote - He didn’t listen, he published, and now the people have spoken..." "Poppycock" - echoed his friend, confidant, and admirer Gaszyński (Siemieński's faithful correspondent!), and Julian Klaczko - who fuelled Krasiński's anti-Norwid fury with his gossip about Norwid - succinctly summed up (in print!) his personal critical opinion: "Promethidions, Zwolons and other nonsense." Their comments did not deviate much from the judgments passed by Koźmian's posse: old Kajetan, Jan’s uncle, characterized Norwid's writing as "unheard of nonsense," and his son, Andrzej Edward, even questioned the poet's mental health: "the poor man has assuredly gone mad..." In this choir of derision and insult you could even hear the voices of two outsiders, who had most likely not read Promethidion at all, but 
had nevertheless formed an opinion about it on the basis of Siemieński's review. They were two otherwise venerable old men: Franciszek Wężyk and Franciszek Morawski, who - distinguishing themselves from their companions at least in this - mocked Norwid in verse.

In learning about the mechanism of this type of "criticism," which - having spread rather quickly - shaped the opinions of the most enlightened layers of the literary public of that time, it is hardly surprising that even those who had completely different opinions about the nature and value of Norwid's works subscribed to it. Even Józef Bohdan Zaleski gave in. At first he was as equally thrilled with Promethidion ("the longer and more closely I read into it, the more I see, the depth of the spirit therein"), as he was with its author ("undeniably brilliant, but also an apostle of truth, a prophet, and a great artist"), but with each following year spoke out more and more abstemiously about his younger poet-friend, and finally got to the point that he simply treated him as a "kind eccentric." Not to mention the writers of minorum gentium, who not only willingly read about Norwid's purported handicap, but with equal enthusiasm joined the ranks of his oppressors, consequently deriding the most readable and most beautiful of his poetic works, like, for example, Eustachy Januszkiewicz did in relation to the poem Szczęsna, and Marceli Motty in relation to "Fortepian Szopena" ["Chopin's Grand Piano"].

\section{5}

This discussion of the mechanics behind the cliquey criticism which was harmful to Norwid, and whose opinions were so eagerly adopted by the jokesters of the salon and literati, allows us to better understand the enigma of why Norwid left behind so many handwritten works. Many of them are manuscripts simply because no one wanted to print them for him. They ran from all his literary proposals like fire, above all from his more ambitious works, and so, obligatorily, from his most extensive.

An excellent example of one such "escape" were the actions of Jan Koźmian, when he was the editor of Przeglad Poznański. Many of Norwid's poetic works found themselves in his hands before 1850, but he - without the least intention of publishing them himself - either gave them away, for free, to the philanthropic publisher Pokłosie [The Aftermath] (e.g., Pompeja [Pompeii] ended up there), or else he "forgot" them among his own papers (the charming Wesele [The Wedding] met this fate).

Similarly, Władysław Bentkowski "forgot" about the brilliant apostrophe "Do obywatela Johna Brown" ["To Citizen John Brown"], and even about such 
a Polish poetic masterpiece as "Bema pamięci żałobny-rapsod" ["A Funeral Rhapsody in Memory of General Bem"]. Józef Ignacy Kraszewski did not allow the poem Epimenides to go to print and did not wish to familiarize himself with the mystery of Krakus at all. Siemieński gave up the poem Cienie [Shadows], as Starkel did Noc tysiaczna druga [The Thousand-and-Second Night]...

The same thing happened, of course, with the books Norwid proposed to publishers, because they were even more sensitive to public opinion than magazine editors. One can hardly wonder at a man like Wolff, who, after having published the poem Szczesna found out from the Cracovian Czas [Time] that "there are certain responsibilities men in publishing have towards the public" and that the reviewer doubts, whether "Mr. M.B. Wolff fulfilled them this time." The same goes for German Brockhaus, who, in turn - having waited in vain for a single review to come out after the publication of Norwid's Poezje [Poems], which undoubtedly constituted some sort of breakthrough point in the history of modern Polish poetry - in 1866 passed up the advertising of the second volume, which was even more sensational than the first.

Jan Konstanty Żupański, a bookseller from Poznań who was exceptionally unfriendly towards the poet, broke the record in this respect by getting out of publishing contracts with him four times. The fourth time was in 1878, and the agent was August Cieszkowski, a millionaire, who could have easily covered the costs of the meagre fee demanded by Norwid at that time (650 francs) from his own pocket. He did not do this, though, just as twenty years earlier he had not been willing to do that for the poem Quidam. His parsimony drew one last painful complaint from the chest of the tormented poet concerning his manuscripts: "już NIKOGO nie szukam, żeby mię zrozumiał w administracji prac moich - bo nie ma z kim gadać o tym - żaden możny nic nie rozumie” (PWsz X, 122)/“I am no longer looking for ANYONE, to understand me in the administration of my copyrights - because I have no one to talk to about this - not a single man in power will understand."

Norwid's words were not platitudinous, because he never again made a similar request to any Polish or foreign publisher. When he bade farewell to this world less than five years later, the most exquisite portion of the legacy he left behind which was later passed down to the poet's Parisian relative, Józef Dybowski were the manuscripts of his unpublished literary works.

II

...co najlepiéj,

Podsunąć, aby pisano, a potem,

Gdy zamrze pisarz, rękopismów śledzić,

I wołać $\mathrm{z}$ wielkim na trzy wiatry grzmotem: 
"Gdzież są - ba! żeby tylko można wiedziéć!..."

C. Norwid (PWsz I, 166)

...what's the best thing,

To put forth, to prompt their review, and then,

When the writer is dead, to track down the manuscripts,

And call with the thunder of three winds:

"Where are they - oh! if we only knew!..."

The manuscripts Norwid left behind were given to Józef Dybowski, upon whose death they were passed along to Wacław Gasztowtt by his son Aleksander. They did not encompass, of course, all the unpublished works of the deceased poet, which would include:

a) unknown works, which were burned by the Sisters of Charity from Saint Casimir's Poorhouse shortly after the poet's death;

b) works, which perished in the editorial portfolios of various national magazines (e.g., Noc tysiaczna druga in the editorial office of Lviv's Dziennik Literacki [Literary Daily]);

c) works, which at the moment of the poet's death were still in the hands of the agents previously mediating their potential publication (e.g., the comedy Pierścień Wielkiej-Damy [The Noble Lady's Ring], entrusted to Lenartowicz; the poem Assunta, entrusted to J. B. Zaleski);

d) the works gifted by the poet to his friends and acquaintances (e.g., the poem Psalmów-psalm [Psalm of Psalms], given to August Cieszkowski, the poem Rzecz o wolności słowa [On the Freedom of Speech], given to Marian Sokołowski, as well as countless small poems, which the poet gave away, for example, to Trębicka, Deotyma, Górska, Dziekońska, Kuczyńska etc., etc.);

e) the works which were already lost during the poet's lifetime (e.g., the first editions of Wanda and Krakus).

Of course, nobody knew the exact number, ownership, or "geography" of those manuscripted extravagances, which in many cases had changed their original owners or proprietors. Nobody had also organized or catalogued the manuscripts submitted to Gasztowtt, although it was precisely among these that the most outstanding works of the deceased poet were to be found: lyrical, dramatic, novelistic as well as essayistic. They had been entrusted to Gasztowtt along with an entire stack of folders, notebooks, diaries, and even loose papers, and left just the way they were in some corner of his apartment. 
The enormous value of all these works, so carelessly changing owners, can easily be estimated according to the value of the ten most extensive of Norwid's works, which were found therein:

Vade-mecum - a lengthy (eighty-eight preserved poem-elements) poetic cycle, which is one of the most brilliant and most original works of its kind in 19th-century European poetry: with its roots planted in The Odyssey and The Divine Comedy, and its structure wrapped around The Flowers of Evil, to which it was, to a certain degree, its own dialectical negation;

A Dorio ad Phrygium - an unfinished (at least in the recovered final draft) philosophically satirical poem, written in innovatively adapted free verse, which was to the literature of 1871 , more or less what T. S. Eliot's The Waste Land was to the literature of 1917;

three dramatic works: Aktor [Actor] (1861-1862) - a comedic drama addressing the problem of 19th-century class transformation and shifts in an original way; Za kulisami [Backstage] (1865-1869) - a dramatic "fantasy" based on the Shakespearian "play within a play" concept, allegorically illustrating the issues with the January uprising, and at the same time commenting on the relations between poet and society; and finally Kleopatra [Cleopatra] (1870-1872) - an ambitious historical tragedy, depicting not only the poignant collision of two great civilizations of the ancient world, with a latent allusion to the present (Poland - Russia), but also the ideal of the woman-companion personified by the queen-heroine;

three novelistic works: Stygmat [Stigma], "Ad leones!", and Tajemnica lorda Singelworth [Lord Singelworth's Secret] (all from 1883) - an allegorical "Italian trilogy" in which the detail consistently related to the big picture, the trivial corresponded with the sublime, and the whole was a deeply thought out tragic mockery of the entire 19th-century European civilization;

the legend Ostatnia $z$ bajek [The Last of the Fables] (1882) - an original antiapologue written in poetic prose, in which the animals were not the usual "illustrations" of some human traits, but rather austere and just judges of man and his relation to nature;

the philosophical essay Milczenie [Silence] (1882) - an important introduction to some of the peculiarities of Norwid's aesthetics, and in particular to his theory of "understatement," which he treated not only as a personal "part of speech," but also as a necessary dialectic element in the development of history.

Many of these works survived only in fragments, many others revealed smaller or greater gaps in the text, but we may never find out to whose negligence we should attribute this sort of damage: the Sisters of Charity from Saint Casimir's 
Poorhouse, the Dybowski family, or finally Gasztowtt. Likewise, we will never know who removed the large volume of Album Orbis from these materials, or the number of letters to Norwid, which were subsequently scattered throughout various private collections.

All of these manuscripts evaded any kind of archivo-literary registration for a dozen or so years, and very few people even knew of their existence in the first place. During this whole time, it was not particularly important, however, because it was not until eleven years after Norwid's death that the first "Norwidologist" (Wiktor Gomulicki) appeared, looking for materials related to his life and works, but unable to locate Wacław Gasztowtt, and not until three years later the second one (Zenon Przesmycki), who had been corresponding with Gasztowtt since as early as 1886, but who did not know anything about Norwid back then, and if he did, was completely uninterested.

The appearance of these two Norwidologists marks the beginning of a great quest for Norwid, still ongoing today, and that dozens of people have, to a lesser or greater degree, participated in: Norwid's fans, philologists, literary historians, art historians, archivists, librarians, as well as collectors.

\section{2}

Norwid's first Discoverer, but not his Resurrector, was Wiktor Gomulicki (1848-1919), a poet and poetry enthusiast, a collector and amateur historian at that, who was captivated by Norwid's poetry even as a student. However, it was not until 1894 that he began to consciously accumulate Norwid materials, encouraged by the painter Pantaleon Szyndler, who was one of the dead poet's three favourite students (the second was Marian Sokołowski, and the third Mieczysław Geniusz).

Gomulicki, who also personally knew Ludwik Norwid, and in 1888 tried to find out about Cyprian's grave from him in vain, amassed a large collection of Norwidiana, including, among others, many of the poet's originals, engravings and drawings (a substantial sketchbook from the 1870s, among others), a few books from his private collection, and also two of his portraits: an oil portrait painted by Szyndler (the so-called "Norwid śpiący" [“Sleeping Norwid”], 1879, Fig. 10) and a photograph taken by Hamaret.

He obviously dreamed of getting his hands on some of Norwid's unpublished works; however, in 1896, when he advertised his Norwidian appeal in the Cracovian Przeglad Literacki [Literary Review], the only response he received was young Feliks Kopera's publication of the poet's unknown autobiography from 1872 , a document characterized nota bene by one of the editor's interlocutors as 
"misleading and full of the vain self-exaltation of a conceited man of unsound mind" (!).

As a result, the only of Norwid's inedita he was able to obtain was the illustrated humoresque Klary Nagnioszewskiej samobójstwo [The suicide of Klara Nagnioszewska] (Fig. 28) as well as a small series of Norwidiana from the papers of Łucja (née Giedroyć) Rautenstrauch, consisting of one unknown poem, fragments of the poem Ziemia [Earth], as well as several letters (one with a fragmentary translation of Byron).

He did not give up his search, of course, and in 1900 wrote to Felicjan Faleński (who had referred him to the papers of his late wife, Maria Trębicka, which were filed in the Jagiellonian Library) that "he would be happy and proud, if he succeeded, with the help of people of good will sharing his intentions, to breathe life into Norwid's ashes." This role did not ultimately fall to him, but to Zenon Przesmycki; the only joy the elder poet could find in this was that it was his very own Cracovian appeal which alerted that other writer to Norwid's name and person.

3

Zenon Przesmycki (pseudonym Miriam, 1861-1944), a poet, translator, and literary critic, who became a Norwidist in Vienna in the spring of 1897, influenced by Norwid's Leipzig Poezje [Poems] (1863) which he read at that time, had much greater luck than Gomulicki in his search. It just so happened that from Vienna he went straight to Paris, where he rekindled his old friendship with Wacław Gasztowtt (both were passionate about Czech literature) and likely soon found out from him that it was precisely Gasztowtt who was the lucky depositary of almost the entire Norwid archive.

Shortly afterwards this archive ended up in the hands of Przesmycki, who brought it to Warsaw in 1900, devoting most of his time to his beloved poet, on whom he became a renowned expert, editor, as well as commentator.

In taking advantage of the printed manuscripts (1901-1939), which he received from Gasztowtt, Przesmycki did not forget about the scattered manuscripts, which he was often able to track down based on the remains of the poet's correspondence that was brought from Paris.

"Hence the manic odyssey of this type of search - Przesmycki later wrote of his difficulties with Norwid - this is why, where by all probability there should have been many findings, there were only disappointments, this is why occasionally there were unexpected trouvailles, in places where, in fact, nothing was to be expected, and this is whence the sad conviction comes, that many of these things have irrevocably disappeared." 
In this work and research he was not alone, anyway, first because - upon receiving news of his active interest in Norwid - a few fans, friends and students of the deceased poet came to him with the materials in their possession (the first of them was Gomulicki), and then because he was able to take on two volunteer assistants: Adolf Sternschuss (from 1904 onward), a collector and art lover, and later (1907), by his agency, Leopold Wellisz, a young graphics aficionado, who conducted a few invaluable Norwid enquiries for Przesmycki in Paris.

The joint effort of the three searchers led to the acquisition, or at least to the copying, of many new works and letters of Norwid's, which were able to shed additional light on his output as well as his biography.

Thus in 1901 a second edition of the long-lost Wanda surfaced (thanks to Anna Norwid).

In 1902, those of Norwid's poems and letters that had been sitting among the papers of J. B. Wagner, Mieczysław Geniusz and Seweryna Duchińska surfaced, as well as translations from "The Odyssey" that had been in Adam Pług's possession for over twenty years.

In 1903, La Philosophie de la guerre [The Philosophy of War] emerged from the papers left behind by Józef Reitzenheim.

In 1904, access was gained to the Norwidiana kept in the Potocki collection in Krzeszowice, in the Polish Museum in Rapperswil, as well as the Polish Library in Paris.

In 1905, several dozen letters, several lyrical poems as well as the manuscript of Rzecz o wolności słowa were gained - all of them from Professor Marian Sokołowski.

In 1907, new works of Norwid’s were extracted from the papers of Władysław Mickiewicz.

In 1908, numerous Norwidiana came out of the papers left behind by the late Jadwiga Łuszczewska (Deotyma) as well as a large bundle of the poet's letters in the possession of the Kleczkowski family.

In 1909, those of Norwid's letters and poems belonging to the Hornowski and Koźmian families were copied.

In 1910, the same was done with the Norwidiana left behind by Mieczysław Pawlikowski.

In 1911, Norwidiana which had been the property of Leopold Méyet were obtained.

In 1912, numerous letters and poems of Norwid's emerged from the papers left behind by Teofil Lenartowicz (among them the autograph of Pierścień Wielkiej-Damy) and Konstancja Górska. 
That same year Przesmycki set out again to Paris, where he was able to obtain those of Norwid's letters that were in Count Henryk de Charencey's possession, and finally get to the collection of his valuable watercolours and drawings, which had been laying around for a half-century in Aleksander Dybowski's apartment. This enquiry concluded the first phase of his Norwid quest, which dragged on, truth be told, all the way up until 1939, but never again yielded such great finds as those from the first decade of the 1900s.

Przesmycki kept the manuscripts from public collections in copies of his own or others. Those which were in private hands, in turn, he tried to acquire for his own, and when he was unable to - he rented them for as long as it took until the owners simply reconciled themselves to their loss. The method the brilliant Norwidologist worked out sometimes brought about excellent results, and allowed for the rescue of such manuscripts, as were often destined for loss, scattering, or simply ruin at the hands of their incidental owners.

And here it needs to be added that Przesmycki's entire Norwid archive, encompassing not only Norwid's papers and those of his manuscripts acquired after 1900, but also the countless duplicates and notes made by Przesmycki himself, fortunately made it through both world wars and today can be found at the National Library in Warsaw.

\section{4}

The work and research of Zenon Przesmycki, who we can confidently call Norwid's Resurrector, and who saved the most valuable manuscripted literary works from complete destruction, takes first place in the history of "discovering" Norwid. This does not mean, however, that this history did not have any further Norwidian discoveries of value, although it is worth admitting that almost all such discoveries, especially those made after 1912, took place after the time of Przesmycki, who did not reveal the rich contents of his personal Norwid portfolio for many long years.

It was a little different during the first phase of that unconventionally founded Norwidology, when it was the inedita Zenon Przesmycki printed in specific notebooks and volumes of his journal Chimera [Chimera] (1901-1907) - and especially the large volume Pamięci Cypriana Norwida [In Memory of Cyprian Norwid] (1905), comprised almost entirely of inedita - that inspired a whole series of other researchers. They had either been amazed to learn that those of Norwid's works in their possession had become literary sensations overnight (as was the case for Adam Krechowiecki and Józef Kallenbach, who had the Norwidiana given to them by Dionizy Zaleski at their disposal for many years, along with the 
correspondence with his father, as well as for Kazimierz Bartoszewicz, who had copies of letters from Norwid to Kraszewski), or had come across whole blocks of such materials by chance (as was the case of Tadeusz Smoleński, to whom Mieczysław Geniusz, at that time holding a grudge against Przesmycki, gave access to the rest of the poet's letters and poems he possessed), or finally, had once happened upon Norwid's unknown texts, now retracing their steps and broadening the scope of their searches, before carefully publishing the tracked works of the great poet, furnishing them with the most essential explanations (one such conscientious researcher was Bolesław Erzepki).

However, most Norwidian discoveries were made during the twenty-year interwar period, when the rich Rapperswil and Batignolles collections were brought to Warsaw, and simultaneously, previously unavailable portions of the manuscript collections in the Jagiellonian, Czartoryski and Krasiński Libraries were put together, or made accessible to researchers for the first time.

These new opportunities created new collectors (and Norwid editors), to whose guild belonged Władysław Arcimowicz, Roman Brandstaetter, Zofia Ciechanowska, Stanisław Cywiński, Adam Czartkowski (who came across, but not until after Przesmycki, the gold mine in Konstancja Górska's papers), Juliusz W. Gomulicki, Piotr Grzegorczyk, Edward Krakowski, Tadeusz Makowiecki, Józef Mikołajtis, Jan Muszkowski, Stefan Pomarański, Tadeusz Przypkowski, Stefan Rygiel, Zofia Szmydtowa, Tadeusz Turczyński, Józef Ujejski, Stanisław Wasylewski, Kazimierz Wyka, and Roman Zrębowicz.

The greatest and luckiest of all of them was actually Stanisław Pigoń, who following in Przesmycki's footsteps - was consequently able to penetrate the Jagiellonian, Czartoryski and Krasiński Library as well as Rapperswil collections, from which he extracted and almost immediately published countless of Norwid's letters and smaller texts.

In publishing the correct text of one of Norwid's letters to Bronisław Zaleski (1879) in 1947, he actually foretold the early end of any further Norwidian discoveries.

"Nigh is the end - he wrote - of the half-century-ago initiated search for Norwid's scattered literary legacy. Especially when it comes to Polish territory, the libraries and private collections have generally been exhaustively searched, and we should not expect much more from here on out. Unless somewhere in France..."

Pigońs pessimistic predictions did not come true, thankfully, because even at the time of his declaration it was common knowledge that such unknown and highly important texts of Norwid's were to be found in the Norwid archives of Przesmycki, who had either overlooked them, or had kept them secret on purpose (considering them a bit trifling), or had found them simply illegible. 
After all, it is enough to recall the most important literary and epistolary inedita extracted from his manuscripts between 1948 and 1970, to deduce that their source had not dried up and it could be expected - especially abroad - that more valuable and totally unexpected Norwidian discoveries would yet be made.

In 1948, two poems that Przesmycki had been unable to read were printed, as well as two more, hitherto completely unknown ones: "Moja Ojczyzna" ["My Country"] and "Sfinks" ["Sphinx"].

In 1951, the unknown letters of Norwid to Stanisław E. Koźmian were published. In 1956, the comedy Hrabina Palmyra [Countess Palmyra], the humoresque "Co słychać? i co począć?" [“What's new? and what's to do?"], unknown fragments of Kleopatra, a handful of unknown lyrical poems, the dissertation Sztuka $w$ obliczu dziejów [Art in the Face of History], as well as letters to Eleonora Czapska, were published, among other things.

In 1957, letters to Cezary Plater as well as twenty letters to various addressees from the years 1846-1882 appeared in print.

In 1958, the poems and letters preserved among Antoni Waga's papers and the essay "O miłości" ["On Love"] were recovered and published.

In 1960, a substantial collection of his letters to the Resurrectionist Priests were published, as well as three letters to Wojciech Gerson.

In 1963, an entire volume of letters to Joanna Kuczyńska was published.

In 1965, an unknown translation from Dante surfaced.

In 1966, another translation from Dante, five unknown letters to Kuczyńska, and a handful of aphorisms were printed.

In 1968, eleven letters to Antoni Zaleski and the important dissertation Obywatel Gustaw Courbet [Citizen Gustave Courbet] appeared in print.

In 1969, French letters to Lawrow came out.

In 1970, a letter to Bronisława Studniarska was published and among others, an unknown letter to Bronisław Zaleski was found.

All the above inedita, as well as those, which were not mentioned therein, were published by Danuta Acecka-Poklewska (in cooperation with W. Mincer), Jerzy W. Borejsza, Wacław Borowy, Franciszek German, Juliusz W. Gomulicki, Adam Mauersberg, Hanna Malewska, Zofia Muszyńska, Matylda Osterwina, Irena Piotrowska, and Jadwiga Rudnicka.

Sądzę także, że nie byłoby niekorzystnym, aby publiczność miała przed oczyma ciagg jakiejkolwiek pracy przerywanej biegiem wypadków, które całymi narodami trzęsły, pokoleniami rzucały z kraju w kraj - mogłaby wtedy, ciąg taki pieśni podruzgotanej rozpatrując, nauczyć się rozeznawania, co jest pracą ducha walczącego, a co pisaniem atramentem. 
I do not think it would be disadvantageous, for the public to have before their eyes any continuous work, that had been interrupted by a string of events, which shook entire nations, threw entire generations from one country to another; they could then, in consideration of this shattered song sequence, learn to discern, what is the work of a fighting spirit, and what is writing in ink.

C. Norwid

The death of Cyprian Norwid (23 May 1883), who for the last several years had been buried alive at Saint Casimir's Poorhouse, did not evoke any particular reaction from the literary public of that time, who blindly believed critics and literary "researchers," that he was a second-rate writer, who "disappointed" the expectations which had once been associated with his person and output.

However, in this crowd were three righteous men, who - sincerely believing in the remarkable talent of the deceased - demanded that all his writings, scattered at that time throughout books, magazines, and manuscripts, be gathered "into one whole."

The first of them was Agaton Giller, who had in previous years been enthusiastic about Norwid's Rzecz o wolności słowa, claiming with conviction that its author is "a completely original poet, with great creative powers and inspiration of the same;" the second - Aleksander Niewiarowski, a former classmate of Norwid's, who predicted that if it ever came to the publication of some sort of "collected works," a shrub of "laurels" would blossom at the foot of Norwid's grave, properly commemorating his poetic prowess; the third - Teofil Lenartowicz, a Varsovian turned emigré companion to the dead poet, who asserted, in turn, that "Cyprian's truly beautiful poems could be compiled into a small volume, which would weigh up against the best European talent..."

The postulates were justified, of course, however, their audience was unclear, which called the whole matter into question: namely, Giller was appealing to some theoretical "publisher," Niewiarowski, in turn, was dreaming of "a mighty and noble eccentric," and Lenartowicz doubted the success of such a project from the beginning. "But could someone who would grant him [Norwid] this posthumous honour be found? -he wrote, skeptically. - If I could, if my health and means allowed me to, I would do it myself, and write an introduction educating those Cracow-Warsaw know-it-alls, but I am nearing my end, and my grave will be covered to the echoes of Varsovian critics' laughter."

This matter seemed doomed until Zenon Przesmycki arrived on the Norwidian horizon (1897). Having acquired the original manuscripted literary legacy left behind by the great poet, he began to slowly consider its publication. 
This, of course, could not happen until it had been compiled with the handwritten materials, as well as those which were already in print, albeit scattered throughout books and magazines.

He was aware, naturally, that in the case of Norwid it was futile to dream of a "complete" publication, but by 1904 he had already announced a multi-volume edition of his collected writings, whose first three volumes were allegedly already being printed, and which was intended to encompass everything that he had already gathered and that which would be added "as new works came along."

The promised volumes (two volumes of prose, and one encompassing "larger poems") were not actually published, but in 1905 the large volume of Chimera was, bearing the title Pamięci Cypriana Norwida and comprised almost entirely of his inedita, among which Kleopatra $i$ Cezar [Cleopatra and Caesar] as well as the first handful of lyrcis from the Vade-mecum cycle were also found.

The brilliantly compiled volume concluded with the fresh announcement of a collected edition:

"Con altra voce ormai ritornerà poeta, when, without middlemen, he will call out from Pisma zebrane [The Collected Works] at full volume, to whose edition the following book will serve as the pre-introduction."

These words were not an empty promise, because between 1909 and 1910 the first volumes of the predicted Pisma zebrane had already made their way to the Anczyc publishing house in Cracow. They were calculated to be eight overall, and three years later the first three of those appeared, encompassing more or less half of Norwid's poetic works, half of his dramatic works, as well as the first portion of his prose, which, together with his letters, would fill altogether four volumes of the new edition.

"Thanks to this first collected, and for the most part first in general, edition of writings and works of art - Przesmycki wrote with understandable pride, and complete justification - Poland is finally regaining a great creator, in his fullest possible form today. May history do the rest."

\section{2}

The future, unfortunately, was kind neither to Przesmycki nor to this new edition. Firstly, because the editor himself did not finish annotating the fourth volume of Pisma (the second, prose one), which had been printed almost in its entirety (406 pages of Norwid's text as well as the first 90 pages of Przesmycki's), but which precisely for this reason could not ultimately be bound and sold, and secondly, because the First World War erupted shortly afterwards, paralysing all publishing and editing. 
Even worse, in the first years following the war, there was no rush to resume the interrupted project, on account of the deplorable state of printing and publishing at that time, which did not allow for work on Pisma to continue in the same exterior design, as it had been in 1912.

This was actually not the only obstacle standing in the way of its final realization, because it just so happened that Przesmycki was called to the office of Minister of Art and Culture of the liberated Polish state, which necessarily pulled him away from his editing career. Additionally, the years which had passed since the moment the first volumes of Pisma were submitted for printing saw many new Norwidian findings, of which some ought to have been incorporated into the volumes that had already been published.

The situation was further complicated by the commitments the publisher of Pisma (Jakub Mortkowicz) had made to the subscribers (Pisma had also been purchased as a subscription), because they made it harder to break definitively with this issue and start another, more humble one, which would make up for it by including the new texts and new academic achievements in the field of Norwidology. Przesmycki provided eloquent proof of all these sorts of troubles and dilemmas during two interviews, in which he twice announced - once in 1927 and once at the beginning of 1933 - that the subsequent volumes of Pisma were already being printed, which was obviously not true, because even the second volume of prose works that had been printed in 1913 was still laying crudely in the Anczyc warehouse, waiting for the rest of its annotations.

Meanwhile, Norwid's fame grew with each passing year and more and more voices were heard demanding the continuation of the collected edition, which had been so brilliantly started, and had whet researchers' and poetry lovers' appetites all the more. It also whet the appetites of certain editors and publishers, who finally decided to take advantage of the situation and quickly put out their own popular "omnibus" editions of Norwid's thus far published works, discounting the Przesmycki-Mortkowicz initiative and reaping the fruit of the trees they had planted and cultivated.

This is how the impressive volume of Norwid's Dzieła [Works] came to be published in early 1934, having been prepared for printing by Tadeusz Pini, and published by the publishing house "Parnas Polski" ["The Polish Parnas"] as part of the popular Library of Polish Poets series. The publication was limited to sensu stricto literary works (omitting numerous texts in the field of literary and artistic criticism, philosophy, journalism, and so on) and encompassed - including the smaller poems - 342 entries, of which 320 had already been published by Zenon Przesmycki, and the remaining 22 reprinted from other editors. The advantage of this new publication was that all of those valuable but scattered works had been 
gathered under one cover, the disadvantage - the sloppy text, the improper and disorderly layout, the naive explanations, and editor's introduction, insulting not only to academic and critical requirements, but even those of common decency, because he did not write a single word acknowledging the enormous "loan" he had taken from Zenon Przesmycki.

Pini's edition became the subject of a lawsuit (because he had published several dozen texts which Przesmycki had published between 1924 and 1933 without authorization), which, true, was lost by the publishers, but unfortunately did not rectify the damage which had been done to Norwid and his rightful Resurrector. The latter did not break down and abandon the work he had so wonderfully begun on his edition of Norwid's collected works. He soon took it up again, but luckily under different circumstances, no longer burdened by any obligations to Mortkowicz and his subscribers, but planning the new and ambitious whole from start to finish, intending to include all of Norwid's texts that had been recovered up until 1936.

The new edition - advertised by the venerable Norwidologist since 1937 - was supposed to consist of nine volumes, and would be finished in approximately four years. Unfortunately, higher forces intervened in this case as well, derailing Przesmycki's intentions and efforts for a second time. The truth was that he had printed seven volumes of the new edition (i.e., everything except for the poetic works, which were meant to fill the first two volumes), but had given subscribers only four (III-IV and VIII-IX), because the expedition of the remaining ones was interrupted by the outburst of the Second World War.

The epilogue of that edition was the Warsaw uprising in 1944, during which the entire stock of the seventh volume (his philosophical and political writings) went up in flames, and whose end coincided with the death of Przesmycki himself (17 October 1944). He died in the 48th year of his Norwidian odyssey, not crowned by the attainment of his coveted goal, unfortunately, but nevertheless by a partial success abounding in such remarkable achievements, that we can boldly call it "Columbine."

\section{3}

The first decade following the end of the Second World War (more specifically, the years 1946-1957), passed in the vein of finishing and completing Przesmycki's brilliant work, as well as undertaking discussions about a future collected edition of Norwid's writings.

Wacław Borowy then published, and wrote the introduction to, the legendary fourth volume of Pisma zebrane that had been compiled in 1913, extracted from 
the storeroom of the Anczyc publishing house and finally bound (1946), as well as published a facsimile of the autograph of Vade-mecum (1947); in London, Zbigniew Zaniewicki, who had already helped Przesmycki with the publication of Wszystkie pisma [All Works] (1937-1939), published (1957) the seventh volume of that edition (which had burned in 1944) based on the salvaged proofreading copy; Juliusz Wiktor Gomulicki finally compiled and printed Okruchy poetyckie i dramatyczne [Poetic and Dramatic Crumbs] (1956), bringing under one cover several dozen of Norwid's texts, which had either never been published, or had been scattered throughout various books and magazines, and for that reason not previously included in published collections.

Borowy had been exploring the possibility of a new collected edition, an initiative which was taken over after his death by the Scientific Society at the Catholic University in Lublin. This did not result, however, in the realization of Norwid's Dzieła zebrane [Collected Works], whose organization and publishing ultimately fell to the PIW [State Publishing Institute], with Juliusz Wiktor Gomulicki as its editor.

Initial work on the new edition, conceived to be much more ambitious than any previous, took from 1960 to 1963, leading to the completion of the first two volumes of Dzieła in 1964, which appeared in print in 1966 and encompassed all of Norwid's lyrics, equipped on this occasion with a critical supplement of over 1000 pages.

Lyrics are of course the most wonderful and most mature part of Norwid's output, so it is not unusual, that their publication for the first time as a whole was met with real enthusiasm.

"I do not know, if in any other literature we could find such clear examples of society's neglect of great poets, as in Polish - Julian Przyboś wrote, then Słowacki, a poet not recognized during his lifetime, was not fully returned to national memory until half a century after his death, and Norwid... This year marked the 83rd anniversary of his death. And it was only this year that we received the first two volumes of the monumental edition of his collected works. These volumes will be the ones - when in a few years the edition is complete that will return all of Norwid to our national culture."

Przyboś voice was joined by many other voices of the poets and critics, who had been waiting for the comprehensive edition of Norwid's work for so many years.

"This is a literary event, whose meaning is impossible to exaggerate" - expressed Mieczysław Jastrun. "The appearance of the first volume of Norwid's works is a holiday for Polish poetry" echoed Zbigniew Bieńkowski. "The most important publishing event in the field of restoring the classics" - was how Professor Jan 
Zygmunt Jakubowski evaluated this fact. Marian Piechal took it one step further - "The most outstanding Polish book of 1966," and Lesław Bartelski even raved that the publication of the first volumes of Dzieta zebrane "truly marks the beginning, if we are to use grandiloquent expressions, of a Norwidian epoch.”

How far we have come from the verdicts of Krasiński, Koźmian, Siemieński and their imitators!

\section{4}

The complete edition of Norwid's Dzieła zebrane, in the form that was designed for it and with which the publication of his lyrics was presented, required a little longer, however. Meanwhile, the great poet having become the patron of all of modern Polish poetry, the literary public yearned for as many new texts as possible to be produced as quickly as possible.

The response to these postulates came in the form of five volumes of Pisma wybrane [Selected Writings], compiled by Juliusz Wiktor Gomulicki, and constituting - although it sounds somewhat paradoxical - the broadest (besides the Przesmycki or Pini editions) set of Norwid's texts to this day, and so as a result his collected works. With its 5 generic sections, this popular and sparingly annotated edition namely encompassed 226 small poems, 14 narrative poems (of these, 11 in their entirety), fragments of translations from The Odyssey and The Divine Comedy, 9 dramas (of these, 7 in their entirety), a translation of a fragment of Hamlet, 82 prose texts: 17 fictional and 65 discursive, as well as 300 letters.

The selection of some of those works seemed controversial on more than one occasion - as does the selection of the works of any writer as complicated and controversial (in the best sense of the word) as Cyprian Norwid - the editor, however, did not at all worry about certain properties of his publication. He considered, that at a moment, when there were not yet any complete editions of Norwid's works on library shelves, it was imperative that the biggest possible collection of his various texts be made accessible to the readers (even if a few of them were to be found only in the form of pages choisies). Only such a broad set - not one that was a "selection" in the common sense of the word, and unfit for new editions of identical form - could shed sufficient light on the brilliant, rich, and diverse output of the author of Vade-mecum.

This collection was most favourably received by critics, and even more favourably by poetry fans, who took mere months to buy out the entire 30,000 copy supply of Pisma wybrane, which finally made available to them so many of the poet's texts that they had been searching for on bookshop and library shelves in vain. 
"Thanks to this edition - Professor Kazimierz Wyka correctly wrote - Cyprian Norwid got the chance, to enjoy the readership of the young generation and secure his presence in the cultural bloodstream of the People's Poland."

Pisma wybrane appeared in the fall of 1968 , so three years before Norwid's 150th birthday, the greatest celebration of which would have been, of course, the complete edition of his writings, inaugurated in 1966 by the first two volumes of Dzieła zebrane.

This postulate was entirely understandable, but unusually difficult to execute in the scope of that edition, because the partially ready to print volumes III and IV (poems) took the editor so long, and would have taken up so much room in print, that there was no talk of continuing it as an anniversary edition.

As a result, in 1969 a decision was made about the State Publishing Institute's participation in the publishing of a separate edition of Pisma wszystkie [Collected Writings] (work on Dzieła zebrane had been suspended for some time), whose editorial shape - having been the subject of many discussions as well as abandoned first attempts for several months - was finally defined in December 1969. Then Juliusz Wiktor Gomulicki began work on its first volumes, supported in this responsible work - thanks to the kind management of the State Publishing Institute, who not only wished to publish Pisma wszystkie in the anniversary year of 1971, but to publish it as well and as beautifully as possible - by the entire staff of merit and technical editors, graphic designers, photographers and correctors, who passed the compiled volumes on to the M. Kasprzak Graphics Institute in Poznań.

At the moment these words are being written, the first corrections to volume I of Pisma have already been made, volume II is in the process of being corrected, volumes III-V are being compiled, volumes VIII and IX are awaiting compilation, volume $\mathrm{X}$ is getting sent to the printer within the next days, volume $\mathrm{XI}$ is pending book design (240 illustrations!) and the editor is working on volumes VI and VII.

IV

A kto me pieśni, kiedyś rzucane zza świata

I pobite jak starych urn dzika mogiła,

Złoży duchem: jedna z nich będzie, i skrzydlata...

C. Norwid (DW III, 87)

Whoever takes my songs, once cast from beyond The world, and beaten up like an untended grave of old urns, and puts them together with spirit they will be one and will be winged... 
The discussions, which were mentioned in the previous section (III 4), pertained to the fundamental character of the edition of Pisma wszystkie, the completeness and criticality thereof which the editor upheld in all cases. The shape and scope of the ultimately accepted edit was not decided right away, initially it was intended to encompass a broader and more precise description of the autographs, a more exhaustive bibliography, as well as a comprehensive critical apparatus (set of variants), along with a specific justification of each larger emendation as well as a potential discussion on the topic of the emendations that had been rejected.

Nevertheless! Pisma wszystkie is the first complete edition of Norwid's collected work, eagerly awaited for many years not only by specialist-philologists, but also by poets and poetry lovers and Norwid's fans, and also by Polish teachers, literary historians and cultural historians, to whom the most important thing was the completeness of the edition, the correctness of the text, and the accuracy of the auxiliary text accompaniment of useful information. The desire to mollify exactly these concerns - combined with the desire to finish the editorial work by such a deadline that would allow for the printing of all the volumes of Pisma wszystkie within Norwid's anniversarial year - ultimately decided the character of the whole edition. It is comprehensive and critical, but the critical apparatus is limited, by necessity, to a greater or lesser selection of variants, and the philological discussion, only to the more important or characteristic instances.

When it comes to its completeness, it should be noted that the editor endeavoured to include all of the texts, which either came from Norwid's pen or were dictated by him; these are not just the narrowly understood "works" or "pieces," but also those texts which have a distinctly personal nature, such as, for example, letters, notes, marginalia, dedications, and so on. This was, however, under the condition that they had already appeared somewhere, or were at least known to the editor, with one limitation, regarding the captions and accompanying descriptions, alongside Norwid's drawings, which "are not alive" without these drawings, and which will be considered only in the fullest possible catalogue of all of Norwid's works in the broadly considered field of art, which has been prepared for Dzieła zebrane.

The arrangement of Pisma wszystkie is the combination of an arrangement according to genre divisions (the main sections) and a chronological arrangement (within those sections), in which the series Norwid created, cyclical works and similar literary constructions, are preserved in unaltered form, and only in specific, rather rare cases, are any of their fragments (e.g., the translation of a fragment from Dante's Purgatorio found in Modlitewnik dla Włodzimierza 
Łubieńskiego [A Prayer Book for Włodzimierz Łubieński]) replicated in other sections (in this particular case in volume III, alongside other translations from The Divine Comedy), left, however, unchanged in the mother arrangement. It also needs to be noted with particular emphasis that - in contrast to Kleiner's arrangement of the edition of Słowacki's work - in Pisma wszystkie there is no distinction made between the works published during their author's lifetime, and those which were not published until after his death, because Norwid strove in vain throughout his whole life to publish his works, and many of them remain as manuscripts (e.g., "Bema pamięci żałobny-rapsod," Assunta, Pierścień WielkiejDamy), distributed by the poet among his friends and acquaintances, only because no publisher wanted to put them to print.

When it comes to the furnishings of Pisma wszystkie, in turn, above all it needs to be highlighted that each of the five main sections of the edition (Poems, Narrative Poems, Dramas, Prose, Letters) ends with an individual critical Supplement, consisting, in each case, of two parts. The first concerns the source and selection choice of the texts belonging to each section (typical division: 1 . Scope; 2. Lost works; 3 . Text sources [with table]; 4. Editorial history [with a bibliography of previous editions]; 5. Arrangement; 6 . Description of the text). The second is devoted to printer's imprints and explanations, in which archival (manuscript) and bibliographical data are found, as well as the critical apparatus, along with the most essential information about the work's date (with a potential discussion on the topic), the circumstances of its coming to be and addressee, and others of its realities, as needed.

In multi-volume sections, the critical Supplement is found at the end of either the last volume (Poems, Dramas), or each individual volume (Prose, Letters). The sources and choice selections of the entire edition are found at the end of volume II.

Independently of the critical supplements, Pisma wszystkie is equipped with an annotated bibliography of the collected editions of Norwid's works, with a chronology of his life and creative work, with a rich, illustrated supplement, as well as with specific indexes of his own names and titles for those mentioned in the specific sections of this edition.

\section{2}

Turning next to a review of those five sections in Pisma wszystkie, it needs to be noted that the first section (volumes I-II), containing poems, brings relatively the least novelties, and has the shortest imprints and explanations. One and the other are explained by the fact that all those poems were already published in 
Dzieła zebrane in 1966, where they were accompanied by a very comprehensive critical supplement, now shortened and reorganized accordingly. Though in this section there are still certain changes, because the text of all the poems was newly collated with their autographs or first printed editions, and their punctuation was rethought and better rendered than in that edition, on more than one occasion. The same applies to the chronological corrections made to several poems, as well as to the entire Vade-mecum cycle, whose initial and definitive edits (or, also the pseudo-definite) were carried over to a separate supplement.

The second section, containing narrative poems and cyclical works (volume III) - the second of those not distinguished by Zenon Przesmycki's Pisma zebrane, and scattered by Pini over several sections - is richer than those editions by the humoresque Co stychać? i co poczaćc? (1876) as well as by two fragmentary translations from The Divine Comedy (Inferno, III, and Purgatorio, XXVIII). Assunta (1870), which had up until now been printed on the basis of a copy of its autograph, was now based directly on the autograph, and the same goes for - and to an even greater degree - Rzecz o wolności słowa (1869), to which numerous emendations were made and which was supplemented by the variant of the first song (Stowo $i$ 'słowo' [A Word and the 'Word']), as well as "Psalmówpsalm" (1850), reprinted by Pini on the basis of Stanisław Wasylewski's fragmentary first edition.

Even more changes were made to the section with dramas (volumes IV-V), supplemented not only by five miniatures, which Przesmycki had printed among the poems and narrative poems, but above all by two completely unknown before texts: a fragment of the lost comedy of his youthful writing Dobrzy ludzie [Good people] (1840 or 1841) as well as the unfinished comedic drama Hrabina Palmyra (1862). Kleopatra, in turn, into whose text over 100 emendations were introduced on the basis of its autograph, gained, among other things, eight roughly drafted sketches of specific fragments of act III, as well as the specific outlines of its unwritten scenes. The diptych Tyrtej-Za kulisami [Tyrtajos-Backstage] (18651869) was finally broken up and arranged according to the author's intentions.

The prose works (volumes VI-VII), in which speeches, polemical writings and memorials, notes and appeals, are separated, among others, gained a range of important entries in this edition. They were either completely unknown to Przesmycki (Dwie aureole [Two Halos], Sztuka w obliczu dziejów, Obywatel Gustaw Courbet, O miłości ksiag dwie [Two Books on Love] and others), found out about too late (Filoktet [Philoctetes]), or overlooked (Autobiografia [Autobiography], Klary Nagnioszewskiej samobójstwo), or finally, completely not considered, like, for example, various marginalia, casual remarks and aphorisms, dedications, small prose translations, and above all lengthy notebooks, which 
contained prime information on the readings, studies and interests of the great author of Vade-mecum.

This very section contains the most inedita, which - almost entirely unknown to researchers and not used even as manuscripts - will help them in many cases to determine more precisely the up until now unsuspected sources of Norwid's creativity and views, also shedding entirely new light on how his ideas were shaped.

For example, how eloquently - of course for those, who are familiar with Norwid's work - will the words which the poet quickly wrote in pencil in one of his "archeological" albums, sound:

Historia: legenda - epopeja - historia - anegdota - rewolucja

(PWsz XI, 393)

[History: legend - epic - history - anecdote - revolution]

Eloquently, for it is the first seed of the formulation of an important rule which Norwid perceived in the history of the development of mankind, and which he later incorporated, along with a wider discussion, into the pages of his profound Milczenie (1882).

What is even more interesting is that by the word "anecdote" in the abovementioned note, we find an asterisk leading to a separate gloss, which reads:

Anegdota zwłaszcza zasłużonego człowieka, który nigdy profilu swego nie widział nareszcie medal etc. (PWsz XI, 393)

[An anecdote, especially of a deserving man, who never even saw his own profile - finally, a medal etc.]

Well, that postscript is again the first handwritten trace of a real event, whose hero was none other than Antoni Waga, gifted by his Parisian friends with a portraitmedallion, and for the first time in his life then observing, with philosophical interest indeed, "a profile of his own forehead, lips and nose." Norwid began his entire Milczenie with this anecdote. Proof of what weight he attributed to this otherwise trivial fact, is further provided by the circumstance that he also immortalized it in the form of a laconic note ("Nos - medal" [Nose - medal"]), in another one of his notebooks, adding that one to the section "Philosophy. Philology. Preliminary" and adding it after the following remarks, which he also included, after having edited them, in the course of the conclusions of Milczenie, once again revealing thanks to all these excerpts certain secrets about his literary process:

Literatura gdyby rosła z człowiekiem naturalnie, to literatu ra dzie cinna: książki dla dzieci - byłyby pierwszymi, a nie hymn, epos, tragedia.

Gdy tymczasem żadna od komedii nie zaczyna. (PWsz VII, 377) 
[If literature grew naturally with man, then children's literature: books for children -- would come first, not hymns, epics, tragedies.

Meanwhile not one would begin with comedy.]

There are significantly more of these kinds of clues and signals. It suffices to say that Norwid's three notebooks: "philological," "historical," and "mythological," accounting for 215 handwritten pages neatly written in the poet's tiny scrawl, are confirmation of their enormous informational value (and not only informational).

But these notebooks, of course, to which we should also add the numerous notes scattered throughout Norwid's artistic albums, do not exhaust the great poet's prosaic inedita included in this edition. Thus, now Modlitewnik dla Włodzimierza Łubieńskiego (1846) will appear for the first time in print, and alongside it the aforementioned Filoktet (1863), and further - in their original arrangement - the meditations "at the cradle of the nation," as well as various small texts: casual remarks, notes, dedications, glosses and translations (e.g., from Tertullian).

The last section (volumes VIII-X) is devoted to letters, which Pini did not publish at all, and to which Przesmycki devoted the two last volumes of his 1937 edition, printing 846 of them there, in reality many less, because in them he included notes, appeals, translations, critical considerations, and even receipts, all of which have now been moved to the prose section (and mainly to volume VII, devoted to all kinds of miscellany). This did not at all diminish that important section, which has become enhanced by over 20 new letters (including eight complete inedita) and now numbers over 1041 epistolary entries, for the first time subjected to a thorough chronological analysis, which led to in several dozen cases to the changing of their dated years (Norwid very rarely dated his letters), and in a hundred dozen - to a change regarding the day, month or time of year, not to mention the handful of cases with a change of addressee.

In seventy-five cases, Norwid's letters have been enhanced with letters to Norwid, namely those, which either evoked a specific response from the poet, were responses to his letters, or finally, concerned matters discussed by him. All such letters were published within their corresponding epistolary specifications, of which fifty-two were put to print for the first time.

Norwid's writings end with the tenth volume of this edition. It is known, of course, that Norwid was also a drawer, watercolour painter, engraver and medallist, and even the designer of cemetery compositions (in which his literary work often corresponds with his artistic work). This aspect of his creative output was also not overlooked in the collected edition, and most of volume XI is devoted to it. The first portion of the illustrative material contained therein documents 
Norwid's biography (genealogical tree, baptismal certificate, confirmation certificate, and death certificate, portraits of relatives and friends, landscapes of places, etc.) and the second - his works of art, for the first time presented by over a hundred reproductions of drawings, watercolours, engravings, medallions, medals as well as sculpturo-architectonic compositions.

In selecting those materials, an attempt was made to consider as many unpublished works as possible, which does not mean, of course, that we resigned from those that had already been published, or that were otherwise valuable or corresponded to Norwid's biography and literary output in some important way.

And here it should be added that in many cases an omission of some important entry was the result of pressing publishing needs, which forced the editor to rely in great measure on the Warsaw collections, because there was no time left to take advantage of the Norwdiana found in Cracow or Wrocław in the same way.

\section{3}

Readers will find any remaining remarks pertaining to this edition either at the end of the second volume (in the critical Supplement), or in the Afterword thereof, which will be printed in the last volume.

Here it suffices to repeat the same words, which concluded the 1966 Introduction to Dzieła zebrane: "Completed in this way - but completed only in a given historical moment - Norwid's writings do not constitute the entirety of all that, which came from his pen, because each year to come may bring some new and joyful surprises in this measure, meaning heretofore unknown texts, which, if only possible, will be included in the Supplement. (This Supplement should not sound threatening, but rather hopeful.) And after all, that which has been collected here, constitutes a treasure trove, and at the same time - in spite of all its imperfections, gaps, and twists - an almost ideal whole, which any sensitive reader can complete or round off in his or her soul..."

One last thing.

In publishing Norwid's Dzieła zebrane in 1966, Juliusz Wiktor Gomulicki dedicated that edition to the memory of the two poets and lovers of poetry, to whom he owed the most: Wiktor Gomulicki (1848-1919) his father, who was the first of Norwid's contemporaries to publically proclaim the greatness of his poetry and thought, and Zenon Przesmycki (1861-1944), his master, who resurrected Norwid, and made Norwid's legacy whole for his descendants. 
And so in repeating that exceedingly important dedication today, he also wishes to expand it, to include the names of these two renowned philologists, and also exceptional literary historians: Professor Wacław Borowy (1890-1950) and Professor Stanisław Pigoń (1885-1968), who always regarded his Norwidian work with great understanding and kindness, all the more dearer to their hearts, in that both - whether commenting on Norwid's work, or publishing his handwritten texts, or finally designing the collected edition of his works - often wandered down the same paths, that he later tread, and more than once conquered the same obstacles, as stood in his way.

\section{Bibliography}

Norwid, Cyprian. Pisma zebrane. Vol. A. Part 1-2. Vol. C. Vol. E-F. Ed. Zenon Przesmycki. Warszawa - Kraków: Jakub Mortkowicz - Druk. W. L. Anczyc i Sp. w Krakowie, 1911-1914.

Norwid, Cyprian. Dzieła (Drobne utwory poetyckie - Poematy - Utwory dramatyczne - Legendy, nowele i gawędy - Przekłady - Rozprawy wierszem $i$ proza). Ed. Tadeusz Pini. Warszawa 1934. "Parnas Polski”. Biblioteka Poetów Polskich. Ed. Tadeusz Pini. T. V.

Norwid, Cyprian. Wszystkie pisma. Vol. III-VI, VIII-IX. Ed. Zenon Przesmycki. Warszawa: Kasa im. Mianowskiego, 1937-1939.

Norwid, Cyprian. Okruchy poetyckie i dramatyczne. Ed. Juliusz W. Gomulicki. Warszawa: PIW, 1956.

Norwid, Cyprian. Pisma polityczne i filozoficzne. Ed. Zenon Przesmycki (Miriam). Ed. Zbigniew Zaniewicki. Rev. text Kazimierz Sowiński. Londyn: Oficyna Poetów i Malarzy, 1957.

Norwid, Cyprian. Dzieła zebrane. Vol. 1-2. Ed. Juliusz W. Gomulicki. Warszawa: PIW, 1966.

Norwid, Cyprian. Pisma wybrane. Vol. 1-5. Ed. Juliusz W. Gomulicki. Warszawa: PIW, 1968. 


\title{
Elżbieta Feliksiak \\ The World of Norwid's Thought
}

\begin{abstract}
The task of this chapter is to outline the main directions of Norwid's philosophical reflection, that is, his historiosophical, aesthetic, anthropological, metaphysical, and epistemological views. Norwid's reflection on the nature of truth and the paths that lead to its learning seem particularly significant for his view of reality: the world, people, history, and artistic practice. The chapter foregrounds that Norwid's philosophical views always follow his poetry: art and philosophy permeate each other in his work to create an organic whole. Hence, the text follows Norwid's philosophical views both on the basis of his discursive statements and strictly literary works - even though they often verge on both fields - which are analytically equal but undoubtedly different in methods. The extraction of worldview from Norwid's literary works means their comprehensive comparative analysis. Let us add that Norwid's worldview that appears from his poetic works - especially the most mature ones - is more important here than his "discursive" statements, because it was in poetry that Norwid aspired to the fullest expression of the truths he acquired (sought).
\end{abstract}

Keywords: Cyprian Norwid, philosophy, aesthetics, anthropology, metaphysics

Ile razy przypominam sobie ostatnie rozmowy z osobami, co już w niewidzialny świat odeszły, zmarłszy tu, tyle razy nie wiem, jak pominąć to, co ze zbioru razem wspomnień tych samo czasem zdaje się określać, i dlatego właśnie w dagerotyp raczej pióro zamieniam, aby wierności nie uchybić - inaczej przyszłoby mi bowiem zacytować słowa jedyne Voltaire’a, jakie kiedykolwiek na myśl mi przychodzą lub przychodziły z autora tego, a te są:

Je tremble!... car ce que je vais dire

Ressemble a un système.

(Voltaire)

- Może też to najfilozoficzniejszy filozofa tego apoftegmat. (C. Norwid, Czarne kwiaty, DW VII, 45-46)

[However many times I recall the last conversations with people who have already passed on to the invisible world, that many times I do not know how to ignore that, which from the collection of memories appears to define them, and that is why I rather exchange my pen for a daguerreotype in order not to betray faithfulness - otherwise I would have to quote the only words from Voltaire's work which have ever come to my mind, and those are as follows:

Je tremble!... car ce que je vais dire

Ressemble a un systéme.

(Voltaire)

- This may just be the most philosophical apothegm of this philosopher.] 
The objective of this study is to outline the main directions of Norwid's philosophical reflection, so it will concern his historiosophic, aesthetic and anthropological conceptions, his views within metaphysic and cognitive theories. The reflections of the author of Milczenie [Silence] on the nature of truth and the ways to learn it seem to be highly significant for his worldview and artistic practice.

At the current stage of studies on Norwid's work, this task may be fulfilled only partially, as the knowledge of the poet's connection to the intellectual life of his time, as well as his readings and sources of inspiration, still has blanks. The turbulent history of the literary work of the author of Vade-mecum is the reason why many fruits of his considerations are lost, perhaps irretrievably. As this study is written, not all of Norwid's Pisma wszystkie have been published yet, and they are meant to provide many inedita, in particular as concerns his essay prose. $^{1}$

In writing about the philosophical views of the author of Rzecz o wolności stowa [On the Freedom of Speech] one cannot forget that he was foremost a poet art and philosophy were interwoven with him, creating an organic unity. It is for those reasons that the approach used in this paper - discussing Norwid's philosophical views both based on his discursive statements and strictly literary works (and the forms he uses often border on both), and on equal rights - is highly justified methodologically. The rights are equal as concerns the sources of the analysis, but undoubtedly different when one considers the methods. I am fully aware that gleaning the worldview from literary works must be based on their broad comparative analysis. Such an approach is used here. It ought to be added that the worldview read from the poet's works - especially the most mature ones - is, in fact, of greater interest here than the "discursive" statements. After all, it was in his poetic works that Norwid strived for the fullest expression of the truth he found (and sought).

\section{The Concept of Truth}

Norwid's picture of the world was a dualistic image. A basic and lasting foundation of Norwid's worldview was Christianity, and more precisely: Catholicism (which broadened over the years to include many new reflections). Questions about the nature of existence were thus not the focus of his considerations,

1 I would like to once again express my gratitude to the Editor of Pisma wszystkie, Mr. Juliusz W. Gomulicki, for kindly allowing me insight into the still corrected volume VII, containing Notatki z mitologii, [Notatki z historii] and [Notatki etno-filologiczne] [Notes on Mythology; Notes on History; Ethno-Philological Notes]. 
although his interest thereof increased when he noticed a challenge to his worldview in biological evolutionism, in particular Darwinism. He then also reached for arguments from within metaphysics. In the late essay Milczenie [Silence] (1882), he beautifully expressed his belief in "analogijnym stosunku pomiędzy prawami rozwoju rzeczy świata tego a prawami rozwoju ducha..." (PWsz VI, 236) [an analogous relation between the rights of development of the matters of this world and the rights of development of the spirit...]. It is also worth noting a quotation on Swedenborg (author uncertain), found in one of Norwid's notebooks: "Swedenborg établit dans ses ouvrages que toutes les choses matérielles représentent autant de choses spirituelles, et leur correspondent... Il assure que cette science des correspondances était connue des anciens, mais quelle s'est perdue par la succession de temps."2 [Swedenborg establishes in his works that all material things represent so many spiritual things, and correspond to them ... He assures that this science of correspondence was known to the ancients, but that it was lost in the passage of time.] It ought to be stressed again that this is not a statement made by Norwid himself, yet it seems that he approved of Swedenborg's view.

Norwid's version of dualism is, however, different from the version of his predecessors in Polish Romanticism, in particular from the later attitude of Mickiewicz, who gave absolute primacy to the spiritual world. Let us quote the following sentence from Prelekcje paryskie [Paris Lectures] as an example:

Nie masz nic równie względnego, równie zmiennego jak to, co nazywamy rzeczywistością, to znaczy świat widomy, to, co umyka, co przemija, to, co ma nadejść, co nie ma teraźniejszości. Jedynie duch chwyta stosunki świata widomego, duch je utrwala i nadaje im w ten sposób niejaki byt rzeczywisty; duch wytwarza idee, instytucje, dzieła, jedyne rzeczy realne, jedyne rzeczy, co przechodzą w ducha i stanowią żywą tradycję rodu ludzkiego. ${ }^{3}$

[There is nothing as relative, as changeable as that which we call reality, that is the visible world, that which escapes, that which passes, that which is to come, that which has no present. Only the spirit captures the relations of the visible world, the spirit records them and thus gives them a somewhat real existence; the spirit produces ideas, institutions, works, the only real things, the only things which transform into the spirit and constitute the living tradition of humankind.]

Norwid's world, in comparison, was shown as a real whole consisting of two equally entitled components: matter and spirit. The starting point of his reflections was the reality of the real world in time, especially social reality

2 C. Norwid, [Notatki z historii], PWsz VII, 329.

3 A. Mickiewicz, Dzieła, Vol. XI (Warszawa: Czytelnik, 1955), p. 61. 
viewed from a historical perspective. When speaking of reality in Norwid's view, one must always remember that it existed for him as the temporal world in constant connection with the world of the spirit, the divine world. While it existed and functioned independently, it did have its place in the final plan, and learning the truth about reality was equal to getting closer to the absolute truth. According to the author of the lectures O Juliuszu Słowackim [On Juliusz Słowacki], "człowiek na to przychodzi na planetę, ażeby dał świadectwo prawdzie." (PWsz VI, 434) [man is born on this planet in order to bear witness to the truth.] And he understood the role of man as the learning subject in a very active and creative manner.

The concept of truth was a constant focus for Norwid. Analysis of his views on cognition seems to present the image of his path towards overcoming the dual character of the world. In his case, one may speak of an attitude of moderate cognitive realism.

The matter of truth, methods of learning it and suitable manners of conveying it with its subtle differentiations takes - directly or indirectly - one of the central places in his works. The significant presence of those issues proves how deep Norwid's philosophical reflection reached; he undertook the fundamental questions of philosophy and sought original solutions to them. What originality means here is, of course, what the poet himself described in one of his lectures O Juliuszu Słowackim (PWsz VI, 425) as "sumienność w obliczu źródeł" [conscientiousness towards the sources] and what often was the "sumienność dodatnia" [positive conscientiousness] that he frequently postulated.

The sources of his views were extensive and highly varied. Establishing (or seeking to establish) his take on the problems brought on by modernity, the philosopher-poet sought arguments for and against them among the thinkers of all and any times, as well as carefully studied the messages of ancient cultures, discovered so intensively in the 19th century. Yet one of the main sources was the Bible.

Norwid was, as a principle, averse to any systems and closed ideologies, seeing the dangers of a schematic view of the world and introducing artificial harmony where he saw not fully resolvable antinomies. Neither did he create a system of his own, but he was aware that the observed and critically analysed reality constantly gave premises for generalisations. In seeking the truth, he did not think it right to limit himself to gaining partial truths - particular elements, particular "pages of truth" were to create a coherent, complementary unity: the activity of learning, of cognition was to ensure embracing "the whole truth."

Norwid wrote of the complex nature of truth and the criterion of learning it, for example, in his lectures O Juliuszu Stowackim (1860): 
Nie mogę ja albowiem utrzymywać, że prawda jest teorią samą, gdyż nie wiedziałbym, czym się sprawdza, gdyby, mówię, praktycznej i sprawdzającej ją strony nie miała? Prawda obejmuje życie, jest więc niejasna, bo obejmuje rzecz ciemną; gdybym odjął prawdzie życie, odjąłbym jej to, co ją sprawdza, ale byłaby jasnym fałszem. (PWsz VI, 434)

[For I cannot claim that truth is theory alone, as I would not know, what to verify it with, if, as I say, it had no practical and verifying side to it? Truth embraces life, and is therefore unclear, because it embraces an obscure thing; if I were to take life away from truth, I would rob it of what verifies it, but it would be a clear falsehood.]

That was one of the main arguments in his constant polemics (although it was one enforced by regrettable necessity) with those who required "clarity" or "light" from him. The necessity to refer to "life" when conveying a truth thus viewed was, according to Norwid, the source of its rejection by indolent people:

Każden przyjmuje prawdę teoretyczną, ale niejeden odepchnie ją, skoro się pokaże, że ona nie tylko logiczna jest, ale i współpracy wymagająca - a więc, jeżeli wołamy o jasność, czyż nie wołamy czasem o nasz spokój, o naszą bezwładną wolność - o inercję. (PWsz VI, 450)

[Everyone accepts a theoretical truth, but many will spurn it, should it appear that it is not only logical but also demands co-operation - and so, when we call for clarity, don't we at times call for our peace, our powerless freedom - for inertia? $]^{4}$

The above-quoted fragments clearly show that for Norwid, the function of personality was very important in the cognitive process. That postulate of "cooperation" means that the richer the personality, the greater its chances of reaching the "whole" truth. It is an existential, and not epistemological, understanding of truth, close to the concept of "living truths" in Mickiewicz's Paris lectures.

A symptomatic example of such a view on cognition may be poem XLI from the Vade-mecum cycle, titled "Królestwo" ["Kingdom"]. Its criticism of one-sidedness does not just concern moral issues (indicated by J. W. Gomulicki in his comment, where he calls "Królestwo" a "philosophical and poetic meditation on the issue of human value and dignity"), ${ }^{5}$ but also matters of studying nature and truth. The whole structure of the work conveys Norwid's criterion of truth - a specifically understood criterion of practice. At the same time, it opposes pragmatism (the poet stresses numerous times that ends are more important than means). Rather, it means conformance to experience, based on moral grounds. As has been mentioned before, for Norwid the warrantor of cognition integrating

4 English translation by Adam Czerniawski, in: Cyprian Kamil Norwid, Poems (Kraków: Wydawnictwo Literackie, 1986), p. 201.

5 J. W. Gomulicki's comment on the poem "Królestwo," cf. C. Norwid, Dzieła zebrane, prep. by J. W. Gomulicki, Vol. II (Warszawa: PIW, 1966), pp. 793 (further as: Dz II). 
the dual world is completeness of personality, which will be able to practise the gained truth. In the poem "Królestwo," reflections on the essence and criteria of truth concern human reality, viewed as historic reality, also subject to moral criteria:

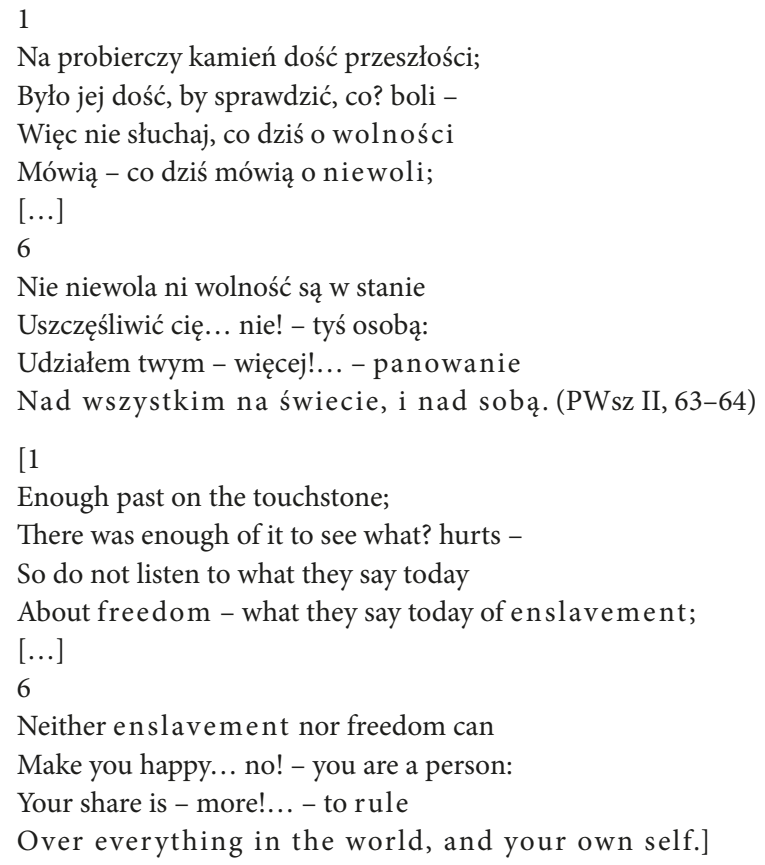

It seems that this "rule over everything in the world" does not only mean Christian stoicism here (mentioned by Gomulicki in the same comment), but also refers to "ruling" the world of things thanks to cognition and moral discipline, which is a condition of personality.

The criterion of practice characterised here is thus inseparably connected with the ethical criterion. For Norwid, "true" also means "moral." In that respect, Norwid was no different than Mickiewicz. He definitely shared the view noted on one of the pages of [Notatki etno-filologiczne] (probably in the late 1870s):

Prawdą jest zupełną ta, która wytrzymuje krytykę moralnych następstw. (Scholastica?)

(PWsz VII, 417)

Complete truth is the one which withstands the criticism of moral consequences.

That moral-ethical criterion of truth was expressed in his philosophical anthropology and in his historiosophy. 
While he recognised the complex structure of truth, Norwid did not see it merely as a play of opposites. Despite some elements of Hegel's dialectics in his thinking, a dialectic concept of truth cannot be assigned to Norwid in any case. That is proved by, for example, the following fragment of the poem "Królestwo":

4

Lecz ten ze wszystkich nieudolny lekarz,

Kto, nie wiedząc, z chorób leczyć którą?

Pomięsza dwie - nie mędrzec - aptekarz!

- Prawda nie jest przeciwieństw miksturą...

5

Orzeł? - nie jest pół-żółwiem, pół-gromem.

Słońce? - nie jest pół-dniem, a pół-nocą.

Spokój? - nie jest pół-trumną, pół-domem.

Łzy? - nie deszcz są, choć jak deszcz wilgocą. (PWsz II, 63-64)

$[4$

But among doctors this one is incapable

Who, knowing not which disease to cure?

Mixes both - no sage - a pharmacist!

- Truth is not a concoction of contrasts...

5

An eagle? - is not half-turtle, half-thunder.

The sun? - is not half-day, half-night.

Tranquility? - is not half-coffin, half-house.

Tears? - are not rain, though like rain they dampen.]

What ways did Norwid consider to lead most faithfully to learning the truth? It is clear that he considered it insufficient and purposeless from the point of view of truth criteria to construct systems, as he saw in them the one-sidedness of the notional apparatus, abstract character and artificiality - all that he once called "upiorowe myślenie myślenia" [ghastly thought of thought]. Criticism of systembuilding tendencies appeared early in his works. He wrote in Białe kwiaty [White Flowers]:

Kto by myślił, że poszukiwania świadome nowych estetyki zdobytków byłoby na polu szerszym, po francusku na przykład, stosowniej wypowiedzieć, myli się. [...] może by trzeba władzę pierw mieć albo systemat sławny na to, a obie te rzeczy wprost przeciwne są celom takowej i mojej pracy. (DW VII, 70)

[Whoever would think that the conscious search for new embellishments in aesthetics would be more suitably expressed on a broader scope, in French, for instance, is wrong. [...] perhaps one ought to have power first, or a famous system for that, and both those things are simply opposite to the aims of such work, and my work.] 
In the lectures O Juliuszu Słowackim (1860), he stated that "filozofia niemiecka jest w błędzie pod tym względem, bo nie wie, że jest tylko pewna warstwa prawd i że są tylko pewne strony prawdy, które się idealnie przedstawić i idealnie formami myśli objaśnić dają" (PWsz VI, 433) [German philosophy is wrong in that regard, because it does not know that there is only a certain layer of truths and that there are only certain sides of the truth which can be ideally presented and ideally explained with forms of thought]. Those words contain criticism of Hegel, and maybe even Kant, of whom Norwid wrote around the same time: "umysł człowieka abstrahowany od wszystkiego"6 [a human mind abstracted of everything].

The question arises, what Norwid juxtaposed to systems. He realised the need to answer that question very early on, actually along with his protest against the tendency to create systems. Yet, the most mature formulation of that issue is brought by one of Norwid's last texts, the essay Milczenie (1882), beautiful in thought and artistic shape. In the essay, the poet poses the question:

Czy przez przybliżenie (à peu près), jak pierwotni czynili, czy (jak po-Arystotelejscy) przez system otrzymuje się i udziela słuszniej światło i dobro?... (PWsz VI, 225)

[Is it through approximation (à peu près), as the primitive people did, or (like postAristotelian people) through a system that light and good is better received and shared?...]

As he criticised one-sided abstractness in the tendency to build systems, and foremostly - rejected inner coherence and conformance to mental constructs as a criterion of truth, he chose what he called "acting through approximation," and what is, in fact, a specific form of the induction method. The form of approximation suggested by the author of Milczenie also drew from direct intuitive perception of reality, linking rational and empirical elements. Norwid considered the $a$ priori assumed lack of contact with reality, the interest in only the "ideal truth" to be the fundamental sin of systems. Below is a quotation of his expressly formulated criticism:

Czy system posiłkuje w czymśkolwiek prawdę, czy sprawdza ją albo jej świadczy?... on, który zarówno rzeczom fałszywym, jak niefałszywym może służyć!... gdzie i po co wciąż nowe i zastępujące dawne systemata prowadzą, przewalając uprzedzicieli swoich?... [...] Wiem, że, czemu niebądź system służy, zawsze on nie większą ani mniejszą cząstkę prawdy obejma, to jest, że, budując się na pojęciu całości, zupełności i harmonii, jużci że wyrażać musi ideę symetrii, miary i promienności... oto wszystko!... (PWsz VI, 226)

6 [Notatki $z$ historii], PWsz VII, 361. 
[Does the system aid the truth in anything, does it verify it or prove it?... a system, which can serve both false and true things!... where and what for do the constantly new systems lead, replacing the old ones, abolishing their predecessors?... [...] I know that, whatever the system may serve, it always embraces no greater and no smaller portion of truth, that is: built on the concept of the whole, completeness and harmony, it naturally must express the ideas of symmetry, measure and radiance... that is all!...]

And one more important accusation, quite characteristic of Norwid's active, always searching approach:

Czy nareszcie system, sam w sobie uważany, kształci się także i postępuje?... Myślę, że nie! (PWsz VI, 226)

[Finally, does the system, in and of itself, also evolve and progress?... I think not!]

Convinced of the need of an empirical element in the cognition process, Norwid understood it as an inner and outer experience - intuitive and sensual contact. But neither experience nor a discursive mind were able, in his view, to embrace the whole truth separately. Reservations as to the exclusiveness of rationalism, lack of full truth in intuition alone (which was, after all, privileged with typical Romantic writers) are signalled in many of his works, among them some from the Vade-mecum cycle. And so, for example, in the poem "W Weronie" ["In Verona"], Norwid puts Mickiewicz's opposition of "czucie i wiara" [feeling and faith] versus "szkiełko i oko" [lens and eye] in a quite different, not as clear-cut, perspective. Similarly to what Mickiewicz's Romantyczność [Romanticism] does, Norwid's work presents two views, two stands towards the world: a poetic approach based on intuition (in the poem, it is symbolised by sympathetic nature, and in Mickiewicz by folk perspective) and a verifiable scientific truth (in natural science). Yet, in Norwid's poem, neither of the opposing sides is exclusively right - while Mickiewicz stands clearly on the side of intuition - and neither embraces the whole truth. ${ }^{7}$

The two stands coexisting in the poem: the scientific one and the poetic, intuitive one, express the irreconcilable antinomy between the world of matter and the world of spirit, between the bitter truth of earthly life and the comforting faith in the existence of an ideal sphere, between the magic fiction of art and the hope-robbing knowledge of life. It seems that this inability to choose between the two possibilities is an attempt by Norwid to integrate them through dual cognition: intuition with the level-headedness of scientific approach. Yet that is an only superficial integration, realised in this case in the world of art. That

7 Vade-mecum: VI. “W Weronie," PWsz II, 22. All other quotations from Vade-mecum follow the same publication. 
awareness of the dual truth and dual lie, integrated only in the world of art and bringing a painful laurel to the man-artist, brings to mind a different poem by Norwid, "Do Nikodema Biernackiego" ["To Nikodem Biernacki"], where the fate of the artist is forecast tragically (if morally worthy): "skoro kłamstwo zdradzisz kłamstwem sztuki." [when you betray the lie with the lie of art.] Norwid turns out to be a moderate sceptic, doubting the possibility of reaching the full truth without obliterating its complex nature - unless by way of intuitive approximation, joining rationalism and empiricism, which may be the only manner allowing one to embrace the whole dualistically viewed world.

For Norwid, such a way of cognition is a necessary condition, a consequence of the nature of the cognitive process. There is a highly interesting note on the nature of studies of the material world in Notatki etno-filologiczne [EthnoPhilological Notes] (1870s):

Materia (?).

Kwestia realności.

- - Wrażenia zewnętrzne przez nerwy mózgowi i szpikowi podawane telegramami.

Do-tknięcie wszechzmysłowe.

(Atoli całość takowego wrażenia jest natury duchowej).

Atomu nikt nie widział - jest koncepcją, jak prostopadła.

(Ale to, że istnieje prostopadła i atom, mamy ze świata spirytualn ego). (PWsz VII, 416)

[Matter (?).

Question of reality.

- - Outer impression forwarded by telegram through nerves to the brain and marrow.

Omni-sensory touch.

(Yet the whole of such an impression is of a spiritual nature).

No one has ever seen an atom - 'tis a concept, like perpendicularity.

(But the knowledge of the existence of a perpendicularity and an atom, we have from the spiritual world).]

Also, the following opinion on the insufficiency of empirical cognition, found in Milczenie, could be added to the above:

Jesteśmy w każdym zmyśle i rozmyśle naszym otoczeni kryształem przezroczystym, ale u-obłędniającym poglądy nasze. Podobno, że cokolwiek bądź czynimy, zagaja się albo uzupełnia przez przybliżenie. Jesteśmy sami poniekąd nie inaczej istniejącymi na wirującym Planecie szybciej od uderzeń pulsu... (PWsz VI, 226-227)

[In each of our senses and intentions we are surrounded by a transparent crystal that, however, makes our views deranged. It is said that whatever we do, is initiated or

8 “Do Nikodema Biernackiego," PWsz I, 268. 
complemented by approximation. We ourselves exist in a sense no differently on this Planet spinning faster than heartbeats...]

That is a clear formulation of Norwid's conviction that the studied reality is transformed in the process of studying - sensual perception is deformed by the mind's forms. This suggests the possibility of Kantian influences (maybe through Neo-Kantianism, which enjoyed its renaissance in the 1870s and later), yet those are all hypotheses, as there is no sufficient data as to the orientation of the author of Milczenie in the philosophical trends contemporary to him. He processed signals received from various sides (often from random readings) in his original reflection. The poet's philosophical thought thus bore a strong eclectic mark.

The consequence of the above-mentioned deforming perception was for Norwid the manner of cognition which he chose as the only possible one. One reads of it further in that same fragment of Milczenie:

A przeto można by nawet rzec, iż działanie przez przybliżenie nie jest dla nas przypadkiem, lecz podbitym sobie warunkiem. Stąd to, obejmując one - i jednocząc dwa wielkie klejnoty umysłowe, czyli: rozwagę umiejętności i nierozwagę instynktu przyrodzonego, jest zupełnie człowieczym. Toteż my, tak rzecz pojmujący, nie odpowiadamy przemilczeniami na pytania żywotne - bynajmniej... (PWsz VI, 227)

[And, therefore, we could even say that acting through approximation is not a coincidence for us but a self-subdued condition. Hence, embracing it - and uniting - two great gems of the mind, that is: prudence of skill and imprudence of innate instinct, is a completely human feature. And so we who understand the matter thus, do not respond with understatement to vital questions - far from it...]

Norwid's concept of cognition through approximation expresses his conviction of the inability to fully learn reality and general truths. It is a maximalist's succour against the defeat of resignation. A form of that "activity" for Norwid is the parable.

Parable is the means used by Norwid most often, one could almost say, constantly, both in his philosophical treaties and in poetry. It is a method which inseparably links both spheres of the writer's activity - it is present in all the genres he practised as a construction medium of a greater whole, images and metaphors. The parable of a scholar (J. W. Gomulicki named Antoni Waga as the protagonist $)^{9}$ who was surprised at seeing the profile of his nose for the first

9 Cf. C. Norwid, Pisma wybrane, selected and prep. by J. W. Gomulicki, Vol. IV (Warszawa: PIW, 1968), p. 593 (notes for Milczenie). 
time in his life as etched on a commemoration medal, introduces an important issue in Milczenie. Parables are also the command axis in Rzecz o wolności stowa; they form the outline of the story Cywilizacja [Civilisation], of Czarne kwiaty and Białe kwiaty. The poem "W Weronie," analysed above, is also a parable, rooted in literary tradition. The works listed in the few previous sentences are only examples of that most versatile of literary forms and statements of the world suggested by Norwid.

Quoted below is a fragment of the story Cywilizacja (1861) for a closer look at the consequences of Norwid's concept of cognition for his philosophy and for the shape of his literature. It is an allegorical work. Norwid would have called it parabolic, and yet he named it a legend. The framework of the story's construction is confronting the content of the term "civilisation" with the experience of modernity, by describing a cruise on a sailing ship named Civilisation which is to serve as an allegory. In that story, the author asks a fundamental question about the nature of truth in the context of interhuman relationships, and finds a half-bitter, half-ironic answer about the extreme materialisation of the contemporary world:

Prawda jest że tylko ostatecznością wynikłą ze starcia się i wzajemnego odpychania jednostronnych humorów rozmawiających z sobą obywateli? Ale sama przez się azali, powtarzam, prawda nie jest niczym, tylko czczością myślenia? tylko jestże ona jakoby tym miejscem na coś przypadkowego, i tą jakoby idealnie pojętą próżnią, o której się mawia w umiejętnościach, wiedząc wszelako, iż próżni nigdzie nie ma? Jednym słowem - jestże więc prawda kłamstwem?

Albo - mamże raczej przypuścić jako obowiązujące ostatecznie pojęcie: iż prawda jest wynikiem tylko samej redakcji myśli i zdań? [...]

[...]

Zaiste, że jedna jest rzecz łącząca doskonalej obywateli okrętu tego - rzecz, mówię, jedna jest."

A słowa te wyrzekłszy, uderzyłem nogą w ruchomy pokład statku, jakoby powiadając sobie samemu: „Oto jest ta rzecz jedna i nic więcej. (Cywilizacja, PWsz VI, 55)

[Is truth merely the ultimate result of the clash and mutual repulsion of individual temperaments of the citizens talking to each other? But is truth in itself, I repeat, nothing but the futility of thought? - is it merely a kind of place for something incidental, and that vacuum assumed to be ideally understood, spoken about in theoretical terms, knowing full well that vacuum exists nowhere? In a word - is truth a lie? Or - should I rather assume this notion as finally binding: that truth is solely the result of putting thoughts and sentences into words? [...]

$[\ldots]$

Truly, there is only one thing uniting the citizens of this ship more perfectly - one thing, I say."

Having said that, I stomped my foot on the moving deck of the ship, as if answering myself: “That is the one thing and nothing else."] 
The parable, sometimes reduced only to a gesture (cf. the considerations on the function of gesture in Rzecz o wolności słowa), ${ }^{10}$ is thus, like the "daguerreotype" used in Czarne kwiaty "by wierności nie uchybić" [to not transgress faithfulness], the kind of statement which becomes the most efficient means of conveying the truth. Norwid's parable links the material and spiritual world, thought and intuition, form and content in an individual experience - bringing one closer to the truth, it becomes a foundation of poetry, a principle of art. As a mediator facing the dual structure of the world, the parable is often connected with irony, indicating opposites which cannot be overcome despite any attempts thereto.

Cognition is thus in Norwid's interpretation a continuous process, living and open to new signals from reality, yet still resting on a solid foundation. Norwid wrote about his views on the principal role of the parable numerous times (e.g., in Białe kwiaty (1856): "A zaś świadomość paraboli sama przez się coraz dalsze pokaże kresy, braki, dobytki..." (DW VII, 68) [And the awareness of a parable will in and of itself show further limits, deficiencies, additions...]), yet let us quote once again that uncanny essay Milczenie:

Pochopnie, lubo nie najrozważniej, mówi się, że: "parabola nie dowodzi niczego..." Jużci, tak jest, bo paraboli zadaniem nie jest dowieść, ale u-oczywistnić - jedna zatem parabola oczywistni, lecz wszystkie razem uważane parabole nie tylko że dowodzą, ale dowodzą tak bardzo ogromnej rzeczy, iż strach święty bierze pomyśleć o tym!... Dowodzą one albowiem analogijnego stosunku pomiędzy prawami rozwoju rzeczy świata tego a prawami rozwoju ducha... (PWsz VI, 236)

[It is said hastily, though not the most wisely, that "the parable proves nothing..." 'Tis true, for the task of the parable is not to prove, but to make-obvious - thus one parable makes things obvious, but all parables treated together not only prove, but they prove such an immense thing that to think of it makes you shudder in holy fear!... Because they prove the analogous relationship between the laws of development of the things of this world and the laws of development of the spirit...]

It seems that a closer analysis of Norwid's concept of cognition (which is not an element of any system, as far as he is concerned) allows or at least facilitates the understanding of many issues and "behaviours." The poet's whole surprisingly intensive polemics with natural evolutionism, with Darwinism, drew arguments mainly from the epistemological area (it needs to be remembered that one of the sources of cognition for Norwid was the Bible, often taken quite literally). That polemics ended with a surprising escape of the author of Fabulizm Darwina

10 Rzecz o wolności słowa, IV, v. 4-11, DW IV, 229. 
[Darwin's Fabulism] and Ostatnia $z$ bajek [The Last of the Fables] into a parable; yet in fact, it was a consequence of his own method.

The presence of such antinomies as the world of matter and the world of spirit, or reality and ideal with Norwid does not have to be considered the crown proof for his insurmountable Romanticism, as it usually is, because it is only the setting of the dualist view of the world. On the other hand, it is a fact that Norwid's attempts to control that antinomy occurred in a conscious opposition against the worldview of Polish Messianic Romantics. It seems that when, for example, Cieszkowski believed in the future reintegration of dualism, believed in "the post-Christian era of God's Kingdom on earth," ${ }^{11}$ when Mickiewicz came close to spiritualist monism in the above-quoted fragment of Prelekcje paryskie - Norwid tried to overcome the "duality of the world" by embracing it without negation in the cognitive process. Without negation, that is, without obliterating the complexity of the world, and the "split" between the result of cognition and the essentially unreachable ideal was expressed mainly in irony. The integrating function of personality which is learned through "approximation" and communicates its achievements through parables bordering on irony favoured the attitude of critical conservatism, striving to bring reality closer to the ideal through gradual emendation. On the other pole, the attitude of Mickiewicz, who definitely subordinated temporal reality to the spiritual world, led him towards utopian revolutionism; it strived towards a violent realisation of the ideal in reality. The attitude of Norwid was the stand of a moralist who stated the need of slow workings of history when "Nie-prze-palony jeszcze glob, Sumieniem!"12 [the globe is not-yet-burnt-through with Conscience!] There is a doubtless close connection of that attitude with the above-discussed cognition issues.

Finally, one more problem should be mentioned. Norwid's theory of language as a means of conveying the truth was based on the conviction of an equally dual nature of the word (treated autonomously, in connection with Revelation). The function of communicating (communicativeness, in a word) was fulfilled by the "external" word, close to a parable, which is the "drama of life" and which occurs in a situation of a dialogue - man-man contact and world-world contact. This chapter will not provide a closer analysis of Norwid's concept of the word, which he presented mainly in Rzecz o wolności słowa (that would require a separate study). Let us only say that for the poet, who saw the world of matter and the world of spirit as being parallel, the integrating, mediating function belonged to names (whose origins he sought in Revelation - but not only). Names could also

11 Cf. A. Walicki, Filozofia a mesjanizm. Studia $z$ dziejów filozofii i myśli społecznoreligijnej romantyzmu polskiego. (Warszawa: PIW, 1970), p. 63.

12 Cf. poem III. "Socjalizm" ["Socialism"] from the Vade-mecum cycle, PWsz II, 19. 
function on the border of the two worlds and in interhuman communication. In one of Norwid's notebooks, already mentioned here, there is a note (whether of his own or someone else’s idea): "Nazwa - wyjście z monologu - - ze snu."13 [Name - exit from monologue - from dream.]

\section{Man and History}

The dominating feature of Norwid's worldview is a humanist concept of man and his fate, functioning alongside the Christian thought that "człowiek na to przychodzi na planetę, ażeby dał świadectwo prawdzie."14 [a man is born on this planet in order to bear witness to the truth.] Norwid does not assign an instrumental role to man seen in the context of society and history, and at the same time viewed dualistically. For him, man is an entity who creatively shapes his fate. To the typically Romantic opposition: I versus others, he juxtaposes a different view: "I" as one of many, a man with a high degree of awareness - quidam. He notes the following thought in one of his notebooks:

ONI. Ilekroć mówimy “oni," godzi się nie zapominać, że zarazem i "my" powiadamy, nikt albowiem tak się wyosobnić nie może, aby dlań istotnie "oni" istnieli. Nawet i on stawiony pod gilotyną zbrodzień nie bywa nam "onym," i dlatego to zarazem sarkamy na karę śmierci i zarazem jej doraźnie zmazać z kart prawa społecznego nie możemy (raczej chyłkiem, omackiem).

Nikt

Żaden. ([Notatki etno-filologiczne], PWsz VII, 379)

[THEY. Any time we say "they," we should not forget that in that same breath we say "we," for no one can isolate himself so much that "they" actually exist for him. Even he the felon standing before the guillotine is not some "he" to us, and that is why we both grumble at the death penalty and yet cannot outright erase it from the pages of social law (rather furtively, stealthily).

No one

Not a one.]

Man is thus seen by Norwid as a naturally social creature. According to the poet, egoism is not an inborn feature, and it can and should be fought by functional integration in the social mechanism.

An individual is seen in the context of others, yet their most valuable feature is personality shaped in conscious confrontation with the surrounding reality

13 [Notatki etno-filologiczne], PWsz VII, 392. This notebook contains many interesting comments about language.

14 O Juliuszu Słowackim, PWsz VI, 434. 
and allowing to achieve what Norwid calls "całością żywota dojrzałego"15 [the whole of mature life], meaning full self-realisation. For Norwid, one of the main means of the self-realisation of personality was work. That work did not have to be tantamount to physical toil, but it involved something more: creative effort:
"Pracować musisz" - głos ogromny woła -
Nie z potem dłoni lub twojego grzbietu,
(Iż prac-początek, doprawdy, że nie tu), in Brow's Sweat "], PWsz II, 91)
["You must work" - calls a great voice -
Not by the sweat of your hand or your back,
(the work-beginning is not found there),
You must work by the sweat of your brow!]

Pracować musisz z potem twego czoła! (Vade-mecum: LXIII. "Prac-czoło" ["Work

Norwid's concept of work remained in close connection with his religious worldview, as work was for him the consequence of original sin - not just a punishment, but mainly a factor for internal development, a means allowing man to get closer to the lost original ideal state:

Gdy jak o pięknem rzekłem, że jest profil Boży,

Przez grzech stracony nawet w nas, profilu cieniach,

I mało gdzie, i w rzadkich odczuwań sumieniach,

Tak i o pracy powiem, że - zguby szukaniem,

Dla której pieśń - ustawnym się nawoływaniem. (Promethidion, DW IV, 107-108)

[When I spoke of beauty, that it was profile of God,

Lost through sin even in us, that profile's shadows,

And hardly anywhere, in rare sensations of conscience,

Thus I shall speak of work - that it is a search for the lost,

For which the song is an ever-lasting call to each other.]

Man's innate social instinct turns into conscious action all the more effectively if it is connected with reflection over his own fate and cognition of the surrounding reality. The sphere in which that instinct is realised and activated, is society, and in perspective - history.

Norwid's historicism, appearing in diverse forms in his poetry and in his philosophical reflections, connects him to a large degree with the consciousness of the era contemporary to him. Historicism marked most 19th-century systems and was a common phenomenon at the time, typical especially of Romantics.

15 Cf. e.g. poem C. "Na zgon ś.p. Józefa Z.” [“On the Death of the Late Józef Z.”] from Vade-mecum, PWsz II, 149. 
Hegel's historiosophy and Hegelianism played a dominant role there. Many Hegelian elements also functioned in Norwid's historiosophy (mainly through Cieszkowski), yet it does not seem quite correct to relate Norwid's views to Hegel's system. ${ }^{16}$ Similarly, they cannot be related to any other contemporary system. Norwid cut himself off not only from systems as such, and "German philosophy" in particular, but also nearly directly from Hegel's determinism and statism. In Listy o emigracji [Letters on Emigration], III (1849) he wrote:

Filozofia niemiecka, w krytycyzmu swego samowładztwie ułożywszy przeszłości ciąg logiczny i orzekłszy, gdzie się zatrzymała, nie obowiązując do niczego prócz do książki zamknięcia: „Tak- powiada - musiało być koniecznie i tak się też koniecznie jakoś stało." (PWsz VII, 25)

[German philosophy, having arranged in the autocracy of its own criticism a logical course of the past and having defined where it stopped, obliging one to nothing more than closing the book: This is - it says - what it absolutely had to be, and what somehow absolutely occurred.]

Norwid's historicism is based on a modern conception of man as an active participant in the historic process, although with some stress on the divine character of history. It is noteworthy that Norwid does not acknowledge the direct interference of Providence in the course of history. His understanding of the mechanism of history is not providential progressivism (e.g., with Ballanche).$^{17}$ According to Norwid, the principal factor of historic developments is human activity in society:

Bo Przedwieczny w człowieku przez się działa, ale $\mathrm{w}$ historii przez człowieczość. (Listy o emigracji, PWsz VII, 38)

[Because the Eternal (Father) acts in man through Himself, but in history through humanity.]

Norwid's philosophy of man and of history has a striking number of similarities to the views of 18th-century philosopher Giambattista Vico, the author of Scienza Nuova. ${ }^{18}$ Vico was a forerunner of many 19th-century ideas, and his

16 More on the topic is seen in the study "Norwid i Vico," pp. 215-217, 232.

17 On Norwid's historicism, cf. Alicja Lisiecka’s paper “Z problemów historyzmu Cypriana Norwida. Na marginesie tomu 7 'Pism,'” Pamiętnik Literacki, Vol. 1/2 (1959), which is rich in observations but offers some simplified and even mistaken conclusions, and another work by the same author (with similar reservations): "Romantyczna "filozofia przyszłości” Cypriana Norwida," in: Nowe studia o Norwidzie, eds. J. W. Gomulicki and J. Z. Jakubowski (Warszawa, 1961).

18 For more extensive considerations on the analogies and affinities between Norwid and Vico, see further in "Norwid i Vico," pp. 213-248, in: Elżbieta Feliksiak, Poezja i myśl. Studia o Norwidzie (Lublin: TN KUL, 2001). 
influences are noticeable in the works of French Romantic historiosophers, mainly Jules Michelet. He was also an inspiration for many other modern systems. A particularly significant role in the renaissance of that Neopolitan philosopher some hundred years later was played by Michelet's translation of Scienza Nuova (1827), with the introductory treaty Discours sur le système et la vie de Vico. The existence of Michelet's version of Vico (the translation was quite free) constituted the basis of the 19th-century model of a "Viconist."

Of course, the author of Promethidion could not be called a "Viconist." He was certainly not a follower of that system. Yet, the undeniable presence of analogies is worth stressing due to the fact that it proves how far the roots of Norwid's concepts reached, and how rich their traditions were. Norwid could have come across Vico's ideas very early on, through August Cieszkowski. It is known that those two thinkers were in close contact. In his youth, Norwid was definitely under the great influence of Cieszkowski. In his first volume Ojcze nasz, issued in 1848, Cieszkowski suggested a "correction" to "brilliant Vico's" theory by acknowledging a spiral course of history. Even though the comment about Vico is only present in a footnote ${ }^{19}$ Cieszkowski's interest in the author of Scienza Nuova is certain beyond doubt. Cieszkowski was likely using Jules Michelet's translation (which was much more popular than the German one issued a few years earlier), and perhaps Norwid also read the translation by Michelet. There is direct evidence of Norwid's familiarity with Vico (two comments in a notebook $)^{20}$ and of his knowledge of Michelet's version, yet it is difficult to state to what extent that was first-hand knowledge. This does not seem to be the most essential issue, as "Viconism" was similar to Hegelianism in that it was present in common and variously modified circulation. The conviction of the historiogenic role of the sensible and social man - allowing for superior but passive rule of Providence - is especially common to both thinkers.

To Vico, Hercules was the mythical image of human nature. The key role of the Herculean myth in Vico's anthropological conception is stressed by Eginhard Hora, the author of the afterword to the German translation of Scienza Nuova (by Erich Auerbach). ${ }^{21}$ Hora claims that for Vico, the Herculean myth was a

19 Introduction to: A. Cieszkowski, Ojcze nasz, Vol. I (Paris: Maulde et Renou, 1848), p. 174.

20 [Notatki $z$ historii], PWsz VII, 361 and 366-367.

21 G. Vico, Die neue Wissenschaft über die gemeinschaftliche Nature der Völker, nach der Ausgabe von 1774 übersetzt von Erich Auerbach, mit einem Essay "Zum Verständnis des Werkes" und einer Bibliographie von E. Hora (Rowohlt, 1966). 
synonym for the history-creating individual who controls chaos by actively changing it into a structure serving human needs. The chaos is controlled by way of inventory and discovering work. Vico takes the myth into a humanist view on the complex nature of man, as well as a theory of universal history, whose subject is man's individuality, full of imagination and creative powers.

The Hercules motif appears with Norwid in an analogous conceptual context in a poem from Vade-mecum titled "Prac-czoło." Yet, the actual functional equivalent of Vico's Hercules with Norwid is Prometheus, who symbolises inventory genius and a personality which contradicts egoism. For the author of Rzecz o wolności słowa, Prometheus is the mythical creator of civilisation, and not just in the sense of technical progress, but also in a social sense:

Stąd Orfej, miast założyciel i mistrz; stąd Prometej - pierwsi apostołowie cywilizacji, którzy spólność kobiet i dóbr wyniszczają. (Notatki z mitologii, PWsz VII, 281)

[Hence Orpheus, the founder and master of cities; hence Prometheus - the first apostles of civilisation, who destroy the sharing of goods and women.]

Quoted above is a fragment of Notatki z mitologii, which already at first glance seems nearly an outline of the issues of Rzecz o wolności słowa (or the French paper on the topic, written earlier). Even a similar line of reasoning is visible, with almost identical considerations and arguments. Those Notatki constitute the source from which material will be drawn here for the interpretation of that fragment of Norwid's philosophical poem where he speaks of the myth of Prometheus in connection with the tradition of Moses. For Norwid, Prometheus represents human nature only to a degree; the complete symbol of an "eternal man" is the synthetic figure of Prometheus-Adam, appearing in Promethidion and born from a mythological interpretation of the most ancient historical times. Norwid's mythological components of the image of the "eternal man," Adam, are Prometheus and Moses, symbols of two traditions and at the same time of two sides of human nature. It is, basically, a dualism of spiritual life and practical activity ("deeds"), a dual line of tradition which strives for synthesis in the shape of creative and spiritual work: a factor facilitating the integration of personality and the actual stimulator of history. The traditions of Prometheus and Moses also include revolution, purposeful revolt and law, protection of the sacred. Among the notes on the various myths of Prometheus (e.g., Hesiod's), Norwid wrote:

Ale Prometeusz, Japeta syn, rewolucję tu wyraża: helleński, północny animusz. (Notatki $z$ mitologii, PWsz VII, 293)

[But Prometheus, son of Japet, expresses revolution here: the Hellenic, northern spirit.] 
Two pages earlier, he wrote of Moses:

Stanowisko Mojżesza do egipskiej mądrości jest z góry: z władzy, tak jak niegdyś Józefa, który z góry sny czyta i od razu do jawności doprowadza realnej. [...] Wąż ów Agatodemon - słodki demon, dobry demon, ale w kółko zawinięty i opętujący - zawieszony jest przez Mojżesza na słupie; pierw w kiju podwójnym tylko. Od razu ta świętość panująca i dla panowania osiągnięta agato-demoniczna, przechodzi przez sprawę liberatora w Prawo. (Notatki z mitologii, PWsz VII, 291)

[The stance of Moses towards Egyptian wisdom is from above: from the position of power, just like that of Joseph, who reads dreams from above and makes them real at once. [...] That snake, the agatho-daemon - a sweet daemon, a good daemon, but coiled in a circle and possessive - is hung by Moses on a pole; at first only in a double stick. At once, that holiness ruling and achieved for ruling, agatho-daemonic, becomes Law through the liberator's deed.]

One of Norwid's most mature poems, "Moralności" ["Moralities"] from the Vade-mecum cycle (LI), must be mentioned here. The basic component of its ideological and artistic shape is the figure of Moses, the creator of "Law," that "moralność-zbiorowych-ciał" [morality of collective-bodies], and thus a symbol of social ethics. That poem contains one of Norwid's most uncanny metaphors ("czoła się nam mojżeszą" [our foreheads Moses-ify]), one of those metaphors which open immense mental horizons with their structure: when the fate of Moses' tables is spoken of, one of them is broken in anger (broken "o twardość ludu" [against the hardness of the people]):

Wobec pierwszej?... każdy a każdy - rzeszą!

Lecz - by drugą od-calić,

Czoła się nam mojżeszą

I zaczynają się lica blaskiem palić.

- Wiatr ogromny, jak na Synai szczycie,

Tętnią echa i gromy z błyskawicami;

Dłonią czujesz, że tknąłeś życie...

Podejmując Prawa odłamy. (PWsz II, 79)

[Towards the first?... each and everyone - a throng!

But - to de-whole the other,

Our foreheads Moses-ify

And our faces start to glow.

- Great wind, like on Mount Sinai,

Echoes and thunders throb with lightning;

You feel you have touched life with your hand...

Collecting the fragments of the Law.]

For Norwid, Moses is often the symbol of social and at the same time moral responsibility. Moses is also - traditionally - the one who stores and saves God's truths, the revealed word. He is a liaison between man and God, according to biblical tradition. 
Again, in Notatki z mitologii, there is the statement: "komunia Mojżesza z Bogiem" (PWsz VII, 288) [Moses' communion with God]. Prometheus is the one who breaks the covenant with the world of gods to serve only man. Norwid organised his rich and extensive reflections and notes on the most ancient history of humanity ("legendary" times, in his words) around the concept of "two traditions." Following some historiosophers of the time, he takes Central Asia to be the place where the human race began, according to Genesis ("U dzisiejszych historiozofów: mity, etymologia, języki, tradycje, pomniki - szesnaście wieków przezd Zbawicielem Azję Centralną naznaczają na kolebkę rodu ludzkiego" (PWsz VII, 255) [With today's historiosophers: myths, etymology, languages, traditions, monuments - they mark Central Asia as the birthplace of the human race sixteen centuries before the Saviour]) and collects materials on the subsequent migrations of peoples, taken mostly from mythology and philology. The two-sidedness of those migrations becomes, in his view, the source of division in tradition, of the diversity of myths and cultures:

Z wysokości azjatyckich płyną ludy i rozdzielają się w dwa pasma: jeden ku środkowi kontynentu, na wschód, i tam przylega... drugi ku Europie dalej - dalej w XV wieku pod przywództwem Kolumba dalej jeszcze, i Nowy Świat odkrywa, i obiega glob, i łamie mury chińskie! (PWsz VII, 255)

[Peoples flow down from Asian heights and divide into two streams: one heads for the centre of the continent, towards the East, where it stays... the other heads further towards Europe - further, in the 15th century under Columbus further still, and discovers the New World, and circles the globe, and breaks the Chinese Walls!]

In the cultural circle closest to Europeans, Norwid notices a dualism of tradition, two lines of myths which are still versions and symptoms of common descent. That dualism of tradition bears different names with the author of Rzecz o wolności słowa. Once he calls it "Ludy mające nadzieję i nie mające nadziei..." [Peoples who have hope and who have no hope], and another time "sekretna i niesekretna strona doktryny" (PWsz VII, 241) [the secret and non-secret side of the doctrine]. Yet, the most interesting definition seems to be: "Pierwsze dwie tradycje: rozejścia - spotkania" (PWsz VII, 242) [The first two traditions: of parting - of meeting], as it seems to correspond with the myths of Moses and Prometheus: the one who teaches man the covenant with God, and the one who "wykrada ogień i zuboża niebiosa" (PWsz VII, 292) [steals fire and impoverishes the heavens]. Despite the apparent opposition, both give man fire, connecting him to the divine world; both bring about change and moral and social progress. Norwid actually binds the two myths together, both in the fragment of Rzecz o wolności słowa quoted below, and in Notatki z mitologii, where in chapter XVII, the introduction of the first paragraph states: "Mojżesz. Prometeus" (PWsz VII, 292) ["Moses. Prometheus"] - Moses was the topic of the previous 
pages, and the following ones analyse the myth of Prometheus based on Hesiod and other ancient authors. Moving through various cultures with equal interest, Norwid always strives to prove their fundamental commonality and analogy. $\mathrm{He}$ seeks structural similarities in mythologies which may seem diverse. All that is seeking the traces of the primary covenant of man and God:

[...] religii człowiek nie ulepsza i nie wynajduje religii, ale owszem te się zaciemniają i skorupieją z czasem. I wracając do źródeł, np. orfijne - italskie-pierwsze - egipskiepierwotne - indyjskie - chińskie - odnajduje czystymi i wzniosłymi w pojęciach Boga. (PWsz VII, 261)

[[...] man does not improve upon or invent religion, but those do darken and petrify with time. And returning to the origins, e.g. orphic - first-Italian - primaryEgyptian - Indian - Chinese - he finds them pure and noble in their perception of God.]

Convinced of the unity of the terms "gwałt i kara" (PWsz VII, 263) [violence and punishment] in various traditions, Norwid believes that the most perfect explanation of that basic issue of man is the one given by the Bible -original sin. A punishment for rebellion against divine laws was imposed on both Prometheus and Adam. Prometheus-Adam from Promethidion is a man sentenced to penance, but also, at the same time, facilitating social progress and history through his attitude. He creates civilisation and culture through work with moral and aesthetic values. Moses, on the other hand, has to bear the resistance of the people for whom he creates law in a covenant with God. The poem Rzecz o wolności słowa, both a humanist and a religious-theological poem, with scientific elements, ${ }^{22}$ presents history as the history of "the word" (understood automatically, as logos) ${ }^{23}$ realised by man in a specific manner - according to the latter's dual nature. That history of the word "suffering enslavement" reflects Norwid's ontological dualism and philosophical attempts to overcome it. The "inner" and "outer" word shows the dualism of spiritual life and practical activity, values kept by the chosen ones and values realised by society. ${ }^{24} \mathrm{~A}$ parable using

22 The terminology used here is taken from Stefania Skwarczyńska. Cf. S. Skwarczyńska, "Struktura rodzajowa Genezis z Ducha", in: Juliusz Słowacki. W stopięćdziesięciolecie śmierci: materiały i szkice, eds. Marian Bizan and Zofia Lewinówna (Warszawa: PIW, 1959), pp. 262-263.

23 Cf. Notatki z mitologii, PWsz VII, 246: "Człowiek miałby język i mowę, ale nie mówiłby i nie rozumował bez Obiektywnego Słowa. Tu światło do oka tak samo ma się.” [Man would have language and speech, but would not speak or reason without the Objective Word. Same is the relation of light and the eye.]

24 Cf. Notatki z mitologii, PWsz VII, 246: "Dwie doktryny: 1. és otérique - sekretna, ale magią i ta okraszona; 2. éxotérique - przystępna dla miejscowego ludu. Tajemnica 
approximation, when "obraz każdej myśli jest nawiasem" [the image of each thought is a bracket], allows to see the whole. At the primary stage of human communication, Norwid assigns a great role to signs, symbols, gestures: those stones and aerolites which act as the altar, ${ }^{25}$ "gwoździe" [nails] and "hieroglify" [hieroglyphs] which form the writing, the medium, initiation. The parable links two spheres as the "zwierzchnia doktryna" [superior doctrine]: the absolute, divine truth unavailable directly and the cognition process, full of mental, moral and physical effort. This is how Norwid presents his conviction of the dualism of history in a mythological parable in Rzecz o wolności słowa:

Odtąd dwie sq doktryny: JEDNA z ojca w syna

Testamentem tradycji wewnętrzna doktryna, DRUGA zaś dla dalekich krewnych i czeladzi

Lub podróżnych, skoro je w namiot traf sprowadzi;

Ta - zewnętrznie odbrzmiewa pierwszej, jak w orzechu

Rdzeń ma się do łupiny, jak słowo brzmi w echu.

(Podobieństwo zależne formą od ilości:

Im pokolenie większe, tym większe różności

Doktryn dwóch; aż nareszcie zgodzić się nie mogą

I dwie tradycje, każda swoja idzie drogq...)

Stąd Mojzes, stąd Prometej o dobie téj saméj

Niebieski biorąc ogień dwojakimi bramy,

Skoro jeden szemraniem ludu jest trapiony,

Drugiemu sęp wnętrznoście maca co dzień szpony.

Stąd tam - ówdzie - sa mitów ciagłe podobieństwa,

Walki też same, cudy, znaki i męczeństwa,

stąd." [Two doctrines: 1. ésotérique - secret, but also spiced with magic; 2. éxotérique available for the local people. Hence mystery.]

25 Notatki z mitologii, PWsz VII, 265: "Sabeizm, naturalizm. U schyłku sabeizmu, jakoby więc poniekąd u schyłku samejże Epoki Patriarchalnej, aerolit jest pośredniczym punktem między gwiaździarstwem a sztuką plastyczną. Gwiazd cześć do upadłego kamienia. Kamień - znakiem miejsca uświęconego; zarodkiem ołtarza, budową, posągiem (Od Chin do krańców Zachodu i dziś do odległych wysp - wszędzie)." [Sabians, naturalism. At the decline of Sabianism, and so almost at the decline of the Patriarch Era, aerolith is the mediating point between star-science and fine art. Worship of stars to a fallen stone. The stone - a sign of a sanctified place; the embryo of the altar, a construction, a statue (from China to the ends of the West and today to the far islands - everywhere.] 
Które, nie wie geograf i chronolog nie wie, Czemu? jedne a różne, jak liście na drzewie.

Mąż, czoło-pokolenia, nie tylko już samem Słowem, przez spadkobierców obcuje z Adamem, Lecz ważne miejsce nieraz naznacza kamieniem, Gwoźdź zabija, by świecił stałym przypomnieniem, A szeregi tych gwoździ nieraz rdzą wyparte Inicjowany czyta jak pisaną kartę $[\ldots]$

Słowo jest odtąd pełne tym krąglej, że miało Niezadługo już z-psalmić w Epos doskonałą I na zewnątrz, gdzie drama lub codzienne czyny, Parabole w kształt zwierzchniej postawić doktryny; Wewnątrz, pod lekkim cieniem przezroczystej palmy Złotą harfę Dawida, rozgorzałą w psalmy. ${ }^{26}$

[Since then there are two doctrines: ONE from the father into the son A testament to tradition, the internal doctrine, And the OTHER for distant kin and servants Or travellers, if fate brings them to your tent; That - one resounds on the first externally, like in a nut The core is to the shell, like the word's sound in an echo. (The similarity dependent in form on the quantity: The greater the generation, the greater the differences Of the two doctrines; until they cannot agree And the two traditions: each - go their own way...)

Hence Moses, hence Prometheus at the same time Taking heavenly fires through two gates, One of them is bothered by people's repining, The other has a vulture sink its claws into his insides every day.

Hence here - there - constant similarities of myths, Same fight, miracles, signs and martyrdoms, And neither geographers nor chronologists know Why? are they same and different, like leaves on a tree.

Man, the generation-head, no longer with mere Word, through his descendents communes with Adam,

26 Fragments of Rzecz o wolności słowa, DW IV, 231-233. 
But often marks an important place with a stone,

Hammers in a nail, to have it shine as a constant reminder,

And rows of those nails, often rusted out,

The initiated one reads like writing -

$[\ldots]$

The word has since then been all the more complete

That it was soon to psalm into perfect Epos,

And outside, where there are dramas or daily deeds,

To present the parable as a superior doctrine;

Inside, under the light shadow of a transparent palm -

To put David's golden lyre, flaring with psalms.]

And so only when tradition (the Christian one) joins the unchangeable nature of man, and its divine origin, with his activity, it can give the full image of man, in Norwid's eye. Prometheus-Adam, the "eternal man," co-creates history. He is the creative man through whom Providence works now only in an individual plan. To quote Notatki $z$ mitologii once again:

Jedność tradycji. Naturalności. Pozostałość. Tradycja. Harmonia ducha. Albowiem człowiek jest historią... i częścią prawdy. Ogółem. (Notatki z mitologii, PWsz VII, 297)

[Unity of tradition. Of naturalness. Remnants. Tradition. Harmony of spirit. For man is history... and part of the truth. The community.]

Let us now take a closer look at Norwid's views on history. In the surviving fragment of the introduction to Filozofia historii polskiej [The Philosophy of Polish History], Norwid specifies his view on the general character of history:

Gdyby historia (zdaniem moim) nie miała nic boskiego w całokształcie ustroju swojego (to jest: gdyby właśnie przez to samo ona nie była historią...) (Notatki z mitologii, PWsz VII, 66)

[Had history (in my opinion) had nothing divine in the entirety of its system (that is: had it not been history based on that fact alone...)]

That human history developing under the supervision of Providence should be realised through nations:

Pracowanie tedy na Królestwo Boże nie przez naród, to jest nie przez wnętrze - to jest nie przez ducha-Bożego w człowieku, a w następstwie nie przez człowieka w dziejach (czyli naród) - jest robotą omylną, jest robotą wsteczną, jest eksploatowaniem tylko Królestwa Bożego. Mówię o tym, bo to kwestia jest dzisiejsza. (Listy o emigracji, PWsz VII, 27)

[And thus, working for the Kingdom of God not through a nation, that is: not through the inside - that is: not through the Divine-spirit in man, and consequently not through man in history (meaning nation) - is the work of error, the work of regress, is only the exploitation of the Kingdom of God. I speak of it, for the matter is of today's concern.] 
This text contains a clear allusion to Mickiewicz's Slavophilia, a protest against the Messianic inclination towards a universalist redemption of the world. Not "Humanity" as an abstract platitude, but "Humanity" as a set of independent nations realising their unique characters - that is the difference between the Messianic and Norwidian view on nationality. He defined "nation" in opposition to the term "state"; that was a polemics with Hegel's state as a sensible and necessary creation, as well as with Slavophilia melting nations away into a supranational tribal unity.

Co to jest naród? - Historycy i filozofowie polscy nie określili albo raczej nie opracowali dostatecznie tego, tyle ważnego - osobliwie dla Polski, i w dzisiejszym jej stanie dla Europy - zapytania. Odpowiedzieć też na nie ostatecznie tylko w realności swojej naród cało-głosem zupełnym by potrafił. Ale częściowo odpowiadać w stosunku do tego lub owego zapytania można i potrzeba. Owóż naród jest wewnętrznym powinowatych ras sojuszem - tak jak państwo jest zewnętrznym blisko siebie będących ras s-kupieniem, z-traktowaniem, z-niewoleniem. Naród tedy z ducha, a więc z woli i z wolności jest (sojusz z Litwą, niezaborczość oręża polskiego etc.), a państwo jest z ciała albo raczej z zewnętrza, z tego świata - z niewoli. (Listy o emigracji, PWsz VII, 27)

[What is a nation? - Polish historians and philosophers have not specified, or rather, have not sufficiently resolved this highly important question - important in particular for Poland, and its situation in Europe today. Only the nation, in its own reality and in its full-voice, would be able to fully answer it. But one could and should at least partially answer this or that question. So, the nation is an internal alliance of akin races like the state is an external grouping, treatment, enslavement of races close to one another. Thus a nation rises from the spirit, and so out of will and freedom (the Lithuanian alliance, the non-possessiveness of the Polish army, etc.), and a state is from the body, or rather from outside, from this world - from enslavement.]

The reservations stipulated by Norwid onto his definition of a nation are a perfect example of his concept of cognition, characterised already in the previous part of this chapter: a final arrival at the truth, the full definition of cognition are not possible by way of theory - yet the attempt to answer basic questions should not be abandoned prematurely.

Norwid's historiosophy is based on the conception of a cyclical development within eternal striving (similarly to Vico's) towards the fulfilment of ideal - that is, divine - history. The motif of repeated cycles, with returns to savagery and rebirths, ${ }^{27}$ appears clearly in many of Norwid's works, mainly in Salem (1852), the lectures O Juliuszu Słowackim (1860), Rzecz o wolności słowa (1869) and Milczenie

27 Cf. G. Vico: "The nations mean to dissolve themselves, and their remnants flee for safety to the wilderness, whence, like the phoenix, they rise again." Conclusion of New Science: On an Eternal Natural Commonwealth, transl. T.G. Bergin and M.H. Fisch (New York: Cornell University Press, 1948), p. 382. 
(1882). Norwid's cycles actually revolve in spirals, however (in accordance with Cieszkowski's correction in the above cited note from Ojcze nasz). As Norwid's historiosophic considerations deepened, a certain shift of the gravity point could be observed. In an earlier period, progressive development was mainly accented; the poet strongly stressed the repetitive and analogous nature of history then. The element of progress was particularly stressed in Niewola [Enslavement] (1848), and in the essay Widowiska... [Spectacles...] (1852) the author notes:

[...] nic się ślepo i mechanicznie w historii nie powtarza! Wszystko, co się powtarza w historii, powtarza się zawsze z jakiejśs strony w potędze wyższej. (PWsz VI, 392)

$[[\ldots]$ nothing in history is repeated blindly and mechanically! All that is repeated in history, is always repeated in some respect at a higher power.]

In the same place, he thus wrote of the history of the ancient stage:

Jest to koło, które się samo przeciwnymi końcami obrębu zawiązuje i nowe zeń wywija się. (PWsz VI, 391)

'Tis a circle which links the opposite ends of its circumference itself, and a new one coils out of it.]

In the name of an eternal history with an unknown destination point, which in his teleological conception would mean ending penance and clearing the conscience of the effects of egoistic desires, Norwid protested sharply and firmly against the claim of the "end of history," meaning the destination point being close, as announced by utopian socialists. He definitively rejected millenarianism and chiliastic dreams. His historiosophic thought of a rebirth through an inevitable and necessary cataclysm (one rebirth of many) is expressed in the suggestively drawn parallel between two worlds in the unfinished poem $A$ Dorio ad Phrygium (where the duality of the world is at the same time the constantly repeated dynamics of history). ${ }^{28}$ The earliest direct appearance of the idea of historic repetition is a fragment from the Salem cycle:

Bo świat już kończył się po wiele razy,

Przemazywając skończone obrazy

Tej albo onej znów rzeczywistości,

Co wciąż to samo wyraża, wciąż prościéj... (DW IV, 182)

28 This concept also contains very sharp criticism of the civilisation contemporary to Norwid; it is for him an argument in the polemics with his times. Cf. a study on A Dorio ad Phrygium (see E. Feliksiak, Poezja i myśl pp. 171-212), as well as her polemics with J. M. Kasjan (Przeglad Humanistyczny No. 2 (1965)) on the first printing of the text in Przegląd Humanistyczny No. 4 (1964). 
[For the world has already ended numerous times,

Erasing completed images

Of this or that reality,

Which keep expressing the same thing, more and more simply...]

As seen, the repetitiveness is relative - thus it is a spiral ("more and more simply").

The text of key significance for Norwid's historiosophy is Milczenie. There, Norwid conducts a periodisation of human history from the perspective of the art of the word - the development of forms of expression, understood as the variable expression of a variable human awareness. This idea coincides entirely with Vico's views. Starting with the assumption that "pierwotny umysłowy człowiek jest poetą" [the first thinking man is a poet], Norwid lists further eras: legend, epic poem, history, then anecdote and revolution. Each of those, in his view, is based on what was left "unsaid" in the preceding period. The eras distinguished by Norwid match Vico's division to a large extent, especially because the repetition of the cycle is stressed. On the other hand, those eras have nothing in common, for example, with Cieszkowski's triad conception, with the historiosophy of Ojcze nasz. In that manner, the cyclical system was related to the concept of historical "polarity," which expresses Norwid's more general conviction about an all-permeating dualism. A parabolic presentation of that polarity is found in the lectures $O$ Juliuszu Stowackim:

Cywilizacja każda, nawet u ludów starożytnych, miała dwa bieguny: punkt wyjścia i punkt zamierzchu swojego. [...]

Tak jawiły się światu Galle, Germany, Hunny, Tatary, rewolucje socjalne: a razem znów biorąc te masę całą [...], będziemy mieli świat pogański na wierzchu i świat katakumb spodem... (PWsz VI, 435, 436)

[Each civilisation, even among ancient peoples, had two poles: the starting point, and the point of its decline. [...]

The Gauls, the Germanics, the Huns, the Tartars, and social revolutions appeared this way to the world: and if we consider this whole mass again [...], we will have the pagan world on the surface, and the world of catacombs below... ]

An attempt to outline a similar historiosophic conception is already found in Rzecz o wolności słowa, but Milczenie gives a synthesis of Norwid's views, and its versatility contributes to the ideological purity and perfection of its expression. According to the thesis that every cognition is incomplete, that consequently there is the need to learn "through approximation," as set out in the introductory part of the essay, the poet presents the image of history as a whole, using the parable-based theory of silence (or "not-saying"/"understatement"). The rhythm of history's epoch changes is shown as a continuum of repetitive antinomies, 
with one pole gaining domination in a given epoch (Norwid calls this "wygłos" [expression, projection]), while the other pole remains in opposition (remains "unsaid"). Only the consideration of several epochs, while consciously applying the principle (which Norwid considered a scientific discovery), allows for an approximated understanding of the mechanism of history - understood here as the history of culture.

Thus Norwid states:

[...] tak samo, jak we składniowym budowaniu się zdań: pierwsze zdanie osadza się na przemilczeniu, które następnego logicznie zdania stawa się wygłosem, a przynosi ze sobą drugie przemilczenie dla nastręczenia wygłosu trzeciemu zdaniu i tak dalej... Tak samo (mówię) i we wielkich umysłowych wyrobach wieków i epok to, co było przemilczeniem całego umysłowego ogółu jednej Epoki, stawa się wygłosem literatury Epoki drugiej następnego wieku, a co ta przemilcza, wygłosi jeszcze następny, swoje znowu dla trzeciego przemilczenia ze sobą wnosząc.

Prawo przeto maleńkie, które odkryliśmy i podawamy, jest zasługującym na uwagę, albowiem okazuje się być całym i na rozmaitych polach zarówno żywym. (PWsz VI, 244)

[[...] same as in the syntactical structuring of sentences: the first sentence is based on the unsaid, which then becomes the expression of the sentence which logically follows, and brings with it a new unsaid to give expression to the third sentence, and so on... In the same way (I say) even in the great intellectual products of ages and epochs, that which is unsaid in the whole intellectual community of one Epoch becomes the expression of the literature of a second Epoch in the next age, and what that latter one leaves unsaid, is expressed in the next one still, making its own contribution to the third unsaid.

Thus this small law, discovered and given here, deserves recognition, because it turns out to be fully and equally functional in various fields.]

Norwid considered reflection on history to be extremely important for conscious participation in creating the historic process. In the introduction to [Filozofia historii polskiej], he wrote:

[...] nie tylko sama historia jest historią, ale i urobione o niej pojęcia. (PWsz VII, 65)

[[...] history alone is not history, but also the established concepts about it.]

This is Norwid's postulate of "od-poznawanie siebie w dziejach" [de-recognising the self in history], similar to Vico's mirror of history ${ }^{29}$ in which man can see the whole of himself. Learning history is thus for Norwid equal to learning human nature, the nature of social man.

29 Cf. S. Krzemień-Ojak, Wstęp to: G. Vico, Nauka Nowa, transl. J. Jakubowicz (Warszawa: PWN, 1966). 
It has already been said that in Norwid's view, nations are the proper environment for human historic activity. Norwid's decisive anti-nationalist attitude must be stressed here. He often opposed national megalomania and the related overglorification of one's own nation. He saw all nations as legitimate members of the whole which he called humanity. That was related to his aversion towards any sort of exclusiveness:

Nie trzeba robić się karykaturą

Twórcy - mniemając o naszym planecie,

Że on wszech-świata środkiem, albo górą;

Gród zaś ojczysty, że - najpierwszym w świecie,

A w grodzie jeszcze, że nad geniusz wszelki -

Sąsiad, z którym się wypienia butelki.

Nie trzeba siebie, wciąż siebie, mieć środkiem,

By mimowiednie, się nie stać wyrodkiem -

(Vade-mecum: LXIX. “Początek broszury politycznej...," PWsz II, 98)

[You need not become a caricature

Of an artist - believing that our planet

Is the centre of the universe, or the summit;

The homeland is the first in the world,

And in this land, over and above all genius -

Is the neighbour with whom one empties the bottle.

You should not have yourself, always yourself, in the centre,

Or you may unwittingly become a degenerate - ]

The manner in which Norwid saw the role of a nation in the history of humanity placed him in polemics against many emigré politicians of his time, especially Mickiewicz and his Messianism. In a letter to Władysław Zamoyski from February 1864, Norwid wrote:

Kto patriotyzm zamieni na wyłączność (qui de patriotisme ne ferait que l’exclusivité), jak to Polacy pojmują, a pojmują jedynie przez prześladowania Mikołaja i przez ucisk cenzury mikołajewskiej, ten musi koniecznie z ojczyzny zrobić sektę i skończyć fanatyzmem!! - oto co sIĘ DZIś DZIEJE! (PWsz IX, 131)

[Whoever turns patriotism into exclusiveness (qui de patriotisme ne ferait que lexclusivite), as Poles understand it, and they understand it only through the persecution of tsar Nikolai and the oppression of his censorship, turns his homeland into a sect and ends up a fanatic!! - that is WHAT Is HAPPENING TODAY!]

In earlier years - the late 1840s and 1850s - he polemicized sharply with Messianic conceptions and stood in opposition to the old and the new emigration. 
In Listy o emigracji (1849), when criticising German historiosophy, he warned:

A mistyczne Polski uważanie ( $w$ niewłaściwym użyciu), lubo rozumowemu samowładztwu najgorliwiej przeciwnie, do tychże dochodzi rezultatów. I dlatego powiadam, że jest błędnie lub niezdrowo użyte - i że nie obowiązuje do niczego. I że jest niewczesne, i że czcze...

Nie idzie o to, ażeby używać pokoju, ale żeby czynić pokój, bo błogosławieni są czyniący...

A zaś czynić nie jest to formalnie przeciw słowu powstawać, ale przeciw rozdarciu i nieharmonii słowa z czynem. Bo słowo, które nic nie czyni, a czyn, co nic nie mówi równa czczość. Takie obie akcje - ruchem tylko.

Owóż, cierpieć na to, aby cierpieć - jest to gorzej poniekąd, aniżeli z krewkości tej człowieczej w zniecierpliwienie jakie popaść!... (PWsz VII, 25)

[And Poland's mystical consideration (improperly applied), though most ardently opposed to reason's autocracy, yields just such results. That is why I say that it is mistakenly or unhealthily used - and that it binds you to nothing. And that it is untimely and idle... It is not about benefitting from peace, but about making peace, for blessed are the peacemakers...

And to make is not to formally go against the word, but against the split and nonharmony of the word and the deed. For a word which does nothing, or a deed which says nothing - are equally idle. Both such actions are mere motions.

And so, to suffer for the sake of suffering - that is nearly worse than to fall from that human impetuousness into some impatience!...]

Already in the first phase of his emigration, the author of the article Rasa, naród, ludzkość, życie [Race, Nation, Humanity, Life] took a completely independent attitude towards the new issues. For a while, he did sympathise with Czartoryski's circle, yet kept his sobriety of judgement. Norwid's critical view on the phenomenon of emigration itself is particularly striking, as stated in a discussion on the situation and demands of the new emigration of late 1840s, to which he himself belonged based on his age and the time of his arrival. His refusal to sanctify an enforced situation can clearly be seen there. Norwid considered emigration an "abnormal" phenomenon; it should be aware of its own abnormality and carry that awareness in itself as a self-contradiction. The third letter on emigration states:

Mówiąc więc o emigracji w ogólności, to jest jako o organie anormalnym - przez nienormalność warunków, w jakich się ten lub ów naród znajduje, wywołanym muszę przyjść do wniosku stanowczego, iż emigracja jako proces musi być przeciwną emigracji i że dopóty nią jest tylko, póki jej jest przeciwną. (PWsz VII, 28-29)

[So, speaking of emigration in general, i.e. as an abnormal body - caused by the abnormality of the conditions in which one nation or another finds itself - I must come to the firm conclusion that emigration as a process must be contrary to emigration, and that it is only emigration as long as it maintains that opposition.] 
That stand was closely connected with Norwid's historiosophic conceptions; he did not mythologise nationality, and considered work on changing social and political attitudes, work on the development of a modern society, despite difficult conditions, to be the main issue and task for an enslaved nation. This adhered to his definition of a nation as a "wewnętrzny pokrewnych ras sojusz" [internal alliance of akin races], so he believed an inner fusion of all strata to be the most urgent task. His programme was a solidarist utopia, but based on a modern understanding of civil duties. In Memoriał o Młodej Emigracji [Memorial on Young Emigration] (1850) he wrote: "Że Ojczyzna jest to wielki - zbiorowy Obowiązek, un devoir collectif..." (PWsz VII, 109) [That the Homeland is a great - collective - Duty, un devoir collectif...], and postulated the establishment of a committee which "każdego przychodzącego na emigrację zobowiąże i wezwie do sprawozdania i udowodnienia prawdą dla prawdy - dla jakich powodów przystępuje do Ciała-Emigracji?..." (PWsz VII, 113) [will oblige and call upon each person joining the emigration to report and prove with the truth for the truth - why he joins the Emigration-Body?...] For him, the appropriate arena of action was the home country. In his view, that was the only field of action with a chance at actual effectiveness. He attributed to the leaders of the post-November ${ }^{30}$ emigration an undue detachment from life, and the creation of one-sidedly spiritualised liberation plans. In accordance with his conviction of the necessity of work in society, he decidedly opposed conspiracy as the main form of activity. He was also critical of those who relied on fortuity - political help from abroad or, in the emigré environment, philanthropy. In an essay in which he gave a polemic reply to the criticism of his Listy o emigracji, he stated, for example:

Bonie od środków do życia, ale od życia środki doń i sposoby bezpośrednio zawisły. [...]

Życie - jest to przytomność, a przytomność - obecność, a obecność jest jawność, z której rośnie su mienie, więc moc, więc krzepkość wielo-woli... - - i to jest wszystko, com powiedział. ( [Odpowiedź krytykom "Listów o emigracji"] [Reply to the Critics of 'Letters on Emigration'], PWsz VII, 39)

[Because it is not on the means to live, but on life that the means and manners to live directly depend. [...]

Life - is consciousness, and consciousness is presence, and presence is the openness, from which conscience grows, and thus power, thus strength of multi-will... - and that is all I have to say.]

30 After the fall of the November Uprising 1830-1831 [translator's note]. 
Norwid was aware of the political distinctness of his generation. ${ }^{31} \mathrm{He}$ also frequently drew arguments in his polemics with the "old" emigration from the area of generational experiences. Interestingly, it was not the events of 1846-1848 but rather work on society's development which he considered a particularly significant achievement. He wrote to Lenartowicz in 1852:

P. Adamowi dawaj wyobrażenie o tym, czego wiedzieć literalnie nie może, a co potrzebne jest. Świadcz o rzeczach, które się robiły od [18]30 roku - co poczynaliśmy, jakie były usługowania nasze $\mathrm{w}$ społeczeństwie litery i co do ludu etc. Jak się duchy usługujące porządkowały w następstwach sprawy, pojęć i osób etc. O tym wszystkim nigdy dość mówić nie można, bo to drabina z zaświata do realności - czynu klamra. (DW X, 420)

[Give Mr. Adam an idea of what he cannot know literally, but what is necessary. Speak of things which have happened since [18]30 - what we did, what our services were to the literary society, and for the common people, etc. How the serving spirits have arranged themselves as a consequence of the matter, notions and people etc. You can never speak too much of all that, because it is a ladder leading from the outer world to reality - the binder of deed.]

Norwid also had a positive conception of the role of emigration, which he saw facing the task of spiritual leadership based on a real analysis of the situation in Poland. He considered action to be in the domain of a well-organised and educated society. Very interesting in that respect is the letter to Józef Bohdan Zaleski from 10 May 1851 (DW X, 331-333). The premise of Norwid's reasoning is the sentence: "Nie ma sił, które by co warte były tam, gdzie nie można dewelopać sił" [There are no powers which would be worth anything there, where you cannot develop power]. Thus, practical conclusions should be drawn from the differences in situation of the emigration and Poland. Norwid believed that if the differences between those two Polish communities were not obliterated, but stressed and enhanced (by emphasising their polarity), it may lead to concessions of the tsar government, which would not understand the relationship between practical activity in Poland and emigré ideological thought. With those concessions, the government would try to deepen the (apparent) opposition. Norwid saw the bipolarity of Poland and the emigration as the dualism of "spirit and body," "the ideal and the practical."

Norwid's theses indirectly polemicize with Mickiewicz, as they are critical of some of Ignacy Domeyko's unspecified advice on emigration issues. In that respect, Domeyko's views were similar to those of Mickiewicz, as proven,

31 Zofia Trojanowicz gives an interesting analysis of Norwid's generational bond in her book Rzecz o młodości Norwida (Poznań, 1968). 
for example, by the fragment of Domeyko's letter to Mickiewicz quoted by Gomulicki in a footnote to the discussed letter by Norwid. ${ }^{32}$ Following his theory of conscious action, activity preceded with cognition, Norwid presents a different view of the matter. He thus writes in that same letter to Józef Bohdan Zaleski:

W miarę więc jakby w Emigracji położyło się krzyczącymi barwy akcent na wiecznym, a w kraju na czasowym - rząd by zrobił koncesje czasowemu, za fragment i odłam, a nie za kategorię tylko tej samej je całości uważając. I tak też się już poczyna robić. Różnice więc te są właśnie całą tajemnicą możebnego niestracenia sił - a siły, które tu się marnują, jak mówi Domejko, są tak, jak mózg np. się marnuje, kiedy dlatego walczy z życiem człowieka (biedząc się), a by to życie godnie zużyć i utrzymać. Jasno więc, zda mi się, widzę, że światłemu człowiekowi takie głupstwo zepsucie tylko społeczeństwa, w jakim żył, natchnąć mogło. (DW X, 333)

[And so, if in Emigration the stress were placed with screaming colours on the eternal, and in Poland on the temporal - the Government would make concessions to the temporal, considering it a fragment and faction, and not a category of that same whole. And it is beginning to happen so. So those differences are the whole secret of the possible non-loss of strength - and the strength which is wasted here, as Domejko says, is such as e.g. when brain is wasted as it fights against man's life (in toil) in order to worthily use and maintain that life. Methinks I see clearly that only such foolishness as the degeneracy of society in which he lives could inspire a sapient man.]

Social enslavement and the abnormal situation of people in society were the source of political enslavement, in Norwid's opinion. He wrote of that in the Epilogue to Promethidion:

Żadne się społeczeństwo nie ostoi i żaden naród nie utrzyma, jak przez pracy harmonię tradycyjną powiązane ze sobą stowo ludu i stowo społeczeństwa $\mathrm{w}$ dwie się strony rozprzęgną. (DW IV, 136)

[No society will survive and no nation will endure if the word of the people and the word of society, linked by the traditional harmony of work, split in two separate ways.]

The criticism of Polish society and its civilizational underdevelopment was a constant topic with Norwid. He cut himself off from Mickiewicz's revolutionary utopia, recognizing the opportunity for changes in reformist activity. When he said of the homeland that it was a "wielki - zbiorowy - Obowiązek" ["great collective - Duty"] in Memoriał o Młodej Emigracji (1850), he meant the need for

32 Cf. C. Norwid, Pisma wybrane, prep. by J. W. Gomulicki, Vol. V (Warszawa: PIW, 1968), p. 166. 
mutual service, consisting of that "obowiązującego Ojczyznę dla człowieka i z obowiązującego człowieka dla Ojczyzny" (PWsz VII, 113) [obliging the Homeland to man and obliging man to the Homeland].

From his ideological and political standpoint, in the late 1840s Norwid made a sharp public protest against Mickiewicz's Skład zasad [A Collection of Principles] (at the meeting in Rome in March 1848). In Mickiewicz's statements he saw a final infringement on the already unstable traditional social structure. According to his solidarist stand, Norwid believed collaboration with the whole society of "obywatele-posiadacze" [owner-citizens] to be one of the aspects of the Homeland's duty towards the citizen. He was convinced that ownership was connected with moral duties (cf. Niewola, 1849, and Pieśni społecznej cztery stron [Social Song in Four Pages], 1848) and it should be the basis for active striving towards raising the individual dignity of all society members. To quote once again Memoriał o Młodej Emigracji:"

Jeżeli właściciele posiadaczami tylko będą, to jest - poza obrębem interesów posiadania - własności-moralnej (to jest przymiotów posiadania) przepomną; jeżeli tej nieśmiertelnej prawdy, około której krążą dziś wszystkie społeczeństwa, nie postarają się wcielić w czyn u siebie - prawdy tej, mówię, że od zwożącego mierzw parobka do pracy człowieka uczonego powinien być cały łańcuch prac coraz to idealniejszych zachowany... to i ich posiadanie (bez własności-moralnych do posiadania przywiązanych) ciężarem się stanie i zawadą $\mathrm{w}$ następstwie rozwijania się społeczeństw. (PWsz VII, 110)

[If the owners are only possessors, meaning that - beyond the range of possession interests - they forget mora 1 -values (i.e. possession attributes); if they do not attempt to turn this immortal truth, around which all societies revolve nowadays, into deed by themselves - the truth, I say, that from a manure-shovelling hand up to the work of a scholar there should be a whole chain of ever more ideal works maintained... then their possession (without the moral-values connected to possession) will be a burden to them and an obstacle as a result of societies' development.]

Norwid's criticism of social structure clearly did not reach its basis, but was limited to social and moral postulates. In that respect, it was the proposition of a utopia on the opposite pole of Mickiewicz's socialist utopia. Another element of that opposition was Norwid's Catholicism; he accused the author of Skład zasad that "w rzeczach Kościoła dąży do najdokładniejszego wyniszczenia dogmatu i rozwolnienia duchowego - a iż tam starszy brat Izrael przeważne miejsce ma zajmować - tedy w ostatecznym skutku (krótko mówiąc) do Synagogi zmierza." (DW X, 143) [in the matters of the Church, he strives for the most diligent destruction of dogma and spiritual dilution - and as older brother Israel is to take an important place there - as a final result (in short) he heads towards the Synagogue.] 
At the same time, Norwid opposed undervaluing the real society in favour of the utopian "promised land." He protested against "abstract idealism" leading to dogmas which he saw in Mickiewicz's manifesto. He stood against "mystic radicalism" and infringing on the duality of the spirit and matter in favour of one-sided spirituality. In the above-quoted letter to Józef Bohdan Zaleski from 24 April 1848, he wrote, for example:

Manifest ten w polskości dąży do zupełnego wyniszczenia tradycyjnej Ojczystości. Ojczyzna jest to miejsce tylko, ale czasu w niej nie ma - jest to tylko miejsce najpróżniejsze - najpiękniejsza arena. I dlatego ziemią nazwana obiecaną, że tam najłatwiej wznieść gmach nowy i nową próbę-społeczeńską - ona jest dlatego tyle drogą, iż niczym jest. Najnierozsądniejszy teoretyk do takiego bluźnierstwa posunąć się jeszcze nie raczył. -

Nie wiem, jak z takimi pojęciami pogodzić znowu żądzę nieuhamowanej praktyczności i czynu, dla którego i przez który Pan Adam doszedł tam, gdzie nienawidzeni przez niego filozofowie przez teorię. (DW X, 144)

[This manifesto in Polishness strives towards the utter destruction of traditional Homeland-ness: the Homeland is only a place, but it holds no time - 'tis only the most empty place - the most beautiful arena. And it is called the promised land for the reason that it is easiest to raise a new edifice and a new societal-attempt there - it is only worth so much in that it is a nothing. The most unreasonable theoretician has not yet dared such blasphemy. -

I know not how to reconcile such beliefs with the lust for unrestrained practicality and deed, for which and through which Mr. Adam arrived at the same point as the philosophers he hates achieved through theory.]

In the letter, Norwid also condemned the similarities of Skład zasad to utopian socialism ("Ale toż samo pojęte jako prawo, jako ukaz-mistyczno-Furierowski, jest niedorzecznością - i jest fałszem, rad bym, żeby nie krwawym!" (DW X, 144) [But that same understood as a law, as a mystic-Fourier-commandment, is nonsense - and it is falsehood, and I do hope not a bloody one!])

The criticism of Mickiewicz's political concepts was related to criticism of Messianism and Towiański's philosophy. It was not only immediate, but mainly, since the very beginning, it occurred on the plane of historiosophy and morality, and also concerned ontological and epistemological issues. Norwid's aversion towards "radical mysticism" and the spiritualism of Towiański's followers is clearly proven by the following comment in a letter to Józef Bohdan Zaleski from 9 February 1848: "Słyszałem o braciszku moim, że się w Duchy zapisał." (DW X, 129) [I have heard my little brother enrolled with the Spirits.] Moving away from reality into mysticism, overemphasising the role of martyrdom, questioning ownership, Pan-Slavism with simultaneous deification of nationality were his fundamental charges against the Messianism of Towiański. He 
wrote of Mickiewicz as Towiański's follower in a letter to Jan Skrzynecki from 15 April 1848:

Trudno zapewne by opisać, jak się tu znalazł, jaką formę względem Kościoła i Polaków ten poeta wielki zająć raczył; dość że (smutno mi wyrzec) znalazłem go albo nałogowo tak już ugrzązłym w tym kierunku radykalizmu mistycznego, że się wydobyć zeń nie może, albo najpotężniejszym oszukańcem, jakiego przykładu dotąd nie ma. Ten człowiek straszny jest dla Polski. (DW X, 140)

[It would be truly difficult to describe how he got there, what form towards the Church and Poland that great poet decided to take. 'Tis enough to say (though with sadness) that I found him either so deeply addicted to that direction of mystic radicalism that he cannot get out of it anymore, or that he is the greatest fraud, the extent of which thus far has no matching example. That man is a fright to Poland.]

Norwid was thus ruthless and almost too strict in his opinions. In the later years, he criticised the myth of Mickiewicz as a national poet with equal intransigence (which will be discussed further along in this paper). And yet despite fundamentally different views on specific issues, he valued the eminent personality in Mickiewicz, close to his own ideal of a "great man."

Considering history the domain of the conscious activity of social man, Norwid allowed for "martyrdom" as a necessary evil at some of its stages. Yet his fundamental postulate towards the historic process was quite the opposite:

Cała tajemnica postępu ludzkości zależy na tym, aby coraz więcej stanowczo, przez wcielanie dobra i rozjaśnianie prawd, broń największa, jedyna, ostateczna, to jest męczeństwo uniepotrzebniało się na ziemi... ("Epilog" of Promethidion, DW IV, 135)

[The whole secret of human progress depends on ensuring that by incarnating goodness and illuminating truths, that greatest, unique, final weapon, that is martyrdom, became more and more firmly unnecessary on earth...]

Norwid's concept of a nation (as characterised above) also placed him opposite Messianism, with its irrational and nearly mystic understanding of nationality. He saw the underdevelopment of the Polish nation (as a society) as compared to stages achieved by other European nations as a serious danger to national existence. He postulated the need to follow the civilizational development of other countries ${ }^{33}$ and to understand the right historic time, and consequently, to choose the right behaviour model. How foreign were to him the words from

33 Cf. Z. Stefanowska, "Norwid - pisarz wieku kupieckiego i przemysłowego," in: Literatura, komparatystyka, folklor. Ksiega poświęcona Julianowi Krzyżanowskiemu, ed. M. Bokszczanin, S. Frybes and E. Jankowski (Warszawa: PIW, 1968). 
Ksiegi narodu i pielgrzymstwa (VI) [The Books of the Polish People and of the Polish Pilgrimage]:

Zaprawdę powiadam wam: nie wy macie uczyć się Cywilizacji od cudzoziemców, ale macie uczyć ich prawdziwej cywilizacji chrześcijańskiej. ${ }^{34}$

[Truly, this I tell you: it is not you who should learn Civilisation from foreigners, but you are to teach them true Christian civilisation.]

Or those:

Nie wszyscy jesteście równie dobrzy, ale gorszy z was lepszy jest, niż dobry cudzoziemiec; bo każdy z was ma ducha poświęcenia się. ${ }^{35}$

[You are not all equally good, but any of you who is worse is still better than a good foreigner; for every one of you has the spirit of sacrifice.]

Contrary to Mickiewicz's advice not to look only for mistakes and sins in the past, Norwid considered activity based on the awareness of past mistakes to be the most effective means of renewal. Historiosophic interests provided him with materials and reflections which could bear contemporary results. For him, history was often a costume for thought on contemporary matters. He saw the Messianists' mythologization of nationality done as the main barrier on the way to freedom:

Oni kochają Polskę jak Pana Boga, i dlatego zbawić jej nie mogą, bo cóż Panu Bogu pomożesz? (DW XI, 42)

[They love Poland like the Lord, and so they cannot redeem it, for how can you help the Lord?]

One of the fundamental motifs of Norwid's criticism of Polish society and the historical situation conditioned, among others, by the state of that society, was complaining against one-sided practicism, the hasty tendency towards ill-considered (in Norwid's view) deeds, especially armed action. He stood against vain bloodshed and the readiness to make "z pokolen ofiary" [a sacrifice of generations]. He saw the reason for the futility of Polish uprisings mainly in an insufficiently considered programme (which should come from emigration, according to his postulates, and which he himself tried to outline during the January Uprising of 1863-1864). That insufficiency was caused by the lack of

34 A. Mickiewicz, Dzieła poetyckie, edition and explanations by T. Pini (Nowogródek: Nakł. Komitetu Mickiewiczowskiego, 1933), p. 226.

35 Mickiewicz, Dzieła poetyckie, p. 227. 
such intelligentsia in Poland who could have real impact on political activity. In January 1865, he wrote in a letter to Marian Sokołowski:

Powiedz ode mnie, komu chcesz, że (fa nfaron) C.N. mówi, iż nic nie będzie poczciwego w narodzie, w którym Energia jest 100, a Inteligencja jest 3 - albowiem tam zawsze pierwsza, uprzedzi drugą, i wyskoczy, i zdradzi wszelki plan, i uniemożebni go, i będzie tylko co kilkanaście lat rzeź, rzeź niewiniąt jednego pokolenia.[...] [...]

Trzeba 80 drukarni - 20 dzienników różnej treści - 15 towarzystw uczonych i pracy w pocie czoła, natężonej stale i uważnie.

Na to zaraz odpowiedź Melancholii, ale nie tej, którą Albrecht Dürer silną zarysował ręką, jeno Melancholii z fletem w ręku i włosem plugawie nie uczesanym, która Ci rzecze (na nutę piosnki Kalinowej lub Aldony):

Gdzież rozwinąć te prace - gdzie?

Kiedy my nie mamy piędzi ziemi?

etc... etc... (PWsz IX, 154)

[Tell anyone you wish from me that (the buffoon) C.N. says that nothing decent will come in a nation where Energy is 100 , and Intelligence is 3 - for always the former will beat the latter, and jump out, and betray any plan, and make it impossible, and every dozen years there will only be slaughter, slaughter of the innocents of one generation. $[\ldots]$

$[\ldots]$

We need 80 printing houses -20 journals of various content - 15 scientific associations and work by the sweat of your brow, constantly and carefully intensive.

To that we have the immediate answer of Melancholia, but not the one sketched by Albrecht Dürer's strong hand, but the Melancholia with a flute in her hand and her hair foul and unkempt, who tells you (to the melody of Kalina's or Aldona's song):

Where to develop that work - where?

If we have not even a span of land?

etc... etc...]

The polemic allusion to Mickiewicz is quite striking (as a matter of fact, Aldona often met the ironic tongue of Norwid, criticised for "unreality"). Norwid assigned the inability to control the crises of Polish society to Romantic ideology. Neither did he see positives in the changes started in Poland in the 1860s. Throughout his life, he saw no possibility for the modern implementation of his historiosophic idea connected with the conviction that only a man of complete personality was a conscious creator of history. Yet he did not give up political reflection, which was a mixture of realism and utopia with him. He wrote of the situation to Jan Koźmian as early as in in 1850:

Błogosławiony to czas, kiedy człowiek stać się cegiełka może - to jest, kiedy plan i ogół jest. Inaczej - do czegóż dołożyć tę cegiełkę? Zawsze to będzie kupa cegieł. (DW X, 226) 
[Blessed is the time when a man can become a brick - that is, when there is a plan and a whole.

Otherwise - where to put this brick? There will always be a pile of bricks.]

\section{Aesthetic Utopia}

The first part of the considerations on Norwid contained herein focused on the poet's views on the nature of truth and on his chosen manner of cognition through approximation. Norwid considered the parable to be one of the most universal forms of cognition. And the parable shifts these considerations into the sphere of art.

For Norwid, art was, more than anything, the domain of truth. Expressing the truth, revealing the process of achieving it, was the artist's main task in his view. It was in a work of art that the temporary integration of two worlds: the material and the ideal, was possible. Thanks to its properties of a pictorial presentation, still rooted in the grounds of an intellectual insight into the world, a work of art had the greatest chance to grasp the truth - the approximate truth about reality. That is the motif of the poem "Lapidaria" (1876):

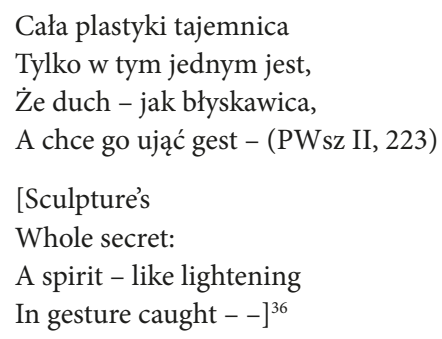

In 1844, the poet already expressed (in a letter to Antoni Zaleski from 2nd November; DW X, 41) his conviction that reality was art's proper object. Specifically, he was praising Fedi's statue of Sebastian, which he saw in Florence, as he noticed therein "to uczucie rzeczywiste, które prawdziwą jest poezją, bo ani marzeń (jako słabych i nie ujętych, nikłych), ani też rzeczowości (jako nazbyt cielesnej), ale prawdziwą rzeczywistość za rzecz sztuki uważam" [that real emotion which is true poetry, for I consider not dreams (as they are weak and uncapturable, fleeting) nor concreteness (which is too carnal) but true reality to be the object of art]. Here, "reality" with the attributive "true" means a dualistically understood entity. The need for the intellectual element to be present in a work

36 English translation by Adam Czerniawski in: Cyprian Kamil Norwid, Selected Poems, (London: Anvill Press, 2004) p. 87. 
of art is mentioned at the very beginning of the dialogue in Promethidion (1851), in polemics against "melancholia romantyczno-mglista" [romantically hazy melancholy] and the naturalist "udanie" [imitation].

Lecz ja bym główniej myśl artysty badał

I czy dosłownie Naród on spowiadał,

Czy się nie wstydził prawdy i nie stłumił,

Mogąc łatwiejszy oklask zyskać sobie,

Mogąc być prędzej i szerzej uznanym;

Czy, mówię, prawdę na swym stawiał grobie,

Czy się jej grobem podpierał ciosanym? (DW IV, 103)

[I would still rather examine an artist's thought,

I'd prefer to ask whether he spoke the whole truth of his nation,

Whether he was able to make a complete confession within his form of creation,

Or whether he was ashamed of the truth's vulgarity

So that he had to stifle it to get quick popularity

Whether he buried truth or the truth buried him $]^{37}$

Norwid considered the need to strive to express the "whole truth" in art to be the moral duty of the artist, who often paid for it with conflict with the recipient, "urągowisko albo zapomnienie" [mockery or oblivion]. That need connected the attitude of an artist aware of his tasks with heroism, enforced by a public unprepared to receive art thus understood:

Lecz - skoro kłamstwo zdradzisz kłamstwem sztuki,

Bądź wpierw pod lauru szerokiego cieniem,

Gdzie donieść krzywe nie potrafią łuki

Urągowiskiem albo zapomnieniem...

Aż inny, ówdzie, gdzie upadną strzały,

Przyjdzie je zebrać, jak Ty zbierasz cudze,

I wspomni Ciebie, łatwiej-doskonały,

I powiesz: „Prawda!..” - a ja się obudzę... (PWsz I, 268-269)

[But - when you betray a lie with the lie of art,

First be under the broad shadow of laurel,

Where crooked bows cannot reach

With mockery or oblivion...

Until another, somewhere, where the arrows fall,

Comes to collect them, like you collect someone else's:

And remembers you, perfect-more-easily.

And you'll say: “True!.." - and I will wake...]

37 English translation by Jerzy Peterkiewicz and Burns Singer, in: Five Centuries of Polish Poetry (London: Secker \& Warburg, 1960), p. 78. 
- he wrote in the poem "Do Nikodema Biernackiego" (1857). The words contain an obvious allusion to the author's personal life.

One of the programme works on the relation of art to its object is the poem "Ogólniki" ["Generalities"], serving "as the introduction" to the Vade-mecum cycle. It is both Norwid's poetic credo (the need to strive to present reality in the most adequate manner possible) and multi-layered irony conveying the bitter conviction that society demands only such poetry which would not go beyond the commonly accepted and conventionalised platitudes. Norwid did not wish to make any concessions for immature audiences. That view on aesthetics contains a conscious criticism of the Romantic convention. The poet saw its continuation in the late 19th century, inevitably in epigonic form, as idle and outright harmful for the development of Polish art. He saw Romantic poetry as yielding to easy solutions, pursuing showiness and disregarding the main problem of the contemporary time - work on the moral change of society. Those issues take up much space in his poetic works and are also a constant motif in his correspondence. In the foreword to the programme lyrical cycle Vade-mecum, Norwid stressed (in the 1860s) the need for Polish poetry to take a radical turn - from immediate political issues and one-sided patriotism towards moral and social matters. He did appreciate the momentous role played by the poetry of the three Polish bards at its proper time, which was already in the past. What he saw differently were the tasks in the new historic period.

Norwid's aesthetic programme was not limited to the art of the word. Quite contrarily, the concern for art in general is exceptionally present in his work. The scope of artistic activities considered in the fundamental reflections on the role of art in human life and in history is thus far broader with Norwid than it was with Mickiewicz. When Mickiewicz wrote the following words in Pieśń Wajdeloty [Song of Wajdelota] about folk poetry:

O wieści gminna, ty arko przymierza

Między dawnemi i młodszemi laty ${ }^{38}$

[Oh folk tradition, you ark of covenant

Between the distant and younger years]

Norwid assigned a similar integrative function to art as such:

O! sztuko - Wiecznej tęczo Jeruzalem,

Tyś jest przymierza łukiem - po potopach

Historii - tobie, gdy ofiary palem,

Wraz się jagnięta pasą na okopach... ${ }^{39}$

38 A. Mickiewicz, Konrad Wallenrod.

39 Wstęp [Introduction] to Promethidion, v. 11-14, DW IV, 95-96. 
[Oh, art - the Eternal rainbow of,Jerusalem

You are the bow of covenant - after the floods

Of History - when we burn offerings to you

Lambs are grazing in the trenches...]

For him, art as a general category was the bearer of models.

The 1850s saw Norwid's most important texts concerning the place of art in society, and in particular in Polish society. Those are Promethidion (1851) - two dialogues on art and truth and the programme Epilog [Epilogue] in prose; the polemic essay O sztuce (dla Polaków) [On Art (for Poles)] (1858), arguing against Julian Klaczka; and a fragment related to Promethidion, titled Sztuka w obliczu dziejów jako Syntetyki ksiega pierwsza [Art in the Face of History as Synthetics Part One] (1850), published posthumously only in 1956.

In Promethidion, which is a dialogue-poem, or a conversation-poem, Norwid placed aesthetic considerations on a historiosophic plane. He presented art connected with work as the territory for integrating material and ideal elements, life and theory. The categories of beauty, truth and goodness met in the concept of creative work whose crown achievement was art. Thus understood, art became a mediatory ground between "song" and "practicality," between heaven and earth, between mental work and physical work. It facilitated the integration of general human culture by grace of the presence of universal elements in national culture. Art as a stimulus for creative work increases the value of human activity in history, and reintegrates the complete personality, symbolised in the poem by the character of Prometej-Adam.

The issue of work-art is developed in two directions in Promethidion. On the one hand, this is utopian reflection on expiatory work-art. The poet transfers art as "najwyższe z rzemiosł apostoła/I jak najniżsa modlitwe anioła" [the highest of an apostle's crafts/And as the lowest prayer of an angel] (Bogumit, w. 336-337) to the sphere of eschatologically understood history. Its tasks are as follows:

Bo nie jest światło, by pod korcem stało,

Ani sól ziemi do przypraw kuchennych,

Bo piękno na to jest, by zachwycało

Do pracy - praca, by się zmartwychwstało. (DW IV, 108)

[For light is not to be kept under a bushel,

Neither is the salt of the earth a kitchen spice,

For beauty is there to inspire

To work - and work to be resurrected.]

Yet, the most valuable reflections in Promethidion concern practical issues, crucial for Polish society. Norwid related the concept of work-art to the notion of its 
utility. He wanted everyday objects to also have an aesthetic value, and for work to transform from arduous toil into joy, thanks to a communion with nature. This was supposed to bring about a specific synthesis of art with life, combining aesthetic categories with social ones. Moral criteria would then partake in the evaluation of art.

Norwid treated art as a definitively superior and autonomous value, free from direct didacticism and from the temptation of formalist abstracts. So despite the apparent utilitarianism, despite the subordination of art to practical aims and tasks, within the Romantic utopia it appeared as a power capable of evoking changes in the meta-aesthetic sphere. In his later works, the poet would stress the priestly character of art even more strongly. The ministry of an artist - the mediating function - is one of the motifs of Rzecz o wolności słowa or the lectures O Juliuszu Słowackim.

Against the backdrop of thus understood objectives of art, Norwid's basic requirement was an active, co-creative attitude of the recipient towards the work. Whether that cooperation was successful depended both on how the artist had shaped the work and on the audience's preparation and good will. Convinced of the immaturity of the Polish audience as compared to such reception, he considered the educational function to be one of the tasks of art.

Norwid found folk art, combining "song" and "practicality," to be the sphere best prepared to perform those varied tasks:

I stąd największym prosty lud poetą,

Co nuci z dłońmi ziemią brązowemi,

A wieszcz periodem pieśni i profetą

Odlatującym z pieśniami od ziemi. (DW IV, 109)

[And hence simple folk is the greatest poet,

Who hums with hands browned by soil,

And the bard is the meter of the song and a prophet

Flying away from earth with his songs.]

Thus in his Polish national art development projects, the author of Promethidion reached for folk sources. He attributed the fact that no fully fledged national style had been developed yet, to abnormal social relations. The national art developing in the future was to become, in his view, a factor of the inner integration of society, and even one of the main stimulators of change.

The concept of national art growing from and generalising folklore, and thus not limited to national particularism, was one of the most significant elements of Norwid's aesthetic programme, linked at the same time to his social programme. The concept contained evaluation criteria for the aesthetic 
realisations contemporary to him. So he viewed Chopin as a truly national artist, and Mickiewicz as a writer who definitely did not deserve the "national" epithet. In the Epilogue to Promethidion, he thus wrote of Chopin:

Podnoszenie ludowych natchnień do potęgi przenikającej i ogarniającej Ludzkość całą - podnoszenie ludowego do Ludzkości nie przez stosowanie zewnętrzne i koncesje formalne, ale przez wewnętrzny rozwój dojrzałości... oto jest, co wysłuchać daje się z Muzy Fryderyka jako zaśpiew na sztukę narodową. (DW IV, 133)

[Elevating folk inspirations to a power permeating and encompassing all of humanity elevating folklore to Humanity not through its external use and formal concessions, but through the internal development of maturity... that is what you can hear in Frederic's Muse as a melody of national art.]

About Mickiewicz, in turn, one reads in the letter to Marian Sokołowski from 6 February 1864:

[...] można - zdaje mi się - ze stanu Inteligencji polskiej wnosić, co następuje:

W sensie swoim krytycznym np. Polacy są głęboko (!) przekonani, że ś.p. Adam Mickiewicz był narodowym-poetą - niestety, wcale tak nie było, a pochodzi to z przyczyny zupełnej nieświadomości tego, co jest narodowość. Mała rzecz!! mała!! Otóż, kto się tak mógł pomylić na najsłynniejszym ze swych autorów, cóż chcesz, aby w rzeczywistości narodowej począć był na siłach?...

Narodowy autor jest ten, w którego utworach naród jego zajmuje ten udział i tę część, jaką tenże naród zajmuje w dziejów-ludzkości rozwoju. To, co robił Adam Mickiewicz, i z czego cała Polska nie posiadała się i nie posiada ... c'est tout bonnement de l'exclusivité, mais ce n'est pas de la nationalité. Genialny ten poeta był wyłączny, nie narodowy -- dlatego ślicznie on pomyślił swój wstęp, kiedy powiada: „Litwo, ojczyzno ...” - tj. prowincjo! tj. wyłączności! Sam najlepiej to orzekł byl." (PW IX, 128 f)

[[...] one may - I believe - conclude from the condition of Polish Intelligentsia, the following:

In their critical sense e.g. Poles are deeply (!) convinced that the late Adam Mickiewicz was a national-poet - however, that was not so, and this comes from the utter unawareness of what nationality is. A small thing!! small!! So what can you expect those who could be so mistaken about the most famous of their authors, to achieve in national reality?... A national author is the one in whose works his nation takes the share and the part which that nation takes in the development of human-history. What Adam Mickiewicz did, and what all of Poland rejoiced and still rejoices in... c'est tout bonnement de l'exclusivité, mais ce nest pas de la nationalité. That brilliant poet was exclusive, not national - hence his beautifully thought out introduction: "Lithuania, my homeland..." - i.e. province! i.e. exclusiveness! He said it best himself."]

Fighting what Norwid called the myth of Mickiewicz - a fight which had some exaggerations and misunderstandings - was a life-long obsession of the author 
of the lectures on Słowacki. This can be seen in the letter to Józef Bohdan Zaleski from 5 December 1882, where Norwid wrote, for example, about the attitude of Mickiewicz's son, Władysław, towards his father's heritage, and in the letter to Ludwik Nabielak, written around 5 December 1882:

nie zostanie ze śp. Adama ani poety, ani pisarza - tylko fenomen (Mit), rzecz niebezpieczna dla człowieka, bo fenomena pokazują na jarmarkach. ${ }^{40}$

[neither poet nor writer will remain of the late Adam - only a phenomenon (Myth), a dangerous thing for a man, as phenomena are exhibited on market squares.]

However, the above never stopped Norwid from valuing Mickiewicz highly as a person and as a poet. This issue deserves a closer look, however, that would exceed the framework of this study.

The thesis of art's folk origins was connected to the conviction that art was related to mythical imagination. Similarly to Vico (and Libelt in Poland), Norwid believed that "lud myśli postaciami" [folk thinks in images/figures], and so the basic means of expression in folk thought is the parable. He also considered that feature to be characteristic of the oldest historic eras. At the primitive stage of human development, and now among folk, poetic truth played an important cognitive function, according to Norwid. Hence the historiogenic role of poetry in the poet's interpretation. Norwid was convinced that since the earliest stages of the development of humankind, there had been poets and philosophers, co-existing (while Vico saw them come in succession). According to the religious concept of the origin of art when the artist expressed divine truth, mediating between two worlds - Norwid did not acknowledge evolution in that scope. In Rzecz o wolności stowa, where history is presented as the history of the realisation of the word (the Revealed Word), 'poezja jest inicjacją, gdyż słowo zanim stało się narzędziem, było celem.' [poetry is initiation, because before becoming a tool, the word was first the goal.]

Striving to solve the complex problems of contemporary Polish society, Norwid created an aesthetic utopia. Elements thereof are found in numerous of his works, but it is probably expressed most fully in "Fortepian Szopena" ["Chopin's Grand Piano"], a poem from the Vade-mecum cycle.

In the Epilogue to Promethidion, Norwid expressed the thought that "Narodowy artysta organizuje wyobraźnię jak na przykład polityk narodowy organizuje sity stanu..." [A national artist organises imagination as e.g. a national politician organises powers of the state...] "Fortepian Szopena," dedicated to the memory of such a national artist (in the sense suggested by Norwid), provides

40 Both references from PWsz X, 193. 
a vision of a nation of the future, morally transformed thanks to the mediation of art, which - as the synthesis of beauty and truth into goodness - should lead to change:

I była w tym Polska, od zenitu

Wszechdoskonałości dziejów

Wzięta, tęczą zachwytu --

Polska - przemienionych kołodziejów! (PWsz II, 465)

[And in this was Poland - from its zenith

Through Ages' all-perfection,

Captured in songs of rapture -

- That Poland - of wheelwrights transfigured into kings! $]^{41}$

"Wheelwrights transfigured" - thus a society free from class conflicts, built on the cooperation of all strata, based on the folk element which thanks to the liberating power of work-art had become a truly creative factor in history. The idea is to a large extent reminiscent of Cieszkowski's ideas from Prolegomena do historiozofii [Prolegomena to Historiosophy], yet is, in fact, quite different. ${ }^{42}$ The change was not supposed to occur within historiosophic theodicy (Norwid did not create one, as opposed to Cieszkowski) but the future should partially be realised already in the present. That realisation was, however, foiled with the immaturity of the contemporaries. Here the cycle of utopia closed. Yet hope for the future remained, and the author of "Fortepian Szopena" did not intend to give up on it. He found premises for that future in the contemporary times, even in his own defeats:

Lecz Ty - lecz ja? - uderzmy w sądne pienie,

Nawołując: „Ciesz się, późny wnuku!...

Jękły - głuche kamienie:

Ideał - sięgnął bruku - - “(PWsz II, 147)

41 English translation by Danuta Borchardt in collaboration with Agata Brajerska-Mazur, in: Cyprian Norwid, Poems (New York: Archipelago Books, 2011), p. 73.

42 Cf. A. Cieszkowski, Prolegomena do historiozofii (Poznań, 1908), p. 578: “Tak skupia się w sobie organicznie duch świata, przez urzeczywistnienie w Czynie Piękna, Prawdy i Dobra i rozwija się ze siebie konkretnie w uczłonkowany całokształt rzeczywistych Instytucji. [...] A tak owe trzy najwyższe predykaty Absolutu mają stać się udziałem życia ludzkości [...] najwyższym ducha przemienieniem." [Thus the spirit of the world concentrates in itself organically, through realisation in the Deed of Beauty, Truth and Goodness, and develops from itself specifically into a membered entirety of real Institutions. [...] and so those three highest predicates of the Absolute are to become part of human life [...] the highest transfiguration of the spirit.] 
[But You? - but I? - let's break into judgement chant, And exhort: "Rejoice, our grandson yet to come!...

The dull stones groaned:

The Ideal - has reached the street - - "] ${ }^{43}$

\section{Man and Nature}

Speaking of Norwid's philosophy of man, one cannot ignore his reflection on man's place in the world of nature. A stand in this matter was particularly important in the era of increasingly intense disputes over natural evolutionism, and in particular discussions about Darwinism. At the same time, it clearly demonstrated his attitude with regard to positivist philosophy, naturalism and materialism. With Norwid, criticism of evolutionism (and in particular Darwinism) - in the sociological context - was related to a harsh criticism of modern civilization. His view of man and nature also contained significant polemic accents towards the worldview of the Romantics, who leaned towards pantheism.

Man, a divine and at first perfect creature, driven out of paradise because of his desire for unlimited knowledge, and thus stigmatized by original sin, was of interest to Norwid as a social being, who in the eternal pursuit of the lost ideal realised his personality through creative work, art and history. Universal categories, common to the whole species, are (according to Norwid) firstly moral values, which prove that "niżeli środki, wprzód istniały cele!" (DW IV, 223) [before means, there were ends first!] The finalist concept of man as the incarnation of moral values was to the author of Rzecz o wolności słowa tantamount to his fundamental separateness from the animal world or, in general, from the world of nature. The vision of genesic transformations of the spirit, as presented by Słowacki the mystic, was not the vision of Norwid. The author of the lectures O Juliuszu Stowackim certainly did not share the basic idea of Genezis $z$ ducha [Genesis from the Spirit] (a work still in manuscript form at the time):

Albowiem na tych słowach, iż wszystko przez Ducha i dla Ducha stworzone jest, a nic dla cielesnego celu nie istnieje... stanie ugruntowana przyszła wiedza święta Narodu mojego... a w jedności wiedzy pocznie się jedność uczucia... i widzenie ofiar, które do ostatecznych celów przez ducha świętej ojczyzny prowadzą ${ }^{44}$.

[for on those words that everything has been created through the Spirit and for the Spirit, and nothing exists for the carnal aim... will stand firm the

43 English translation by Borchardt, Poems, p. 77.

44 J. Słowacki, Genezis $z$ Ducha, in: the same author,Dzieła, ed. W. Floryan, Vol. XII (Wrocław: Zakład Narodowy im. Ossolińskich, 1959), p. 31. 
future holy knowledge of my Nation... and in the unity of knowledge the unity of emotion will be conceived... and seeing the sacrifices which lead to the final aims through the spirit of the holy homeland.]

Norwid's position on this matter appears obvious when you recall his critical attitude towards the spiritualist monism of Towiański followers, which was both a defence against heterodoxy and a protest against national Messianism.

In Norwid's religious worldview, God was at the same time the direct Creator and Providence; thus both deism (of many evolutionists, including even Charles Darwin) and genesic mysticism had to be foreign to the author of Ostatnia $z$ bajek. Neither did he take a clear position in the dispute between Romantic mysticism and Enlightenment rationalism. Quite unlike Słowacki, of whom Stefania Skwarczyńska writes in her dissertation Struktura rodzajowa Genezis z Ducha:

God [for Słowacki - E. F.] may not be a direct Creator, but he is Providence. With that stance, Słowacki positioned himself on the antipodes of 18th-century deism, which had God as the Creator, but not as Providence. The consequence of that difference is the mystical tone of Genezis $z$ Ducha, fundamentally different from the rationalist hue of some of the 18th-century poems on nature, a subject familiar to him and based on evolutionism. ${ }^{45}$

As a creationist and fundamental opponent of the idea of transformism, Norwid did accept the connection between man and nature in the sphere of prayer, which in this case was related to the hymn of creation. ${ }^{46}$ It is significant that the said connection with nature took place within poetry - understood in a typically Romantic fashion in terms of the attitude of the lyrical "I," though in conscious opposition to the three Polish bards. That thought is found in the final fragments of the poem "Do Walentego Pomiana Z.", included as Epilog in the Vade-mecum cycle:

Tak, mówię Ci, że skoro istota Poety

Zebrać u piersi swoich nie umie planety

Całego chóru ludzkich współ-łez i współ-jęków,

Od ziemi do macicy tej najwyższych sęków,

Od karła do olbrzyma, od tego, co kona,

Do tego, co zawisnąć ma jutro u łona,

Zaiste, niech mię taki nie uczy, co? jasne,

A co ciemne?- on ledwo że wie, co przyjemne!

Bo jam nie deptał wszystkich mędrców i proroków,

45 Skwarczyńska, "Struktura rodzajowa Genezis z Ducha," p. 232.

46 Skwarczyńska, "Struktura rodzajowa Genezis z Ducha," p. 236, where the author writes of "a group of hymns which could be termed hymns of creation." 
Ale mię huśtał wicher, ssałem u obłoków

I czułem prochów atom na twarzy upadłéj.

Sfinksy znam, czerwieniły się skąd? czemu bladły?

Boga? - że znikający nam przez doskonałość

Nie widziałem, zaprawdę, jak widzi się całość,

Alem był na przedmieściach w Jego Jeruzalem:

W wodzie obłoków krzyżem pławiąc się czerwonym,

Zwierzo-krzewowe psalmy mówiłem z koralem,

Z delfinem - pacierz, z orłem? -glorię - uskrzydlonym... (PWsz II, 157-158)

[Yes, I tell you, that if the Poet's essence

Cannot collect at its chest the planet

Of the whole choir of human co-tears and co-wails,

From the ground to the matrix,

From a midget to a giant, from the dying one

To the one who is to rest at the bosom tomorrow,

Truly, such a man shall not teach me, what is? clear,

And what is obscure?- he barely knows what's pleasant!

I have not treaded upon all wise men and prophets,

But I was rocked by the wind, breastfed by clouds

And I felt the atom of dust on my fallen face.

I know sphynxes, why they blushed? why they paled?

God? - disappearing from us through perfection

I have not seen, truly, in the way you see the whole,

But I was at the outskirts of His Jerusalem:

Like a red cross soaking in the water of the clouds,

I recited animal-shrub psalms with a coral,

Rosary - with the dolphin, with the winged eagle? - glory...]

Neither was Norwid a follower of Schelling's pantheism, according to which all nature, including man, was subordinated to the soul of the world. Assuming a duality between man and the rest of the world, Norwid saw the kinship of man and nature only on a parabolic level. In the dual image of the world, material reality acquired symbolic meanings to him.

It seems that a certain developmental line can be observed - not so much in Norwid's views on evolution, as those were always critical, but in his approach to those issues. In the poet's early work, through the $1850 \mathrm{~s}$, he did not consider those matters at all. That is perfectly understandable due to the aforementioned indifference of the author of Promethidion to the genesic concepts inspired by 18th-century pre-evolutionism. Following Plato and Aristotle, he believed that existence had unchanging, eternal forms. Progressivistically understood evolutionism following spiritualist monism was just as foreign to him as transformationism based on causal and natural grounds (like Lamarck's 
or Geoffroy St. Hilaire's). In the later years, there are several references to Linnaeus to be found in Norwid's works, which shows that he shared the view of that scholar, who was convinced that God simultaneously created all species of the plant and animal world. As a matter of fact, it was Linnaeus who placed man and apes in the same order of primates, but he kept emphasising the artificiality of this classification which according to him was not meant to indicate actual kinship. Interestingly, some views common to the philosophers and scholars of the 18th century can often be found with Norwid (mainly, Vico and Linnaeus).

In the 1830s and 1840s, the ideas of the catastrophist and creationist Georges Cuvier, winner of the memorable scientific dispute with Geoffroy St. Hilaire in February 1830, triumphed unquestionably. Evolutionary thought in natural sciences was in a critical situation - especially considering the fact that the concepts of St. Hilaire were poorly documented and quite simplified. ${ }^{47}$ Perhaps it is the arguments of Cuvier in this dispute, among others, that Norwid meant in his frequently stated opinion about the vagueness and immaturity of evolutionary ideas and their illusory nature.

When Charles Darwin's work On the Origin of Species was published in 1859 in England, and soon translated into foreign languages (including French), natural evolutionism took new paths, mainly due to the widely documented scientific reasoning method. Darwin's introduction of regressive processes ${ }^{48}$ into the set of concepts on evolution modified the previous, strictly progressive approach to the issues of transformism. That is not to say that evolution was no longer associated with progress, since that association was the foundation of positivist philosophy. The transfer of natural evolutionism concepts to the area of social phenomena become particularly popular as early as in the 1860s, mainly thanks to Herbert Spencer's universalist system. His basic idea, covering all branches of knowledge, was the idea of development. Full of admiration for Darwin, the author of A System of Synthetic Philosophy contributed to his fame:

47 On Cuvier's conflict with St Hilaire cf. e.g., J. Tur, Stulecie historycznego sporu: Et. Geoffroy St. Hilaire - Cuvier. Odczyt wygłoszony na posiedzeniu Warszawskiego Oddziału Towarzystwa Anatomiczno-Zoologicznego dn. 19 lutego 1930 r. (Lwów, 1931).

48 On the significance of the term "regressive processes" for the history of evolutionary thought cf. the comment in chapter V of S. Skwarczyńska, Wstęp do nauki o literaturze, Vol. III (Warszawa: PAX, 1965). 
Darwin influenced Spencer's theory, but also Spencer influenced the fate of Darwin's theory, which spread the most in Spencer's terminology: Darwin originally did not use the word "evolution," which was introduced by Spencer and only later applied to Darwin's theory. ${ }^{49}$

Thus, it was no longer the spiritualistic monism of the Romantics but the naturalist monism of the late 19th century which Norwid saw as the worldview and system to be opposed. In the late 1870s, he expressed it with the title of the poem: "Naturalizm (spółczesny ekstrem)" ["Naturalism (Modern Extremum)"]. Norwid must have been repelled by Spencer's naturalist, hedonist ethics, and by the naturalist relativism of Karl Vogt and Ludwig Buchner, materialists and naturalists. Materialists presented their views in the 1850s; the 1860s began with Darwin and Spencer. One of the greatest scientific and philosophical discussions of the 19th century flared up - a debate on evolution. In the late 1960s, it began to occupy more and more space in the pages of the Polish press, especially in Warsaw. ${ }^{50}$

It has already been mentioned that the human and the animal world were related in Norwid's view by parabolic affinity, purely external and only apparent analogies, interpreted on a symbolic plane. That parabolic nature had its roots mainly in the Bible, in the realm of religious thought. It would seem that the poem "Waga" ["Scales"] from 1860 may be considered Norwid's earliest work which contains indirect but clear polemics with natural evolutionism and its most shocking (to opponents) theorem about man originating from the animal world through its gradual improvement (that was the early, typically progressivist evolutionism). Addressed to an outstanding zoologist and teacher (he taught young Norwid in secondary school in Warsaw), Antoni Waga, the poem used to be interpreted as a hermetic poem concerning moral and patriotic issues. ${ }^{51}$ Not denying the presence of those two basic topics in the work, it may still be surmised that it actually opposes the concept of the evolutionary origin of man from the said moral stand. At the very beginning, the poem emphasizes the idea that only a person such as the addressee of the poem is allowed to descend to the animal world, down "to the littlest worm" - after all, man gained a complete personality through his actions and long, worthy life. The said "worm" decidedly

49 W. Tatarkiewicz, Historia filozofii, Vol. III (Warszawa: PWN, 1958), p. 97.

50 On Darwinism's reception in Poland cf. J. Feliksiakowa, "Bibliografia dzieł Darwina w języku polskim oraz wybór opracowań z zakresu darwinizmu,” Biologia w Szkole, No. 6 (1958), and "Dalsze opracowanie...," Biologia w Szkole, Nos. 2, 3, 4 (1960).

51 J. W. Gomulicki’s comment in C. Norwid, Dzieła zebrane, ed. J.W. Gomulicki, vol. II (Warszawa: PIW, 1966), p. 584-587. 
refers to the researcher's scientific interests, yet it seems that more meanings may be involved. The word "he," highlighted by Norwid in the poem, serves as a means of opposition or polemics: "wolno mu" [he is allowed] may mean: who is not? Perhaps it holds the following thought: a man lowering himself to the simplest of creatures is actually not allowed, and only those who are fully aware of the real place of nature in God's plan and in the moral plan - those who have an understanding of the truths present in the Bible - acquire the right to reflect on nature. At the end of the poem, symbolic (parabolic!) animals of the Apocalypse appear, symbols of the evangelists. It is thus only at that parabolic level that the lion, eagle, ox, and man can occur together. Below the poem "Waga" (1860):

Wolno $\mathrm{mu}$ jest - aż do robaczka

Schylać się, będąc człowiekiem:

Bo schodził o n pierw do prostaczka,

$\mathrm{Na}$ równi będąc $\mathrm{z}$ swym wiekiem!

I jednym był - wśród wielu - wielu -

Nad pokoleniem włodarzy,

Co gwiazdę czcił pokoleń-celu

I błysk jej - na dzieciąt twarzy.

Dlatego lew, orzeł, wół i człek

Wspomną w nim - uprzedziciela:

Będzie jak Jan... (pustynią jest wiek

Oczekujący Zbawiciela!) (PWsz I, 328)

[He is allowed - to bow down to the tiniest worm

Being a man:

For he first descended to the unlearned,

Equal to his own age!

$*$

And he was one - among many - many -

Over the generation of rulers,

He revered the star of generation-aim

And its glow - on children's faces.

*

So the lion, the eagle, the ox and the man

Will remember him as - a predecessor.

He shall be like John... (the time awaiting the Redeemer

Is a desert!)]

One may wonder, why devote so much space and attention to an analysis of that small piece. It is for the simple reason that if the assumption of polemic allusions 
to evolutionism therein is true, it clearly shows the immediacy of Norwid's reaction to Darwin's ideas. Of course, it is not possible to prove that such an allusion would concern Darwin, and not the various evolutionist ideas of the time. However, the fact that before then, there is no trace of interest in the matter in the poet's work, and that the poem, addressed to a learned naturalist (not a supporter of Darwin), was written a year after the publication of the work On the Origin of Species - that is, when at least its press echoes reached Norwid - much greatly favour such an interpretation. Moreover, the context of the polemics and the type of argumentation are characteristic of Norwid's later, direct and unquestionable criticism of Darwinism. This includes: moral arguments, reference to man's dignity, emphasis on the dominant role of culture and clear elevation thereof over nature, and finally the Bible-rooted conviction of man and animals being only parabolically related. Norwid wrote of the latter in 1875 , as an overt critic of Darwin, in a letter to Marian Sokołowski from ca. 15 September 1875:

System Darwina jest tak miałki, że dziecko mogłoby go obalić (zwierzęta są tylko parabolicznymi braćmi naszymi). (PW X, 53-54)

[Darwin's system is so tenuous that a child could refute it (animals are only our parabolic brothers).]

In the late 1860s, Darwin's name appeared in Norwid's writing for the first time, in the words of a character from the comedy Aktor [Actor], named Nicka. The context of that jocular-ironic allusion to "systemat Darwina" [Darwin's system] is highly significant. The comment appears among Nicka's reflections on the links of fashion to history and science. Nicka is one of those characters in the comedy who are definitely satirized; that whole scene in Act III (second edition) contains very harsh criticism of a specific social sphere - the bourgeoisie, whom Norwid hated as the example of the new, materialized epoch. Irena Sławińska thus writes about the character:

Her mouth is always full of maxims, she declares her views, she passes moral judgements! [...] She decides the principles of good taste, "chic and genre." No situation evokes any doubt or hesitation within her - she has a ready-made formula for all situations, always pleased with herself. She may likely be termed the embodiment of "esprit bourgeois"... 52

Such a person (a tailor, by the by) declares her views on history with all seriousness, reducing it to the history of fashion. The impulse for the statement was one of the simplified motifs - very common among anti-Darwinists of the time of reducing Darwin's theory to the issue of man descending from a "monkey."

52 I. Sławińska, O komediach Norwida (Lublin, TN KUL 1953), p. 97. 
A popular theme of ridicule in that scope was the motif of the tail. It is a discussion about the length of the "tail" of a dress which ends with the following conclusions by Nicka:

Daruj, Panie! - skromniejszej nad mnie dzisiaj nie ma!

$[\ldots]$

Można być przyzwoicie w zakrystii z ogonem,

Kto ma gust i zarazem zaufał nauce -

Nauce, bo historia jest modą ludzkości:

Rewolucja hiszpańska dała beret z piórem,

Gdy Napoleon krynolinę prości,

A Abd-el-Kader bernus podaje $\mathrm{z}$ kapturem -

$[\ldots]$

Tak dalece, że nawet systemat Darwina

Ma swój udział... przynajmniej na fracta pagina. (Aktor (second edition), DW $\mathrm{V}, 438)$

[Pardon me, sir! - there is not one more modest than I, today!

$[\ldots]$

One can still be decent in the vestry wearing the tail,

If you have good taste and also trust in science -

Science, for history is the fashion of humanity:

The Spanish revolution gave us a beret with a feather,

Napoleon straightened the crinoline,

And Abd-el-Kader offers a hooded caftan -

$[\ldots]$

So far that even Darwin's system

Has its share... at least in fracta pagina.]

For a reader familiar with Norwid's concepts of history, and also his great appreciation and respect for the Emir of Abd-el-Kader, it is easy to see how deeply ironic and satirical Nicka's words are. Contrary to appearances, this earliest mention of Darwin made by Norwid cannot be disregarded. When exactly did that mention appear? The second version of Aktor was prepared by the poet in 1867, according to J. W. Gomulicki. ${ }^{53}$ In the first edition of the third act, dated 1862 , the above scene is completely absent. Yet hasty conclusions should be withheld, because - as Gomulicki claims - when developing the new version, Norwid relied on the earlier version and destroyed the fragments he had already used. Theoretically, the possibility that this mention of Darwin already existed in 1862 cannot be excluded. Still, it is most probable that it was written as late as around 1867, as the issues of evolution (or more precisely, man's origin) were

53 Cf. Gomulicki's comments about the two versions of Aktor, PWsz IV, $391 \mathrm{f}$. 
undoubtedly present in the sphere of Norwid's interests in that period. As it was in Waga, the criticism of new concepts on nature was accompanied by a criticism of modern civilization. That century, which "pustynią jest" [is a desert], is the actual theme of the comedy Aktor. Later, in the 1870s, the social conditions and influence of Darwinism would become (nearly) the only point of reference for Norwid's critical reflection. In 1875, in his letter to Marian Sokołowski from ca. 15 September, quoted above, the poet explained the success of Darwinism in Poland in sociological terms: with the possibility of using Darwin's theory as an argument for democratization:

[...] system Darwina rozgłos swój ma dla tej wnętrznej społeczeństwa przyczyny, iż z kast się chrześcijańskie ciało nie wyjarzmiło. Jest to dyscyplina pokory filozofijnej, w rudymentach dopiero założonej.

Kto inny założyłby jawne towarzystwo, mające na celu uszanowanie - ludzi, a które okazałoby, że Słowianin może coś początkować i tworzyć. [...]

Słabe, chore, tchórzliwe ciała muszą od-działywaniami działać. Istni nie chodzą tam i sam, ale wiedzą, gdzie, i kroczą prosto, jak światła promień. Systemu Darwina rozgłos jest od-działaniem socjalnym. (PWsz X, 54)

[[...] Darwin's system has its fame for that innate reason of society that the Christian body has not freed itself from castes yet. It is a discipline of philosophical humility, so far only rudimentary.

Someone else would have started an open association aimed at respecting - people, and it would show that a Slav is able to start and create something. [...]

Weak, sick, cowardly bodies must act in re-actions. The real ones go not here and there, but know where, and take straight steps, like a ray of light. The fame of Darwin's system is a social re-action.]

The fact that the first critical allusion to Darwin was probably made by Norwid in 1867 can be easily explained. That exact time saw a systematic promotion of Darwinism in some Polish magazines and, above all, in Przeglad Tygodniowy. At the same time, the attacks of its opponents intensified. For Norwid, who was critical of Polish society and considered the publishing activities of the press and periodicals to be one of the symptoms of the crisis, the enthusiastic acceptance of the new natural views was yet another proof of the legitimacy of his position.

The above-quoted statement from 1875 could have easily been written a few years earlier. In the West of Europe, including France, which had contributed the most to the development of naturalist thought, discussions on the origin of man had been quite animated even before the publication of Darwin's The Descent of Man (1 ed. 1871; 2 ed., revised and augmented, 1874). The discussion started primarily with the speeches of German materialists: Vogt, Büchner and Haeckel. Especially in 1867-1869, their views enjoyed great publicity. In 1869, the French 
translation of Büchner's lectures was published under the title Conférences sur la théorie Darwinienne. Norwid certainly followed those discussions, as he was a regular reader of the "Revue des Deux Mondes." He also likely knew the articles about Darwin's theories published in "Biblioteka Warszawska" (critical but moderate) and (perhaps occasionally) in Przeglad Tygodniowy. ${ }^{54}$

Norwid decidedly opposed materialism, naturalism, and positivism. Yet, that fact cannot be an argument to prove the poet's "Romanticism." The divisions run differently, that is, on the plane of general philosophical views. It is known that Darwin's theory was a polarizer of worldviews and attitudes. Norwid's critical statements do not in any way testify to his "backwardness"; on the contrary, they prove his active participation in the intellectual life of the epoch.

Norwid's philosophical and scientific poem Rzecz o wolności stowa (1869) is the work in which he opposes natural evolutionism with philosophical justifications, providing numerous arguments from within his own historical observations. Yet first and foremost, his arguments arise from the concept of truth he had adopted, which did not allow limitation to just empirical or logical arguments, but which demanded moral justifications. In his ethno-philological notebook he wrote:

Tak samo więc można wszystko oddać witalistom, jak i fizyko-materialistom.

To tylko dwa poglądy będą.

[...] Powstaje pytanie: nie, czy jedni lub drudzy, ale: o ile jedni i drudzy są i bywają w prawdzie.

Metoda

Logika-moralna. ([Notatki etno-filologiczne], PWsz VII, 417)

[And so everything can just as well be given to vitalists, as to physical-materialists. Those will just be two points of view.

[...] A question arises: not, is it this or the other, but: is either this or the other in truth always or at times.

Method

Moral-logic.]

54 The author of the essay on the place of Darwinism in the work of Przeglad Tygodniowy thus writes of the period of interest here: "in 1866-71, and thus before Darwin's treatise The Descent of Man, and Selection in Relation to Sex was published, the problem of the animal origin of man was discussed in Przeglad Tygodniowy as one of the basic conclusions resulting from the theory of the origin of species. Some publicists even believe that discussing the issue is equal to discussing Darwin's theory. Twelve extensive papers have been dedicated to the matter in Przeglad Tygodniowy, with the authors referring to German, English and French publications." T. Długokęcka, "Miejsce darwinizmu w działalności, Przegladu Tygodniowego (1866-1890)," in: Materiały do dziejów myśli ewolucyjnej w Polsce, Vol. 1 (Warszawa: PWN, 1963). 
Rzecz o wolności stowa is a polemics with the theories of naturalists and social evolutionism from the said position of "moral logic." It is also clearly polemic towards naturalist evolutionism, the génération spontanée theory, the idea of transferring the laws of biology to human society. The argumentation proves that Norwid understood the essence of the concept of the naturalists correctly, and was far from confusing it with genesic spiritualism. What he focused on in the poem was the matter of man's origin. Yet he drew his polemic arguments, with a few exceptions, from the sphere of culture. Thus the examples come from the field of archaeology, art history (especially the art of primitive peoples), ethnography, and religious history.

The attempt to scientifically prove his truth, which he was essentially convinced of on the basis of the Book of Genesis, is highly interesting and very typical of Norwid. It proves how seriously he took the richly documented arguments of contemporary naturalists, and how strongly he felt his moral responsibility and duty to fight them in the name of his own convictions. Due to the essence of the problem of interest, that is, the matters of man's origin, the enemy camp included not so much Darwinism with its struggle for existence, but general evolutionism based on materialistic assumptions, on causality.

And so, progressivism, which assumed a constantly improving chain of creatures with man at its zenith, as a logical result of the uniformly binding changes, was one of the main issues questioned by Norwid. The opinion about those who proclaim that "stopą jest dzisiejszych, co wczorajszych głową" [the head of the people of yesterday is the foot of the people of today] evokes an association with the 18th-century concept of the "ladder of living creatures," Échelle des Etres vivants, suggested by Charles Bonnet. In Genezis $z$ Ducha ${ }^{55}$ Słowacki referred to Bonnet and to Erasmus Darwin, yet he merged the ideas of those deist-naturalists into his own mystical-genesic vision following spiritualist monism. The affinity of Słowacki's ideas with early evolutionism is therefore rather superficial, because a completely different ideological principle underlies the connection of the whole. It seems that Norwid saw the difference between the transformism of spiritualists and the transformism of naturalists perfectly well - his polemics concerns only the latter, in all its forms:

Mędrcy dzisiejsi głoszą, kto powolny, słucha:

Że Człowiek jest następnym ogniwem łańcucha

Stworzeń ciągu; że łańcuch ten wyjrzał człowiekiem

Ponad kryształ i koral, i pierś zdętą mlekiem.

55 Skwarczyńska, “Struktura rodzajowa Genezis z Ducha," pp. 245 and 266-271. 
I że tak się stał człowiek, istnienie spotkane

W logicznym ciągu rzeczy, "d’une manière spontanée."

Żart wywinąć z doktryny tak wielce misternéj

I tyle kosztującej prac, byłby żart mierny...

Sprawdzić ją?... nie dopełnia się tego $w$ godzinę!

Pominąć?... niepodobna - przeto nie pominę.

I wypowiem: że stoję na polu przeciwnym,

Będąc wiernym podaniom Ludzkości, naiwnym;

Zaś, czemu? wierny jestem - nad tym się rozszerzyć

Zechcę: by nie myślano, że śmiem lekcewierzyć!

(Lekkowierność ze wszech miar wiary jest daleka,

Obrażająca godność prawdy i człowieka.)

Nie!... Człowiek był wytwornym. - I Ludzkości prolog

W Raju jest - tam pomniki... kędyż? archeolog,

Który by te dalekie, te wysokie karty

Podjął i jako napis przeczytał zatarty.

Gdzie ten stuchacz? czytelnik gdzie? do tyla względny,

By się nie dat uwikłać $w$ tok wiedzy podrzędnéj,

I pomnił, że na puszczy wiatr dziś równie szuka

Jak badacz, a z ruiny czerpie całość - sztuka! (Rzecz o wolności słowa, II, w. 1-24.

DW IV, 221-222)

[Today's sages say, and the willing listener follows:

That Man is the next link in the chain

Of creatures' progression, that the chain rose up with man

Over the crystal and the coral, and the milk-filled breast,

And that thus occurred man, a being encountered

In the logical course of things, "d'une manière spontanée."

To make fun of such an elaborate doctrine,

Which took so much work, would be a measly jest...

To check it?... that is not done in an hour!

To ignore?... impossible - hence I ignore not.

And I say: I stand on the opposite field,

Faithful to the legends of Humanity, naïve;

But why? am I faithful - I would like to expand on

that: so you think not that I dare believe lightly!

(Believing lightly is by all measures far from faith, And offends the dignity of truth and man.)

No!... Man was dignified. - And the prologue of Humanity

Is in Paradise - there are the monuments... where? is the archaeologist

Who would take those distant, those lofty pages

To read like obliterated writing. 
Where is that listener? the reader? considerate in so far As not to be entangled in the coils of mediocre knowledge, And to remember that today, the wind runs in the forest seeking Like a researcher, and art - draws wholeness from ruin!]

Typical of Norwid in his polemics with evolutionism is the method of proving that he is right, without indicating the opponent's mistakes. The latter was a classical strategy of naturalists in polemics. In other words, the poet does not fight in someone else's area - which beautifully shows his intellectual responsibility - but he accepts it in his own field, in the area of the general philosophy of man. Thus it is a dispute about principles.

The main motif of Norwid's argumentation is a set of evidence for the fundamental uniformity of culture, with variable forms, but the culture itself is not subject to the laws of progressive development. For that, Norwid uses the latest archaeological and ethnographic discoveries. Those are all arguments supporting the thesis of the perfection of the first people and their subsequent fall - as a result of original sin - and then rebirth through creative work, culture and history. Yet, the essence of culture is always the same: protection of the original ideal, unchangeable and revealed by God. A sense of beauty is innate to man from the very beginning. It is also from the beginning that man - created as a perfect being - tried to realise that beauty in any available material: stone, fabric, and with time, in words. Having said that, Norwid regarded the means of expression as a secondary thing - various cultural signs were always signs of goals given from above, signs of the revealed Word, the one that was "in principio..."

As a result, any and all truths concerning only the material existence of man could not be complete truths. According to Norwid, the truth is only available in approximation, it can only be expressed in a parable, which connects both worlds, the spiritual and the material. According to that concept, the author of Rzecz o wolności słowa was convinced that anything that ever appeared in culture and already fulfilled its active function, remained. Nothing was lost. A ruin is thus not only a testimony to the transitoriness of forms, but also - and above all - a testimony of fulfilment. In saying that " $z$ ruiny czerpie całość - sztuka!" (DW IV, 222) [art - draws wholeness from the ruin!], the poet expressed his conviction that only the world of art, the world of culture was the sphere which could provide synthesis, convey the truth ("in approximation," as he wrote over ten years later in his essay Milczenie). That sphere was predisposed for the task because of its nature, its parabolism, its significant character. Purely external, material knowledge did not give the whole picture (which is also a motif in Milczenie): 
I

Co? znaczyłaby Ludzkość, gdyby ją kto zmierzyt,

Jak ona jest... i w taka, jak jest ona, wierzyt -

Co? ona by znaczyła widziana tak szczerze,

Jak ją znam i oglądam - nie zaś, jak w nią wierzę -

Co by ona znaczyła!...

Dziewięćset milionów

Skazanych na śmierć istot - - parę zaludnionych

Półwyspów...

*

oto wszystko!...

*

... i trup w każdej chwili

Zowąd - a zowąd słabe niemowlę zakwili.

Oto i wszystko...

*

...Ludzkość? z takowym obliczem,

Lubo to jej oblicze - - nie byłaby niczém.

Jakby do samej siebie twarzą poniżona (Rzecz o wolności słowa, I, w. 1-11; DW

IV, 217)

[I

What? would Humanity mean if one were to assess it

Such as it is... and believe in it such as it is -

What? would it mean when seen as honestly

As I know and see it - not as I believe in it -

What would it mean!...

Nine hundred million

Beings sentenced to death - - several inhabited

Peninsulas...

*

that is all!...

*

....and a corpse at each moment

From there - and elsewhere a weak infant wails.

And that is all...

*

With such a face, Humanity

Or the face thereof - - would be no different...

Than reduced to itself with its own face]

Such is the beginning of the poem Rzecz o wolności stowa, and such are the philosophical foundations of Norwid's polemics with Darwinism.

It is impossible for this article to discuss the entire wealth of problems connected with this work from the point of view of polemics with evolutionism. 
Thus, just one more interesting confrontation of that polemics with Darwinism shall be indicated, based on the philosophy of culture, with the extensive work of Edgar Quinet, La Création, published a year later (1870). ${ }^{56}$ One of the chapters of Quinet's book titled Monkey and Man ("Livre sixième: Le singe et l'homme") was reprinted immediately in Przeglad Tygodniowy, in the translation of Bolesław Limanowski (in many editions in $1870-1871$ ), ${ }^{57}$ preceded by a very favourable review by Limanowski. Quinet's idea, realized on such a large scale, had its sources in the ideas on the antipodes of Norwid's views. In La Création, Quinet outlined the history of the earth: from the tectonic movements that particularly fascinated him through a description of geological epochs to the development (evolution) of the world of plants and animals, and finally, of man. His basic assumption was the similarity of the laws governing nature and human society. The chapters (or "volumes") were titled as follows: Principes d'une science nouvelle, Parallélisme des règnes de la nature et de l'humanité, so their content was to demonstrate the omnipresent principle of causality, and at the same time, polemics with the idea of man having lost his original ideal state. Quinet's work is cited to prove just how close Norwid was to the heart of the problems of his time, and how clearly he specified his stance towards them.

It has been mentioned at the beginning of these considerations that Norwid's attitude towards natural evolution was expressed differently in various periods. Before the publication of Darwin's next great work, The Origin of Man, the polemics was of a general philosophical nature. Some criticism of modern civilization did accompany it from the beginning, but it remained in the background. At that time, the author of Vade-mecum saw evolutionism primarily as a theory opposing his views, and sufficiently serious and well documented to make it necessary to take up the challenge. The situation changed after 1871 faced with the theory of man's direct lineage within the animal system, of kinship between man and animal, supported by innumerable examples, and in particular in the face of the thesis about the common ancestry of men and apes, Norwid became a virulent ironist. Darwin and Darwinism became to him the child of the "wicked" epoch, which "jest małpa sprzedająca wszystko za pieniądze" 58 [is a monkey selling everything for money], thus an epoch in which he saw the

56 E. Quinet, La Création (Paris: Librairie Internationale, 1870). Date of the foreword: February 1869.

57 Unsigned cycle of articles "Małpa i człowiek," Przegląd Tygodniowy (1870, 1871). Review by Limanowski, "Przegląd czasopiśmiennictwa francuskiego," Przegląd Tygodniowy (1870), p. 195.

58 Letter to Konstancja Górska from July-August 1866, PWsz IX, 254. 
extreme materialization and domination of new values, ones that he did not accept. In the 1870s, his criticism concerned a still broader issue, what he called "social anthropology," seeing the common impact of Darwinism as a proof of the condition of 18th-century societies:

Nie tylko nie podzielając rozgłośnego systematu Darwina, ale nawet rozgłośność jedynie tegoż za godną szczególnej uwagi poczytując, usłusznione u mnie jest, że mi antropologia społeczna nie wystarcza. Myślę, że to raczej kraniologia, że to osteologia!... albowiem samą czaszką i szkieletem obchodzi się. Gdzież jest człowiek w tym wszystkim? (Letter to Seweryna Duchińska from 1879, PWsz X, 130)

[As I not only refuse to accept Darwin's famous system, but even consider just the fame thereof to be of special interest, I am convinced that I find social anthropology insufficient. I think that is rather craniology, that it is osteology!... for it works only with the skull and skeleton. And where is man in all that?]

Opinions similar in tone are found in several letters of that time, ${ }^{59}$ and two more in literary works (“Co robić?" [“What to Do?"], 1875, and "Naturalizm (spółczesny ekstrem)", 1977). Norwid's opinions often seem quite justified compared to the numerous simplified, primitive transpositions of Darwinism into social studies. There were, in fact, many statements even by eminent philosophers who - with satisfaction worthy of a better cause - claimed that the human community arose from a group of tree-climbing monkeys.

Below is an example of Norwid's very sharp irony, which nonetheless is also full of witty humour. In a letter to Seweryna Duchińska, a passage of which has already been quoted here, the poet thus describes his visit to a zoological garden:

Podobno, że Łaskawa Pani, będąc w progach tych tu murów, raczyła o mnie zapytywać - otóż właśnie że wyszedłem do Ogrojca roślin i zwierząt [...].

Spółcześni [...] tłumnie biegną do Ogrodu-aklimatyzacji, ażeby widzieć ich (wedle Darwina) przodka orangutanga, a nie pojmuję u tych osób podzielających system naturalisty angielskiego, dlaczego one antenata $\mathrm{w}$ klatce $\mathrm{z}$ małpami osadziły i parasolami przez kraty do niego bodzą?... Obyczaj, którego żaden ze spółwyznawców moich nie dopuściłby się względem portretu dziada swego!... Orangutang też z politowaniem i newralgią na tę zdziczałą-cywilizacją rzeszę pogląda... W tym to jednym pokrewny mu jestem, tak jak i całemu ogółowi parabolicznie pokrewnych mi zwierząt i tworów - czyli: według mojego-systematu. (Letter to Seweryna Duchińska from1879, PWsz X, 130-131)

59 To Jadwiga Łuszczewska from October 1871, PWsz IX, 497; to Aleksander Jełowiecki from June 1871, PWsz IX, 483; to Marian Sokołowski from ca. 15th September 1875, PWsz X, 53-55; to Artur Bartels from 1st September 1875, PWsz X, 50-51; to Seweryna Duchińska from 1879, PWsz X, 130. 
[I was told that when you stepped in these walls, you kindly asked about me - as it was, I just happened to have gone to the Garden of plants and animals [...].

The contemporaries [...] rush in crowds to the acclimatisation-Garden to see their (according to Darwin) ancestor, the orangutan, and I cannot understand those people who partake in the system of the English naturalist, why they have locked their ancestor in a monkey-cage and poke at him with their umbrellas?... That is a custom which none of my co-believers would have dared practice towards the portrait of their grandfather!... And the orangutan also looks with pity and neuralgia upon that crowd rabid-withcivilisation... In that one thing I am related to him, as to all animals and creatures parabolically related to me - that is: according to my-system.]

In the 1870 s, that trend is not the only one present in his letters and literary works. There is also a different trend in Norwid's interest in the problems of Darwinism and other new biological and physicochemical concepts. That trend is found in numerous notes, abstracts and reflections on the pages of his notebooks. The nature of those notes, sometimes very meticulous, and sometimes his own generalisations, proves that the naturalist image of the world which became the dominant feature of the modern era was an ineluctable problem for Norwid. He was also concerned with linguistic studies, following any arguments against the natural origin of speech with special attention. The results of those considerations and inquiries were sometimes comical, especially when Norwid accepted some of the arguments of biologists and drew his own conclusions from them. All of that clearly proves Norwid's efforts to defeat by way of reasoning the theories contradictory to the fundamentals of his worldview, to prove them wrong to himself.

But in 1882, in the year of Darwin's death, Norwid steps down from the fight. Having failed to defeat the opponent in an open fight, he makes him his ally. He writes a short essay titled Fabulizm Darwina, ${ }^{60}$ which seems to escape into a parable. Darwin's work (presumably The Origin of Man, as the example of the artist-spider comes from the second English edition) is treated by Norwid in his essay as a link in the development of certain literary forms. He claims that "apolog wyogromnił się w rzeczy Darwina i że umiejętnie czytający (to jest ci, na których zwykle każdy autor oczekuje) wiedzą i widzą, że delficka bajka do zenitu swego doprowadzona jest Darwinowym arcydziełem." [The apologue has grown immense in the matter of Darwin, and that those who know how to read (i.e., those whom each author usually awaits most eagerly) know and see that Darwin's masterpiece is the Delphic tale brought to its zenith.] Thus, Norwid claims that Darwin came up with his theory in order to mock the gullibility

60 Fabulizm Darwina, PWsz VI, $427 \mathrm{f}$. All quotations from the same. 
of modern people, to express his contempt for them by equating them to the animal world:

Stanowczy [w przypisku mamy: „czytaj: stan-Owczy. Stan-owczy!“ - E. F.] ogół czytelnictwa dzisiejszego, to jest: Czytelnicy-Kaligrafii, jedni i jedyni mogą Darwina za egzegetę przyrody poczytywać. On bardzo dobrze wiedział, że ma do czynienia ze społecznością tak skamieniałą w pychę, iż gilotyna bezskutecznie wyszczerbiłaby się na niej, i że pyłem popiołu rzucić jej na czoło, to tylko jak pudr na perukę - ale odnieść ją do Małpy... to zastanowi się!

[The resolute [the note divides the original Polish word into: "stan-Owczy. Stanowczy!," i.e. "condition of Sheep" and "State of sheep" - E. F.] entirety of today's readership, that is: Readers-of-Calligraphy, only those can consider Darwin to be an exegete of nature. He knew very well that he was dealing with a community so fossilised into pride that a guillotine would chip away at it in vain, and that to cast the dust of ash on its forehead, would be like dusting powder over a wig - but to compare it to Monkeys... that will bring it to thinking!]

In this essay, Norwid shows the allegedly Indian sources of Darwin’s idea: “[...] też z Indów Awantura zetknięcie się dało parabolijny indyjski pogląd na biologię i jej process." [[...] also the contact with the Indian Disturbance gave the parabolic Indian view on biology and its process.] He also writes words which indicate how great a dilemma it was for him, not to be able to find arguments which would help him refute the detailed premises of Darwin's theory:

Wszyscy zauważyli, że Darwin bardzo przebiegle rzecz swą przedstawiał. Inaczej być nie mogło, bo każda kartka wyjęta z jego dzieł jest genialna i prawdziwa... a wszystkie kartki razem zebrane są niedołężne i błędne.

[Everyone noticed that Darwin presented his matter very craftily. It could not be any different, for each page taken out of his works is brilliant and true... and all the pages taken together are impotent and misleading.]

It is not obvious whether Fabulizm Darwina is an ironic text or whether it is written seriously. As a matter of fact, that is completely irrelevant. After years of investigation and polemics, of searching for rational counterarguments, Norwid was left only with a magical gesture: a grip transforming the enemy into an ally.

\section{Norwid among His Contemporaries}

It is a known fact that Norwid never found recognition among his contemporaries. After a brief period of triumphs in his literary youth, he fell ever deeper into an increasingly hopeless conflict with critics. It is difficult to speak of a conflict with his audience, because few read him, and later in life he published much less. The history of his endeavours to have the second volume of his poetry, which was to 
include, for example, Vade-mecum, the top achievement of his poetry, published by Brockhaus in Leipzig, is particularly dramatic. A question arises regarding the reasons behind the poet's situation as such.

Elements of the answer can be found in various fragments of this essay. On the one hand, there was the conflict with the worldview and artistic practice of the Romantics - perhaps not antagonistic, but constantly present. On the other hand, Norwid did not notice processes occurring in Poland which in detailed achievements and acts were often convergent with his own postulates. His understanding of the category of nation and the ways leading to national liberation, different from the Romantic views, placed him in conflict with the Romantics, but did not make him a follower of the ideals of the next epoch. That resulted mainly from a different philosophical and worldview basis of positivist thought. That was shown in the previous subchapter. Even when the post-uprising epoch turned away from armed resistance, towards which Norwid was always averse, that had a different motivation than in the case of the poet, who condemned bloodshed within his eschatological vision of history. Both renouncement of bloodshed and creative work were supposed to lead to a complete transformation, spiritual rebirth of the individual and society, and so were postulates of someone thinking in religious and eschatological categories.

To understand that apparent paradox of Norwid being misunderstood by his time which was basically changing in the direction of what he postulated, one must be aware of the fact that he was absent from the circulation of philosophical thought and literature. That circulation was hindered by his own attitude which stood against the naturalist worldview of positivists.

Suspended between Poland and Europe, a critical observer of both, he saw himself as doomed to the impossibility of an unconditional choice. And he was not a man of compromise. "A writer of the trade and industry age," as Zofia Stefanowska described him in an essay of the same title, ${ }^{61}$ could not resolve the antinomies distressing him. Yet, it seems that those were not necessarily the antinomies of Romanticism.

Ill-disposed towards the monism of spiritualist Messianists, he was all the more averse towards the materialist monism of the following era. He formulated the problem already back in 1849 in Niewola:

Więc - badam w sobie dwa pierwiastki różne,

Ten, co widzialny, ów, co niewidzialny,

Jakby zwaśnione z sobą dwa podróżne

61 See footnote 49. 


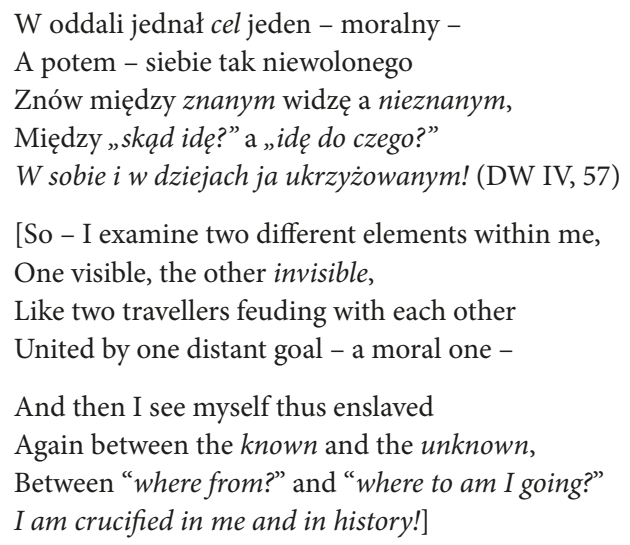

\section{Bibiography}

Cieszkowski, August. Ojcze nasz. Vol. I. Paris: Maulde \& Reuon, 1848.

Długokęcka, Teodozja. "Miejsce darwinizmu w działalności, Przeglądu

Tygodniowego (1866-1890)." In: Materiały do dziejów myśli ewolucyjnej w Polsce, ed. Kazimierz Petrusewicz and Anna Straszewicz. Vol. 1. Warszawa: PWN, 1963, pp. 11-111.

Feliksiak, Elżbieta. “Norwid i Vico." In: Poezja i myśl. Studia o Norwidzie, ed. Elżbieta Feliksiak, Lublin: TN KUL, 2001, pp. 213-248.

Feliksiakowa, Janina. "Bibliografia dzieł Darwina w języku polskim oraz wybór opracowań z zakresu darwinizmu." Biologia w Szkole, No. 6, 1958, pp. 342-371.

Feliksiakowa, Janina. "Dalsze opracowanie bibliograficzne wyboru publikacji w języku polskim z zakresu darwinizmu." Biologia w Szkole, No. 2, pp. 65-80; No. 3, pp. 141-152; No. 4, pp. 183-204, 1960.

Gomulicki, Juliusz Wiktor and Jan Zygmunt Jakubowski. Nowe studia o Norwidzie. Warszawa: PWN, 1961.

Krzemień-Ojak, Sław. Wstęp to: Giambattista Vico, Nauka Nowa. Trans. Jan Jakubowicz. Warszawa: PWN, 1966.

Limanowski, Bolesław. "Przegląd czasopiśmiennictwa francuskiego." Przegląd Tygodniowy, No. 24, 1870, p. 195-197.

Lisiecka, Alicja. “Z problemów historyzmu Cypriana Norwida. Na marginesie tomu 7 'Pism.' Pamiętnik Literacki, Vol. 1/2, 1959, pp. 331-421.

Mickiewicz, Adam. Dzieła poetyckie. Edition and explanations by Tadeusz Pini. Nowogródek: Komitet Mickiewiczowski, 1933. 
Mickiewicz, Adam. Dzieła, Vol. XI. Warszawa: Czytelnik, 1955.

N.N. “Małpa i człowiek.” Przegląd Tygodniowy, 1870, 1871.

Quinet, Edgar. La Création. Paris: Librairie Internationale, 1870.

Skwarczyńska, Stefania. "Struktura rodzajowa Genezis z Ducha." In: Juliusz

Słowacki. W stopięćdziesięciolecie śmierci: materiały i szkice, eds. Marian

Bizan and Zofia Lewinówna. Warszawa: PIW, 1959, pp. 262-263.

Skwarczyńska, Stefania. Wstęp do nauki o literaturze. Vol. III. Warszawa:

PAX, 1965.

Sławińska, Irena. O komediach Norwida. Lublin: TN KUL, 1953.

Słowacki, Juliusz. Genezis z Ducha. In: Juliusz Słowacki. Dzieła, ed. Władysław

Floryan. Vol. XII. Wrocław: Wydawnictwo Zakładu Narodowego im.

Ossolińskich, 1959.

Stefanowska, Zofia. "Norwid - pisarz wieku kupieckiego i przemysłowego."

In: Literatura, komparatystyka, folklor. Księga poświęcona Julianowi

Krzyżanowskiemu, eds. Maria Bokszczanin, Stanisław Frybes and Edmund Jankowski. Warszawa: PIW, 1968, pp. 423-460.

Tatarkiewicz, Władysław. Historia filozofii. Vol. III. Warszawa: PWN, 1958.

Trojanowicz, Zofia. Rzecz o młodości Norwida. Poznań: Wydawnictwo Poznańskie, 1968.

Tur, Jan. Stulecie historycznego sporu: Et. Geoffroy St. Hilaire - Cuvier. Odczyt wygłoszony na posiedzeniu Warszawskiego Oddziału Towarzystwa Anatomiczno-Zoologicznego dn. 19 lutego 1930 r. Lviv, 1931.

Vico, Giambattista. Conclusion of New Science: On an Eternal Natural Commonwealth. Trans. Thomas Goddard Bergin and Max Harold Fisch. New York: Cornell University Press, 1948.

Vico, Giambattista. Die neue Wissenschaft über die gemeinschaftliche Nature der Völker, nach der Ausgabe von 1774 übersetzt von Erich Auerbach, mit einem Essay „Zum Verständnis des Werkes” und einer Bibliographie von E. Hora. Rowohlt, 1966.

Walicki, Andrzej. Filozofia a mesjanizm. Studia z dziejów filozofii i myśli społeczno-religijnej romantyzmu polskiego. Warszawa: PIW, 1970. 


\title{
Michał Głowiński
}

\section{Norwid's Poem-Parables}

\author{
Żeby ci posłać cały świat w obrazku \\ i uogólnić, co się dniowo kréśli... \\ ("Do mego brata Ludwika"; PWsz I, 68) \\ [To send you the whole world in a picture \\ And generalise what happens in a day... \\ ("To my Brother Ludwig")] \\ A o czym pisać?... Dziś do Pamiętników, \\ Do lada piosnki, nawet i miłosnéj, \\ Tak wiele zimnych trzeba ogólników, \\ Że dreszcz mię bierze, acz z początkiem wiosny. \\ (“W pamiętniku L. A.”; PWsz I, 73) \\ [And what to write about?... In today's Diaries, \\ In any song, be it even of love, \\ You need so many cold platitudes \\ It makes me shiver, despite the beginning spring. \\ ("In the Album of L. A.")]
}

\begin{abstract}
The author begins with defining parable - a specific narrative mode - as a separate literary genre, which, however, combines and coexists with other genres with relative ease, or are introduced into the area of another genre, and not just as quoted text (although this is also a frequent phenomenon). According to the analytical observations made here, Norwid puts parable into an unusual context, one of a different type. The author deals with the functioning of parable only in Norwid's lyrical poetry. Here, this archaic structure appears in an utterly new context - which is yet another expression of Norwid's literary situation. There is also a fundamental difference between Norwid's parables and the greatest achievement of the Romantic parable - The Books of the Polish Nation and Pilgrimage. Mickiewicz brings back the old function of parables; Norwid's approach is much more complex and sophisticated. Parable becomes both a philosophical and an artistic category. Poetic discourse, focused on reading the signs that exist in the world, cannot be a description of the world in phenomenological terms. On the one hand, it is a homological structure in relation to the world's structure, and on the other, an interpretation thereof - not quite a notional interpretation, but rather an evidential, "demonstrational" one.
\end{abstract}

Keywords: Cyprian Norwid, poetics, parable, lyrics 
Norwid consistently rejected the novel. ${ }^{1} \mathrm{He}$ did dream of writing a Christian epic, but in the mid-19th century that dream was bound to remain unfulfilled. For various reasons, both narration as mimesis and narration as myth were unavailable to the poet, so he could not stand for realism or for Romanticism that is what happens when we look at the matter from this perspective. Yet, a poet active in the third quarter of the 19th century could not be a purely lyrical poet, especially if - like Norwid - his literary activity had such immense cognitive, moralist and ideological ambitions. Thus, he could not liberate himself from the problems of narration, either; however, outside the mimesis of a novel and the epic myth, there existed other options. Two of those are particularly important when discussing Norwid.

The first of them is narration subject to overt decisions by a speaker who is in the foreground and informs those decisions: narration is their result, not the result of the world's order which it should reflect, and so it is treated mainly as a creative activity. In this case, the experiences of a digressive poem are most important. In the second case, narration does not rely on the speaker's caprice (the speaker may even remain nearly invisible), yet it does not flow freely - it is limited by other factors, such as more general perspectives, it is subject to a certain set of issues, worldview, moral or ideological beliefs, even a doctrine. It interests the poet insofar as it does not occur independently and has a specific task to accomplish. In short, it is important as a means, not as an aim. In Norwid's work, both of these narrative approaches, which go beyond myth and mimesis, occur in various configurations, but this chapter focuses only on the latter: narration bound by general assumptions, regulated and subordinate, an element important to the poet only as long as it is capable of bearing the adopted assumptions.

Norwid's narrative choices were of a contrasting nature, for many reasons. Both of the tendencies he favoured, if taken in isolation, were related to various concepts of literature, sometimes even opposing ones, and each of those tendencies ascribed different functions to poetry. They also differed in their historical roots, and in this particular case historic differences amounted to structural and functional differentiation. Narration as a creative activity of the speaker was related to the discoveries of Romanticism. Narration as a vehicle to carry general meanings dealt with antiquity - the antiquity which, one might assume, had

1 Cf. my essay “Wokół 'Powieści' Norwida," Pamiętnik Literacki 1971, vol. 3; this paper is intended as a fragment of a more extensive study I am planning on Norwid's poetics. 
been made a relic of history by Romanticism. This narration attempted to resurrect a tradition which seemed obsolete; it required the reader to think of allegory, parable, exemplum, and thus such categories of literary speech with which - with few exceptions - the 19th century had nearly completely parted, regardless of whether it was inclined towards Romantic fantasy-making or natural descriptiveness. Those very allegories, parables, or exemplums constitute the main element of Norwid's archaism, and at the same time are the basic conceptual devices of the considerations presented herein.

I treat allegory as a starting point and concept, ${ }^{2}$ understanding it in its most general meaning: as a two-level semantic construction in which the relations between both levels are in some way established or at least aspire towards such establishment. It may result from a writer's arbitrary decision, yet during the epochs in which allegory was used it commonly resulted from a reference to social awareness, where allegorical images functioned in a fixed form, based most strongly on the system of religious beliefs. Allegory may appear both in

2 I used the following works on allegory: C.S. Lewis, The Allegory of Love. A Study in Medieval Tradition (Oxford: 1953) (1st ed. 1936); A. Fletcher, Allegory. The Theory of Symbolic Meaning (Ithaca, NY: 1964); R. Tuve, Allegorical Imagery (Princeton: Princeton University Press 1966); A. C. Hamilton, The Structure of Allegory in "The Faerie Queen" (Oxford: Clarendon Press, 1964); A. D. Nuttall, Two Concepts of Allegory. A Study of Shakespeare's "The Tempest" and the Logic of Allegorical Expression (London: Routledge \& K. Paul, 1967); E. Honig, Dark Conceit. The Making of Allegory (London: Faber and Faber, 1959); D. L. Sayers, The Writing and Reading of Allegory, in: The Poetry of Search and the Poetry of Statement (London: V. Gollancz, 1963), pp. 201-225; T. Todorov, Introduction à la littérature fantastique, chapter La poésie et lallégorie (Paris: Editions de Seuil, 1970), pp. 63-79. From Polish studies, noteworthy are: the essay by J. Krzyżanowski "Alegoria w prądach romantycznych," Przegląd Humanistyczny 1962, vol. 5; a chapter in E. Sarnowska-Temeriusz's Świat mitów i świat znaczeń (Wrocław: Zakład Narodowy im. Ossolińskich, 1969), pp. 122-166; A. Krzewińska’s study Alegoria w "Wizerunku własnym żywota człowieka poczciwego" Mikołaja Reja, in Tradycja i nowoczesność by many authors, ed. by J. Trznadlowski (Wrocław: Zakład Narodowy im. Ossolińskich, 1971). After already having written this paper, I came across an interesting article by G. Spivak, "Allégorie at histoire. Hypothèse de travail, Poétique 1971, No. 8. The author assumes that allegorical poetry, which has its place in both Romantic and modern poetry, asserts that the understanding of poetry, which dates back to Mallarmé and focuses on the text itself, is not of a universal nature, but only one among many historically defined theories. Allegory situates the work against what is beyond the text. Capturing that relation is most crucial for understanding poetic statements using allegory. Spivak demonstrates the role of allegory in more recent poetry by analysing Wordsworth's "The Prelude" and Yeats's "The Black Tower". 
an isolated form, for example, as a specification of the abstract, often related to personification, ${ }^{3}$ and in a continued form ${ }^{4}$ as a plot where events are understood only in the context of some more general meaning. Parable is one of the forms of this concept of continued allegory; it is a story-telling narration, referring distinctly to a certain order beyond it. That order may be a moral or religious doctrine, or a less institutionalised set of beliefs functioning within a given culture. Exemplum, ${ }^{5}$ in turn, is a kind of parable. On the one hand, it is a kind of embryonic, undeveloped parable; on the other, a parable performing a maximally utilitarian function. That utilitarian character may answer to the adopted teaching purposes (as it did in the medieval works of that kind) or to the context in which the exemplum appears, which is not necessarily didactic in character.

To separate a parable from other narrative forms, one may use the distinction between story and discourse introduced by Benveniste. ${ }^{6}$ A parable is a narrative subordinated to a certain type of discourse, where the speaker refers overtly or covertly to a set of beliefs functioning in a given society, or only appears to make such a reference. One thing remains the same: the speaker in the discourse to which the parabolic narrative is subordinated operates under certain general concepts out of sheer necessity. Those concepts may, again, be verbalised directly or just implied. The above does not mean, however, that within a thus understood discourse the parable is merely an illustration. ${ }^{7}$ Quite contrarily - it impacts the discourse itself, as well as serves a persuasive function; oftentimes, these are the main reasons for bringing the parable to life.

It is clear that the parable is distinguished by its structural, not thematic elements. The one which is most fundamental of them is the relation of narration to the discursive environment. There are also other ones, which shall appear further along in the analysis, namely a specific dialectic of the concrete and the

3 On relations between allegory and personification see e.g. R. Tuve, Allegorical Imagery, pp. 25-26.

4 "Continued allegory" is the commonly used term in the English-language publications indicated above.

5 For more on exemplum, cf. J.-Th. Welter's L'exemplum dans la littérature religieuse et didactique du moyen âge (Paris: Occitania 1927).

6 E. Benveniste, Les relations de temps dans le verbe français, in: Problèmes de linguistique générale (Paris: Gallimard,1966), pp. 237-250.

7 Z. Stefanowska, Historia i profecja. Studium o "Ksieggach narodu i pielgrzymstwa polskiego" Adama Mickiewicza (Warszawa: PIW, 1962), p. 177 defined the matter as the "domination of the superior sense over the story motif," which refers to a tendency to schematise the plot. Cf. the author's considerations on illustrative elements in parable (ibid., pp. 166-169). 
schematic, lack of individual features of characters, and so on. This has to be stressed with particular emphasis: the criteria of the parable are approaches, not topics. That emphasis needs to be made especially because within a given culture there usually emerges a set of topics or stories which are somehow reserved for the parable. As a result, there is a natural tendency to treat them as the basic element of a parabolic narrative. In Christian culture, such an arch-pattern of a story in the form of a parable are, obviously, the Gospels. However, even the parables which serve to prove the validity of the principles of Christian faith are not usually repetitions of the Gospel parables, but at best modernisations of the pattern by which they are constructed. The plot of the parable may be built from any story, anecdote, or even isolated event; the topic may actually be anything. The usefulness of the given plot substance is decided only by whether and how it can be adjusted to the requirements posed by the parable, and in what manner it may fulfil the tasks set by the parabolic strategy. Norwid's works confirm those general principles very clearly. He takes the motifs for his parables from various sources, introduces elements like various everyday scenes, which in his time found haven in the novel he scorned so much; the difference is that he does not treat them according to mimetic aesthetics. ${ }^{8}$ On the other hand, those of Norwid's works which borrow motifs from the New Testament are not usually parables, although - as could be expected - they are markedly predestined to become such. They are not parables because the stories they present are already filled with meanings, the poet does not need to impose them. Thus, the poet does not look at the object of the account from the outside, but rather, identifies with it. Consequently, a type of story is born which may be called an empathic narrative, based on identification and empathy (this tendency is particularly visible e.g., in such poems as "Dwa męczeństwa" ["Two Martyrdoms"] or "Czemu nie w chórze?" ["Why not in Chorus?"]). An empathic narrative, in which the speaker identifies with the recounted story and not with the meanings superimposed on it, stands in opposition to a parabolic narrative, just like mimesis does. Similarly, although for different reasons, the plot does not need to fulfil the function of a parable, although genetically - for example, in folklore - it did have parabolic ${ }^{9}$ functions; it may only be the domain of the fantastic.

8 Fletcher (Allegory, pp. 147-150) writes about the relation of mimesis to allegory, believing them to be utterly contrasting approaches.

9 Such is the case of the story of frozen words, thus genetically a parable, in Norwid's poem “Znów legenda" ["A Legend Again”]. Cf. J. Krzyżanowski’s essay "Norwidowa parabola o zamarzłym słowie," in: Paralele. Studia porównawcze z pogranicza literatury i folkloru (Warszawa: PIW, 1961), pp. 407-412. 
As a specific narrative method, the parable is its own literary genre. However, it belongs to genres which combine and coexist with other genres with relative ease, or are introduced into the area of another genre, and not just as quoted text (although this is also frequent). It is thus that type of literary construction where the general context in which it appears is particularly important. During the epochs in which the parable was a common literary technique, that context was immediately provided, in a sense. In the 19th century, the issue was quite different, as it became an outdated method. The context was the poet's choice to a much greater extent than ever before, dependent on the poet's individual decisions. Norwid introduces the parable in various environments which are far from typical. Here, I only discuss its functioning in lyrical poems, setting aside the matter of its presence in larger poetic compositions. Archaic construction in a previously unfamiliar context - that is Norwid's literary position. It also shows the difference between his parables and the greatest achievement of Romantic parabolic literature - Ksiegi Narodu i Pielgrzymstwa Polskiego. Despite all the uncommonness of that work, ${ }^{10}$ Mickiewicz restores the parable's former functions, while Norwid's activity in that area is far more complex. ${ }^{11}$

\section{2}

A poet as wonderfully and amazingly aware of literary matters as Norwid could not possibly be a novice to the problems the parable presents. It is expressed not only by the fact that he made this genre classification the subtitle of a few of his poems (it ought to be noted that not all of them meet the requirements for a parable, yet even in such cases the overt classification should not be disregarded, as it expresses the poet's intention). ${ }^{12}$ It was expressed in a note in one of his poetic letters to Lenartowicz (Na jakie stać mię, bracie - takieć piszę listy [I write you such letters as I can afford, brother]), where he speaks of "ciemna parabola o człowieku na gody prowadzonym" [the obscure parable of a man led to his nuptials], or in this explanation of "Człowiek" ["A Human"]: "Dzieciom w Polsce

10 Cf. the perfect analysis thereof in the above mentioned book by Stefanowska.

11 One more issue should be noted. In Ksiegi Narodu i Pielgrzymstwa Polskiego - as indicated by Stefanowska - the basic category is the figure. It is foreign to Norwid; his point of reference is usually allegory. On the difference between figure and allegory, cf. E. Auerbach, "Figure," in: Scenes from the Drama of European Literature (New York: Meridian Books, 1959), esp. pp. 54-55.

12 It may be worth noting that the subtitles usually contain the word "przypowieść", while in his theoretical considerations Norwid prefers to use the word "parabola" (both translating to "parable" in English). 
mówią, iż człowieka na świat przynosi bocian lub żuraw: w czym leży parabola, iż z górnych stron i od wschodu ludzkość bierze początek" (PWsz I, 272) [Children in Poland are told that a child is brought into this world by a stork or a crane: in which lies the parable that humanity takes its beginnings from the above and the east]. That comment on a typical answer to a child's question of where they came from is perhaps not quite a theoretical reflection on the parable, but perfectly illustrates how the poet viewed this category. The following difficult prose fragment from Milczenie [Silence] takes a different approach to the issue already discernable in the stork story commentary:

Pochopnie, lubo nie najrozważniej, mówi się, że: „parabola nie dowodzi niczego...” Jużci tak jest, bo paraboli zadaniem nie jest dowieść, ale u-oczywistnić - jedna zatem parabola oczywistni, lecz wszystkie razem uważane parabole nie tylko że dowodzą, ale dowodzą one tak bardzo ogromnej rzeczy, iż strach święty bierze pomyśleć o tym!... Dowodzą one albowiem analogijnego stosunku pomiędzy prawami rozwoju rzeczy świata tego a prawami rozwoju ducha... (PWsz VI, 236)

[It is said hastily, though not the most wisely, that "the parable proves nothing..." 'Tis true, for the task of the parable is not to prove, but to make-obvious - thus one parable makes things obvious, but all parables treated together not only prove, but they prove such an immense thing that to think of it makes you shudder in holy fear!... Because they prove the analogous relationship between the laws of development of the things of this world and the law of development of the spirit...]

Here, Norwid approached the issue philosophically, but the category appeared in his considerations on art, as well. In the essay Obywatel Gustaw Courbet [Citizen Gustave Courbet], the poet wrote:

Podziwiać tylko zostawało tę niesłychaną delikatność, z jakową Gustaw Courbet potrafił ciężką prawdę objąć w najlżejsze włókna nie każdemu od razu widnej paraboli, i samemu niejasnej mistrzowi. (PWsz VI, 486-487)

[The only thing left to do was marvel at that unparalleled delicacy with which Gustave Courbet could envelop the hard truth in the lightest fibres of a parable not immediately visible to everyone, and not [fully] clear to the maestro, either.]

The parable is thus both a philosophical and artistic category here. Both "this world" and a work of art have a two-level structure; the task of the parable is to catch the analogy. The poet's calling, according to Norwid, is - in Błoński's words - "to read the signs spread by Providence throughout reality (and not just the historic one, naturally)." ${ }^{13}$ A poetic work whose essence is to read the world's

13 J. Błoński, "Norwid wśród prawnuków," Twórczość 1967, vol. 5, p. 77. Elsewhere (p. 87), Błoński notes that Norwid applied literary categories to reality and made them 
existing signs cannot be a description thereof in phenomenological terms. On the one hand, it is a homological structure in relation to the world's structure, and on the other, an interpretation thereof - not quite a notional interpretation, but rather an evidential, "demonstrational" one. Those conditions are easily met by allegory as a two-level and at the same time interpretational construct, intellectually saturated, referring to a doctrine, free of any randomness. Norwid is "anima naturaliter allegorica," ${ }^{14}$ and allegories are at the core of his poetic system. This also concerns parables, namely continued and developed allegory, allegory in motion; yet it ought to be noted that the issue of allegorisation is not limited to matters of parabolic narration, although the latter may be the central issue of this area's discussion. Norwid also uses a type of allegory which could be called emblematic; he uses allegories such as personification and materialisation of the abstract. The search for just one type of allegory must be protested categorically - especially the interpretation of poetic visions as allegories of the poet's life events. It is not known why, for example, the image of Greece as a statue (in the poem "Marmur-biały" ["White-marble"]) should be the image of Mrs Kalergis; it seems as though that romantic grande dame has turned the heads of some of Norwid's exegetes rather than his own. Such interpretation of any poetry - and especially Norwid's - is doomed to arbitrariness, and mostly trivialises it. ${ }^{15}$ For this reason, I do not take such "allegories" into consideration, deeming them to be pseudo-allegories. Those strange aberrations do not contradict the fact that Norwid's researchers were aware of the role which allegory played in his works, as well as defined the parable's place within it. Here one must note the pioneering comments made by Miriam, who wrote of the parable in connection with such works as Wita Stosa pamięci estetycznych zarysów siedem, "Pokój," "Dwa męczeństwa" [In Memory of Veit Stoss - Seven Aesthetic Sketches, "Peace," "Two Martyrdoms"]. ${ }^{16}$ One ought to mention the study by Irena Sławińska ${ }^{17}$

elements of his historiosophy, and so the parable should be included among those categories. Incidentally, Norwid is not entirely original in that tendency, following a practice introduced by Vico in Scienza Nuova and common in Romanticism, just to mention the theoretical works of Victor Hugo.

14 The expression is borrowed from Nuttall, Two Concepts of Allegory..., p. 152.

15 Cf. the above cited Hamilton's book on criticism of such activity consisting in reading real historic figures into allegorical creations.

16 Z. Przesmycki (Miriam), "Przypisy wydawcy," in: Cyprian Norwid, Pisma zebrane, vol. A - part two (Warszawa: Jakub Mortkowicz, 1911), pp. 831, 972 and 1044.

17 I Sławińska, "O prozie epickiej Norwida," Pamiętnik Literacki, 1957, vol. 2, pp. 467-498. 
which analyses the parabolic structure of short stories. J. W. Gomulicki ${ }^{18}$ also made many valuable observations in this area - when he was able to free himself from treating poetic works as biographic records.

In the works of a poet committed to "reading signs," allegory (and, in effect, its specific form: the parable) had to play a role. It is an element of a more extensive phenomenon, immensely significant for Norwid's works; there is a tendency within it to treat the object of consideration as an item for dual interpretation literal and essential. The two levels of meaning are not only a semantic process used in this poetry, but in many cases also the protagonists. A good example is the already quoted explanation of why it is said that babies are brought by storks. For Norwid there are no random stories, images or superstitions without deeper meanings. The poet is the one to reveal them; a poem contains the process of such revelation, and the work itself becomes a quest for meaning - even if it only concerns two buttons at the back of a dress. That is the difference between Norwid and the allegorists of former epochs. They did not question meanings or sense in most cases, they felt certain and comfortable in that area, the domain of meanings was defined and provided in advance, while Norwid looks for meaning when he is certain that the commonly given answer is false, and thus may only become an object of ridicule. One of the best examples is a poem dedicated to common interpretations of various everyday events; the poem exists in several versions, and one of them is titled - characteristically - "Sens-świata" ["Sense-of-the-world"]:

Do uczty gdy z gwarem siadano za stół,

Mnie jednemu zbrakło siedzenia:

Tłumaczy to zwyczaj, bym za złe nie wziął,

Wróżąc, iż traf taki - ożenia!

(“Sens-świata," PWsz II, 117)

[When seats were taken at the table amidst the buzz of voices,

I was the only one lacking a seat:

Custom explains, not to take it as a bad omen,

This chance occurrence - predicts a wedding!]

18 J. W. Gomulicki, “Komentarz,” in: C. Norwid, Dzieła zebrane, vol. II (Warszawa 1966). Cf. mentions of the parable in S. Kołaczkowski's classical study "Ironia Norwida," in: Portrety i zarysy literackie, ed. S. Pigoń (Warszawa: PIW, 1968) and S. Świontek's article "Paraboliczność struktury scenicznej Pierścienia wielkiej damy C. Norwida," published in a book Dramat $i$ teatr by various authors, ed. J. Trzynadlowski (Wrocław: Zakład Narodowy im. Ossolińskich, 1967), pp. 45-59. 
Such a "sense of the world," contained within widespread, common beliefs, can only be turned into irony. In such cases, however, the irony does not question the principle itself, but turns against flat or trivial interpretations. The principle remains one of the basic factors organising Norwid's poetry. In the poet's view, the inability to ask questions about the sense of things is discrediting:

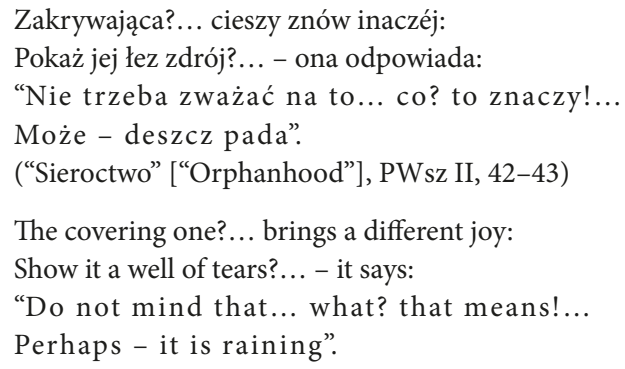

"Sieroctwo" introduces antinomy, so typical of Norwid, although in this case both its elements are ironically negated: covering and discovering. Discovery is the set of cognitive activities inscribed in the poem, the effort of uncovering the truth which is recorded in the poem itself. ${ }^{19}$ Allegory (just like its parabolic form) is harnessed into those activities and becomes a cognitive tool. ${ }^{20}$ However, this basic feature of Norwid's poetics does not merely concern the allegory, but extends its reign over all the story elements present in his poetry. As parts of the discovery process, they cannot become the main object of focus, either, they cannot be a story for the sake of a story, they are never justified by mimetic aesthetics. So, is every story about facts actually a parable here?

As has been mentioned before, there is a difference between the parable and empathic narrative. There are also other, different forms, although it seems that many intermediate approaches can be found. Those can definitely not be treated as parables, yet one cannot overlook the occurrence of elements typical of the parable within those other forms. In Norwid's early work, the legend is such a form - that is the term he provided in the subtitles (and in one case, in the title) of several narrative poems. They definitely mean more than they mean, the

19 Cf. Błoński’s comments on the topic, "Norwid wśród prawnuków," p. 88.

20 An excellent formula of allegory, not quite free from irony, was proposed by Musil: “... an intellectual device to make everything mean more than it has any honest claim to mean" (R. Musil, The Man Without Qualities: Picador Classic, transl. S. Wilkins (London: Picador, 2017), p. 442.) 
general message shines through the narration, and is sometimes even expressed openly in the ending:

Więc był Apostoł Paweł pętany jak zwierzę,

I jako Bóg obwołan - a wytrwał przy wierze,

Że człekiem był. - Albowiem stało się wiadomo,

Że człowiek zwierząt bogiem, gdy Bóg: ecce homo.

(“Dwa męczeństwa," PWsz I, 121)

[So Peter the Apostle was bound like an animal,

And called a God - and he abided by the faith,

For he was a man. - For it became known

That man is the god of animals, when God: ecce homo.]

It is thus undoubtedly an element of the parable. Yet some significant differences can be noticed. In this case, the generalising conclusion has a much stronger connection with the narration and recounted events than in a typical parable; it results directly from those events, follows from their order, and is formulated in the same language used to describe them. The same thing also happens in the legend "Amen," where a story from the era of Christian martyrdom is directly modernised in the ending; again - as shall be further noted - modernisation is one of the privileges of the parable. But in the discussed poem, it is implemented in a slightly different manner: it is not a statement, a "moral," a conclusion, but a vision of the future. One may say that the poet conducts a certain revaluation or translation, changing the language of a story into the language of prophecy. In the later period of his work, when the parable gains the dominant function, Norwid no longer practises such methods.

Another difference is that in legends, a strong emphasis is on the narration itself. The poetic narrative "I" is visible mainly in the verbalising of events within a story, while in the parable the speaker identifies mainly with the general meanings imposed on him or her. So when the subject speaks directly, his words concern the narrative content:

Na greckim rynku ludzie zgromadzeni stali,

Pod łagodnego cienia rzucanymi plamy

Od dziadów, którzy w błękit powracali - biali -

Od bohaterów, mówię. [...]

(“Dwa męczeństwa," PWsz I, 118)

[People gathered in the Greek forum,

Under the patches of gentle shadows thrown

By the ancestors who returned into the blue - all white -

By the heroes, I say. [...]] 
Powieść tę w chacie kmiecej nad Bugiem słyszałem:

Był dziad, którego Dziwem zwano osowiałem;

(“Znów legenda," PWsz I, 130)

[This story I heard in a peasant's cottage along the Bug river:

There was an old man, called an Odd glum thing;]

There are various reasons behind this. Particularly important is the fact that narration is not a creation here, but a kind of repetition of an already known story known to either hagiography or folklore. The narrator may reveal the very act of speaking, as the aim is not to give autonomy to the outlined story, but to stress that it is a repetition. ${ }^{21}$ It is worth noting that the poem "Wzroki" ["Eyesights"], defined as a parable in the subtitle, is closer to Norwid's legends than parables proper - even though it contains allegories and no fantastical elements. This is because the narration within it is largely independent. It may be surmised, that in this case the subtitle was mainly intended to indicate the narrative nature of the work.

One more such intermediate case should be noted, even though it is actually represented by only one poem, namely "Sen" ["Dream"]. It is basically constructed as an account of a dream, although the first line ("Miałem sen, nie wiem, o ile bezsenny" [I had a dream, I know not just how sleepless it was]) already forces the reader not to treat it as one. Poems composed as dream accounts have been the realm of allegory for ages. Thus, Norwid calls upon a sanctioned tradition, an immensely significant practice for pre-Romantic literature. His poetic "dream" is definitely parabolic in character. The story, the "dream vision," is extremely disciplined and based on contrast, which - as usually happens in a parable - is a moralist contrast. In all appearances, the account leads towards a clearly outlined conclusion. Yet that conclusion is different than in a parable, as it does not refer to general truths, but to the protagonist's individual situation, so its nature is not moralist, but psychological. There is, therefore, an unusual arrangement in this poem, completely exceptional for Norwid, present likely only in this one work: individual events have not been subordinated to general parabolic meanings, but quite the contrary - elements of the parable (undoubtedly present) add to the knowledge of his individual, unique situation. In parables proper, Norwid does not use the motif of a dream, not even in its traditional role - he does not give it the function of a motivator of what composes the narrative. His parables need no justifications of the kind.

21 The disclosure of narrative decisions is one of the important features of Norwid's poetics, although in other poems it is usually connected to digressive poem traditions. 
"Sen," so untypical among Norwid's other works, still represents a phenomenon of great importance to him: he uses genre-characteristic approaches within works which are not in that particular genre (even if the genre is not unfamiliar to the poet), introduces them in context not provided by tradition, and so this fact alone assigns them new functions and meanings. This practice is particularly important for Norwid's allegorisation. Where allegory was expected according to traditional rules of the literary game, for example, through genre customs, it may appear only negated in Norwid's work. An allegoricaldidactic tale may only be a mockery of the tale as a genre (e.g., in the poem "Bajka" ["Fairytale"]), persistent allegorisation of minor items from everyday life in the style of former didactic works may only be a satirical game, a play with clever wit (cf. "Co słychać?" ["What's New?"]). ${ }^{22}$ The parable appears in lyrical poetry - a genre it did not use to appear in before (leaving aside the issue of whether or not the category of lyrical poetry fits the poet's mature works). Norwid's original take on literary genres was certainly one of the reasons for conflict with his readership.

\section{3}

An early form of Norwid's parable is extended comparison. In his study on Quidam, Łapiński noted that comparisons based on external similarity are rare, as metaphorised aphorism encroaches upon them, and the point of reference is always the mental background. ${ }^{23}$ Those similes, as detailed as the Homeric ones, although completely different ${ }^{24}$ in nature, appear not only in elaborate epic compositions; they work just as well in small lyrical poems. Here, they may also include an element of action - like with Homer - although it is not meant to describe or imitate some other activity, but rather serves to indicate intellectual activities, moral problems, and so on. Activities in the physical world are devoid of autonomy in those similes. The aim is not to introduce a visual detail which would be valuable in and of itself, so they are mostly treated instrumentally:

22 For this reason, it seems wrong to use the term "apologue", as Błoński did in his essay on Norwid.

23 Z. Łapiński, “Obrazowanie w Quidamie,” Roczniki Humanistyczne Vol. VI, 1958, No. 1, pp. 134-135, 168. Cf. K. Górski's comment on the issue in the study "'Ad leones!' (próba analizy)," in: K. Górski, T. Makowiecki, I. Sławińska, O Norwidzie pięć studiów (Toruń: Księgarnia Naukowa T. Szczęsny i S-ka, 1949), p. 88.

24 On Homeric simile cf. H. and A. Thornton, Time and Style. A Psycho-linguistic Essay in Classical Literature (London: Methuen, 1962), esp. pp. 5-6 and 51. 
Od rezultatów mylnego zamętu

Z kagańcem w ręku do przyczyn zstępuję,

Jak smutny żeglarz po schodach okrętu,

Kiedy kotwicy szuka... burzę czuje...

([“Od rezultatów mylnego zamętu...”], PWsz I, 137)

[From results of mistaken confusion

I descend to causes with a lamp in my hand,

Like a sad sailor descends the ship's stairs,

Looking for the anchor... sensing the storm...]

An action within any simile, especially one as intellectualised as in the abovequoted stanza, cannot exist independently. It thus resembles a parable and leads directly to it. Such a construction is not Norwid's invention - Mickiewicz used it, ${ }^{25}$ too, and its tradition can be traced back to the Bible. The singularity of this approach lies in the fact that with Norwid, it also appears in areas which were absent from any other poet. In Romantic lyrical poetry, an extended simile could be observed to disappear; even if it occurred, it served a descriptive purpose or - first and foremost - was connected with the creation of the speaker as experiencer, and so was rather a matter of expression than reflection. In Norwid's poems, it serves various functions, but it is usually not a simple "translation" of abstract ideas into the language of the specific. It brings the idea closer rather than translates it, more so by the fact that - as Lapiński clearly demonstrated - the strictly "intellectual" part of the simile is not notional reasoning, but a highly metaphorised statement, employing various privileges of poetic speech. The similes - with the quoted stanza being a distinct example - are not constructed as a clash of heterogenic languages. Sometimes, the extended comparisons appear in an almost paradoxical role, in places never used for them traditionally. The poem may be a lyrical discourse (like "Wielkość" ["Greatness"]), the simile appears in its ending - and suddenly becomes the point:

Podobnież niedźwiedź: pierw trupa zakopie,

By dobył z trumny.

Lecz to w Syberii, nie zaś w Europie

Bywa rozumnéj.

(“Wielkość," PWsz I, 349)

25 Stefanowska writes of the phenomenon appearing in Ksiegi Narodu i Pielgrzymstwa Polskiego in her Historia i profecja, pp. 147-149. 
'Tis similar with a bear: first it buries the body,

To later retrieve it from the grave.

But this in Siberia, not in reasonable Europe

Happens.]

The simile may be so extended (in "John Brown," only one part takes up a whole 10-line stanza) that it actually gains autonomy, it is taken as an independent description or story, and only when reading further can it be seen to return to its actual role. This happens when the second part appears ("Tak, wy" [You, too] - in the above cited "John Brown”). In one case - the poem “'Ołówkiem” na książeczce o Tunce" ["'In pencil' on the booklet on Tunka"] - the whole work is filled with two extended simile parts parallel to one another, while the second part is in each case reduced to one line of a mere five syllables, which makes it as good as omitted: “- Tak... w owej «Tunce»!..." [- Yes... in that «Tunka»!] It suffices to quote either of these two stanzas to see how highly parabolised the simile is:

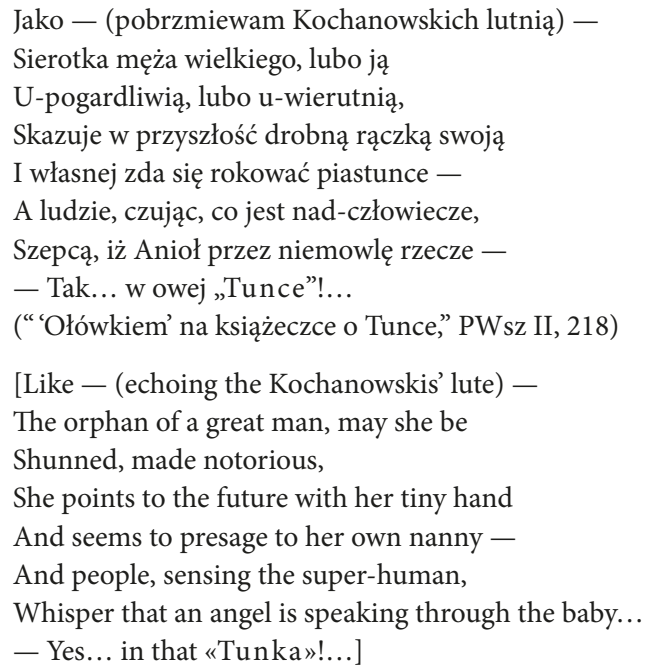

When one part of a simile is saturated so highly with elements of a parable, its connection to the second part loses significance. Another tendency also appears: the whole poem being one huge simile - as happens in "Święty-pokój" ["Blessed Peace"] and in "Słowianin" ["The Slav"]. The poet does not juxtapose heterogenic approaches; both parts, together forming a stanza, are dynamised visions in which the boundary between narration and description is impossible to identify. Those visions - like in a proper parable - are detailed and general at the same time. In "Słowianin," the poet gives a clear, direct indication of his 
parabolic intention, when he advises Lenartowicz - the poem's addressee - in a parenthetical interjection: “Co sam sobie w jaśniejszą alegorię zamień!” [Which you yourself can turn into a clearer allegory!] The relation of a simile to a parable may be even closer - when the parable is simply introduced by the word "jako" [like]:

Wiedzy spółczesnej kierunek-przyrodny,

Powodujący wszystkość umysłowę,

Zda mi się jako MŁodZIEŃCZYK dorodny,

Co zwiedzał Grecji brzegi safirowe -

Lecz gdy pochylił w cieniu kolumn głowę,

S e n mu usunął ziemie i narody,

Miasta, miast gruzy, ludzkości oblicze:

I z Aten przewiał go w Lasy-dziewicze...

("Naturalizm [Spółczesny ekstrem]" ["Naturalism [Modern Extremum]”], PWsz II, 229)

[The natural-direction of modern knowledge,

Causing mental completeness,

Seems to me like a handsome Youth,

Who visited the sapphire coast of Greece -

But when he bowed his head in the shadow of columns,

Sleep took away lands and nations,

Cities, ruins of cities, the face of humanity:

And blew him from Athens over to Virgin-forests...]

Sometimes the simile introduces a new parabolic element in a poem otherwise already close to a parable. Such is the case in the second stanza of "Przeszłość" ["Past"]. In the last of the discussed approaches, the boundary between simile and parable actually blurs, and the reader enters into the unquestionable realm of the parable. You do not need an "as" or any other word to suggest a juxtaposition of the two elements. Yet - perhaps not always, but often - a mechanism similar to that of a simile is active within the parable. In a sense, a parable has to consist of two parts, like a simile, with the one difference that the other element may be merely implied and not verbalised - mainly as the doctrine which lies at the basis of the story, a doctrine known not only to the author, but also to his virtual readers. With Norwid, that other element of the parable is often absent from a poem, although in many cases it is formed by the lyrical discourse into which the parable has been composed. Both those cases are equally important and need to be analysed.

Let us start with the parables clearly fixed into the context. That context guarantees the parable's interpretation. It acts most often as an exemplum, and 
in the sphere of the concrete expresses those poetic issues which have saturated the discourse. Sometimes it is limited to a mini-insertion, just a brief example:

Dziś właśnie przeto nic nie jest dostałe

W życiu i w sztuce, i w dziejów osnowie,

Że, co się robi, w myśli pierw jest całe,

Czyli ułomne, bo dopiero w głowie.

I nikt nie waży się, czy on dokona?

(Przykładem męża, co ma stawić wieżę,

Lecz zali wieża może być stawiona?...) -

(“Teofilowi” [“To Teofil”], PWsz I, 232)

[And so today nothing is ripe

In life and art, and in history,

As what one does, is first complete in thought,

Meaning defective, for it is only in the head.

And no one wonders, can he accomplish it?

(Like a man who is to build a tower,

But can the tower be built?...) - ]

Here, one can observe the relatively close fusion of the parable and the discourse, which results, for example, from the fact that the parable is actually too small to become independent. Yet this is not a rule. It is worth noting in the first place that the passage from discourse to parable does not have to be signalled, quite contrary to the quoted example (here, the passage opens with the word "przykładem" [like]). In general, in such situations Norwid avoids words which would indicate that the parable acts within the discourse on special terms. It is thus usually not a quotation, it appears as a quote only if the speaker is clearly defined in a situation built by dramatic means - and so the parable of the three pyramids, provided by Wariat [Madman] in the dialogue "Scherzo [II]," is preceded by the words: "I tę wam tylko powieść dam." (PWsz I, 140) [And I shall give you this story only.] This blurring of passage between the discourse and the parable might prove the tendency of a maximal fusion of the two. However, the matter is far more complex. In a sense, that fusion is a fait accompli, since there is no clear distinction between general considerations and an example. This is enhanced by the fact that in most cases - like with the similes - Norwid avoids strict distinctions between the "notional language" and the "poetics language." His reflections appear in a language where - even if constructions yielding to logical analysis are present - approaches typical mainly of poetry dominate. The uncommon and original nature of Norwid's poems lies among others in the fact that he combined those two spheres in an unprecedented manner to literature. Such a tendency assures advanced unity, 
yet there is also another tendency in lyrical poetry which is equally unprecedented (and certainly not just in Polish literature). It may be termed free editing, consisting in the loose combination of elements, developing the poem in a manner justified by neither its object nor the situation it presents. Norwid's editing is a matter of immense significance which requires a separate and extensive analysis. In this paper, I can only say that parables are an important component of those free editing constructions. The case when a parable is tightly fused with the discourse surrounding it, as well as clearly subordinated to it, I shall call a hypotactic composition. The case when a parable is loosely embedded in the discourse and appears to disturb its flow will be termed a "paratactic composition."

A paratactic composition is by no means revealed just through the juxtaposition of notional reasoning and a specific story. A parable introduced in a loose combination is simply more narrative than the context and has a different topic:

Treść - wypowiesz bez liry udziału,

Lecz dać duchowi ducha,

Myśli myśl - to tylko ciało ciału.

Cóż z tego? - martwość głucha!...

Handlarz także odda grosz zwierzony,

Lecz nie odda wesela -

Nie uściśnie ręki zawściągnionéj;

Maszże w nim przyjaciela?

O! żar słowa, i treści rozsądek,

I niech sumienia berło

W muzykalny złączą się porządek

Słowem każdym, jak perłą!

(“Liryka i druk," PWsz II, 24-25)

[Content - you can give without the lyre,

But to give a spirit to the spirit,

A thought to the thought - that is merely giving body to the body.

And what of it? - hollow deadness!...

A tradesman will also return the entrusted coin,

But not the joy -

He will not shake the withheld hand;

Is he a friend to you?

Oh! the heat of the word, and the sense of the content,

And the sceptre of conscience

Will join in musical harmony

Each word like a pearl!] 
This example is particularly interesting for a number of reasons. First of all, the poet himself had to be aware of the relatively loose connection of the parable of a tradesman with the context, as he deleted it in a later version of the poem, described in Gomulicki's 1966 edition as "an attempt at new editing." True, in this programme poem, the parable creates only a distant analogy towards the main object and definitely disturbs the flow of the main course of reflection. However, even here where the rules of a paratactic composition are so clearly at work, the poet suggests a connection between the parable and the context, a strictly formal connection. The word "także" [also] serves this purpose, which allows the reader treat the given example as a continuation of something that came before. Some grammatical procedures are at work here, as well: the whole poem is typical Du-Lyrik, where the basic compositional approach is directly addressing the interlocutor. The second person singular also appears in the stanza about the tradesman, and so the fragment is included in the general development of the poem.

An unusual example of paratactic composition is parallel approach. It is worth noting its two basic versions. The first concerns a parallel layout of exempla, concise and thematically homogenous, which in a way enable the conclusion formulated at the end. There is a certain amassment, without dramatic turns of the elements (such poems as "Klątwy" ["Curses"] and Vanitas are built in that manner). The other version is more interesting: there Norwid creates strict parallelism between a general statement and a parable:

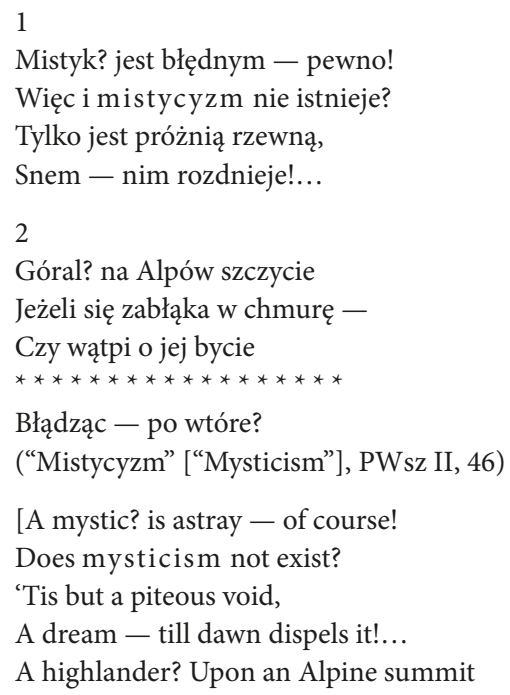


When straying in a cloud -

Does he doubt the cloud's existence

$* * * * * * * * * * * * * * * * * *$

When astray - again? $]^{26}$

Formally speaking, that is quite an advanced parallelism, equipped with distinct equivalents: mystic/highlander, the existence of mysticism/the existence of the cloud, going astray metaphorically/going astray literally. Yet as a narrative subordinated to discursive content, the parable cannot be merely a component of parallelism, and so - despite the appearance of full parallelism to the discourse - it is a commanding element in "Mistycyzm." What is more, it was given a very responsible function, as it is the answer to the question formulated in the directly reflexive part of the parallel sequence. Thus, it is more a point than an exemplum.

In a hypotactic composition, the most significant phenomenon is the interweaving of the two elements: the discursive and the parabolic. In fact, the parable cannot be clearly distinguished; it is linked closely to the reflexive context. Those compositional rules are visible in such well-known poems as "Przeszłość" or "Laur dojrzały" ["Mature Laurel"]. The first sentence:

Nikt nie zna dróg do potomności,

Jedno - po samodzielnych bojach;

("Laur dojrzały," PWsz II, 100)

[No one knows the paths to posterity,

But through solitary struggles; ]

is a highly intellectualised maxim formulating a general thought and - at the same time - initiating the parable. The parable is uncommon and paradoxical, as it tells of someone named No-one entering an allegorical temple. The poem develops in overlapping planes at the same time: it is simultaneously reasoning and storytelling, and both jointly aim towards the final generalising reflection, intellectually clear like an aphorism and narratively closing the account of that no-named No-one (= everyone) who set out to obtain the mature laurel. The unity of the discourse and parabolised story is expressed through the reflexive generalisation being realised in a language whose main domain is the parable, and the parable is permeated by linguistic elements which are at home in the discourse.

26 English translation by Danuta Borchardt in collaboration with Agata Brajerska-Mazur, in: Cyprian Norwid, Poems (New York: Archipelago Books, 2011), p. 41. 
A similar thing occurs in "Przeszłość." 27 It starts with a general reflection, and a figure is introduced into it ("ów, co prawa rwie" (PWsz I, 18) [he who breaks the laws]) who becomes the subject of concisely signalised actions. Here you can already notice an outline of the unity of the discourse and the parable, although at this stage it is still merely an outline. The second stanza has another parable (of a "dziecko, co wozem leci" [child dashing by in a cart]) introduced on terms resembling the simile, and fully narrative. The closing stanza provides a summary: the aphorism is accompanied by elements taken from the parable. The parable ceases to be an example and enters the discourse:

Przeszłość - jest to dziś, tylko cokolwiek daléj:

Za kołami to wieś,

Nie jakieś tam coś, gdzieś,

Gdzie nigdy ludzie nie bywali!...

(“Przeszłość," PWsz II, 18)

[The past is here today, and today is even further:

Beyond the wheels the village is there,

Not - something, somewhere,

Where people never gathered!... $]^{28}$

Such overlapping of the two spheres does not have to occur throughout the poem. Sometimes it happens over one stanza, with only a secondary impact on the general composition of the poem:

Lecz ten $\mathrm{z}$ wszystkich nieudolny lekarz,

Kto, nie wiedząc, z chorób leczyć którą?

Pomięsza dwie - nie mędrzec! - aptekarz!

- Prawda? - nie jest przeciwieństw miksturą...

(“Królestwo," [“Kingdom”] PWsz II, 63-64)

[But among doctors this one is incapable

Who, knowing not which disease to cure?

Mixes both - no sage! — a pharmacist!

- Truth? - is not a concoction of contrasts...]

The hypotactic composition peaks when the fusion of discourse and parable becomes so strong that the boundaries between them blur. Many features of Norwid's poetry are at the root of that. Mainly, to allow that to happen, the context

27 Cf. analysis of this poem in R. Jakobson's “Przeszłość Cypriana Norwida," "Pamiętnik Literacki" 1963, vol. 2, pp. 449-456, as well as M. Jastrun's considerations on the topic in Gwiaździsty diament (Warszawa: PIW, 1971), pp. 228-233.

28 English translation by Danuta Borchardt, p. 21. 
in which the parable appears has to meet certain criteria. In Norwid's poems, the parable appears in a variety of contexts, starting with a prayer (cf. "Psalm wigilii" ["Christmas Eve Psalm"]). The fusion of both elements is favoured most by such discourse in which general notions are treated with a more or less distinctly narrative approach, where they are specified, and so allegories appear, either overtly or discreetly covertly, often resembling personification. Such are the approaches towards which the above-analysed poems were inclined.

This fusion is favoured by a tendency characteristic of all of Norwid's works (and subjected to multiple critical analyses): a specific dialectic of the general and the detailed, the generic and the specific. There is no general reflection in that poetic work which would not be rooted in some realities, and no detail which would have been only a detail, unrelated in one way or another to broader issues. It was succinctly summarised by Sławińska: “The general truth must be related to the genuineness and authenticity of a detail."29 And further: "Even at strong close-ups $[\ldots]$ the generalising sense of the poet is active."30 Striving towards such a synthesis creates favourable conditions for the development of any kind of parable, and especially for a parable hypotactically related to the discourse. In a way, the parable is in and of itself an arc of covenant between the detailed and the general.

That love of detail Norwid has requires reflection. Wacław Borowy wrote about it, ${ }^{31}$ relating it mostly to the tradition of sternism. It is undoubtedly an important tradition, yet it should not overshadow the fact that Norwid was a man of his times, times when literature was fascinated with the everyday, the common little realities and events. That fascination covered not only belletrist prose - although, understandably, there it was able to be expressed to the fullest - its impact did not overlook poetry (as proven e.g., by Heine's works). In short: Norwid uses the achievements of realistic poetics, but for his own purposes, introducing them into the realm of his own aesthetics. He does not approve of the novel, but is active within its range of impact. What used to be the discovery and privilege of prose, he transfers to the parable. It might be said that he draws on the building material but uses it differently from its usual purpose and gives it new functions. The detail, the good old realistic detail, loses its connection with mimetic aesthetics and becomes a vehicle for general meanings.

29 I. Sławińska, O prozie epickiej Norwida, p. 470.

30 Ibid., p. 484.

31 W. Borowy, Główne motywy poezji Norwida, in: O Norwidzie (Warszawa: PIW, 1960). In this vol. see: W. Borowy, Leading Motifs in Norwid's Poetry (pp. ???). 
The poet's inclination towards minor everyday life scenes, the realities of the average day, may just be the most emphatic confirmation of the thesis that the parable may take anything as its object, for it is not the fabric that counts but the cutting thereof. Norwid cuts the fabric in his own fashion, contrary to the aesthetic habits of his time. Such proceedings were necessary to subordinate the detail to general meanings. A set of details did not have to form a cohesive, closed construction. A series of events from everyday life did not have to seek a narrative ending. Viewed from a certain perspective, the parable is a type of noncontinuous statement, and its sense is not exhausted within a closed story layout, as it belongs to a different order. In the cases analysed so far, that discontinuity does not hinder interpretation - it has a precise motivation; since the parable is settled within the discourse, it depends on its development, and may even be limited to a mini-insertion, just a parabolic molecule. The matter is far more complex if the parable occurs on its own.

There is only one area in which Norwid does not use the experiences of realism when composing a story: in the construction of protagonists. This is important not just for dramas, epic poems or stories, but also for small poems if you consider with what intensity narrative approaches occur in them. In this area, the poet is fully faithful to the parable's tradition. His protagonists are not individualised, which can already be seen in the fact that they are not given any proper names, but defined exclusively by the use of general categories. You thus read of a husband, a lady, a youth, a sailor, a carpenter, a mandarin, a doctor, and so on. In one case, already mentioned, the protagonist is named No-one; in another, in the poem "Czemu" ["Why"], no name appears at all - in fact, the main protagonist of the parable is the person addressed („Próżno się będziesz przeklinał i zwodził,/i wiarołomił zawzięciu własnemu - “; PWsz II, 118 [You will in vain curse and delude yourself/and break faith with your own relentlessness]). This unusual onomastic practice emphatically reveals the tendency for generalisation. The action of someone defined as a husband or a doctor and presented only through a rough sketch of a situation cannot be motivated naturalistically, psychological justifications and likelihood considerations are just as inapplicable. ${ }^{32}$ Fletcher ${ }^{33}$ provided extensive analysis on the construction of an allegorical protagonist: wherever they appear, they are directly subordinated to intellectual conceptions, they may be a "walking embodiment of an idea," they do not develop, they are presented emblematically for the most part, they are

32 Cf. on the same topic R. Tuve, Allegorical Imagery, p. 397.

33 A. Fletcher, Allegory..., pp. 25-69. 
never masters of themselves but always have their own demon which defines their actions. Those general considerations perfectly match Norwid's parablepoems: the motivations behind the protagonists' actions - even more: for their existence - are to be found exclusively in the ideological plan. This is bound with a consistently adhered to schematic. In those poems where the parable does not cover the whole text but is rooted in the discourse, that schematic is even more distinct than in epic poems and short stories, which require at least a minimal degree of epic matter. The protagonists of the works discussed here usually act on their own, in a manner of speaking, as they are presented not in conflict with other allegorical figures representing different values, but - almost as a rule - in one individual situation.

One more thing requires emphasis: in the poems analysed so far, there is a significant similarity between the parable's protagonist and the speaker of the lyrical discourse. The speaker is not individualised, either, far from the exuberant "I" in Romantic style; in most cases, he is sketched ascetically in the poems and does not use the parable to confirm his own narrative powers or emphasise the significance of his own subjective decisions. The speaker hosts the parable not as an individualised personality whose main objective is self-expression, but as the proclaimer of certain views grounded in a set of beliefs considered common and binding. The speaker (by Romantic criteria - largely an impersonal subject) is realised in the lyrical discourse, and the parable results from its general order; it would have been quite a different matter if the parable functioned, for example, on the same terms as narrative fragments in a work constructed according to the rules of a digressive poem.

\section{4}

In the cases analysed in the previous chapter, it was not difficult to identify the parable: the task was facilitated by the clear relationship of the narrative element towards the discourse. The matter becomes more complex when the story of a fact is free of such discursive casing. Norwid wrote many poems which only appear to present the story of an event, or the account of a scene. In most cases, however, it is not the kind of narrative poetry dominated by fascination with events in their specific, unique shape; those are also subordinated to general meanings, although the degree and clarity of the subordination vary. The narratives here are also shaped into a parabolic form. Yet, what authorises anyone to say that the given poetic narration is a parable? Norwid himself introduced factors into his poems which allow one to say that with a relatively low degree of risk, as he created intratextual interpretation indicators which 
signalled that the given narrative should be understood as a parable. Norwid used indicators of various kinds; the most distinct one is likely when the ending contains a general conclusion resulting from the story. The conclusion is discursive, there is no other option. However, a different relation of narration to discourse is observed here: it is not the narrative which is implemented into the discourse, but quite the contrary - the discourse (usually in minimalist form, often limited to the point) results from the narrative and is formulated with a close dependency upon it. Its task is in a way to translate the language of events into the language of ideas:

Belizarius, gdy rzymskie osadził okopy

Grecką jeszcze falangą z Konstantynopola,

Nie było czym już miotać na germańskie chłopy:

Marmurowego z wałów więc dalej Apolla,

Dalej Jowisza z brązu, tudzież innych bogów,

Grek, co je tworzył, ciskał z okopu na wrogów.

- Ale jest Bóg, którego i rzymska załoga

Rzucać, gdzie chce, nie może... choćby też na wroga!

("W albumie Juliana Dłużniewskiego" ["In Julian Dłużniewski’s Album"], PWsz I, 300)

[Belisarius, when he manned the Roman trenches

With the Greek phalanx back from Constantinople,

They had nothing left to hurl at the Germanic power:

So the marble Apollo from the wall,

Then the bronze Jupiter, along with other gods,

Were thrown from the trenches at the enemies by the Greeks who made them.

- But there is God whom even the Roman garrison

Could not throw [away] wherever they felt like... even at an enemy!]

It must be said that there are elements encouraging allegorical interpretation in the narration itself - using statues of gods as weapons begs to be interpreted in this manner. Yet in the closing couplet, Norwid evokes a different interpretation than the one which the reader might expect - the story itself suggests a historiosophic reflection on the various fortunes met by works of art in history. And yet the couplet formulates a general truth of a religious nature, and in doing so subordinates the account to a defined sphere of beliefs; it is constructed in close relation with the story told. That is expressed not only in the juxtaposition ("but"); the closing statement revalues the narrative ideologically, imposes an unexpected meaning, but is still constructed from elements present in the story. Since the narrative spoke of gods thrown on the enemy's head, this statement announces the existence of a God whom no one wishes to or is able to throw away. The story of Belisarius' military actions would have been incomplete 
without that generalising ending, the reasons for telling it left unknown. The stories which Norwid narrates endeavour towards an ending, but it is not a narrative ending on the plane of the events, but a moralist one. Similarly, the generalising couplet would not be understandable as a self-contained aphorism; it is not comprehensible in and of itself, the story of Belisarius is its support and starting point. By fusing two elements, a parable clearly identifiable by its features was created.

An intratextual interpretational indicator equally clear to the final generalisation is a story where the main protagonists are allegorically personified abstracts or animated objects. Both approaches are quite common with the poet. ${ }^{34}$ Here, Norwid immediately adheres to a tradition which must have been familiar to his readers. Yet it is not unconditionally reproduced, either - the poet introduces new elements, for example, a paradoxical point. It can be seen in "Echa-czasu" ["Echoes-of-time"] (earlier titled "Saturnalia"), where the dispute between Philosophy and Wisdom is joined by other figures: one defined as somebody, and another as a citizen; thus the figures are shaped according to the customs of a parable, as can be seen by the mere fact that no proper names are given. In a different poem, "Addio!", the dispute between Truth and Popularity is joined by the lyrical speaker, who not only presents his own situation, but formulates a clear judgement. The overlapping of old-fashioned didactic poetry traditions and the fresh achievements of Romanticism can be seen with particular clarity here.

Another example of a parable in which the story told is not - at least officially - overtly subordinated to the discourse is found in poems where the discourse results directly from the dramatic situation, and is often a formula in the dialogue:

\footnotetext{
„Rzeczywistym bądź! co? ci się wciąż o niebie troi, Podczas gdy grób, prądami nieustannemi, Kości twoich, prochów twych pożąda!"

- Och! Tak, wszelako, gdziekolwiek człowiek stoi,

O wielekroć więcej niebios ogląda,

Niżeli ziemi...

(“Niebo i ziemia" ["Heaven and Earth”], PWsz II, 86)

["Be real! why? do you keep on fancying heaven, While the grave, with incessant currents, Demands your bones, your ashes!"
}

34 Cf. Gomulicki's apt comments in Komentarz on poems including "mute things." 
- Oh! Yes, but, wherever you stand,

You see far more heavens

Than earth...]

The poem is constructed as a dialogue. There is no doubt about which part the poet identifies with, as he placed only the first stanza in quotation marks to emphasise the distance, although formally, both stanzas are pieces of dialogue quoted on the same terms. This exchange occurs in a specific situation, although there is not a word written about it by the poet; that definition results from the course of the speech, which was given colloquial features, and the second stanza starts as a direct, immediate response to the preceding statement. Thus the dramatic situation, clearly outlined and unique, becomes an element of the parable; its participants are not even given names, they only state general attitudes, and the situation allows for their formulation. The general truth in the second stanza is worded metaphorically, through translation. Here Norwid uses the juxtaposition of heaven and earth, characteristic of religious thought since ancient times, as indicated by various studies of religion scholars. ${ }^{35}$ That reference further strengthens the general impression of the poem. "Niebo i ziemia" presents two elements characteristic of further parable-poems: reduction of the discourse and presence of images and symbols with meanings determined by culture; as a matter of fact, the two elements are closely interdependent.

We thus come to the poems which must be read as parables, although they do not strictly include discourse. That type of parable is perfectly showcased by poems such as "Spowiedź" ["Confession"] and "Krzyż i dziecko" ["The Cross and a Child"]. ${ }^{36}$ They are interesting if only for the fact that the parabolic form has been imposed on them in genres which are usually distant from the parable, that is, poetic dialogue in the first case, and ballad in the second. In both poems, the same phenomenon can be observed: the narrative text, which traditionally played the role of a generalising commentary, is reduced in favour of pure drama. Naturally, such an approach is necessary in dialogue, but not in a ballad. The ballad has also been extremely dramatized by Norwid; it consists exclusively of statements by the Father and the Son. The question arises of how a form so foreign to moralisation and generalisations as a ballad could be parabolised (all the more so by the fact that Norwid undertakes a recognised ballad motif from Goethe's Erlkönig). The dramatic course of events is fully revealed through the

35 Cf. e.g. E. Bevan, Symbolism and Belief (Boston: Beacon Press, 1957).

36 Cf. analysis of the poem in J. Przybośs essay "Próba Norwida," in: Sens poetycki (Kraków: 1963), pp. 107-110, and in Gomulicki's comments. 
dialogue - and the poem could be read to some extent as a traditional ballad; such reading would be faithful to the letter, but it would completely miss its spirit. It must be seen that all elements present in the poem play an important role in its action, but also remain allegorical.

In "Krzyż i dziecko" there is no division of the image - allegory or parable from the explanatory whole, the image of the "cross of the mast and bridge" is present in every stanza, it has grown into the tissue of the poem. [...] The amazing thing is what Norwid did with his imagination, his view on the world, and his sensibility. He retuned his heart, rebuilt the structure of his imagination, and saw the tangible, real world as a sign of moral laws. ${ }^{37}$

In Christian culture, the cross is an object in which, in a way, the symbolic meaning outweighs the material shape and features; it is first and foremost a sign of values and beliefs. Of course, the cross is all that to Norwid, as well, but he also harnesses it to the dramatic action. The sign is supposed to act ambiguously. At first it is a harbinger of a specific, strictly physical danger, and returns to its role of a religious symbol only in the ending. It may be said that one of the aspects of the action in the ballad is the cross's transition from a material object into a religious symbol. The drama thus includes not just the sphere of events, but also encompasses the sphere of allegory. It is paradoxical to note that in this case giving an allegorical sense to an object is not the poet's individual decision, since he chose the basic symbol of faith. Vincent Buckley undertook the fascinating problem of Christian iconography in poetry and stated that since Christianity stopped being a unified phenomenon, fully specifying the whole world of human imaginings, a Christian poet had to create his or her own iconography, and it may not seem quite Christian at the first glance, either. ${ }^{38}$ This also concerns Norwid who - as we know - referenced the most varying stories and images for the teachings contained in his parables. Here, the process is reversed: the poet's work shows how an object becomes a sign of faith, even though a reference would have sufficed on account of the common understanding of the sign.

Norwid's general symbols of faith appear in the most diverse narrative and descriptive settings, shaped in various ways, and in this manner shift their world from the visible sphere into the realm of those religious, moral and philosophical senses which were of greatest interest to him. Thus, iconographic elements are an important element for changing a story into a parable. In "Krzyż i dziecko," which is definitely a parable in more ways than one, that purpose is clearly served by the

37 J. Przyboś, Próba Norwida, p. 109.

38 V. Buckley, Poetry and the Sacred (London: Chatto \& Windus, 1968), esp. p. 66. 
final words, which not only close the ballad's story, but reveal (non-discursively) its allegorical message:

- Gdziéz się podział krzyż?

*

- Stał się nam brama.

(“Krzyż i dziecko,” PWsz II, 96)

[- And where is the cross?...

- It became our gate.]

A similar role is played by the Gladiator's words closing the dialogue:

Alleluja!... Te salutant, Christe...

(“Spowiedź," PWsz II, 129)

Parables without discursive casing are not limited to the examples analysed above. For instance, in three poems from Vade-mecum, Norwid takes well-known mythological motifs and changes them into parables, reshaping them to a lesser or greater degree ("Sfinks," "Narcyz," "Fatum" [“Sphinx," "Narcissus," "Fate”]):

Zastąpił mi raz Sfinks u ciemnej skały,

Gdzie, jak zbójca, celnik lub człowiek biedny,

"Prawd!" - wołając, wciąż prawd zgłodniały,

Nie dawa gościom tchu.

— „Człowiek?... jest to kapłan bezwiedny

I niedojrzały..." -

Odpowiedziałem mu.

Alić - o dziwy! —

Sfinks się cofnął grzbietem do skały:

- Przemknąłem żywy!

(“Sfinks,” PWsz II, 33)

[The Sphinx barred my way in a dark cave,

Ever hungry for truths

Like a taxman, beggar or knave

Molesting travellers with cries of "Truth!”

— "Man?... he's an ignorant callow

Priest..." 
I replied

And marvelling saw

The Sphinx pressed against the rock:

I slipped past alive! ${ }^{39}$

True, the indicators here are not as clear as in "Krzyż i dziecko," yet such poems should also be interpreted as parables. At first glance, it appears to be a dramatized account with a clearly outlined ending; it can be considered a rule that Norwid's parables of this type are highly dramatized. The mythological story turns into a fundamental moral discussion. Yet in a manner characteristic of a parable, moral messages are conveyed not only by what is stated expressis verbis, but are the matter of the whole narration and narrative situation. It may be said that in the group of poems drawing inspiration from mythology, Norwid practices what Tuve called an imposed allegory. ${ }^{40}$ Imposed, as the poet develops the motifs in a different manner than in the original versions, and so the Sphinx or Narcissus become protagonists of moral dramas in the shapes and forms important to him. Like the medieval authors of the allegorised versions of Ovid's Metamorphoses, known as Ovide moralisé, he translates narration - to borrow Weinrich's apt expression - into an argumentative style. ${ }^{41}$ Yet with Norwid, that argumentative style is not external with regard to the narration - it permeates it, and a unity is fostered. For those particular reasons, poems such as "Sfinks" cannot be read as poetic stories of individual facts (thus they cannot be read as ballads), nor can they be read as just another reproduction of a myth. The narration becomes argumentation, even if the theses it conveys are - as is often the case with Norwid - not just unstated, but not even clearly indicated, and yet the narrative construction alone assumes their existence. Therefore, such poems are undoubtedly parables.

In Norwid's output, there are many narrative poems which appear to speak of minor, unimportant matters; one may wonder if those can be treated as parables, too. Certainly, in the majority of cases, the narrative therein is constructed on the above-specified terms, yet it is difficult to incontestably name those works parables. Although it is one of the most important elements in Norwid's works,

39 English translation by Adam Czernawski, Cyprian Norwid, Selected Poems (London: Anvil Press, 2004), p. 62.

40 R. Tuve, Allegorical Imagery. The author analyses the phenomenon thoroughly and in a highly suggestive manner.

41 H. Weinrich, "Structures narratives du mythe," Poétique 1970, vol. 1, p. 30. 
the parable is not a universal key that can open all the secrets of his poetics. Poems of that type might likely be coined paraboloid poems, since the parable element takes up a fair portion thereof, even if it does not subordinate whole poems to itself. It is expressed mainly in the fact that they consistently activate a broader semantic perspective, which encourages the reader to seek a deeper meaning behind the recounted events - like in "Po balu," "Marionetki" or "Nerwy" ["After the ball," "Marionettes," "Nerves"], just to list a few poems. Norwid introduces or perhaps suggests - that reflexive perspective through various approaches and means. At times, it may just be a metaphorised point, like in the poem "Po balu," where it is prepared throughout the poem's development, but also reasseses that same work:

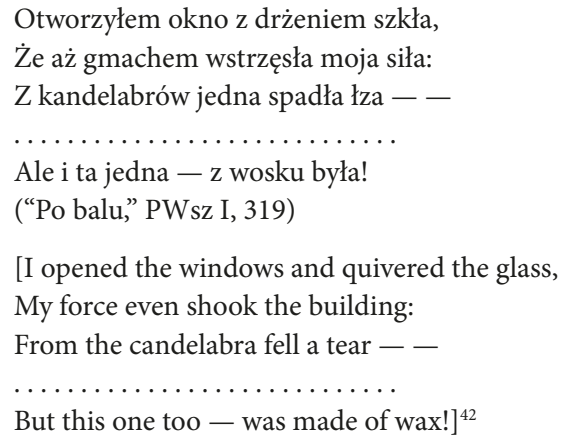

In other cases, in an account of the everyday world contemporary to the poet, Norwid introduces a mythological, eschatological, or cosmic dimension to a street or refined living room space - yet those are not myth-poems ${ }^{43}$ works in which the most significant achievement is suggestive vision; as in most of Norwid's poems, those are usually highly rationalised statements. Semantic contrasts are far more important here than free imaginative play:

I ziemia stoi - i wieków otchłanie,

I wszyscy żywi w tej chwili,

Z których i jednej kostki nie zostanie,

Choć będą ludzie, jak byli...

Jak się nie nudzić na scenie tak małéj,

Tak niemistrzowsko zrobionéj,

Gdzie wszystkie wszystkich Ideały grały,

42 English translation by Danuta Borchardt, p. 125.

43 It seems that Norwid only wrote one poem where he shaped the narration to resemble a myth - "Fortepian Szopena" ["Chopin's Grand Piano"]. 
A teatr życiem płacony -

(“Marionetki," PWsz I, 345)

[And the earth is standing - so are the chasm of ages,

And all living this moment

Of them not a single bone will remain,

Though people will be, without change...

How not to be bored on this small stage

So inexpertly raised,

Where everyone's Ideals are played

And the theatre with life is paid - $]^{44}$

There are also more important expressive values than the direct, narrowly understood ones with which that poetic method is usually associated. All the features of such poems are revealed in an immensely condensed form in one of the greatest works of Norwid's lyrical poetry - in "Nerwy." That account of two visits is built on the basis of contrast, and it is a typically moralist one. Furthermore, Norwid introduces established symbols of Christian culture in it: a Pharisee and the cross. The role of the cross has already been mentioned; it is a phenomenon of particular significance for the very reason that it introduces a different dimension by itself. That process is visible just as distinctly in "Nerwy" as in "Stolica" ["Capital"], which is more descriptive and narrative. The cross above the city, shown both in the first and last stanzas of the poem, is an allegorical frame for several descriptive sequences which in no way go beyond "realistic" aesthetics. ${ }^{45}$ Allegory subordinates to itself elements whose main reason for existence seem to be mimesis.

\section{5}

Norwid's predilection for the parable requires a few more comments. First of all, it took place at a time when the distinction between allegory and symbol was a general intellectual provision. The question is not whether it was justified - the important issue is that it was an essential cultural fact. Goethe juxtaposed symbol and allegory in a decisive manner in 1797. That contrast must have answered the

44 English translation by Danuta Borchardt, p. 121.

45 This vision of the cross over the city brings to mind a rather modern analogy - the first sequences of Fellini's Dolce Vita which show a helicopter with a cross hanging down from it flying over Rome. Both in the poem and in the film, the cross is similarly symbolic. If one were to assume that Fellini could have known Norwid's "Stolica," it might be suggested that the film included a poetic quotation. 
needs of the era, since it entered the repertoire of the binding conceptions so quickly. German ${ }^{46}$ and British ${ }^{47}$ Romantics adopted it, and soon all of literary Europe took it for granted (and it is a known fact that nothing has changed in this area even up until today). It is equally well known that the said contrast was accompanied by a clear valuation - only the symbol is truly poetic and worthy of poetry - and allegory is born of a rationalist simplification which reduces the dynamic matter of life to general, dead templates. True, it was symbolism which turned that contrast into a programmatic motto, but even back in the time when Norwid was active it was an important component of literary awareness. Under such circumstances, a return to parable (one of allegory's forms) takes on a particular meaning. It may have seemed like an element of poetic archaism, and the ancient - just like what is termed "innovative" - is at times incomprehensible: the reader may not know how to approach the reading of works derived from the archaic. All the more so because, as pointed out above, that ancient touch appears in combinations previously undefined by tradition.

A 19th-century reader, whose awareness had been shaped by the experiences of Romanticism and realism, was utterly unprepared to process parabolic works, based on allegory. Updated allegory ${ }^{48}$ refers to any - ancient as they may be - images, stories, perspectives on the modern worldview, and in doing so, it assumes the latter's commonness and stability. In former eras, the parable referred to universal images and beliefs, assumed their existence, was ready to function in a world where they were not only a sanctioned mode of communication, but were transparently equipped axiologically, they were a matter of values. Therein was the clarity of a parable, as well as its didactic function. Yet, here it operates within the literary output of a writer whom his contemporaries annoyingly and downright indecently considered "obscure." However, it is not the parable that became obscurely unclear, it was the world of its addressees. It lost its references in the common, binding worldview; it could not refer to

46 Cf. information on the spreading of the idea in the initial chapter of S. Bayrav's book, Symbolisme médiéval (Istanbul: Maatbasi, Paris: Presses Universitaires,1957). Cf. also the interpretation of the phenomenon by R. Langbaum, The Poetry of Experience: The Dramatis Monologue in Modern Literary Tradition (London: Chatto \& Windus.1957), p. 63. Yet, Winckelmann still uses the term allegory in a programmatic manner. Cf. E. M. Szarota’s treaty “O Winckelmannowskiej koncepcji alegorii," Estetyka, year II, 1961, pp. 161-176.

47 Coleridge's statements on that are analysed by Honig, Dark Conceit..., pp. 45-46.

48 On elements of actualisation in allegory, cf. the comments of P. Szondi in his article "L'hermeneutique de Schleiermacher," Poétique 1970, No. 2, p. 142. 
ideological generalities as if they were unchangeable, universal, and undisputable. A naturally unequivocal form became ambiguous, and that process deepened with time, if you compare such works by Norwid with those of a later great parable writer - Kafka. A modern critic compared his parables to the Rorschach test: they similarly call for interpretation, but tend to show the qualities of the interpreters rather than their own. ${ }^{49}$ Of course, Norwid did not attain such an advanced level. Perhaps, as a religious poet, he was unable to reach it, since his work was rooted in the doctrine. It may seem paradoxical that this Catholic poet writing for a Catholic society was not embraced by its members. The explanation may be as follows: after all the innovations of Enlightenment and Romanticism, poetry no longer held the connection to the sphere of doctrinality, its point of reference - even for a religious reader - was not a set of established beliefs, convictions, or dogmas anymore. ${ }^{50}$ It simply found its point of reference in a different type of social and individual experience, which was not a systematised set of convictions, but the inner workings of an individual, the poet's soul ${ }^{51}$ Norwid wrote his parables in such a way as if the set of unchangeable principles also ruled over poetry, and so a conflict with his audience was ineluctable. This was exacerbated by the fact that Norwid did not treat the parable as a relic, since it appeared in new functions and new combinations.

The reading of the poems is also a critical issue - as is any question concerning the reading of allegories. Historians and theoreticians of allegory give contrary answers in that field. In his book on Spencer, Hamilton argues that when interpreting allegorical works, one should focus on analysing the literal layer and determine its structure, since it is here that the poetic value is found, the "depths of literal meaning" ${ }^{\prime 2}$ must be revealed. Dorothy Sayers is of a different opinion; among three mistakes made in the reading of allegory, she considers the basic one to be reading it for the "poetry," for the story told, and not for what it stands for. ${ }^{53}$ It is obviously a difficult task to reconcile such extreme views. It seems, however, that each of those statements refers to different kinds of works. The directive presented by Miss Sayers is fully binding when you speak of parenetic, didactic, utilitarian literature, and cannot be applied when allegory - parable included - becomes

49 H. Politzer, Franz Kafka Parable and Paradox (Ithaca, NY: 1962), p. 21.

50 This process is very well demonstrated by Langbaum in the work cited above.

51 Cf. an interesting discussion on the topic offered by R. A. Foakes in The Romantic Assertion. A Study in the Language of Nineteenth Century Poetry (London: Methuen \& Co., 1958), pp. 39-43.

52 A. C. Hamilton, The Structure of Allegory..., p. 12 and others.

53 D. L. Sayers, The Writing and Reading of Allegory, p. 225. 
the means of poetic speech. In such cases, only Hamilton's approach may bring valuable critical results, and it was this approach that I endeavoured to follow in this essay. However, it does not mean that I am inclined to disregard the didactic functions and doctrinal references of the parable even in works as complicated and sophisticated as Norwid's writings. After all, for him the relation of those various elements was an important matter, as well. He would have definitely agreed with such a statement by a modern critic:

We touch here on a central dilemma of literature. If literature is didactic, it tends to injure its own integrity; if it ceases wholly to be didactic, it tends to injure its own seriousness. ${ }^{54}$

This essay discussed forms the parable takes in Norwid's short poems. Yet, it does not exhaust the topic. It requires further amendments and developments. Firstly, the parable appears in other forms of his work - epic poems, dramas, short stories, discursive texts - and it desires elaboration in those areas, as well. Secondly, for the purposes of analysis, this essay isolated the parable from the context of other forms functioning within Norwid's poetry. This isolation resulted from the needs of this particular analysis and not from the conviction that the parable deserved a separate place. Quite contrarily, it is only one of the many voices in Norwid's choir of forms, or to put it differently, it is only one of the actors in Norwid's drama of form. This naturally impacts its functions and meanings. Finally, parables are an important component of the rhetoric typical of Norwid, and play an important persuasive function within it. Yet those issues remain to be analysed in further possible discussions.

\section{Bibliography}

Auerbach, Erich. Scenes from the Drama of European Literature. New York: Meridian Books, 1959.

Bayrav, Sucheyla. Symbolisme Medieval. Istanbul: Maatbasi, Paris: Presses Universitaires, 1957.

Benveniste, Émile. Les relations de temps dans le verbe français. In: Problèmes de linguistique générale. Paris: Gallimard, 1966, pp. 237-250.

Bevan, Edwyn. Symbolism and Belief. Boston: Beacon Press, 1957.

Błoński, Jan. "Norwid wśród prawnuków." Twórczość, 1967, Vol. 5, pp. 67-94.

54 N. Frye, "The Road of Excess," in a volume by multiple authors: Myth and Symbol: Critical Approaches and Applications, ed. B. Slote (Lincoln: University of Nebraska Press, 1963), p. 14. 
Borowy, Wacław. Główne motywy poezji Norwida. In: Wacław Borowy. O Norwidzie. Rozprawy i notatki. Warszawa: PIW, 1960.

Buckley, Vincent. Poetry and the Sacred. London: Chatto \& Windus, 1968.

Fletcher, Angus. Allegory. The Theory of Symbolic Meaning. Ithaca, NY: Cornell University Press, 1964.

Foakes, R. A. The Romantic Assertion. A Study in the Language of Nineteenth Century Poetry. London: Methuen \& Co., 1958.

Frye, Northrop. "The Road of Excess." In: Bernice Slote, Myth and Symbol: Critical Approaches and Applications, Lincoln: University of Nebraska Press, 1963, pp. 3-20.

Głowiński, Michał. “Wokół 'Powieści’ Norwida.” Pamiętnik Literacki, 1971, Vol. 3, pp. 3-31.

Gomulicki, Juliusz Wiktor. “Komentarz." In: Cyprian Norwid. Dzieła zebrane, Vol. II. Warszawa: PIW, 1966.

Górski, Konrad. “'Ad Leones' (próba analizy).” In: Konrad Górski, Tadeusz Makowiecki, Irena Sławińska, O Norwidzie pięć studiów. Toruń: Księgarnia Naukowa T. Szczęsny i S-ka, 1949, pp. 65-91.

Hamilton, A.C. The Structure of Allegory in "The Faerie Queen". Oxford: Carendon Press, 1964.

Honig, Edwin. Dark Conceit. The Making of Allegory. London: Faber and Faber, 1959.

Jakobson, Roman. “'Przeszłość' Cyriana Norwida.” Pamiętnik Literacki, 1963, Vol. 2, pp. 449-456.

Jastrun, Mieczysław. Gwiaździsty diament. Warszawa: PIW, 1971.

Kołaczkowski, Stefan. “Ironia Norwida." In: Stefan Kołaczkowski. Pisma wybrane, Vol. I: Portrety i zarysy literackie, ed. Stanisław Pigoń. Warszawa: PIW, 1968, pp. 131-166.

Krzewińska, Anna. Alegoria w "Wizerunku własnym żywota człowieka poczciwego” Mikołaja Reja. In: Tradycja i nowoczesność. Konferencja teoretycznoliteracka $w$ Ustroniu, ed. Jan Trzynadlowski. Wrocław: Zakład Narodowy im. Ossolińskich, 1971, pp. 9-26.

Krzyżanowski, Julian. "Norwidowa parabola o zamarzłym słowie." In: Paralele. Studia porównawcze z pogranicza literatury i folkloru. Warszawa: PIW, 1961, pp. 407-412.

Krzyżanowski, Julian. "Alegoria w prądach romantycznych.” Przegląd Humanistyczny, 1962, Vol. 5, pp. 1-18.

Langbaum, Robert Woodrow. The Poetry of Experience. Dramatic Monologue in Modern Literary Tradition. New York: Random House, 1957. 
Lewis, Clive Staples. The Allegory of Love. A Study in Medieval Tradition. London: Oxford University Press, 1953.

Łapiński, Zdzisław. "Obrazowanie w Quidamie." Roczniki Humanistyczne, Vol. VI, 1958, No. 1, pp. 117-173.

Musil, Robert. The Man Without Qualities. Trans. Sophie Wilkins. London: Picador, 2017.

Nuttall, Anthony David. Two Concepts of Allegory. A Study of Shakespeare's "The Tempest" and the Logic of Allegorical Expression. London: Routledge \& K. Paul, 1967.

Politzer, Heinz. Franz Kafka Parable and Paradox. Ithaca, NY: Cornell University Press, 1962.

Przesmycki, Zenon. "Przypisy wydawcy." In: Pism zebranych Cypriana Norwida tom A - part two. Warszawa: Wydawnictwo Jakuba Mortkowicza, 1911, pp. 705-1075.

Przyboś, Julian. “Próba Norwida.” In: Julian Przyobś. Sens poetycki. Szkice. Kraków: Wydawnictwo Literackie, 1963, pp. 96-116.

Sarnowska-Temeriusz, Elżbieta. Świat mitów i świat znaczeń. Maciej Kazimierz Sarbiewski i problemy wiedzy o starożytności. Wrocław: Zakład Narodowy im. Ossolińskich, 1969.

Sayers, Dorothy L. The Writing and Reading of Allegory. In: The Poetry of Search and the Poetry of Statement. London: V. Gollancz, 1963, pp. 201-225.

Sławińska, Irena. “O prozie epickiej Norwida." Pamiętnik Literacki, 1957, Vol. 2, pp. 467-498.

Spivak, Gayatri. "Allégorie at histoire. Hypothèse de travail." Poétique, 1971, Vol. 8, pp. 427-444.

Stefanowska, Zofia. Historia i profecja. Studium o "Księgach narodu $i$ pielgrzymstwa polskiego" Adama Mickiewicza. Warszawa: PIW, 1962.

Szarota, Elida Maria. “O Winckelmannowskiej koncepcji alegorii." Estetyka, year II, 1961, pp. 161-176.

Szondi, Peter. "L'hermeneutique de Schleiermacher." Poétique, 1970, Vol. 2, pp. 141-155.

Świontek Sławomir. "Paraboliczność struktury scenicznej Pierścienia wielkiej damy C. Norwida." In: Dramat i teatr. Konferencja teoretycznoliteracka w Świętej Katarzynie, ed. Jan Trzynadlowski. Wrocław: Zakład Narodowy im. Ossolińskich, 1967, pp. 45-59.

Thornton, Harry and Agathe. Time and Style. A Psycho-linguistic Essay in Classical Literature. London: Methuen, 1962.

Todorov, Tzvetan. Introduction à la littérature fantastique, chapter La poésie et l'allégorie. Paris: Editions de Seuil, 1970, pp. 63-79. 
Weinrich, Harald. "Structures narratives du mythe," Poétique 1970, Vol. 1, pp. 25-34.

Welter, Jean-Thiébaut. L'exemplum dans la littérature religieuse et didactique du moyen âge. Paris: Occitania, 1927. 


\title{
Stefan Sawicki \\ On Norwid's Poetic Semantics
}

\begin{abstract}
This chapter - referring to the methodological trend initiated by William Empson - draws attention to a group of phenomena in the field of poetic semantics, which seems to be particularly characteristic for Norwid's poetics. These are various tensions created between the meanings of individual words, tensions, which are based on polysemy (actual, potential, and created by the author), synonymy, opposition, and association. These phenomena seem to be particularly important for Norwid, even more important than metaphor. Moreover, his repertoire of "operations on meanings" is much wider: creating new semantic wholes by merging or splitting the meanings of words, exploiting the phonological system for a pun-like effect, tending to make meanings allegoric and symbolic. All of this situates Norwid's poetry within a particular current of linguistic initiated in Polish literature in the Baroque period and later strongly present in contemporary poetry, for which Norwid's work is not only a frame of reference but also a founding stone.
\end{abstract}

Keywords: Cyprian Norwid, poetics, poetic semantics, polysemy, linguistic poetry

In this chapter, I would like to draw attention - with reference to the methodological trend initiated by Empson ${ }^{1}$ - to a certain group of phenomena within poetic semantics which seems particularly characteristic of Norwid's poetics.

One of the poet's last poems was the ballad titled "Rozebrana" ["Disrobed"]:

I

Ani jej widzieć wieczorem, ni z rana,

Bo rozebrana...

$* * * * * * * * * * * * *$

Więc śpi zapewne! - niech raz rzekną szczerze

Służebne panny,

Lub że, gdy wstawa i nim się ubierze,

Używa wanny.

II

Tymczasem szwaczek trzy stoi z pudłami

I szewców sporo,

Co, nic nie widząc, swymi domysłami

Miary Jej biorą.

1 I am thinking here of the book by William Empson, Seven Types of Ambiguity, 1st ed. (London: Chatto \& Windus, 1930). 
III

Tymczasem dzieci o rannej godzinie Gdzieś do szkół idą;

Oracz wywleka pług, i Wisła płynie, I Warta z Nidą.

IV

Błogi jest pejzaż, błogą woń poranna,

Gdy wstają zorze -

Ale cóż, kiedy ona, rozebrana,

Wyjrzeć nie może!

$\mathrm{V}$

Świat rzecze na to: „Niechże się ubierze

Na trzy sposoby:

Zachodnio-wschodnio-pstre weźmie odzieże

Lub - wór żałoby!..."

VI

To ja gdy słyszę, mam zdanie odmienne

O Rozebranéj:

Wszakże niekryte jest, a tak promienne

Łono Dyjany!

VII

Akteon blednie blaskiem uderzony,

Nie cofa psiarni trąb hałas;

Hyperborejski las drży przerażony,

Jak wiotki trzęsąc się szałas...

VIII

Gdy ona przecież bez zbroi - bez togi Pełna powagi i krasy,

Pamiętna tylko, że po wszystkie czasy

Tak - karzą Bogi!

(PWsz II, 249-250)

[I

You will not see her morning or night,

Because she's undressed...

$* * * * * * * * * * * * *$

She must be sleeping! - let her acolytes at least once Honestly say,

She's up, but still undressed, taking a bath. 
II

Meanwhile three seamstresses stand with their boxes

And many a cobbler,

Who, without seeing anything, onlyguessing

Take Her measurements.

III

Meanwhile, in the morning, children

march somewhere to school;

The ploughman tills, the Vistula river flows,

As do the Warta and the San.

IV

Blissful is the landscape, and so is the morning air

At daybreak -

But alas, she's undressed,

Unable to lean out!

$\mathrm{V}$

The world responds: "Let her dress herself

in three ways:

Western-Eastern-motley dress

Or a mourning sackcloth!...”

VI

When I hear this, I have a different view

Of the Undressed:

Although uncovered, how radiant

is Diana's bosom!

VII

Caught in brightness, Actaeon grows pale;

Hounds ignore the blazing horns;

The Hyperborean Wood stands terror-struck,

Quivering like a tottering shack...

VIII

While she's without armour - without gown -

full of both dignity and fairness,

ever mindful that for all eternity

This is how Gods punish crime! ] ${ }^{2}$

The title adjective "rozebrana" [undressed, disrobed] is surrounded in the first, partial, and second stanza by words and phrases stressing a meaning closer to

2 English translation based partially on the translation by Adam Czerniawski, "Undressed," 14 July 2018 http://sites.utoronto.ca/tsq/10/chernavsky10.shtml. 
that of our times, which is associated with "uncovering," "dishabille," "nakedness," "in the morning," "sleeping," "waking up," "getting dressed," "taking a bath." These expressions not only confirm this meaning, but also give it a certain tinge of privacy and cosiness. This meaning is also present in stanza III, ${ }^{3}$ but the group of cobblers and seamstresses disturbs the cosiness, the capitalization of the pronoun "Jej" [Her] brings the privacy of the scene into question, while basing the measurements solely on guesses renders the whole situation surreal and vague. Stanza IV stretches the lyrical setting beyond the walls of the flat, while the vast national landscape with the Vistula and Warta rivers arouses suspicion and speculation. These are crystallised in stanza VI. "The world" that is invoked as witness to the described events and the geographical terms referring to the robes of the undressed testify to the wide scope of issues addressed in the poem, and the "three ways," reminiscent of the "three seamstresses" from stanza III, make it clear that it refers to partitions, to a Poland partitioned by three external powers. This new meaning of the title word, suddenly illuminated so clearly, fades away in the subsequent stanzas following the introduction of the myth about Actaeon. Undressed Diana alludes to the initial scene, although the general character of the last stanza reminds us again that the poem concerns neither fictional nor private matters.

We have thus discerned the structural framework of Norwid's ballad: the beginning and end strongly emphasise - simultaneously attributing different values to it - the meaning of the title word connected to "exposing," while the middle of the poem is about "dividing into parts." The first meaning is present throughout the whole poem as a consequence of the personification of Poland, the second meaning - radiating outward from the middle of the work always accompanies the first.

The undressed woman is not only stripped of her robes, but also of her essential property and rights, and the landscape painted in perspective - deviates from the conventional personification of the poem towards the critical meaning, where the adjective "undressed" refers to the Polish territory between the Vistula and Warta rivers. Therefore, Norwid's ballad is built around two meanings of one word. It seems that in Norwid's time, both meanings were of equal importance. Linde's Dictionary and the Warsaw Dictionary of Polish list the meaning related to analysis and "partition" first, but the Vilnius Dictionary (1861) reverses the

3 Since the first two verses are treated as a partial stanza I, the numbering in the analytical part is different from that in Norwid's Pisma wszystkie, edited by J. W. Gomulicki (Warszawa: PIW, 1971). 
order. It could thus be supposed that Norwid, aware of the double meaning of the word "rozebrana" [undressed, disrobed], based the two-plane construction of the poem on this polysemy.

Norwid's ballad is a good example of how the composition of the entire poem can be based on a word's polysemy. But this also points to the poet's characteristic use of semantic ambiguity in the titles of his works and in formulating allusions.

Examples of this can be found, in particular, in the titles of works belonging to the Vade-mecum collection. In the poem "Zapal" (LXII) ["Fervour"], the title discloses the fundamental topic: commitment, dedication, devotion, alluding to the figurative meaning of the word. However, in Norwid's time, the literal meaning of the word was still very strong. Both the Vilnius and Warsaw dictionaries define it first as lighting, igniting, catching fire, fire, and blaze. Thus, the "zapal" [flame, enthusiasm, fervour] referred to in the title simultaneously indicates two types of fire, which in the poem are symbolised by two different attitudes. The past - holy fire, flame; the present - matches, a little flame lighting a pipe. This is an apotheosis of "legendary" times and an ironic take on "historical" times, which are closer to us. It is the juxtaposition of divine fervour/ enthusiasm, which has a religious motivation, and cheap lighting which serves a utilitarian purpose.

However, not only are the individual titles comprising Vade-mecum semantically ambiguous, so is the title of the entire work. On the one hand, it is a blend commonly used to refer to a collection of essential, critical information. Norwid's volume of poems would be a poetic "vade-mecum," something that should be obligatorily known, something to come back to, an essential poetic source of wisdom about man. On the other hand, the literal, undoubtedly prevalent in Norwid's time, Latin translation "come with me" comes to mind, which J. W. Gomulicki - with reference to the Divine Comedy - even translates as "follow me." This is a call to readers and poets: Follow me in my poetic wandering, participate with me in my poetic experiences, let the presented poetry win us over, create similar things, let us create new poetry together. Especially in the light of a foreword titled "To the reader," this second meaning of the title is very likely.

Let us now stress Norwid's allusiveness by recalling a passage from the prayer to the Mother of God [“Maryjo, Pani Aniołów!...”]:

Maryjo, Pani Aniołów! - u Ciebie

O Twej korony prosim zmartwychwstanie - -

A niech się wola Syna Twego stanie

Na ziemi-naszej, tak, jako jest w Niebie. 
I niechaj wielkie będzie zmiłowanie

Odgóry-jasnej ku biegunom-nocy:

*

Bo zapatrujem się na krzyżowanie

I Eloj-lamma!...* — wołamy — pomocy!...

(PWsz I, 75)

[Mary, Lady of Angels! - you

We beg for the resurrection of Your crown - -

Thy Son's will be done

On our-earth, as it is in Heaven.

May the mercy be great

From the luminous-mount to night-poles,

Because we are looking at the crossing

And Eloi-lama! ...* — we call - help!...

In each stanza, there is a word which is at the core of semantic, allusive play. These words are "crown," "earth," "mountain," and "Eloi-lama." The context is created very carefully. On the one hand, the words are articulated in a way that clearly gives them religious qualities. "Crown" is something naturally linked to Mary, Queen of Angels. "Earth" is very close to the paraphrased model of the Lord's Prayer. "Mountain" linked with a hyphen to the adjective "luminous" is a clear reference to the sanctuary in Częstochowa (Jasna Góra: Luminous Mount, Clarus Mons). "Eloi-lama" is a slight alteration of the words uttered by Christ on the cross (Mk 15, 34). But, on the other hand, the same context shifts the meaning of these words to other designata. It cannot possibly be Mary's crown if this collective plea for the resurrection of the crown is addressed to her. "Earth" cannot be the earth in general, the earth of all the people from the Lord's Prayer, if it is clearly designated as our earth. "Luminous-mount" juxtaposed with "night-poles" seems to rather demarcate a space with not only geographically but also morally defined borders. Christ's question "Eloilama!..." ("Eloi, Eloi, lama sabachthani?", i.e., "My God, my God, why have you forsaken me?") takes on another meaning when uttered by a community - a social, national meaning. Thus, besides the religious sequence of meanings, an allusive sequence of national meanings appears as well. The crown is Poland (the Crown and Lithuania), earth - Homeland, luminous-mount - the border of Polishness, and "Eloi-lama!..." - the cry of an exhausted nation. Norwid's entire poem is based on the constant tension between these two sequences of

* * Eloi, Eloi, lamma Sabachtani? - Boże mój, Boże mój, czemuś mnie opuścił? 
meanings, or rather their designata. It is a crypto-patriotic prayer veiled in religious meaning.

The allusion is often accompanied by irony, also implemented through the use of polysemy. In Norwid's time, the adjective "niespracowany" [non-workworn] meant "not working much," "not overtired," but also "not overcome by work," "tireless," "indefatigable." Both these meanings are triggered by the poet when he writes of "niespracowanym/Krytyku" [a tireless/Critic] "W niespracowanym czasopiśmie naszym" [in our tireless magazine] ("Krytyka", PWsz I, 140 [“Criticism”]).

In the case of "Rozebrana" and the other works analysed so far (apart from the title of the collection Vade-mecum), Norwid associates, but also clearly delimits two meanings of the same word. However, in his poetic practice, he most frequently blurs both meanings, without retracting either of them:

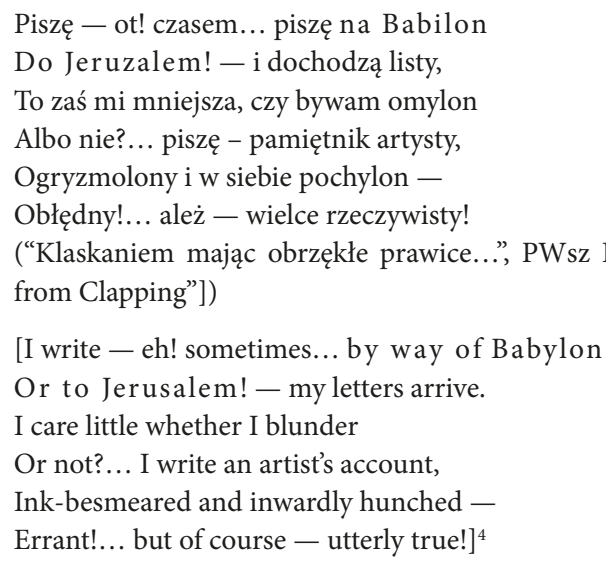

In Norwid's time, the word "obłędny" [errant, deranged] had at least two meanings confirmed by dictionary entries: "unreal," "false" and "mad," "insane." The first meaning is evoked by contrasting it with the word "true." The second is prompted by the preceding expressions: "Ink-besmeared and inwardly hunched." Similar semantic ambiguity concerns the word "omylon" [blunder, loony].

"[...] dni przedostatnie/Nie docieczonego wątku" [...those but last days/Of life's inscrutable thread] ("Fortepian Szopena," PWsz II, 143 ["Chopin's Grand Piano"]) refers to the end of the early days of the great musician's life, but also to life itself, whose shape and sense is impossible to understand. "Rzecz" [thing,

4 English translation by Danuta Borchardt in collaboration with Agata Brajerska-Mazur, in: Cyprian Norwid, Poems (New York: Archipelago Books, 2011), p. 17-19. 
matter] in the verse "Odpowiednie dać rzeczy - słowo!" [to name each matter by its rightful - word!] (“Za wstęp (Ogólniki)," PWsz II, 13 ["As Introduction (Generalities)"]) refers to both the poetic object, what the poem is about, and the poetic statement itself (as in "Czarnoleskiej ja rzeczy/Chcę - ta serce uleczy!" [I want the Czarnolas matter/to heal my heart's flutter!] from the poem "Moja piosnka I" (PWsz I, 66 [“My Song I"])). ${ }^{5}$

The often cited gnomic definition from the poem "Sfinks II":

— “Człowiek?... jest to kapłan bez-wiedny

I niedojrzały..." -

(PWsz II, 33)

[- "Man?... he is an unaware

And immature priest..." - ]

- is based on the simultaneous manifestation of two semantic aspects of the words: unaware and immature/unformed; the current meaning - negative, and the future - a positive one. Each immaturity heralds maturity, each unawareness may potentially turn into awareness. Human life, Christian life should aim towards the maturity of a conscious priesthood.

Hence, Norwid seeks out ambiguous and polysemous words, and takes advantage of their heterogeneity and aspectuality in order to kindle the specific semantic relations on which he bases the poetics of his works. Of course, these mutual relations between opposed meanings can be different and they are incorporated into the text in different ways, the poetic polysemy techniques also tending to differ.

The word play may also rely on phenomena such as quasi-homonymy:

Bądź wola Twoja, nie tak, jak na ziemi

(Więc nie wygodniej jak... lecz jak jest godnie),

(“Bądź wola Twoja..., PWsz I, 150 [“Thy will be done...”])

[Thy will be done, not as on earth

(Thus not more conveniently as... but worthily),]

As in the case of homonymy, the same principle applies here: different meanings, similar sounding words (wygodniej, godnie), but the similarity here is far less, as required by paronomasia. It is based on the similarity of the root (godnie), which sufficiently presents the difference in semantics of the two words and two attitudes. Sometimes, when the meaning is not contrasted strongly enough, the

5 See M. Głowiński, “Odpowiednie dać rzeczy - słowo," Tygodnik powszechny, Vol. 44 (1971), p. 4. 
poet resorts to using a third word, further complicating the word play. In the gnome from Vanitas vanitatis this third word is religion. The community should be such -

Której religią nie umiarkowanie, Ale religia miarą... [...]

(PWsz I, 398)

[In which religion is not moderation, But religion is a measure... [...]]

Only moderation (umiarkowanie), which is a religion in itself, dramatically cuts itself off from measure (miara) which is the function and consequence of religion.

In the previous examples, Norwid relied on words which were then polysemous. In other cases, the poet created such ambiguity through the reactivation or excitation of etymological, obsolete and literal meanings.

1

Jest sztuka jedna, co jak słońce w niebie

Świeci nad wiekiem:

Mieć moc pocieszać - moc zasmucać siebie,

A być - człowiekiem!

2

Trudna - bo Mistrzem jest tylko ten, który

Odszedł daleko:

By kiedyś wrócił na obłokach, z góry,

Światłości-rzeką - -

(“Do Pani na Korczewie", PWsz I, 350 [“To the Lady of Korczew”])

$[1$

There is one art, which like the sun in heaven

Shines over time:

To have the power to comfort - power to sadden oneself,

And be - a man!

2

Difficult - because the Master is only the one who

Went far away:

To someday come back in the clouds from above,

In the river of light - - ]

The word "moc" [power], etymologically related to the verb "móc" [can], is historically linked predominantly to one semantic modality. "Móc" is usually associated with "strength," "force," "power," "authority," "might." Even the old 
expression "siła ludzi" [people's strength], which is equivalent to the expression "moc ludzi" [people's power], testifies to the close relationship between these two meanings. It is more rare to hear of the sense which brings this word closer to a possibility related to a specific skill or ability ("zrobię to, co w mojej mocy" [I will do what I can], "moc czynienia cudów" [the power to make miracles]). Norwid gives these two meanings equal status. "To have the power to comfort - power to sadden oneself" refers to having the capability of feeling compassion towards other people, the ability to participate with them in their plight. But this also means having the resilience and internal strength necessary to choose this attitude towards others. "Skill," "moral aptitude" - these are the meanings suggested by the logic of the sentence in stanza 1, verses 3-4. In particular, "the power to comfort" seems to be just a certain human ability. This sense is stressed by some contextual, lexical clues: "Master," "art," which are always associated with certain skills or abilities. But the context also favours the basic meaning. It is a "difficult" significant, timeless art ("like the sun in heaven/Shines over time"), and the Master will someday return "from above,/In the river of light — _," he will return "with great power and glory" as suggested in a fragment from the Gospel of Mark $(13,26)$, to which we find a clear allusion here. In Norwid's poem, the simple ability or art of living together with people becomes a religiously motivated power.

Here, Norwid appreciates the "weaker" meaning of the word, the one used less frequently, usually in fixed phrases, although etymologically just as legitimate, and logically even more justified. However, he sometimes reaches for very remote, though fundamental, meanings; and he does so by actually creating new dictionary definitions for certain words.

"Śmierć"

1

Skoro usłyszysz, jak czerw gałąź wierci,

Piosenkę zanuć lub zadzwoń w tymbały;

Nie myśl, że formy gdzieś podojrzewały;

Nie myśl — o śmierci...

2

Przed-chrześcijański to i błogi sposób

Tworzenia sobie lekkich rekreacji,

Lecz ciężkiej wiary, że śmierć: tyka osób,

Nie sytuacji - -

3

A jednak ona, gdziekolwiek dotknęła, 
Tło - nie istotę, co na tle - rozdarłszy,

Prócz chwili, w której wzięła — nic nie wzięła:

— Człek — od niej starszy!

(PWsz II, 113)

"Death"

$[1$

When you hear a worm bore a bough,

Hum a song or strike timbals;

Don't think of forms ripened elsewhere;

Don't think - of death...

Pre-Christian this and blissful way

Of creating for oneself s oft dalliances,

And hard faith that death: touches beings,

Not circumstances - -

And yet, whatever death touched,

It's the backdrop - not the essence - that he's rent,

Barring the moment when he took, but took nothing:

Man - is death's elder! $]^{6}$

In this poetic treatise on death - poem LXXXII in Vade-mecum - we will focus on the last verse: “- Man — is death's elder!" Here, the adjective "starszy" [elder] is actually in no opposition to any dictionary meaning in Polish. Man is elder than death, since he simply precedes it in time, naturally, in relation to himself. Death is the consequence of his birth. Man is elder than death, that is, more important, more dignified than death. It does not tower over him, it does not destroy him, it is man who lives eternally; death is only assigned to everything that lives: after all, everything that lives explains and determines it. Life has a positive value, while death is something apparently negative. This meaning of the word "elder" would be close to that, to which we are accustomed through the popular old Polish expressions such as "starszeństwo" [seniority], "starszyzna" [the elders], "starszy w radzie" [elder], and so on. But these meanings are not the most important here. Norwid's work is a poetic manifestation of the Christian concept of death, which is only the temporary transition of a human being to another plane of existence. ${ }^{7}$ Man is thus elder than death, because he can "outlive" it, he can outlast it, when it has already passed. Hence here, "elder" is given

6 English translation by Danuta Borchardt, p. 57.

7 A good, concise commentary on "Śmierć" was offered by J. W. Gomulicki in vol. 2 of Cyprian Norwid's Dzieła zebrane, pp. 830-31. By contrast, the work was misunderstood by S. Grygiel in his review of J. Pieper's book Śmierć człowieka, Znak, Vol. 213 (1972), pp. 431-440. 
a totally different meaning compared to the one we usually find in dictionaries and to which we are accustomed. It would seem Norwid is alluding here to the meaning found today in several foreign languages, for example, in German, but also common to Old Polish. In a known legend from the Middle Ages, we learn that Saint Alexis "był star dwadzieścia k temu cztyrzy lata" [was 24 years old]. "Star" - stary [old] is a semantic sign of age, duration of time; it is only the adjacent numeral that somehow measures it. The gradus comparativus built from this adjective could thus designate someone or something more durable, longer living; both in relation to the time of birth and - eventually - death. This understanding of the word "elder" is closer to Norwid. However, the meaning to which it refers is so remote and blurred that we may be talking about a change in the dictionary meaning, especially if we consider the adjective in the comparative (elder). This procedure is characteristic of Norwid and, at the same time, undetectable in the poem, as it is so well incorporated into the context and well concealed by the possibility of activating other meanings of the same word. The shift in meaning was as if hidden behind the polysemy of the word, and additionally, behind its still valid relation to the category of time, with which the word "elder" is associated in popular use.

However, Norwid's semantic audacity did not only rely on his appreciation of weaker, implementation of older, or creation of new meanings of particular words, but also on his introduction of tensions within fixed sayings and phrases. A good example of bringing a fixed expression down to its literal, primary meaning and constructing the lyrical plot around these two meanings is the poem "Ruszaj z Bogiem" ["Go with God"]. The poem deals with the lack of Christian mercy, and Christian forgiveness. The opening scenario of the work is reversed at the end - the one who did not have mercy, now needs it; while the one who did not receive mercy, now shows it. The juxtaposition of the two meanings of a well-known saying is the juxtaposition of two attitudes: the dead and living Christianity. In another poem from the collection Vade-mecum, "Prac-czoło," ["Work in Brow's Sweat"], Norwid reinterprets the popular phrase "z potem czoła" ("w pocie czoła") [by the sweat of one's brow] and makes it the structural framework of his poem. The reinterpretation involves shifting the stress. In popular understanding, "sweat" is emphasised as a symptom of being tired, the brow is just the place where it is visible. Yet, Norwid stresses the "brow," the mental effort, which manifests itself in the proverbial "sweat of one's brow," the effort without which there is no intellectual - and thus human - work. The juxtaposition of both meanings of the fixed phrase ("z potem czoła" - " $z$ potemCzOŁA" [with the sweat of one's brow - with the sweat of one's BROw]) is the juxtaposition of two styles of work; it mediates poetic polemics with the poetic 
programme of efficient work. Yet another approach can be found in the poem "Do Wielmożnej pani I." ["To her Ladyship I."]. The poem is about Rome and Cicero. In the history of Rome, we can find both the premonitions (prophecies) of Christ's arrival and (even!) the figures of His Passion (Cicero's hands nailed to the podium). This Rome should be specifically linked to the Saviour; there $\mathrm{He}$ could have his "stopy [...] swobodniej oparte" (PWsz II, 206) [feet more comfortably rested].

"Czoło mówcy nie znało kropelki chrztu - wcale" [The speaker's brow had not experienced a droplet of baptism - at all]. Starting with the first verse, the poet already introduces a new word to the fixed pattern of a popular expression, instead of "pot" [sweat] - "chrzest" [baptism]. This initiates word play between those words and the entire expressions. Cicero's statement stretches between the ordinary and the supernatural, between a Roman speaker's composure (routine) and the sacred and prophetic character of the information, that is, exactly between "sweat" and "baptism." In this way, the disrupted semantic stability of the lexical expression makes a breakthrough, announces the coming of Christianity, brings to the pagans' awareness the feeling that God-Man is about to be born.

Norwid often achieved polysemy through the reinterpretation of concepts, through different understandings of what is the most important in them, what their essence is.

The poem "Słowo i słowo" ["A Word and the Word"] concerns not only two dimensions of the word, but also two dimensions of man and humanity altogether.

Dimension I:

a) anatomico-physical ("od stopy do powiek" [from feet to eyelids] - man);

b) biologico-demographic (the birth and death of millions - humanity);

c) audio-semantic ("kłamny wewnętrznemu znaczeniu" [false to the internal meaning] - word).

Dimension II:

a) experientio-religious (MAN);

b) historico-religious (HUMANITY);

c) culturo-ideologico-religious (WORD).

Thus we obtain two semantic sequences:

man: $\quad$ MAN

humanity: HUMANITY

word: WORD 
which create two semantic dimensions of the words, and eventually, two dimensions of reality. The surface dimension is implied while we are looking at them "separately" inherently. The deeper dimension is determined by the broader context in which the word is encapsulated. We can say (I) is a superficial description and (II) is a deep interpretation. Through interpretation Norwid makes the words homonymous, but at the same time, he binds them to the main plot of the work, where the homonymic meanings are isolated.

Such an accumulation of interpretations or, to be exact, reinterpretations, as in the poem "Słowo i słowo" can be only found in Norwid's lyric "Spartakus," but the poet's reinterpretation of individual words and concepts is something quite common. "Homeland" is given a general human dimension, universal, without losing its national, domestic character ("Moja ojczyzna" ["My Country"]); "death" becomes a transition between two existential planes of man ("Śmierć" ["Death"]); Norwid sees substantial "greatness" in that which people frequently regard as small, this is a reinterpretation deeply rooted in the Gospel ("Wielkość" ["Grandeur"]); the poet transfers "wildness" to the sphere of intellectual attitudes based on one-sidedness (here he uses the polysemy of the word "jednostronnośc" [one-sidedness]), the inability to liberalise and synthesise, to put matters into broader contexts ("Dwa guziki" ["Two Buttons"]). Norwid draws attention to the fact that "przeszłość ma wieczność w wieczystej połowie!" [the past keeps the eternity in perpetual halfway] ("Post scriptum I", PWsz I, 366). At any given time we have eternity behind and ahead of us. We are immersed in eternity. The past and future are the stages of eternity, divided based on our subjective perspective. What is done "will not be undone," not only because it cannot be, but also because it does not have to be: it remains eternally parallel to what is being done now and what will be done in the future. The category of eternity makes the past, present, and future facts equal.

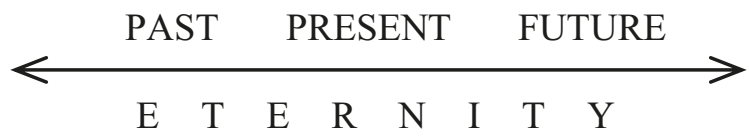

That is why we should try to come closer to the past, as we do to the living present.

Everywhere we see the splitting of one meaning into two: the original and the new one, as a result of reinterpretation. Everywhere we see the clash of these two meanings, a clash won by the new meaning - this is very creative for Norwid's poetry. Sometimes the new, reinterpreted meaning is given its own name, 
which leads to clear synonymy. This is what happens in the poem "Historyk" ["Historian"].

Wiele jest — gdy kto pomierzył stary cmentarz

Albo i genealogiczny-dąb;

Wiele - jeśli inwentarz

Skreślił - zajrzał Epokom w głąb

I upostaciował opis...

Ale - jeśli on w starca, w męża, w kobietę

Powrócił strach ów, z jakim dziad ich drżał,

Patrząc na pierwszego kometę,

Gdy po piewszy raz nad globem stał:

....... to - Dziejopis!

(PWsz II, 134)

[It's great - if one measured the old cemetery,

Or a genealogical-oak;

Great - if one took

Inventory - looked into the depths of the Epochs

And gave shape to the description ...

*

But — if to the old man, the husband, the woman

One returned that fear with which their forefather trembled

Looking at the first comet,

When for the first time it stood over the globe:

.he is a - Historiographer!]

Norwid also tries to separate established synonyms, tries to create distance between their meanings. A good example of this is his well-known distinction between "śmierć" [(sudden) death, mors] and "zgon (skon)" [(timely, mature) death, exitus letalis].

— Dlatego to w Epoce, w której jest więcej

Rozłamań - niźli Dokończeń...

Dlatego to w czasie tym, gdy więcej

Jest Roztrzaskań - niżeli Zamknięć;

Dlatego to na teraz, gdy więcej jest daleko

Śmierci - niżeli Zgonów:

Twoja śmierć, Szanowny Mężu Józefie,

Doprawdy, że ma podobieństwo

Błogosławionego jakby u czynku!

(“Na zgon ś.p. Józefa Z...., PWsz II, 148 [“On the Death of the Late Józef Z....”])

[-That is why in an age in which there are more

Breaches - than Completions... 
That is why at this time, when there are more

Shatterings - than Closures;

That is why now, when there are far many more

Deaths - than timely Departures,

Your death, Dear Sir. Józef,

Truly bears similarity to

A blessed deed!]

"Śmierć" (sudden death) means departure without consent, in pain, in disorder, without faith in the afterlife. "Zgon" (timely death) is a mature, serene and Christian departure. Norwid places these words in the sphere of the two semantic fields in the work:

$\begin{array}{ll}\text { Breaches } & \text { Completions } \\ \text { Shatterings } & \text { Closures } \\ \text { Deaths ("śmierci") } & \text { Departures ("zgony") }\end{array}$

Whereby: $z g o n=s k o n=s-k o n=s$-konanie [timely death, departure] $=$ do-konanie [completion of one's life; accomplishment]. The time of accomplishment, ripe fruit, fulfilment of earthly life.

The ostensibly inconsistent attitude towards synonymy is, of course, understandable. When the starting point is explicitness, a distinction, even if only through synonymy, introduces change, disrupts the stability, and semantically enlivens the text. When what we encounter is the fixed synonymity of the words, they must be separated from one another, the differences between them must be made greater in order to achieve a similar effect, that is, a new relation that draws one's attention, surprises, amazes, worries, gives the words a sense of freshness, and eventually, leads to a new, deeper and reenvisioned outlook on reality. This can be observed in Norwid's works even in the realm of morphological phenomena. When Norwid wants to juxtapose secular, exemplary speech with what Paul says in the name of Christ in the poem "Dwa męczeństwa" ["Two Martyrdoms"], he creates a distance between the meanings of the words "mowa" [speech] and "słowo" [word] by creating a neologism based on an analogous construction with the prefix: "wy-słowa" [lit. out-words]. This shows how extensive Norwid's operations on meanings were.

I would like to draw attention to one more of Norwid's semantic techniques. In the previously examined examples, Norwid was simultaneously engaging different accepted meanings of words or producing polysemy through recognizing "weaker," revealing faded and obsolete, or even creating new meanings (e.g., through reinterpretation). Finally, he was dismantling synonyms through ascribing separate meanings to synonymous words. This produced tension 
between different meanings of different semantic potency and value. The poet generated this tension also in another way - through the contextually cultivated possibility or necessity to create associations.

... Pod sobą samym wykopawszy zdradę,

Coś z życia kończę, kończąc - mecum-vade,

Złożone ze stu perełek nawlekłych,

Logicznie w siebie, jak we łzę łza, wciekłych.

Wstrzymuję pióro... niżeli... niżeli

Zniecierpliwiony się wstrzyma czytelnik:

Poszyt zamykam cicho, jak drzwi celi - -

*

Tak Flory-badacz, dopełniwszy zielnik,

Gdy z poziomego mchu najmniejszym liściem

Szeptał o śmierciach tworów, chce nad wnijściem

Księgi podpisać się... pisze... śmiertelnik!

(“Finis”, PWsz II, 139)

[... Digging out treason from beneath me,

Something of life I end, by ending mecum-vade,

Composed of a hundred pearls and threaded,

Logically as tear flows into tear one into another;

I halt my pen ... before ... before

Impatient reader halts his reading:

I softly close the book's cover, like a cell door - -

Thus a b otanist having completed his book of plants immortal

- After he has, with lowly moss's smallest leaf

Whispered of animal death - wants on the front seath

Of the book to pen his name... he signs ... a mortal!! $]^{8}$

The noun "śmiertelnik" [mortal] originally designated someone, whose earthly life must ultimately be terminated by death, who cannot escape death. However, in linguistic practice - due to the absolute nature of this necessity - this word quickly became a synonym for "everyone," an ordinary, average man. In practice, scope outweighed content. By bringing this word into a context which "whispered of animal death," Norwid revives its etymological, literal meaning. "Śmiertlenik" [mortal], "Flory-badacz" [botanist, researcher of flora], creator

8 English translation by Danuta Borchardt, p. 67. 
of the herbarium, comes closer to the dead specimens he collected, since he is the one that must die. If we stopped at this interpretation, we would have yet another example of returning words to their etymological sources, to their literal contexts. However, the context provided by the herbarium creates yet another semantic possibility. The word "śmiertelnik" [mortal] - accompanied by an associated set of words: "flora," "zielnik" [book of plants, herbarium], "mech" [moss], "liśćc" [leaf] - immediately conjures another word, or rather the opposite word "nieśmiertelnik" [lit. immortal; here a name of the flower: xeranthemum]. A semantic tension characteristic of Norwid is produced between these words. It exposes a paradoxical confusion of names; what is mortal is given immortality by its name, human immortality is put into question by the language. This, though rare for Norwid, is a slightly ironic indication of the lack of logic or the lack of authority in the original meanings of these words. In this poem, which actually concludes the Vade-mecum collection, the poet brings man closer to the world of mortal nature, at the same time, questioning this closeness.

A similar antithetic association - calling on external connotations - expands the meaning of the title "Pieśń od ziemi naszej" ["A Song from Our Land"]. The entire work constitutes an indirect polemic about the image of Poland in Wincenty Pol's Pieśń o ziemi naszej [A Song about our Land]. There we find simplicity and noble, good-natured idyll, whereas here we have the image of an oppressed country "gdzie łez winobranie/I czarnej krwi!..." [where tears are harvested like grapes/and black blood!...] (PWsz I, 124), a country with gallows as its symbol. The allusive association is based on the almost identical title. Phonetically, the difference lies only in the prepositions "o" [about] and "od" [from]. This difference, though, is in fact huge. Norwid's work is not a representation of his own ideas or dreams "about," but a realistic account derived "from" reality.

Nonetheless, the association may be governed not only by opposition, but also by similarity, or even the metonymic principle of contiguity.

Gdy w głębi serca purpurę okrutną

Wyrabia prządka cierpienia,

Smutni - lecz smutni, że aż Bogu smutno -

Królewskie mają milczenia.

(“Ty mnie do pieśni pokornej nie wołaj...”, PWsz I, 231 [“Do not summon me to a humble song...”])

[When at the heart's core cruel purple

Is spun by the spinner of suffering,

Sad - but so sad that even God is sad -

They have royal silences.] 
Gomulicki provides the following commentary: "The 'purple' is a scarlet fabric spun of the threads situated at the core of the heart, i.e. as if of a stream of blood."' But the scope of associations also includes the royal purple, and the executioner's purple, and the scarlet robe of tortured Christ - these are the most established, symbolic "props" Mediterranean culture associates with the word "purple." At this point, we should also consider the second stanza of the poem "Pielgrzym" (PWsz II, 28 ["Pilgrim"]).

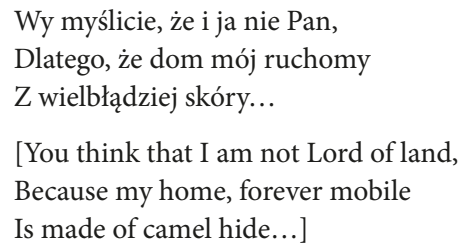

C. Jellenta interpreted this image as that of a "camel," J. Pietrkiewicz and S. Szuman understood it literally ("a house"), J. Przyboś interpreted it as a "tent," whereas Gomulicki as "a sandal made of camel skin."10 Although Przybošs understanding seems the most probable, it is impossible to agree on a single, conclusive interpretation. We are dealing with an entire bundle of associations suggesting the lack of a permanent, normal house/home, emphasising mobility, changeability, an unstable situation, being "underway." Associations are also evoked with regard to the camel - a travelling animal, and the tent - a house typical of nomadic peoples, and the robes worn by biblical prophets, which contribute an additional sacred dimension. Norwid was the master of accumulating mutually interfering meanings, the master of polysemous poetic synthesis.

The associations discussed so far have been external associations, that is, absent directly in the text. Sometimes they are actually "exposed," brought into the body of the work. This is what occurs in the poem "Purytanizm" ["Puritanism"]. The word "purytanizm" [puritanism], which is the main subject of Norwid's poetic focus, is surrounded by a whole semantic field comprised of different words that are associated with it on the basis of their "cleanliness" or "whiteness," such as soap, foam, a goose feather, (white, clean, because "pluskało się przez żywot cały" [it was bathing its entire life]), stearin, snow, alabaster troubles, innocent white virgins, a satin (also white) dress, pearls, jasmine. Practically, all these words are painted negatively by the context in which they appear. The first word "soap" became the most strongly linked to "puritanism" as an element of a comparison

9 Cyprian Norwid, Dzieła zebrane, vol. 2 (Warszawa: PIW, 1966), p. 462.

10 See J. W. Gomulicki's commentary in C. Norwid, Dzieła zebrane, vol. 2, pp. 760-761. 
which has not been formally realised. Throughout the entire work it is used instead of the term featured in the title, the value of puritanism is indirectly tested on the soap, and because of it puritanism is compromised:

\section{[...] mydło — nie jest rzeziebnym marmurem; \\ Dobre na bańki, nie - na ideały! \\ (“Purytanizm", PWsz II, 67 [“Puritanism"]) \\ [[...] soap - is not a carving marble, \\ Good for bubbles, not - for ideals!]}

Purity in itself is not a value, puritanism is not a virtue - that is the message Norwid's poem sends.

In the previously examined texts, Norwid based his word plays on highlighting the existing or potential presence of two or more meanings, on the synonymic stratification of meanings, on the simultaneous actualisation of associated meanings. However, every difference necessary for the word play was accompanied by some kind of similarity - semantic or phonetic. It was not enough for the poet. When this similarity was not discernible, he placed an equal sign between the meanings; he affirmed the contradictions through executive poetic power, relying on his personal understanding of reality. This was how Norwid's paradoxes emerged, which on the surface level appear in the form of absurd juxtapositions. Christ "wszystko za nic ma, a nie ma za nic" [(To Christ) everything is nothing, and nothing is] ("List", PWsz I, 107 ["Letter"]). The gladiator throws a double accusation at the crowd of spectators: "Cała już światłość wasza - noc!" [Already your whole light - night]; "Całe już życie wasze - śmierć!" [Already your whole life - death] ("Spartakus", PWsz I, 286, 285 ["Spartacus"]). The tempted in the poem "Scherzo I" answers the tempter: "Chcę - abyś odszedł ... nie chcę sa mot ności!" (PWsz I, 84) [I want you to leave ... I don't want loneliness!]. The clergyman is someone "którego moc jest niemoc" [whose power is powerlessness] ("Vanitas vanitatis", PWsz I, 396). Heaven is referred to as a place "[...] gdzie jest Nikt i jest Osobą" [... where No-body and is a Person] ("Do zeszłej...", PWsz II, 120 [“To the Deceased..."]). But let us repeat, the absurdity is only superficial. A paradoxical expression also has to rely to some extent on semantic word play. The absurd exterior leads to a deeper interpretation, to the discovery of different levels of meaning of the individual words and of the whole passage. "No-body" may be identified with a "Person," because person has an analogous meaning here God is none of us, is a person in another sense, which eludes our understanding. Spiritual strength may go hand in hand with physical, material impotence, lack of meaning in the world. "Loneliness" is of a purely internal nature here; 
it can be experienced most intensely even in the presence of another person. "Is nothing" in the first phrase means: "can do everything, nothing can stop him," whereas in the second phrase it means: "takes nothing lightly, respects and appreciates everything." Only "light" and "night" represent the same, in any case metaphoric, level of the word. But the entire phrase is ironic, and this irony makes it more reasonable by taking it to another semantic dimension. This rare cumulation of paradoxes, which is tempered slightly by the introduction of the verb "znaleźc" [find] can be noticed in the last stanza of the song "Dookoła ziemi naszej" (PWsz I, 126 [“Around our Land”]):

I znajdziesz żywot $\mathrm{w}$ śmierci, a potęgę

W słabości, w słowie latającym księgę,

W ciemności jasność, a w jasności cienie!

To wiedz - i z plewy szczere czyść nasienie.

[And you will find life in death, and power

In weakness, a book in the flying word,

Brightness in the darkness, and shadows in the brightness!

Know this - and pick the pure seed from the chaff.]

The presented examples are limited to a certain group of phenomena from the realm of poetic semantics: to different tensions created between the meanings of individual words. Tensions based on polysemy: actual, potential, and created by the poet; based on synonymy, antynomy and association. It seems that these phenomena are particularly important for Norwid. Probably more important than Norwid's metaphor, which is often an affront on widely held traditions. Perhaps more characteristic than his reticence technique or tinting the meanings of words and their groups is irony. One can also point out other "operations on meanings" in Norwid's poetry: creating new semantic wholes by merging or splitting the meanings of words, exploiting the phonological system for a punlike effect, tending to make meanings allegoric and symbolic. ${ }^{11}$ All of this situates Norwid's poetry within a particular current of poetic tradition and suggests the appropriate frame of reference.

Norwid's semantic habits - though described here very selectively - are most similar, if previous traditions are to be considered, to Baroque poetry with its predilection for semantic ambiguity and contrast, allegory and paradox. Maybe

11 For Norwid's language and his poetic semantics, see in particular: I. Fik, Uwagi and językiem Cypriana Norwida (Kraków, 1930); J. Błoński, "Norwid wśród prawnuków," Twórczość, Vol. 5 (1967), pp. 67-94; Z. Łapiński, Norwid (Kraków: Znak, 1971), pp. 9-49 (Chapter: "Filozofia i poezja języka"). 
the poet had the most in common with Mikołaj Sęp Szarzyński ${ }^{12}$ and Sebastian Grabowiecki, the precursors of what was new in Polish poetry at the turn of the 16th and 17th centuries. However, Norwid's poetics, and in particular his poetic semantics also bring to mind contemporary poetry, especially the trend we have come to call linguistic poetry and its predecessors. Przybošs overcoming of semantic tensions: bringing closer together the words and phrases that are semantically distant through the use of third words, which come into contact with both sides as if reconciling them within themselves. The syntactical ambiguity of statements in Czechowicz's poetry. The poetic analysis of language in Białoszewski's works: highlighting the constitutive elements and links, exposing the systemic deficiencies and impossibilities, testing words in different situations, parodic complementation of speech or its intentional desemantisation. Exploring linguistic ambiguity in Tymoteusz Karpowicz's poetry. Various "plays on word" by Tadeusz Nowak. These are some of the contemporary frames of reference for Norwid's poetic semantics. ${ }^{13}$

The similarities are striking, which also allows us in this respect to regard Norwid as a poet closer to our times. However, the differences are also apparent. First of all, it seems that in the works by contemporary poets, the operations on meanings have a more autonomous, shall we say "inbred" character. It is more about poetic interpretation of the language, about generating certain poetic qualities based on the decomposition or merger of the words. Norwid more strongly subordinates poetic linguistic operations to the ideas contained in his works, he links semantic reinterpretation with the continuous reinterpretation of concepts, attitudes and beliefs. He affects and reveals language as a specific and separate system, but he does not sever its relations to the plane of designata. The poetic function emerges as if from the maximal intensification of its normal

12 See J. Błoński, Mikołaj Sęp Sarzyński a początki polskiego baroku (Kraków: Wydawnictwo Literackie, 1967), (in particular Chapter 4: "Retoryka paradoksu").

13 See, among others, J. Prokop, “Poezja językoznawcza," in: Euklides i barbarzyńcy. Szkice literackie (Warszawa: Czytelnik, 1964), pp. 45-53; J. Sławiński, “Próba uporządkowania doświadczeń,” in: Z problemów literatury polskiej XX wieku (Warszawa: PIW, 1965), Vol. 3, pp. 263-277; J. Prokop, "Budowa obrazu u Przybosia”, Ruch Literacki, Vols. 1-2 (1960), pp. 72-78; M. Głowiński, “Kunszt wieloznaczności," Pamiętnik Literacki, Vol. 3 (1970), pp. 129-141; Z. Łapiński, “Gramatyka poezji,” Znak, 1959, Vols. 61-62, pp. 1007-12; M. Kaczmarzyk, “Tadeusza Nowaka igranie ze słowem,” Polonista (Lublin 1968 February), pp. 1-32, reprinted in "Historycznoliterackie prace ćwiczeniowe" (Lublin: 1972); A. Dąbrowski, "Metaforyka Tadeusza Nowaka," in: Studia $z$ teorii $i$ historii poezji (Wrocław: Zakład Narodowy im. Ossolińskich, 1970), pp. 403-427. 
features. ${ }^{14}$ Through the exposition of words, Norwid wants to reach an exposed reality. The changing of meanings accompanies the distinct perception and distinct understanding. ${ }^{15}$

\section{Bibliography}

Błoński, Jan. Mikołaj Sęp Sarzyński a początki polskiego baroku.

Kraków: Wydawnictwo Literackie, 1967.

Błoński, Jan. “Norwid wśród prawnuków." Twórczość, Vol. 5, 1967, pp. 67-94.

Dąbrowski, Mieczysław. “Metaforyka Tadeusza Nowaka.” In: Studia z teorii i historii poezji, ed. Michał Głowiński. Wrocław: Zakład Narodowy im.

Ossolińskich, 1970, pp. 403-427.

Empson, William. Seven Types of Ambiguity. London: Chatto and Windus, 1930.

Fik, Stanisław. Uwagi and językiem Cypriana Norwida. Kraków: Kasa im.

J. Mianowskiego, 1930.

Głowiński, Michał. "Kunszt wieloznaczności." Pamiętnik Literacki, Vol. 3, 1970, pp. 129-141.

Głowiński, Michał. “Odpowiednie dać rzeczy - słowo.” Tygodnik powszechny, Vol. 44, 1971, p. 4.

Grygiel, Stanisław. Śmierć człowieka. Znak, Vol. 213, 1972, pp. 431-440.

Kaczmarzyk, Marek. “Tadeusza Nowaka igranie ze słowem.” Polonista, Lublin, 1968 (February), pp. 1-32.

Łapiński, Zdzisław. “Gramatyka poezji.” Znak, Vols. 61-62, 1959, pp. 1007-1012.

Łapiński, Zdzisław. Norwid. Kraków: Znak, 1971.

Prokop, Jan. "Budowa obrazu u Przybosia." Ruch Literacki, Vols. 1-2, 1960, pp. 72-78.

Prokop, Jan. "Poezja językoznawcza." In: Euklides i barbarzyńcy. Szkice literackie, ed. Jan Prokop. Warszawa: Czytelnik, 1964, pp. 45-53.

Sawicki, Stefan. “O ‘Śmierci’ C. K. Norwida.” Teksty, Vol. 4, 1972, pp.100-112.

Sławiński, Janusz. “Próba uporządkowania doświadczeń.” In: Z problemów literatury polskiej XX wieku. Warszawa: PIW, 1965, Vol. 3, pp. 263-277.

14 See Z. Łapiński, p. 16.

15 See S. Sawicki, “O ‘Śmierci' C.K. Norwida,” Teksty, Vol. 4 (1972), pp.100-112, reprinted in: Z pogranicza literatury i religii (1st ed. Lublin, 1978; 2nd ed., 1979). 



\title{
Edward Kasperski \\ The Problem of Questions in Norwid's Work
}

\begin{abstract}
Every reader of Norwid's writings is struck by their saturation with questions, their abundance of various forms of questions. The chapter focuses on the mechanisms that govern the structures of questions and their function in the poet's work. What draws particular attention is the dialogical nature of Norwid's questions: hence, answers are not something external to their structure, but rather complement it. In the course of his discussion, illustrated by appropriate analytical examples, the author shows that the interpretation of questions in Norwid's work provides the key to solving many other issues, such as the poet's system of knowledge about the world, the concept of consciousness, cognition or truth, the method of communicating with, and affecting, the reader.
\end{abstract}

Keywords: Cyprian Norwid, poetics, the structure of questions, theory of dialogue

1

Each reader of Niewola [Enslavement], Rzecz o wolności słowa [On the Freedom of Speech] and Milczenie [Silence] - to list the works written in 1849, 1863 and 1882 respectively, that is, in different periods of Norwid's creative work - is struck by how saturated they are with questions, the richness of their interrogative forms and the diversity of their application. Actually, this applies not only to the mentioned works, but virtually the poet's entire artistic output. For him, question marks seem to resemble - in the words of his early poem "Pióro" ["My Quill Pen"], from 1842 - "skrzywiona wędka, łowiąca myśl, co opodal ledwo skrzelą błyska" [a bent fishing rod, catching the thought, which barely flashes a gill nearby]. Undoubtedly, the interrogative attitude plays a primary role in the thought process, in the shape and expression of Norwid's attitude towards the world, environment, readers and himself (after all, the poet's suggestions do not stray from the truth). Interrogative forms leave a characteristic mark on the sphere of ideas, composition and style of his works. They contribute to an atmosphere depicting the problematics of writing, the high temperature of the ideas contained therein, as well as depth, passion and agility of the word. They add an element of dispute, discussion, quest and thoughtfulness.

Furthermore, questions also became the circumstantial subject of Norwid's remarks and reflections, which would indicate his desire to gain specific self-knowledge in this regard and would testify to the intentionality of interrogative forms in his means of expression. Unfortunately, the poet's remarks 
concerning questions, scattered throughout his works, have not been discerned, appreciated, or systematised by scholars. Additionally, no research has been undertaken regarding how these interrogative forms, which in many works are quite conspicuous in their concentration and form clear compositional dominants, function in his work and what their place is. What is the nature of Norwid's "art of questioning," what philosophy and worldview does it reflect? It must be acknowledged that this state of affairs is partially on account of a generally poor recognition of the specificity of questions in literary output and in literary studies. The sore lack of theoretical studies on this topic is also to its disadvantage.

One of the intriguing problems is the genesis of Norwid's interrogative attitude, the emergence of the conditions conducive to its shaping. The poet's social situation was probably not without influence in this matter, that is, that among other things, he lacked definitive placement within a specific community (gentry? clerk? intelligentsia? bohemia?). This lack of attribution, and as a consequence - lack of a fixed reference point, existing as if on the border between the patriciate and emigré proletariat - favoured Norwid's problematisation of social processes and arrangements, his exposition of the changeability of their attributes, and his questioning of the rules of conduct applicable to interpersonal relationships. This attitude was also influenced by the many heartbreaks which forced him to ask the dramatic "czemu? dlaczego?" [why? what for?] and periodically come to terms with his own past. This attitude was motivated by conflicts with his surroundings, accusations made about him, his replies to these charges, and so on. In the area of literary relationships, the atmosphere of controversiality was a result of conflict with the critics focusing on the alleged "obscurity" and "incomprehensibility" of his works. Finally, Norwid's interrogative attitude was also shaped by the general conditions of his era, the threat of the approaching revolution at the time of the Spring of Nations, the failure of the uprisings, civilizational, social and political transformation in Europe, the deep revision of values and the crisis of values. This crisis was inducive to formulating fundamental questions concerning the past, present and future, the direction of events, the meaning of life, man's place in the world and seeking safe footholds and new ideological orientations in their answers.

It is impossible not to notice that "wołanie o prawdy" [the appeal for truths] expressed through questions usually appears in places where one can feel their lack, where the previous systems of knowledge about the world are shaken. They are the so-called research questions, which Norwid was particularly fond of and often used. We ask whenever we want to learn something and, as a consequence, in asking we simultaneously define what we do not know. The most important 
aspect of a question is thus the unknown, which should be recognised in two ways. If questions aim to acquire missing and desired knowledge, they simultaneously aim to (1) determine the unknown, define it as precisely as possible, and (2) eliminate the unknown through an answer. Therefore, the question aims to identify the unknown and find the answer to the unknown.

By contrast, a closer determination of the nature of the answer depends on whether we are dealing with a decision-making question, such as the one from the first line of Norwid's poem "Czy ten ptak kala gniazdo, co je kala" ["Does this bird sully the nest that sullies it"] or a so-called complementing question ("czemu żaden historyk nie wie, odkąd rozpocząć historię?" [why does no historian know from which point to start history?]).

In Norwid's understanding, questions are just as much the evidence of a lack of knowledge as they are evidence of an awareness of this lack of knowledge. They reflect self-knowledge on the part of the asking subject, which according to him should be both positive, with reference to what we know with certainty, and negative, aware of our cognition's constraints. For this reason, the interrogative attitude constituted the counterbalance to the "systematorstwo" [systemcentrism] against which the poet fought, it was the basis for the criticisms of great philosophical systems, which were built, as Norwid claimed in Milczenie [Silence] "na pojęciu zupełności, całości i harmonii" [on the concept of completeness, wholeness and harmony], promising through their proponents' words to provide the ultimate cognitive absolute.

[...] taki tylko system mam za słuszny - pisał Norwid w "Sztuce w obliczu dziejów" - który nie dla udania odłamku prawdy za jej całość, ale dla tym lepszego okazania braku ma posłużyć. Bowiem nadto dobrze mi wiadomo, że tu kompletności innej nie ma, jedno naprzód w uznaniu, a potem w wyraźnym określeniu tego, co do kompletności zbywać może. (PWsz VI, 272)

[[...] I deem rightful only such a system - wrote Norwid in Sztuka w obliczu dziejów [Art in the Face of History] - which does not pretend a fragment of the truth is its whole, but serves to better represent that deficiency. For I am also well aware that there is no other completeness, besides first recognising, and then clearly defining what is not essential for completeness.]

It is difficult to find a clearer motivation for interrogative practice, which by its very nature is centred on what is lacking for the completeness of knowledge and which is based on determining the unknown.

We shall emphasise that the basis for confidence in a knowledge system is thus not the conviction of its perfection or its offer of seemingly ultimate and ready truths. Norwid argued that "Systemat więc taki tylko pewnym, który ile systematem jest, uznaje i jakoby trafnie wątpić umie o kompletności własnej” (PWsz 
VI, 272) [Thus the system is only certain if, provided it is a system, it recognises and can accurately doubt its own completeness]. This is an important confession, as it shows that doubt constituted a consciously cultivated element of the poet's theory of cognition. The aim of doubt was to demonstrate the incompleteness of a system of knowledge "ku tym doskonalszemu rozwinięciu" [for its ever more perfect development]. When applied to the principles of interrogative practice, this meant the transformation of ready answers which were unquestioningly recognised as perfect into questions challenging them, that is, the brave problematisation of these answers - stereotypes, and vice versa - replacing the questions asked with answers contributing to the progress of previous knowledge. Hence, Norwid's interrogative practice was an element of dialectological tension in the system of knowledge. In accordance with its principles, it should counteract the absolutisation and one-sidedness of the propagated truths. But of course, it does not mean these principles were always followed and that the elements of dogmatism and categoricity were entirely eliminated from his work.

The main importance of questions also arises from the notion of speech adopted by Norwid. Its premise was probably the criticism of the innate origin of human speech, where it was explained as speech "per se" and "by its own," that is, speech realised without foreign speech mediation, without any associations with it. The thesis that human speech has its origin in itself would also mean that religious interpretation referring to a supernatural source of power (cf. Gospel of John) is wrong. Norwid, who defended religion, was fully aware of the disastrous consequences of recognising either the innate origin or the autonomous existence of human speech. However, it is characteristic that his defence of the supernatural origin of language was at the same time the defence of the universal principle of speech dialogism. In the introduction to Rzecz o wolności słowa, Norwid stresses that "Słowa człowiek nie wywiódł ze siebie sam - ale słowo było $z$ Człowieka wywołane [...]" (DW IV, 213) [Man did not derive the word from himself - but the word was brought out of Man...]. "Dział się przeto akt absolutny do człowieka i spowodował te odrzeczenie, które mową się rozwinęło i rozwija" (PWsz VII, 388) [An absolute act was taking place with regard to man and it brought about a response which developed into speech and has been developing ever since]. By opposing the understanding of speech as "ze siebie samej mówiącej absolutnie" [speaking from itself absolutely], Norwid at the same time claimed that "mowa przeto ludzka jest jakoby odpowiad ającą" [human speech is thus

1 Cf. also PWsz VII, 401 with the statement "lénsemble du langage est plutôt une réponse..." 
as if responding]. It also meant: it was responsive speech, invoked by another person's speech (in this case he mainly meant the "akt absolutny do człowieka" [act absolute to man], the Creator's words addressed to biblical Adam), in which it had one of its footholds.

It is thus impossible to overlook the fact that interrogative speech is a type of speech which by its own nature aims to elicit someone else's reply or answer. After all, answering speech is invoked by interrogative speech. In Norwid's works, both these types of speech are indeed dependent on each other; one cannot exist without the other. Works or their fragment in the form of an answer always lead to the implied questions and vice versa, questions always provide an outline of possible answers, even if the addressee or reader must answer them himself. Both types of speech blend together in the process of explicit or implicit dialogue. Connecting them is the key to interpreting the problem of questions in Norwid's work.

The problem of the occurrence and function of questions in the individual literary forms practised by Norwid is a completely different issue which cannot be addressed here in sufficient detail. It is well known that Promethidion is modelled after ancient dialogues, in which - as the author writes in the introduction to "Do Czytelnika” [“To the Reader"] - "najważniejsze dla ludzkości pytania rozstrzygały się [...]" (DW IV, 97) [humanity's most important questions were settled]. It is also known that the rhapsody Niewola [Enslavement] was titled Trzy pytania [Three Questions] in one of its first drafts, and that the principle behind its compositional division into separate parts in the final version is a series of consecutive questions: (I) "co niewola?" [what is enslavement?], (II) "skąd niewola?" [where does enslavement come from?], (III) "jak daleko w wolności trudach naród mój przestawa?” (DW IV, 48-67) [how far along in the hardships of freedom is my nation?], and the answers to these questions. The order determined by the posed questions is characteristic of many treatises, drafts, notes, memorials, and letters, whether in their entirety or just in fragments. The appendix "Dziewięć zaspokojonych pytań" ["Nine Satisfied Questions"] addressed to Władysław Zamoyski could be considered an example of the use of the question-answer technique for a journalistic-persuasive purpose.

Without going into the rich and diverse exemplary material in detail, it can be assumed that the form, appearance, and use of questions in Norwid's work goes far beyond what is traditionally associated with their role as so-called linguistic and stylistic means. In fact, they constitute one of the most fundamental formation principles for his works, common to many genres within which he operated, although in all of them - depending on the assumed constructions - they play specific functions and are subject to special modifications (in this respect, it is 
enlightening to juxtapose his poetry and prose). However, we must exclude this very interesting problem from the investigation at hand.

Because we will generally refer to examples from poetry (although not exclusively) in our further considerations, it is worth taking a moment to elaborate on the place of questions in Norwid's poems. They constitute a compositional dominant, among others, in poems such as "Marmur-biały" ["White Marble"], "Coś ty Atenom zrobił, Sokratesie" ["What Have You Done to Athens, Socrates?"], "Czy ten ptak kala gniazdo, co je kala" ["Does This Bird Sully the Nest which Sullies It"], "Bohater" ["Hero"], "Wielkie słowa" ["Big Words"], "Czemu” ["Why"] (in this case the interrogative word rose to the rank of the title of a work), "Vanitas vanitatis." Questions implied by the subtext also determine the character of these works, which Norwid constructed in the form of a reply. Examples of these are "Deotymie. Odpowiedź" ["To Deotyma. A Reply"], "Odpowiedź (III)" ["Reply (III)"], "Na zapytanie: Czemu w konfederatce? Odpowiedź" ["Response to the Question: Why Wear a Four-pointed Confederate Cap"], "Co robić?" ["What to Do?"], "Do Bronisława Z." ["To Bronisław Z."]. These examples allow us to distinguish a group of poems, which we could decisively call questioning and replying poems. The last group consists of works which are determined by a question-answer structure (e.g., among the poems from the Vade-mecum cycle these would be: "Wakacje" ["Holiday"], "Zagadka” ["Riddle"], "Gadki” [“Gabs"], "Dwa guziki (z tyłu)” [“Two Buttons (at the back)"], "Ostatni despotyzm" ["The Last Despotism”]).

A characteristic compositional device used by Norwid is the interrogative beginning of a poem, which, especially if it is a question in quotation marks, having an external source and addressed to the poet, lends a replying tone to its appearance, a dialogic stance to the matter raised in the question. Below we present a few markedly clear examples:

Na purytanizm, jak na rzecz obrzydłą,

Czemu? się gniewam (pytasz). [...]

("Purytanizm (z listu do M. S.)", PWsz II, 67

["Puritanism (from the letter to M. S.)"])

[At puritanism, like at an abominable thing,

Why? am I angry (you ask). [...]]

Malarz, skończywszy Tassa wizerunek

Owinionego w aksamitnej szubie,

Pyta - co? w dziele oceniam i lubię.

(“Wierny-portret”, PWsz II, 52 [“An Accurate Portrait”])

[Upon finishing Tasso's portrait

Wrapped in a velvet overcoat,

The painter asks - what? in the work do I assess and like.] 
Zaledwo się myśl tego wydawnictwa wszczęła, Pytasz mię, jak? je nazwać - PISMA, albo DZIEŁA? Jakbyś do obu nazwisk tajemne miał wstręty Przyjmuję to, i wraz Ci odpowiem, Walenty!

(“Do Walentego Pomiana Z.”, PWsz II, 151

[“To Walenty Pomian Z.”])

[As soon as the publication was conceived of, You ask me, how? to name it - WRITINGS or WORKS? As if you were secretly disgusted by both names I accept it, and I will answer you right away, Walenty!]

Śród Europy, nie dla obyczaju

Chrzczonej - co począć w rozebranym kraju?

Co robić? - pyta ten, tamten i owy,

Rozłamanego narodu trzy głowy.

(“Co robić?", PWsz II, 214 [“What to Do?"])

[In the midst of Europe, not for custom Baptized - what to do in a partitioned country?

What to do? - asks this, that and another, The three heads of the broken nation.]

Besides the questions addressed to the lyrical subject of the poem (if the term "lyrical subject" has any meaning in this context - a more adequate term might be "dialogic subject") we could gather numerous examples of the questions asked by him or herself and addressed to the poem's protagonist or addressee. It is thus possible to draw the conclusion that both these acts - answering the question and asking the question - were two complementary aspects of Norwid's poetic personality, which showed the willingness to engage in dialogue, the willingness to "dogłębiania" [deepen] all "kwestie żywotne" [matters of life] which surfaced on the horizon of his epoch and in his immediate surroundings.

The richness of interrogative forms is particularly characteristic of Vade-mecum, which is in a way a landmark work with regard to Norwid's use of the poetic question. In general, his innovations involved considerably broadening of the scope of questions, and boldly introducing the lyric of elements with problematisation, discourse, meditation and conversation. As previously mentioned, they were expressed in the ingenious creation of interrogative frames for the entire poetic work ("Bohater" ["Hero"], "Wielkie słowa" ["Big Words"]), as well as in the penetration of interrogative intonations to the lower levels of poems' linguistic organisation.

If the elementary interrogative form is a sentence (cf. the traditional division of sentences into affirmative, interrogative, and imperative sentences), the poetic practice of Vade-mecum's author would suggest revising or abandoning 
this approach. This is because the question-answer relation in his texts does not match up with the interrogative sentence-affirmative sentence relation. The first relation is - to use Bakhtin's term - of a metalinguistic nature: the questionanswer systems define not only the relations between sentences (or statements composed of sentences), but also penetrate the structure of the sentence itself, they define the relations between its composite elements. As a consequence, the question-answer systems break the sentence structure, subordinating it to the needs of interrogative speech, the needs of dialogic confrontations of attitudes, thoughts, and ideas. Consider the following essential examples:

— "Człowiek?... jest to kapłan bezwiedny

I niedojrzały..." -

(“Sfinks (II)”, PWsz II, 33 [“Sphinx (II)”])

["Man?... he's an ignorant callow

Priest...” $]^{2}$

Odkrywająca?... - wciąż idzie do słońca: [...]

Zakrywająca?... - cieszy znów inaczéj: [...]

("Sieroctwo", PWsz II, 42 [“Orphanhood"])

[Uncovering?... - still goes to the sun: [...]

Covering?... - pleases again differently: [...]]

Mistyk? jest błędnym - pewno!

(“Mistycyzm”, PWsz II, 46 [“Mysticism”])

[A mystic? he's astray - of course] ${ }^{3}$ !

Rym?... we wnętrzu leży, nie w końcach wierszy,

(“Kolebka pieśni (Do spółczesnych ludowych pieśniarzy)”, PWsz II, 114

[“The Cradle of Songs (To Contemporary Folk Songsters)”])

[A rhyme?... lies within, not at the ends of poems.]

- Prawda? - nie jest przeciwieństw miksturą...

[...]

Orzeł? - nie jest pół-żółwiem, pół-gromem.

Słońce? - nie jest pół-dniem, a pół-nocą.

Spokój? - nie jest pół-trumną, pół-domem.

Łzy? - nie deszcz są, choć jak deszcz wilgocą.

2 English translation by Adam Czerniawski in: Cyprian Norwid, Selected Poems (London: Anvil Press, 2004), p. 62.

3 English translation by Danuta Borchardt in collaboration with Agata Brajerska-Mazur, Cyprian Norwid, Poems (New York: Archipelago Books, 2011), p. 41. 


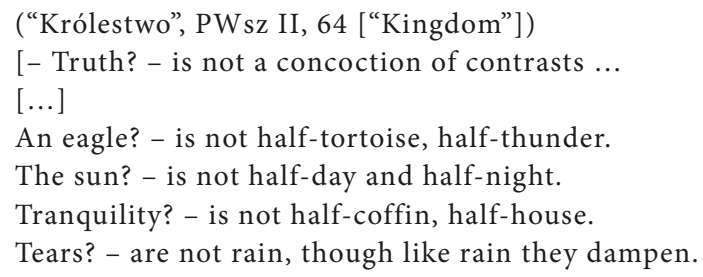

Each of these examples can easily be transformed into a non-dialogic ("monodic") variant in the form of an affirmative sentence as shown below:

"Człowiek jest to kapłan bezwiedny

I niedojrzały...”-

["Man is an ignorant callow

Priest..."]

Odkrywająca wciąż idzie do słońca: [...]

Zakrywająca cieszy znów inaczej: [...]

[The uncovering one keeps going towards the sun: [...]

The covering one pleases in a different way: [...]]

Mistyk jest błędnym - pewno!

[A mystic is astray - of course]

The comparison of both versions - the original and the transformed - reveals a profound difference between the realisations found in Norwid's works and their paraphrases. Of course, the expressions - "Człowiek?... Jest to kapłan bezwiedny/I niedojrzały..." ["Man?... he is an ignorant callow/Priest..."], and "Człowiek jest to kapłan bezwiedny/I niedojrzały..." ["Man is an ignorant callow/Priest..."] cannot be seen as equivalent, not only from an intonational, but also a stylistic, semantic, and compositional perspective. Taking the context of the poem into account, we could not assign both these expressions to the same person. The relation between the subject and the predicate of the original sentence is transformed into the question-answer relation, a relation of foreign speech (- "Człowiek?..." [“Man?...”]) and own speech (“...jest to...” [...is...]), into a dialogic clash of the attitudes of the person asking the question and the one receiving it, one reply with another. In turn, the paraphrase has a declarative, aphoristic, monologic overtone. It lacks the dramatism of the cited intrasentential dialogue. In the poem, which reveals the solution to the sphinx's riddle, that is, the solution to the mystery of man, this kind of paraphrase would create a dissonance, would be a poetic cliché. Against the backdrop of the above example, it seems that an analysis of the remaining examples is unnecessary. 
These remarks aim not to solve or exhaust the problem of questions in Norwid's work, but rather to define them. In attempting to clarify some of the premises and features of his interrogative attitude by defining them from the perspective of their subject-matter, we should simultaneously conduct a preliminary theoretical analysis. It is thus necessary to provide an answer to the question "what is a question?" As it is known, questions may be conceived of as a link in the research process, ${ }^{4}$ a branch of the theory of cognition, ${ }^{5}$ a subject of interest in logical syntax, ${ }^{6}$ a special type of sentence in the system of natural language, ${ }^{7}$ a didactic means, ${ }^{8}$ a dialectical-rhetorical device, ${ }^{9}$ a phenomenon of writing style, and so forth. In our further considerations - by contrast to the approaches mentioned above - we will try to treat the question as an element of a dialogue and in the context of that dialogue's problems. The position closest to these considerations would be an approach that could be referred to as the dialogic theory of question.

\section{2}

Before we move on to the specific problem of questions, it is first necessary to characterise the elements of the theory of dialogue, which would be the starting point and foundation for the theory of question. A few remarks on Norwid's adopted model of dialogue, which determines his interrogative practice, would also be helpful.

The driving force of a dialogue is the process of mutual linguistic influence in which the dialogic subjects participate - always situated towards each other

4 R. Ingarden, "O pytaniach esencjalnych," in: Z teorii języka i filozoficznych podstaw logiki (Warszawa: 1972), pp. 327-482; S. Nowak, "Sformułowanie problematyki badań," in: Metodologia badań socjologicznych. Zagadnienia ogólne (Warszawa: 1970), chapt. IV, pp. 214-251; T, Pawłowski, “Teoria pytań i jej zastosowania," in: Metodologiczne zagadnienia humanistyki (Warszawa: 1969), chapt. III, pp. 67-121; W. Marciszewski, "Analiza semantyczna pytań jako podstawa reguł heurystycznych," in: Studia Semiotyczne V, published and with introduction by J. Pelc, (Wrocław 1974), pp. 133-146.

5 W. F. Berkow, Vopros kak forma mysli (Minsk 1972); J. Lange, The Cognitive Paradox. An Inquiry Concerning the Claims of Philosophy, (Princeton, New Jersey: 1970);

Z. Cackowski, Problemy i pseudoproblemy, (Warszawa: 1964).

6 T. Kubiński, Wstęp do logicznej teorii pytań (Warszawa: 1971).

7 M. Świdziński, “Analiza semiotyczna wypowiedzi pytajnych we współczesnym języku polskim," in: Studia Semiotyczne IV, published and with introduction by J. Pelc (Wrocław 1973), pp. 221-249.

8 K. Ajdukiewicz, "Pytania dydaktyczne," in: Logika pragmatyczna (Warszawa: PWN, 1965), pp. 93-94 and Logiczne podstawy nauczania (Warszawa: Nasza Księgarnia, 1934).

9 R. Whately, Elements of Rhetoric (Oxford: John Murray, 1828). 
in some way. The processuality of dialogue is always connected to the fact that the statements made by the dialogic parties develop through time, they mutually co-determine each other, modify or strengthen the arrangement of relations between the participants of the dialogue. Dialogic replies in the broad sense are various "speech acts" expressed and formulated through words, gestures, facial expressions, postures, and all other signs. In turn, the term "dialogic subjects" refers both to real persons and - especially in literature - fictitious persons and personified beings. It is understandable that the mutual influence of subjects operates under rules which determine their duties towards each other, orders and prohibitions concerning the freedom of speech, speaking order, expressive overtone of their statements, and the degree of matter-of-factness. The entirety of these rules makes up the dialogic convention which determines the course of a dialogue.

Conventions of this sort determine, among other things, the order of questions and answers, the domain of polite questioning, different interrogative "taboos," and so on. In individual cases, provoking questions or, on the contrary, asking inappropriate questions, often violates dialogic tact, and as a result persuades the dialogic subjects to take actions that include confirming or modifying the convention. An example could be the first scene in Norwid's comedy Miłość-czysta u kapieli morskich [Pure Love at Sea Baths], where the topic of Julia and Marta's conversation is exactly those "indiscreet questions" asked by Marta, who wants to learn from her interlocutor "więcej niż wszystko" [more than everything], that is, more than she is willing or able to share, and Marta is finally met with Julia's refusal to answer. Crossing the accepted boundaries of dialogic convention usually brings the existence of such boundaries to our awareness, and illuminates the silently adopted rules of dialogic exchange.

The exchange of statements becomes the nerve of mutual influence. It transforms the sequence of replies into a relation of simultaneity, it imposes the comparability of statements, and it creates a "common language" for communication. The commensurability of replies concerns, among other things, the form of expression, topic, and content of the dialogue, the expressivity of statements therein. It is one of the conditions for the integrity of the dialogue. Furthermore, it becomes a basis for expressing differences, the development of the dialogue. The act of dialogic exchange, that is, delivering word for word, phrase for phrase - and within the field discussed here: replacing a question with an answer, or an answer with a question - consequently means establishing verbal relations, social contact between the interlocutors.

Dialogues can unfold in a specific time-space, which often creates an important frame for them, becomes a subject of reflection, topic. Salome's question 
in the conversation with Mak-Yks "Dlaczego pan tu mieszka?... nie owdzie. W pawilonie, obok krewnej swojej?" [Why do you live here?... not there. In the pavilion, next to your relative?] hints at the complicated relationship between the tenant Durejko and Maria Harrys, it exposes the dramatic situation of a man deprived of his living space, without a significant "place" in society and the world, "obcego wśród swoich" [foreign among his own]. As it is well known, Norwid repeatedly stressed the influence of location on the thought process and trajectory of conversations - an example would be the fragment of Pięć zarysów [Five Sketches] beginning with the words: "Nie tylko bowiem z myśli jest myśli osnowa" (DW IV, 157) [For the fabric of thought is not made of thought only]. In this case, the main idea is that the dialogic relation question-answer should also be specified with reference to the broad time-space of the dialogue, the spatial and content-related situation here and now, and finally with reference to the occasional character of the conversation, such as an accidental meeting, joint undertaking, confidential confession, ideological discussion, and so forth.

In searching for the principles and assumptions of Norwid's understanding of dialogue, it must first be stated that the author of Milczenie was opposed to treating it in exclusively formal or instrumental-functional categories. $\mathrm{He}$ wrote: "Mowa dlatego że jest mową, musi być nieodzownie dramatyczną! Monolog nawet jest rozmową ze sobą albo z duchem rzeczy" (PWsz VI, 232) [Speech, because it is speech, must be necessarily dramatic! Even the monologue is a conversation with one's self or with the spirit of things]. According to Norwid, besides the conversation proper between two persons - the scope of dialogue encompasses "rozmowę ze sobą" [the conversation with one's self] and "rozmowa $z$ duchem rzeczy" [the conversation with the spirit of things], internal and rhetoric monologues, or content-related speech encompassing stories and descriptions.

Quite characteristically, Norwid was against any forms of pointless dialogue, against the exchange of words that leaves the dialoguing persons indifferent towards each other, and where there is no authentic mutual influence, understanding, progress of knowledge, or personal development. In Zwolon, a critical attitude towards some dialogic forms was expressed, among others, in the idea of "różno-głosy monolog" [multi-voice monologue] that was to reconstruct "tłum-pustek - ciszy-wrzawę samotniczą" [crowd-emptiness -hubbub of a solitary silence]. The criticism of the ostensible dialogue was also expressed in the categories of personalism and assimilation that were often evoked by the writer. As part of his or her personal attitude, the person involved in a dialogue takes nothing from the partner, while as part of the assimilation attitude - the same 
person gives nothing from himself/herself. In both cases, there is no authentic dialogue, because they lack the actual and mutual exchange of content.

According to Norwid, the basis for authentic dialogue was conversation, in which "słychać mówienie treść powiadające"(DW VI, 410) [speech can be heard conveying the content]. The model of dialogue postulated by Norwid excluded everyone who "nie baczą, O czym mówią? - lecz tylko: z kim? toczą rozmowę" [does not pay attention to what they talk about? - but only: with whom? they converse] and those "których obchodzi tylko to, co mówią -" [who are concerned only with what they say -]. As a consequence:

Jedni z księciem o główce maku egipskiego

Będą poważnie mówić... O głowie człowieka

Mówiąc (nie z księciem), lżej ją uważą jak kwiatek!

Drudzy, do siebie tylko, co myślą, odnosząc,

Ten, z kim mówią, jest dla nich świadkiem niepotrzebnym.

(DW VI, 417)

[Some will be talking seriously to a prince about

The head of Egyptian poppy... About the man's head

Talking (not to the prince), giving it less consideration than a flower!

Others, referring what they think only to themselves,

The one to whom they speak is for them an unnecessary witness.]

In one of the variants of the ostensible dialogue, that is, the assimilation variant, the principle of adapting to the addressee completely destroys the principle of speech content-relatedness. By contrast, in the personal variant it is the opposite, but the presence of the addressee has no influence on the course of the conversation. He is "świadek niepotrzebny" [an unnecessary witness]. An ostensible dialogue, that is, "gadanie" [talking] is thus a unilateral dialogue, which eliminates any of the three main conditions for a conversation: a speaker, co-interlocutor, and subject. The positive model is determined by Norwid indirectly in the statement about its rarity:

I rzadko kto, na względzie mając strony obie, rozmawia z nami o czymś!... (DW VI, 171)

[And rarely does anyone, considering both sides, talk to us about something!...]

To recapitulate the above considerations, an authentic dialogue, according to Norwid, should bring us closer to the truth, which is both object-related, since it reflects the properties of the matter referred to by the interlocutors in their speech, and inter-subject-related, since it emerges at the intersection of different 
points of view. It is an outcome of what is being talked about and, at the same time, of who is talking to whom. It emerges in the confrontation and exchange of views, it combines various approaches to a given object. The positive value of the dialogue is that all unidirectionality arising from divisions into me and you, my own and other, undergo weakening and constraining, since they become relative differences in the framework of a higher-order, common platform of understanding. Of course, the dialogue weakens natural differences and builds bridges, but it also requires differences so that both parties can have a productive and beneficial exchange of values. The ground of unity and differences should be the interpersonal community, which is simultaneously the condition, frame, and objective of the dialogue.

The role of questions can be explained in the light of the already mentioned cognitive aims of dialogue, and Norwid's recurring postulate of cooperation between interlocutors. Since questions both expose and delimit a lack of knowledge, they propose an active role for the addressee, encouraging him to participate in the search for truth. Wherever questions such as "what to do?" appear, they provoke different answers, reflect varying standpoints and socio-political tendencies, and therefore initiate - in accordance with Norwid's ideals - authentic polyphonic dialogue, which allows for a confrontation of viewpoints, their clash (highly praised by Norwid as essential to progress, the universal right to life), comprehensive elucidation of different aspects of the discussed issue. By contrast, if the dialogue's point of departure is a ready answer, the questions posed demonstrate its incompleteness, reveal the historical relativity of the propagated truth, show possible and multiple ways in which the discerned lack of knowledge can be supplemented. The polyphony of the dialogue is then expressed in a variety of formulated issues.

The considerable social significance that Norwid assigned to questions, the ability to adequately formulate them and to give appropriate answers, must also be underlined. In the poet's opinion, all "pytajniki, napomknienia i powołania" [questions, mentions and references] made by society are always indicators of the needs and aspirations concerning a given community, they express the transformations and processes that this community is undergoing. The questions of this sort, penetrating "głębiny i stopnie szczerości ducha i oczywistości" [great depths and degrees of sincerity of the spirit and the obvious" are oftentimes suppressed and repressed, they are denied the right to be expressed - in the name of so-called "jawności względnej, zakreślone z góry szranki mające" [relative overtness, which has pre-defined limits]. In Milczenie Norwid stated, "W całości zatem naszej umysłowej rzeczy jest coś z-fałszowanego, coś za-kłamanego powierzchownie i nie znoszącego szczerych, 
prostych zapytań, jak to zwykło się zdarzać w fałszywych położeniach!" (PWsz VI, 230) [Thus, in the entirety of our mentality there is something falsified, something superficially deceptive, which can not stand honest, simple questions, as usually happens with false assumptions!]. In the sketch Obywatel Gustaw Courbet [Citizen Gustave Courbet], he noticed: “Jest jednakże w naturze rewolucyjnego działania, że ono poczuwa jak najtrafniej zaległości społecznych pytań, lecz nigdy onychże na swoim miejscu postawić ani z obowiązującą określić ścisłością i powagą nie umie" (PWsz VI, 484-485) [It is, however, in the nature of revolutionary activity that it most accurately perceives arrears of social questions, but is never able to put them in the right place or define them with the proper accuracy and seriousness]. Hence, Norwid aimed at creating a specific hermeneutics of questions, which would allow for reading and understanding their deep meaning, and - on a different plane - at developing pragmatics, which would in turn be the ability to properly formulate big and small "social questions," to define them "with the proper accuracy and seriousness" and to "put them in the right place." This was the direction of many of his writing endeavours. Hermeneutics and pragmatics of questions constituted an integral element of his postulated model of dialogue.

\section{3}

Questions stand out on account of their characteristic structure, they come in many varieties, and play different dialogic functions. They are unique creations which can and should be considered irrespective of their contextual embedment. In research practice, it has even been postulated to establish a new discipline whose subject of study would exclusively be questions, creating a kind of general theory of questions. ${ }^{10}$ However, the contemporary study of questions tends to be fragmentary, conducted from the perspective of logic, psychology, sociology, philosophy, information theory and other disciplines. Following the model of detailed disciplines, such as the logic of questions, it is possible to conceive of a poetics of questions that would study the forms and functions of questions in literature, showing their meaning in the history of artistic style and forms. Of course, it requires a broader perspective than just considering them in the context of a set of linguistic and stylistic means. It is also essential to narrow the field of research down to fit within the limits of the general theory of the question itself.

10 Pawłowski, “Teoria pytań i jej zastosowania,” p. 69. 
In the study titled "On Essential Questions," Ingarden wrote: "Upon pronouncing the word question, we can understand it in two different ways: (1) question in the sense of a certain act of awareness, or questioning, (2) an interrogative sentence which is the product of the act of questioning and a certain semantic unity." ${ }^{11}$ But other meanings of the term could also be adduced, including, among others:

1) Question in the sense of a speech act, which expresses a directed action of the speaker with reference to the subject of his speech, the interlocutor, and himself.

2) The above sense is only indirectly related to understanding question as a means or tool of influence, with the use of which the speaker aims to obtain necessary information, tries to persuade the person asked to confess his own truth, confirms or questions the views propagated by him.

3) In specific cases, question can serve as the objective of operations undertaken by the person asking the question, for instance, when it is necessary to formulate an accurate research question or when it should provoke the interlocutor's interest.

4) Question may also refer to the interrogative practice, where asking questions becomes a methodological activity akin to investigation, interrogation, student examination, questionnaire development, interview conduct, the instrument of parliamentary question.

5) In connection with the listed understandings of question, it is necessary to characterise the interrogative attitude which should be properly distinguished from affirmative, imperative, requesting attitude, and so on.

6) In the last meaning that interests us, question - or, to be more precise, the ability to be made into a question - reflects the entirety of a worldview, which is expressed in taking a so-called interrogative attitude towards the world and by an interrogative practice which branches off into different spheres of cultural activity, such as philosophy, art, literature, journalistic activity.

Let us first take a look, in particular, at the first and last meanings of question.

Although in research practice we deal solely with questions in the form of statements, it would be advisable to relegate them to the extra-linguistic position, in which they are grounded. As suggested by Ajdukiewicz, its feature is "the state

11 Ingarden, “O pytaniach esencjalnych,” pp. 327-328. 
of psychological tension," similar to a desire, manifested in the aspiration to seek satisfaction through obtaining an answer to the question. By manifesting the "aspiration to obtain a certain message,"12 questions, that is, research questions, express: (1) the asking person's lack of knowledge, (2) the willingness to eliminate this lack of knowledge, and (3) the knowledge allowing for the search for the missing knowledge. ${ }^{13}$ This aspiration contains elements of passivity, being defined by the lack of knowledge, and active moments, which are reflected in the undertaken search for knowledge through the plying of specific partners with questions. The process of plying with questions introduces question to the area of understanding and dialogue.

It would be essential, from our point of view, to conceive of questions as complex semantic structures comprising constative, epistemic, and volitional components. ${ }^{14}$ The constative components are a linguistic equivalent of the reality the question addresses, as a result revealing something about the phenomena highlighted by question marks. The only important thing in this case is what properties of the phenomenon are recreated through questions and in what ways. In the statement from the poem "Grzeczność" (PWsz II, 104) ["Politeness"]:

"Któż jest? - pytam - tyle uprzejmy dla gości

Wśród podejrzewających się bliźnich owych?”

["Who is? - I ask - so kind to guests

Among those neighbours suspecting one another?"]

The statement that "w wielkim Chrześcijan natłoku" [in a great crowd of Christians] there was someone "tyle uprzejmy dla gości" [so kind to guests] is constatation. The epistemic component, in turn, determines what is known but is not known to the person asking the question. It is thus certain that there exists a person who is "kind to guests," but it is unknown who that is. Finally, the volitional components express the conviction motivating the question that "dobrze byłoby wiedzieć" [it would be good to know] who that person standing out from "a great crowd of Christians" is. The desire to learn something motivates the resultant statement, which is intended to make someone answer the question of who that kind person is.

The division into these components is largely symbolic and only approximately distinguishes the interrogative content. It does not consider, among other

12 Ajdukiewicz, "Pytania dydaktyczne."

13 L. Koj, "Analiza pytań. II. Rozważania nad strukturą pytań," in: Studia Semiotyczne, Vol. III (Wrocław 1972), p. 24.

14 Marciszewski, "Analiza semantyczna pytań...." 
things, the properties a question gains in a communicative situation and in the process of dialogic interaction.

In such an interaction, the question becomes an exponent of the dialogic relations held between the person asking the question and the one answering it, it determines the course of communication (exchanging information, exposing activities, refuting charges, etc.), the type of interdependence between interlocutors (the person seeking the information - the one possessing it), their intentions and aims towards each other (obtaining information - not providing it despite persistent questions on the part of the interlocutor). Within the question itself, it often comes to a clash of different or even controversial points of view, standpoints, and values. Commenting on Mickiewicz's Pan Tadeusz to Karol Ruprecht, Norwid wrote: "Będzie to zawsze arcydziełem przez sztukę i przez tła od Ruisdaelowskich doskonalsze - ale!!! poema arcy-narodowe-polskie?”... (PWsz IX, 213) [It will always be a masterpiece through art and through Ruisdael's more perfect canvas- but!!! poems arch-national-Polish?]. In the quoted statement, putting a question mark against the classification of Mickiewicz's work commonly accepted by all Poles is an attempt to revoke it, expose the lack of motivation for it in the content of the work, thus demonstrating its groundlessness. The value of the question mark in this case brings it closer to the value of negation. It shows the dialogic, polemical attitude of the author of the letter towards people's attempted - in his opinion - "ubóstwianie" [idolizing] of Mickiewicz and, at the same time, towards the danger of the affirmation of the values that are utterly foreign to his ideal of a Pole-Catholic. In relation to the addressee of the letter, Norwid wants to deprive him of the certainty of society's assessment of the work, problematising his standpoint towards the raised issue, turning his thought into a dialogue. The function of dialogising the attitude of the addressee is one of the general features of Norwid's questions.

In the broadest worldview sense, the interrogative approach can mean the comprehensive attitude towards the world, lending the interrogative practice a universal dimension - both in the object-related (literally everything can be supplied with a question mark) and subject-related sense (everyone has an inalienable right to ask any questions and seek the answers to them). Norwid's ideal in this regard was "okres heroiczny greckiej filozofii" [the heroic period in Greek philosophy], when, he thought, "nieledwie że na ulicy zapytać było przecie można, co jest dusza? jak i ile nieśmiertelna? co życie i żywot? na co i dla czego filozofia?" (PWsz VI, 223) [even in the street one could ask, what is a soul? how and to what extent is it immortal? what is life and existence? what for and why is there philosophy?]. Posing such "pytania istotne" [relevant questions] was also a condition of social dialogue, the scarcity of which the writer experienced in 
his lifetime. Such a dialogue is realised in the process of permanent contact and cooperation between minds, in the mutual asking and answering of questions, in the joint search for and practice of the truth. For Norwid, like for Socrates, a rational man is a being that is able to provide an answer to a rational, "szczere $\mathrm{i}$ prostotliwe" [sincere and straightforward] question.

In The Theory of the Novel, Lukács made a remark quite useful to the understanding of an interrogative worldview, when he juxtaposed the cultural formation, oriented "towards the coherent and closed whole," with the formation occurring on "a historical scene," as a set of questions that must be answered. ${ }^{15}$ As it was believed, these last formations emerge during great cultural crises, the collapse of the established system of faith, customs, interpersonal relations, threats to the personal identity and existence of individuals and whole communities. This is accompanied by unstable authorities, a loss of confidence, the fading of "the light of internal obviousness" which is the guide in the sphere of cognition and decision-making. Comprehensive questions are thus born of a situation of loss or threat of loss of psychological, moral, and social anchors, the ability to properly identify phenomena, attitudes, processes, and the disturbance of the classification systems functioning in society; in the face of having to make choices without precedent, the consequences of which cannot be predicted.

This worldview creates an atmosphere of controversiality which inspires or allows the fractures and cracks in the stagnant social and cultural structures to be revealed, highlighting their arbitrariness and randomness, demonstrating the gaps in the picture of the world based on the old worldview. It is expressed, among other ways, by negation, questioning, criticism. The result of the interrogative approach is a picture of the world with an unknown; an open, unfinished, and incomplete world, from which various possibilities emerge. However, it must be noted that the hallmark of this worldview may also be the search for constructive answers, positive problematicity, and specific cognitive activism. This search for an answer usually means looking for a new orientation system in the field of cognition, ethics, art, and ideas. As a result, questions lead to a deep revision of the value systems functioning within a particular epoch, to a renewal of authentic values, a change of cognitive paradigms, and ideological or artistic trends.

15 G. Lukács, Teoria powieści [The Theory of the Novel]. Esej historyczno-filozoficzny o wielkich formach epiki, transl. by J. Gościcki, with an afterword by A. Brodzka (Warszawa: PIW, 1968), part I. 
Questioning readily available answers ties into the collapse of ritualised communication forms, a fiasco of dead dialogic conventions (cf. Norwid's "Ostatni despotyzm" ["The Last Despotism"]), a reaction to the violation of elementary principles of dialogic exchange, such as reciprocity, symmetry, and productivity of the dialogue; exposing - using Norwid's words again - "z-milknień" [silentfalls] and the "spół-milczenia ogółu" [co-silence of the whole community] which hide the truths demanding to be brought to light; the need for authentic dialogue that could replace "różno-głosy monolog" [polyphonic monologue], which hides the already mentioned "tłum-pustek" [crowd-emptiness] and "ciszy-wrzawasamotniczej" [hubbub of solitary silence]. This kind of questioning is usually accompanied by a restructuring of "wspólny język" [the common language], which forms the basis of the dialogue, and the testing of its new models.

\section{4}

Let us reflect now on some of the problems of the structure of the question, and on its dialogicity. Besides questions that are object-oriented, there are also questions that are subject-oriented, asked by the person asking the question to him or herself, or addressed to the interlocutor, the potential respondent. Questions of this sort could also be called personal. Here are some examples of the latter ones:

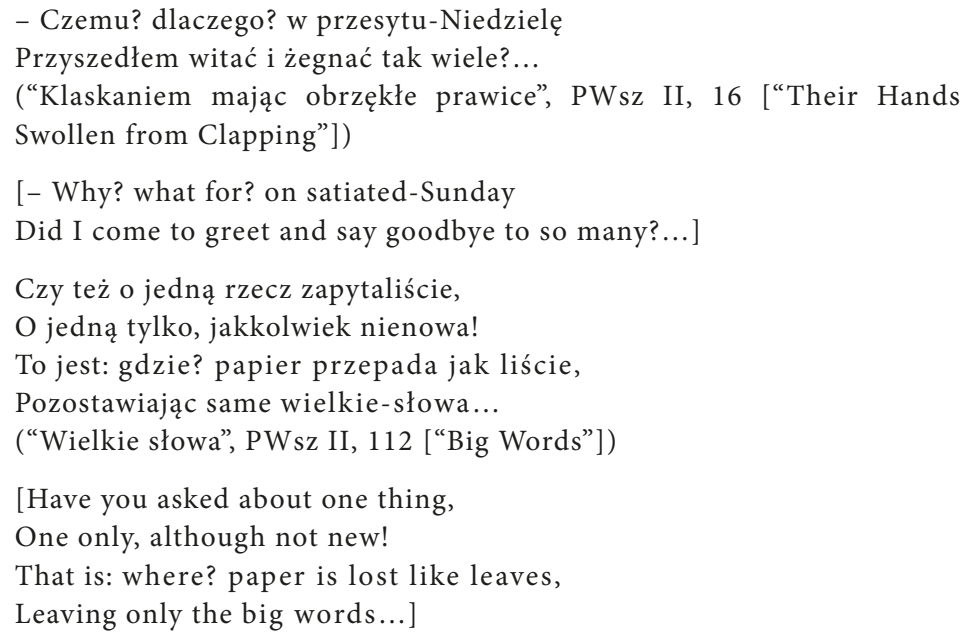

In the second example, there is a question within a question, that is, an object-oriented question starting with "gdzie? papier..." [where? paper...] included in the superordinate frame of the personal question "czy zapytaliście" [have you asked]. 
It is also an example of a question about a question, that is, a question that makes the addressee aware of the need to solve the mystery of "wielkie słowa" [the big words], a question about the place of their appearance.

Depending on the context, exclusively object-oriented questions have implicit personal frames, which point to the addressee and indicate the type of relationship between the person asking the question and the one answering it (or their plural equivalent). An example of an object-oriented question:

Czemu? ten świat - nie jako Eden,

Czemu - nie Ideałem?

(“Specjalności”, PWsz II, 40 [“Specialties”])

[Why? is this world - not like Eden,

Why - is it not the Ideal?]

Such a question may be appropriately oriented in a particular context by attributing to it meta-interrogative frames, such as "czy zapytaliście" [have you asked], "czy wiecie" [do you know], "czy chcecie wiedzieć" [do you want to know], "czy zastanawiałeś się" [have you thought about], and so forth. Asking a question about a question brings us to the area of dialogic relations.

In its dialogic attitude, a question does not only assume an answer, but through its own structure determines the schema of the answer. Questions such as "who wrote Vade-mecum?" already contain an answer template which, following Ajdukiewicz's suggestion, we call a question datum (datum quaestionis) and which in the above example can be expressed by the formula " $\mathrm{X}$ wrote Vade-mecum." This formula contains a variable "X," which must be solved by the person answering the question. At the same time, the variable determines the question's unknown. It also provides certain clues as to the character of the unknown; it includes, among other things, the suggestion that Vade-mecum has an author, the scope of the unknown is in this case equivalent to the semantic scope of the indefinite determiner "somebody."

This example shows that determining the scope of the unknown is hugely dependent on the so-called interrogative operators, ${ }^{16}$ including question words such as "who," "what," "which," and "why". We use the term "interrogative operator" here, because in Norwid's writings we often deal with default questions, and because question words are polysemous, they sometimes express several interrogative operators at once. Confronted with the expression "Idziesz?" [You are coming?], where the question is expressed solely through the content or the

16 T. Kubiński, op. cit. 
graphical sign, it is only through the context that we can attribute operators such as "do," "where to," "where," or "with whom" to it, all of which specify the question. As known, these operators are also the key to the classification of questions. One of the most important operators is, among others, the particle "czy" [in English - questions starting with the auxiliaries: "do/have" etc.] which is typical of so-called decision or choice questions, which allow for either the confirmation or negation of the question datum. Questions of this type are particularly important in Norwid's question practice.

Apart from the unknown, questions also deliver data called knowns. In the question "gdzie? papier przepada jak liście" [where? paper is lost like leaves], the known is thus what happens to this "zapisany papier" [writing-covered paper] which received ironic treatment in the poem. It concerns deep meaning, that is, it says that the greatness of words does not depend on the magnificence and decoration of the books in which they are published. This greatness is precisely "ksiąg tajemnica" [the mystery of books], and solving this mystery should be the goal of the poem's reader. As the poem unfolds, this question gives rise to another question, which additionally motivates the use of the question word "gdzie" [where]:

Gdzie? tych słów-wielkich jest wspólna kraina, Jedna dla ludzi wszystkich i taż sama, Która nie kończy się, lecz wciąż zaczyna Dla nas Ojczyzna dziś, jak dla Adama!

(PWsz II, 112)

[Where? is the common land of these big words, One for all people and the same, Which does not end, but always begins -

For us, the Homeland today is, as it was for Adam!]

Quite characteristically, the relation between the known and the unknown in the question creates a dialogic relation sui generis. Let us take a closer look at the phrase "Gdzie? tych słów - wielkich jest wspólna kraina" [Where? is the common land of these big words]. It is characteristic that Norwid refrained from placing the question mark at the end of the whole expression; as a result, it is divided as if into two separate parts:

1) Gdzie? [where?]

2) tych słów - wielkich jest wspólna kraina [is the common land of these big words]. 
On the one hand, there is the operator "gdzie" [where] which defines the unknown, on the other hand, there is an expression of a clearly constative nature, it conveys a certainty. In fact, the question refers not to whether there "is" a common land for big words, but to "where" it lies. In the structure of the whole question there is a confrontation of the known, recognized as a certainty, and the unknown, which demands supplementation and thus elimination. It could be said that two voices clash in this question - one categorically states a certain fact ("tych słów wielkich jest wspólna kraina") and the other categorically demands its localisation ("gdzie?").

As suggested by the above examples, the structure of questions contains a particular structure of judgements about the world, the structure of the knowns, which themselves seem to be the answers to the previously asked questions. Questions determine the answer templates, they thus determine the fields of desired activity of the person asking the questions, but themselves - this concerns supplementing questions in particular - can be explained as a dialogic reaction to statements which are imperfect, incomplete in one respect or another. Of course, the formal interpretation of such a question as, "who wrote Vade-mecum," which distinguishes an answer template by the formula " $\mathrm{X}$ wrote Vade-mecum," is also correct. However, looking at this problem from the perspective of the dialogic function of questions, this line of reasoning should be reversed and the answer template should be treated not only as an intentional product of the question, but on the contrary, the question should also be perceived in terms of a dialogic reaction to a heard statement that "somebody wrote Vade-mecum," a reaction demanding the identification of precisely "this somebody" as the author of the mentioned collection of poems.

One of the elements of the structure of questions is their assumptions. They involve a system of beliefs which are, as it were, prior to the question, they form the foundation, on which it is based. Let us introduce a question which requires a brief discussion. The questions presented below

Czemu? ten świat - nie jako Eden,

Czemu - nie Ideałem?

[Why? is this world - not like Eden, Why - is it not the Ideal?]

include two constatations concerning the world, two certainties which, nonetheless, according to the person asking the question, do not exhaust the knowledge about the world if they require its supplementation, which is evidenced by the very fact that they are being asked. Both statements are expressed negatively they do not say what the world is, but what it is not. 
ten świat - nie jako Eden

(ten świat) - nie Ideałem.

[this world - is not like Eden

(this world) - is not the Ideal.]

They serve as points of departure for the question. If the person asking these questions were not convinced of their absolute truthfulness, the dramatic "czemu?" [why?] just would not have any point.

When we say "ten świat" [this world], we allow for the existence of a world that is different from the one we are thinking of right now, the one to which we direct our interlocutor's attention. In the cited statements we thus guess that "tamten świat" [that world] exists, the world longed for by the subject of the poem as an ideal world which has pre-determined properties:

(tamten świat) - jako Eden

(tamten świat) - Ideałem.

[(that world) - is like Eden

(that world) - is the Ideal.]

As shown in the above analysis, the question involves a hidden comparison of "this" and "that" world, states a deep difference between those, whereby this difference is explicitly evaluative. The question word "czemu?" [why?] defines an unknown, which is the focus of the whole question and which also concerns the raison dêtre of this situation and the reason behind the emergence of this difference. After all, the question here is what makes the real world so much different than the ideal representation. The question thus assumes that the current state of affairs is not self-explanatory, but has some reasons which should be known when "this world" turns out to be a disappointment and one considers fixing it. The ending of the poem "Specjalności" ["Specialties"] confirms this line of thought.

Among the assumptions of this question, we could also find the conviction that looking for the reasons behind the current states of affairs, looking for answers to the question why this is the way it is and not otherwise, constitutes an important fragment of knowledge about the surrounding world and ourselves. A closer look into Norwid's works shows that the questions into the reasons of the existing state of affairs - next to the already mentioned decision and essential questions, such as "what is work?" "what is originality?" and so on - form the group of questions that most often appear in his works. In addition, such questions often play an exposing function, as they reveal the lack of motivation, arbitrariness, randomness, or absurdity of the questioned truths, statements, customs, and actions. They 
are often a testimony to Norwid's principled disagreement with order that is only superficial, without any deep justification. They generally arise from the conviction that the existing or future states of affairs are not without an alternative, that it is possible to take effective action aimed at the elimination of the negative states of affairs or the preservation of the positive, if their raisons d'être are just.

Therefore, questions such as "czemu? dlaczego?" [why? what for?] - and their conscious, intentional use by Norwid cannot raise doubt - introduce in the subtext of a concrete question various deep meanings, certain kinds of arrangements preceding the question, which we generally called assumptions. If they concern the knowledge sought by the person asking the question, if they determine it categorially (knowledge about the reasons and origin of phenomena, about their ideal form, about their features, structural relations, etc.), they can be called epistemological. They reveal a matrix of cognitive categories and a matrix of so-called problems ${ }^{17}$ which are at Norwid's disposal and which he imposes on the world. Both matrices are very significant for questions, as they determine the conditions and possibilities of answers, not to mention the fact that they also characterise the epistemological stance of the person asking the question.

The theories of questions also discuss the pragmatic assumptions concerning the relations between the person asking the question, the question itself and the person who is asked the question. For instance, such an assumption is the conviction on the part of the person asking the question that his or her question will cause the person asked to give an answer that will allow him or her to satisfy his or her thirst for knowledge (information). It means that the person asking the question expects to supplement the unknown or choose the alternative through the answer elicited from the person asked. Asking questions becomes pointless if they do not yield a direct or indirect answer, if "chcenie odpowiedzi" [the desire for an answer] is not satisfied. However, there are few exceptions to that, such as rhetorical questions which communicate an already known answer - in an interrogative form, which thus often overrules the possibility of questioning the a priori assumed, the only possible answer:

Gdzież? kiedy? czyje? ostały się miecze,

Bez słów, bez myśli, bez prawd i ich części? -

(Fulminant, DW IV, 195)

[Where? when? whose? swords have remained,

Without words, without thoughts, without truths and their parts? -]

17 Ingarden, "O pytaniach esencjalnych", p. 334. 
The rhetorical question here polemically refers to the question that would aim at undermining what Norwid considers undeniable truths. As a matter of fact, the analysis of Norwid's rhetorical questions deserves a separate dissertation.

The striving for an answer - which is silently assumed in the question - is often revealed and made independent, is the main subject of the efforts made by the person asking the question. These efforts become all the more explicit, the greater the resistance and refusal on the part of the person being asked the question is. The elements of "żądanie odpowiedzi" [demanding an answer] in the question are then transformed into the elements of an order, request, that is, forms which seem to border on questions.

To sum up these rather fragmentary reflections, the dialogic character of questions is manifested both from the perspective of the functions of the questions in the dialogue (oriented to the addressee and orienting the addressee to the person asking the question, eliciting an answer and including it in the dialogue, etc.) and from the perspective of the dialogue determinants in the structure of the question. Above all, it is significant that, after all, answers are not entirely external in relation to the question, but they also form an element of its structure. Generally, a question is understood as a reaction to answers and as their anticipation. From the form of the answer one may conclude the type of the prior question, just as from the form of the question one may conclude the answer expected by the person asking the question. The delivered answers assume appropriate sets of possible questions, whereas the existing questions allow the reconstruction of the prior answers. Not all components of an answer defined by the question are determined beforehand, but the fact that questions are the addressee’s "zadania do rozwiązania" [tasks to solve], allows, among other things, to stimulate him or her to think and manipulate his or her awareness, introduce elements of own speech to foreign speech, or in other words - the active cooperation of persons participating in an interrogative situation. In addition, there is no doubt that the interpretation of questions in Norwid's works is a key to solving many other problems, just to mention his adopted system of knowledge about the world, concept of awareness, cognition or truth, the method of communicating with and influencing the reader.

\section{Bibliography}

Ajdukiewicz, Kazimierz. Logiczne podstawy nauczania. Warszawa: Nasza

Księgarnia, 1934.

Ajdukiewicz, Kazimierz. "Pytania dydaktyczne." In: Logika pragmatyczna.

Warszawa: PWN, 1965. 
Berkow, Vladimir F. Vopros kak forma mysli. Minsk: Izdat. Belorus. Gos. uniw. im. V.I. Lenina, 1972.

Cackowski, Zdzisław. Problemy i pseudoproblemy. Warszawa: Książka i Wiedza, 1964.

Ingarden, Roman. “O pytaniach esencjalnych.” In: Z teorii języka i filozoficznych podstaw logiki. Warszawa: PWN, 1972, pp. 327-482.

Koj, Leon. "Analiza pytań. II. Rozważania nad strukturą pytań." In: Studia Semiotyczne, Vol. III, ed. Jerzy Pelc. Wrocław 1972, pp. 22-39.

Kubiński, Tadeusz. Wstęp do logicznej teorii pytań. Warszawa: PWN, 1971.

Lange, John. The Cognitive Paradox. An Inquiry Concerning the Claims of Philosophy. New Jersey: Princeton University Press, 1970.

Lukács, György. Teoria powieści. Esej historyczno-filozoficzny o wielkich formach epiki. Trans. Jan Gościcki, with an afterword by Anna Brodzka. Warszawa: PIW, 1968.

Marciszewski, Witold. "Analiza semantyczna pytań jako podstawa reguł heurystycznych.” In: Studia Semiotyczne V, ed. Jerzy Pelc. Wrocław 1974, pp. 133-146.

Nowak, Stefan. "Sformułowanie problematyki badań." In: Metodologia badań socjologicznych. Zagadnienia ogólne. Warszawa: PWN, 1970, pp. 214-251.

Pawłowski, Tadeusz. “Teoria pytań i jej zastosowania.” In: Metodologiczne zagadnienia humanistyki. Warszawa: PWN, 1969, pp. 67-121.

Świdziński, Marek. "Analiza semiotyczna wypowiedzi pytajnych we współczesnym języku polskim.” In: Studia Semiotyczne IV, ed. Jerzy Pelc. Wrocław 1973, pp. 221-249.

Whately, Richard. Elements of Rhetoric. Oxford: John Murray, 1828. 



\title{
Danuta Zamącińska
}

\section{Discovering Norwid's Poetry}

"Co piszę?" - mnie pytałeś; oto list ten piszę do Ciebie Zaś nie powiedz, iż drobną szlę Ci dań - tylko poezję! Tę, która bez złota uboga jest - lecz złoto bez niej, Powiadam Ci, zaprawdę jest nęd zą-nędz... Cyprian Kamil Norwid "Do Bronisława Z."

[“What am I writing?” you ask; well I'm writing you this letter -

But don't say I've sent you a token gift - it's only poetry! Poetry without gold is poor - but gold without her, I tell you, verily is vanity of vanities...]

"To Bronisław Z."

So who was Norwid and where is his place in 19th -century literature?

He was a Romantic, but a different one than his great predecessors. If he does not fit the model of Polish Romantic poetry it is not because he was a bad Romantic but because our model of Romanticism is simply wrong. Instead of casting Norwid outside the cycle of epochs in which Polish literature developed we need to expand our understanding of Romanticism to accommodate Norwid.

Zofia Stefanowska, "Norwid's Romanticism"

\begin{abstract}
The present chapter aims at revising some of the popular opinions on Cyprian Norwid as a poet (Norwid - intellectual, innovator, etc.), which often hinder the reader from truly understanding of Norwid's poetry. The analyses include major elements which make Norwid's lyrical poetry so attractive:1. Perfect rhetoric of Norwid's literary style, which, according to the author, finds its roots in the poetry of the Enlightenment.2. Emotional character of Norwid's poetry.3. Norwid's individual and personal experience of life.
\end{abstract}

Key words: Cyprian Norwid, lyric poetry, Enlightenment, emotions

1 PWsz II, 238. English translation by Adam Czerniawski, Cyprian Norwid, Selected Poems (London: Anvil Press Poetry, 2004), p. 92. 
The more we try to define the internal laws of a work's "microcosm," the more we deviate from grasping its participation in the historical process. Conversely, the more we focus on the "event-like character" of the work and its participation in evolution, the more it disappears from before our eyes as a stable and finished system; it loses the boundaries of its identity, de-crystallizes and dissolves in its genetic conditioning. Certainly, one can imagine various formulas for a practical compromise between the two approaches, but it is bound to remain merely that: a compromise between two mutually exclusive tendencies. ${ }^{2}$

As is easily confirmed, this methodological quandary does not stop literary historians from doing their work. Although the interpretations of particular works are outpaced by reconstructions of systems, worldviews, and attitudes, the most reliable method of confirming one's findings remains providing an apt quotation. Thus, when we seek orderly accounts of Norwid's views on, say, humanity in general, women in particular, society, nation, Poland, Russia, Christianity, the Pope, civilization, America, emigration, the 19th century, language, love, goodness, or despotism, we cannot and should not reach for a collected edition of his works, as this would be an insult to specialists on Norwid. We can only regret that not all of his insightful essays have been collected in edited volumes, and that we need to make the effort to recover them from archived annual journals. Literature on the subject grows against - as it were - Norwid's vital "interest," which is his dream of finding truly self-reliant readers. The famous "servant" illuminating his specific works assumes many forms: various women figures, Juliusz Wiktor Gomulicki, Michał Głowiński, Zdzisław Łapiński, and even Wacław Borowy!

Still, despite the convenience and great pleasure of following these subtle Guides to the Poet's work, we continue to feel the need to read his writings. What is more, we also seem to feel the need to remove these mediating Guides and their bright light from our mental space. ${ }^{3}$

Initially, my main aim was to discuss Norwid's lyric poems because I aspired to seek the value of his oeuvre elsewhere than in the linguistic components of his works, and elsewhere than in the meanings that are recommended for extraction by the poet's great discoverers and researchers. However, I overestimated my capabilities. A re-reading of studies on Norwid (including the extensive and

2 Janusz Sławiński, "Synchronia i diachronia w procesie historycznoliterackim," in: Dzieło - język - tradycja (Warszawa: PWN, 1974), p. 11.

3 However, they cannot be completely eliminated! "Sometimes you might think that you produced an original sentence, but it..." as Professor Irena Sławińska would say during her wonderful lectures I was able to attend as a student. 
most decidedly personal book by Jacek Trznadel, in which many pages perfectly present Norwid as my generation would read him ${ }^{4}$ ), made me realise that all I can do is offer "glosses to," humble corrections, or alternative interpretations. In the remarks that follow, I wish to present "my" Norwid: a poet of emotions, not one of intellect, a poet of "explanations" ["dopowiedzenia"], and a visionary.

Structural knowledge of the various systems that, together, form the whole designated by the name "Norwid" is not the essential key to understanding those of his works which I am examining. It is only a close reading of short excerpts from this whole that allows me to find myself in the role of a true recipient, who, in her own way, understands the message contained within these poems. When Norwid is reconstructed as a great poet, he lures us with his multi-dimensionality and complexity, but he can be also repulsive on account of his monumental consistency. The man who inhabits the space of a single lyric allows me to sometimes forget about the strict rules, the internal discipline, the obligations of a man towards social convention, because he occasionally reveals the kind of emotionality, injustice, or lack of self-control that make him seem less like a "lyrical subject" and more like a real person.

Alicja Lisiecka argues, "Norwid was a deeply intellectual writer." Whose claim is she repeating? This may be less important because no study of Norwid fails to mention this formula. But why is it brought up over and over again if it is an obvious and accepted opinion? If every interpreter is obliged to reiterate it, I am beginning to suspect that the matter may be far from clear, and that we may be dealing with a persuasive measure meant to convince us that he is intellectual even though he may not be. Perhaps this formula protects the self-esteem of the poet's learned readers. After all, if the object of study is so intellectual, its researchers must be exponentially so.

- Więc słusznie gań - a smucić pozwól się niesłusznie,

Bo któryż smutek (rzeczy biorąc wielkodusznie),

Któryż bo smutek słuszny?!... [...]

(“Z listu. (Do Włodzimierza Łubieńskiego)”, PWsz I, 97 [“From a Letter. (To Włodzimierz Łubieński)”])

[- Then rightly reprove - but let me be sad without good reason,

Since which sadness (to put things magnanimously),

Which sadness is justified?!...]

4 Jacek Trznadel, Czytanie Norwida. Próby (Warszawa: PIW, 1978).

5 Alicja Lisiecka, Norwid - poeta historii (London: Veritas, 1973), p. 66. 
By means of several selected poems, I wish to demonstrate how we usually fail to recognize the poet's right to "unjustified sadness" - how we convince ourselves of his objectivity and consistent rationality, even when the linguistic shape of his thoughts displays distinguished marks of a reaction that does not necessarily cast the object in the clear light of reason, and contains no appeal to the readers' rationality. What in fact happens is that these marks ostentatiously invite the participation of none else but our own "nerves," phobias, or simply life experiences.

I would like to begin with a verse letter, of loose form, addressed to a specific person: Maria Trębicka (PWsz I, 217-219). The poem observes all epistolary conventions: date and address ("New-York, United States of America, 10 April 1853"); appropriate style ("Pierwszy list, co mnie doszedł z Europy,/Jest ten od Ciebie" [“The first letter I received from Europe/Was yours"]); numerous direct words to the recipient ("Pani" ["Dear Mrs"], "O! wierz mi, Pani" ["O! please believe me, my Lady"], "nie myśl, Pani” ["please do not think so, Dear Lady"]; attempts to recount stories from the journey, unknown to the addressee, including the trip's moral equations; a brief indication of future correspondence prospects ("Proszę mi pisać o bracie i sobie,/O rzeczach, które Pani są najbliżej,/ [...] - albo o tym,/Co się podoba Pani" ["Please write about your brother and yourself,/About things that are closest to You/[...] - or about whatever/You want"]); and finally, not without a specific epistolary flirtatiousness, sketches of people, including crisp portraits of the addressee ("Pani jesteś/Dobra" ["You are, my Lady, a Good Person"]) and self-characterizations, which were later widely used by critics (“ja to jestem/Na świecie jako w trupie doskonałej/Nadkompletowy aktor" ["I am,/In this world, as in a perfect troupe,/Just an extra actor"]).

After its fifty-six lines, which accustom readers to regard the text as an intimate letter addressed to the "good" Lady, the poem takes a sudden turn that disrupts its regulated flow: "O, Boże... jeden, który JESTEŚ - Boże,/Ja także jestem..." (PWsz I, 219) [“O, God... the one who IS,/I do exist too...”]. Was the letter torn apart and discarded? Was the addressee ignored (and consequently insulted as a person)? What are we to make of this entirely unmotivated (not even in literary terms) transformation of the Author? Still, this turn - one towards the only proper Addressee and Listener of humans - does not mark the end of the poem, which actually closes with a not at all extensive, equally surprising nine-line coda: "A Wy? o! moi wy nieprzyjaciele" ["What about You? o! my enemies"]. In this way, epistolary convention is completely broken with and the text becomes haunted by passages redolent of prayers or invectives, although "forma $\mathrm{z}$ formą nie zlewa się" ["[these] forms do not fit together tightly"]. Through these crevices we can see the figure of the Desperate One emerge. The subjective emotional 
experience was too overwhelming to be contained in the objectivized forms and conventions characteristic of letters, prayers, or speeches.

It seems to me that no lyrics written by Mickiewicz and Słowacki contain analogous examples of such a thorough rejection of an initially assumed lyrical stance, or feature the same kind of an emotional arc: one leading from a friendly confession to a scornful severing of ties, from the warm "O! please believe me, my Lady" and the intimate "you" to the cruel, estranging and repelling "my enemies."

The verse-letter addressed to Maria Trębicka served Łapiński as an example showing how religious components function in Norwid's poetry. ${ }^{6}$ Łapiński argues that their role is to provide order and introduce premises that integrate the human being. My interpretation, however, pursues a different path - that of the destruction (perhaps its only instance in Norwid's poetry) of "dekoracji cnót, wiary" (PWsz I, 218) ["the façade of virtues and faith"]. This text's composition contains clear traces of the moments in his personal life when incoming waves of emotions substantially ruined his intricately crafted system of beliefs. All that was left of the religious foundation of Norwid's worldview sufficed only to assume the superficial pose of one who is bestowing a blessing, a gesture not really stemming from the imperative to love your enemies but mimicking it in a purely rhetorical fashion.

The same enraged and contemptuous "lack of justification" (how surprising in the case of an artist who is typically ascribed a just character on account of his intellectual, multilateral analysis of human reality) can be observed in Norwid's imagery when it captures, in the flash of metaphor, the question of "small social groups," of "our close ones," "fellows" as well as of social and domestic "circles." Consider the understanding and objective tone of the language used in the poem "Kółko" ["The Little Circle"]:

Jak niewiele jest ludzi i jak nie ma prawie

Pragnących się objawić!... - [...]

(PWsz II, 84)

[How few are the people, hardly any at all

Who wish to self-reveal!... - [...]]

This passage remains a reflection only insofar as the object captured in its perspective is seen in categories of "wielka liczba" ["large numbers"]. When the matter is

6 Zdzisław Łapiński, Norwid (Kraków: Znak, 1971), pp. 110-112. Cf. also Zofia Szmydtowa, "Listy poetyckie Norwida," in: Studia i portrety (Warszawa: PIW, 1969), pp. 314-315. 
removed from the sphere of social abstraction ("Ni współcześni, ni bliscy, ani sobie znani" ["Neither contemporaries, nor close ones, nor acquaintances"], seen in a flash and recognized in the literalness of the "pair" of dancers ("Ręce imając, śliniąc się szczelnym uściskiem" ["Holding hands, drooling in a tight embrace"], it becomes necessary to adopt the same peculiar perspective with regard to the dance. Detachment evaporates and there is no transition from the intellectual, "tamed" albeit sad diagnosis of a certain dysfunction in social interactions:

Odpychają się, tańcząc z sobą w zabawie

Poufnej, kłamią płynnie, serdecznie się zwodzą;

(PWsz II, 84)

[Push each other away while dancing, or in intimate

Play they glibly lie, warmly deceiving each other;

towards the sudden concreteness of seeing:

Ręce imając, śliniąc się szczelnym uściskiem.

(PWsz II, 84)

[Holding hands, drooling in a tight embrace.]

This centre of the poem - in terms of imagery - does not allow us to participate in such a personal vision in ways other than through the sharp aesthetic categories of repulsion and disgust. The actual horror of relations between "the closest ones" is expressed subjectively, through the language, and is not levelled by any further images later in the poem. Metonymies direct our attention towards more conventional signs of otherness:

- Oni zaś tańczą: łonem zbliżeni do łona,

Polarnie nieświadomi siebie i osobni;

Dość, że nad nimi jedna lampa zapalona

I moda jedna wszystkich wzajemnie podobni.

(PWsz II, 84)

[- So they dance: bosom close to bosom,

Yet poles apart, unaware of themselves and separate;

Suffice that one lamp is lit above them all

And one single fashion makes them all alike. $]^{7}$

7 English translation by Danuta Borchardt in collaboration with Agata Brajerska-Mazur, in: Cyprian Norwid, Poems (New York: Archipelago Books, 2011), p. 51. 
Anchoring the metaphor in subjectively experienced, painful social life (what a contrast the "drooling" creates with our image and knowledge of elegance and self-restraint in 19th-century society) as well as positioning the subject as the observer, and not participant of the party leads readers to modify their idea of what attributes should be expected of the recipients of Norwid's lyrical works. Even if these readers judge their own intellectual background harshly - as one not guaranteeing that they would "understand" the poet - they need not worry. More often than it would seem, the poet relies on the sense of sharing certain experiences with us. The discovery that reading Norwid requires "merely" analogous, negative life experiences ("Human life is impossible. But it is only affliction which makes us feel this," Simone Weil says ${ }^{8}$ ) would lead us to ascribe these qualities to "mature people," whereas the "immature," before they gain the proper experience, would have to rely on studies devoted to Norwid.

It sometimes seems that the general thesis about Norwid being "a deeply intellectual writer" has relieved readers of the duty to stay in touch with his text. Consider the case of the poem "Jesień" ["Autumn"]. The critic writes:

Both the poem's melancholy character and moralistic message are entirely objectivized and almost entirely eliminate the lyrical "I" of the poet. It is not Cyprian Kamil Norwid who is speaking to us but the Spirit of History $\left[\ldots . . .^{9}\right.$

However, when we read the following passage:

O - ciernie deptać znośniej - i z ochotą

Na dzid iść kły,

Niż błoto deptać, ile z łez to błoto,

A z westchnień mgły...

(PWsz I, 117)

[Oh - easier to tread on thorns - and agog

Walk onto spikes of spears,

Then tread on mud if it's all of tears

Of sighs is the fog... $]^{10}$

we honour its intonation, the wishful mode, the vocabulary that spitefully addresses the meanings preserved in sentimental conventions - we cannot interpret the poem otherwise than as a radically subjective expression of the poet's

8 Simone Weil, Gravity and Grace, trans. Emma Crawford \& Mario von der Ruhr (London: Routledge, 2002) p. 94.

9 Alicja Lisiecka, Norwid-poeta historii, p. 91.

10 English translation by Borchardt, Poems, p. 85. 
feelings. A flat prose translation would read: "Well, I would gladly prefer to confront something clear, even if it were sharp and hurtful, than to be stuck in this overwhelming, sticky and languishing mass of emotions." A metaphorical variant could be proposed as well: "let a bitter frost come and finally freeze this mud." Clearly, Norwid is organized and intellectual in dreaming this up. However, we are primarily dealing with his specific manner of speech, in which emotions are generally revealed through the initial intonation - one reminiscent of such common outbursts as "I have had enough of this!"

A similar situation is encountered in several of Norwid's lyrical masterpieces, which - as Borowy points out - "reveal truths from beyond the sphere of illusions.”

"One particularly charming story," he continues, "is the one about star-tears thrown down by the sky onto the graves of ill-fated lovers [...], but it is true that [...] falling stars are only stones." ${ }^{11}$

3

Cyprysy mówią, że to dla Julietty,

Że dla Romea, ta łza znad planety

Spada - i groby przecieka;

4

A ludzie mówią, i mówią uczenie,

Że to nie łzy są, ale że kamienie,

I - że nikt na nie nie czeka!

(PWsz II, 22)

[It is for Julietta, cypresses say,

For Romeo, that tear from above the planet's ray

Falls and through graves seeps.

But people say, and say with learned shocks,

That these are not tears, but rocks,

And - that no one for them vigil keeps. $]^{12}$

It seems striking that in quoting popular opinion ("the embodiment of cold reason," Gomulicki $\left.\operatorname{argues}^{13}\right)$, Norwid employs means that come across as

11 Wacław Borowy, O Norwidzie. Rozprawy i notatki (Warszawa: PIW 1960), p. 14.

12 English translation by Edmund Ordon, "O tłumaczeniu Vade-mecum C. K. Norwida," in: Przekład artystyczny, ed. S. Pollak (Wrocław: Zakład Narodowy im. Ossolińskich, 1975), p. 244.

13 Cyprian Norwid, Dzieła zebrane, ed. J. W. Gomulicki, vol. 2 "Wiersze. Dodatek krytyczny" (Warszawa: PIW, 1966), pp. 358 \& 786. 
technically inept ("mówią, i mówią" ["say, [...] and say"]; "Że to nie [...], ale że [...] I-że [...]" ["That [...] but [...] And that [...]"]), emotional, and stammering. The words of the literary cypress trees are more distanced and objectivized than the emotionally tainted expression of the person or people quoting them. Is syntactic clumsiness, or the intonation that gains momentum, not more important and telling in semantic terms than the ordinary lexical meanings?

Let us consider the poem "Fatum" ["Fate"] (PWsz II, 49), which is an example of Norwid's most objectivized lyricism. Stefan Szuman recommended it to poetry lovers as the epitome of absolute perfection in lapidary lyricism. ${ }^{14}$ This assessment of the poem's form and meaning was confirmed by Borowy, who argues that "human 'Fate' is merely the necessity to face misfortune." ${ }^{15}$ Gomulicki also writes, in the context of this piece, of the "conscious and deliberate use of suffering." 16 The meaning of the poem as well as the metaphors it employs seem to confirm even more general claims about Norwid's poetry:

$[\ldots]$ this kind of lyricism is never despairing or even depressing. At its foundation lay harsh stoicism, Catholicism, and hope driven by faith. The most painful statements are transformed in this poetry into lofty resignation or a spiritual ascension in prayer. ${ }^{17}$

This lesson of Norwid's is rooted in the famous passage by Marcus Aurelius:

Can you call that a misfortune for a man which is not a miscarriage of his nature? [...] Then does this accident debar you from justice, magnanimity, prudence, wisdom, caution, truth, honour, freedom, and all else in the possession of which man's nature finds its full estate? Remember, therefore, for the future, upon all occasions of sorrow, to use the maxim: this thing is not misfortune, but to bear it bravely is good fortune. ${ }^{18}$

Naturally, bearing the philosopher's thought in mind, some other reader or listener of parables would know perfectly well that it is equally crucial how the narration is developed. Should he or she forget, in this situation, about the equal importance of the "what" and the "how" when it comes to reading literature? Readers notice that the monumental design of the first stanza does not really fit the similar style of the second stanza. How noble the phrases

14 Stefan Szuman, O kunszcie i istocie poezji lirycznej (Toruń: Państwowe Toruńskie Zakłady Graficzne, 1948), pp. 113-120; Wacław Borowy, O Norwidzie. Rozprawy i notatki, p. 55; Cyprian Norwid, Dzieła zebrane, vol. II, p. 786.

15 Wacław Borowy, O Norwidzie. Rozprawy i notatki, pp. 54 \& 55.

16 Cyprian Norwid, Dzieła zebrane, vol. II, p. 786.

17 Wacław Borowy, O Norwidzie. Rozprawy i notatki.

18 Marcus Aurelius Antoninus, Meditations, trans. George Chrystal (Project Gutenberg, 2017), book IV, paragraph 49. 
from the first part sound: "dziki zwierz" ["wild beast"], "Nieszczęście" ["Misfortune"], "człowiek" ["man"], "fatalne oczy" ["fateful eyes"]. They bring to mind some classical tragedy. What about the second part? As far as vocabulary and collocations are concerned, "już wiek XIX" ["it is already the 19th century"]: "artysta/Mierzy swojego kształt modelu" ["the artist/measures his model's form"], "skorzysta/Na swym nieprzyjacielu" ["will profit/from his foe"], "postaci waga" ["the full weight of its being"]. And the last line? It also does not sound as if it came " $\mathrm{z}$ tragedii całego antycznego świata" ["from the tragedy of all of antiquity"]: the line “- - I nie ma go!" [“- - And it is gone!”] features a rhythmical shortening and demands the use of displaced accent, all the while containing no nouns! The rhyme ("wagą" - "nie ma go") also seems rather comical.

I am fully aware of the risk my reading takes, as it does not endeavour to point out the poem's artistic flaws, but rather aspires to question the general meaning of the poem, turning away from Marcus Aurelius towards Simone Weil's ambiguous above-mentioned formula of "impossible life." It shifts the focus from human grandeur, intellectualism, and moralism to mechanisms that are simple yet common to everyone: "defence mechanisms," as psychologists prosaically call them. Though they operate in all living beings, Norwid allows us to see the encounter with fate in more human categories, without the lofty solitude of a chosen one. This, in turn, does not allow the image of Norwid as a stiff moralist. He understood well the ruining power of misfortune ${ }^{19}$ and this knowledge unsettles the poem's monumental architecture.

What is really at stake here? Certainly not the slight interpretational corrections to the above-mentioned poems. It seems to me that the reconstruction of Norwid's image - a process we are currently undertaking - is based on a view I wish to reconsider, namely the opinion that Norwid's artistry is proof of his intellectual control over the experience of life, achieved - as it were through complete objectivization. Contrary to this prevailing critical claim about Norwid's work, I am drawn to its emotional (or Romantic) aspect. The

19 We read about this in the Book of Job (also taking into account Czesław Miłosz's introduction to his translation, published in 1980 in Paris). Is it really necessary to read "Fatum" as a poem "with a giggle" ("wagą" - "nie ma go"!)? Though its artistic form is monumental, it does appear somewhat fractured, hiding deep within itself a contradiction between the positive pressure of tradition (religion and culture) and the negative pressure of experience. 
impact of the personal dimension on the language of his poems naturally affects their overall message and raises the question of "Norwid's Romanticism." ${ }^{20}$

Psychology ${ }^{21}$ teaches us that language best captures the degree of confusion created in situations where emotions affect cognition. "Blind rage," "blind hatred," and "blind love" - all of these phrases seem to suggest that the object of these emotions becomes, in its truth and essence, "invisible," while the cognizant subject loses the ability to see the object in its "naked truth." Could we "catch" Norwid in precisely such situations, that is, in instances when the "language of emotion" reveals the distortion of its object so clearly and perceptibly that readers are forced to notice the subjective bias?

It is not without astonishment that we read Norwid's phrase: “czyści i matematyczni, jak błąd" ["pure and mathematical, like an error"]..$^{22}$ Could it be that the "poet of culture" is revealing his preference for spontaneity and directness? (Many years later the kind of aversion to "wymyci" ["scrubbed clean"] that manifests itself here was taken up by Stanisław Grochowiak.) Since when did a detached ironist speak like an "angry young man"?

The encouragement found in Mickiewicz's early lyricism - "Hej, użyjmy żywota!/Wszak żyjem tylko raz" ["Hey, let us live it up!/After all, we only live once"] - becomes justified yet loses its semantic sharpness thanks to "zbiorowe

20 Zofia Stefanowska, "Norwidowski romantyzm," Pamiętnik Literacki, Vol. 59, No. 4 (1968). Do any new arguments need to be added to this exhausting study indicating Norwid's place in the history of literature? Perhaps what is necessary is merely a practical matter: to allow the general audience to know who they are dealing with (the textbook by Henryk Markiewicz informs us that Norwid was an unambiguous positivist!). This goal was finally achieved with great clarity by Alina Witkowska in her book Wielcy romantycy polscy. Mickiewicz, Słowacki, Krasiński, Norwid (Warszawa: Wiedza Powszechna, 1980).

21 Kazimierz Obuchowski, Kody orientacji i struktura procesów emocjonalnych (Warszawa: PWN, 1970), p. 248 and other. Another representative of this discipline makes the opposite claim: "[...] our emotions not only fail to close our perspective on the world, but - on the contrary - they all form, together, an organ or system of perception. Of course, this is not perception of objective reality, which we cannot access at all, and which remains unimaginable to us. What these emotions provide us, with unfailing reliability, is an account of reality made to our measure. [...] interpretation of reality through our own moods has nothing to do with the freedom of rational encounters with the objective world, which exists independently of the experiencing subject. However, at the evolutionary stage we have reached there is still no such freedom" (Hoimar von Ditfurth, Duch nie spadt z nieba [Der Geist fiel nicht vom Himmel], trans. Anna Danuta Tauszyńska [Warszawa: PIW, 1979], pp. 394 \& 398).

22 “Do spółczesnych (Oda)” [“To my Contemporaries (Ode)”], PWsz II, 182. 
usta" ["the collective mouth"] that sings it. An additional justification of the carefree programme for life is contained in the poet's explanation: "The first stanza imitates the traditional, German Burschenschaft song."

The second stanza of Norwid's "Trzy strofki" ["Three Stanzas"] concludes with the call: "Lecz żyj - raz - przecie!..." (PWsz I, 222) [“But live - once - after all!..."]. It functions as a farewell, a caution to the woman, both provocation and insult, as well as a measure of distance from the enunciations which classically objectivize one emotion: "Nigdy, więc nigdy z tobą rozstać się nie mogę!” [“Thus never, I can never part with you!"].

Julian Przyboś made the following remark about "Trzy strofki”:

Nowhere else in lyricism have I encountered such a superior spiritual tone and such a noble style of loving, even though it is unrequited. Others would curse or forgive, but Norwid, having stifled the ordinary and natural reactions of the heart, stood victorious over his emotions and spoke from the highest moral podium - the kind that advocates the necessity to attain the only (and most difficult) condition of humanity: thought. ${ }^{23}$

The bizarre consequences of the reading offered by Przybos - that is, "the sentencing of the thought-less to think" - were pointed out by Zofia Stefanowska ${ }^{24}$ and later by Gomulicki (in his commentary). ${ }^{25}$ However, what seems even more striking to me is the submissiveness displayed by Przyboś with regard to the image of Norwid emerging from his description as "an intellectual and a moralist." 26

It seems to me that the distanced and objectivized language of Mickiewicz's lyricism unexpectedly brings into focus the tempestuous emotional character of Norwid's texts. Let us consider stanzas from the poem "Czemu" ["Why"], simultaneously recalling Mickiewicz's Odessa sonnets, especially Nos. XVIII and XIX (“Do D.D. Wizyta” [“To D.D. A Visit”], “Do wizytujących” [“To the Visitors”]):

23 Julian Przyboś, "Próba Norwida," in: Sens poetycki (Kraków: Wydawnictwo Literackie, 1963), p. 101.

24 Zofia Stefanowska, "Nowe studia o Norwidzie," Pamiętnik Literacki, Vol. 52, No. 2 (1962), p. 550 and other.

25 Cyprian Norwid, Dzieła zebrane, ed. J. W. Gomulicki, vol. 2, pp. 454-455.

26 The same submissiveness is found in the last printed analysis of the poem, written by Marian Tatara and titled "O 'Trzech strofkach' Cypriana Norwida" (Pamiętnik Literacki, Vol. 71, No. 3 [1980], p. 141): "The emotional restraint displayed here certainly contradicts the Romantic emotionality revealed, for example, in Mickiewicz's

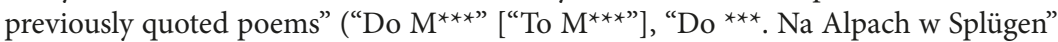
[“To ${ }^{* * *}$. In the Alps, Splügen”]). 
Szczęśliwi przyjdą, jak na domiar złemu:

Kołem osiędą ją - chwilki nie będzie,

By westchnąć szczerze... ach! czemu i czemu

Przyszli szczęśliwi? rozparli się wszędzie,

Wszędzie usiedli z czołem rozjaśnionem -

Dom napełnili - stali się Legionem!...

(PWsz II, 118)

[The happy will come, on top of it all:

Sit in a circle - with not a moment

To sigh in honesty... oh! why, o why

Did they come happy? lounged everywhere,

Sat all over the place with bright foreheads -

Filled the house - became a Legion!...]

These scenes appear comic in Mickiewicz, but in Norwid they are closer to a nightmare. The "lounging everywhere" - sprawling, flooding, filling of space with enemy crowds (when in reality they are merely a handful of bores) - has been aptly captured by psychological theories of emotion. ${ }^{27}$ What about the exit from the salon? Who would leave this inherently neutral meeting place? Would it be Mickiewicz's "miły gość" ["pleasant guest"]? The quick-tempered lover, impatient with worry, from Sonnet No. XVIII? No. It is the final departure of "kamienny z rozpaczy" ["the one stony with despair"]. Beyond the threshold, we find equally obdurate scenery: "księżyc... niemy" ["the moon ... mum"], motionless stars, and the sky's emptiness. Indeed, whoever writes of Norwid's elliptical statements or lowered tone should revisit this grandiloquent text.

The most memorable passages from Promethidion are the ones formally alluding to emotional speech structures:

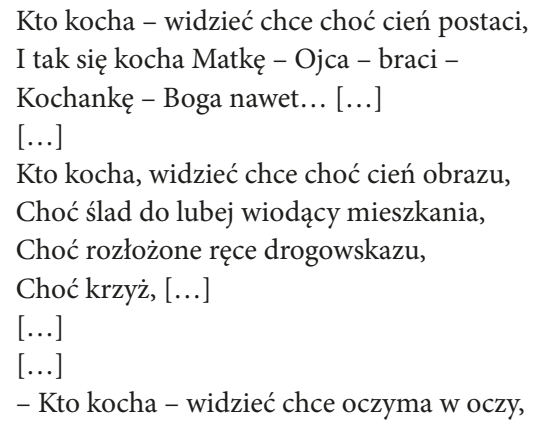

27 Cf. Przełom w psychologii, ed. Kazimierz Jankowski, trans. Kazimierz Jankowski, Anna Kołyszko, Piotr Kołyszko (Warszawa: Czytelnik, 1978). 
Czuć choćby powiew jedwabnych warkoczy,

Kto kocha, małe temu ogromnieje

I lada promyk zolbrzymia nadzieje;

Upiorowego nie dość mu myślenia,

Chce w apostolstwo, czyn, dziecię - wcielenia:

$[\ldots]^{28}$

[Whoever loves - longs to see at least the figure's outline,

That's how one loves Mother - Father - brothers -

A lover - God even... [...]

$[\ldots]$

Whoever loves, longs to see at least the shadow of an image,

At least a clue leading to the beloved's apartment,

At least the outspread arms of road sign,

At least a cross, $[\ldots]$

[...]

$[\ldots]$

- Whoever loves - longs to see eye to eye,

Feel at least a waft of the silky plaits;

Whoever loves - feels that small things grow

And a mere ray can raise hopes;

Not satisfied with ghostly thinking,

They desire apostlehood, acts, child - incarnation:

[...]]

It is as if the entire "dialogue regarding the matter of art and its place" was written only in order to protect oneself from the vividness of sensually experienced truth; as if the abundance of didactic and moralizing expressions, and radically rationalized structures, was meant to hide and conceal the suffering person's face.

Norwid's elaborate "theory of silence and understatement" has been the subject of numerous dissertations in literary studies. ${ }^{29}$ The most recent interpretation belonging to this trend was offered by Zdzisław Łapiński. ${ }^{30}$ Many other readers of Norwid also analyse the use and meaning of this method in the poet's lyrical pieces. However, I would like to point to an entirely obverse tendency, that is, the one to provide resolution and closure, or literally emboss the parabolic meaning.

Let me quote an extreme example provided by the parabolic poem "Ruszaj z Bogiem" ["Go with God"] (No. XXXI in Vade-mecum). Its five quatrains tell

28 DW IV, lines 218-220 (p. 110), 237-240 (p. 111), 278-283 (pp. 112).

29 This subject is addressed by Irena Sławińska in her studies of Norwid's epic prose and dramatic works.

30 Zdzisław Łapiński, Norwid, Chapter "Filozofia i poezja języka." 
the story of an evil wealthy man and a noble pauper. The main support of the poetic construction is the very phrase contained in the title. "Go with God" is a Christian farewell rooted in the belief that one literally "travels with God," for example, with viaticum... The reversal of the two protagonists' fate, the turn of the wheel of fortune, seems to be an award for the internal richness of the pauper, and a punishment for the internal poverty of the wealthy man. The poetic story is supported here by the living context of the Gospels. Indeed, were its formal structure to be laconic and its meaning oblique, the poem would have to end after the fourth stanza because the fifth insistently clarifies:

Więc nie wszedł w dom ów, tylko kląkł na progu,

Wołając: "Wszechmocny Panie!

Zmiłuj się nad nim, może nie był w stanie:

Któż równy Bogu?...”

(PWsz II, 51)

[And so he did not enter the house, but knelt on the threshold,

Calling: "O Lord Almighty!

Have mercy on him, for he was not able:

Who could match God?..."]

"This parable," Gomulicki comments, "is guided by the Christian concept of Providence." ${ }^{11}$ However, readers cannot feel good about this, primarily because we could lose all that remained of our sympathy for the "breadless" man because his call suggests a strangely conceited conviction that the wealthy man's paralysis was the simple result of not showing mercy. ${ }^{32}$ At the same time, the poem carries on, leading to the sixth stanza:

Nie powiem dalej, bo może przelęknę -

To nadmienię tylko jeszcze,

Że - nie zmyślili sobie tego wieszcze,

Bo - zbyt jest piękne!

(PWsz II, 51)

31 Cyprian Norwid, Dzieła zebrane, ed. J. W. Gomulicki, vol. 2, p. 787. What should one make of my critical view of Gomulicki's comments, and the fact that I allowed myself to look down on them? Well, I could fare well without the many works affirmatively quoted here, but simply could not do without the fruits of his work.

32 Stefan Kołaczkowski speaks in this context about irony wedded to "the notion of some vengeful trait in God." In: Pisma wybrane, vol. 1 "Portrety i zarysy literackie," ed. Stanisław Pigoń (Warszawa: PIW, 1968), p. 151. 
[I shall stop here, for I may be scared -

I will only add one thing,

That - no bards made up this,

Because - it is a bit too beautiful!]

The commentator, fully trusting Norwid the poet, adds:

"for I may be scared" - the missing part of the parable could refer either to some further form of "divine punishment" befalling the dying sinner, or perhaps (more probably) to his conversion. ${ }^{33}$

What is missing? What further punishment, if this is the viaticum brought to the dying man! What conversion, if we are still dealing with a "Christian" who both uses pious phrases ("Go with God") and sends for the priest!?

What if we note that in Norwid's text a passage from the Gospel (Luke 16: 19-31) shows through? Reverend Marian Wolniewicz, Polish editor of the New Testament, even provided the special title "Biada niemiłosiernym" ["Woe betide the unmerciful"] to this story:

There was a certain rich man who was clothed in purple and fine linen and fared sumptuously every day. But there was a certain beggar named Lazarus, full of sores, who was laid at his gate, desiring to be fed with the crumbs which fell from the rich man's table. Moreover the dogs came and licked his sores. So it was that the beggar died, and was carried by the angels to Abraham's bosom. The rich man also died and was buried. And being in torments in Hades, he lifted up his eyes and saw Abraham afar off, and Lazarus in his bosom.

Then he cried and said, "Father Abraham, have mercy on me, and send Lazarus that he may dip the tip of his finger in water and cool my tongue; for I am tormented in this flame." But Abraham said, "Son, remember that in your lifetime you received your good things, and likewise Lazarus evil things; but now he is comforted and you are tormented. And besides all this, between us and you there is a great gulf fixed, so that those who want to pass from here to you cannot, nor can those from there pass to us."

Then he said, "I beg you therefore, father, that you would send him to my father's house, for I have five brothers, that he may testify to them, lest they also come to this place of torment." Abraham said to him, "They have Moses and the prophets; let them hear them." And he said, "No, father Abraham; but if one goes to them from the dead, they will repent." But he said to him, "If they do not hear Moses and the prophets, neither will they be persuaded though one rise from the dead." ${ }^{4}$

33 Cyprian Norwid, Dzieła zebrane, ed. J. W. Gomulicki, vol. 2, p. 788.

34 Luke 16: 19-31. All quotations from the Bible in the New King James Version translation after: www.biblegateway.com. 
One Polish edition of the Bible provides the following commentary on this: The parable advises that we show mercy to the poor, turning material goods into means of supporting the needy $[\ldots]$ and it teaches us that there shall be no mercy in the afterlife for those who lack mercy on Earth, supposing that the wealthy man abuses material goods. Although the text does not state this explicitly, the parable reassures us that the poor, who are patient and humble in their poverty like Lazarus, shall find eternal happiness $[\ldots] .^{35}$

In the Epistle of James, we find a summary of this issue: "For judgment is without mercy for the one who has shown no mercy. Mercy triumphs over judgment." ${ }^{36}$ Norwid naturally knew the Bible well (the composition of "Ruszaj z Bogiem" features a characteristic two-stage construction, the same as in the parable from the Gospel); also, his contemporaries would have known it well, better than we do today. Once again then, what is it that made Norwid "stop here"? What is it that he would be scared to tell us, especially if his readers would not really listen to "Moses and the Prophets"!? Gomulicki argues the following, supporting the poetics of silence:

Though "this is a bit too beautiful," we do not know what that is exactly. Do these words refer to the entire parable, or merely to its oblique ending, which could bring, for example (and this would be the most beautiful), the curing of the paralysed man through the prayers said by the poor Christian who was hurt by him? ${ }^{37}$

Why does this commentary sound naïve to me? ${ }^{38}$ Why does the poem seem poetically false? Just consider the obtrusiveness of its compositional joints, the ostentatious, flamboyant use of the phrase "Go with God," the style reminiscent of Konopnicka ("I am without bread today, I sigh to myself, I do not know what I shall do, the bread was cheap again today," etc.), the tearfulness in place of the Gospel's ruthlessness, and the way the poem forcibly "makes one think."

I was once amazed after coming across the following confession of a beggar featured in a poem by the model 18th-century sentimentalist:

Dawne człeka panowanie

Nie wyniszczone do końca!...

Zostało mi używanie

35 Pismo święte Starego i Nowego Testamentu w przekładzie z języków oryginalnych ze wstępami i komentarzami, ed. Rev. Michał Peter et al. (Stary Testament) \& Rev. Marian Wolniewicz et al. (Nowy Testament), vol. 3 "Nowy Testament" (Poznań: Księgrnia Świętego Wojciecha, 1975), pp. 195-196.

36 James 2:13.

37 Cyprian Norwid, Dzieła zebrane, ed. J. W. Gomulicki, vol. 2, p. 788.

38 It is simultaneously the measure of the Editor's absolute loyalty to the Poet. 
Wolne powietrza i słońca.

[...]

Boże! przy mym prawie stoję,

Zwę Cię Ojcem ze wszystkiemi:

Nie widzisz!... Ja, dziecko Twoje,

Poniewieram się po ziemi! ${ }^{39}$

[Man's former dominion

Is not wasted completely!...

I still have use of

Free air and sun.

$[\ldots]$

O God! I stand by my right,

I call you Father, along with others:

Can't You see!... I, a child of Yours,

Am wandering on the face of Earth!]

This poem by Karpiński also features a "wealthy man" who "saw a cripple and went past him." However, apart from the conventional theme of "a rich man on a cart" and a pauper dusted with earth we hear a truly proud voice, worthy of a Child of God: "Ja, równym człekiem stworzony" ["I, too, was created an equal man”]. Karpiński's beggar speaks like the Indomitable Prince of human dignity, while "ktoś kiedys'" ["someone, somewhere"] - like a judge from a vignette by Maria Konopnicka.

Still, Norwid's story only seemingly gives voice to the protagonists. In fact, readers are acutely aware of its "exemplary" fabrication, a distortion of "somebody else's voice," a manipulation of enunciation - how much more truthful and cruel is the mighty voice of Abraham and the human voice of the wealthy man who, after all, loved his father and brothers, but could not (as Norwid's narratorwitness) tell people "what came after."

Think of the shattering experience of terrible poverty and evil in "Larwa" ["Larva"] (PWsz II, 30-31). Consider the synthetic character of the grand poetic phrase: "Rzekłbyś, że to Biblii księga/Zataczająca się w błocie" ["You’d say that book is the Bible/Rolling thus in mud"]. Does it need any further explanation? And yet, the lines "Takiej-to podobna jędzy/Ludzkość, co płacze dziś i drwi" ["Such is Mankind - a witchlike crud/That weeps today and finds things funny"] reduce the piercing recognition of the one encountered "na śliskim bruku w Londynie" ["on London's slippery cobbles"] to abstract "humanity," "history," and "society."

39 Franciszek Karpiński, “Żebrak przy drodze,” in: Wiersze wybrane (Warszawa: PIW, 1966), pp. 96-97. 
The mechanism of explaining is revealed most directly in the poem "Jak..." ["Just As..."] (PWsz II, 82-83); "something" is "as":

gdy kto ciśnie w oczy człowiekowi/Garścia fijołków

gdy akacja z wolna zakolysze,

gdy osobie stojącej na ganku/Daleki księżyc wpląta się we włosy,

Jak z nia rozmowa, gdy nic nie znaczaca,/Bywa podobna do jaskótek lotu,

[Just as one throws in your face/A bunch of violets

Just as one slowly sways an acacia,

Just as the distant moon weaves/Through her hair, as she stands on the porch,

Just as a talk with her - devoid of meaning,/Is like the swallows' flight $]^{40}$

The ever more elaborate comparisons more and more concretely describe the nature of the given experience, the person who is both the source of that experience and of these similes, leave no doubt as to "what is like what." However, Norwid relapses into distrust: after having said everything using poetic methods, he adds: "[...] lecz nie rzeknę nic - bo mi jest smętno" (PWsz II, 83) [“[...] yet I will say nothing - for I'm full of grief"]. How can he refuse to "say a word" - we might ask - after having said so much and making it clear from the first line that he is miserable!? Nevertheless, the commentator also speaks of "pregnant silences" in this case.

Anyway, who does not do that? Every instance seems relevant, including the matter of the Slavs:

To some degree, they [the Slavs] generally wait. They wait for their role, for knowledge of themselves, for their identity. This is how Norwid sees it in the late, beautiful poem "Słowianin" ["The Slav"] addressed to Teofil Lenartowicz. His Slav is stuck by a dirt road as if he were a stone "co sługiwał był w różnych szturmach na okopy" ["that has served in trenches in various attacks"], indifferent to the fact that there are telegraph cables and railways running somewhere. We cannot even be sure it is a stone. Perhaps it is a giant's bone, as the local legend says.

Norwid does not make it any easier to settle the symbolism of stone and bone. As he used to say himself, he leaves a trail of mysterious vagueness, relying on the intellectual cooperation of the reader: "co sam sobie w jaśniejszą alegorię zamień" ["which you're free to exchange for a more lucid allegory"]. ${ }^{41}$

Witkowska exchanges the allegory, however, pretending that she does not:

[...] there is no need to reduce the ambiguity of associations linking the stone and the Slav to any simple formula or fully clarified allegorical relationship. Let it remain crucial

40 English translation based on Borchardt, Poems, p. 49.

41 Alina Witkowska, "Ja, głupi Słowianin"(Kraków: Wydawnictwo Literackie, 1980), p. 48. 
for many possibilities to exist, inherent to the stone as the building block of art and civilization. Norwid saw the Slav as one such potential project awaiting future realization. ${ }^{42}$

Naturally, even without such a clearly verbalized invitation, the allegorical structure forces readers to replace the Slav's image with abstract meanings. The question “Czy to kość?, czy kamień?”[“Is it bone?, or a stone?”] is answered earlier; in the first line the central conviction is already voiced directly: "gdy brak mu naśladować kogo" ["when he lacks anyone to imitate"], "Oczekiwa na siebiesamego" ["he awaits his own self"]. In this case, Norwid seems to be mocking those readers who seek "mysterious meanings" rather than those who "do not make everything clear." Could it be any clearer than in the phrase "On sterczy" ["it sticks out"]? (in Polish saying well-meaning people remind others: "Do something, avoid sticking out" - which means do not be lazy and get down to work.)

Clearly, the "lyricism of understatement" cannot suddenly be transformed in the reader's mind into a "lyricism of further comments," but it seems fit to agree that the two tendencies coexist in Norwid's lyricism. The knowledge of how language is structured as well as his disquisition on silence as a grammatical part of speech lead to the extensive use of understatement's semantic potential in Norwid's poetry. The passions of a moralist, and the needs of an abstractionist lead to quasi-silences and promises that are purely flirtatious and rather empty, for example "nie powiem dalej" ["I shall stop here"]. It seems that Norwid could not reconcile the contradiction between his own concept of poetic language and a passion for didacticism - he was unable to do so not only in intellectual terms, but also practically, in his own poetry.

Whoever speaks in primordial images speaks with a thousand voices; he enthrals and overpowers, while at the same time he lifts the idea he is seeking to express out of the occasional and the transitory into the realm of the ever-enduring. He transmutes our personal destiny into the destiny of mankind, and evokes in us all those beneficent forces that ever and anon have enabled humanity to find a refuge from every peril and to outlive the longest night.

That is the secret of great art, and of its effect upon us. The creative process, so far as we are able to follow it at all, consists in the unconscious activation of an archetypal image, and in elaborating and shaping this image into the finished work. By giving it shape, the artist translates it into the language of the present, and so makes it possible for us to find our way back to the deepest springs of life. ${ }^{43}$

42 Alina Witkowska, "Ja, głupi Słowianin,” p. 49.

43 Carl Gustav Jung, "On the Relation of Analytical Psychology to Poetry," in: Spirit in Man, Art, and Literature. The Collected Works of C.G. Jung. Volume 15, trans. \& ed. Gerhard Adler \& R.F.C. Hull (Princeton: Princeton University Press, 1971), p. 108. 
As we know, Norwid's style does not take advantage of this potential often. Surely, we could reconstruct the imaginary pre-eternity encoded in Norwid's lyrics, for example, the idea of life as a distance to be traversed, existence as pilgrimage or voyage; however, these are versions of abstract symbolism, not of imagery (cf. e.g., "Pielgrzym" ["Pilgrim"]), allegorical interpretation ("Krzyż i dziecko" ["The Cross and the Child"]), or simple allusion to old themes:

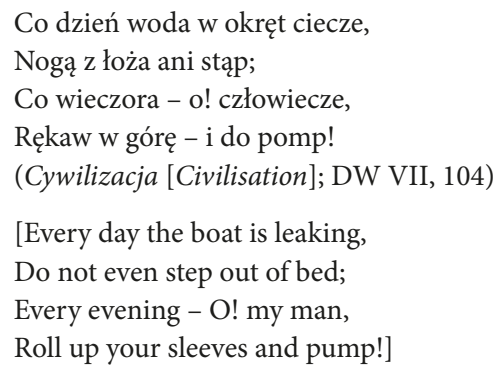

Does Norwid ever speak to us, as a poet, in primordial images, or is his writing strictly speaking "a poetry of language," that is, one of irrefutable formulas, irony, sentences - just like the 18th-century fables by Krasicki?

On numerous occasions, Norwid employed in his lyrical works the kinds of means that Enlightenment-era poets used in openly didactic genres such as fable and satire - means reserved for moralistic functions in poetry. "The muse of anger and satire" still uses the same language - concise, compact, and striking from Krasicki to Barańczak.

Podli!... bo niemi, i niemi, bo podli!

(„Dziennik Warszawski” [„Warsaw Journal”], PWsz I, 392)

[Base!... because mute, and mute because base!]

One could easily indicate the overwhelming rhetorical power of language - the power that often crosses out so-called broader convictions, opinions, and theories. After all, the equation sign between baseness and muteness was placed by the author of Assunta and Milczenie [Silence]. Here are the predecessors of the judgement passed by Norwid - phrases used by Ignacy Krasicki in the satire "Pochwała milczenia" ["In Praise of Being Silent"]:

Dusze podłe, nurzcie się w otchłaniach milczenia!

Dobrze milczyć, bo płacą; [...]

[Foul souls, wallow in the abysses of silence!

It's good to be silent because they keep paying; [...]] 
Finally, there is the ironic address: "Święta niemoto..." ["Holy muteness..."]. ${ }^{44}$ The same approach can be identified in relation to other matters and other texts by Norwid: the angry "cacka, cacka" ["trinkets, trinkets"] have their predecessors in Krasicki's "Pochwała wieku" ["In Praise of Our Epoch"]:

[...] ksiąg rozlicznych mnostwo,

W których rozum, naukę, dowcip, wynalazki

Zastępuje druk, papier, pozłota, obrazki.

Stąd, niby gazą kryte, wyrazy wszeteczne,

[scores of numerous books,

In which reason, learning, wit, invention

Are replaced with print, paper, gold leaf, images.

Hence the lewd words, as if covered in gauze]

and in the poem preceding "Bajki i przypowieści" ["Fables and Parables"], addressed to children who are:

Za cackiem bieżyć gotowi w zapędy,

Za cackiem, które zbyt wysoko leci,

[Ready to chase after trinkets,

Ready to pursue trinkets that fly too high]

It seems to me that Norwid's "Powieśc" ["Novel"] also features the same cracking whips that "Wziął [...] gumienny" ["Were taken [...] by the master thresher"] and "podstarości” ["deputy foremen"]. They certainly often fall cracking in Krasicki’s account of the "Podróż pańska" ["Royal Journey"]. And the following - are they not Norwid's thoughts and words?

Znać, czuć, mówić, dać przykład - to jest być kapłanem

[To know, to feel, to speak, to give examples - this is what being a priest means]

Pełno Dyjogenesów nie w beczce, lecz z beczką $a^{45}$

[There are plenty of Diogeneses, though not in barrels, but with them]

44 Quotations from Ignacy Krasicki after Pisma poetyckie, ed. Zbigniew Goliński, vols. 1-2 (Warszawa: PIW, 1976): vol. 2, p. 252, ll. 32 \& 49; p. 253, 1. 66; p. 256, 11. 72-75. Quotations from fables: vol. 2, p. 101; p. 252, 1. 56; p. 272, 1. 75.

45 Even in matters regarding family Norwid is close to the Bishop: "I could not help myself and I am not mocking here but just sending a friendly smile - when I read your report, provided in tender pity, about having a daughter instead of a son. 'If it is a misfortune, as the letter suggests,/Then I humbly call it so and lay the matter to rest.' I thus suppose that the elemental project of your noble highness was none other than that the wife ought to give birth to sons." Krasicki's delicate irony (Wiersze z proza, vol. 2, pp. 81-82) nevertheless attracts Norwid's "little children" who were chosen on the basis of... height and affluence. 
Many other examples could be provided, for example: "[...] Dobrze to nawiasem/I samemu przy piwku co przeczytać czasem" ["On a side note, it is good/.Sometimes to read something with a beer in hand"]. ${ }^{46}$

It seems that, in general, Norwid achieves the best poetic results when he utilizes the rhetorical tradition, that is, that of language characterized by efficiency and conciseness, one appealing to the sense of order, demanding accuracy and forcefulness, and simultaneously revealing the value of novelty and independence from popular beliefs.

At the same time, Norwid was well aware of the subterranean sources of art, long before Freud and Jung:

Stąd, choć ja śpię... nie ja to śnię - co? śnię:

Ludzkości-pół na globie współ-śni ze mną;

[...]

Tam to wszczęła się pieśń gminna, jakby z dna

Uspokojonej na skroś głębi

[...]

(“Kolebka pieśni” [“Cradle of Song”], PWsz II, 115)

[Hence, even though I sleep I do not dream - what? I dream:

Half of humanity on this globe is co-dreaming with me;

This is where the song of the folk began, rising as if from the bottom

Of a thoroughly becalmed depth]

A great work of art is like a dream; for all its apparent obviousness it does not explain itself and is always ambiguous. A dream never says "you ought" or "this is the truth." It presents an image in much the same way as nature allows a plant to grow, and it is up to us to draw conclusions. ${ }^{47}$

Norwid also successfully uses this "poeticized" variant of style - a language characterized by imagery traditionally used to render "countries of tranquility." Take the example of figures carrying light (always in the context of dreaming, waking up, or resurrection). Here is Dulcinea:

[...] już zbudzona i odczarowana

Pomiędzy smoki wychodzi z wieżyce,

Że lampę trzyma w ręku, a potwory,

Nie mogąc światła znieść, w ziemię się ryją,

$[\ldots]$

(“Epos-nasza” [“Our Epic"]; PWsz I, 161)

46 Adam Naruszewicz, "Chudy literat" ["A Skinny Writer"].

47 Carl Gustav Jung, "On the Relation of Analytical Psychology to Poetry," p. 136. 
[already awakened and disenchanted,

She leaves the towers into the dragons' midst;

Holding a lamp in hand, while the monsters,

Unable to bear that light, burrow themselves in the ground]

"Przyjaciel domowy" ["A Friend of the House"]:

[...] szedł, palcami gwiazdę objąwszy świecznika,

Co biła z rąk złotymi na sufit smugami,

A palmą cieniu na twarz, [...]

(“Znów legenda” [“A Legend Again”]; PWsz I, 131-132)

[went, clutching with his fingers the star of the candlestick,

Which cast golden streaks from his hands, onto the ceiling,

Leaving his face in the palm of the shadows]

In the shop, full of appliances, at the grey hour, "już, już z świecą w ręku wyglądano sługę" ["with candle in hand they looked for the servant"]. Another "człowiek ze światłem" ["man wielding light"] becomes part of a metaphor defining our laziness or engagement in the reception of poetry:

- Czy też świecę zapalałeś sam?

Czy sługa ci zawsze niósł pokojowy

Światłość?... [...]

(“Ciemność" [“Obscurity”]; PWsz II, 26)

[- Have you yourself ever lit a candle?

Or did your servant always bring you

Light?.... $]^{48}$

You, Mother,

[...] stajesz cicho, gdzie drobne jest łoże;

A świecy jasność okrywszy prawicą,

Cień-ręki rzucasz, wielki jak komnata,

Którego palce szyte błyskawicą

Drżą - [...]

("Wtedy Ty, Matko" [“Then You, Mother"]; PWsz II, 7349)

48 English translation by Borchardt, Poems, p. 25.

49 Images from "Epos-nasza" and "[Wtedy Ty, Matko!...]" live on in Czesław Miłosz’s poem "Schody" from the cycle Świat. Poema naiwne contained in the volume Ocalenie (Warszawa: Czytelnik, 1945), p. 109: “The boar's head is alive, enormous in shadow./At 
[stand silent, where the tiny bed is;

Having covered the light of the candle with your right hand,

You cast a hand-shadow, large as a chamber,

Whose fingers, pierced by lightning,

Tremble -]

It needs to be added, however, that such poetic motifs typically have their own ironic variants:

Jak na Leandra czekająca Hero

Zapala światłość i nuci jej: „Prowadź!” -

Tak my - [...] (“Krytyka” [“Criticism”]; PWsz II, 141)

[Like Hero waiting for Leander

Lights the brightness and hums to her: "Lead!" -

So do we - ]

or their credibility is questioned:

Miałem sen, nie wiem, o ile bezsenny? (“Sen” [“Dream”]; PWsz I, 245)

[I had a dream, I know not just how sleepless it was?]

This is the only "dream" recorded in Norwid's lyrical works. The themes of dreaming and sleeping are generally treated by Norwid in a scathing and un-Romantic manner. In the poet's lexicon, "dream" and the very act of sleeping do not have a particularly poetic dimension. "Och! jakże spałby sobie człowiek" ["Oh! how one could use some sleep"] - this sigh invites the most naïve and approving interpretation! However, we have already learned that in Norwid's world there is no place for tolerating lazy whims, which leads us to accept it on moralistic terms, in spite of ourselves. The problem of care-free sleep in Polish lyricism was finally settled by Miron Białoszewski, while the apology for "lying down" ["leżenie"] was analysed, with great understanding, by Janusz Sławiński. ${ }^{50}$

first, just the tusks, then as it grows/The snout roams the ceiling, sniffing the stairway vault/While the light dissolves into vibrating dust. // Mother carries down a flickering light./She walks slowly, tall, her robe tied at the waist,/Her shadow climbs up to the shadow of the boar./And so she struggles, alone, with the cruel beast." ("Stairs," translated by Czesław Miłosz and Robert Hass, in: Czesław Miłosz, New and Collected Poems 1931-2001 [New York: HarperCollins, 2003], p. 40.)

50 Miron Białoszewski’s cycle Leżenia was published in the volume Mylne wzruszenia (Warszawa: PIW, 1961), pp. 7-52. The analysis by Janusz Sławiński is contained in the volume Czytamy utwory współczesne. Analizy (Warszawa: Państwowe Zakłady Wydawnictw Szkolnych, 1967), pp. 156-168. 
"Go to sleep," says the dancer to the "vapid" woman (is this a salon version of Norwid?). A man is reading "a Dream Dictionary" in the company of his "silly wife," making him worthy of the "Warszawski Dziennik." This is a splendid caricature of the "archetypal situation" depicted by Juliusz Słowacki:

Było to rankiem - pomnę - pod kaskadą -

Byliśmy niczym nie strwożeni - sami -

Czytając książkę pełną łez, ze łzami.

Wtem duch mi jakiś podszepnął do ucha, Ażebym na nią z książki przeszedł okiem. -

Była jak anioł, co myśli i słucha I nagle $-[\ldots]$

$[\ldots]$

Odtąd jużeśmy nie czytali sami.

[It was morning - I recall - under cascades

We were unafraid - and alone -

Reading a tearful book, shedding tears ourselves.

Suddenly some spirit whispered in my ear,

To raise my eyes from the book and look at her. -

She was like an angel that thinks and listens -

And suddenly - $[\ldots]$

$[\ldots]$

Since that time we have never read alone.]

A situation concluded with "Dante-like" lines:

Soli eravamo e senza alain sospetto - Quel giorno

Piu non vi leggemmo avante. ${ }^{51}$

Previously, I quoted several images of people carrying candles in bedroom settings, but there are also several well-known lines featuring sleep, which is metaphorized and acquires the negative connotations of lifelessness, ignorance, and love of comfort:

[...] smęcąc ujęte snem grody, (PWsz I, 187)

[saddened slumbering forts]

- Niźlim wiedział, pierwem śnił, (PWsz I, 200)

[- Before I knew, I dreamed it]

I w snu obłok lekkiego wyobraźnię skrywa, (PWsz I, 278)

[And hid his imagination in the light cloud of a dream]

51 Juliusz Słowacki, "W Szwajcarii" ["In Switzerland"]. Cf. also Stanisław Makowski, W szwajcarskich górach. Alpejskie krajobrazy Słowackiego (Warszawa: PIW, 1976), p. 99. 
A - czy też ona wié

Nie z jawu - to choć z snów, (DW VI, 95)

[But - does she know:

If not from reality - then maybe at least from dreams]

Niewiasty zaklęte w umarłe formuły także "odeszły, senne...” (PWsz II, 16)

[Women enchanted in dead formulas also "departed, drowsy...”]

One śnią: że szyba?... to - posadzka! (PWsz II, 131)

[They dream: is it glass?... no - the floor!]

[...] książka była klamrą spięta,

A była śniącą coś w promieniu -

Jak gdy chce $z$ trumny powstać Święta,

Gdy zawoła ją Pan, po imieniu. (PWsz II, 226)

[the book was clasped

And dreaming something in rays -

Like when a Saint wishes to rise from a coffin,

When the Lord calls her by her name.]

[...] Harfa swe zamilkła słowo,

Marzyć począwszy, po czym śnić i spać na nowo, (PWsz II, 264)

[The harp fell silent,

Began to dream, then dream and sleep again]

Także "Rozebrana" "śpi zapewne!" (PWsz II, 249). Thus, "Disrobed”, she "is probably asleep!"

This catalogue is aptly summarized by a translation " $\mathrm{Z}$ Buonarrotiego" ["From Buonarroti”] (PWsz II, 225):

Słodko jest zasnąć, słodziej być z kamienia

Dziś, gdy tak wiele hańb i poplamienia;

Nie czuć, nie widzieć, leżąc jak w mogile -

Cóż z tak uroczą porównałbyś Nocą?

- Przeto, zaklinam, ucisz się na chwilę,

Mógłbyś przebudzić mię... na co? i po co ${ }^{52}$

52 No such negative associations arise from the description of the Roman grave of Saint Stanisław Kostka (PWsz I, 267): "W komnacie, gdzie Stanisław święty zasnął w Bogu,/ Na miejscu łoża jego stoi grób z marmuru -/Taki, że widz niechcący wstrzymuje się w progu,/Myśląc, iż Święty we śnie zwrócił twarz od muru" ["In the chamber, where Sainst Stanisław went to sleep with God,/In place of his bed a marble tomb stands -/ It makes visitors unwittingly freeze on the threshold,/Thinking that the Saint turned his face away from the wall in his sleep"]. 
[It is sweet to fall asleep, sweeter to be of stone

Today, with so much dishonour and tarnishing;

Not to feel, not to know, to lie as in a grave -

What would I compare this splendid Night to?

- Thus, I implore, be silent for a while,

You might just wake me... what for? and why?]

This image of the night could be associated by readers of Norwid with the last record from "Kronika" ["Chronicle"]:

Wieczorem odwraca się do ściany i zasypia, mówiąc jeszcze do Zaleskiego: "Przykryjcie mnie lepiej". Umiera nad ranem. "Raczej zasnąt, jak umarł" - komentuje ten zgon Mikułowska. ${ }^{53}$

[In the evening he would turn towards the wall and fall asleep, saying to Zaleski "cover me up better". He died in the morning. "It was more like he fell asleep than died," Mikułowska said upon his departure.]

Dance, both solo and ensemble performances, has been particularly useful in Polish literature for metaphorical and symbolic purposes: from Dziady [Forefathers' Eve] to Wesele [The Wedding], from the poem "Na pochwałe Kossowskiej w tańcu" ["In praise of Kossowska dancing"] to "Tancerz mecenasa Kraykowskiego" ["The dancer of Lawyer Kraykowski"]! Certainly, the most beautiful description of dancing (and the prime example of "perfect artistry" and "particularly striking use of metaphor"54) is found in the poem "Do słynnej tancerki rosyjskiej - nieznanej zakonnicy" ["To the Famous Russian Dancer Anonymous Nun"] (PWsz I, 393). This text is particularly well suited for "linguistic analysis" because it offers a skilful combination of imagery, metaphorical description, and elements of 18th-century rhetorical tradition.

A jednak Tobie!... która niżej jeszcze

Wejrzałaś w głębie, nie nucą dziś wieszcze -

Lecz ja, syn Polski, rzucam wieńcem z głowy

Pod Twoje stopy ruskiej białogłowy

I łzę posyłam, co prawdziwie świeci,

Bo ani znasz jej, ni Cię TU doleci!... (PWsz I, 393)

[After all to You!... who looked even deeper Into the depths; the bards do not sing today But I, son of Poland, throw my wreath Under your Russian lady feet

53 Cyprian Norwid, Dzieła zebrane, ed. J. W. Gomulicki, vol. 1, p. 123.

54 Zdzisław Łapiński, Norwid, p. 81. 
And send my tear, which shines truly,

Because you neither know it, nor could it ever reach you HERE!...]

Such an analysis can be made quite freely if we read Norwid's homage in the context of the praise voiced by Kossowska:

Nóżki się ledwo widzieć pozwolą

I tylko czasem tykają ziemi,

Wszystkie w niej członki razem swawolą,

A zefir igra z szaty wiotkiemi.

[The legs barely allow themselves to be seen

And only rarely touch the ground,

All of her limbs frolic in harmony,

While zephyr blows through her fine robes.]

There can be no doubt - the dancer's performance was observed through the eyes of a happy Arcadian. Trembecki or Szymanowski, "lube natury dzieło" ["the beloved work of nature"], "world," "Krasicki," "Cupid," and "Szmuglewicz" all find themselves in the same charming circle. The painter's "eye and hand" freely and "masculinely" record the impressions.

"Patrz, patrz! Wybiegła, jak jaskółka [...]”(PWsz I, 393) [“Look, look! She ran out like a swallow [...]"] - is this how a ballet expert would tempt us? A master of literary description? That one too. In order to properly understand the reason behind the unusual homage paid to "tanecznica" ["the dancer"] it is not enough to shed light on Norwid's predilections: his cult of spiritual and religious values. First, let us consider the pronouns. "Tu" ["here"] and "teraz" ["now"] are characteristically juxtaposed with the magical "tam" ["there"]! "[...] tu mój trup w pośrodku was zasiada,/[...] Tam widzę ją, [...]” [“[...] here my dead body sits amidst you, /[...] There I see her, [...]"]. The reason is also clearly voiced by contemporary artists whose experiences are related to the "here."

[- - - ] [a portion of the text was censored - translator's note]

... Przed śmiercią jeszcze Chopina zaszedłem był raz na ulicę Ponthieu przy Elizejskich Polach do domu, którego odźwierny z uprzejmością odpowiadał, ile razy kto zachodząc pytał go, jak się Monsieur Jules ma?... Tam na najwyższym piętrze pokoik był, ile można najskromniej umeblowany, a okna jego dawały na przestrzeń, jaką się z wysokości zawsze widuje, tym jednym tylko upiększoną, iż czerwone słońca zachody w szyby biły łunami swymi. Kilka doniczek z kwiatami na ganku przed oknami tymi stało, a ośmielone przez mieszkańca wróble zlatywały tam i szczebiotały. Obok drugi maleńki był pokoik - to sypialnia.

Było więc jakoś około piątej godziny po południu, kiedy przedostatni raz byłem tam u Juliusza Słowackiego, który właśnie kończył obiad swój, z zupy i pieczonej kury składający się. Siedział przeto Słowacki przy stoliku okrągłym na środku pokoju, ubrany 
w długie podszarzane paltot i w amarantową spłowiałą konfederatkę, akcentem wygody na głowę zarzuconą. I mówiliśmy tak o Rzymie [...].

Do pokoiku tego, który jak Juliusz mawiał: “Zupełnie byłby dla szczęścia człowieka zadowalającym, gdyby nie to, że w jednej stronie jego kąty nie są zupełnie proste, źle będąc skwadratowanym" - do tego, mówię, pokoiku innego dnia wieczorem wszedłem był, a Juliusz stał przy kominie, fajkę na cybuchu długim paląc, jak to używa się w Polsce na wsi; [...].

$[\ldots]$

[...] było to tak, że wszedłszy pierwszy widziałem ciało zimne Juliusza, bo [...] zasnął śmiercią i w niewidzialny świat odszedł. Mało piękniejszych twarzy umarłego widzi się, jako była twarz Słowackiego, rysująca się białym swym profilem na spłowiałym dywanie ciemnym, coś z historii polski przedstawiającym, który łoże od ściany dzielił. Ptaszki zlatywały na niepielęgnowane doniczki $\mathrm{z}$ kwiatami [...].

(DW VII, 47-49)

[...Before Chopin died, I once wandered onto Ponthieu street, next to the Elysian Fields, into a house where the porter would always kindly reply whenever someone asked how Monsieur Jules was faring... On the top floor, there was a room, furnished as humbly as you can imagine, with windows looking out onto that characteristic view from on high, which was adorned only by the red sun setting and casting its rays against the glass. Several flower pots stood on the passage before the windows, where sparrows, encouraged by the occupant, would gather and twitter. Next to this room was another, tiny one - the bedroom.

It was around five in the afternoon when I visited Juliusz Słowacki in this place for the next to the last time. He was finishing his dinner of soup and roasted chicken. Sitting at a round table in the middle of the room, he was dressed in a greying paletot and a faded, purplish red, four-pointed confederate cap, thrown on casually. And we spoke of Rome [...].

On another day, in the evening, I visited him again in this room - which, as Juliusz said himself, "would be completely sufficient for a man to be content in, if not for the fact that on one side its corners are not at the right angle, the room being badly squared" - and he was standing by the chimney, smoking a pipe on a long stem, just like they do in the Polish countryside; [...].

$[\ldots]$

[...] it was like that: because I came inside first, I saw Juliusz's cold body, because [...] he passed away and departed into the invisible world. One rarely sees a more beautiful dead face than that of Słowacki whose white profile was so distinct on the faded dark carpet separating the bed from the wall. It represented something from Polish history. Birds were flying down and sitting at the untended flower pots [...].]

The prose cycle Czarne kwiaty [Black Flowers] was written in 1856 - twenty-one years before Norwid came to live at St. Casimir's. However, when we read this masterpiece from the perspective of a small poorhouse cell, what is most piercing is the revelation - found not only in passages regarding Juliusz Słowacki - of his 
"homeless eyes." Only such eyes could record all the joys of a real home, including the porter, dining room and bedroom, one's own view from the window, flowers and birds, a bed and a faded dark carpet. As we know, Słowacki had his own place but Norwid would "call on the Baroness," "cross the threshold," visit the "deathly chambers," look around "the arena," and be comforted by God's leaf "stuck to the window" (but to which one?). We can almost always recreate the physical space surrounding the lyrical subject in poems by Mickiewicz and Słowacki. However, Norwid's lyricism resounds in some kind of abstract space that is not tamed by either house walls or any natural vastness: "napotykałem w życiu" ["I stumbled upon in my life"], "Nad stanami jest i stanów-stan" ["Over the states there is the state of states"]... What emerges with greater clarity are alien territories - official and administrative:

Znalazłem się był raz w wielkim Chrześcijan natłoku,

Gdzie jest biuro lasek, płaszczów i marek;

- Każdy za swój chwytał się zegarek,

Nie ufając bliźniej ręce i oku!...

(“Grzeczność" [“Politeness"]; PWsz II, 104)

[I once found myself in a great throng of Christians,

A bureau of canes, coats and brands;

- Everyone clutching at their watches,

Not trusting thy neighbour's hand and eye!...]

In this context, it appears quite striking how detailed the spatial account contained in the verse letter "Do Bronisława Z." ["To Bronisław Z."] is:

Patrz - oto tam i owdzie mało okaźne mury.

Wnijdź - ma się pod wieczór, mniemałbyś może,

Iż na Malcie w zakonu gdzieś rycerskiego ostatku

Zatułałeś się... tu, tam - uchylone Ci drzwi okażą

Rdzawą na murze szablę albo groźny i smętny profil:

O mało nie stuletni ówdzie mąż w konfederatce, jak cień

Nie dołamanej chorągwi przy narodowym pogrzebie,

Przeszedł mimo i zagasł w długim jak nicość korytarzu - -

$[\ldots]$

Patrz! - oto i gdzieniegdzie, tam i sam,

Ożałobione blisko od dwóch tysięcy lat

Kochanki Tego, który był umarł na Golgocie,

Przechadzają, [...]

[...]

Kilkadziesiąt panienek w tyleż zakwita uśmiechów.

Ruch niezwykły dostrzegasz - kury nawet i kogut 
Oglądają się w słońcu skąpo błyszczącym na murze;

Nieleniwo pies kroczy z ciężkiego spuszczon łańcucha.

[...] (PWsz II, 238-239)

[Look - here and there you see unremarkable walls.

Enter - it's late afternoon, you might think perhaps

You've strayed into remnants of a knights' monastery

Somewhere on Malta... and here or there through doors ajar

You'll have revealed a rusty sword hung from a wall,

Or a fierce and melancholy profile:

Like a shadow of a broken banner at a national funeral,

A near-centenarian in a confederate's cap

Of an almost broken banner at a national funeral,

Has passed and faded into a corridor as long as nothingness - -

[...]

Look! - here and there Lovers of Him,

Who died on Golgotha, widowed for near

Two thousand years, now perambulate,

Doing good in His memory, [...]

[...]

Dozens of maidens blossom into as many smiles.

You notice extraordinary bustle - even the cock and hens

Disport themselves in the sun that scarcely warms the wall;

Let off its heavy chain, the dog has a sprightly gait.

$[\ldots]^{55}$

We now know - this is the place from which "list ten piszę do Ciebie" ["I am writing this letter to you"]. At the same time, it is clear to me that this is not the place, not only because of Gomulicki's commentary. Inhabiting a miserable and dirty place, lacking one's own room and being unable to choose your neighbours (the curse of today's anthill-like high-rise buildings) - these are the pains we share, and which are particularly acute for artists. Miron Białoszewski would try to tame this kind of reality with a prayer:

Boże, dokończ im tę szafę

do sufitu nad sufitem!

Bo korzystają

i obijają, obijają,

prawda, że w subtelnościach,

ale ja mam uszy przebite

55 Passage translated by Adam Czerniawski, Cyprian Kami Norwid, Selected Poems (London: Anvil Press, 2004), p. 93. 
i co gorsze - mam ich w sobie

pełno.

(“Boże, dokończ im tę szafę...")

[God, please finish this wardrobe for them

to the ceiling, over the ceiling!

For they use it

and knock and bump,

subtly, it is true,

but my ears are pierced

and what is worse - I have, inside me,

so many ears.]

Does Norwid attempt to beautify, that is, idealize external reality? No - his greatest effort is to overcome the silence about: to notice and allow in his poetry those "długie jak nicość korytarze" ["corridors long as nothingness"] and "Cheruby ze skrzydłami z papieru" ["Cherubs with paper-like wings"], "mężowie w konfederatkach" ["men wearing four-pointed confederate caps"], and "zakonne matrony" ["convent matrons"]. Is it because he feels that the duty of art is to "bliskie [...] idealnym znamienować" ["signify that which is close with that which is ideal"]? Probably not. Who would pay attention to children playing "wzajem złamkami rozbitej szyby" ["together with broken glass"]? A wandering "szklarz" ["glazier"] or a "Mędrzec" ["Wise-man"], whose "[...] myśl zawróciła teleskopem/W słońc miliardy i w światów szlak przez drogę melczną!" ["[...] thought turned back with the telescope/Towards billions of suns and the trail of worlds across the milky way!"]? Who writes a letter to "rodak" ["a compatriot"] from "Świętego Kaźmierza murów po-zastołecznej krasy" ["within the walls of St. Casimir's, a place of un-metropolitan charm"]? One of the men wearing a four-pointed confederate cap? A naïve witness of the name-day show? Well, the words are written by the one to whom "Michelet stary [...] Mówił [...] był" ["the old Michelet [...] would [...] speak"] - the one who talked to "mistrz w teoriach skąpy" ["the master poor in theories"]. "Dziadów autor, pomnę, jak to mówił ze mną" ["The author of Dziady, I recall, as he spoke with me"] - the one who writes letters in hexameter and quotes Ovid. It must be someone who is perfectly aware that he shall not be buried beneath the crumbling walls of the poorhouse.

The prophecy-like words about "siostry dwie" ["two sisters"] and the constantly quoted sentences that define the vital role played by art:

Z rzeczy świata tego zostaną tylko dwie,

Dwie tylko: poezja i dobroć... i więcej nic...

(PWsz II, 238) 
[Of the things of this world only two will remain,

Two only: poetry and goodness... and nothing else... $]^{56}$

make it difficult for readers of Norwid's poetry to discern the author of these sentences: a man who finally accepted the artist's fate in an industrial civilization. It is not the fate and calling of a glazier, but that of a wise-man.

In the verse letter "Do Bronisława Z.," we can observe the poetic overcoming of loneliness - it is even from this very place that "list ten piszę do Ciebie" ["I am writing this letter to you"]. He is "za murami" ["outside the walls"] - the man to whom he can give himself over. It is also the simplest way to enter the "archetypal situation."

What made Przyboś admire Mickiewicz's lyricism so much? Imagery, versification, trope or figures? No. It was his "model of humanity" - one that the avant-garde poet discovered to be close to his own, an "external perspective of looking at oneself": radical objectivization. What is so discouraging about Słowacki's lyricism? The language? Difficulties in solidifying metaphors? No. Is it the sense of our triviality, the complete inability to identify with the person to whom Our Lord is really listening? What about Norwid? There is no intellectual obstacle rising before the readers here. The difficulty would rather lie in our reluctance to show solidarity with the one who is suffering - to endure the sufferer's personality. "Przed nieszczęśliwym, ach wszystko ucieka...” ["From the miserable, oh! everything is fleeing...”]. Martin Buber writes:

Thus, to look inside a man means primarily to see him as a whole, as a person who is defined by spirit: to discern the dynamic centre which affects all of that person's behaviours, manifestations and attitudes, leaving identifiable, unique marks on them. Such an in-depth look is impossible, however, as long as the other person remains, in our eyes, an isolated object of considerations or observations, because they cannot penetrate the centre and witness the whole. This is only made possible when I enter into a primal relation with another person - when that person becomes a presence to me. That is why the concept of looking-in, in this specific sense, is what I call making the person present. ${ }^{57}$

Like no other lyrical expression, the message of "Do Bronisława Z." is precisely that kind of making the person present.

In the process of discovering Norwid's poetry, especially at its very beginning, one notion prevails, namely that we are about to stumble upon great difficulties requiring a huge effort in order to understand it. The work of this writer reveals

56 Translated by Czerniawski, p. 92.

57 Martin Buber, “Życie między osobą a osobą” trans. Jan Doktór, Więź, Vol. 23, No. 5 (1980), p. 17. 
anxieties about intellectual immaturity as well as a lack of erudition and intelligence. ${ }^{58}$ It is only much later that we discover and learn how this anxiety distorts our more ordinary encounters with the poet. The image of Norwid created by the critics and imposed on us obfuscates those areas of his humanity that belong to the realm of human community, especially with regard to the sphere of trying life experiences. When I suffer, I can understand other people's suffering too. If I am in love, I shall not turn to philosophy or morality to seek justification of the phrase "- Kto kocha - widzieć chce [...]"(DW IV, 110) [“- Whoever loves wishes to see [...]"] because this is a truth I know myself.

What would be the main factors determining Norwid's attractiveness as a lyricist?

1. The first factor is captured in Norwid's perfect rhetorical phrase: "Podli!... bo niemi, i niemi, bo podli!" (PWsz I, 392) ["Base!... because mute, and mute because base!"]. It comes straight from the Enlightenment's best poetry, mainly from Krasicki. His didactic ambition, his civic attitude and preference for certain genres (letter, fable, ode, and epigram) all tie Norwid firmly to the 18 th century - hence the frequent "sense of his being archaic." This is also the reason for my own elaboration on explanations, which naturally runs against the critics' persistent need to write about "silence and understatement." The rhetorical impulse is too strong in Norwid, that is, the need to state something perfectly. It created the fine formulas recommending "understatement" in order to marvel at the submissiveness of opinions on Norwid's verbal declarations on "pregnant silences."

2. The second factor is related to the expansion of the sphere of those matters "that one usually does not talk about." Trznadel wrote that "all of Norwid's poems could be read at salons and in the presence of ladies." ${ }^{.9} \mathrm{My}$ present

58 "The difficulty with reading poetry often stems from the fact that we fail to immediately find the position necessary for proper reception of a given work, as a result of which we focus on moments that are not crucially important. Something similar happens when we begin to read a poem and struggle to find the right rhythm." This side comment by Wacław Borowy, made while discussing the poetry of T.S. Eliot ("Ziemia Jałowa," Przegląd Wspótczesny, No. 6 [1936], p. 43), can shed light on our own troubles with reading Norwid. After all, the poet himself suggested to his readers several misleading "rhythms": the call for intellectual effort and the emphasis on obliqueness.

59 Trznadel exclaims: "What narrowing did the sensual model undergo, for example! Passions, crimes! Norwid's concept of human nature and world as a specific theodicy, constructed with logical stubbornness and consistency, divides humanity into two kinds of people: the innocents or saints, on the one hand, and the charged, guilty, 
aim would be to demonstrate that ladies, priests, and moralists would quite frankly be appalled if they read such works as: "Trzy strofki," "Pierwszy list, co mnie doszedł z Europy...," "Kółko," or even "Fatum." These poems are not at all calm and rational analyses of the human situation in relation to God, fate, or even fellow people. “'Zaśnij’.. - mówi po tańcu mdłej kobiecie” (PWsz II, 183) [" 'Go to sleep,' says the dancer to the vapid woman"] - here Norwid clearly shows his 19th-century face, his Romantic and emotional character, which somewhat stands in opposition to his image as an ageless intellectual.

3. Thirdly, I would indicate the quite frequent immediate records of his times: "the age of trade and industry," and his records of experiences as a man "who is one of many": experiencing suffering, difficulty and poverty, far from the grandly Romantic spiritual elitism, exaltation, and indifference to the pains of everyday life. It has been identified and described that Norwid had a tendency to rehabilitate "mundaneness" and "dust." However, what has not been accounted for is - in my view - the need to oppose such conditions (a need deeply concealed, as it were, and yet revealed in his poetic language) and disdain for such existence, as in the phrase "przepełznie obfitość rozmaita" ["varieties of opulence will slither away and vanish"] (PWsz II, 238), where we can metaphorically read an aversion to reptilian glimmer. In such passages, Norwid appears to be a 20th-century writer. I would call these moments "visions" of the contemporary world as a whole, experiences - preserved in writing of this world's most sublime and dirty aspects, its superficiality, hypocrisy, stupidity, and vulgarity. Whoever had the once-in-a-lifetime occasion, like I did, to take the Roman street to Paul's, beyond the Wall, crossing the street littered with rubbish, will appreciate the aptness of Norwid's phrase: “[...] że to Biblii księga/Zataczająca się w błocie" (PWsz II, 30) [“[...] that book is the Bible/Rolling thus in mud"]. The poet's efforts aim to accept this kind of world as well, but the acceptance has to involve resistance and suffering. On such occasions critics would often speak of Norwid's irony, but I wish to point out its actual source, which would lie not with his intellectual sharpness and

guilty without question, dual, tainted on the other. Certainly, his vision is striking in its perceptiveness and innovativeness as far the material he presents is concerned. Can a writer be criticized for not being interested in a certain problem area? At the same time, it is difficult to forget that all of Norwid's poems could be read at salons and in the presence of ladies (it remains an entirely different matter whether these poems would be understood)" (Jacek Trznadel, Czytanie Norwida. Próby, p. 242). The question remains whether Trznadel is not interpreting the concepts of "salon" and, primarily, "ladies" in terms too contemporary here. 
ambition, but with his deeply personal experience of the world. It is in this sphere that Norwid stands as the most self-sufficient and authentic poet, it is here he is venturing beyond the broad horizons of the poetry of yore. In this, he is neither an heir nor a fellow believer, but a discoverer and an artist.

\section{Bibliography}

Białoszewski, Miron. Mylne wzruszenia. Warszawa: PIW, 1961.

Borowy, Wacław. O Norwidzie. Rozprawy i notatki. Warszawa: PIW, 1960.

Buber, Martin. “Życie między osobą a osobą.” Trans. Jan Doktór. Więź, Vol. 23, No. 5, 1980, pp. 11-24.

Ditfurth, Hoimar von. Duch nie spadł z nieba. Trans. Anna Danuta Tauszyńska. Warszawa: PIW, 1979.

Jung, Carl Gustav. "On the Relation of Analytical Psychology to Poetry." In: Spirit in Man, Art, and Literature. The Collected Works of C.G. Jung, Volume 15, trans. \& ed. Gerhard Adler \& R.F.C. Hull. Princeton: Princeton University Press, 1971.

Jankowski, Kazimierz, ed. Przełom w psychologii. Trans. Kazimierz Jankowski, Anna Kołyszko, Piotr Kołyszko. Warszawa: Czytelnik, 1978.

Karpiński, Franciszek. Wiersze wybrane. Warszawa: PIW, 1966.

Kołaczkowski, Stefan. Pisma wybrane, Vol. 1 "Portrety i zarysy literackie." Ed. Stanisław Pigoń. Warszawa: PIW, 1968.

Krasicki, Ignacy. Pisma poetyckie. Ed. Zbigniew Goliński, Vols. 1-2. Warszawa: PIW, 1976.

Lisiecka, Alicja. Norwid - poeta historii. London: Veritas, 1973.

Łapiński, Zdzisław. Norwid. Kraków: Znak, 1971.

Makowski, Stanisław. W szwajcarskich górach. Alpejskie krajobrazy Słowackiego. Warszawa: PIW, 1976.

Miłosz, Czesław. Ocalenie. Warszawa: Czytelnik, 1945.

Obuchowski, Kazimierz. Kody orientacji i struktura procesów emocjonalnych. Warszawa: PWN, 1970.

Ordon, Edmund. "O tłumaczeniu Vade-mecum C. K. Norwida." In: Przekład artystyczny, ed. Seweryn Pollak. Wrocław: Zakład Narodowy im.

Ossolińskich, 1975.

Pismo święte Starego i Nowego Testamentu w przekładzie z języków oryginalnych ze wstepami i komentarzami, Vol. 3 "Nowy Testament," ed. Rev. Marian Wolniewicz et al. Poznań: Księgarnia Świętego Wojciecha, 1975. 
Przyboś, Julian. "Próba Norwida." In: Sens poetycki. Szkice. Kraków:

Wydawnictwo Literackie, 1963, pp. 96-116.

Sławiński, Janusz. Czytamy utwory współczesne. Analizy. Warszawa: Państwowe Zakłady Wydawnictw Szkolnych, 1967.

Sławiński, Janusz. "Synchronia i diachronia w procesie historycznoliterackim." In: Dzieło - język - tradycja. Warszawa: PWN, 1974.

Stefanowska, Zofia. "Nowe studia o Norwidzie." Pamiętnik Literacki, Vol. 52, No. 2, 1962, pp. 548-554.

Stefanowska, Zofia. "Norwidowski romantyzm.” Pamiętnik Literacki, Vol. 59, No. 4, 1968, pp. 3-23.

Szmydtowa, Zofia. "Listy poetyckie Norwida." In: Studia i portrety. Warszawa: PIW, 1969.

Szuman, Stefan. O kunszcie i istocie poezji lirycznej. Toruń: Państwowe Toruńskie Zakłady Graficzne, 1948.

Tatara, Marian. "O 'Trzech strofkach' Cypriana Norwida." Pamiętnik Literacki, Vol. 71, No. 3, 1980, pp. 129-141.

Trznadel, Jacek. Czytanie Norwida. Próby. Warszawa: PIW, 1978.

Weil, Simone. Gravity and Grace. Trans. Emma Crawford \& Mario von der Ruhr. London: Routledge, 2002.

Witkowska, Alina. "Ja, głupi Słowianin.” Kraków: Wydawnictwo Literackie, 1980.

Witkowska, Alina. Wielcy romantycy polscy. Mickiewicz, Słowacki, Krasiński, Norwid. Warszawa: Wiedza Powszechna, 1980. 


\title{
Michał Głowiński \\ Norwid's Obscure Allegories
}

\begin{abstract}
The starting point of the author's reflection is the traditional conviction about the "obscurity" of Norwid's language and use of allegory. The presence of allegory in the poet's works is combined with exemplary storylines and discourse. The author lists four basic factors that made up Norwid's obscurity in the field of allegory, making it difficult to enter communication with the viewer. The first and most important factor is the multi-perspective perception of the world. The second factor should be described as a combination of elements, which are not sanctioned by tradition, and which make it difficult for the recipient to understand how individual parts are connected to form a whole. The third factor is a specific treatment of time and space - not only as an object of reflection or metaphysical contemplation but also as a structural element of poetic expression. The fourth factor is polythematics (the use of digression, open composition). Comments on the elements that determined the obscurity of Norwid's poetry are presented by the author on the example of the poem "Rozebrana" ("Disrobed"). Generalisations and analytical remarks lead to the conclusion that Norwid operated in the areas defined by tradition, taking over traditional forms, traditional motifs, and traditional stylistic solutions, but he used them in a non-traditional way. He acted as if by referring to tradition he was building bridges to ensure contact with his reader, but was demolishing them at the same time. Therefore, Norwid's poetry is labelled as a poetry of agitated forms.
\end{abstract}

Keywords: Cyprian Norwid, poetic, allegory, polythematics, stylistics

When sending Jan Koźmian "Wigilie" ["Christmas Eves"], Norwid wrote to him: "Miejcie trochę pokory i wyznajcie, żem nie wariat - że nie ciemno piszę, ale wy ciemno czytacie" (DW X, 270) [Have some humility and profess I am no madman - admit that my writing is not obscure, but that you read obscurely]. In a letter to August Cieszkowski from May 1860, he stated in relation to his lectures: "Wyłożyłem rzecz o jasności i ciemności języka poetów i mojego... czynem!" (DW XI, 437) ${ }^{1}$ [I have explained the matter of the luminosity and obscurity of the poets' language and mine... in action!]. This matter troubled him for many long years. He returned to it also in his poetry. That

1 The letter from which this sentence is taken is to a large extent a lecture on luminosity and obscurity. 
"obscurity," was a permanent element of both his literary and human condition. It was a component of the communicative situation in which he found himself unwillingly. The allegation of obscurity is equal to an accusation of incomprehensibility; he who writes obscurely cannot establish contact with those who expect clarity and luminosity from poetry. And how to define that clarity? The answer to that question is difficult, all the more so because there are just as many answers as there are styles and conventions, and clarity itself belongs to utterly ambiguous categories. We will not concern ourselves with this, however, and assume that each epoch works out its own definition of clarity and knows what it consists of. For the time being, this will have to suffice. I am claiming this from the very beginning to avoid complaints about the poet's contemporaries not understanding him. It seems more valid to ask: would they have even been able to understand him? Did his writing style conform to the binding conventions and styles of that time to the degree that it could be understood at all?

Luminosity and obscurity, when not treated as popular, colloquial metaphors devoid of deeper meaning, can be defined as specific communicative potentialities of poetry. Those potentialities do not have to be general, deciding poetry's functioning in advance - they can determine its reception at a given time. Luminosity and obscurity are thus historical categories. They were undoubtedly such for Norwid himself. Aware that he could not reach an understanding with his contemporaries, he nevertheless did not deny his works their communicative capabilities, as that would have rendered them obsolete. As a matter of fact, this issue concerns all his works in its various shapes and forms. In this essay, I do not aspire to exhaust the matter. I will limit the scope of my consideration to just one phenomenon - Norwid's allegories.

At this point, I should explain why we will be discussing Norwid's allegories, and not his symbols. One could justify this choice by the fact that in 18th-century Polish (as seen in dictionaries, from Linde to Karłowicz) and Polish literary terminology from that time up until the 1890s (as seen in textbooks on poetics and rhetoric, from F. N. Golański to A. G. Bem) the meanings of "symbol" and "allegory" were not clearly differentiated, their scopes overlapped, and they were often treated as synonyms. Yet such a justification seems off the mark, for at least two reasons. First, the linguistic and terminological customs of the epoch do not apply to literary historians, who should be using contemporary language. Second, the contrast between symbol and allegory, which later became a dogma of the aesthetics of symbolism, was systematically specified for the first time by Goethe in the late 18th century and had a strong impact on European literary 
awareness. ${ }^{2}$ The contrast made must be taken into account even if one thinks it irrelevant to Norwid or Polish literary thought at that time.

Thus the decision must be justified differently. First of all, we need to acknowledge the fact that those of Norwid's works which are considered allegories clearly refer to tradition, and - as we shall see - a very specific tradition. Reference to tradition, in turn, is one of the essential indicators of allegory (which belongs to those forms of expression nearly always drawing attention to their antecedents) which is irrelevant as far as symbols are concerned, even when it is easily identified. Allegory takes its past and modernises it in one way or another, while a symbol never does that - even if taken from tradition, a symbol is shaped in such a way as if it crystallised only in the course of expression. This specific traditionality of allegory is an important fact for Norwid's poetics.

It is particularly visible when considering which literary genres the poet reactivated. ${ }^{3}$ The scope of his interests includes ancient genres in the vast majority, which in the literature of his times - both Polish and European - were either long obsolete or, at best, marginalised in literary output, quiet and unassuming. What is most important here is that those genres were in some way related to allegory, and some of them - above all the parable - may be simply called allegoric genres. Symbols never occur within such genealogical entanglements; they are much less related to specific genres than allegories, which results from the assumed one-time nature of a symbol (even in those frequent cases when it only appears to be of one-time use).

Those genres exhibit features which are charactertistic of allegory but at the same time do not relate to symbolism. We should name two of those, seemingly fundamental, features: fictionalisation (story-telling) and relation to discourse. Allegory can turn into a story at any moment. Some theoreticians and historians of allegoric speech consider this fictionalisation - not always merely potential - to be one of its essential distinguishing features. This is a very unique fictionalisation characterised by advanced schematisation, which results mainly from the fact that the elements constituting a certain course of events are barely, or not at all, independent. They are first and foremost carriers of certain meanings or they have been directly subordinated to such meanings, as is often the case. Such a phenomenon is called an exemplary storyline. It can

2 See T. Todorov, Théories du symbole, (Paris: Seuil, 1977).

3 I discuss this issue in the paper "Norwida wiersze-przypowieści" (in the collection: Cyprian Norwid. W 150-lecie urodzin, Materiały konferencji naukowej 23-25 września 1971, ed. M. Żmigrodzka. Warszawa: PIW, 1973). In this vol. see: M. Głowiński, "Norwid’s Poem-parables," pp. 337-374. 
never relate to symbolism, because even if a storyline develops as the result of a symbol (which is typical, e.g., of Leśmian), it has a completely different nature to some extent, it is similar to a myth. And exemplary storylines of little independence are what is constantly offered in Norwid's poetry. It is filled with just such storylines (in his lyrical poetry perhaps micro-storylines) - meaningful, barely outlined, extremely schematised. And it is exactly these storylines which are the domain of allegory.

The role of discourse in such genres is already clear from the above discussion on fictionalisation. Exemplary storylines are based not only on demonstrating or even imposing meanings; to various degrees of suggestiveness, the derivative of what has previously been directly formulated in a more or less discursive form. They may also transition to discourse, in a manner sanctioned by centuries-old tradition. Such a relation is impossible with a symbol, because it cannot be discursive in and of itself or enter into symbiotic relations with discourse. Again, discourse coexisting with storyline is one of the most typical features of Norwid's texts, yet a feature quite unusual against the backdrop of his epoch's poetry.

All the reasons presented above allow us to choose allegory over symbol as the topic of our discussion. The shaping of allegory reveals the basic mechanisms of Norwid's poetry, and its specific communicative position. Those mechanisms are all the clearer for the fact that, based on its tradition, mid-18th-century allegory should have been something "clear and luminous," well placed, and immediately understandable. Perhaps in reality it was, but this was never the case with Norwid. It must be stressed right away that the potential obscurity of allegory did not result from its nature. The poet often used well-known allegories, ones that already enjoyed topos status, the allegory of the sailor, just to name one, banalized by hundreds of repetitive presentations.

Od rezultatów mylnego zamętu

Z kagańcem w ręku do przyczyn zstępuję,

Jak smutny żeglarz po schodach okrętu,

Kiedy kotwicy szuka... burzę czuje...

(“Od rezultatów mylnego zamętu”, PWsz I, 137

["From results of mistaken confusion"]])

[From results of mistaken confusion

I descend to causes with a lamp in my hand,

Like a sad sailor descends the ship's stairs,

Looking for the anchor... sensing the storm...]

Here the already well-worn allegory of the sailor appears in a new arrangement meant to help describe a cognitive effort. One may ask whether that allowed a 
last century reader to better understand the stanza or - to the contrary - whether it presented an additional obstacle, as the revival of the allegorical stereotype only multiplied perceptional difficulties. What is certain, however, is that the two following stanzas did not facilitate the reader's task, and not simply because the allegory of sailor - which only serves as an exemplum - is discontinued. The allegory was included in an elliptically constructed reflection - similarly, in fact, to the reference to the Danaids' myth in the last stanza. The comprehensibility and thus luminosity of the allegorical thread is defined - which I would like to reiterate, with particular emphasis - by the place it takes in the whole poetic structure, as well as the purpose it serves. By taking a motif as common as the sailor, Norwid seems to promise the reader that he will navigate a well-known, nearly exhausted territory - and yet he does not fulfil that promise, because he uses the motif in a manner tradition never designed. And here we reach the central issue related to Norwid's obscure allegories.

Before I discuss them, I need to consider under what circumstances and in which relations allegory appears in Norwid's poetry. It seems appropriate to indicate the two basic forms it takes. The first - ostensibly dominant - one is allegory included in discourse, often in the form of a parable or an exemplum; an example being the above-quoted poem ["Od rezultatów mylnego zamętu"]. The inclusion may be of various kinds - either permeating the substance of the discourse, or set apart in one way or another, and developed to a lesser or greater degree the range of possibilities is broad. Yet, I will not devote a separate discussion to this matter; I have already attempted to analyse it in my paper "Norwida wierszeprzypowieści" ["Norwid's Poem-parables"] . The other possible form is allegory that is to a large degree emancipated, if not fully independent, and always superior to the discourse, if the latter appears at all.

But are all of Norwid's allegories "obscure," regardless of the manner and form in which they occur? One thing is certain: making the distinction between allegories included in the discourse and independent ones determines neither luminosity nor obscurity. The discourse is not necessarily a deciding factor; often - itself complicated - it further blurs the allegory, suggests multiple interpretations, steers the reader's attention in different directions, until ultimately it is up to the reader how to relate to and understand the allegory. It is not predetermined by the allegory itself, either, which may be luminous, or may be obscure (as noted numerous times by theoreticians of this phenomenon, so important to European culture). It thus seems that we have those allegories one

4 In this vol. see p. 337-374 (editor's note). 
might intuitively categorize as luminous, as well as those which one might classify as obscure with the same level of certainty, although the motivations behind such distinctions may not always be equally clear.

And thus poems in which discourse features prominently, like "Bohater" ["Hero"], and those completely devoid of it, like "Krzyż i dziecko" ["The Cross and the Child"], may seem totally clear ("luminous") to today's readers. The latter one especially contains a self-explanatory allegory which requires no comment, and if it were to be compared to the concept of a poetic idiom - which was already starting to take shape in Norwid's time (and to which he contributed, it ought to be noted) - it may even seem too clear, not leaving any room for the reader's effort or initiative. This is one extreme of Norwid's poetry: extreme luminosity. Yet it is not certain whether this poem, so clear to today's reader, would have been as clear to a reader from the mid to late 19th century. As a matter of fact, it did not necessarily have to be; the clarity or luminosity also depends on whether the given literary element appears in a place sanctioned by the given time's tradition, in other words, whether it appears where it is expected. We must take into account that in Norwid's times such allegorical poems were no longer written, and that the poet used allegory in places not reserved for it. The notion of luminosity might thus have been obscurity, after all. But that is a different matter, all the more so because this paper must focus on the realm of obscurity - and with the certainty that it was obscure not only because its past literary audience "read obscurely."

We should therefore ask what determined that obscurity, alleged or real mainly focusing on the domain of allegory, although I do realise that the issue is not limited thereto. We could list four main factors which contributed to that obscurity of Norwid's, and which made it so difficult to establish a communicative connection with his readers.

The first and, in my opinion, most critical factor is multi-perspective. In other words, the poet does not follow the principle of speaking about a matter from one point of view, revealing it from only one, clearly defined distance, and therefore from just one easily reconstructed perspective. Instead, Norwid seems to violate tradition with particular intensity. And not just one tradition, but all of the ones functioning at that time - the rhetorical tradition which assumed the clear construction of a speaker who had absolute control over his expression, as well as the tradition of intimate romantic poetry, where the subject was also an undisputed master of everything, although that dominance appeared in different forms and for different purposes. However, the above does not mean that in the poetry adhering to earlier rhetorical principles, or in romantic verse, only one voice dominated, whose audibility was never disturbed. It happened in other ways, but 
with the one difference that the passing from the speaker-subject to any other one was clearly delineated, creating spheres which did not interrupt one another. With Norwid, it is quite the opposite: he does not follow the splitting of voices, shifting instead from one perspective to another in a manner which blurs the borderlines. There is no one dominating voice, polyphony rules. The voice which is intended in the poem to be the poet's own overlaps another or transforms into that other in a more or less (usually less) noticeable way. In "Rozmowa umarłych" ["Dialogue of the Dead"], Norwid has Byron declare: "mam dumania nałóg nałóg monologu" (PWsz I, 278) [I have the (bad) habit of pondering - a habit of monologue-ing]. Those words only partially show the poetics of their author.

It is an obvious and indisputable fact that the "habit of pondering" is characteristic of Norwid and a main feature of his poetics. Yet, the "habit of monologueing" is a different matter. It was in this area that the poet infringed on the basic poetic rules of his era - not just because he treated monologue so discursively. The main reason was that he stretched it to include what I coined multi-perspective, that he practised various approaches towards the object of the poem within the monologue, that he showed it close-up and - a little later - from far away. In an early poem he said: "Z wysokości dziejów patrzę/Na rzecz ludzką...” (“To rzecz ludzka!...”, PWsz I, 63 [“It is a Human Matter!...”]) [From the heights of history I look/Upon the human matter], but he was looking at it not just from above, but also from ground level, close by, just a step away. Both multi-perspective and the distance related thereto are mobile and variable categories to Norwid. To find proof, it suffices to read such poems as "Moralność" ["Morality"], "Wczora-i-ja" ["Yesterday-and-I”], "Czemu” ["Why”], "Dwa guziki (z tyłu)" [“Two Buttons (at the back)"], just to name a few of many examples.

The second factor, closely related to the previous one, could be defined as a combination of elements not sanctioned by tradition, such as may cause the reader difficulty to discern what holds the individual parts (discursive considerations, images, symbols, etc.) together, what welds them into a meaningful message. Another question is, what the rules of passing from one element to another are. An unprepared reader - and such was the contemporary recipient of Norwid's - could even be led to believe that no rules applied here, at least, not such rules that were intersubjectively accessible and possible to rationalise. One might say that in many of his poems, Norwid used sharp editing methods to combine the elements in various manners, but at the same time he did not employ the method commonly used at that time: a more or less clear and simple parallelism, which could have been considered a common means, and therefore luminous, clear, and "familiar." In a way, the reader was not equipped with the means which would have allowed him to follow the variability of the components 
(very characteristic in this respect is the poem "Sława" ["Fame"], particularly the opening stanzas). This sharp editing, executed by Norwid so consistently, is one of the basic symptoms of his specifically shaped multi-perspective.

Related to multi-perspective is also a third factor - the specific treatment of time and space, and not only as the object of reflection or metaphysical consideration, but also as a structural element of poetic expression. A 19th-century reader was used to an exacting discipline in both those areas. If space and time were to be treated in a mimetic manner, they had to abide by conventional societal experience, in no case infringing upon the accepted rules of rationality. Fantasy or mythicalness required a clear modal frame to indicate that it was a reality of a specific nature, a reality which did not relate directly to the aforementioned experience. In Norwid's case, the matter of fantasy is nearly unimportant, whereas mythicalness has fundamental significance. This is expressed mainly by the said formation of time and space. In many of his poems, Norwid shapes them as you would in a realistic novel, but he is inconsistent. Time, even when that of a nearly "realistic" salon scene, becomes the time of great history or even eternity, and often simply loses its concrete dimensions. ${ }^{5}$

However, it is not the same case for the great poets of European and Polish Romanticism, who were fascinated by the specific dialectics of moment and eternity. ${ }^{6}$ A moment here is not the manifestation or realisation of a time so great it eludes comprehension. The time of a realistic scene becomes the time of parable, subject to allegorisation. A similar procedure applies to space. The defined space of a salon, city or any other place loses its contours and - like time - becomes an allegorical space. ${ }^{7}$ Norwid switched from one to the other directly, without the slightest hint to the reader that a change had occurred in that sphere, and such a significant one, at that. This agent of obscurity seems particularly important, as it disrupted any established reading habits and went against the style of shifting from detail to the bigger picture which was commonly practised at that time.

The fourth element of obscurity is a kind of polythematics, or - if you prefer the digressiveness of Norwid's poems; in other words, open composition. Based

5 The clearest example of Norwid's complications in shaping time is most likely the poem "W pamiętniku" ["In an Album"], incorporated into the prologue of Tyrtej.

6 Historians of Romanticism wrote about it numerous times. See mainly M. H. Abrams, Natural Supernaturalism, Tradition and Revolution in Romantic Literature, (New York: W.W. Norton \& Company, 1971).

7 See the comments on space shaping in Norwid's poetry in my paper "Przestrzenne tematy i wariacje" (in the collection: Przestrzeń i literatura, Ed. Michał Głowiński, Aleksandra Okopień- Sławińska, Wrocław: Zakład Narodowy im. Ossolińskich, 1978). 
on the open concept of multi-perspective, his poems allowed for foreign plots, in a manifestation of free ("digressive") shaping of discourse or such a formulation of allegory as would sanction various thematic twists and turns. An example of this behaviour in Norwid is the introduction of reminiscent images to poems which otherwise have no such nature (e.g., some stanzas of "Purytanizm" ["Puritanism"] and "Rozebrana" ["Disrobed"]).

My comments so far on those elements of Norwid's poetics which determined the poetry's obscurity for his contemporaries may seem rather abstract and poorly rooted in the details of his works - definitely lacking documented examples. Aware of this possible allegation, I will attempt to illustrate the mechanisms which have been emphasised above, using a specific poem as the example. I have chosen one of Norwid's most outstanding poems, one of his most daring and original ones, which is also undoubtedly an allegorical poem. It is the poem "Rozebrana" (PWsz II, 249-250 [“Disrobed”]). Clearly, a thorough interpretation is not the objective, as this would require a separate paper; I would only like to focus the attention on the elements which make this unusual story limited in evidence to facilitate contact even with those contemporary readers who did not "read obscurely." To start with, the poem's subtitle is: a ballad. Historians of the Polish ballad write:

Norwid's poetry kept itself at an even greater distance from the poetic beauties of a ballad. He did know how to use its conventions to achieve his own means. He also knew how to ridicule those conventions in the jocular nature of parody. But one would search in vain for serious commitment to the ballad's poetry in his works. ${ }^{8}$

Regarding "Rozebrana," authors speak of the "jocular allusiveness of the subtitle" in their footnotes. ${ }^{9}$ And so, is "Rozebrana" a ballad, or is it not? - this question required some initial decisions on the reader's part, important decisions dictating the further course of reading. It would seem that this category of genre suggests a specific uncommonness in the common; after all, it relates to the stage of the genre's development when it became a poetic story of the ordinary day when its only ever interest in the uncommon was the uncommonness of that ordinary day. The "jocular allusiveness of the subtitle" thus refers to the salon ballad, so characteristic of the second half of the 19th century. Yet, such a ballad was usually far from resembling allegory.

8 I. Opacki, Cz. Zgorzelski, Ballada, (Wrocław: Zakład Narodowy im. Ossolińskich, 1970), pp. 135-136.

9 Ibidem, p. 136, note. 
Not only did the subtitle suggest various interpretations to the reader, including ones that could be viewed as contradictory. This was also accomplished by the title, and with equal, if not greater, emphasis. Norwid's allegory results from a play on words, and not only in this poem. Moreover, even the play on the meanings of the word "rozebrana" [which can mean "undressed, disrobed, taken apart, dismantled, demolished, partitioned" or even "peeled" - translator's note] appears in more than this one poem by Norwid. In another poem he wrote (as part of his contemplation of Poland):

- Cóż stąd?... jeżeli owoc tej cytryny,

Co tu na stole leży, kto rozbierze,

(“O historii”, PWsz I, 164 [“On History”])

[- So what?... if this lemon fruit,

Lying here on the table is peeled [translator's emphasis]]

And in another poem:

Śród Europy, nie dla obyczaju

Chrzczonej - co począć w rozebranym kraju?

Co robić? - pyta ten, tamten i owy,

Rozłamanego narodu trzy głowy.

(“Co robić?”, PWsz II, 214 [“What to Do?”])

[In midst of Europe, not for custom

Christened - what to do in a partitioned country? [translator's emphasis]

What to do? - asks one, other and then another,

The three heads of a nation broken in parts.]

In the first of the quoted stanzas, the play on words is clear and immediately visible; in the other, it is not as clear, but the adjective does not lose its basic meaning. In any case, both instances are relevant to the poem we are considering. What appeared as a mere episodic measure in the above-quoted fragments, in "Rozebrana" became the structural foundation. Through his play on words, Norwid called upon a popular allegory - the patriotic idea which formed an integral part of the national imaginarium of the last century. ${ }^{10}$ In her interesting essay "Śmierć Polonii", Alina Witkowska writes of "the allegory of the Partitions of Poland viewed as the murder of a woman." The allegory appeared not only as a poetic topic, but also as a motif in iconography. Yet, as proven clearly by

10 That handy term - equivalent to the French "imaginaire" - was introduced by A. Tatarkiewicz in her translation of A. Malraux's book L'Homme précaire et la littérature (Pl. Przemijanie i literatura, trans. Anna Tatarkiewicz, Warszawa: PIW, 1982). 
Witkowska, that image was shaped in a completely different manner than in Norwid's poem: the woman was linked to death.

Hence the combination of allegory and expression of horror, as that allegorical woman is tormented, tortured, nailed to a rock, trampled by horses, pushed into her grave, even exposed, by shamelessly stripping clothes off of the body which is about to receive a fatal stroke. ${ }^{11}$

There is nothing of this sort with Norwid; his protagonist is not a martyr, she leads the hygienic life of a refined lady. The poet borrows a common allegorical image, as he often does on various occasions, but does not feel obligated by its previous shapes or usage. ${ }^{12}$ Thus, one of the general principles characteristic of Norwid's poetry is confirmed: the functioning of an allegory is not defined by tradition, but by that which one may call its substance. Looking at that kind of poetic procedure from a communicative point of view, it might have a double meaning: on the one hand, it refers to what is commonly known; on the other, it disturbs the usual functioning of the highly familiar elements. A familiar allegory, though based on a commonly used image, became obscure.

Multi-perspective also contributes to the obscurity in "Rozebrana." It appears throughout the poem in various ways. First of all, in its classical shape - very schematised by Norwid's time - allegory assumed full translatability, it required the reader to maintain the constant awareness while reading that the subject directly at hand was in fact something else. And so it happens in this quasi-ballad,

11 A. Witkowska, "Śmierć Polonii", Teksty, 1979, No. 3, p. 181.

12 It is worth indicating that the motif was used in a parodic version by Boy in Replika kobiety polskiej (quoted after: T. Żeleński (Boy), Pisma, ed. H. Markiewicz, Vol. 1. Warszawa: PIW, 1956, p. 139):

A ten... trzeci wasz poeta...

No, ten... hrabia... z dużym nosem,

Któremu każda kobieta,

Co ją ujrzał bez bielizny,

Była symbolem Ojczyzny,

A łóżko ofiarnym stosem!

[And that... third poet of yours...

You know, that... count... big-nosed,

To whom every woman

He saw without underwear

Was the symbol of the Homeland,

And a bed [was] a sacrificial pyre!] 
since the female protagonist is supposed to represent Poland, even when death poses no threat to her. At the same time, something else is happening. The same story - at least up to a certain point - is the story of a lady in the evening and in the morrow. It is a specific account to a far greater extent than required of an allegorical message.

That would appear to facilitate its reception - and from a certain point of view, it definitely does. However, in reality it actually hinders the reading, leaving the reader in endless uncertainty, constantly having to focus on the concrete and - with equal consistency - going beyond it. The myth of Acteon and Diana, referred to in the last three stanzas, further complicates things. The complication occurs despite the fact that the myth was undoubtedly known to the poet's 19th-century readers, as well as the fact that the place and role of the myth are clearly defined in the poem: it acts as the second half of a comparison. That technique of introducing a parable was consistently practised by Norwid (since his earliest works), yet sharp editing occurs here, as well. It is more an instance of juxtaposition than a specific poetic development.

As usual with Norwid, multi-perspective is related to the formation of space and time. There appear to be two times and two spaces in the poem. The time of the first stanzas, which present the protagonist at a moment when the reader does not know yet whether she is a lady or an allegorical figure, may seem like the time of everyday life, ordinary time, taking almost the same shape as in a novel. Then time stretches - in both stanzas starting with "tymczasem" [meanwhile], especially the second one. And then it suddenly changes radically, departing from the time of the poetic scene. What kind of time is it, then? One would most likely call it allegorical, generalised - at least to some extent - and unspecified, because it can be neither delineated as the moment at which the "plot" started, nor is it a direct consequence thereof.

Space is shaped in a similar manner. The beginning suggests the space of a home, well known to literature, the everyday space of no particular distinction. That living space is also broadened at some point, undergoing a proper transformation:

Tymczasem dzieci o rannej godzinie

Gdzieś do szkół idą;

Oracz wywleka pług, i Wisła płynie,

I Warta z Nidą.

(“Rozebrana”, PWsz II, 249)

[Meanwhile, in the morning, children March somewhere to school; 
The ploughman tills, the Vistula river flows,

As do the Warta and the San. ${ }^{13}$ ]

This fragment introduces the already vast expanse of the country. ${ }^{14}$ By the end of the poem, the space becomes general and non-specific. The shaping of time and space, closely related to the poem's allegorical composition, undoubtedly challenged the recipient's habits and expectations, and was thus a substantial factor of obscurity.

It is a similar case with what I called foreign elements. This feature of Norwid's poetry is distinctly apparent in "Rozebrana." The main theme, the plot of "Rozebrana," was thus constructed specifically to allow the introduction of various motifs, mainly the reference to the myth of Acteon, but also the above-cited stanzas of an undoubtedly reminiscent nature. A reader who is very familiar with the nature of Norwid's poetics may detect the principles which link those various elements into one consistent whole. A reader contemporary to the writer could have found a poetic statement constructed in this manner lacking coherence to a large degree. And "incoherence" translates to "obscurity."

The general considerations presented in this essay, as well as the more specific comments on "Rozebrana," allow us to draw some humble conclusions. What is the obscurity of Norwid's allegories, which we treat as one of the fundamental components of his poetry, and if not the most important, than one of the most paramount? One can see here its most general feature: Norwid continually works with areas delineated by tradition, often archaic and very venerable tradition. It might seem that this fact would ensure the poet's good contact with his audience

13 English translation based partially on the translation by Adam Czerniawski, "Undressed," 14 July 2018 http://sites.utoronto.ca/tsq/10/chernavsky10.shtml.

14 J. Słowacki sometimes used a similar method. One example of that might be the second stanza of the sonnet starting with the words "Gdy noc głęboka wszystko uśpi i oniemi" [When deep night puts everything to sleep and silence] (quoted after: Dzieła wszystkie, ed. J. Kleiner, Vol. 12, part 1, Wrocław: Zakład Narodowy im. Ossolińskich, 1960, p. 272):

Pode mną noc i smutek - albo sen na ziemi,

A tam już gdzieś nad Polską świeci zorzy pręga,

I chłopek swoje woły do pługa zaprzęga,

Modli się. - Ja się modlę z niemi i nad niemi...

[Below me [there is] night and sadness - or sleep on earth,

And somewhere over Poland there glows the band of aurora,

And a peasant harnesses his oxen to the plough,

Praying. - I pray with them and over them...] 
and help establish this channel of contact more easily. Yet quite the contrary happens, so this phenomenon requires explanation. That explanation is most likely to be found in Norwid's treatment of allegories. He took traditional forms, traditional motifs, traditional stylistic solutions, but proceeded with them in a quite non-traditional manner. To put it differently: traditional elements appear in Norwid's writings in non-traditional places, places previous poetry would not have suspected. He acted as if by referring to tradition he was building bridges to ensure contact with his reader, but was demolishing them at the same time. I shall therefore label Norwid's poetry: a poetry of agitated forms. As shown by his experience, this practice obstructed the readability of his texts much more than earlier Romantic innovations did. If one were to treat obscurity - the obscurity which the poet himself wrote about multiple times, and quite ironically - as a unique communicative situation, then here lies the key thereto. It appears that the most difficult thing to be is a non-traditional traditionalist.

\section{Bibliography}

Abrams, Meyer Howard. Natural Supernaturalism, Tradition and Revolution in Romantic Literature. New York: W.W. Norton \& Company, 1971.

Głowiński, Michał. "Przestrzenne tematy i wariacje." In: Przestrzeń i literatura. Ed. Michał Głowiński, Aleksandra Okopień-Sławińska, Wrocław: Zakład Narodowy im. Ossolińskich, 1978.

Malraux, André. Przemijanie i literatura. Trans. Anna Tatarkiewicz. Warszawa: PIW, 1982.

Słowacki, Juliusz. Dzieła wszystkie. Ed. Juliusz Kleiner, Vol. 12, part 1. Wrocław: Zakład Narodowy im. Ossolińskich, 1960.

Todorov Tzvetan. Théories du symbole. Paris: Seuil, 1977.

Witkowska, Alina. “Śmierć Polonii." Teksty, 1979, No. 3, pp. 181-185.

Zgorzelski, Czesław and Ireneusz Opacki. Ballada. Wrocław: Zakład Narodowy im. Ossolińskich, 1970.

Żeleński-Boy, Tadeusz. Pisma. Ed. Henryk Markiewicz, Vol. 1. Warszawa: PIW, 1956. 


\title{
Rev. Antoni Dunajski \\ Norwid and Theological Tradition
}

\begin{abstract}
What is important for the "Christian tradition" is the subject-matter, value system, motif, idea, and institution; what matters for the "theological tradition" is structures of thought and argument. The Christian inspiration in literature does not need to be "theological." In Norwid, however, it assumes theological features. Therefore, it is useful to study Cyprian Norwid's attitude to the "theological" tradition. The crucial point is his attitude towards Revelation.

Over the centuries, the tradition has been expressed in various forms, first in the Gospels themselves, then as a variety of theological tradition. Four such traditions have taken a particularly clear shape: the Lucan type, the Pauline type, the Johannine type, the philosophical type. Norwid approvingly adopts and in his own way develops the first three, but fairly outspokenly dissociates himself from the fourth tradition (and current of thought) - cf. his unequivocal criticism of "scholasticism." To explain this, we need to bear in mind Norwid's understanding of "originality" as "conscientiousness towards the sources," which coincides with the theological understanding of tradition. The fourth current seemed the least "conscientious" to him. It also explains why Norwid took hardly any interest in contemporary theology, while he was greatly interested in the Bible and Patristic writings, which were closer to the sources.
\end{abstract}

Keywords: Cyprian Norwid, theology, Christian tradition, theological tradition, Bible

The title's formulation of the subject immediately raises several auxiliary questions: Is it possible or even necessary to speak about "theological tradition" when referring to the sources inspiring Cyprian Norwid's work? Is it not enough just to refer to the broadly understood "Christian tradition," as has been usual for Norwid Studies scholars? How should one understand "theological tradition" itself? In which sense and to what extent did theological tradition inspire and determine Norwid's literary output? What are the implications for literary research (and for theology itself)?

In order to slightly simplify the matter, it can be said that for "Christian tradition," the most important aspects are the subject, system of values, motif, idea, and institution; while for "theological tradition," these would be argumentation and thought structure. Christian inspiration in literature need not have a theological dimension, but such is the case in Norwid's works. I have tried to demonstrate it consistently in my previous publications. ${ }^{1}$ I like to refer to Norwid

1 See Antoni Dunajski, “Norwid - teolog?” Przegląd Powszechny Vol. 99, No. 5 (1982), pp. 153-167; No. 6, pp. 353-367; “Człowiek - 'Boga żywego obraz”' Studia Norwidiana 
as a "theologian" (of course in the broadest, unspecialised sense of the word), although I realize that not everyone can see the purpose behind such an approach. ${ }^{2}$ In speaking about Norwid's attitude towards the "theological" and not only "Christian" tradition, I would like to emphasise his specific attitude towards Revelation.

In teaching about God's Revelation, the Second Vatican Council reminds us:

Hence there exists a close connection and communication between sacred tradition and the Holy Scripture. For both of them, flowing from the same divine wellspring, in a certain way merge into a unity and aspire towards the same end. [...] Sacred tradition and the Holy Scripture form one sacred deposit of the word of God, committed to the Church. But the task of authentically interpreting the word of God, whether written or handed on, has been entrusted exclusively to the living teaching office of the Church, whose authority is exercised in the name of Jesus Christ.3

Such an understanding of the "sacred tradition" of the Church, which in connection with the Holy Scripture constitute one "sacred deposit" flowing from "the same divine wellspring," was regarded in theological post-conciliar commentaries as very original (for several centuries two sources of Revelation were usually recognised: the Holy Scripture and Tradition). It is worth noting that for Norwid this was quite obvious:

żaden albowiem zakon i reguła żadna żadnego Świętego nie jest Ewangelią - i żadna z czterech Ewangelii nawet nie jest pierwszą i jedynie stanowczą. Tylko ta, co jest jedna na dnie i w posadzie onych czterech. ${ }^{4}$

[the Gospel is no order or rule of any Saint - and none of the four Gospels is even the first and only decisive. Only that which is singularly at the bottom and is the foundation of those four.]

In short, the most important thing for Norwid is Tradition, which lies "at the bottom and is the foundation" of all other traditions - first "evangelical" and then (as a consequence) also "theological." Therefore, the poet is aware that biblical

Vol. 1 (1983), pp. 81-88; Chrześcijańska interpretacja dziejów w pismach Cypriana Norwid (Lublin: RW KUL, 1985); "Mariologia Cypriana Norwida," in: Niepokalana. Kult Matki Bożej na ziemiach polskich w XIX wieku, ed. B. Pylak and Cz. Krakowiak (Lublin: RW KUL, 1988), pp. 579-590.

2 H. D. Wojtyska CP, “Norwid teolog?," Studia Norwidiana Vol. 5-6 (1987-1988), pp. 248.

3 Dei Verbum 9-10.

4 A letter to Konstancja Górska [beginning of July 1866], PWsz IX, 241. 
theology, also derived from the New Testament, is pluralistic. This means that the "theology" of each of the evangelists is "original" in its own way. However, these differences are not a disadvantage, but rather an advantage of the "sacred Tradition" of the Church.

At this point, we should cite Norwid's concept of "originality" as "[...] summienności dodatniej w obliczu źródeł" [positive conscientiousness towards the sources]. ${ }^{5}$ Although it was expressed in a completely different context, it perfectly explains Norwid's attitude towards theological tradition, or rather theological traditions. On the one hand, this refers to the awareness of their multiplicity and the conviction that each of them carries certain "positive" values, without which theology itself would be poorer. Each of them, as long as they are "conscientious" towards the sources, is able to lead us to the ultimate source of Tradition lying at the bottom of all theological reflection. On the other hand, Norwid's concept of "originality" makes it possible to distinguish and evaluate individual theological traditions and suggests a specific criterion, that is, precisely the closeness and faithfulness ("conscientiousness") towards the "source" of the Church's sacred Tradition.

This explains to a large extent why Norwid, in his argumentation, so readily refers to the Holy Scripture and Church Fathers, and almost never to the theologians who were his contemporaries. The poet usually asserts his Christianity and his Catholicism to be those "at the source" of the Church's sacred Tradition. He shows it great reverence and tries not to distort it himself. When he doubts whether his commentary on the Scripture is correct, he warns the reader:

[...] w tym odsełam usilnie czytelnika do Ewangelii Świętej.

[...] odsełam usilnie dla zgłębienia, jak pojęte są i czyli nie tłomaczę błędnie.

(Psalmów-psalm. Objaśnienia, DW IV, 88)

$[[\ldots]$ in this I am insistently referring the reader to the Holy Gospel.

[...] I am insistently referring to it for exploring how they are understood and if I do not explain them incorrectly.]

In interpreting biblical texts that are difficult to understand - in accordance with the rules respected by professional Catholic theologians - Norwid acknowledges the primacy of the opinions of the Church Fathers, and himself refers relatively often to Patristic literature. For example, a fragment of one of the footnotes in Quidam reads:

5 O Juliuszu Stowackim, PWsz IX, 425. 
Co do właściwego znaczenia odpowiedzi Zbawiciela: [...] - ta przez Ojców Kościoła objaśnianą jest w apologiach [...] (Quidam, DW III, 157, footnote )

[As to the proper meaning of the Saviour's response: [...] - it is explained by the Church Fathers in apologias [...].]

The statements of the oldest Christian writers, which in his commentary on "Boga-Rodzica" ["Mother of God/Theotokos"] he called "zdrowym i szerokim słowem Ojców Kościoła"6 [the healthy and broad word of the Church Fathers], occupy a somewhat privileged place in the poet's Notatki [Notes], since he considered them to be a testimony to the faith of the Church, the source closest to the apostles' teaching, and sometimes the only testimony to this teaching:

Tak utrzymują pisarze Kościoła na zasadzie szczegółów jedynie przez Łukasza S-o cytowanych. ${ }^{7}$

[This is what the writers of the Church claim on the basis of details quoted only by St Luke.]

In addition to the Christian historian Eusebius, he best knew - it can be supposed - Saint Augustine, Saint Clement of Alexandria and Tertullian, but we also find references to Saint Ambrose, Saint Athanasius the Great, Saint Basil, Saint John Chrysostom, Dionysius the Areopagite, Saint Ignatius of Antioch, Origen, and many others. These are often insignificant mentions. Norwid must have known the majority of these writings indirectly; however, it cannot be ruled out that he may have reached out to some of the Patristic sources directly. Sometimes - as in the case of Tertullian - he produced his own translations. The inspiring presence of the statements of the Church Fathers in Norwid's writings manifests itself in different ways. Sometimes it is only the motto of a work, such as the thought of Saint Augustine in the poem "Salem. Do A. T." addressed to Towiański. Sometimes, a particular Patristic work inspires the content and shapes certain elements of Norwid's works, as in the case of, for instance, Tertullian's Apologeticus in relation to the drama Słodycz. Tragedia $w$ scenie jednej [Sweetnes. Tragedy in One Act]. However, quite frequently, Patristic thought constituted the poet's worldview, though, in terms of its basic principles, determined, for example, the direction of the interpretation of history. In his first draft, for example, he added in reddish ink (which according to J. W. Gomulicki indicates an afterthought) the following note:

6 "Boga-Rodzica" pieśń ze stanowiska historyczno-literackiego odczytana, PWsz VI, 512.

7 Wita-Stosa pamięci estetycznych zarysów siedem, PWsz III, 525, footnote 2. 
Chrystianizm podnosi i stawia historię przez jedyność Boga i jedyność rodu ludzkiego. Ś. Augustyn - Euzebiusz - Sulpice-Sevére i niektórzy pod koniec państwa rzymskiego [Leon Wielki? - A. D.] tak się dają słyszeć. (Notatki z historii, PWsz VII, 366)

[Christianity exalts history through God's uniqueness and the uniqueness of the human race. St Augustine - Eusebius - Sulpicius-Severus and some others at the end of the Roman state [Leo the Great? - A. D.] can be heard saying that.]

Such comments prove that Norwid not only read the writings by the Church Fathers, but that he also tried to understand them properly by comparing their views. ${ }^{8}$ This could be seen as a willingness on his part to rank and differentiate different Patristic traditions.

With this background and contact with priests from the Congregation of the Resurrection of Our Lord Jesus Christ: Hieronim Kajsiewicz, Piotr Semenenko and Aleksander Jełowicki, the virtual absence of professional theologians who were Norwid's contemporaries should indeed be puzzling. The influence of the theology promoted by Resurrectionist priests is evident in Norwid, especially with reference to Father Semenenko. I have shown this in previous publications. Here, I would like to point out that it was not only relevant to the biography of the poet, but also to the manner in which theology was practised by representatives of this congregation. Of course, detailed comparative studies could reveal similarities (perhaps even influences) to the representatives or individual trends of 19th-century theology, but it seems that such studies would not yield any more significance for Norwid Studies; not only because it can be assumed a priori that Norwid was not familiar with contemporary theological literature, but also because there are reasonable grounds to suspect that he did not see the need to become familiar with it. He did not see the need to further verify what he had already verified to be at the "source," unless it was by "direct" reference to the "institutions" that safeguard the purity of the source of Tradition, that is, the catechism and the Teaching Office of the Church. This is the basis of Norwid's respect for the papacy and his fascination with the Church, where, in the area of basic, fundamental truths, "[...] papież jako uczony człowiek tyle wie zupełnie doktryny, ile pierwsza lepsza dziewczyna bosa, co gęsi pasie, a umie katechizm -" [...the pope, as a learned man, knows the doctrine as well as any barefoot girl who keeps geese and knows the catechism -].

8 See Antoni Dunajski, “Norwid - teolog?”, Przegląd Powszechny Vol. 99, No.6 (1982), p. 359.

9 A letter to Maria Trębicka of May 1854. DW X, 499-500. 
It seems, however, that in addition to the above-mentioned, there is one more important reason explaining Norwid's meager interest in contemporary theology, and even - I would say - his hidden aversion to it. This reason is also linked to Norwid's attitude towards the broader theological tradition, and more specifically - to his relation to the various types of theology that this tradition shaped.

Czesław Bartnik, an eminent expert in this field, pointed out that in structural terms one can notice and reconstruct the process by which four great types of theology are formed..$^{10}$ This process, already initiated at the "biblical" stage, was shaped and deepened by Patristic thought, which established the fundamental directions and types of theology for the distant future. In this sense, one may speak of four different theological traditions:

1. Lucan theology, corresponding to the "historical" structure of Christianity, understood theology as a broad reflection on the history of salvation. This current is particularly characteristic of many Church Fathers in the West, such as Clement of Rome, Eusebius of Caesarea, Saint Augustine, and Leo the Great. Later, this current seemed to expire. In the Middle Ages, only John of Salisbury practised this type of theology. It revived and flourished in the first half of the 19th century, mainly thanks to Catholic theologians from Tübingen, but this was only for a short period of time, as it gave way to absolutely offensive Neo-Scholasticism;

2. Pauline theology, seeking the deepest content of the Christian faith mainly in the life of the Church community, a kind of practical theology. Its main aim is that "the man of God may be perfect" ( $2 \mathrm{Tm} 3,17)$. The emphasis here is put mainly on liturgical, moral, and ascetic problems. This type of theology did not flow in such a broad current as the previous one, but it managed to preserve as if a "better" continuity (mainly owing to the monastic environment). This current is typical of, among others, Diadaché, Saint John Chrysostom, and later Saint John of the Cross, Saint Bonaventure, Duns Scotus and almost the entire Franciscan tradition, and today of the so-called theology of earthly realities;

3. Johannine theology, referring to the old religious theory of creation through the word, treated the knowledge of God's Word as the key to understanding all other theological problems. The incarnate word "expresses itself", it turns to man and expects him to answer in the form of human word, commitment

10 Cz. Bartnik, “Teologia chrześcijańska”, in: Katolicyzm A-Z, ed. Z. Pawlak (Poznań 1989), pp. 370-372. 
of heart, action, and intellectual contemplation. This current is characteristic of different types of Christian gnoses, Patristic thought of the East (including Pseudo-Dionysius the Areopagite), and the 19th-century types of historiosophy.

4. Philosophical theology was formed by applying strict philosophy to Christian thinking. At the beginning of this process, Greek philosophy played an important role, which can be seen starting with Clemet of Alexandria and Origen (in the East) and in Saint Augustine (in the West). Theology is understood here as a "philosophical understanding of faith" (e.g., Saint Gregory of Nyssa, and in the Middle Ages - Saint Anselm of Canterbury). Over time, Aristotelianism began to play a crucial role in the process (almost as a monopolist), mainly thanks to Boethius and Saint Thomas Aquinas. Scholastic theology, and from the second half of the 19th century - neo-scholastic theology, which remain in this philosophical current, have almost completely eclipsed the other currents of theological thought.

If we wanted to define Cyprian Norwid's attitude towards these four currents of theological tradition, we would notice that in a creative sense he approves of and in his own way develops the first three, but clearly distances himself from the fourth. This is not a coincidence. The first three types of theology, that is, Lucan, Pauline, and Johannine, are "conscientious towards the sources," rooted in the oldest, sacred Tradition of the Church. The fourth type, though also cultivated by some Church Fathers, is in this respect ostensibly less "conscientious." In this current, theology seemed to cease to be a science drawing from the divine wellspring and began to rely more on natural intellect. Norwid found it difficult to reconcile himself to this.

Commenting on Cicero's De natura deorum, he put it bluntly:

[...] filozoficzne pogańskie dzieło, ale wiele więcej od większej połowy chrześcijańskiej-nowożytej-filozofii warte, bo mniej frazjologiczne ${ }^{11}$.

[...] a philosophical pagan work, but of a much greater value than the larger half of Christian-modern-philosophy, because it is less phraseological.

What did Norwid mean by "Christian-modern-philosophy"? Did he mean philosophy or theology? It is difficult to answer this question unequivocally. Nevertheless, the problem of theology in Norwid's lifetime was that it became less and less theological, and more and more philosophical.

11 A letter to Maria Trębicka of 21-23 February 1854. DW X, 487. 
It is characteristic that Norwid criticised contemporary scholastic theology, primarily because of its aversion to everything historical. And, unfortunately, he was right. It was an ahistorical form of thought, incapable of theological interpretation of historical events, a thought system detached from life and, therefore, insufficient. He wrote twenty years later:

Od roku 1830 aż do czasów obecnych nie było ani jednego jeszcze księdza na pobojowisku tym szerokim i na tych Kościoła-okopach, które zowiemy Polską; księdza, mówię, który by pojęcie ofiary i męczeństwa od zamęczeń fatalnych śmiał wyróżnić ku użytkowi wiernych, pojęcie odwagi, tego Ducha Świętego daru, od świetnych zarysów nierozwagi, pojęcie tego, co Opatrznym, od tego, co fatalnym, który by rozpędzał tym sposobem mgły przed armatami, jak to czynił gorącością modlitwy ksiądz Kordecki na wałach Częstochowy.

Zaprawdę, one subtelności, które bym tu nazwał nasien nymi, nie scholastycznym tylko cyrklem [...] dawałyby się zrozumiewać i wyróżniać z użytkiem chrześcijaństwa. [...] kwestia męczeństwa, która przez lat dwadzieścia wywłóczy wnętrzności młodzi polskiej poza granice ziem przez ludzi zamieszkałych na globie, nie znalazła dotychczas Justyna świętego przed najniższym imperatora urzędnikiem.

(“Z pamiętnika (O zemście)" [“From an Album (On Revenge)"], PWsz VII, 41)

[From 1830 until the present time there has not been even one priest on this vast battlefield, and in those trenches of the Church, which we call Poland; I say a priest, who for the faithful would dare to distinguish the concept of sacrifice and martyrdom from fatal torments, the concept of fortitude, that gift of the Holy Spirit, from the splendid outlines of imprudence, the concept of what comes from Providence from that which is is fatal, who in doing so would dispel the fog in front of the cannons, as Father Kordecki did with his passionate prayer on the ramparts of Częstochowa.

Indeed, those subtleties, which I would call here fertilizing, could be understood not only by using a scholastic compass [...] and distinguished by the use of Christianity. [...] the issue of martyrdom, which for twenty years would drag the entrails of the Polish youth outside the boundaries of the lands inhabited by people on the globe, has not yet found Saint Justin before the lowest official of the emperor.]

Evoking - in opposition to the scholastic "compass" - the figure of Saint Justin, Norwid refers not only to the great apologist, but also to concrete Patristic (and theological) tradition, conceiving of theology as the art of interpreting historical events in the light of Revelation (see Lucan theology). Besides, the "archistrategia dziejów"12

12 O Juliuszu Stowackim, PWsz VI, 435. 
[arch-strategy of history] proposed by Norwid belongs precisely to this current of Christian thought.

It has already been noted that in order to reconstruct Norwid's Christian worldview, we may choose between three safe paths: to follow his concept of history, anthropology, or the word. It has also been noted that these threads cannot be completely isolated from one another. However, addressing any one of them offers the chance to reconstruct the entirety of the great writer's thought. Norwid Studies scholars are generally aware that they must take one of these paths, but they are not necessarily aware why. It seems to me that Norwid's attitude towards theological tradition and the "theological" dimension of his entire work, which is permeated by an extremely coherent Christian system of thought, explains a lot in this respect.

Let us note that the three first types (and traditions) of theology perfectly correspond to the three ways of reconstructing Norwid's worldview. In my opinion, it is of great significance for the research conducted on Norwid, for if his thought is essentially Christian and the structure of his thinking is theological, then:

1. Norwid's concept of history should be interpreted within the framework of Lucan theological tradition;

2. Norwid's anthropology (and related moral issues) should be interpreted in the spirit of Pauline theology;

3. Norwid's concept of the word should be interpreted in the spirit of Johannine tradition;

4. But also - consistently - one should steer away from the interpretation of Norwid's texts using purely philosophical categories (i.e., outside the theological system of reference). Otherwise, the interpreter could fall into a trap.

Consider, for example, a well-known fragment from the poem Niewola [Enslavement]:

\section{$[\ldots]$}

Poczęty jestem: wiem, że skończyć muszę,

Ile formalną tu bywam osobą -

Więc i nie czekam, aż mi wezmą duszę,

Lecz duchem formę z każdą niszczę dobą -

U-nadforemniam się i palę ciało,

By jako mirra w woń się rozleciało:

Przez pot, co trudom zacnym towarzyszy,

Przez łzy - lub czynne cierpienia w zaciszy,

Częstokroć przez krew, dla celu wylaną.

Tak że nareszcie śmierć, ta form mistrzyni,

Gdy przyjdzie, dusza będzie rozebraną

I rzuci resztę szat do czarnej skrzyni - 


\section{$[\ldots]$}

$[\ldots]$

U mnie duch treść jest, pozorem jest ciało.

(Niewola, DW IV, 49-50, 52.)

[I am conceived: I know that I must cease,

Such formal a person I am here -

So I do not wait until they take my soul,

But every day I destroy the form with the spirit -

I go beyond the form and I burn the body,

For it to disperse into the smell of myrrh:

Through sweat that accompanies good hardships,

Through tears - or active suffering in seclusion -

Often through blood, shed for the cause:

So that finally when death, this mistress of form,

When she comes, the soul will be disrobed

And it will throw the rest of the robes into a black trunk -

$[\ldots]$

$[\ldots]$

For me, the spirit is the content, the body is the appearance.]

The terminology used in this text suggests a philosophical - Aristotelian frame of reference. In particular, I am thinking of his hylomorphism: the distinction between the matter and the form of a being, and the treatment of the soul as a substantial form of the human body. But in Norwid's texts, it is the "body" that is understood as the "form" ("[...] every day I destroy form with the spirit)." In turn, the words: "For me, the spirit is the content, the body is the appearance," seem to betray the Platonian mood of Norwid's reflections, and the dialectic contained within them would indicate Hegelian inspiration. Meanwhile, this becomes quite clear when we begin to interpret this text in the spirit of Pauline theological tradition, and in particular, when we recall the categories of "man of the flesh" and "man of the spirit" developed within this tradition (see 1 Rom $1-12 ; 1$ Cor 3: 1-3, Gal 5, 16-22). It is not the soul and body that fight with each other in the cited passage of Niewola. It is simply that "[...] z człeka się wywalcza człowiek"13 [...from a human being a human being is won].

We can find more such texts in Norwid's output. Many complicated problems related to the interpretation of his writings and the reconstruction of his views are "clarified" by referencing specific theological traditions. This method has already been well tested and, from my point of view, has significantly enriched Norwid 
Studies. ${ }^{14}$ Norwid's originality in this respect also cultivates theological tradition itself. From a theologian's point of view, Norwid is simultaneously original and traditional, because his concept of originality as "positive conscientiousness" towards the sources coincides with the theological understanding of tradition.

\section{Bibliography}

Bartnik, Czesław. “Teologia chrześcijańska.” In: Katolicyzm A-Z, ed. Zbigniew Pawlak. Poznań: Księgarnia św. Wojciecha, 1989, pp. 370-372.

Dunajski, Antoni. “Norwid - teolog?.” Przegląd Powszechny, Vol. 99, No. 5, 1982, pp. 153-167; No. 6, pp. 353-367.

Dunajski, Antoni. “Człowiek - 'Boga żywego obraz.' Studia Norwidiana, Vol. 1, 1983, pp. 81-88.

Dunajski, Antoni. Chrześcijańska interpretacja dziejów w pismach Cypriana Norwida. Lublin: RW KUL, 1985.

Dunajski, Antoni. “Mariologia Cypriana Norwida." In: Niepokalana. Kult Matki Bożej na ziemiach polskich w XIX wieku, ed. Bolesław Pylak and Czesław Krakowiak. Lublin: RW KUL, 1988, pp. 579-590.

Wojtyska, Henryk Damian. "Norwid teolog?" Studia Norwidiana, Vol. 5-6, 1987-1988, pp. 247-252.

14 I have elaborated on these conclusions in more detail with reference to specific issues in my book Chrześcijańska interpretacja dziejów w pismach Cypriana Norwida, pp. 242-251. 



\title{
Jadwiga Puzynina \\ Norwid's Concept of the "Whole"
}

\begin{abstract}
In this chapter, the author tries to trace different meanings of "the whole" in Norwid's writings and to indicate some other linguistic means of expressing these meanings. At the same time, she shows the particularly important groups of phenomena and problems which Norwid understands as wholes (real or postulated). The opposition part-whole is an object of Norwid's constant interest, especially when "the whole" means something that contains all essential, constitutive elements; the poet usually emphasizes the presence of spiritual, transcendent elements.
\end{abstract}

Keywords: Cyprian Norwid, linguistics, linguistic means, wholeness, semantics

1

Within Norwid Studies, much has been written about Norwid's intellectualism. In this article, I would like to share some reflections on this aspect of his interests, or intellectual-emotional passions even, and examine how it relates to his understanding of całość [wholeness]. ${ }^{1}$

With this in mind, I focused my analysis, first and foremost, on the use of the noun całość [wholeness], the adjective cały [whole], and the adverb cało [wholly] in Norwid's texts. ${ }^{2}$

1 Norwid generally used to interpret the world in terms of fundamental ontologicosemantic categories. Apart from the opposition part-whole he was very much interested in relations such as identity - otherness - similarity - opposition; aim - condition cause - result - product. I omit temporo-spatial relations as the obvious ones.

2 It is worth noting the frequency of their appearance in Norwid's texts: the noun is used ca. 250 times (compare that with 37 cases in Mickiewicz's texts!), whereas the adjective appears ca. 1380 times (1170 in Mickiewicz's case), the adverb - ca. 4 times ( 7 for Mickiewicz). Also striking is the number of compounds with the first element cato- [whole-/ all]: 36 nouns such as całogłos [lit. whole-voice], całoksztalt [entirety, lit. all-shape]; 13 adjectives such as całokształtny [entire, lit. all-shaped], całoserdeczny [lit. allcordial]; 2 adverbs. In Mickiewicz's writings the only example of a compound noun is całoksztatt; in Linde's Dictionary of Polish there are caloksztalt (in the sense of 'outline') and całopalenie [burnt offering]. Unfortunately, it is impossible to present a detailed analysis of Norwid's compounds with the element cało- here.

Not all instances of Norwid's use of these words (in particular, the adjective caly) present meanings analysed in this article (which will be explained later). But the adduced 
Because I am interested in the meaning of Norwid's "całośc'" [wholeness] and the different ways in which it can be verbalised, I will also elaborate on the use of words that are closely related to całość and its metaphors, of which there are many in Norwid's (not just poetic) works.

\section{2}

\section{1}

The starting point of our considerations will be two quotes featuring the words cały [whole] and całość [wholeness]:

Tak samo jest $\mathrm{w}$ każdej niepełnej wiedzy, że im ona mniej całą, tym więcej mnemonijnych metod i ułatwień zażywać człowiek musi [...] Pamięć albowiem naturalnie nie przyjmuje rzeczy nie-całych; wyjątków to i odłamków trzeba się uczyć nałogowo: „uczyć się na pamięć”...

(Filozofia historii polskiej [Philosophy of Polish History], PWsz VII, 63)

The same applies to each case of incomplete knowledge, i.e. the less whole it is, the more mnemonic techniques and associations one must resort to [...] It is unnatural for memory to accept non - whole things; exceptions and fragments must be learned compulsively: "learned by heart"...

[...] narody są całościami, w których częściowe władze powzajemniają się i dopełniają całościami, jak się rzekło, syntetycznymi; powiedzieć by można: Miłościwymi [ponieważ są dziełem miłości (naprzód natchnionej [...] potem uświadomionej)].

([Znicestwienie narodu] [Annihilation of the Nation], PWsz VII, 85)

[...] nations are wholes in which partial powers reciprocate and complement each other - it has been said, synthetic wholes; it could be said: Gracious [because they are a work of love (first inspired [...] then conscious)].

In the first quote, caly [whole] means 'consisting of elements connected by relations,' while całość [a whole/wholeness] in the second quote designates 'a thing consisting of elements connected by relations.' Here I am referring to "relations" in general terms, without specifically defining them, because for Norwid these relations are different for different objects, that is, for the whole knowledge from the first quote this would certainly be relations based on implication, inclusion within a set, cause and effect, identity; Norwid is thinking of connections which

numbers already indicate the importance of the family of words with the root cat[whole-] for Norwid's discourse. Details on the use of lexemes in Mickiewicz's writings are supplied from Stownik języka Adama Mickiewicza, ed. K. Górski and S. Hrabiec, Vol. 1 (Wrocław: Zakład Narodowy im. Ossolińskich, 1962). 
are to a certain degree regular, which do not have "exceptions and fragments." The poet considers love to be an essential relation for nations as wholes - this is why he refers to them as całości miłościwe [gracious wholes] in the quoted passage.

In his sketch [Asocjacja, ilość i jakość] [Association, Quantity and Quality], Norwid cautions, among other things, against all connections between people which have grouping ("associating") as their only aim, and more generally - against all form as a goal. On numerous occasions, in his reflections on the relationship between spirit and form ("letter"), for example, the poet elaborates on what kind of binding elements create good wholes: form should only be a means, not the goal of the spirit. ${ }^{3}$ This is one of the things that determines man's freedom.

The poet considers the relations connecting people in "salonowe kółka" [salon circles] to be superficially binding: whether they be the men from Serionice in A Dorio ad Phrygium, ironically referred to as "całość błoga i zacna" (DW III, 386) [a blissful and good whole], or the "kółko" [little circle] in Vade-mecum, where man's sense of community is determined only by dance, "jedna lampa zapalona" [a single lit lamp] and "moda jedna" (PWsz II, 84) [a single fashion] they have no meaningful interpersonal relations.

\section{2}

In Norwid's works, wholeness understood as organically interrelated, complementary elements is expressed through the metaphor of flower and root, which is presented in Odpowiedź krytykom Listów o emigracji [A Reply to the Critics of Letters on Emigration], ${ }^{4}$ and later in "Dwa guziki" ["Two Buttons"] (PWsz II, 127). In turn, Norwid refers to Wita Stosa pamięci estetycznych

3 Cf. the well-known quotes: "Niewola - jest to formy postawienie/Na miejsce celu" [Enslavement - it is putting form/in place of aim] (DW IV, 49) and further "więc już formie przeczę,/Więc chcę, by środkiem była mi do mety,/Więc jej używam ja, nie mnie użya" [thus I negate the form,/Thus I want it to be my means to reach the finish line,/Thus I use it, it does not use me] (DW IV, 50).

4 "Kwiat nie zarzuca korzeniowi, iż ten w ziemi przestawa ani korzeń się na kwiat nie obraża, który wyżej purpurę swą rozwiesił, pokąd życie rośliny i publica salus ich połącza" [The flower does not accuse the root of living in the soil, nor is the root offended by the flower which hangs its purple petals up above, as long as the life of the plant and salus publica unites them] (PWsz VII, 35).

5 Here the poet criticises the attitude of the personified root, which does not understand that together with the flower they constitute two different elements of the same whole: "Dzikość bowiem stąd pochodzi,/Że się jest jednostronnym, jak kwiatów korzenie,/I że się przeciw -wrotnych połowic nie godzi./Kwiat śpiewa: 'Ja - do 
zarysów siedem [In Memory of Veit Stoss - Seven Aesthetic Sketches] as a work that presents "całość jednej gamy" (PWsz III, 535) [the wholeness of a single scale], at the same time adding that "do czytelnika należy odgadnąć powody, dla których przenoszę dziś taką rapsodyczną inicjację nad doktrynę okrągłą, systematyczną, abstrakcyjną" [it is the reader's task to guess the reasons for which today I place such a rhapsodic initiation above the round, systematic, abstract doctrine]. The work is in direct opposition to the iconoclasticism of Towiański's followers, it presents characters and facts from different epochs that (in Norwid's opinion) testify to "prawomocność sztuki chrześcijańskiej" [the final and binding validity of Christian art] (Letter to Józef Zaleski, PWsz VIII, 264); this common trait is the relation that appears to bind them to "a single scale."

Another figure of wholeness, that is, the metaphor from the poem "Finis," which talks of "mecum-vade,/Złożone ze stu perełek nawlekłych,/Logicznie w siebie, jak we łzę łza, wciekłych" (PWsz II, 139) [mecum-vade,/Made up of a hundred pearls threaded/Logically, shed tear into tear], ${ }^{6}$ is even more ambiguous for the reader than the metaphor of the scale from Wita Stosa pamięci estetycznych zarysów siedem. It is well known that the debate over the nature of relations between individual poems in the Vade-mecum cycle is still ongoing, all the logical relations between them having recently been questioned by Ralf Fieguth; ${ }^{7}$ he treated the above quoted words from the poem "Finis" as ironic, which seems to be a misunderstanding. ${ }^{8}$

The problem of the relations connecting elements into certain wholes, demonstrated here by the metaphors of the scale and the pearl necklace, among others, is undoubtedly important for the poet not only with regard to his own poetic cycles. An interesting example where the results of actions have greater

słońca prosto drgam!' - a korzeń:/Że kwiat mu jest korzeniem... że różność? - z położeń/Idzie, lecz nie z natury" [For the wildness comes from the fact/That one is one-sided, like the roots of flowers,/And that the two opposite halves are not reconciled./The flower sings: 'I - I am moving directly towards the sun!' - and the root:/That the flower is his root... the difference? - from the situation/Results, not from nature] (PWsz II, 126-127).

6 English translation by Adam Czerniawski in: Cyprian Kamil Norwid, Selected Poems, (London: Anvill Press, 2004) p. 81.

7 See R. Fieguth, "Poezja w fazie krytycznej," Studia Norwidiana, Vols. 3-4 (Lublin: 1985-1986), p. 39.

8 In his "Wstęp" ["Introduction"] to the edition of Vade-mecum in the National Library (S. I No. 217, Wrocław: Zakład Narodowy im. Ossolińskich, 1990, pp. XC and XCII), J. Fert also interprets the metaphor in the poem "Finis" as one speaking of "the logic of tears," "which unites these hundred rhapsodies with a subtle thread." 
importance in determining the whole rather than just the quality of its individual elements is the comparison of a "waleczny regiment" [brave regiment] of mainly stupid soldiers, to an assembly of academy members; Norwid writes:

Tak jak regiment waleczny złożony z światłego generała, pułkowników i pewnej liczby głupiego żołnierza jest nieskończenie wyższą całością, w rezultatach przezeń otrzymanych w historii, od sesji akademików fakt jaki historyczny paleograficznie na posiedzeniu traktujących, acz w tej drugiej całości wszyscy ją składający mądrzy są i głupstwo tam świętego udziału swego nie ma.

([“Uwagi o Pamiętniku pieśniarza"] [“Notes on Diary of a Bard"], PWsz VI, 399)

A brave regiment composed of an enlightened general, colonels and a certain number of stupid soldiers forms an infinitely superior whole, when judged by its historical results, than the assembly of academics meeting to discuss some historical fact palaeographically, though in the second whole everybody that comprises it is wise, and stupidity has none of its holy say there.

All the uses of catość [wholeness, the whole, entirety] and its metaphors discussed so far are characterised by an emphasis on the existence of a certain kind of cohesion between the elements of the whole object, a cohesion based on the relations indicated more or less directly by the poet.

3

\section{1}

In Norwid's writings, we find many uses of the lexemes that are of interest to us, which emphasise that a whole is a (single) object composed of (many) elements. For example, the poet speaks of "całości pieśni Boga-rodzica" (PWsz VI, 528) [the whole of the hymn Boga-rodzica], of "całość społeczeństwa" (PWsz VII, 53) [the whole of society], of the shiver that "przenika zupełnie całość istoty" (PWsz IV, 491) [wholly penetrates the whole essence]. In all these examples, catośc $x$ - $a$ [the whole of $\mathrm{X}$ ] is 'the multitude of the elements of $\mathrm{X}$ as a single object (as one)'. Sometimes it is obvious that he does not mean all the elements of the object, but just the coherent ones, like in the sentence: "kiedy całość swej myśli mieć już będziesz" (PWsz VIII, 329) [once you have the whole of your thought], and when the quote from Zmartwychwstanie historyczne ${ }^{9}$ [Historical

9 "Kiedy naród umiera, następuje koniecznie ten fenomen, który E mig racją nazywamy, choćby siły do walki wystarczyły, a mówię: siły materialne, choćby okoliczności wiele sprzyjać raczyło, choćby generałowie zdolni, a wojsko było bitne, a rządcy zacni i szanowni... dlaczegóż? 
Resurrection] speaks of "całość narodowa" [the national whole] or the wholeness of the prize-essay from the letter to Bronisław Zaleski (1870). ${ }^{10}$

Some uses reveal that just as a definition must consider the necessary qualities of an object, so it is in Norwid's case, that an object referred to as caty [whole] (or całość [a whole]) must consider its essential elements. Such use is observed in his reflections on truth, which man cannot comprehend in its entirety using his mind alone, he can only do it through the combination of "myśla, uczuciem $i \dot{z} y$ ciem razem" (DW X, 467) [thought, emotion and life working together]. Here we can also mention the epithet used to describe a bard as someone in whom we seek "zalety całości"11 [the virtues of wholeness], as well as the description of lecture as that "która zawiera całość, aby kto możniejszy dolał sobie wody i zrobił

Oto dlatego, że śmierć narodu jest z zaparcia się ducha, czyli całości-moralnejnarodu, więc na pojedyńczości, na osobne całości rozsypuje się całość narodowa, i tyle jest ducha, ile duchów, tyle Osoby narodu, ile osobistości narodowych, tyle historii narodu, ile biografii i martyrologii narodowej." (PWsz VI, 614).

[When a nation dies, this phenomenon which we call Emig ration inevitably takes place, even if there is enough strength to fight, and I say: material strength, even if circumstances were greatly favourable, even if generals were capable, and the army was valorous, and the rulers were good and honourable... why?

This is because the nation's death comes from the denial of the spirit, that is the whole moral tradition of the nation, thus the national whole breaks into singularities, into separate wholes, and there is as much spirit as there are spirits, there is as much national Person as there are national personalities, as much history of the nation as there are biographies and national martyrdom].

10 "Rozprawa konkursowa zawsze zostanie dziełem zwracającym uwagę i uwagi godnym. Ale to jest la morale de l'histoire, nullement la philosophie!

Zaś co do jej całości: to gdyby autor aforystycznie tę sobie właściwą a niepospolitą wiedzę historyczną przedstawił był lub przedstawiał, byłoby to ze wszech miar szczęśliwie dla natury umysłu i pióra jego" (PWsz IX, 452).

[The prize essay will always be a work that draws attention and is worthy of this attention. But this is la morale de l'histoire, nullement la philosophie!

As for the whole of it: if the author had presented or had been presenting this historical knowledge intrinsic to him but generally uncommon in an aphoristical manner, this would by all means have been fortunate for the nature of his mind and his pen].

11 "Jako więc prorok, wychodząc $\mathrm{z}$ sumienia,/Prawda dla prawdy gore $\mathrm{w}$ kształt promienia,/Tak wieszcz z piękności wychodzi poczucia/(A piękność kształtem Prawdy i Miłości),/Więc od snowania wchadza do wysnucia,/Określa profil... Stąd zalet całości/ Szukamy w wieszczu - stąd wszyscy wieszczowie/Rozpoczynali piękności podziwem" (Promethidion DW IV, 124).

[Thus just as a prophet, starting with conscience,/Truth for the truth glows in the shape of a flame,/The bard starts with the sensation of beauty/(And beauty takes the shape of 
książkę dużą" [which contains all, so that the more capable might waffle and make a big book] (a letter to M. Dziekońska, DW XI, 270).

4

\section{1}

The lofty evaluation of the entirety of phenomena and concepts, that is, that they encompass all relevant elements and that they are internally coherent, results in the presence of many expressions such as skażona całość (PWsz IV, 494) [contaminated whole], psować całość, rozłamywać ją (PWsz IX, 328, 627) [ruin, break up the whole], roztrzaskać całość (PWsz IX, 129) [shatter the whole] in Norwid's writings, and on the other hand, skończona całość (PWsz VI, 460-61) [complete whole], zalety całości (PWsz VI, 473) [virtues of wholeness], sequences such as “Cywilizacja (...) szuka (...) okrągłości, całości i skończoności swojej” (PWsz VI, 434) [Civilisation (...) looks for (...) its roundness, wholeness and completion], confessions such as "Wierzę, iż celem jest wszech-doskonałość/Przez wykonania stopniowe - po całośc" (DW IV, 66) [I believe that the aim is omni-perfection/ Through gradual realisation - to the wholeness]. Hence the word play (based on the polysemy of the word całość [wholeness]) that the author revealed in a letter to Józef Łussakowski (DW X, 536)): “Żyjemy w całości, która całości nie ma” [We live in a whole which does not have wholeness], that is we live in a community that lacks the coherence which Norwid so highly valued with regard to social life.

In the poet's writings, there are many uses of całość [wholeness] in which it is something encompassing elements of a particular, spiritual, or sacred value. This is how the generally forgotten "całość żywota dojrzałego" [whole of mature existence] in the poem "Na zgon ś. p. Józefa Z." ${ }^{2}$ ["On the Death of the Late Józef Z."] should be understood. The same applies to "całości (...) cichej sprawy,/

Truth and Love),/Thus from spinning he goes over to weaving,/Defines the profile... Hence the virtues of wholeness/We are looking for in a bard - hence all bards/Started with admiration of beauty].

12 “- Może byśmy już na śmierć zapomnieli

O chrześcijańskim skonu pogodnego tonie

I o całości żywota dojrzałego...

Może byśmy już zapomnieli, doprawdy!...

Widząc - jak wszystko nagle rozbiega się

I jak zatrzaskuje drzwiami przeraźliwie -

Lecz mało kto je zamknął z tym królewskim wczasem i pogodą,

Z jakimi kapłan zamyka Hostię w ołtarzu.” (PWsz II, 149) 
Krwią coraz więcej pijanej" (DW III, 242) [the whole of the (...) quiet matter/ Increasingly drunk on blood] from the description of the scene of Quidam's murder, or to "całość (...)/Taka!... że jej nie wypowiem całéj" (DW IV, 271) [a whole (...)/Such!... that I cannot express it wholly] from the ending of Rzecz o wolności słowa [On the Freedom of Speech]. The words addressed to Mary: "Tobie się stała całość jedno-słowna,/I pąk, i górny kwiat wszech-ideałów” (PWsz I, 197) [The one-word wholeness betided Thou/The flower bud, and the upper flower of omni-perfection] in "Litania do NPM" ["Litany to the Blessed Virgin Mary"] also belong here. This is also how I would understand ogót [the whole] from Pierścień Wielkiej-Damy [The Noble Lady's Ring] and ogót [the whole] from Song IX of Rzecz o wolności stowa [On the Freedom of Speech], mentioned in the paper by Mieczysław Inglot, where the reaction to Christ's birth was captured in the following words: "Nie sama Boskość - Ludzkość ludziom objawiona./Ogót stat się..." (DW IV, 242) [Divinity - Humanity was not the sole thing revealed to the people./The whole happened...]. Given this meaning of całośc [wholeness], it is possible to interpret "całość narodowej sztuki" [the whole of national art] from the Epilogue of Promethidion (DW IV, 133) somewhat differently than usual, the art which would develop from Chopin's grave "jako powoju wieniec, przez pojęcia nieco sumienniejsze o formie życia, to jest o kierunku pięknego, i o treści $\dot{z} y c i a$, to jest o kierunku dobra i prawdy" [as a wreath of ivy, through a bit more conscientious concepts of the form of life, that is of a direction of beauty, and of the content of life, that is a direction of good and truth].

Norwid's całość [wholeness] clearly evolves towards the concept of 'całość doskonała' [perfect wholeness], and even further simply towards 'coś doskonałego ${ }^{13}$ [something perfect]. This can also be seen, for instance,

[- Maybe we would for the life of us forget

About the serene tone of Christian death

And about the whole of mature life...

Maybe we would truly forget already!...

Seeing - how everything is suddenly scattering

And how it is frightfully slamming the door -

But hardly anyone closed it with the royal poise and timing,

With which the priest closes the Host in the altar.]

With this metaphor of closing the door, Norwid expresses an important element of the entirety of human life.

13 None of the dictionaries list this meaning either under the entry całość or cały. However, in some quotes both these lexemes have positive connotations; cf. e.g. a fragment from Mickiewicz: "zawsze tam przebijała się nieforemność, potworność, brak porządku, związku i całości” [it has always showed shapelessness, monstrousness, lack 
in quotes from Stygmat [Stigma] where we read: "Całość tej małej postaci (tj. to, jak była harmonijna, doskonała) [...] zatrzymała na chwilę wejrzenie moje" (DW VII, 199) [The wholeness of this small figure (i.e., the way in which it was harmonious, perfect) (...) captivated my gaze for a moment], or in the fragment about the broken "izraelska całośc" [Israeli wholeness] from the lecture $O$ Juliuszu Słowackim [On Juliusz Słowacki] (PWsz VI, 410).

Radosław Pawelec wrote about the positive valuation of the adjective caly [whole] in Norwid's texts. ${ }^{14}$ Pawelec defined this adjective in certain contexts, for instance, in the following passage:

Mąż to był, wierzaj, skończony, mąż cały -

Równego temu nie spotkasz za chwilę...

(Hamlet DW V, 268)

[This man was, believe me, complete, the whole man -

You will not often meet a man equal to him...]

as 'comprising all relevant features without which it would not be itself and thus good' (pp. 72-73). Having analysed all the contexts in which the charged words całość, cały, cało [wholeness/all, whole, wholly] are featured positively in Norwid's texts, I assume that they do not express 'having all essential features', but the coherence and harmony of the composing elements - or both of these at the same time. For instance, consider:

- Człowiek, aby się różnił, że ma zbroję całą,

Nie dosyć jest - rozdarcie w sercu pozostało.

Zbroja czystsza, gdy tenże razem jest znamieniem,

Symbolem!... z sercem całym i z całym sumieniem

(Rzecz o wolności słowa [On the Freedom of Speech] DW IV, 245)

[Man, to be distinguished, has the whole of his armour,

Which is not enough - a tear has remained in his heart.

His armour is purer, when the tear is also a mark,

A symbol! ... with the whole of the heart and the whole of conscience]

of order, relation and wholeness] ("O poezji romantycznej" ["On Romantic Poetry"], in: Dzieła, Vol. V: "Proza artystyczna i pisma krytyczne" (Warszawa: Czytelnik, 1997), p. 114]). "Poema o Pułaskich nie ma całości organicznej, szczegółów nadto" [The poem about the Pułaski family lacks organic wholeness, there are too many details] (Dzieła, Vol. XV: Listy część druga 1830-1841 (Warszawa: Czytelnik, 2003), pp. 284-285).

14 R. Pawelec, "Część prawdy o słowie 'cały," in: Studia nad językiem Cypriana Norwida, ed. J. Chojak and J. Puzynina (Warszawa: Wydawnictwa Uniwersytetu Warszawskiego, 1990), pp. 63-77. 
This fragment speaks of "a tear in the heart," that is, the destruction of coherence, harmony. At the same time, the heart and conscience of the man-symbol must contain all the features essential to what we call heart and conscience. The comparison describing Caesar in the drama Kleopatra i Cezar [Cleopatra and Caesar]: "cały mąż jak filar" [the man whole as a pillar] seems to emphasise, by the word caly [whole], the power Caesar derives from his cohesive, internal harmony. The importance of harmony and its associated positive valuation should correspond to "zupełna całość proporcji” [the perfect wholeness of proportion], which according to Anthony from Kleopatra $i$ Cezar "is ruled" by Apollo, ${ }^{15}$ as well as the adverb cało [wholly] in the following fragment of a letter to Marian Sokołowski (PWsz IX, 160):

U mnie, na rue Fontaine, w kawiarni Al-bouy (ALBOUY), od godziny dziesiątej rano do piątej wieczorem masz salę, w której konno jeździć można, [...] a z dala w cieniu ledwo że dwóch Francuzów poczciwych grających w bilard [...]. Tak bywa pusto i cało w tej kawiarni od dziesiątej rano do piątej wieczorem - istnie, najpiękniejsze miejsce w Paryżu!

[Near me, on Fontaine Street, in the café Al-bouy (ALBOUY) from ten in the morning to five in the evening there is a room where you can ride a horse, $[\ldots]$ and some distance away in the shade there are barely two Frenchmen playing billiards [...]. This is how the café exists emptily and wholly from ten in the morning to five in the evening - truly, the most beautiful place in Paris!]

\section{5}

A very important consideration on the topic at hand is Norwid's often repeated opinion that wholeness, with all its positive connotations, is also frequented by negative elements, lack, evil, or ugliness. A well-known statement concerning this topic is the fragment from a letter to Bronisław Zaleski (1867; PWsz IX, 328), in which Norwid writes that "barbarzyniec tylko" [only a barbarian]

15 "Centaury i frygijskie karły (ile wiemy)

Mieli sękate czoła i nabrzmiałe mózgiem;

Apollin nie tą jedną panuje skorupą,

Lecz zupełną całością proporcji...” (DW VI, 394)

[Centaurs and Phrygian dwarves (as far as we know)

Had gnarled foreheads, swollen with brain;

Apollo rules not only over that one skull,

But over all proportions...] 
removes "kresy i szpary" [borders and cracks] from a plaster cast, and by doing that "psowa całość" [ruins its wholeness]. Equally well known are the words of Promethidion's Bogumił, who says "ogniw z ogniwem/Złączenia właśnie są przez przeciwności” (DW IV, 124) [a link with a link/Is connected exactly by contrast]. In Song XII from Rzecz o wolności słowa [On the Freedom of Speech], there is a perhaps less known and not as clear fragment; it is about shortages "które, / Ujemne będąc, kreślą całości naturę / I są jakoby twórczą narodów pokorą” (DW IV, 260-261) [which,/While negative, define the nature of wholeness,/And are a sort of creative humility of nations]. This passage becomes clearer after its juxtaposition with what Norwid wrote a bit earlier:

Każdy język okaże się w czymś niebogaty!

Lecz: jeżeli mąż, członek narodu już stoi

Tam, gdzie o swe słabości człowiek się nie boi

I gdzie ze stron ujemnych urabia się nowa

Bezstronności potęga, dodatniość zbiorowa,

Niechże Narodu-język strony swe mniej chwalne

Zna, i prawdzie zeń łuki wiąże tryumfalne.

(DW IV, 259)

Every language will turn out to be deficient in something!

But if a man, a member of a nation, is already standing

There, where he is not concerned with his weaknesses

And where negative traits become a new, powerful

Impartiality, a collective positive,

May the language of the Nation know its less glorious

Aspects, and turn them into triumphant arches of that truth.

It also becomes clearer in juxtaposition with the excellent poetic explication of całość stowa [the wholeness of the word] via the image of the ruins of Palmyra in the ending of Rzecz o wolności słowa. ${ }^{16}$ The ruin covered with ivy symbolises the human word completed by God. Both this image and the seventh stanza of "Fortepian Szopena" ["Chopin's Grand Piano"] with its "Doskonałymwypełnieniem" [Perfect completion] introduce the element of transcendence, or sacredness, to the problem of "wholeness" in a particularly clear way. This element can also be seen in many other (as well as the above cited) images and descriptions of Norwid's "wholes."

16 I wrote about this in more detail in the book Słowo Norwida (Warszawa: 1992), pp. $48-51$. 
The word catość [wholeness] is not used with reference to the merger of Doric and Phrygian elements, which Stefan Sawicki equates to the "obscure" authorship and simplifying, clear vulgarisation in Rzecz o wolności słowa. However, it is precisely here, that the author and vulgariser are defined as two strings of the same instrument, or two human hands forming one wing (DW IV, 248-249) thus again by the metaphor of a functional, coherent "whole."

\section{6}

According to Norwid, man has "tajemnicze a mistrzowskie poczucie-ogótu" [a mysterious and masterful sense of the whole]. "Im (...) przedmiot widzenia zupełniej jest rozumny w swej całości, tym zupełniej i prędzej obejmujemy go jednym oka rzutem ze wszech miar"17 [The more completely the object of our vision makes sense as a whole (...), the more completely and quickly we can capture its every respect with a single glance]. Man also has an inherent aspiration to seek participation in a whole, a community. In a letter to Jan Koźmian from 1850 (DW X, 226) Norwid writes:

Błogosławiony to czas, kiedy człowiek stać się cegiełka może - to jest, kiedy plan i ogół jest.

Inaczej - do czegóż dołożyć tę cegiełkę? Zawsze to będzie kupa cegieł.

Blessed is the time when a man can become a brick - that is, when there is a plan and a whole.

Otherwise - where to put this brick? There will always be a pile of bricks.

The epigram "Pascha" ["Easter"] dramatically describes the human desire for community:

Gdzie miłości tak mało, że się nie jednoczą,

Tam trzeba w nienawiści trzeciego człowieka

Połączyć się - [...]

Tam choć w ciosaniu krzyża i wbijaniu ćwieka

W całość się zlać fatalnie kłótne muszą wole.

(PWsz I, 176)

Where there is so little love that they do not unite,

There in the hate of the third man they should

Join together $-[\ldots]$

There, at least in hewing the cross and hammering in the stud

The dreadfully quarrelsome wills must merge into a whole.

17 Those are the words of Omegitt from the drama Za kulisami [Backstage], DW VI, 90-91. 
Man belongs in this positive, good whole. In Zmartwychwstanie historyczne [The Historical Resurrection], the author says that "tylko przez całość wyższą od tej, której się zaparło, powrócić w prawdzie można do niej” [only through a superior whole than the one that was renounced, can one truthfully return to it] and adds "to jest przez Ludzkość do Ojczyzny" [that is through Humanity to Homeland] (PWsz VI, 615). Norwid sees this path in the situation when "Całości-moralnej narodu już więcej nie ma, jest tylko ciąg wysileń pojedyńczych" (PWsz VI, 614) [There is no moral wholeness of the nation any more, only a sequence of individual efforts].

In the article ["O idei interpretacji"] ["On the Idea of Interpretation"], the poet says that "każdy człowiek wolny reprezentantem jest całości, w której energia jego - jakiejkolwiek bądź treści jest ona - ma swoje pole, obrót swój, i jest przykładem" (PWsz VII, 53) [each free man is a representative of the whole, in which his energy - in whatever form - has its own field, rotation, and sets an example]. An individual representing that whole needs to care about "co się godzi" [what is appropriate] and fight "co się nie godzi" (PWsz VII, 52) [what is not appropriate]. Thus:

Idea-Reprezentacji z tej przyczyny tak wielka i tak wielce chrześcijańską jest, iż przez nią cały-człowiek zyskany jest dla społeczeństwa i całe-społeczeństwo dla człowieka. Gdyby albowiem od osoby człowieka oddzielić przyszło wszystko to, co on reprezentuje, a przyjąć to jedynie, czego on praktycznie dopina - tedy ani człowiek taki nie byłby cały, ani społeczeństwo takie całości mieć by nie mogło.

(PWsz VII, 51)

The Representation-Idea is so great and so greatly Christian for the reason that through it society gains man as a whole and man gains society as a whole. Because if we were to separate from man all that he represents, and accept only that which he realises in practice - then neither would such a man be whole, nor could such a society have wholeness.

By placing such strong emphasis on the relationships between an individual and society, nation, or humanity as a whole, Norwid simultaneously stresses the rights of individuals and minorities within the whole, as well as the importance of non-conformism, civil courage, and independent thinking. In a letter to Joanna Kuczyńska from 1862 (PWsz IX, 59), he writes:

Nie odpisałem na to, co Pani mówi o postawieniu się jednej osoby, jed nego człowieka, przeciw całości umysłu społecznego.

Mam przekonanie, że nic piękniejszego nie ma nad to, kiedy jeden człowiek wzywa cały choćby świat do walki.

Może - to tylko ludzie, może ci tylko coś zrobili.

[I did not reply to what you said about one person, one man, standing up against the whole of the social mind. 
I am convinced that there is nothing more beautiful than when one man summons even the entire world to fight.

Maybe - these are just people, maybe they are the only ones who did something.]

Many times Norwid also says that the sacrifice of an individual for the benefit of the society is not allowed. In his opinion, the failure to acknowledge this ethical imperative, which found its expression in Christ's crucifixion, was one of the reasons of the failure of "wielka całość" [the great whole] that Israel could have become (O Juliuszu Słowackim [On Juliusz Słowacki], PWsz VI, 410) was broken up.

\section{7}

Man, generally capable of discerning "wholeness," should also perceive it in his life; he should notice "harmonię pomiędzy uważaniem dnia każdego jako całości i całości sprawy dokonanej jako żywota. (...) harmonię tę każdego ziarnka osobnego, każdej perły do grona całego nazwałbym gronem-winnym" [the harmony between considering each day as a whole and the whole of an accomplished matter as life. (...) this harmony - every single grain, every pearl in the whole bunch - I would call grapes] - as Norwid writes in a letter to Maria Trębicka from 1854 (DW X, 494) using yet another metaphor, in this case the image of life, composed of the wholes of individual days.

\section{8}

In seeking wholeness with such passion, Norwid simultaneously disavows the construction of systems as a tool of complete cognisance. The creation of systems can - as he puts it - serve both good and evil. Scientific work becomes dangerous, when it does not leave time to practise the truth. Meanwhile, the truth, as he formulates it in a letter to Maria Trębicka, "nie jest nigdy tu w całości swojej objęta wiedzą i myślą albo samym uczuciem - prawda jednak nie-cała nie jest prawdą i dlatego $t u$, to jest na tym planecie, prawda tylko myśla, uczuciem i życiem razem może być objęta" (DW X, 467) [can never here be captured in its entirety by knowledge and thought, or emotion on its own - however, the non-whole truth is not the truth and therefore here, that is, on this planet, the truth can only be captured with thought, emotion and life working together].

This is, according to Norwid, the whole spectrum of man's cognitive capabilities: thought, feeling, life, that is, practising the truth itself, its ethical aspect. As the poet says, reality is not entirely clear to man; he can get acquainted with it 
only through approximation. ${ }^{18}$ For Norwid, this expression holds a double meaning: not only the meaning of 'inaccuracy', but also of approximation as a human action; it is characteristic that approximation is defined as action (cf. footnote 18). In the second part of Milczenie [Silence], we read about how this "action" was implemented by the Pythagoreans, who represented Norwid's model of seeking the truth: through silence and concentration. ${ }^{19}$ However, as seen in Norwid's

18 "Nie wiem, zaprawdę, czyli jest jaka forma działalności umysłowej odpowiedniejsza położeniu naszemu, jak przybliżenie! Jesteśmy w każdym zmyśle i rozmyśle naszym otoczeni kryształem przezroczystym, ale u-obłędniającym poglądy nasze. Podobno że cokolwiek bądź czynimy, zagaja się albo uzupełnia przez przybliżenie. Jesteśmy sami poniekąd nie inaczej istniejącymi na wirującym Planecie szybciej od uderzeń pulsu... A przeto możnaby nawet rzec, iż działanie przez przybliżenie nie jest dla nas przypadkiem, lecz podbitym sobie warunkiem*. Stąd to, obejmując one - i jednocząc dwa wielkie klejnoty umysłowe, czyli: rozwagę umiejętności i nierozwagę instynktu przyrodzonego, jest ono zupełnie człowieczym."

* Godziłoby się zapytać czynnego generała, doświadczonego kapitana-okrętu, biegłego czło wieka-stanu, do ila oni w głównych i stanowczych działaniach swoich opierali się na bystrym à peu près - a o ile na systematycznem działaniu? C. N. (Milczenie [Silence], PWsz VI, 226-227).

[I do not know, verily, whether there is such a form of mental activity that would be more appropriate to our position than approximation! In each of our senses and intentions we are surrounded by a transparent crystal that, however, makes our views deranged. It is said that whatever we do, is initiated or complemented by ap proximation. We ourselves exist in a sense no differently on this Planet spinning faster than heartbeats... And, therefore, we could even say that acting through ap proximation is not a coincidence for us but a self-subdued condition. ${ }^{*}$ Hence, embracing it - and uniting - two great gems of the mind, that is: prudence of skill and imprudence of innate instinct, is a completely human feature.

* It would be right to ask an active general, an experienced captain of a ship, an expert statesman, to what extent they have relied in their main and firm actions on the sharp à peu près - and to what extent on methodological acting? C. N.]

19 "Dostąpienie przeto, zbliżenie się albo zbliżanie do kanonu wiedzy (...) było zapowiedzią obiecalną przedsiębierącemu milczenia praktykę (...) co do praktyki, szło o osobiste zastosowanie ustatkowanego swojego myślnego organizmu do ustroju nieustanego $\mathrm{w}$ harmoniach stworzenia m o n ologu - wi eczn ego, i to na takie zbliżenia lub oddalenia, do jakowych ta albo owa osobistość rzetelnie się mogła była doprowadzić..." (PWsz VI, 236). [Therefore, obtaining, approximating or approaching the canon of knowledge (...) was the announcement of a promise to the friend of knowledge who had undertaken the practice of silence (...) as for the practice, it was a matter of personal adaptation of one's own thoughtful organism to a system of continuous eternal monologue in harmony with creation, and to such approximations or remoteness, which this or that personage could honestly have achieved...] 
commentary on the actions of "doświadczony kapitan okrętu" [an experienced ship captain] or "biegły człowiek-stanu" [an expert statesman] (cf. footnote18), the rightfulness of their decisions and acts can only be determined by their experience, in combination with their "bystre à peu prés" [sharp à peu prés] of "instynkt przyrodzony" [innate instinct]. Focus, concentration - these are the conditions for approaching the ultimate truth, through listening intently to the Divine "monolog wieczny" [eternal monologue], "monolog-nieustannie-się-parabolizujący" [that incessantly-self-parabolising-monologue], which reaches man through the natural and cultural signs he has learned to read. "Bystre à peu prés" [sharp à peu prés] helps reveal partial truths. Systems are useful to them; using "systematy" [systems] is reasonable only if one can recognise their limitation:

Rzeczy te znając w ich owocach i w zasadzie, którą w-zwyż odkrywam, taki tylko system mam za słuszny, który nie dla udania odłamku prawdy za jej całość, ale dla tym lepszego okazania braku ma posłużyć. Bowiem nadto dobrze mi wiadomo, że tu kompletności innej nie ma, jedno naprzód w uznaniu, a potem w wyraźnym określeniu tego, co do kompletności zbywać może. Systemat więc taki tylko pewnym, który ile systematem jest, uznaje i jakoby trafnie wątpić umie o kompletności własnej.

(Sztuka w obliczu dziejów [Art in the face of History], PWsz VI, 272)

[Knowing the fruits of these things, in their principle, which I have revealed above, I deem rightful only such a system, which does not pretend a fragment of the truth is its whole, but serves to better represent that deficiency. For I am also well aware that there is no other completeness, besides first recognising, and then clearly defining what is not essential for completeness. Thus the system is only certain if, provided it is a system, it recognises and can accurately doubt its own completeness.]

\section{9}

Norwid is absolutely against the positivist theory of knowledge, against the opinion that the whole truth can be obtained through the sole practice of specialist, fragmentary fields of knowledge. According to him, it is not the path to wisdom, the path of "przyjaciól wiedzy" [friends of knowledge], it is not a path which - as he writes - "udziela (...) światło i dobro" [provides (...) light and good].

In this respect, Norwid is close to many of our contemporary anti-positivist philosophers, such as Capra or Heisenberg, ${ }^{20}$ and even to postmodernists. $\mathrm{He}$

20 The title of the Polish edition of W. Heisenberg's essays is significant itself: Czesść i całość. Rozmowy wokót fizyki atomu [Part and Whole. Discussions on the Physics of the Atom]. Cf. J. Puzynina, Język wartości, (Warszawa: 1992), pp. 80-81. 
is close to the latter in his appreciation of matter, including human body, and his discerning of the value of intuition and "praktykowanie prawdy" [practising the truth], the truth that man is able to access. ${ }^{21}$ At the same time, however, Norwid maintains the deeply held belief that God is good and that man is able to approach objective truth. Thus, unlike a classical postmodernist, he is not lost in the endless subjectivist and relativist ocean, dependent on the motion of its waves. He believes that he is a particle of a meaningful whole, which he can (at least approximately) come to know, and not just a designer of his little own temporary wholeness.

Norwid's "całość" [wholeness], in its most significant aspect of searching for a way and the point of life, is derived from Plato's trinity and the Christian association of truth with good, abstract with concrete, transcendence with matter. Norwid belongs to the trend in the history of human thought which demands human wisdom and maturity. And according to him, there is no wisdom and maturity without the stubborn, not only rational, search for the barely noticeable, but nevertheless existing order, harmony, and wholeness in the world and in one's own life.

\section{0}

\section{1}

As the fragments of the texts analysed in this article indicate, the most essential aspects in Norwid's uses of the words cały, cało, całość [whole, wholly, a whole/ wholeness] include:

a) just consisting of elements and comprising all elements of a given $\mathrm{X}$;

b) consisting of elements that are essential for being $\mathrm{X}$, or;

c) consisting of essential elements, including those particularly important, positive (often spiritual, transcendental in nature), and/or;

d) consisting of elements linked to one another by relations, in some way coherent, or also;

21 Cf., for instance, Z. Bauman, “Socjologiczna teoria postmoderny," in: Postmodernizm w perspektywie filozoficzno-kulturoznawczej, ed. A. Zeidler-Janiszewska (Warszawa: 1991), pp. 7-25; A. Grzegorczyk, "Punkt zwrotny humanistyki," in: Postmodernizm..., pp. 99-114. 
e) consisting of coherent elements, based on appropriate (according to Norwid) relations and/or relations building a harmonious whole. ${ }^{22}$

Type (c) and (e) uses are accompanied by the essential feature of perfection (or at least: a positive value) in the thus characterised wholeness. The other types distinguished above also have positive axiological connotations. ${ }^{23}$

The noun całość [wholeness] appears in Norwid's texts (similarly to how it is commonly used) either as the name of a feature, or as the name of an object possessing this feature.

\section{2}

Words that are close in meaning to całość [wholeness] in the sense of a set of all 'elements of X' in Norwid's writings include: bez-brakliwość [non-lack], kompletność [completeness], ogól [the whole, the generality], petnia [fullness], syntetyka [synthesis], wszystkość [all/everything], zupełność [entireness, wholeness, completeness];

words synonymous with całość [wholeness] in the sense of a set of (somehow) coherent elements: dośrodkowanie [centring], organism [organism], system [system], zespolenie [merger], ześrodkowanie [concentration], zjednoczenie [unification];

words synonymous with całość [wholeness] in the sense of a set of coherent elements with particularly positive valuation: harmonia [harmony], tad [order], petnia [fullness], skończoność [completeness, finiteness], zupetność [entireness, absoluteness].

\section{3}

As we have seen, Norwid resorts to numerous metaphors, comparisons, and examples of 'wholeness.' Among others, these belong to the following fields:

- the arts and architecture: plaster cast, ruins; ${ }^{24}$

- nature: flower and root, grapes, two human hands;

22 This description aims to show the entire scope of (Wittgenstein's) "family resemblances" of całość [whole/all]. I use the cognitive linguistics methodology in that I show the profiled combinations of semantic elements in different ways, in different contexts.

23 As it has already been discussed in footnote 13, the adjective caty [whole] also has positive connotations in general language. Compare the description of the semantics of this adjective in: J Chojak and Z. Zaron, “Ten cały. Refleksja na temat znaczenia," Poradnik językowy, Vols. 5-6 (1991), pp. 206-211.

24 At this point, it also worth mentioning the excellent cathedral metaphor in Song XII from Rzecz o wolności stowa [On the Freedom of Speech]. 
- architecture connected with nature: ruins overgrown with ivy;

- music: scale, two strings of a single instrument;

- artefacts: string of pearls.

This chapter presents source examples that cover only part of the synonyms and metaphors of "wholeness," as it was characterised in Section 2.1., the basis for the discussion presented here constituted the uses of the words cały, cało, and catość [whole, wholly, the whole/wholeness].

\section{4}

The scope of the objects and concepts which Norwid refers to as whole, understood in one way or another, is vastly broad. In particular, Norwid seems to give much importance to "całość" [wholeness] with reference to truth, word, man, society, and "czas dziejów" [history]. ${ }^{25}$

Norwid's concepts of wholeness tend to be paradoxical (e.g., the wholeness whose essential element is lack - evil). In addition, it is not always clear what according to Norwid - binds particular wholes (e.g., Vade-mecum).

\section{5}

The axiologically marked catość [wholeness] started to appear in Norwid's writing quite early on. The first significant metaphor of "wholeness" could be the great giant with his head in the clouds depicting the nation in "Głos niedawno do wychodźstwa polskiego przybyłego artysty" ["The Voice of the Recently Exiled Polish Poet”] (i.e., as early as in 1846). Całość [wholeness], as an important element of Norwid's thought, appears (as we have seen) in Promethidion, and it accompanies the poet up until his last works; the thought of wholeness is particularly significant for the discourse in Rzecz o wolności słowa [On the Freedom of Speech], Tyrtej ${ }^{26}$ and Milczenie [Silence].

25 Cf. the article by A. Dunajski, “Teologiczne implikacje Norwidowskiego 'dopełnienia” ” in: "Całość" w twórczości Norwida, ed. J. Puzynina, E. Teleżyńska (Warszawa: Wydział Polonistyki UW, 1992), pp. 3-20, and the book by A. Dunajski, Chrześcijańska interpretacja dziejów w pismach Cypriana Norwida (Lublin: 1985).

26 Cf. the article by M. Inglot, "Dramatyczna funkcja pojęcia całości w scenicznych utworach Norwida" in: "Całośc”" w twórczości Norwida, ed. J. Puzynina, E. Teleżyńska (Warszawa: Wydział Polonistyki UW, 1992), pp. 75-100. 


\section{1}

This chapter only outlines the subject of "wholeness" as an important general category of Norwid's thought and art. Many chapter delivered in this session supplied more concrete content and presented its multifaceted nature. I believe this is a topic that should be further investigated. Viewing Norwid as a thinker and poet of wholeness is justified and this general aspect of his thought and art constitutes one of the universal and, at the same time, contemporarily important values of his work.

\section{Bibliography}

Bauman, Zygmunt. “Socjologiczna teoria postmoderny." In: Postmodernizm w perspektywie filozoficzno-kulturoznawczej, ed. Anna Zeidler-Janiszewska. Warszawa: Instytut Kultury, 1991, pp. 7-25.

Chojak, Jolanta and Zofia Zaron. "Ten cały. Refleksja na temat znaczenia." Poradnik jezykowy, Vols. 5-6 1991, pp. 206-211.

Dunajski, Antoni. “Teologiczne implikacje Norwidowskiego 'dopełnienia." In: "Całośc" w twórczości Norwida, ed. Jadwiga Puzynina, Ewa Teleżyńska. Warszawa: Wydział Polonistyki UW, 1992, pp. 3-20.

Dunajski, Antoni. Chrześcijańska interpretacja dziejów w pismach Cypriana Norwida. Lublin: RW KUL, 1985.

Fert, Józef. “Wstęp.” In: Vade-mecum, ed. Cyprian Norwid, Wrocław: Zakład Narodowy im. Ossolińskich, 1990.

Fieguth, Rolf. "Poezja w fazie krytycznej." Studia Norwidiana, Vols. 3-4, 19851986, pp. 13-55.

Górski, Konrad and Stefan Hrabiec, eds. Słownik języka Adama Mickiewicza. Vol. 1. Wrocław: Zakład Narodowy im. Ossolińskich, 1962.

Grzegorczyk, Anna. "Punkt zwrotny humanistyki." In: Postmodernizm w perspektywie filozoficzno-kulturoznawczej, ed. Anna Zeidler-Janiszewska. Warszawa: Instytut Kultury, 1991, pp. 99-114.

Heisenberg, Werner. Część i całość. Rozmowy o fizyce atomu. Trans. Kazimierz Napiórkowski. Warszawa: PIW, 1987.

Inglot, Mieczysław. "Dramatyczna funkcja pojęcia całości w scenicznych utworach Norwida." In: "Całość" w twórczości Norwida, ed. Jadwiga Puzynina, Ewa Teleżyńska. Warszawa: Wydział Polonistyki UW, 1992, pp. $75-100$.

Mickiewicz, Adam. Dzieła. Vols. I-XVII. Warszawa: Czytelnik, 1993-2005. 
Pawelec, Radosław. “Część prawdy o słowie 'cały"' In: Studia nad językiem Cypriana Norwida, ed. Jolanta Chojak, Jadwiga Puzynina. Warszawa: Wydawnictwa Uniwersytetu Warszawskiego, 1990, pp. 63-77. Puzynina, Jadwiga. Język wartości. Warszawa: PWN, 1992.

Puzynina, Jadwiga. Słowo Norwida. Wrocław-Warszawa-Kraków-GdańskŁódź: Zakład Narodowy im. Ossolińskich, 1992. 



\title{
Stefan Sawicki \\ Publishing Guidelines for Cyprian Norwid's Dzieła Wszystkie ${ }^{1}$
}

\begin{abstract}
The chapter provides publishing guidelines for the eighteen-volume Dzieła Wszystkie (Collected Works) by Cyprian Norwid, the first fully critical edition of the writer's legacy. The author addresses the issue of the content of the edition, its structure (genological formula), the range of commentary (including the author's comments), explanations, and preliminary remarks on each of the published texts. The modernised principles of transcription - discussed on a variety of examples - reveal the extent of difficulties faced by editors of the collection. The same applies to Norwid's spelling and graphic structures of his texts - so diverse and multidimensional, while also endowed with semantic functions and artistic values, which manifest themselves especially in his manuscripts.
\end{abstract}

Key words: Cyprian Norwid, Dzieła wszystkie, editorship, critical edition, publishing guidelines

\section{1}

The series Dzieła Wszystkie [The Complete Works] (DzWsz) ${ }^{2}$ is intended to encompass everything ever written by the poet, including his letters and notes.

1 These guidelines have been edited on the basis of statements, both oral (during editorial team meetings) and written, made by the members of the team preparing the critical edition of Cyprian Norwid's Dzieła Wszystkie [The Complete Works]; Vols. I-II Wiersze [Poems] (Zofia Trojanowiczowa, Danuta Paluchowska, Józef Fert, Zofia Stefanowska), Vols. III-IV Poematy [Narrative Poems] (Stefan Sawicki, Adam Cedro, Piotr Chlebowski), Vols. V-VI Dramaty [Dramas] (Julian Maślanka), Vol. VII Proza [Prose] (Rościsław Skręt), Vol. VIII Pisma o literaturze i sztuce [Writings on Literature and Art] (Marek Buś), Vol. IX Pisma filozoficzne i społeczne [Writings on Philosophy and Society] (Jan Gotfryd), Vols. X-XIV Listy [Letters] (Jadwiga Rudnicka), Vols. XV-XVI Notatniki i notatki [Notebooks and Notes] (Piotr Chlebowski), Vols. XVI-XVII Albumy [Albums] (Piotr Chlebowski). Recommendations and suggestions proposed in the Guidelines have been linguistically consulted with Irena Bajerowa. The text of the Guidelines was edited in 1999 by Stefan Sawicki with the participation of Zofia Stefanowska.

2 In the article - due to its specific character - the original bibliographical abbreviations were left untouched. Their author followed the edition of Norwid's Dzieła wszystkie [The Complete Works], in which different abbreviations were used than those in our publication. Their list is provided in footnote 13. (editors' note) 
The texts written by the poet in French will be presented both in the original and in the Polish translation (typographically marked as auxiliary text). Works of uncertain authorship (e.g., "Samotność" ["Loneliness"], "Mój ostatni sonet" ["My Last Sonnet”], Juliusz Słowacki’s obituary) will be marked typographically. Graphics and drawings recognised to have been created by Norwid will be included in their maximal scope, not only in cases when they are closely related to the text or clearly illustrate it (e.g., "harpsichord" in a letter to Joanna Kuczyńska from August 1867: “- - ach!... oni jeszcze i z tego klawicymbała który tu u mnie, widzisz, stoi, trójkątny i długi [tu rysunek] ... oni i z tego jeszcze nie umieją nic zrobić [...]", GomPWsz IX 299). Norwid's notebooks and albums will be published in DzWsz in integral form as silvae rerum sui generis. In this case, works whose authorship by Norwid is uncertain or ruled out will be typographically marked and placed in the main text, not in the appendix.

\section{2}

The texts published in the series should follow the editorial tradition and be organised according to their genre. They will be grouped in the following categories: poems, narrative poems, prose, dramas, letters, notebooks, and albums. Seventeen volumes are planned to be published. In comparison with Gomulicki's Pisma Wszystkie [Collected Works] (GomPWsz), the division of works into individual sections will be different. Notes, which in GomPWsz constitute Vol. VII, are moved in DzWsz to the last volumes. Since notes and albums will be published in their integral form, supplementary texts as well as composite indices (merging indices for individual volumes) will be published in a separate volume that will close the whole edition. Another problem is posed by the placement in DzWsz of some series, which Juliusz W. Gomulicki placed in Vol. III of GomPWsz (Poematy [Narrative Poems]), but which in DzWsz will be included in the section Wiersze [Poems]. Also a number of works placed in GomPWsz in the sections Dramas, Prose, and Letters require a re-analysis of their placement in DzWsz. Works used by the poet on more than one occasion will be published in accordance with their function and genre, for example, a poem (or other individual text) included in the main text of a letter (and not only attached to it!) will be printed both in the Poems (or another respective section) and Letters section (if it appears in several letters, its further occurrences will be marked by an incipit and it will be discussed in Explanations). In turn, a text treated by Norwid

3 “- - ah! ... they still have this harpsichord - which here at my place, you see, is standing, triangular and long [here the figure] ... also with this they still can do nothing [...]" 
as one, comprehensive whole, but characterised by a high degree of autonomy, even if it was not published separately during the poet's lifetime, may be printed in DzWsz twice, also in the section to which it would belong after its isolation. For example, the poem "Plato i Archita" ["Plato and Archita"], which Norwid treated as the epilogue of the narrative poem Niewola, should be present not only in the section Narrative Poems, but also in the section Poems. Each case should be considered individually.

Within the genre-based sections, works will primarily be ordered chronologically. However, this layout will sometimes have to be broken for the sake of series' continuity, for example, in the Poems section - for the Vade-mecum cycle. By contrast, translations, and official letters (e.g., applications) in the section Letters will not be isolated. In both cases, chronological order is to be maintained consistently.

\section{3}

DzWsz is a critical edition, that is, it takes into consideration Norwid's authentic Variants, which appear in autographs, copies of autographs, first editions, and editions published during the poet's lifetime. The whole editions, individual sections and, if needed, even the individual volumes will be supplemented with general editorial remarks, adapted to the scope of their respective texts. Commentaries on the entire edition will be published as Introduction at the beginning of Vol. I, whereas those relating to individual sections (except for Letters) will be placed at the beginning of the critical apparatus. In the case of Letters, general editorial remarks will be placed at the beginning of the first volume of this section. Both in the general remarks and in other editorial texts full names of persons should be provided upon their first mention. From among the abbreviations binding all the editors of DzWsz, each volume will contain only those that are used within it, along with the abbreviations of individual sections and subsections.

\section{4}

Each text should be supplied with a critical apparatus, which consists of typographically marked: Editorial remarks, Variants, and Explanations. Editorial remarks contain information on the time and circumstances of the text origin; information on the text sources (autographs, their philologically significant copies, first editions and prints that appeared during the poet's lifetime); description, and, if necessary, justification of the choice of the basic text; bibliography of editions following the poet's death (sometimes also including larger fragments of his works), limited to important editions; a list of editions referenced in Variants; 
remarks concerning the "architecture" of the text; a list of introduced and abandoned emendations as well as new readings (interpretations) and the most important editorial changes in punctuation with regard to the basic text - along with the justification for such changes (also including the polemics behind the decisions made by previous publishers). Variants should evidence any changes with regard to the basic text. The author's variants (see Section 3) should be complete with regard to vocabulary, syntax, phonetics, and morphology, and in the case of selection - broader than for editorial variants - with regard to punctuation and spelling. Editorial variants are given in selection, whereby this selection with reference to interpunction - considering only important changes - will be larger in the section Poems, smaller in the sections: Narrative poems, Dramas and Artistic prose, and very limited in the sections: Journalistic prose, Letters and Notes. Explanations supplement the strictly editorial work. Their character is discussed in Section 8. In the section Letters, the critical apparatus will be introduced directly after the text of each letter, whereas in other sections it will be presented at the end of each volume.

\section{5}

Information on an autograph should contain the number of sheets and pages (in the case of "laminated" manuscripts, the terms "recto" and "verso" should be used), their dimensions in $\mathrm{cm}$ (first height, then width), paper quality (e.g., watermarks) and colour, possible stains and damage, also words and sentences written by someone else; in the case of letters - the letter container (envelope or locket), also the address and data on the post stamp; in addition to that, the current place of storage (library catalogue number) or a note on the missing status. If the basic text is a first edition or a print published during the poet's lifetime, a full bibliographic description should be provided for books, including the name of the publisher (printing house), sometimes also details concerning the dimensions of the book and its characteristic features (e.g., cover decorations). Journals and collection volumes require full bibliographic descriptions only. In the case of books, the editors should also indicate the copy they used (library, catalogue number).

\section{6}

The choice of the basic text and justification thereof pose serious problems, although in the case of Norwid, the very dominance of manuscripts often determines the basic text. However, when the work is preserved in more than one form, the editor must choose the right manuscript (the autograph or its copy). 
Further, if the work was published, but its autograph has been preserved (as, for instance, in the case of Rzecz o wolności stowa [On the Freedom of Speech]), the editor should examine the degree of authorisation of this print, in order to determine which of the texts is superior. Meanwhile, the degree of Norwid's control over his publications is not clear. It can be assumed it was rather limited. Contrary to J. W. Gomulicki's belief, Jadwiga Puzynina, and Jadwiga Rudnicka deny the volume Poezye [Poetry] published by Brockhouse in 1862 the value of a linguistic document, demonstrating that the publisher unified not only the spelling but also the linguistic forms in the entire series of "Biblioteka Pisarzy Polskich" [Library of Polish Writers]. ${ }^{4}$ Therefore, both this and other works of Norwid that appeared in print during his lifetime require careful examination and assessment.

Another issue that is difficult to resolve is the selection of the basic text in those cases where a single autograph documents at least two phases of the work on the text, two or more successive edits. For instance, this applies to some of the poems from the Vade-mecum cycle. Editorial practice and expert opinions do not allow for an explicit conclusion - Konrad Górski favoured the solution in which the main text is based on the first, calligraphic edition of a series (PamLit 1965, Vol. 2, p. 620), Wacław Borowy - as evidenced in the foreword to the edition of Vade-mecum in the likeness of an autograph (p. XX) - believed that if "the editor is obliged by the author's last intention," the main text should adopt from later editions as much as one can read from those. In turn, Gomulicki, as editor followed an intermediary path: he adopted smaller corrections into the main text, but when the changes encompassed larger fragments, were broader and deeper, he qualified the draft written over the fair copy as a new "version" and printed it in the appendix to the series, while in the main text of Vade-mecum he left the original version. The differences in the treatment of changes in the calligraphic edition result from the situation in the autograph - the poet's notes are of a rough draft nature, their reading may be questionable, some of them are simply illegible; moreover, not all draft paper versions are completed, sometimes the degree of completion is so questionable that it is legitimate to have doubts whether they may be qualified as the ultimate text version or whether they are rather just trial versions. In turn, it may suggest that these later versions emerged when Norwid, after his futile efforts, resigned from the publication of the entire

4 J. Puzynina, Słowo Norwida, Wrocław-Warszawa-Kraków-Gdańsk-Łódź: Zakład Narodowy im. Ossolinskich, 1990, pp. 26-27; J. Rudnicka, "Jak Brockhaus wydawał Norwida", Studia Norwidiana 8 (1990), pp. 123-131. 
series, but corrected individual poems with the intention of including them in contexts other than that of Vade-mecum. Although in practice Gomulicki did not evade some inconsistencies, he formulated a principle according to which the fragments of two different versions forming a syncretic text should not be combined in the main text. As simple as this principle is to formulate theoretically, it is difficult to apply in practice. This issue is clearly fairly complicated. The ultimate decision will always have to be made by the publisher, in this case - the publisher of Vade-mecum. His situation in DzWsz will be better than that of the editors of editions intended for the general public, because he will be able to justify himself in detail in the editor's commentary, additionally he can juxtapose all the editions as part of Variants.

\section{7}

In Variants, the symbol] separates the main text (on the left) from its variants ordered chronologically (on the right), whereby for Przesm ${ }_{1} F$ the completion date of the compilation (1911) is considered, not its publication date (1946). When the basic text is adopted by the main text in unaltered form, this text is not included in variants any more, only the sources that differ from it are provided (Example 1). On the other hand, when the main text is derived from a different text than the basic text, it is given in the first place after the symbol], followed by all the sources (provided in Variants) that differ from both the basic and the main text - along with the basic text (Example 2). When the editor wants to introduce his own emendation, including the change in punctuation, on the right side of the symbol] all the variants that differ from this source (the main text) should be provided (Examples 3 and 4). The quoted texts should constitute semantic wholes. If necessary, longer quotations should be given, where certain fragments are left out, which is signalled by the symbol [...]. Words (parts of words) that were crossed out, blurred, or revised by the author should be put in brackets $<>$, whereby an undeciphered text or uncertain reading should be signalled with the symbol [?]; the number of undeciphered words (letters) will be given in writing (Examples 5 and 6). Any added (interpolated) text should be indicated in writing (Example 7). An added text, resulting from revision, is qualified and marked as revised, without additional information on its revision. More complicated revisions (many variants, multiple rewritings of the same fragment) and change in word order can be shown

5 However, to a certain extent, the chronology is disturbed by providing the localisation of identical variants from different editions in one block (see Example 2). 
through the reconstruction of successive text versions (ver. I, ver. II, ver. III). Variants are given in the original spelling, except for emphases, which are presented in accordance with the style adopted in DzWsz (see Section 13). Variants are separated by semicolons. At the end of Variants there is no full stop. Variants include Norwid's autographs, their copies (in both cases the principle of autopsy shall apply), editions published during the poet's lifetime, post-mortem first editions, and the most important later editions (in particular those published by Przesmycki and Gomulicki). If the basic text is an autograph, wrong or other readings (also the readings of crossed out, blurred, and revised fragments) should be noted down from post-mortem editions, whereas non-indicated will be those differences with regard to DzWsz which in the previous editions result from other, more modernised principles of transcription, such as the change of $\mathbf{o}$ into ó or $\mathbf{u}$. (bole $\rightarrow$ bóle, katakomby $\rightarrow$ katakumby) or the devoicing of $\boldsymbol{z}$ in front of $\mathbf{l}$ (jeźli $\rightarrow$ jeśli).

\section{Examples Ad. $7^{6}$}

\section{Example 1}

które pot łzawy obléwa] które pot trawy obléwa pdr, Pini, GomPWsz

("Psalmów-psalm" VIII, 195; podstawa atg; w Odmianach uwzględnia się atg, pdr, Pini, GomPWsz, GomNWyb) ["Psalmów-psalm" VIII, 195; basic text atg; in Variants atg, pdr, Pini, GomPWsz, GomNWyb are complied with]

\section{Example 2}

co jest Bożym gniewem?...] co jest Bożym gniewem?... Cyw, JastrGom, GomPWsz; co jest gniewem Bożym?... pdr, Przesm ${ }_{1}$ co jest bożym gniewem?... Pini

(Fulminant, w. 46; podstawa pdr; w Odmianach uwzględnia się pdr, Przesm ${ }_{1}$, Cyw, Pini, JastrGom, GomPWsz) [Fulminant, v. 46; basic text pdr; in Variants pdr, Przesm ${ }_{1}$, Cyw, Pini, JastrGom, GomPWsz are complied with]

\section{Examples 3 and 4}

$z$ zaświata] $z$ za świata pdr, Przesm, ZrębProm, Pini; $z z a$ świata BorProm, Gom

(Promethidion, "Wiesław", w. 169; podstawa pdr; w Odmianach uwzględnia się pdr, Przesm $_{1}$, ZrębProm, Pini, BorProm, GomPWsz, GomProm, GomNWyb) [Promethidion,

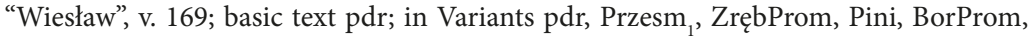
GomPWsz, GomProm, GomNWyb are complied with]

Że bezwidnego filarem kościoła,] Że bezwidnego filarem kościoła pdr, Przesm ${ }_{1}$, Pini, Gom

6 The main text of DzWsz will be in roman type, italics will be used for emphasis. In Variants, Norwid's text will be printed in italics, for emphasis - semi-bold italics, the editor's text - in roman type; in Explanations, the explained text (no emphasis will be used) - in italics, the explanation - in roman type. 
(Próby, w. 76; podstawa pdr; w Odmianach uwzględnia się pdr, Przesm ${ }_{1}$, Pini, GomPWsz, GomNWyb) [Próby, v. 76; basic text pdr; in Variants pdr, Przesm ${ }_{1}$, Pini, GomPWsz, GomNWyb are complied with]

\section{Examples 5 and 6}

Gustaw $]<[$ ?] $>$ Gustaw (one word is illegible) atg; <Konrad $>$ Gustaw GomPWsz

("Psalmów-psalm" III, 35; podstawa atg; w Odmianach uwzględnia się wydania jak w Przykładzie 1) ["Psalmów-psalm" III, 35; basic text atg; in Variants publications listed in the first example are complied with]

Co jakby rosa skier, w źrenic] Co jakby rosa skier, $<c o[?]>w$ źrenic atg

("Psalmów-psalm" I, 7; podstawa atg; w Odmianach uwzględnia się wydania jw.)

["Psalmów-psalm” I, 7; basic text atg; in Variants as above]

\section{Examples 7}

złe [...] fałszywe pokora [...] kryte] in atg fałszywa is added

("Psalmów-psalm," Dedykacja, w. 3; podstawa atg; w Odmianach uwzględnia się wydania jw.) [“Psalmów-psalm," Dedication, v. 3; basic text atg; in Variants as above]

\section{8}

Content-related and linguistic explanations should be scarce, concrete, and devoid of narrative lengthiness. Linguistic explanations refer to the words whose understanding may be wrong or uncertain, for example, "chryja" [row, obs.: speech], which in the poem "Pióro" ["My Quill Pen"] means something totally different than today, or the proper name Echo in "Narcyz" ["Narcissus"], which can be erroneously understood as the personified name of an acoustic phenomenon. Sometimes, an obscure form must be explained, for example, the word Atena [Athena] (Niewola [Enslavement] I 51), created as an inflectional neologism (sing.) from the name of the city Ateny [Athens] (plural). Texts in foreign languages are translated, except for the phrases and sayings that have become common expressions. Content-related explanations are provided when the understanding of the meaning requires knowledge, an identification effort (quotes, paraphrases, allusions, facts, e.g., for the poem "Ołówkiem na książeczce o Tunce" ["In pencil on the booklet on Tunka"]) or research effort, for example, for the poem "Na zgon śp. Jana Gajewskiego [...]" ["On the Death of the Late Jan Gajewski"]. The poet's note to this work: "Roku 95-o, pod Domicjanem Imp., wygnaniec na Pathmos wrzucony był we wrzący kocioł" [In year 95, under the rule of Emperor Domitian, the exile on Pathnmos was thrown into the boiling pot] - requires more or less the following explanation: "Norwid combined here Tertullian's mention of the «immersing in a fiery oil» of St John in Rome (De praescriptione haereticorum 36) with the information from other 
sources on the stay and death of the saint on the island of Pathmos." The names and their designates are not explained if they are clarified in the context or if it can be assumed that educated readers are familiar with them. There should be no interpretation of the text; in the case of metaphorical expressions, only the most necessary explanation of the component meanings is given. Of course, the commentary on journalistic prose and letters should be more thorough and more context-guided than in other sections. The biblical quotations in the commentaries should be derived from the 19th-century editions of the Jakub Wujek Bible and the Gdańsk Bible, whereas the names of the books of the Bible, their abbreviations and text numbering should be given following the Millennium Bible. Quotes from the Bible are provided with the abbreviations used by Norwid. Additionally, information on their sources is provided using one of the translations of the Jakub Wujek Bible or the Gdańsk Bible, without investigating the exact edition, from which the quote was derived. With regard to the biblical quotes there is general freedom whether to cite or only reference them, which is dictated by the specific needs of a given commentary. Explanations adopt the convention commonly used in linguistic dictionaries, that is, the explained words are given in their basic form (singular or plural Nominative, infinitive), whereas narrative fragments, characteristic expressions and phrases, as well as forms which in their basic form lose their characteristic features (e.g., palem 1 st person, plural) are directly cited in the form used in Norwid's text.

If the publisher does not manage to provide a convincing explanation or is unable to explain, for instance, an allusion or identify a person, this gap should be indicated, for example, "This person could not be identified."

\section{9}

The modernisation of spelling should follow the general principles of critical editions, that is, it should preserve the individual linguistic features (not spelling!). The main rule is to use the signs of the currently binding spelling to primarily preserve the semantics, but also the sound of the text. The publishers use the materials collected in the Laboratory of the Dictionary of Cyprian Norwid's Language in Warsaw. The linguistic consultant is Prof. Irena Bajerowa. Some of the adopted guidelines and suggestions are presented below.

The characteristic forms of nouns (e.g., pargamin, drogoskaz, widnokrężek, niedoperz), verbs (e.g., nazowie się, kupiem), adjectives and participles (e.g., letszy, start) are left unchanged, historically justified alternations (e.g., Bogumit - simple compound and Bogomit - compound with infix, arfa and harfa, generat and jenerat) are retained, the same applies to the spelling of some words, which reflects 
their etymologization. Voiced $\mathbf{z}$ and $\dot{\mathbf{z}}$ are left before $\mathbf{l}$ (jeźli, jeżli; niźli, niżli), soft (palatalised) ś and $\mathbf{z}$ are left before soft consonants (e.g., beśpieczny, śpichlerz, draźliwie) and in the endings -śny, źny (e.g., miłośny, nieprzyjaźny); however, assimilations that are not present in contemporary orthography but prevalent in today's speech (e.g., pięset, piędzeisiąt) are not indicated. The soft consonants k' ang $\mathbf{g}$ ' are not retained when they appear in the last syllable (e.g., Polskie, nogie), but are retained when they appear in the word initial syllable (e.g., gienerat, kieks). Possible traces of the dialectal substitution of dental stops and affricates for alveolar stops and affricates (so-called "mazurzenie"), and the hypercorrect rz instead of $\mathbf{r} \dot{\mathbf{z}}$ (e.g. $d r z a c y$ ) should be preserved. The cases of lost softness (palatalization) before soft nasal consonants (e.g., w piśmie $\rightarrow$ pismie, w ojczyznie $\rightarrow$ w ojczyźnie) are not indicated, and the sound $\mathbf{s}$ (instead of $\mathbf{s}$ ) as word initial before a soft stop (e.g., spi, spiewa) is retained only when it is also present in today's pronunciation, for example, spieszyć się. The alternations sz/s, ś (also $\dot{\mathbf{z}} / \mathbf{z}$ ) are retained, for example, szafir and safir, Mojzes and Mojzesz, ślubny and szlubny.

As for the letters ó/o/u - the spelling of the basic text should be preserved if it can be proven that the spelling reflected the pronunciation.

Prof. I. Bajerowa made the following suggestions:

Where ó corresponds to today's $\mathbf{o}$, it should be preserved in the following cases:

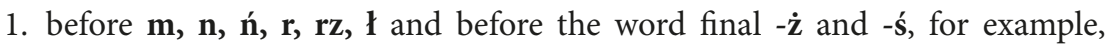
owóż, któś;

2. in the last syllable of singular masculine nouns in Nominative, for example, próch, teológ;

3. in the last syllable of plural feminine and neutral nouns in Genitive, for example, istót, rzemióst;

4. in the prefixes dó- and pó-, for example, spójrzat;

5. in the syllable before the suffix -n (also in the middle of the word), for example, kilkakrótny, ostóżność;

6. in the borrowings, instead of the foreign o, for example, stósować;

7. in the words with original metathesis tort $>$ trot, tolt $>$ tlot, for example, dróga, młódszy;

8. in those words, in which today there are still alternations o/ó or which today in inflectional paradigm have alternate forms with ó, for example, powrótu (because of powrót), mógłem (because of mógt).

Where o corresponds to today's ó, it should be preserved in the following cases:

1. in singular masculine nouns in Nominative before the final $\mathbf{m}, \mathbf{n}, \mathbf{n}, \mathbf{r}, \mathbf{r z}, \mathbf{1}$ (e.g., sokot); 
2. in the last syllable of plural feminine and neutral nouns in Genitive (e.g., sierot $)^{*}$;

3. in those words, in which today there are still alternations, for example, Ogrojec, żtobek, or which were listed in 19th-century dictionaries (also in SWar and SJAM) in the form with $\mathbf{o}$ as the most prevalent or equivalent to those with ó;

4. in the word proba and related words.

* However, o should be replaced with ó in the Genitive ending of plural masculine nouns, in which, according to linguists, the spelling -ow did not reflect the actual pronunciation.

Within the alternation of $\mathbf{o}$, ó, $\mathbf{u}$, the spelling with ó should be retained in cases, where in Norwid's texts we can find the form of this word (today written with u) also with o, for example, tłómaczyć - but also tłomaczyć; Jakób - but also Jakob; or where $\mathbf{o}$ appears as a rhyming partner, for example, stróny (today struny) - uwięziony. The letter ó should be replaced with $\mathbf{u}$ in words that today are spelled with $\mathbf{u}$ and which in Norwid's writing do not alternate with $\mathbf{o}$, for example, wyptóki $\rightarrow$ wyptuki. $\mathbf{U}$ should be replaced with ó in words or morphemes which today are spelled with o, for example, pukąd $\rightarrow$ pókąd. While deciding on a spelling with ó/o/u, attention should be paid to the frequency with which the word forms appear in Norwid's texts, especially in his autographs. The changes relating to ó/o/u should be noted as variants in the critical apparatus, except for the changes of $\mathbf{o}$ into o in the Genitive ending of plural masculine nouns, in the pronouns $m o j$, $t w o j$, swoj, in different forms of the determiner który, in all forms of the verb mowic and in the participles derived from it, and also except for changes of ó into $\mathbf{u}$ and $\mathbf{u}$ into ó - however, only in the cases described above.

The issue of the singular Instrumental and Locative endings -em, -ym (-im) and the plural Instrumental endings -emi, -ymi (-imi) of pronouns and pronominal adjectives, participles and numerals should also be settled. Since, as it is claimed by historians of Polish, the distribution of these endings often reflected the guidelines of the legislators of spelling, thus the theoretical standards, not the actual pronunciation, they should be adapted to today's spelling and uniform endings: -ym (-im), -ymi (-imi) should be introduced without evidencing the changes. The only exception is made for words in rhyming positions, where the rhyming partner - of course, assuming that even Norwid's rhymes were then rather exact - constituted a better phonetic hint (e.g., biczem - niczem).

The so-called narrow e (é) (higher pronunciation of the mid-open vowel) occurs most frequently in the endings -ém, -émi, in the ending -éj of the Genitive, Dative, and Vocative case of singular feminine adjectives, participles, 
and pronouns and in these endings in other words. In the case of the endings -ém, -émi, the problem boils down to their foregoing. In the ending -éj (except for the rhyming positions - e.g., powieki - dalekiéj), the symbol of vowel narrowing should be abandoned, since the current spelling, in fact, is not a sign of a radically different pronunciation - also today e before $\mathbf{j}$ is pronounced slightly narrower (higher). Besides, é is also not preserved in other endings. The changes with respect to the basic text are not evidenced. By contrast, -é is preserved in uninflected words and in inflexional stems, that is, in word stems without inflectional ending, for example, téż, bohatérski, kobiéta. Also, the narrowing of é that is even more clearly marked by the spelling (with $\mathbf{y}$ ) should be preserved, for example, zapłakany (singular feminine adjective in Genitive). Commentary may explain possible ambiguity relating to the forms: jedny, zapłakany. The narrowing symbol should never be added to achieve greater exactness of the rhyme (e.g., in the rhyming pair kobiety - szczyty, the word kobiety should not be replaced with kobiéty).?

Due to obvious phonetic reasons, the final e, even in rhymes, should be replaced - without indicating the change - with ę. According to this editorial tradition, this also applies to neutral nouns such as ciele, imie, ksiaże, although here, the final $\mathbf{e}$ is morphologically justified. By analogy, this change is also applied in middle-word positions (dziewientastego $\rightarrow$ dziewiętnastego). By contrast, the nasalisation that disappeared over time (e.g., mięszać) should be preserved. Due to the similarity of the letters ę and ą, it is impossible to determine in many of Norwid's autographs whether the singular Accusative case of feminine nouns ending with -ia, -ja should be, for instance, religia or religię, nadzieją or nadzieję. In such cases, ę should be chosen for Polish nouns, while ą should be the ending for nouns of foreign origin (including the noun pani). ${ }^{8}$ If it is difficult to determine in Norwid's autograph whether the Accusative case of singular feminine pronouns, adjectives, and participles has the ending ę or a, then (and only then!) the ending a should be applied (except in the case of the determiner te). This should be noted in the critical apparatus. The lack of nasalisation of a should be retained in the final word position, for example, piechoto; in this case, the acceptable replacement of $\mathbf{o}$ with a (e.g., in v. 187 of Bogumiła) should be noted. The former form of neutral pronouns is preserved: te (tamte, owe) dziecko, zdarzenie, and so on.

7 In accordance with the principle that certain forms are left unchanged for the purpose of preserving a rhyme, but nothing should be changed to obtain a rhyme.

8 See I. Brajerowa, Polski język ogólny XIX wieku. Stan i ewolucja, Vol. II: Fleksja, (Katowice: Uniwersytet Śląski, 1992), p. 60. 
In words borrowed from foreign languages, $\mathbf{y}$ before a consonant should be changed - without indication - into i (e.g. Egypt $\rightarrow$ Egipt), and before a vowel into $\mathbf{i}$ (e.g., kuryer $\rightarrow$ kurier) or $\mathbf{j}$ (e.g., herezya $\rightarrow$ herezja), with the exception of rhyming positions (e.g., Babylon - omylon), the ending -yj in the Genitive case of plural feminine nouns (e.g., ekspozycyj), the situations where - due to the rhythm - the group "consonant-y-consonant" must be interpreted as two syllables (herezya - herezyja) or where such a bisyllabic nature is confirmed by the spelling (historyja), and the words whose pronunciation still allows for this two-phase character even today, for example, tryumf, patryotyzm, Marya. By contrast, in words such as periklejski (also in some native words, e.g., wychilit) $\mathbf{i}$ should be changed - in accordance with today's pronunciation - into y. In this category of words (except for the cases motivated by rhythm), the clusters ti should be changed into cj (Egiptianami $\rightarrow$ Egipcjanami), si into sj, ci into cj, and cij into ćj (chrześciaństwo $\rightarrow$ chrześsijaństwo). This should be done always without indicating the change, as this phenomenon will be discussed in the editorial commentary to the whole edition. In words of foreign origin, consonants before other consonants, $\mathbf{j}$ and in final word position should not be doubled (without indication), however, doubled consonants should be kept before vowels, except for in those words whose spelling with one consonant has been strongly preserved by publishing (e.g., in the title Za kulisami [Backstage], which in the autograph is spelled Za kulissami) or cultural tradition (some proper names, e.g., Sokratesa and not Sokratessa), or results from an actual inconsistency (e.g., litera and littera in Rzecz o wolności słowa).

Also without indication should $\mathbf{z}$ be changed into $\mathbf{s}$ before a voiceless stop $(z k a q d \rightarrow$ skad, zwycięztwo $\rightarrow$ zwycięstwo), ś into $\mathbf{z}$ before the soft consonant ć (znaleść $\rightarrow$ znaleźć) - it should be remembered that the modernisation of spelling in fact does not change the phonetics. However, in the word pojedynczy, the palatalised ń is preserved, and in the verb wziasśc both final consonants are retained. The symbol of palatalization of the final consonant in words such as krew' and gołab' should be removed, while dź in the infinitive bydź is replaced with ć. The following should also be changed with indication: weznę/wezna into wezmelwezma and panflet into pamflet.

The contemporary norms regarding the use of capital letters should be adhered to. However, Norwid's original spelling should be retained in cases, where it can be assumed that the use or the lack of the capital letter had semantic value for the poet. Thus, capital letters should be retained in the case of personifications, when they signify the change of a popular name into a proper one, when they increase the rank of the referent, when they appear at the beginning of word-concepts designating categories to which the Romantic philosophy tended to attribute real 
existence (beauty, goodness, truth, holiness) and when they express a particular emotional attitude of the speaking subject, whether individual or collective. Also, Norwid's majuscules in polite expressions such as Ty and Ciebie [You] should be respected. Each individual decision requires a thorough analysis of the text and knowledge of the context. This is particularly important for avoiding obvious inconsistencies. While analysing the text, it is also important to consider the specific properties of Norwid's poetic world and the entire epoch, which was inclined to exaggerate the value of general concepts. Changes should be noted when some doubt remains regarding the legitimacy of a spelling modernisation.

In the case of the pair $\mathbf{c h}-\mathbf{h}$, the current spelling should be used. Except for some particularly justified cases (Promethidion), $\mathbf{h}$ should be kept in the clusters th, gh in words of foreign origin (rhythm $\rightarrow$ rytm). Unhyphenated or separate spelling should be adapted to the current spelling rules without indicating the changes. Deviation from these rules is possible only exceptionally, for instance, when separate spelling in Norwid's texts is a symbol of the mutual relation of words before their blending (e.g., we wnatrz).

The spelling of proper names and toponyms poses a special problem. In the case of Polish proper names, Norwid's original spelling should be retained, for example, Chadźkiewicz instead of Chodźkiewicz, whereby appropriate information should be given in the explanations and both versions of the name should be listed (with references) in the index. In the case of foreign proper names (similarly to words of foreign origin), the possible orthographic mistakes in the original spelling should be corrected without indicating these changes. By contrast, the polonised forms should remain unchanged, even if they appear in the same text also in the original form (e.g., Cezar - Caesar). Should there exist such a need -names should be explained, for example, Nefszatel - the Polish transcription of the French name for Neuchâtel, a county in Western Switzerland. The forms that have been only partially polonised should be completely polonised without indicating the change, for example, $o$ Victorze $\rightarrow o$ Wiktorze. However, mistakes in the polonised version of the foreign proper names should be corrected and the right original version should be provided in the commentary. In French texts, the other spelling of Polish proper names should be retained if it signifies another pronunciation, for example, Miroslawski, or when the change in spelling would change the pronunciation, for example, Rouprecht $\rightarrow$ Ruprecht (French pronunciation $\mathrm{u} \rightarrow \ddot{\mathrm{u}}$ ).

"Clean" transcriptions such as ćiepló $\rightarrow$ ciepło, exotyczny $\rightarrow$ egoztyczny, vers $\rightarrow$ wers, or poiedynek $\rightarrow$ pojedynek will not be indicated. The same applies to changes recognised as orthographic mistakes (e.g., wierza) or obvious typographical errors - so-called typos. If these errors are frequent, they should be mentioned in 
the description of the text in Editorial remarks. Common abbreviations should be given in the current spelling: itp., itd., śp., but others should be retained, for example, ś. or ś-ty, ś-go, W-ny. Latin abbreviations such as $1^{\circ}$ and 1-o should be unified: 1-o. Ordinal numbers should be inflected according to the current spelling: $w$ 3. osobie, na 2. piętrze. Abbreviations should not be developed into full forms if they are comprehensible, but when they are, the developed part should be put in square brackets [].

The dates in Explanations should have the following format: century - Roman numerals; day and year - Arab numerals, month - in writing; after the number signifying the day there is no full stop (e.g., 1 sierpnia); the year should be limited only to the number (e.g., 1858), it is also possible to sometimes add the abbreviation $r$. at the end.

The volumes of individual publications will be marked with Roman numerals.

All important changes in spelling that are not covered in these Guidelines, all deviations from the accepted rules, as well as specific decisions, which - albeit based on these rules - may raise doubts, should be indicated. It is particularly important, since texts written by Norwid - who was a self-educated person in exile - contain numerous mistakes and linguistic forms that may be traces of theoretical norms, tradition or simply lack of spelling skills, and they are not necessarily a reflection of the phonetic features unique to the poet's language. Particular attention should be paid to the spelling of words, which are not listed in 19th-century dictionaries or which these dictionaries recognise as erroneous, rare or non-standard; even if this is generally regulated by these Guidelines. Forms that are drastically different from today's language may suggest that they could have already been undergoing the process of transformation in Norwid's time and that they might reflect more the contemporary spelling norms rather than the pronunciation fading at that time. Particular attention should also be paid to the forms, which differ from the current Polish spelling only in the use of diacritics; it is always possible that they were a result of an author's or typographical error, especially when in Norwid's text the alternative form with respect to the prevalent form that accords with the current pronunciation occurs very rarely or when this different form appears in the text only once.

\section{0}

The problem of Norwid's interpunction is particularly difficult. The general rule "modernise carefully" is sufficient only in relation to the use of the dash, ellipsis, and exclamation point, since these symbols are not that problematic in transcription. Norwid's hyphen -, which in his autographs most frequently takes 
the form of $=$, should be preserved in both functions (linking and separating), whereby the form should be unified, that is, it should always be realised as a hyphen. If for some reason the publisher resigns from using the hyphen or introduces a hyphen where there was none in the basic text, this should be indicated in Editorial remarks, and the change itself should be indicated in Variants. This does not apply to forms with the particles $-\dot{\mathbf{z} e},-\mathbf{\mathbf { z }},-\mathbf{l i},-\mathbf{c}$ and the endings -(e)m, -(e)ś, -(e)śmy, -(e)ście, where a non-hyphenated spelling should be adopted (e.g., masz-że $\rightarrow$ maszże), whereas in the case of forms with the particles -bo, -ci, -to a separate spelling should be used (e.g., żaden-bo śpiewak $\rightarrow$ żaden bo śpiewak). Sometimes, before the endings -(e)m, -(e)ś, -(e)śmy, -(e)ście, -ć, a hyphen may be retained: after forms other than verbs and when the removal of the hyphen could result in misunderstanding, for example, cele-m pośmiewiska, sprawia-ć ból? Forms such as k' niemu are written without the apostrophe: $k$ niemu.

Question marks require a more careful analysis, while commas a more careful decision.

As a general rule, Norwid's question mark should be retained when it is used in ordinary interrogative sentences directly after interrogative pronouns and adverbs, as in stanza 5 of the poem "Wies'" ["Countryside"]:

Lecz, o górnych, tam! kto? myślił lodach,

Modre przecierając szyby;

$[\ldots]$

[But the upper, there! who? has ever thought about,

Wiping blue window panes; ]

By contrast, the question mark is not retained in sentences which do not contain any interrogative intention as, for instance, in the last verse of the narrative poem Fulminant:

Jest przyrodzony-gniew we krwi człowieka, Jak elektryczność w powietrzu... gniew taki,

W roty ujęty, gdy sygnałów czeka

Muzyką, wódką, grozą... to - żołdaki!

- Na lat epokę młodzież on wywleka

Od matek łona - i aż wyczłowieczy

Tak, że pułk ojcem jej, odwach kościołem -

Człowiek, co rany tam czyści i leczy,

Już czynownikiem... już nie archaniołem;

Kobieta? żartem; - przyjaźń, wdzięczność, miłość?...

Pojęcie każde szersze lub myśl wzniosła?

Są śmiesznym w marszach zbytkiem, jak otyłość! 
- Oto... gdzie? Horda-średniowieczna wzrosła!... (XIII, 146-158)

[There is an inborn-anger in human blood, Like electricity in the air... such an anger, Seized in troops, When waiting for signals With music, vodka, terror... these are - soldiers!

- For years it drags out youths

From mothers' wombs - until they are dehumanized

So that regiment becomes their father, guard their church -

Man, who heals his wounds there,

Is already a tschinownik... no longer an archangel,

A woman? a joke; - friendship, gratitude, love?...

Each broad idea or a noble thought?

Are funny frills in military marches, like obesity!

- this is where? A medieval-horde rose!...]

Nevertheless, all instances of Norwid's use of the question mark, especially in the "anticipating" function, should be well analysed. The final decision lies with the editor.

With reference to other punctuation marks, in particular commas, the following guidelines may be helpful:

1. Changes are introduced when they are necessary in the light of the currently binding punctuation rules and when they do not interfere with the artistic structure of the work.

2. The punctuation should also be changed if - with Norwid's original punctuation - the sentence loses its meaning (in the context or generally).

3. While deciding on the punctuation, the logic of the punctuation's context, especially the immediate one, should be taken into account.

4. Punctuation marks should be modernised with the retention of their original function (e.g., a colon can be replaced with a semicolon or a full stop), in particular in places where the marks used by Norwid have a clearly different function today.

5. Generally, the punctuation should not be changed if - with Norwid's original punctuation - the text is meaningful, even if a change in punctuation would somewhat seem to make better sense.

6. No changes are introduced if Norwid's punctuation has a clear artistic function, confirmed by other signals (especially of a systemic character within a particular text), for example, the adverb Tam appearing five times in the poem "Do Zeszłej" ["To the Deceased"] and each time separated by punctuation from the words following it, or the adverb Dziś in the poem "Pięknoczasu" ["The Beauty of Time"]. 
7. Certain examples of Norwid's eccentric use of punctuation should be unified, e.g.!... and ...! or?... and ...? should always take the form of!... and?... respectively. In interrogative sentences!? should be replaced with?! However, sometimes? and! is retained at the end, when? is used in the function of questioning the sense of the preceding statement - in such cases the contemporary punctuation uses (?), or when! is equivalent to today's (sic!).

To put it briefly: (a) in the case of punctuation marks serving a grammatical function, wherever necessary, they should (rather) be added; (b) in the case of punctuation marks with an intonational-rhetoric function, wherever unnecessary, they should (rather) be eliminated.

While modernising Norwid's punctuation, it is worth remembering the rule that may protect the text against excessive "chopping" of the poet's text. The rule was well defined by E. Przyłubska and F. Przyłubski: "If, as a result of incorporating one clause into another one, two linking words stand next to each other (a conjunction and a pronoun), the comma that opens the inserted clause should be deleted. It is also possible to delete a comma between the linking word and the nominal clause or inserted phrase. However, in both cases the closing comma should not be deleted." Examples: Pies, który, gdy poczuje obcego, nie szczeka, niewiele jest wart. Był pewny siebie i, kiedy czegoś nie wiedział, bezczelnie blagowat. Strumyk wił się kapryśnie i, skacząc żwawo po kamieniach zaścielających dno, wesoło sobie bulgotał. ${ }^{10}$

Changes in punctuation with reference to all punctuation marks should always be indicated when they restore the meaning of a particular sentence or a larger fragment of the text, or when they are traces of a choice between different options. As has been mentioned in Section 4, the most detailed documentation of changes in punctuation should accompany lyrical texts, in which case its modernisation should also be particularly careful with reference to the basic text. In the sections: Narrative poems, Dramas and Artistic prose, only the more important changes are to be indicated, while in the sections Journalistic prose and Letters - only the exceptionally important ones. Particularly significant changes in punctuation should be explained in the introduction to the editorial critical apparatus.

For internal quotes, the " " symbol is used, while for texts ending with a full stop and put in parenthesis - the full stop is placed after the closing bracket). No

9 E. Przyłubska and F. Przyłubski, Gdzie postawić przecinek?, (Warszawa: Wiedza Powszechna, 1967), p. 55.

10 Examples taken from E. Przyłubska and F. Przyłubski, Gdzie..., pp. 56, 57. 
quotation marks are used for clearly separated epigraphs and longer quotes that are graphically marked in the text.

\section{1}

In Norwid's French texts, the spelling mistakes of individual words (e.g., ne ce pas $\rightarrow$ n'est-ce pas), accents, punctuation, and grammatical errors (e.g., Mon Bon Madame) should be corrected in accordance with the norms of the contemporary French language, without indicating these mistakes. As a general rule, obvious syntactic (word order) and semantic errors (improper lexical use) are kept with the correct version of the text provided in Explanations. In the case of mistakes (gaps) which make the text illegible (e.g., a lack of the subject in the sentence), such gaps should be filled in square brackets. Consultation with a specialist in Romance studies and even further collaboration is essential. The editorial team's consultant in this matter is Dr. Władysław Kwiatkowski (Lublin) who collaborates with Szczepan Babiński, MA.

\section{2}

When it comes to the graphic layout of the texts, the editor should follow the suggestions found in the basic text, in particular the autograph - this, inter alia, applies to the spatial layout of title elements. The same applies to the structure and layout of stanzas, chapters, parts, paragraphs, etc. of works. The lines of dots and asterisks which outline the spacing between unnumbered sections should be preserved in accordance with the autograph. If in rhyming works divided into irregular wholes there is doubt (both in the basic text and in DzWsz) as to whether the page border also marks the border of the whole, the editor should discuss (explain) it in the text's editorial remarks. New paragraphs should be introduced only exceptionally, in clearly motivated cases - on account of the content and taking into consideration pauses, which in manuscripts are sometimes marked with "tirets" or spaces between the lines. All of the poet's footnotes should be placed in accordance with his intention (at the bottom of the column with reference to or following the main text); deviations from this rule should be explained in Editorial remarks. References used by Norwid in manuscripts (a circle with a dot in the middle, etc.) should be replaced with asterisks. Signatures below the texts should also be retained, for example, below the text of Rzecz o wolności stowa [On the Freedom of Speech]: "AMDG C. N." (Ad Maiorem Dei Gloriam Cyprian Norwid).

If needed, some careful changes to the text's "architecture" are allowed. This concerns the consistent layout of paragraphs, larger fragments of prose texts, 
stanzas, and verse sequence - within a larger part of the work or its entirety. It can be particularly important in the case of dialogical texts: both in dramas and in dialogues that are part of the narration in poems. The aim is to achieve greater legibility of the text and not the order itself, therefore self-restraint is recommended here, especially when the changes concern autographs. One can become familiar with such attempts at "architectural" changes in the edition of Promethidion in the Polish Library (Kraków 1997). All the more important changes to the text's "architecture," and in particular the principles of such changes, should be discussed in the critical apparatus, preferably in Editorial remarks. Such changes also involve the introduction of new or the elimination of existing paragraphs in Norwid's texts. Paragraphs introduced by the publishers, but eliminated in DzWsz will not be indicated.

Concerning letters - details provided by the author, which relate to the time and place of the letter's origin are left unchanged if they are contained within the basic text. All the details about the time and place, that is, also the details established by the editor, are provided (without the week day) below the "titles" of the letters ("Do..." [“To...”]); for the letters written in French, such details are provided in Polish.

The documentation of text references is made easier by numbering every fifth verse - both in poetry and in prose, whereby the following are not numbered: title, dedication, epigraph, signature (details concerning the work signed by the author), date and place of the text origin, etc. For letters - each verse of the text is numbered. With the exception of letters and letter-stylized works, Norwid's conventional signatures, which inform the authorship, are not retained - these are only mentioned in Editorial remarks in the context of the description of an autograph or first edition. The signature at the end of the work can be retained in special cases, for example, when it completes the information on the author from the title page (as in Promethidion) or when it forms part of signature, for example, Tłomaczył Cyprian Norwid 1864.

\section{3}

Typographical emphasis used by Norwid should be preserved, for example, block capitals, capital letters. The whole words written in majuscules (capital letters) are rendered in print as block capitals; additional emphasis in such cases is indicated in writing (Example 1). As for Norwid's various ways of implementing horizontal emphasis, only one level of emphasis should be used, the same applies for single and multiple emphases - this will be realised in print as italics. Double and triple emphasis should be indicated in Variants (Example 2). Enlarged small 
letters and bolder letters are treated as ordinary linear emphasis, but it should be additionally indicated in Variants (Example 3). When a text in an autograph is simultaneously emphasised through the enlargement (or boldface) of small letters and double or triple underlining; capital letters should be used (Example 4). Variants should also contain possible initials. Neither the main text, nor Variants take into account the diversity of emphasis found in an autograph with regard to its shape (wavy, broken line), method of writing (ink, pencil), and colour. ${ }^{11}$

The titles of books, articles, journals, works of art, and quotes appearing in Norwid's texts are marked with quotation marks, regardless of whether or not these are marked in the basic texts with quotation marks, ${ }^{12}$ underlining or are not marked at all. If the basic text contains both quotation marks and underlining, the editor decides whether to use both methods of emphasis (if he considers the underlining to play an emphasising role - this is particularly important in the case of quotes) or keeps only the quotation marks (if he thinks that both the quotation marks and the underlining have the same function, which is emphasis). Sometimes, exceptionally, in a particular context, it can be recognised that the underlining itself simultaneously has two functions: that of quotation marks and emphasis. There may be cases (mainly in the case of works of art) when the name of the work (especially if incomplete) is not a title sensu stricte, for example, Apollo, Madonna; in such cases - if the name is not marked - no quotation marks are used. It may also occur that a quote (most frequently slightly changed) is included in the text without special marking. In such cases the editor, upon the analysis of the context, decides whether the quote should be marked by quotation marks or - if he recognises that the lack of marking was intentional - it should be left without quotation marks and the sources will be provided in Explanations. Editors should bear this in mind especially in the case of paraphrases.

Words of foreign origin are not marked graphically, since their foreign character is already a kind of emphasis. However, if they are underlined in the basic text, such underlining should be retained, provided that after the analysis of the context it can be assumed that this emphasis was intentional.

11 Of course, all of this is taken into account, along with the time of writing for the critical analysis of the text and while justifying the editorial decision.

12 However, the text's genre-related names are used without quotation marks, but are emphasised only with capital letters, for example, Dedykacja [Dedication], Przedmowa [Foreword], Pieśń [Song], Nekrolog [Obituary], unless such a name is the title given by the author to an important part of the work. 
Vertical emphasis is not rendered graphically, but it should be indicated in Variants. In the printed texts forming the basis in which emphasis is marked by spaces, it is difficult to determine whether one-letter prepositions and conjunctions are also emphasised. It seems (it can be observed in autographs and first editions where italics were used for emphasis) that the writer usually emphasised them when they preceded an emphasised word with which they formed a clear whole (e.g., $z$ czym, $w$ sobie), whereas within a longer emphasis he did not emphasise them if they represented difference or contrast between the adjacent words (e.g., słowo ludu i słowo społeczeństwa). This should be taken into account in making editorial decisions and it is worth noting in Editorial remarks whether the emphasis in the printed basic text is marked by italics or spaces.

All emphasis in Variants is to be marked by semi-bold italics (see Example 2), regardless of how it was marked in the previous editions (by space, italics, or roman type). Emphasis in Editorial remarks is marked by the use of italics, as was adopted in DzWsz, whereas in quotes within the editor's text - in accordance with the way it was used in the source of the quote.

\section{Examples Ad. 13}

\section{Example 1}

Naprzód: MĘDRZEC_PUSTELNIK] MĘDRZEC-PUSTELNIK in atg capital

letters and underlining were used; Najprzód: MĘDRZEC-PUSTELNIK Gom

(Rzecz o wolności słowa IV, w. 1; podstawa atg; w Odmianach uwzględnia się atg, pdr, Pini, GomPWsz, GomWyb ${ }^{2-3}$ ) [Rzecz o wolności słowa IV, v. 1; basic text atg; in Variants atg, pdr, Pini, GomPWsz, GomWyb ${ }^{2-3}$ are complied with]

\section{Example 2}

Czytelnik uważny] in atg uważny underlined twice

(„Psalmów-psalm,” Dedykacja, w. 18; podstawa atg; w Odmianach uwzględnia się atg, pdr, Pini, GomPWsz, GomNWyb) [“Psalmów-psalm," Dedykacja, w. 18; basic text atg; in Variants atg, pdr, Pini, GomPWsz, GomNWyb are complied with]

\section{Example 3}

Z napisem „jestes!!'] in atg jesteś - bold font

(Psalmów-psalm VII, 180; podstawa atg; w Odminach uwzględnia się jw.) [Psalmówpsalm VII, 180; basic text atg; in Variants as above]

\section{Example 4}

Jaki też jest CEL-SŁOWA...] in atg cel-słowa has enlarged letters

and double underlining; Jaki też jest cel słowa... pdr; Jaki tez jest cel słowa? Pini; Jaki też jest CEL-SŁOWA... Gom

(Rzecz o wolności słowa I, w. 50; podstawa atg; w Odmianach uwzględnia się jw. w Przykładzie 1) [Rzecz o wolności słowa I, v. 50; basic text atg; in Variants as in example 1] 


\section{4}

The following editorial symbols have been adopted for DzWsz:

] - separates the main text quote from its variants in Variants.

$<>\quad-$ crossing out, blurred fragment or the poet's revisions.

[... - text fragment omitted by the editor.

[] - text completed by the editor.

[?] - undeciphered text.

- uncertain reading.

$<[?]>\quad$ - crossed out, blurred or revised text - undeciphered; this symbol should be supplemented with information (in writing) on what was undeciphered: letter(s), word(s).

[- - ] - damaged text.

\section{5}

The following rules should be observed when using abbreviations in the editorial text of DzWsz:

a) abbreviations should always be maximally readable;

b) libraries are usually marked with the letter $B$ and the abbreviated name of the library: BJag, BNar, etc.;

c) journals with compound titles are usually marked with the first letter of the first word and the abbreviated second word: RLit, SNor;

d) traditionally common abbreviations should be preserved: PamLit, AGAD, BN. ${ }^{13}$

13 List of abbreviations used in these Guidelines: atg - autograph; BorProm - Cyprian Norwid, Promethidion, text checked and revised by W. Borowy, (Warszawa, 1951); Cyw - Cyprian Norwid, Wybór poezyj [Selection of Poetry], compiled by S. Cywiński, (Kraków: Krakowska Spółka Wydawnicza, 1924); DzWsz - Cyprian Norwid, Dzieła Wszystkie [The Complete Works] (see fn. 1 in these Editorial guidelines); Gom all editions by J. W. Gomulicki, in which this text appears; GomNWyb - Cyprian Norwid, Nowy wybór poezji [New Selection of Poetry], selected and compiled by J. W. Gomulicki (Warszawa: PIW, 1996); GomProm - Cyprian Norwid, Promethidion. Rzecz $w$ dwóch dialogach $z$ epilogiem [Promethidion. A Work in Two Dialogues with an Epilogue], introduction and commentary by Antoni Zaleski [J. W. Gomulicki] (Warszawa: Czytelnik, 1989); GomPWsz I-XI - Cyprian Norwid, Pisma wszystkie [Collected Works], Vols. I-XI, selected, edited, and with introduction and critical commentaries by J. W. Gomulicki, (Warszawa: PIW, 1971-1976); GomWyb ${ }^{1-3}$ - Cyprian 


\section{Bibliography}

Bajerowa, Irena. Polski język ogólny XIX wieku. Stan i ewolucja, Vol. II: Fleksja. Katowice: Uniwersytet Śląski, 1992.

Norwid, Cyprian. Pisma zebrane. Vols. A (parts 1-2), C, E, ed. Zenon Przesmycki. Warszawa-Kraków: Wydawnictwo Jakuba Mortkowicza, (1911-[1913]); Vol. F, ed. Wacław Borowy. Kraków: Wydawnictwo Jakuba Mortkowicza, 1946.

Norwid, Cyprian. Promethidion. Ed. Roman Zrębowicz. Warszawa: Ignis, 1922.

Norwid, Cyprian. Wybór poezyj. Ed. Stanisław Cywiński. Kraków: Krakowska Spółka Wydawnicza, 1924.

Norwid, Cyprian. Dzieła. Ed. Tadeusz Pini. Warszawa: Parnas Polski, 1936.

Norwid, Cyprian. Promethidion. Ed. Wacław Borowy. Warszawa, 1951.

Norwid, Cyprian. Poezje, Vols. I-II, ed. Mieczysław Jastrun and Juliusz Wiktor Gomulicki. Warszawa: PIW, 1956.

Norwid, Cyprian. Pisma wybrane, Vols. I-V, ed. Juliusz Wiktor Gomulicki. Warszawa: PIW, 1968, 1980, 1983.

Norwid, Cyprian. Pisma wszystkie, Vols. I-XI, ed. Juliusz Wiktor Gomulicki. Warszawa: PIW, 1971-1976.

Norwid, Cyprian. Promethidion. Rzecz w dwóch dialogach z epilogiem. Ed. Antoni Zaleski [Juliusz Wiktor Gomulicki]. Warszawa: Czytelnik, 1989.

Norwid, Cyprian. Nowy wybór poezji. Selected and compiled by Juliusz Wiktor Gomulicki. Warszawa: PIW, 1996.

Norwid, Pisma wybrane [Selected Works], Vols. I-V, selected and compiled by J. W. Gomulicki, Warszawa: PIW, $\left(1968^{1}, 1980^{2}, 1983^{3}\right)$; JastrGom - Cyprian Norwid, Poezje [Poetry], Vols. I-II, selected and with introduction by M. Jastrun, texts edited and chronology determined by J. W. Gomulicki (Warszawa: PIW, 1956); PamLit Pamiętnik Literacki; pdr - first edition; Pini - Cyprian Norwid, Dzieła [Works], ed., with explanations and critical introduction by T. Pini (Warszawa: Parnas Polski, 1934), Przesm 1 A-F - Cyprian Norwid, Pisma zebrane [The Collected Works], Vols. A (parts 1-2), C, E, ed. by Z. Przesmycki (Warszawa-Kraków: Jakub Mortkowicz, 1911[1913]); Vol. F, ed. by W. Borowy, Kraków (1946); fn. - footnote; SJAM - Słownik języka Adama Mickiewicza [Dictionary of Adma Mickiewicz's Language]; Swar Słownik Warszawski [Warsaw Dictionary]; VM - Vade-mecum; v. - verse; ZrębProm Cyprian K. Norwid, Promethidion, compiled by R. Zrębowicz (Warszawa: Towarzystwo Wydawnicze Ignis, 1922 [recte 1921]). 
Przyłubska, Anna and Feliks Przyłubski. Gdzie postawić przecinek? Warszawa: Wiedza Powszechna, 1967.

Puzynina, Jadwiga. Słowo Norwida. Wrocław-Warszawa-Kraków-GdańskŁódź: Zakład Narodowy im. Ossolińskich, 1992.

Rudnicka, Jadwiga. "Jak Brockhaus wydawał Norwida." Studia Norwidiana, Vol. 8, 1990, pp. 123-131. 



\title{
Zdzisław Łapiński \\ A Poet of the Senses ${ }^{1}$
}

\begin{abstract}
The chapter attempts to explain sensual depictions that are constantly present in Norwid's works - albeit they are sometimes hidden - by means of cognitivist categories. Taking two texts as an example, the author shows two different ways, in which the poet uses these depictions. A passage from the drama Cleopatra and Caesar illustrates Norwid's technique of realistic description, and the poem "Fate" - his technique of allegory.
\end{abstract}

Keywords: Cyprian Norwid, incarnation, senses, mirror neurons, allegory, simulation

In the past, Norwid would have been called "a poet of the intellect" and "a poet of culture." Danuta Zamącińska once teasingly juxtaposed these worn-out phrases with the expression "a poet of strong emotions." Closer consideration shows that she was in fact right, although there is no need to reject the first two characterizations. Still, would it not seem bizarre to call Norwid "a poet of the senses"?

Admittedly, this chapter does not attempt to trace all the various sensual themes in Norwid's work. It seeks merely to indicate several strategic moves made by the poet in order to express his conviction that human corporeality and the material nature of the world are essential components of the larger reality.

Returning to the scarcely questionable thesis about Norwid as "a poet of the intellect," it has to be admitted that he did scale the highest peaks of general truths. However, he also wished to trace the internal process by which he arrived at such universal conclusions, bearing in mind that this process begins with the reception of the basic information about the world provided by our senses. And Norwid was able to relish it in a spirit of disinterestedness, less for itself than for whatever slice of reality it gave access to. This is the first function of the senses in Norwid's poetics - one that is quite self-evident and easy to interpret.

Let us then begin by reminding ourselves of how suggestive Norwid can be, if he is so minded, when sketching images of a world accessible through the senses.

1 This text is a slightly amended version of a paper delivered by the author on the occasion of being awarded the Norwid Foundation Medal "For Contributions to the Popularization of Works by Cyprian Norwid” (John Paul II Catholic University, Lublin, 10 December 2012). 
Consider the following monologue from the drama Kleopatra i Cezar [Cleopatra and Caesar] (Act II, Scene 6), delivered by the Knight, a supporting character:

To szczególna rzecz jest...

Każde miejsce inakszą ma nocy-symfonię!

$\mathrm{Tu}$ - zaczyna się ona huczną wesołością, Spadającą oklasków i śmiechów kaskadą

Na bruk miejski, przez lżejsze akordy. - Następnie

Tony te milkną - - ptaków nocnych słychać poświst -

Szczekanie psa nad brzegiem kanału - plusk w wodzie -

Wykrzyk daleki jakiejś wątpliwej natury -

Uciszenie głębokie - -

- potem szelest drobny

Niewieściego trzewika, lub flet, który zaczął,

Lecz nie dokonał pieśni... potem jakby ducha

Niedotkliwego smętek w powietrzu - i spadek

Jednego listka na bruk - - potem wielka

Nocna cisza!...

- Aż nagle, gromada wielbłądów

Szłapie, z rżącymi osły - koła tętnią - - wreszcie,

Przeklinania woźniców... i modły poranne!

(PWsz V, 107-108)

[This is something special ...

Each place has its own symphony of the night!

Here begins the thunderous merriment,

A cascade of applause and laughter falling

On the city cobblestones, followed by lighter notes. - Then

These sounds fall silent - - night birds' trilling is heard -

The barking of a dog by the canal - a splash in the water -

Some distant cry of dubious nature -

A deep silence -

Then the slight rustle

Of a lady's shoe, or a flute that began,

But never finished a tune... then, something akin

To a hint of sadness in the air - a lone leaf

Falls on the cobbles - - and then the vast

Silence of the night!...

2 Cyprian Norwid, Pisma wszystkie, ed. J. W. Gomulicki, vols. 1-11 (Warszawa: PIW, 1971-1976); hereinafter referred to in abbreviated form as "PWsz" with the volume number in Roman numerals and page numbers in Arabic numerals. 
- Suddenly, a herd of camels

Trudges, along with neighing donkeys - clattering wheels - finally,

Cursing coachmen... and morning prayers!]

In this passage, Norwid directs our attention to the nightlife of an ancient city. It could well be considered one of the most directly experienced images he ever wrote. However, the Knight, who speaks these words, perceives this "first-hand" reality not visually but audibly. These are sounds that spontaneously evoke images originally experienced, in every detail, visually. However, we learn about them through words. Although words indeed have acoustic potential themselves, in this particular example they do not imitate the "symphony" described here in any direct way.

Moreover, the Knight does not speak of current events but recalls a memory. Furthermore, Norwid does not present the night scene as something directly imagined by the character (as would be the case in an internal monologue in a lyrical work), but as a soliloquy (i.e., a specific, highly conventionalized internal monologue delivered on stage). Thus, we approach the last phase of mediation it is, after all, a dramatic work, "tragedia historyczna ściśle w równi do grania, jako i do odczytów napisana” (PWsz V, 7) ["a historical tragedy equally suitable for the theatre and for reading"]. This means that readers have to process a good deal of preliminary information to enable them to concretize a fuller image of the urban night scene described. Actually, all the levels mentioned are able to capture the reader's attention, leading to a more complete concretization. In a theatrical context, no images can cast a veil over perception by the eye-witness of a live actor present on the stage.

Returning to readers, however, and to their relationship with Norwid's actual printed text, the above-mentioned multi-storey structure of cognition and imagination has to be complemented by our mental processing of the writing on the page. Indeed, the very physical character of books can attract our attention, as was the case with Norwid in his childhood ("Epos-nasza" ["Our Epic"], where he says "Bo nawet odcień pamiętam papieru" (PWsz I, 158) ["I even remember the paper's shade of colour"]).

However, when we read or listen to the above passage from Kleopatra i Cezar, all the mental processes just referred to generally take place without any conscious effort on our part. We are not preoccupied with them; our attention is focused rather on the final phase of the cognitive process, namely the emergence of the image of an ancient city at night. This is because such activities are to a large extent subconscious. We may become aware of them only after numerous readings, and an understanding of the mental processes involved demands a specialized knowledge of psychology, to which we shall return later. At this stage, let 
us only note that the effectiveness of the imagery in the passage quoted derives mainly from the fact that the Knight conjures up events in his imagination on the basis of sounds as readily as if he had actually witnessed everything. We are in turn infected with this effortlessness and succumb to the illusion that everything is being unveiled directly before our eyes.

At this point, I would like to turn to the other pole of Norwid's work, moving away from evocative accounts of sensual phenomena to conceptual, allegorical structures.

When considered against the backdrop of the great Polish Romantic poets, who had a penchant for symbolic forms, Norwid's predilection for allegory is striking. He engaged with allegory in many different ways, applying it both in all seriousness and light-heartedly, in his own writing as well as in comments on other authors (thus practising allegoresis). Usually, however, his allegories are rather odd, because they do not carry clear meanings, whereas lack of ambiguity is regarded as an indispensable feature of allegory.

Since the era of Romanticism, allegory has been considered an anachronistic form. The Romantics discovered that poetry is a form of intuitive cognition, which is irreducible to empirical or speculative understanding. It is metaphor and symbol that prove to be the best tools for intuitive cognition. Allegory, on the other hand, would emerge in this light as a pictorial explication of abstract contents - a form adequate only for simpletons.

Today, however, the situation is different. Since the spread of ideas developed by Walter Benjamin (1892-1940) in his study of German baroque drama (1925), allegory has acquired a more sophisticated meaning, although from a popular perspective the Romantic curse still weighs heavily on it. In the light of this, Czesław Miłosz, for example, expressed the following reservation in his discussion of the Song of Songs (in the introduction to his Polish translation of the Five Megillot):

[...] if the word "allegory" seems too cold and limited, since it indicates a certain mask of discourse, while the word "symbol" appears warm, deep and multi-layered, then the Song of Songs could be called a symbolist poem that can be read simultaneously on several different levels. These various levels do not enter into conflict with each other. Quite the contrary, they support and enrich each other. ${ }^{3}$

A similar disregard for terminological subtleties of descriptive poetics can be encountered in many other writers, including specialists in literary studies. For example, Raymond W. Gibbs, one of the leading cognitivists specializing in the

3 Księgi pięciu megilot, trans. Czesław Miłosz (Paris: Instytut Literacki, 1982), p. 25. 
theory of metaphor, is inclined to use the term "allegory" in reference to most elaborate metaphorical expressions. ${ }^{4}$

Nevertheless, even if one preserves the traditional distinction between allegory and symbol, it is clear that allegories abound in Norwid's poems, dramas, fiction, and criticism. He employs them primarily as means of expression, though allegory can sometimes become a subject in itself, as in "Ad leones!" - an allegorical story (or a symbolic one if we insist on differentiating between the two) about the fate of allegory in Norwid's times. On the other hand, a clear example of allegoresis as a tool of literary criticism is provided by his lectures on Juliusz Słowacki.

When speaking of allegory, it is difficult to overcome the deeply rooted conviction that this device is not very effective for expressing one's inner experiences and emotions. Perhaps this is the reason why some of Norwid's openly allegorical poems sparked so much controversy. Allegory seems easier to reconcile with the parable-like character of longer narratives. However, a real dilemma is posed by lyric verse. Several Norwid specialists have already tackled this issue, the earliest of them being Marian Maciejewski and Michał Głowiński. ${ }^{5}$ These authors, and others, have approached the problem of allegory as related to the process of creating meaning. I have chosen a simpler task; I do not intend to investigate the meanings. Instead, I have chosen a poem in which everything is quite clear, ${ }^{6}$ namely "Fatum" ["Fate"] from the Vade-mecum cycle. Let us recall it here in full:

4 R. W. Gibbs, "The Allegorical Impulse," Metaphor and Symbol, Vol. 26, No. 2 (2011), pp. 121-130.

5 Marian Maciejewski, "Norwida Fatum ukrzyżowane," in: 'ażeby ciało powróciło w stowo'. Próba kerygmatycznej interpretacji literatury (Lublin: Redakcja Wydawnictw KUL, 1991), pp. 131-146; Michał Głowiński, "Norwida wiersze-przypowieści i ciemne alegorie Norwida," in: Intertekstualność, groteska, parabola. Szkice ogólne i interpretacje (Kraków: Universitas, 2000), pp. 244-278 \& 279-292. The question of how Norwid himself understood the concept of allegory is discussed by Anna Kozłowska in the article titled "'Symbol,' 'parabola' i 'alegoria' w pismach Cypriana Norwida," in: Symbol w dziele Cypriana Norwida, ed. W. Rzońca (Warszawa: Wydział Polonistyki Uniwersytetu Warszawskiego, 2011), pp. 9-24 (the issue of allegory is also taken up by most other authors of this volume).

6 It needs to be noted, however, that not all critics regard this poem as straightforward. It has, in fact, posed problems for translators. Cf. the paper by Anna Krasuska entitled "Niejednoznaczność składniowa w cyklu 'Vade-mecum' Cypriana Norwida w świetle francuskich przekładów," delivered at a session organized by Warszawskie Koło Norwidologiczne [Warsaw Circle of Norwid Studies] and Pracownia Słownika Języka Cypriana Norwida [Cyprian Norwid Lexicographical Research Group] (Warsaw, 18 February 2013). 
Jak dziki zwierz przyszło Nieszczęście do człowieka

I zatopiło weń fatalne oczy...

- Czeka - -

Czy, człowiek, zboczy?

II

Lecz on odejrzał mu, jak gdy artysta

Mierzy swojego kształt modelu;

I spostrzegło, że on patrzy - co? skorzysta

Na swym nieprzyjacielu:

I zachwiało się całą postaci wagą

- - I nie ma go!

(PWsz II, 49)

[ I

Such beastly Anguish, human-baiting,

With fateful eyes transfixed its prey...

- Waiting - -

Now will he turn away?

II

Instead the stare was fair returned As artists size up subjects top to toe Aware the human had discerned What gain he'd draw from such a foe It shuddered to its very core

- And it's no more! $]^{7}$

Formally speaking, this poem features two comparisons. However, the first of them immediately develops into a narrative. As Cicero once observed, allegory is metaphor expanded to tell a story (or rather - if we can correct Cicero - allegory is an elaborate comparison). In contrast to these allegorical readings, which pose so many problems to those attempting to interpret Norwid's works, the quoted poem's conceptual sense is expressed directly - it is "nieszczęście" ["Anguish"]. However, the title announces something different. The Latin word fatum carries connotations which differ from those of the Polish lexeme nieszczęście [anguish],

7 Cyprian Kamil Norwid, "Fatum” and "W Weronie," translated by Patrick Corness, The Sarmatian Review, no 1, vol. XXXIII (2013), p. 1728. 
because it contains a semantic component denoting the irreversible, necessary, and irrefutable character of the event described using this category.

Of course, from the perspective of the poem as a whole, it becomes clear that it represents a vividly constructed polemic with the ancient philosophy of fate and its modern continuations. As Bishop Józef Życiński writes, "One needs to remember that a pessimistic faith in ominous fate has nothing to do with the truth of the Gospels."

This is basically the poem's message - a rather ingenuous one, although it could acquire subtler shades in the light of other works by Norwid. For example, Marian Maciejewski outlined the broader horizons of Christian imagination and sensibility that could be attained by taking this brief poem as the starting point.

"Fatum" is part of the Vade-mecum cycle, which was intended to demonstrate to the Polish readership what true lyricism was. In accordance with lyrical principles, the story presented is temporally compressed and unveils in the blink of an eye. The "eye" appears to be crucial here because time is measured in moments necessary to exchange glances and to withstand this exchange. However, can we really speak of "lyrical principles" in this case?

Assuming - following Hegel and the genologists - that the chief distinguishing feature of the lyric is subjectivity, then it is exactly the opposite situation that is involved here. This is neither an internal monologue nor an address to another person. It is impossible to detect in this poem any mention of, or allusion to, the identity of the subject. The protagonist of the event described is likewise anonymous: "człowiek" ["a human being"], "quidam." The whole situation takes place outside time and empirical space, in the world of universals.

The dispute regarding universals - which first started in the late Middle Ages was actually at the heart of deliberations on the crisis of allegory in its heyday, that is, the era of the baroque. According to some, this was related to the loss of faith in the reality of general ideas - a faith that had previously allowed such extensive recourse to allegoresis and allegory, adopting the former as a technique of interpretation and the latter as a means of artistic expression. On the other hand, nominalism (the belief that only concrete beings exist) leads, when taken to its logical conclusion, to a total paralysis of both philosophy and literature. This, Angus Fletcher argues, opens the door to one variant of modern allegory "allegory devoid of abstract ideas":

8 Józef Życiński, Ziarno samotności (Kraków: Znak, 1997), p. 237.

9 Here the author refers to Norwid's poem Quidam where the main protagonist Quidam stands for everyone or anybody. [translator's comment] 
The average reader, schooled [...] on the traditional model or on a watered-down version of it, will be baffled by the thought of an allegory without ideas. How can that be? An allegory without ideas would at best seem to be a paradox, not unlike the Liar's Paradox - impossible, but logically and formally necessary. ${ }^{10}$

Further, Fletcher develops his concept in an interesting though convoluted way. I will not comment on it, limiting myself to the observation that his theory seems to resemble, at first glance, Michał Głowiński's theses about Norwid's "dark allegories" and "stirred forms" ["formy poruszone"]. However, this affinity is only apparent. Norwid remains firmly opposed to the perverse line of development of allegory in our own times, a topic addressed by Fletcher. Nevertheless, the Polish poet anticipated some other 20th-century variants of allegory.

Let us return to the poem in question. Maciejewski subordinates its message to the more general trend of Norwid's poetry: "ażeby ciało powróciło $\mathrm{w}$ słowo" ["so that flesh can return to the word"], elaborating on the meaning of this phrase (borrowed from Mickiewicz) on the basis of this very poem. I would like to reverse the direction of enquiry and trace echoes of corporeality in the word itself.

We say that "I met with misfortune" and in our subconscious mind we immediately anthropomorphize this abstract concept (i.e., it was not that I met with misfortune; rather it came across me.) "Oko w oko" ["eyeball to eyeball”], on the other hand, is a popular expression, widely represented in the National Corpus of the Polish Language. ${ }^{11}$ Its meaning is often literal, or - to put it more precisely - it is a synecdoche, as demonstrated in the following quotation: "Surely, few readers will have the occasion to meet a wild animal, eyeball to eyeball, in its natural environment." However, the phrase can just as frequently take on a metaphorical meaning, as in another quotation: "eyeball to eyeball with viral marketing." This expression had exactly the same meaning in Norwid's time, although Polish speakers did not have the opportunity to learn about "viral marketing."

Thus, we speak about meeting "eyeball to eyeball" not only a person, but also an object. In the latter case, we have a metaphor whose meaning has become obscured. However, in both cases Polish phraseology retains the sensual origin of abstract ideas. ${ }^{12}$ As is well known, poets eagerly return to such sources in order to make their messages easier to grasp.

10 A. J. S. Fletcher, “Allegory without Ideas,” boundary 2, Vol. 33, No. 1 (2006), p. 84.

11 See: www.nkjp.uni.lodz.pl (accessed 28 October 2013).

12 An excellent introduction to the question of sensual themes in contemporary phraseology is contained in an article by Anna Pajdzińska entitled "Wrażenia zmysłowe jako podstawa metafor językowych,” Etnolingwistyka, Vol. 8 (1996), pp. 113-130. 
As regards anguish, the states of mind it creates, and the means of imaginatively representing them, I will mention an example drawn from real life. A certain Russian dissident from the Soviet era (I cannot recall where and when I read about him) described how he overcame fear during the never-ending NKVD interrogations. He would attempt to imagine his anxiety states as black lumps that he would then throw behind himself into some undefined external space. The technique worked, greatly surprising the investigators who faced, eyeball to eyeball, a dead-calm prisoner.

The scene described in "Fatum" is much richer in imaginative detail, but the psychological mechanism adopted by Norwid's protagonist is similar to the one that helped the Soviet prisoner. In the poem, the abstract state of misfortune does not turn into an undefined object but into a predator preparing to leap. The predator's behaviour brings to mind a big cat: a tiger or a leopard. The protagonist identifies with the predator's muscle tension and responds with his own, even greater, psycho-physical tension. A similar situation is found in a circus during lion-taming performances. Readers in turn identify with this fictional, anonymous figure as if they were witnessing a real event.

Let me add one more recollection. Many years ago, Gustaw Holoubek - an actor endowed with hypnotic powers - entered a lion's cage during a charity event organized to support sick children, and everything followed exactly as in the poem.

Let us now move on from these anecdotal examples to more structured knowledge about the human psyche. For over fifty years, major developments in this field have been made by cognitive psychologists. In Poland, fruitful research in this area has been conducted at the John Paul II Catholic University in Lublin under Professor Piotr Francuz.

Modern cognitive psychology has adopted as one of its fundamental tenets the concept of the "embodied mind," replacing the "abstracted" model that dominated earlier. Other related terms include "embodied consciousness" and the "embodied 'I"' What follows from this is that even the most unconnected thoughts and refined states are related to our being located in a world that is no longer viewed as an object of disinterested contemplation but as a space for our actions. These internal processes could be called a "sensory motor loop" because in our minds a constant exchange takes place between information derived from external sources and impulses initiating physical actions, somehow prompted by our neurons. Therefore, our cerebral cortex is the stage on which a continually revised rehearsal of our actions takes place, even if these actions would be impossible to put into practice. And so, even when we think in terms detached from a given situation, considering, for example, purely abstract topics, our thoughts 
can imitate certain forms of physical behaviour. For example, experiments have demonstrated that even the very concept of "concept" can be concretized in the imagination as an object that can be "grasped," considered from many angles, and disassembled into its constituent parts. That is why we can believe Norwid when he says that "I każdy wiersz ten miałem w mojej dłoni,/Jak okrętową linę w czasie burzy" ["And I held every poem in my palm,/Like a hawser in a storm"] (“Czy podam się o amnestię?” PWsz I, 260; [“Shall I Request an Amnesty?"]).

Already in the second half of the 19th century, German psychologists discovered something they called Einfühlung. Today, following the Anglo-Saxon tradition, we refer to this as "empathy," lending a moralizing tone to the term. However, it used to have an ethically neutral meaning. The concept was employed to denote all those human experiences that accompany intense observations of the outside world, causing witnesses to feel that they were actively participating in what they were seeing. These hypotheses were developed later in Gestalt psychology. However, it was not until the last quarter of a century that certain facts confirming this could be established on an empirical basis. This especially concerns the famous "mirror neurons" responsible for simulation processes accompanying human perception. As it turns out, whether we act ourselves or merely observe the actions of others, the same areas of our brains are activated. This is the reason why we can acutely feel the things that happen to others before our eyes.

If we combine the above information about simulation processes with information about the sensual origin of abstract concepts, we may perhaps find an important clue that could help unravel Norwid's enigma and understand how he managed to make such abstract ideas as fatum almost tangible, allowing us to practically feel them on our skin and in our muscles.

"Fatum" is a very unconventional poem. At the same time, however, it is radically arbitrary, if we are to measure the situation it depicts in terms of the distance from all literally conceived situations. The first part of the poem features a comparison that begins to materialize into a dramatically presented event. In the second part, however, the author soon introduces another comparison derived from an entirely different domain. First, it is the jungle and then, suddenly, the artist's studio. One allegorical situation is thus constructed on top of another, producing something like a "budding" allegory. It is hardly surprising, therefore, that some critics found such a combination of domains shocking. After all, this precludes homogeneous concretization of representations in the imagination.

When certain literary critics or historians trace hidden sensual elements in a poetic text, other readers can easily find fault in this, arguing that they see nothing of the kind. It is true that literary imagery can be concretized by some 
readers in the form of conscious images, while others may not experience such concretizations at all. Hence the old dispute between advocates and opponents of the thesis that "visual clarity" is one of the features of poetic language.

However, cognitive psychology shows us - once again - that our mental images do not have to be fully concretized in order to be convincing. They do not have to become precise equivalents of perceptual representations. In many cases these are merely outlines of overlapping, continually changing, images. Nevertheless, they do allow us to feel a certain sensual, conceptual, and dynamic reality. What is more, they can remain subconscious yet still determine our cognitive processes, acting virtually undetected.

With greater enthusiasm than other poets of his period, Norwid employed such literary devices as personification, parable, symbol, and allegory. All of them exploit elements of empirical reality - those readily available to the senses - in order to convey other meanings, be they conceptual, abstract, or intuitive, reaching beyond the boundaries of rational knowledge. In each case, however, we encounter parallels between sensually embraceable facts and facts of an entirely different order.

At this point it might be added - following suggestions made by Michał Głowiński - that although allegory could seem anachronistic against the background of Romantic poetics, from the perspective of 20th-century poetics it may be regarded as pioneering. This is confirmed, for example, by such famous poems as Czesław Miłosz’s "Biedny chrześcijanin patrzy na getto" [“A Poor Christian Observes the Ghetto"] and "Ars poetica?" or by numerous works by Zbigniew Herbert, for example, "Pieśń o bębnie" ["The Drum Song"]. The last-mentioned poem reminds us of another well-known fact, namely that the so-called "Aesopian language," which became so popular in Poland after October 1956, is in fact a variant of allegory, whereas the contemporary mode of reading theatrical classics as a single, extended allusion to the People's Republic of Poland (as noticed by Leszek Kołakowski) is, of course, a clear example of allegoresis.

Contemporary cognitivists have developed the concept of the embodied mind by proposing hypotheses and then submitting them to experimental tests. Norwid arrived at similar conclusions in a purely intuitive way, justifying them by referring to the sphere of his deepest beliefs, namely the belief in Incarnation. He would base various normative claims on his faith, both those regarding individual life and those related to social processes. This explains his polemic with the Romantic desire to overcome human corporeality, and his poetics of embodied intellect. 


\section{Bibliography}

Fletcher, Angus. "Allegory without Ideas." Boundary 2, Vol. 33, No. 1, 2006, pp. $77-98$.

Gibbs, Raymond W. “The Allegorical Impulse." Metaphor and Symbol, Vol. 26, No. 2, 2011, pp. 121-130.

Głowiński, Michał. "Norwida wiersze-przypowieści i ciemne alegorie Norwida.” In: Intertekstualność, groteska, parabola. Szkice ogólne i interpretacje. Kraków: Universitas, 2000, pp. 244-292.

Kozłowska, Anna. “'Symbol,' 'parabola' i 'alegoria' w pismach Cypriana Norwida." In: Symbol w dziele Cypriana Norwida, ed. Wacław Rzońca. Warszawa: Wydział Polonistyki Uniwersytetu Warszawskiego, 2011, pp. 9-24.

Księgi pięciu megilot. Trans. Czesław Miłosz. Paris: Instytut Literacki, 1982.

Maciejewski, Marian. "Norwida Fatum ukrzyżowane.” In: 'ażeby ciało powróciło $w$ słowo'. Próba kerygmatycznej interpretacji literatury. Lublin: RW KUL, 1991, pp. 131-146.

Pajdzińska, Anna. "Wrażenia zmysłowe jako podstawa metafor językowych." Etnolingwistyka, Vol. 8, 1996, pp. 113-130.

Życiński, Józef. Ziarno samotności. Kraków: Znak, 1997. 


\section{Illustrations}




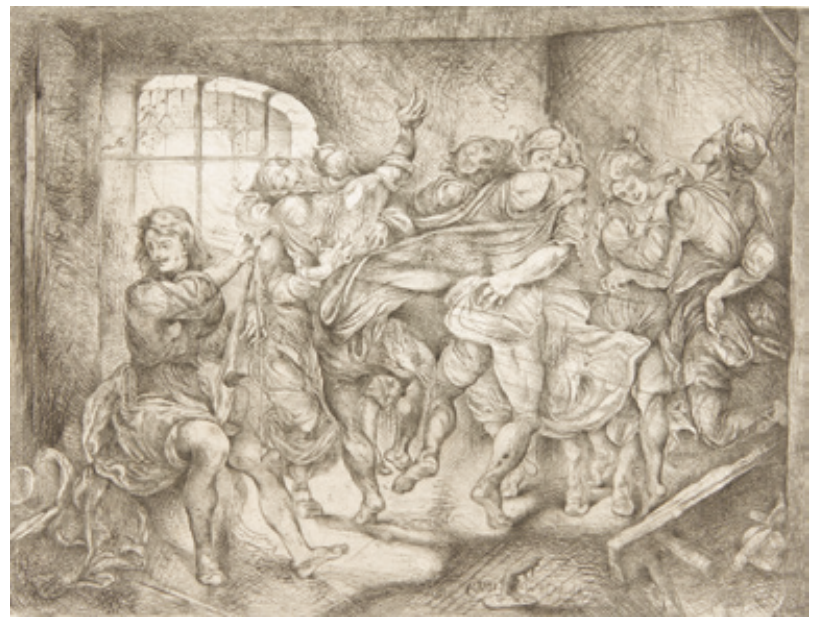

Fig. 1: Cyprian Norwid, "Le Musicien inutile," 1867, etching, National Museum in Kraków/The Princes Czartoryski Museum. Photo Jakub Płoszaj, Karol Kowalik.

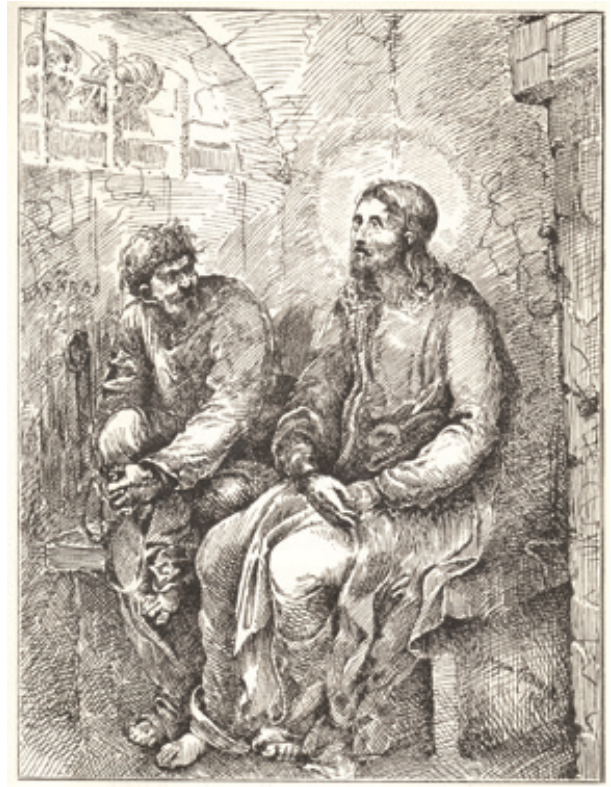

Fig. 2: Cyprian Norwid, "Chrystus i Barabasz" ["Christ and Barabbas”], 1856, lost drawing. Photo after: Chimera, 1904, Vol. VIII, No. 22-23-24, p. 5. 


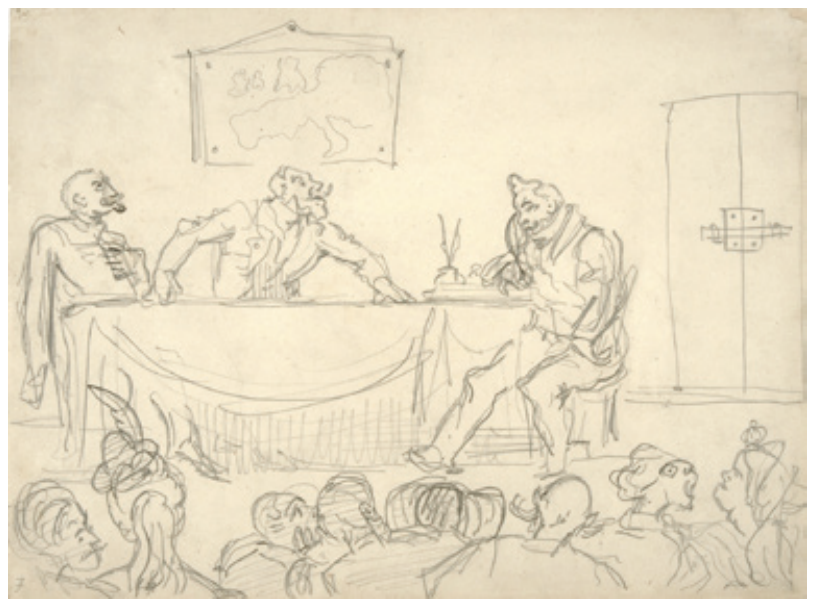

Fig. 3: Cyprian Norwid, "Zebranie emigracyjne” ["Emigre Meeting”], ca. 1870, drawing, National Library in Poland. Photo National Library in Poland.

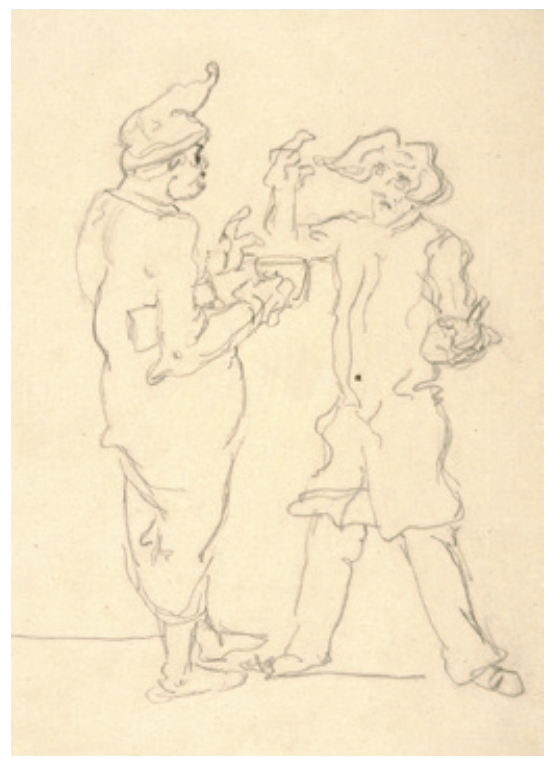

Fig. 4: Cyprian Norwid, "Sąsiedzi w Zakładzie Św. Kazimierza w Paryżu” ["Neighbours at the CEuvre de Saint-Casimir in Paris"], ca. 1877, drawing, National Library in Poland. Photo National Library in Poland. 


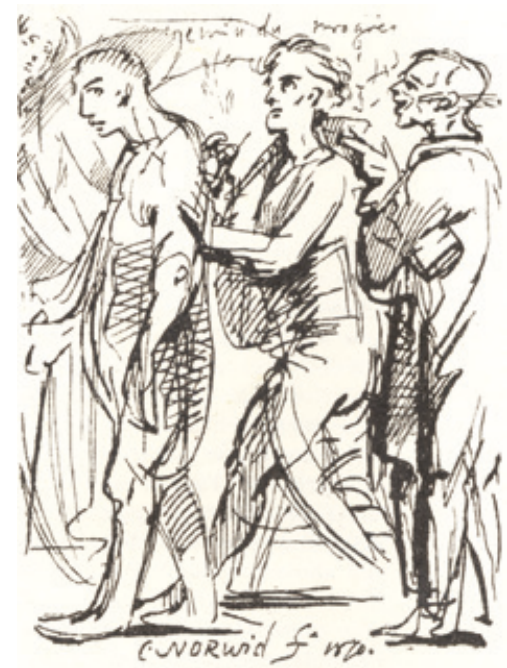

Fig. 5: Cyprian Norwid, “Chemin du progrès," 1870, lost drawing. Photo after: Chimera, 1904, Vol. VIII, No. 22-23-24, p. 428.

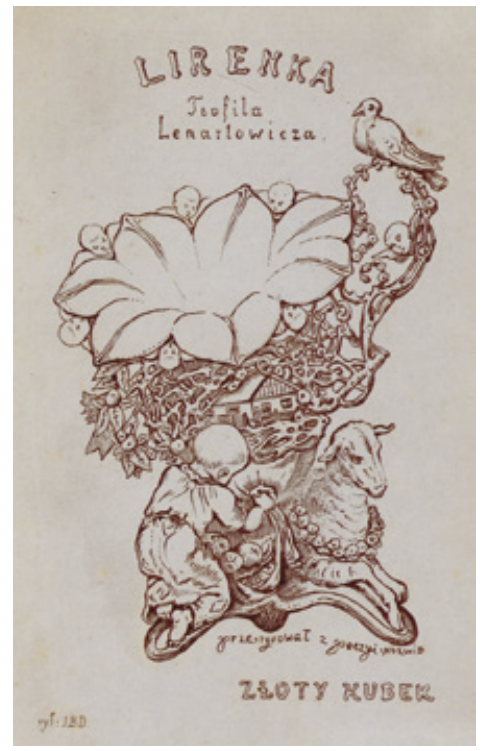

Fig. 6: Cyprian Norwid, "Złoty kubek” [“A Golden Mug”], 1855, copperplate from the cover designed by Norwid for Lirenka by T. Lenartowicz, published by J.K. Żupański (Poznań, 1855). 


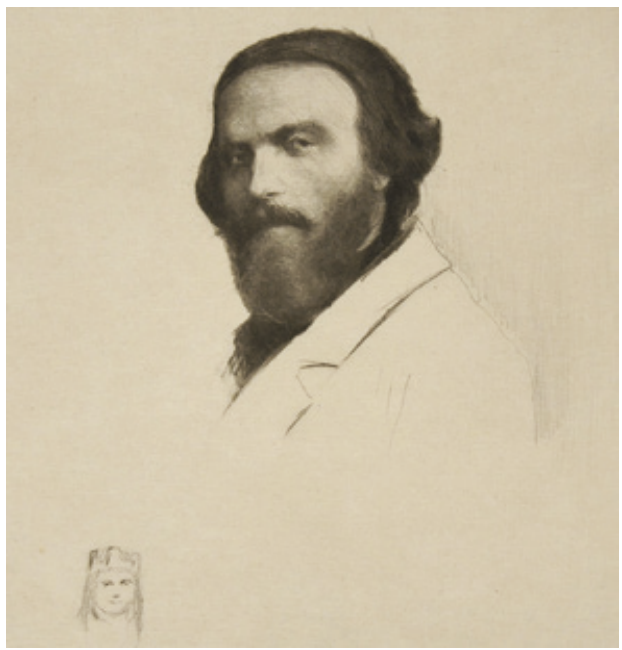

Fig. 7: Franciszek Siedlecki, "Portrait of Cyprian Norwid," 1904, etching, National Library in Poland. Photo National Library in Poland.

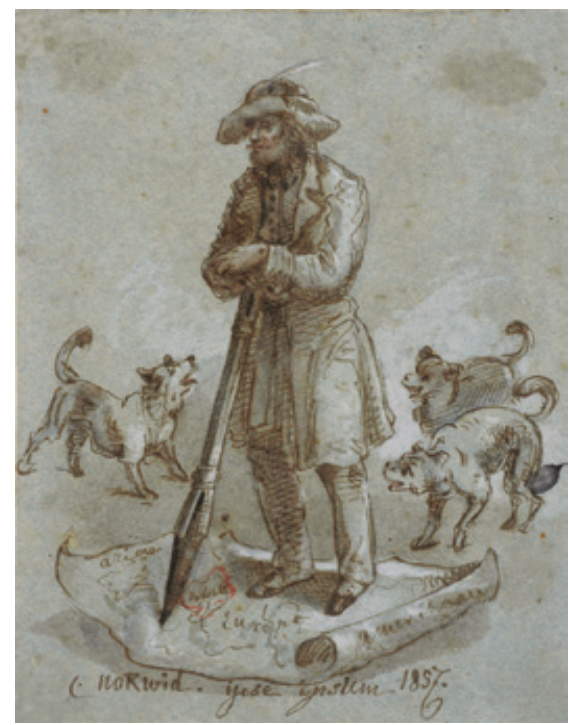

Fig. 8: Cyprian Norwid, "Ipse ipsum," 1857, drawing, watercolour, National Library in Poland. Photo National Library in Poland. 


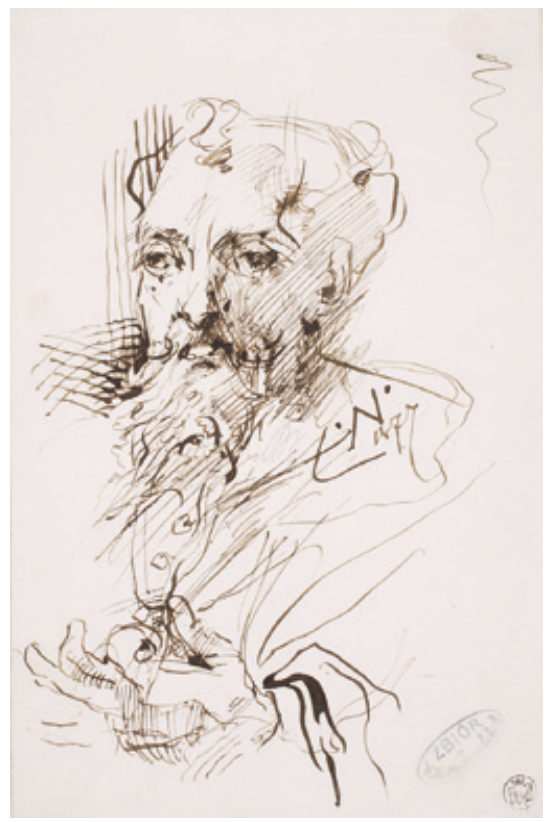

Fig. 9: Cyprian Norwid, "Autoportret" ["Selfportrait”], 1877, drawing, National Museum in Warsaw. Photo Piotr Ligier.

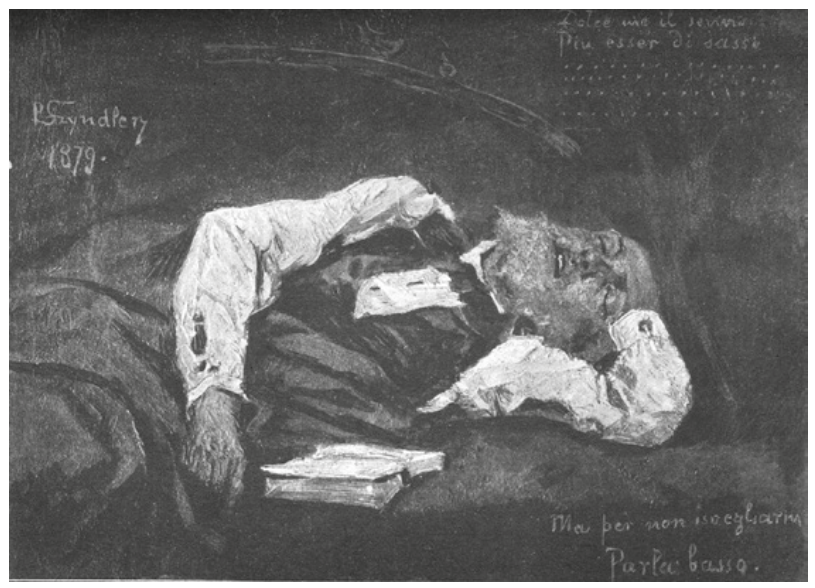

Fig. 10: Pantaleon Szyndler, "Norwid śpiący" ["Norwid Asleep"], 1879, oil on canvas, National Museum in Warsaw (damaged). Photo after: Chimera, 1904, Vol. VIII, No. 22-23-24, p. 295. 


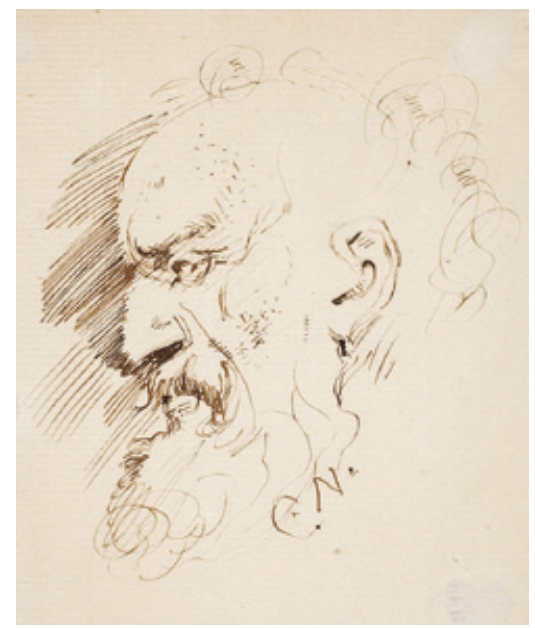

Fig. 11: Cyprian Norwid, "Autoportret" ["Selfportrait”], around 1880-1883, drawing, National Museum in Warsaw. Photo Piotr Ligier.

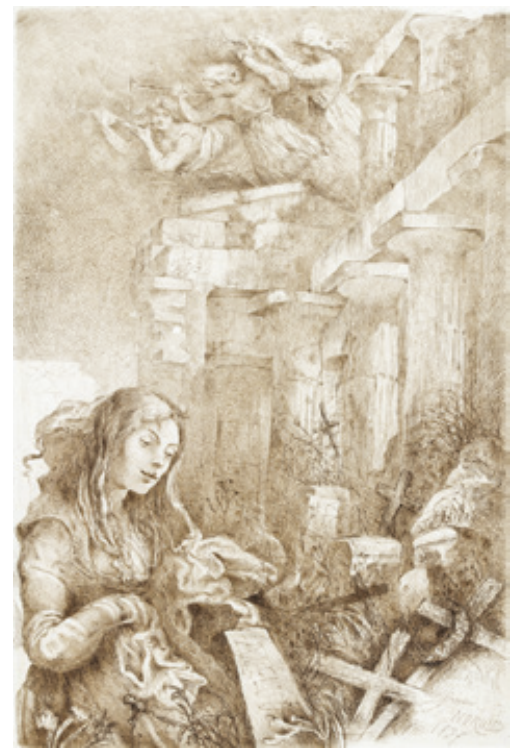

Fig. 12: Cyprian Norwid, "Alleluja I" ["Alleluia I"], 1857, etching, National Museum in Warsaw. Photo Piotr Ligier. 


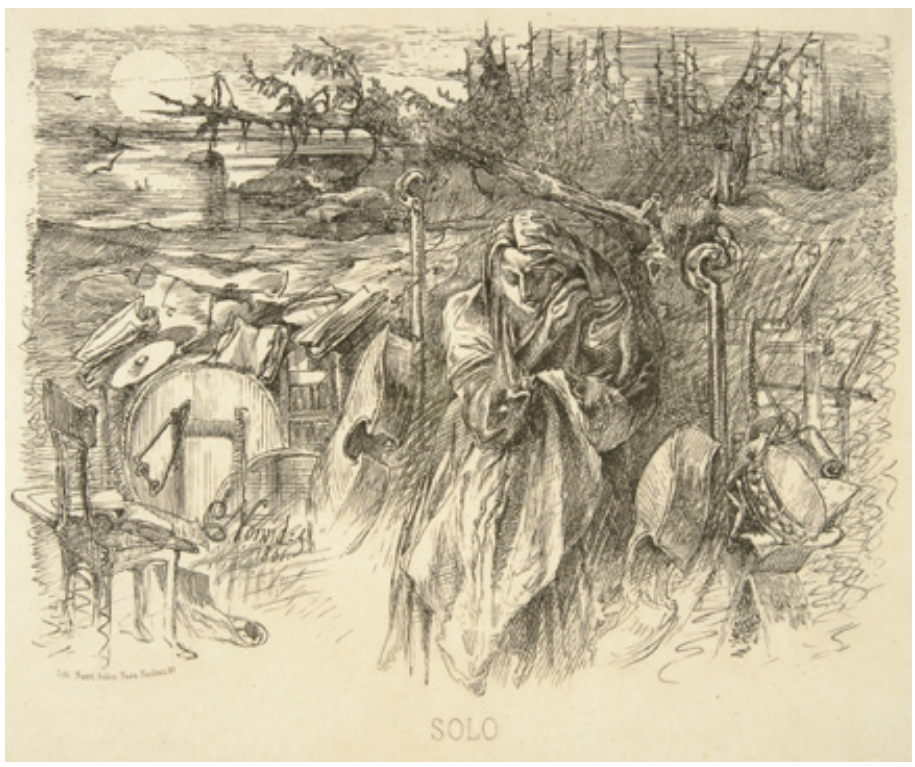

Fig. 13: Cyprian Norwid, "Solo," 1861, lithograph, National Library in Poland. Photo National Library in Poland.

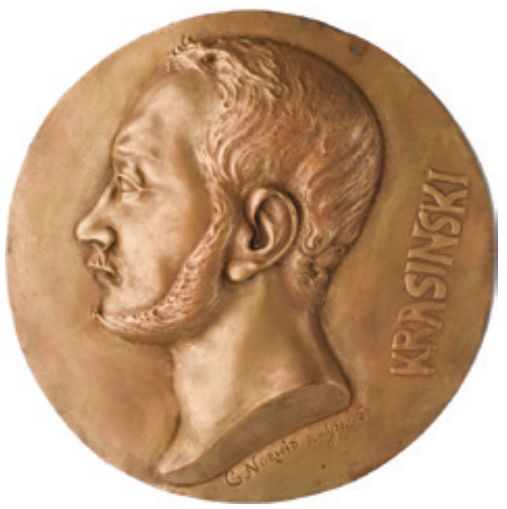

Fig. 14: Cyprian Norwid, "Medalion Zygmunta Krasińskiego" ["Medallion of Zygmunt Krasiński”], 1860, Fr. Józef Jarzębowski Museum in Licheń Stary. Photo Jerzy Czarny. 


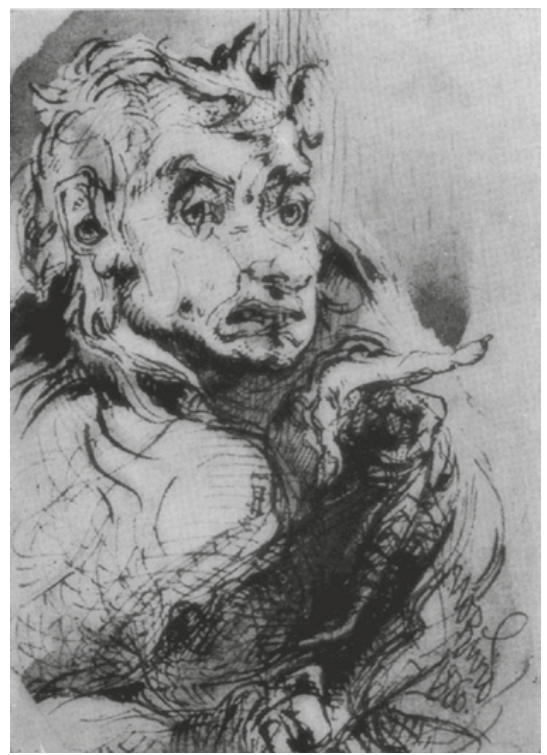

Fig. 15: Cyprian Norwid, "Karykatura leonardowska" ["Leonardesque Caricature"], 1860, lost drawing. Photo in National Library in Poland.

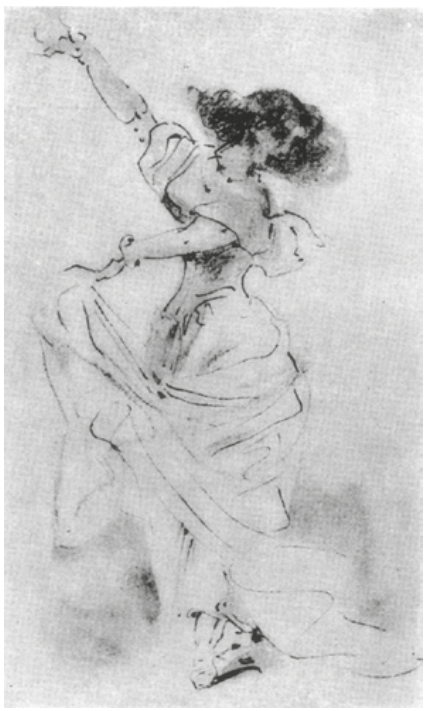

Fig. 16: Cyprian Norwid, “Tancerka” ["Female dancer”], lost drawing. Photo in National Library in Poland. 


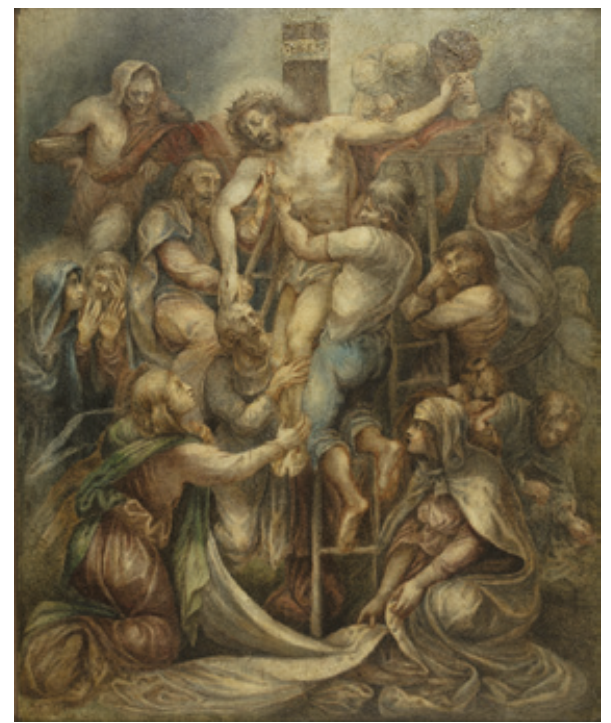

Fig. 17: Cyprian Norwid, "Zdjęcie z krzyża," [“The Descent from the Cross”], 18561857, watercolour, National Museum in Warsaw. Photo Piotr Ligier.

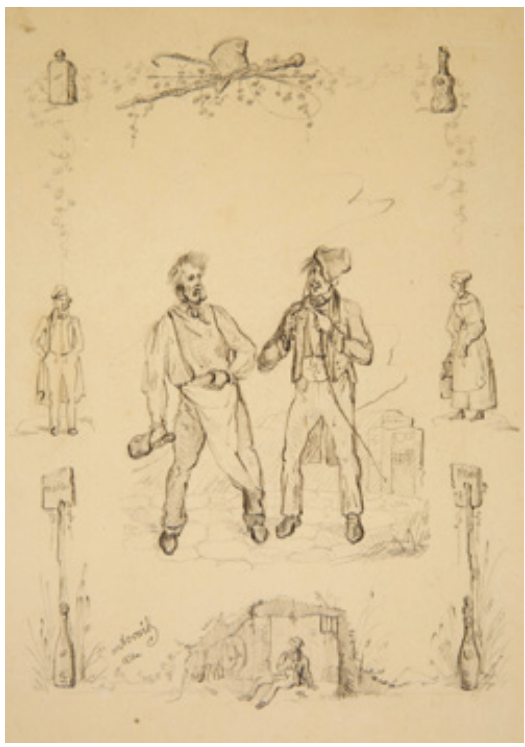

Fig. 18: Cyprian Norwid, "Pijacy," [“Drunkards"], 1838, drawing, National Museum in Kraków. Photo Karol Kowalik. 


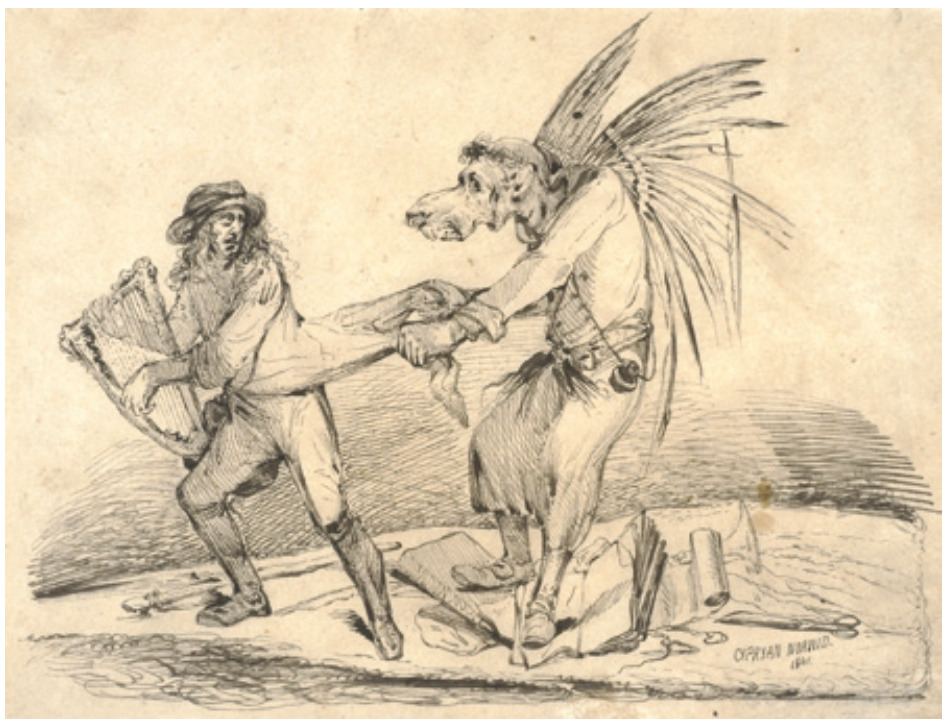

Fig. 19: Cyprian Norwid, “Zoilus," 1841, drawing, National Library in Poland. Photo National Library in Poland.

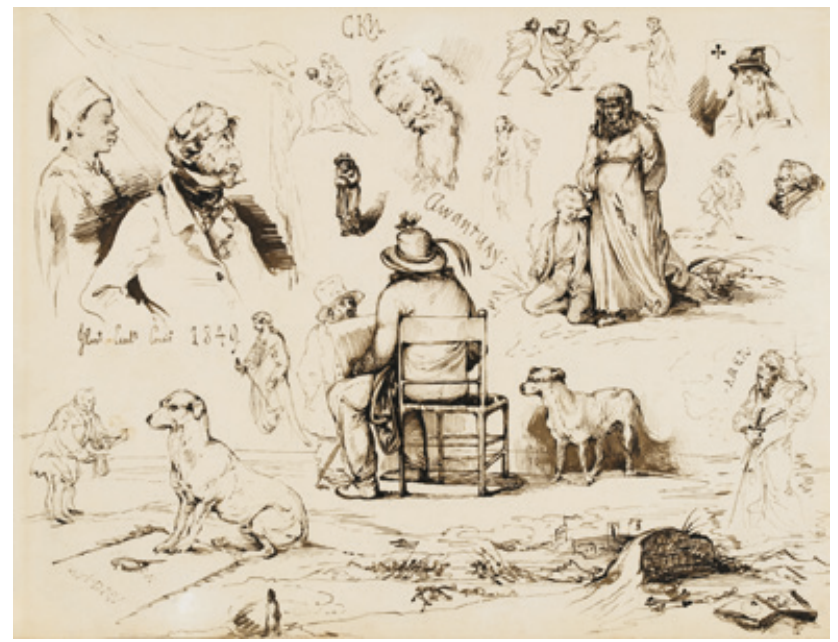

Fig. 20: Cyprian Norwid, "Awantury arabskie I," ["Arabic adventures I"], 1848, drawing, National Museum in Warsaw. Photo Piotr Ligier. 


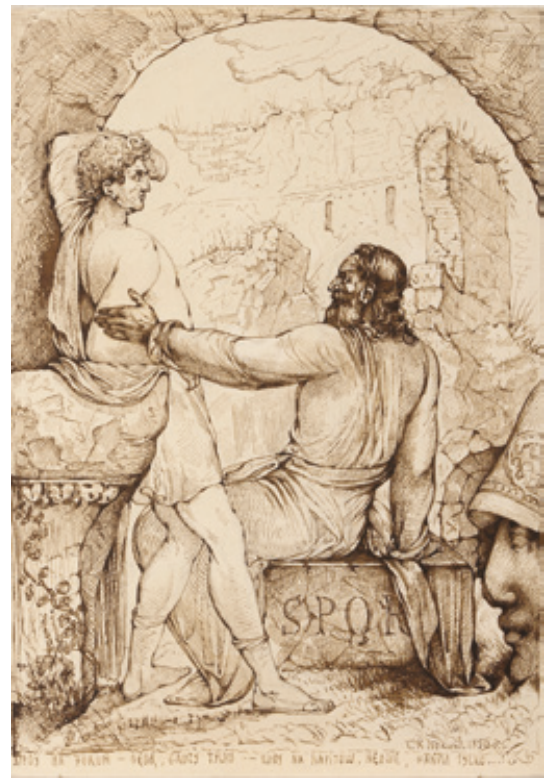

Fig. 21: Cyprian Norwid, "Irydion i Masynissa" ["Irydion and Masynissa"], 1850, National Museum in Warsaw. Photo Piotr Ligier.

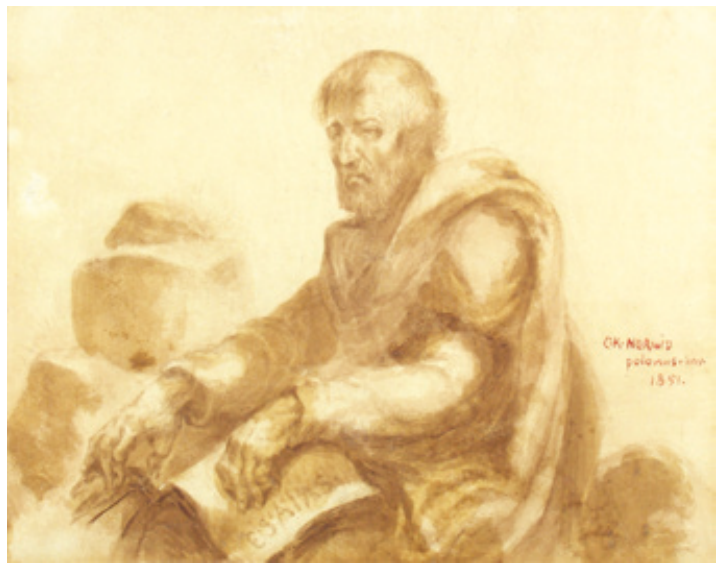

Fig. 22: Cyprian Norwid, “Izajasz," ["Isaiah”], 1851, drawing, The Adam Mickiewicz Museum of Literature in Warsaw. Photo The Adam Mickiewicz Museum of Literature in Warsaw. 


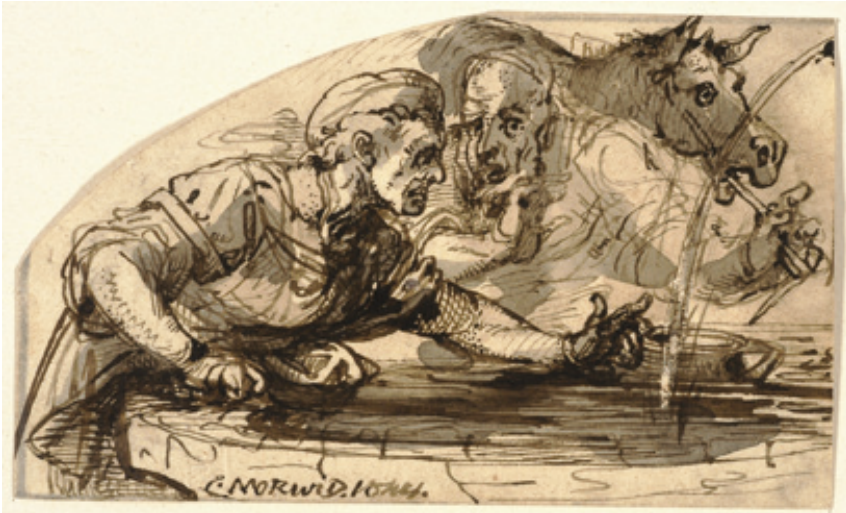

Fig. 23: Cyprian Norwid, "Plotki u wodopoju" ["Rumours at the Waterhole"], drawing, 1844, National Library in Poland. Photo National Library in Poland.

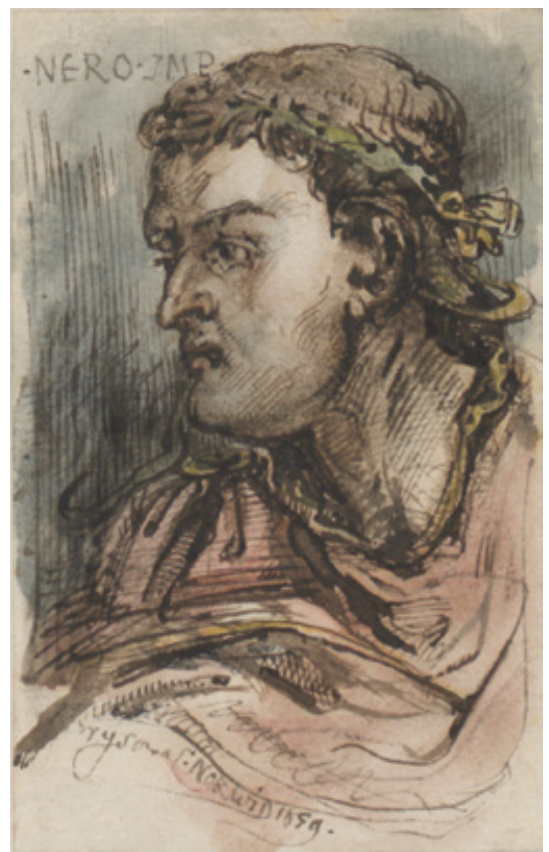

Fig. 24: Cyprian Norwid, "Neron" ["Nero"], 1859, watercolour, National Library in Poland. Photo National Library in Poland. 


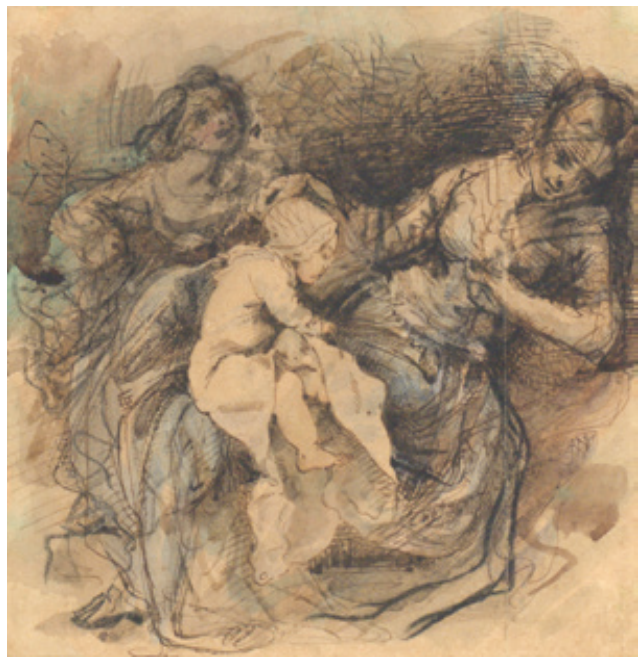

Fig. 25: Cyprian Norwid, "Dwie kobiety z dzieckiem" ["Two Women with a Child"], 1868, drawing, National Library in Poland. Photo National Library in Poland.

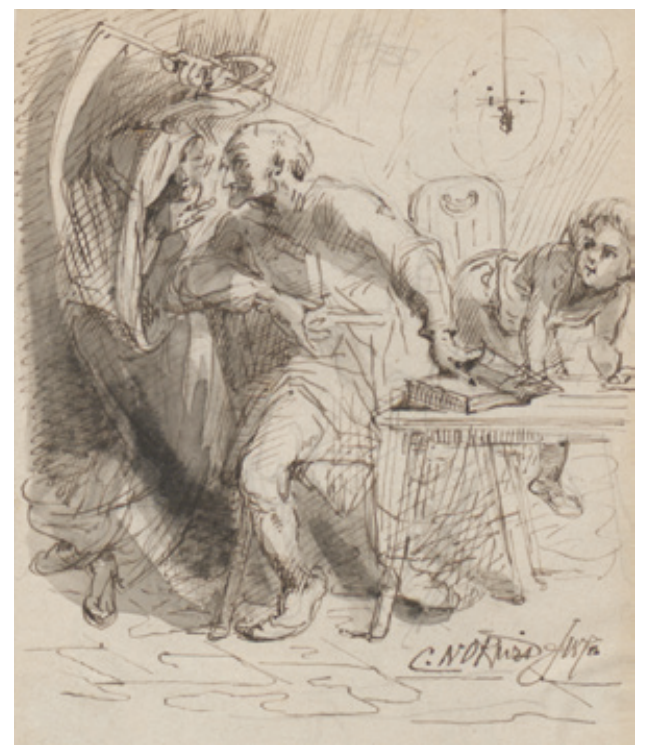

Fig. 26: Cyprian Norwid, "Śmierć, starzec i dziecko" ["Death, an Old Man and a Child"], National Library in Poland. Photo National Library in Poland. 


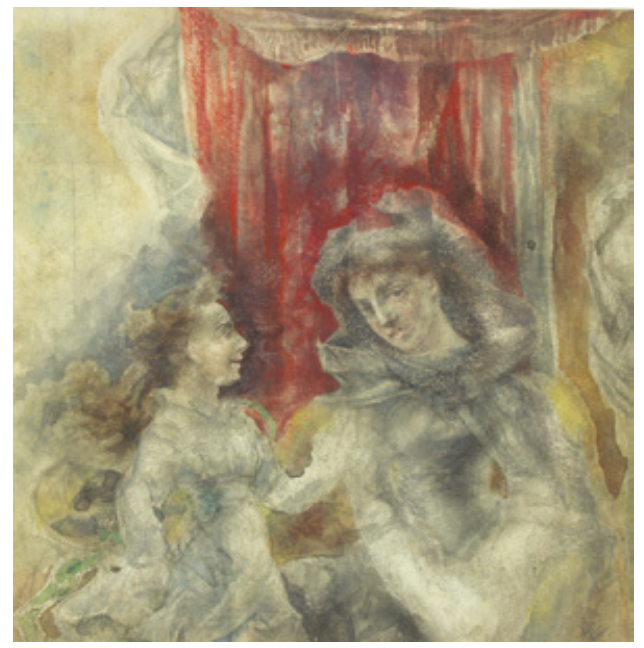

Fig. 27: Cyprian Norwid, "Opowiadanie" ["The Story”], ca. 1870, watercolour, The Adam Mickiewicz Museum of Literature in Warsaw. Photo The Adam Mickiewicz Museum of Literature in Warsaw.

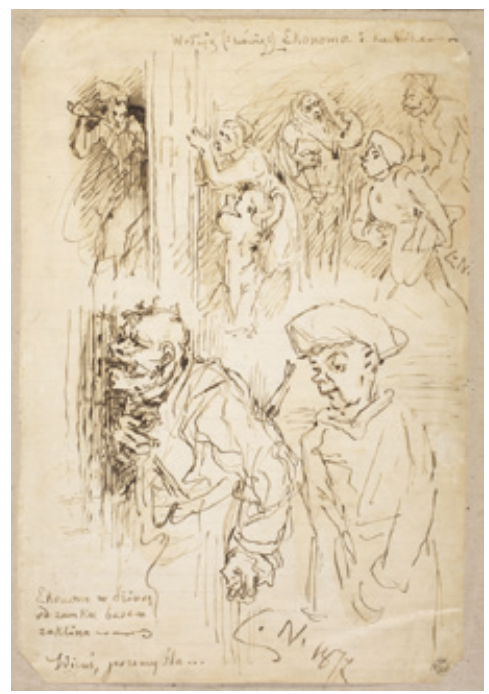

Fig. 28: Cyprian Norwid, Klary Nagnioszewskiej samobójstwo [The suicide of Klara Nagnioszewska], p. 3, 1877, National Museum in Warsaw. Photo Piotr Ligier. 



\section{Text Sources ${ }^{\star}$}

Zenon Przesmycki, "From notes and documents on Cyprian Norwid" as: "Z notat i dokumentów o C. Norwidzie", Chimera, 1904, t. VIII, no. 22-23-24, p. 419-445.

Kazimierz Wyka, “Norwid’s old age”, as: “Starość Norwida”, Droga, 1933, No. 11, pp. 1095-1105.

Wacław Borowy, "Norwid the poet", as: "Norwid poeta", in: Pamięci Cypriana Norwida. Warszawa, 1946, pp. 32-49.

Jerzy Sienkiewicz, "Norwid the painter", as: "Norwid malarz", in: Pamięci Cypriana Norwida. Warszawa, 1946, pp. 61-77.

Wacław Borowy, "Leading motifs in Norwid’s poetry", as: "Główne motywy poezji Norwida”, Zeszyty Wrocławskie, 3: 1949, No. 1-2, pp. 1-25.

Irena Sławińska, "Norwid’s producing hand", as: "Reżyserska ręka Norwida", Przeglad Humanistyczny, IV (1964), pp. 19-37.

Jan Błoński, "Norwid among the great-grandchildren", as: "Norwid wśród prawnuków”, Twórczość, 1967, No. 5, pp. 67-94.

Sławomir Świontek, "Norwid's theatre of the world", as: "Norwidowski teatr świata", Pamiętnik Literacki, 1971, No. 3, pp. 33-50.

Juliusz Wiktor Gomulicki, "Introduction to Cyprian Norwid's 'Pisma wszystkie", as: "Wstęp", in: Cyprian Norwid, Pisma wszystkie, Vol. 1. Warszawa: PIW, 1971, pp. VII-XXXIX.

Elżbieta Felisiak, "The world of Norwid's thought", as: "Norwidowski świat myśli", in: Polska myśl filozoficzna i społeczna, Vol. 1: 1831-1863, ed. A. Walicki. Warszawa: Książka i Wiedza, 1973, pp. 545-593.

Michał Głowiński, “Norwid’s poem-parables", as: “Norwida wierszeprzypowieści", in: Cyprian Norwid w 150-lecie urodzin. Materiały konferencji naukowej 23-25 września 1971, ed. M. Żmigrodzka. Warszawa: PIW, 1973, pp. $72-109$.

Stefan Sawicki, "On Norwid's poetic semantics", as: “Z zagadnień semantyki poetyckiej Norwida", in: Poetyka i stylistyka słowiańska: materiały konferencji Komisji Poetyki i Stylistyki Słowiańskiej Międzynarodowego

* Two articles by Zofia Stefanowska: "Norwid's romanticism" and "The Writer of the age of trade and industry" were planned to be included in this volume. The author's heirs did not consent to the publication of these texts. 
Komitetu Slawistów. Warszawa, 18-20 kwietnia 1972, ed. S. Skwarczyńska. Wrocław: Ossolineum, 1973, pp. 73-80.

Edward Kasperski, "The Problem of questions in Norwid's work", as: "Problem pytań w twórczości Norwida”, Przegląd Humanistyczny, 1977, No. 6, pp. 49-67.

Danuta Zamącińska, "Discovering Norwid's poetry", as: "Poznawanie poezji Norwida”, Studia Norwidiana, 1983, Vol. 1, pp. 5-30.

Michał Głowiński, "Norwid’s obscure allegories", as: "Ciemne alegorie Norwida", Pamiętnik Literacki, 1984, No. 3, pp. 103-114.

Antoni Dunajski, "Norwid and theological tradition", as: "Norwid wobec tradycji teologicznej", Studia Norwidiana, 1990, Vol. 8, pp. 15-22. Jadwiga Puzynina, "Norwid's concept of the 'Whole”, as: "Całość Norwida", in: Całość w twórczości Norwida, eds. J. Puzynina, E. Teleżyńska. Warszawa 1992, pp. 55-71.

Stefan Sawicki, "Publishing guidelines for Cyprian Norwid's 'Dzieła Wszystkie” ", as: "Instrukcja wydawnicza 'Dzieł wszystkich' Cypriana Norwida”, Roczniki Humanistyczne, 2003, No. 1, pp. 103-124.

Zdzisław Łapiński, “A poet of the senses”, as: “Poeta zmysłów”, Studia Norwidiana, 2013, Vol. 31, pp. 5-15. 


\section{Index of Names}

A

Abbott Claude Colleer 20

Abd el Kader 58, 104, 124, 129, 188, 195, 323

Abrams Meyers Howard 472, 478

Acecka-Poklewska Danuta 254

Achremowiczowa Wanda 157, 162,172

Adler Gerhard 446, 463

Aeschylus 226

Ajdukiewicz Kazimierz 408, 414, $415,419,424$

Ambrose, St. 482

Anczyc Władysław Ludwik 13, 31, 256, 257, 259, 268

Anselm of Canterbury 485

Aristotle 318

Athanasius the Great, St. 482

Auden Wystan Hugh 17

Auerbach Erich 286, 336, 342, 371

Augustine, St. 482-485

B

Babiński Szczepan 531

Baczyński Krzysztof Kamil 182, 212

Bajerowa Irena 513, 521, 522, 536

Bakhtin Michaił 406

Baliński Krzysztof 15

Balzac Honoré de 138, 146

Bałucki Michał 169, 176

Barańczak Stanisław 16, 17, 20, 22, 23, 447

Barański J. 65

Bartels Artur 331

Bartelski Lesław 260

Bartnik Czesław 484, 489

Bartoszewicz Władysław 253

Bartynowski Władysław 63, 70
Basil, St. 74, 482

Baudelaire Charles 18, 36, 95, 200-202, 240

Bauman Zygmunt 507, 510

Bayrav Sucheyla 369, 371

Belizarius 361

Bem Antoni Gustaw 466

Bem Józef 124, 129, 195

Benjamin Walter 542

Bentkowski Władysław 12, 21, 243, 245

Benveniste Émile 340, 371

Bereżyński Kazimierz 12

Bergin Thomas Goddard 294, 336

Berkow Vladimir F. 408, 425

Bestuzhev Alexander 138

Bevan Edwyn 363, 371

Białoszewski Miron 369, 451, 458, 463

Bieńkowska Ewa 34

Bieńkowski Zbigniew 205, 259

Biernacka Małgorzata 18

Biernacki Nikodem 136

Bizan Marian 290, 336

Błoński Jan 13, 14, 22, 173, 343, 346, 349, 371, 395-397, 567

Boethius 485

Bohomolec Jan Chryzostom 176

Bokszczanin Maria 305, 336

Bołoz-Antoniewicz Jan 60

Bonaventure, St. 484

Bonnet Charles 326

Borchardt Danuta 20,23, 38, 42, 84, 99, 102, 180, 185, 189, 191, 194, $210,213,223,315,316,356,357$, $367,368,381,385,391,406,432$,

433, 445, 450

Borejsza Jerzy W. 239,569 
Borowy Wacław 13, 14, 17, 22, 27, 29-31, 42, 95, 105, 148, 15, 175, 203-206, 214, 239, 254, 258, 259, $268,358,372,428,434,435,461$, $463,517,535,536,567$

Botsaris Markos 124

Bowring Edgar Alfred 132

Brajerska-Mazur Agata11, 15, 20, $25,33,36,38,42,87,99,180,223$, $315,356,381,406,432$

Brandstaetter Roman 253

Bridges Robert 20, 21

Brockhaus Friedrich Arnold 48, 58, $63,66,68,72,77,78,84,147,246$, $334,517,537$

Brodowski Tadeusz 67, 68

Brodzka Anna 417, 425

Brown John 124, 129, 195, 235, 351

Browning Robert 17

Brzozowski Jacek 32

Brzozowski Stanisław 36, 182, 192

Buber Martin 460, 463

Buchner Ludwig 320, 324, 325

Buckley Vincent 364, 372

Bujnowski Józef 13

Buonarroti Michelangelo 49, 453

Buś Marek 27, 29, 30, 32, 513

Byron George Gordon Noel 63, 68, $130,195,235,250,471$

Bystydzieńska Grażyna 17

C

Cackowski Zdzisław 408, 425

Calderon de la Barca 154, 231, 236

Capra Fritjof 506

Carlyle Thomas 17, 95

Casimir, St. 12, 21, 74, 78, 83, 203, $247,248,255,456,259,553$

Cedro Adam 29, 32, 44, 513

Cervantes Miguel de 229-231

Champollion Jean-François 21, 244

Chardin Teilhard de 226
Charencey Hyacinthe de 75, 252

Chlebowska Edyta 15, 18, 27, 36, 40

Chlebowski Piotr 13-15, 18, 29, 32, $36,44,513$

Chłapowski Franciszek 60, 62, 63, 67, 69

Chodźko Leonard 79

Chojak Jolanta 32, 39, 499, 508, 510, 511

Chojecki Edmund 69, 241, 243

Chopin Fryderyk 70, 124, 130, 154, $313,455,456,498$

Chrystal George 435

Chrzanowski Ignacy 31

Cicero 124, 128, 387, 485, 544

Ciechanowska Zofia 253

Clement of Alexandria, St. 482

Clement of Rome 484

Clough Arthur Hugh 17

Columbus Christopher see Kolumb Krzysztof

Conrad Joseph 36

Corneille Pierre 167

Corness Patrick 128, 149, 544

Courbet Gustave 121, 254, 343

Crawford Emma 433, 464

Curie Skłodowska Maria 13

Cuvier Georges 319, 336

Cybulski-Łada Adam 60

Cywiński Stanisław 27, 28, 30, 239, 253, 535, 536

Czajkowski Antoni 57, 67, 68, 81

Czapska Eleonora 254

Czarkowski Antoni 242

Czarnomorska Jolanta 39

Czarny Jerzy 558

Czartkowski Adam 253

Czartoryska Marcelina 69, 70

Czartoryski Adam 60, 62, 67, 79, 114, 124, 129, 253, 299

Czaykowski Bogdan 11, 14, $16,17,25$ 
Czechowicz Józef 212, 396

Czerniawski Adam 11, 17, 18, 41, $87,100,109,181,205,206,210$, $273,308,377,406,427,458,460$, 477, 494

D

Dakowicz Przemysław 31, 37

Dambek Zofia 20, 39

Dante Alighieri 229, 231, 254, 262, 452

Darwin Charles Robert 317, 319, 320, 322-326, 330-335

Daumier Honoré 121

Dawid (David) 292

Dąbrowski Mieczysław 396, 397

Delacroix Eugène 121

Delaperière Maria 36

Delaroche Horace 87, 121

Delille Jacques 142

Dembiński Henryk 123, 124

Deotyma, see Łuszczewska Jadwiga

Derrida Jacques 35

Descotes Maurice 167

Dębicki Stanisław 50

Dickinson Emily 17

Dionysius the Areopagite 482

Ditfurth Hoimar von 437, 463

Długokęcka Teodozja 325, 335

Dłużniewski Julian 361

Dmochowski Henryk (Saunders H.D.) 70,72

Dmowski Roman 174

Doktór Jan 460, 463

Domaradzki Teodor F. 14

Domeyko Ignacy 301, 302

Domitian, Roman emperor 520

Dostojewski Fiodor 36

Downes David A. 22

Duchińska Seweryna 49, 79, 251, 331

Duchiński Franciszek H. 60
Dunajski Antoni 14, 34, 479, 483, 489, 509, 510, 568

Duns Scotus 484

Dürer Albrecht 307

Dybowska Anna 80

Dybowski Aleksander 80, 252

Dybowski Józef 246, 247

Dybowski Ksawery 64

Dygat Ludwik 79

Dziekońska Maria 67, 247, 497

E

Eliot Thomas Stearns 17, 248, 461

Empson William 375, 397

Engeström Wawrzyniec Benzelstjerna 60, 62

Erasmus Desiderus 229, 230

Erasmus of Rotterdam 229, 326

Erzepki Bolesław 28, 253

Estreicher Karol 55

Euklides 396, 397

Eusebius of Caesarea 482-484

F

Faleński Felicjan 250

Feliksiak Elżbieta 34, 269, 285, 295, 335

Feliksiakowa Janina 320, 335

Fellini Federico 368

Fert Józef F. 14, 22, 32, 34, 494, 510,513

Fet Afanasy 144, 145

Fieguth Rolf 33, 36, 494, 510

Fik Ignacy 13, 14, 31, 395, 397

Filip Tadeusz 14

Fisch Max Harold 294, 336

Flatter Richard 14, 153

Flaubert Gustave 89

Fletcher Angus 339, 341, 359, 372, $545,546,550$

Floryan Władysław 316, 336 
Foakes R.A. 370, 372

Fourier Jean Baptiste Joseph 304

$\mathbf{F}$

Franck Sebastian 227, 228

Francuz Piotr 547

Franzoni, Cardinal 64

Fredro Aleksander 93, 169, 200, 214

Freud Sigmund 449

Frybes Stanisław 305, 336

Frye Northrop 371, 371

G

Gajewski Jan 134, 520

Gardner Willliam Henry 20-22

Gasztowtt Wacław 50, 63, 69, 72, 74-78, 247, 249, 250

Gaszyński Konstanty 57, 67, 81, 244

Gautier Théophile 36, 37

Gawroński Kazimierz 79

Genet Jean 226

Geniusz Mieczysław (Etienne) 49$51,60,62,76,79,80,249,251,253$

German Franciszek 239, 254

Gerson Wojciech 254

Gibbs Raymond W. 542, 543, 550

Giller Agaton 48, 78, 255

Głowiński Michał 22, 34, 42, 337, $372,382,396,397,428,465,467$, $472,478,543,546,549,550$, 567,568

Goethe Johann Wolfgang von 66, $132,363,368,466$

Golański Filip Neriusz 466

Goliński Zbigniew 448, 463

Gollancz V. 339, 373

Gomulicki Juliusz Wiktor 12, 13, 15-17, 21-24, 27, 28, 30, 37, 43, $44,114,174,182,185,198,199$, 201, 203, 214, 232, 239, 253, 254, 259-261, 267, 268, 270, 273, 279, $285,302,320,323,335,345,355$,
$362,363,372,378,379,385,393$, $428,434,435,438,441-443,454$, 458, 482, 514, 517-519, 535, 536, 540, 567

Gomulicki Wiktor 51-53, 60, 62, $65,79,249,250,251$

Goszczyński Seweryn 48, 79

Gościcki Jan 417, 425

Gotfryd Jan 32, 513

Górnicki Łukasz 103

Górny Wojciech 162, 172

Górska Konstancja 154, 219, 247, 251, 253, 330, 480

Górski Artur 49

Górski Konrad 15, 42, 172, 193, $215,349,372,492,510,517$

Grabowiecki Sebastian 396

Gregory of Nyssa, St. 485

Grochowiak Stanisław 15, 25, 212, 437

Grygiel Stanisław 385, 397

Grzegorczyk Anna 507, 510

Grzegorczyk Piotr 253, 507, 510

Grzeszczak Iwona 39

Grzędzielska Maria 13

Grzymała Wojciech 79

Günther Ernest Wilhelm 48, 81

Guys Constantine 113, 121

Guyski Marceli 147, 178, 197, 206

H

Haeckel Ernst 324

Hamilton A.C. 339 , 344, 370-372

Harris Emma 17

Hass Robert 451

Hegel Georg Wilhelm

Friedrich 192, 275, 276, 285, 286, 294, 488, 545

Heine Heinrich 36, 240, 358

Heisenberg Werner 506, 510

Henkler Hellmuth 80

Hercen Aleksander 243 
Herwegh Emma 243

Hesiod 75, 287, 290

Heuser Alan 22

Hilaire Geoffroy St. 319,336

Hoene-Wroński Józef Maria 49, 70

Hoffmann Ernst Theodor Amadeus 36

Holoubek Gustaw 547

Homer 31, 49, 76, 124, 349

Honig Edwin 339, 369, 372

Hopkins Gerard Manley 17, 18, 20-26, 36

Hora Eginhard 286, 336

Horace 58, 87, 143

Hornowska Stanisława 135

Horzyca Wilam 88, 114

Houssaye Arsène 78

Hrabiec Stefan 492, 510

Hryniewicz Aleksander 114

Hugo Victor 36, 198, 344

Huizinga Johan 226, 227, 229

Hull Richard F.C. 446, 463

Hyde George 18

I

Ignatius of Antioch, St. 482

Inglot Mieczysław 22, 34, 498, 509, 510

Irving Washington 138

Irzykowski Karol 203, 214

Izajasz (Isaiah) 115, 562

J

Jacobsen Jens Peter 95

Jakobson Roman 357, 372

Jakubowicz Jan 297, 335

Jakubowski Jan Zygmunt 16, 37, 260, 285, 335

James the Evangelist 443

Jankowski Edmund 305, 336

Jankowski Kazimierz 439, 463

Januszkiewicz Eustachy 245
Jarzębowski Józef 558

Jarzyna Anita 37

Jastrun Mieczysław 15, 16, 22, $130,145,174-176,179,195,198$, 204, 212, 214, 223, 236, 259, 357, 372,536

Jauß Hans-Robert 36

Jellenta Cezary 14, 393

Jełowicki Aleksander 12, 79, 483

Jełowicki Teodor 119

Jesus Christ (Emmanuel etc.) 19, 20, 480, 483

John III Sobieski 11, 66

John Chrysostom, St. 482, 484

John Evangelist, St 402, 520

John of Salisbury 484

John of the Cross 484

John Paul II 22, 28, 38, 539, 547

Jowett Benjamin 227

Judasz Iskariota 196

Juliusz Cezar 24, 49, 75, 125, 126,

$134,143,146,150,166,256,500$, 256, 540, 541

Jung Karl Gustav 446, 449, 463

Justin, St. 486

K

Kaczkowski Zygmunt 176

Kaczmarzyk Marek 396, 397

Kadyjewska Anna see

Kozłowska Anna

Kafka Franz 370, 373

Kajsiewicz Hieronim 483

Kalergis Maria 344

Kallenbach Józef 252

Kant Immanuel 276, 279

Kapolka Gerard T. 26

Karczewska-Markiewicz

Zofia 231, 236

Karczewski Wacław 79

Karłowicz Jan 466

Karpiński Franciszek 444, 463 
Karpowicz Tymoteusz 396

Kasjan Jan Mirosław 295

Kasperski Edward 36, 37, 399, 568

Kasprzak Marcin 261

Kącka Eliza 36

Keats John 144

Ker James 228

Kędzierska Aleksandra 17, 23

Kierkegaard Søren 37

Klaczko Julian 12, 76, 79, 244

Kleczkowski Michał 79, 251

Kleiner Juliusz 263, 477

Kleopatra 24, 48, 49, 75, 90, 91, 93, $125,126,134,143,146,150,156$, $160,161,163-166,171,223,248$, 254, 256, 254, 500, 540, 541

Kluczyński Franciszek 81

Kochanowski Jan 90, 103, 173, 209, 351

Koj Leon 415, 425

Kokoszka E. 114

Kokular Aleksander 115

Kolumb Krzysztof 124, 235, 289

Kołaczkowski Stefan 31, 175, 200, $214,345,372,441,463$

Kołakowski Leszek 227, 237, 549

Kołoniecki Roman 212, 214

Kołyszko Anna 439, 463

Kołyszko Piotr 439, 463

Konopnicka Maria 443, 444

Kopera Feliks 81, 249

Korpysz Tomasz 15, 33, 39

Korzeniowski Józef 169

Kosiński Kazimierz 174, 214

Kossowski Stanisław 49, 454

Kostka Stanisław, St 453

Kostkiewiczowa Teresa 13, 15

Kościuszko Tadeusz 124, 235

Kot M. 14

Kowalczyk Małgorzata Jadwiga 15

Kowalczykowa Alina 15

Kowalik Karol 552, 560
Kozłowska Anna 33, 543, 550, 573

Koźmian Andrzej Edward 12, 89

Koźmian Jan 12, 243-245, 260, 307, 465, 502

Koźmian Kajetan 244

Koźmian Stanisław Egbert 241, 243, 254

Krafft Adam 68, 124

Krakowiak Czesław 480, 489

Krakowski Edward 253

Krasicki Ignacy 103, 447, 448, 455, 461, 463

Krasiński D. Carolus Comes 64

Krasiński Zygmunt 12, 35, 50, 61, $69,79,81,103,111,113,114$, $118,158,242-244,253,260,437$, 464,558

Krasuska Anna 543

Kraszewski Bogusław 65

Kraszewski Józef Ignacy 35, 50, 52, 54, 60-62, 65, 71, 74, 76, 78-80, 112, 138, 246, 253

Krechowiecki Adam 252

Kridl Manfred 175, 206, 214

Krzemień-Ojak Sław 297, 335

Krzewińska Anna 339, 372

Krzyżanowski Julian 15, 305, 336, $339,341,372$

Krzyżanowski Ludwik 26

Kubiński Tadeusz 408, 419, 425

Kuczera-Chachulska Bernadetta 33

Kuczyńska Joanna 247, 254, 503, 514

Kuziak Michał 35

Kwiatkowski Teofil 118

Kwiatkowski Władysław 531

L

Lachnicki Cyprian 79

Lamarck Jean-Baptiste de 318

Lamartine Alphonse de 198 
Langbaum Robert Woodrow 369, 370,372

Lange John 408, 425

Larousse Pierre 63, 72

Lenartowicz Teofil 35, 48, 51, 60, 65, $67,75,76,81,142,158,240,247$, $251,255,301,342,352,445,554$

Leociak Jacek 15, 32

Leon Wielki (Leo the Great) 483

Leonardo da Vinci 113, 114

Lesueur Eustache 145

Leśmian Bolesław 468

Lewinówna Zofia 290, 336

Lewis Clive Staples 339, 373

Libelt Karol 314

Ligier Piotr 556, 557, 560-562, 565

Lijewska Elżbieta 39

Limanowski Bolesław 330, 335

Linde Samuel Bogumił 378, 466, 491

Linnaeus Carl 319

Lisiecka Alicja 385, 335, 429, 433, 463

Lubas Regina 13

Lubomirska Maria Adamowa 49

Lubomirski Marceli 72, 79

Lukács György 417, 425

Luke the Evangelist 442, 482

Lyons Paddy 17

Łapiński Zdzisław 13, 22, 37, 42, 349, 350, 373, 395-397, 428, 431, 440, 454, 463, 539, 568

Ławrow Piotr 254

Łoskoczyński Józef 53

Łubieński Leon 67

Łubieński Włodzimierz 60, 67, 241, 263, 266, 429

Łussakowski Józef 497

Łuszczewska Jadwiga 79, 103, 143, 247, 251, 331, 404

Łuszczewska Nina 67
M

Maciejewski Marian 34, 543, 545, 546,550

MacLennan George 17

Mac-Mahon Patrice 155

Macrina, St. 74

Maeterlinck Maurice 95

Maistre Xavier de 138

Makowiecki Tadeusz 14, 15, 22, 27, $31,148,151,164,172,175,192$, 193, 198, 204, 211, 215, 239, 253, 349,372

Makowski Stanisław 32, 198, 452, 463

Malczewski Antoni 34, 103

Malewska Hanna 254

Malewski Zygmunt Stanisław 81

Mallarmé Stéphane 18, 35, 107, 176, 187, 199, 205, 215, 339

Malraux André 474, 478

Marciszewski Witold 408, 415, 425

Marcus Aurelius 124, 167, 435, 436

Mark the Evangelist 226, 384

Markiewicz Henryk 437, 475, 478

Markowski Piotr 35

Marrené-Morzkowska Waleria 60,241

Mary 379, 380, 498

Maślanka Julian 29, 44, 513

Matliński Jan Kanty 64

Mauersberg Adam 254

Melbechowska-Luty Aleksandra 18

Merdas Alina 14, 15

Mersbach Henryk 78

Meyet Leopold 69, 251

Mianowski Józef 31, 268, 397

Michałowski Piotr 120

Michelet Jules 195, 286, 459

Mickiewicz Adam 13, 16, 24, 33, 38, $66,69,96,103,124,130,132,139$, $146,151,158,167,173,177,188$, $235,240,271,273,274,277,282$, 
294, 298, 301-307, 310, 313, 314, 335-337, 340, 342, 350, 373, 416, 431, 437-439, 457, 460, 464, 491, $492,498,510,536,546,562,565$

Mickiewicz Władysław 251

Mikocka-Rachubowa Katarzyna 18

Mikołaj I Romanow 298

Mikołajtis Józef 253

Mikoś Michael J. 184

Mikułowska Teofila 74, 454

Miłosz Czesław 212, 436, 450, 451, 463, 542, 549, 550

Minasowicz Jan Klemens 67, 68, 115

Mincer Wiesław 254

Modrzejewska Helena 154

Mojżesz (Moses) 124, 287-290, 292, 442, 443, 522

Molier (Jean Baptiste Poquelin) 167

Moraczewski Henryk 69

Morawski Franciszek 245

Morris William 17

Mortkowicz Jakub 29, 105, 257, 258, $268,344,373,536$

Motty Marceli 21, 245

Murray John 408, 425

Musil Robert 346, 373

Musset Alfred de 170

Muszkowski Jan 253

MuszyńskZofia see

Trojanowicz Zofia

Mycielski Jerzy 60, 70, 81

$\mathbf{N}$

Nabielak Ludwik 48, 74, 79, 314

Nalewajk Żaneta 37

Napiórkowski Kazimierz 510

Napoleon Bonaparte 70, 73, 124,323

Naruszewicz Adam 449

Nawrocki Władysław 49

Nero 117, 208, 212, 563
Nerval Gérard de 198, 199

Niedzielski Czesław 13

Nietzsche Friedrich 34, 91

Nieukerken Arent van 14, 36

Niewczas Łukasz 32, 36

Niewiarowski Aleksander 241, 255

Norton William Warder 14 , 472, 478

Norwid Anna 52-54, 251

Norwid Jan 64

Norwid Ksawery 56

Norwid Ludwik 52, 130, 131, 135, 139, 140, 149, 190, 241, 337

Norwid Ludwika née Zdzieborska 64

Novalis 149, 198, 199

Nowak Tadeusz 396, 397, 408, 425

Nuttall Anthony David 339, 344,373

O

Obuchowski Kazimierz 437, 463

Ohryzko Jozafat 67

Okopień-Sławińska Aleksandra 13, 472,478

Opacki Ireneusz 473, 478

Opaliński Łukasz 176

Ordon Edmund 434, 463

Orgelbrand Samuel 53, 63

Origen of Alexandria 482, 485

Orpiszewski Ludwik 241

Osterwina Matylda 254

Overbeck Johann Friedrich 116

Ovid 128, 366, 459

$\mathbf{P}$

Pajdzińska Anna 546, 550

Paluchowska Danuta, see Zamącińska Danuta

Pascal Blaise 85

Paul, St. see Paweł Apostoł, św.

Pawelec Radosław 499, 511 
Paweł Apostoł, św. 124, 129, 143, 347, 390

Pawlak Zbigniew 484, 489

Pawlikowski Mieczysław 251

Pawłowski Tadeusz 408, 413, 425

Pelc Jerzy 408, 425

Peter Michał 443

Peterkiewicz Jerzy 17, 309

Petrusewicz Kazimierz 335

Phidias 146

Pick John 22

Piechal Marian 174, 215, 260

Pieper Josef 385

Pigoń Stanisław 239, 253, 268, 345, $372,441,463$

Pilate 117

Pini Tadeusz 28, 214, 257, 258, 260, 264, 266, 268, 306, 335, 519, 520, 534, 536

Piotrowska Irena 254

Pius IX 59, 66, 124, 142

Plater Adam 60, 62

Plater Cezary 254

Pluta Małgorzata 39

Płoszaj Jakub 552

Pług Adam (Pietkiewicz Antoni) 49, 65, 251

Pniewski Dariusz 14, 32

Poe Edgar Allan 17, 95

Pol Wincenty 240, 392

Polanowska Jolanta 18

Politzer Heinz 370, 373

Pollak Seweryn 434, 463

Pomarański Stefan 253

Pomorski J. 114

Potocka Delfina 79

Potocki Albert Szeliga 69, 79

Potocki Stanisław 79

Pound Ezra 17

Prendowski Henryk Korwin 77

Prokop Jan 396, 397

Proudhon Pierre-Joseph 243
Prus Bolesław 90, 91

Przesmycki Zenon (Miriam) 21, 27-30, 42-44, 47, 150, 239, 240, 249-260, 264, 266-268, 344, 373, $519,536,567$

Przyboś Julian 16, 37, 259, 363, 364, 373, 393, 396, 397, 438, 460, 464

Przyłubska Anna 530, 537

Przyłubski Feliks 530, 537

Przypkowski Tadeusz 253

Pseudo-Dionysius the Areopagite 485

Pszczołowska Lucylla 13

Puzynina Jadwiga 15, 22, 33, 38, 39, 42, 491, 499, 506, 509-511, 517, 537, 568

Pylak Bolesław 480, 489

Q

Quinet Edgar 330, 336

$\mathbf{R}$

Racine Jean Baptiste 167

Rafael Santi (Raphael) 124

Rastawiecki Edward 68, 81, 112

Rautenstrauch Łucja née Giedroyć 52, 67, 71, 250

Reitzenhaim Józef 49

Rej Mikołaj 339, 372

Richard Jean-Pierre 199, 215

Rio Ángel del 231, 237

Rosenwerth Różycki Włodzimierz de 79

Rożniecki Gabriel 69

Rubens Peter Paul 118

Rudnicka Jadwiga 29, 44, 239, 254, 513, 517, 537

Ruhr Mario von der 433, 464

Ruisdael Jacob van 416

Ruprecht Karol 416, 526

Rygiel Stefan 253

Rygielska Małgorzata 37 
Rzepczyński Sławomir 32

Rzońca Wiesław 35, 36, 543, 550

S

Sadowska Maria 79

Safo (Sappho) 62

Sainte-Beuve Charles-Augustin 198

Samsel Karol 36

Sarbiewski Maciej Kazimierz 373

Sarnecki Zygmunt 65, 75, 112, 241

Sarnowska-Temeriusz

Elżbieta 339, 373

Sawicki Stefan 13, 14, 22, 28, 29, 34, 36-38, 42-44, 375, 397, 502, 513, 569,568

Sayers Dorothy L. 339, 370, 373

Schelling Friedrich Wilhelm Joseph 318

Schleiermacher Friedrich 369, 373

Semenenko Piotr 483

Seneca Lucius 228

Sennewald Gustaw 54, 80

Servaes Franz 66

Shakespeare William 14, 126, 153, 229-231, 233, 235, 236, 339, 373

Siedlecki Franciszek 52, 53, 555

Siemieński Lucjan 21, 49, 67, 244-246, 260

Siemion Wojciech 33

Sienkiewicz Henryk 212

Singer Burns 309

Sinko Tadeusz 13

Siwiec Magdalena 36

Skalińska Ewelina 36

Skręt Rościsław 29, 44, 513

Skrzynecki Jan 65, 69, 305

Skubalanka Teresa 16, 37, 42

Skwarczyńska Stefania 290, 317, $319,326,336,568$

Slote Bernice 371,372

Sławińska Irena $14,15,22,33,37$, $42,153,164,167,168,170,172$,
193, 215, 217, 237, 322, 336, 344, $349,358,372,373,428,440,567$

Sławiński Janusz 13, 396, 397, 428, 451, 464

Słowacki Juliusz 13, 16, 24, 58, 63, $70,75-77,80,103,105,158,173$, $177,188,219,240,242,259,263$, $272,276,283,290,294,296,312$, $314,316,317,326,336,431,437$, 452, 455-457, 460, 463, 464, 477, $478,481,486,499,504,514,543$

Smoleński Tadeusz 253

Sobieska Hilaria 11, 66

Sokołowski Marian 75, 79, 247, 249, 251, 307, 313, 322, 324, 331, 500

Sokrates (Socrates) 11, 14, 16, $17,25,62,63,65,124,223,235$, 404,417

Sophocles 229

Sowiński Kazimierz 268

Spartacus 124, 195, 221, 394

Spencer Herbert 319, 320, 370

Spivak Gayatri 339, 373

Stanislaus, St. 74

Stefanowska Zofia 14, 22, 30, 34, $37,42,214,305,334,336,340$, $342,350,373,427,437,438,464$, 513, 567

Stefański Walenty 55

Stelmaszczyk Barbara 32

Stendhal (Marie-Henri Beyle) 36

Sterne Lawrence 137, 138, 141

Sternschuss Adolf 48-50, 54, 60,251

Straszewicz Anna 335

Stróżewski Władysław 15, 18, 42

Strzembosz Władysław 50, 81

Studniarska Bronisława 254

Subko Barbara 15

Suchodolski Bogdan 227, 229, 237

Sulpice-Sévère, St. 483

Swedenborg Emanuel 271 
Syrokomla Władysław 240

Szarota Elida Maria 369, 373

Szczęsna Ewa 36

Szczęsny Tadeusz 15, 164, 172, 193, $215,349,372$

Szmydtowa Zofia 14, 22, 31, 37, 239, 253, 431, 464

Szondi Peter 369, 373

Szopen Fryderyk see Chopin Fryderyk

Szukiewicz Cyprian 64

Szuman Stefan 150, 151, 393, 435,464

Szymanowski Wacław 65, 455

Szyndler Pantaleon 51, 53, 249, 556

Śliwicki D. 49

Świdziński Marek 408, 425

Świegocki Kazimierz 37

Świontek Sławomir 217, 222, 237, $345,373,567$

\section{T}

Tabasz-Krosnowski Adolf 79

Tasso Torquato 404

Tatara Marian 438, 464

Tatarkiewicz Anna 474, 478

Tatarkiewicz Władyasław 320, 336

Tauszyńska Anna Danuta 437, 463

Teleżyńska Ewa 15, 32, 39, 509, 510, 568

Tertullian 266, 482, 520

Thomas Aquinas, St. 485

Thornton Agathe 379, 373

Thornton Harry 379, 373

Thümmel Moritz August von 138

Todorov Tzvetan 339, 373, 467, 478

Tokarzewicz Józef 11

Tomaszewski Mieczysław 15

Toruń Włodzimierz 32, 36

Towiański Andrzej 65, 69, 304, 305, 317, 482, 494

Trembecki Stanisław 103, 455
Trębicka Maria 49, 52, 54, 61, 62, $65,66,69,71-73,76,83,148,173$, $177,195,247,250,430,431,483$, 485,504

Trojanowicz (Trojanowiczowa) Zofia 20, 22, 38, 39, 42, 301, 336,513

Trzcionka Joanna 33

Trzeciak Katarzyna 36

Trznadel Jacek 22, 34, 429, 461, 462, 464

Trzynadlowski Jan 222, 237, 345, 372,373

Tur Jan 319, 336

Turczyński Tadeusz 253

Tuve Rosemond 339, 340, 359, 366

Tyutchev Fyodor Ivanovich 128, $129,132,145$

$\mathrm{U}$

Ujejski Józef 253

Ujejski Kornel 240

V

Vico Giambattista 34, 96, 285-287, 294, 296, 297, 314, 319, 335, 336,344

Villiers de l'Isle-Adam Auguste de 95

Virgil 107

Vogt Karl 320, 324

Voltaire (François-Marie Arouet) 269

W

Waga Antoni 254, 265, 279, 320

Wagner Józef Bogdan 62, 76, 109, 251

Walicki Andrzej 282, 336, 567

Wasylewski Stanisław 253, 264

Wasylewski Zygmunt 215

Weil Simone 433, 436, 464 
Weinrich Harald 366, 374

Wejtke Wacław 52

Wellisch Leopold 54

Welter Jean-Thiébaut 340, 374

Wergiliusz see Virgil

Węgierska Zofia 48, 77, 79

Wężyk Franciszek 76, 245

Wężyk Władysław 67, 68

Whately Richard 408, 425

Whitman Walt 17, 240

Wielogłowski Walery 79

Wilkins Sophie 346, 373

Wilson John Dover 229

Winckelmann Johann

Joachim 369, 373

Witkowska Alina 437, 445, 446, 464, $474,475,478$

Witte Kazimierz 65, 81

Wittgenstein Ludwig 508

Wojciech, św. 443, 463, 489

Wojtkiewicz Witold 118

Wojtyska Henryk Damian 480, 489

Wolff Bolesław Maurycy 48, 57, 67, $77,81,246$

Wolicka Elżbieta 14

Wolniewicz Marian 442, 443, 463

Woronow Ilona 36

Wujek Jakub 521

Wyka Kazimierz 13-15, 22, 25, 27,

$31,83,136,145,151,253,261,567$

Wyspiański Stanisław 50, 95, 174

Wyszyński F. 200

\section{Z}

Zajączkowski Ryszard 15, 16

Zakrzewski Walenty

Pomian 70, 72, 77
Zaleski Antoni 63, 77, 79, 92, 103, 254, 308, 535, 536

Zaleski Bronisław 48, 75, 253, 254, 496, 500

Zaleski Dionizy 252

Zaleski Ignacy240, 241

Zaleski Józef Bohdan 245, 247, 301, 302, 304, 314, 454, 494

Zamącińska Danuta 427, 539, 568

Zamojska-Hutchins Danuta 18

Zamoyski Andrzej 124

Zamoyski Władysław 70, 79, 124, 298, 403

Zanaszewski Fr. 64

Zaniewicki Zbigniew 22, 28, 114, 259, 268

Zaron Zofia 508, 510

Zawodziński Karol Wiktor 129, 151

Zdziechowska Hilaria, see Sobieska Hilaria

Zeidler-Janiszewska Anna 507, 510

Zgorzelski Czesław 473, 478

Zielińska Jolanta 17

Zrębowicz Roman 28, 30, 239, 253, 536

Żbikowski Piotr 32

Żebrawski Teofil 70

Żeleński (Boy) Tadeusz 475, 478

Żeromski Stefan 12

Żmichowska Narcyza 158

Żupański Jan Konstanty 51, 78, 80, 81, 246, 554

Żurowski Maciej 22, 37

Żwirkowska Elżbieta 36

Życiński Józef 545, 550

Życzyński Henryk 86 


\section{Index of Titles of Literary Works and Artworks of Cyprian Norwid}

A

A Dorio ad Phrygium $76,78,86$, $108,130,131,134,137,144,147$, $179,182,183,232,248,295,493$

Ad leones! 21, 24, 29, 75, 83, 90, 92, 93, 248, 349, 372, 543

Aktor [The Actor] 75, 153, 154, 170, $172,217,221,236,248,322-324$

Album Orbis 249

Alleluja I 557

Amen 96, 124, 347

Asocjacja, ilość i jakość [Association,

Quantity and Quality] 493

Assunta 86, 101, 103, 104, 106, 127,

134-136, 140, 145, 146, 155, 178,

$179,247,263,264,447$

Autobiografia [Autobiography] 264

Autoportret [Selfportrait] 556, 557

Autor-nieznany [Author

Unknown] 79

Awantury arabskie [Arabic

Adventures] 115, 561

B

Bajka [Farytaile] 349

Bądź wola Twoja... [Thy Will Be

Done...] 382

Beatrix 178, 221

Bema pamięci żałobny-rapsod [A

Funeral Rhapsody in Memory of

General Bem] 24, 43, 96, 104,

129, 246, 263

Bezimienni [The Nameless] 58

Białe kwiaty [White Flowers] 71, 72, 153, 155-157, 162, 221, 275, 280, 281
Boga-Rodzica [Mother of God] 71, 75, 482

Bogowie i człowiek [Gods and Man] 101

Bohater [Hero] 123, 149, 404, 405, 470

Bransoletka [Bracelet] 24, 58, 88

Burza [Storm] 58

C

Cacka [Pretty Things] 99

Chemin du progress 50, 554

Chrystus i Barabasz [Christ and Barabbas] 50, 552

Ciemność [Obscurity] 205, 450

Co? jej powiedzieć... [What Shall

I Tell Her?] 141

Co robić? [What to Do?] 123, 331, 404, 405, 474

Co słychać? i co począć? [What's

New? And What's to Do?] 349

Coś [Something] 193

Coś ty Atenom zrobil, Sokratesie... [What Have You Done to Athens, Socrates...] 223, 404

Cywilizacja [Civilisation] 88, 280, 447

Czarne kwiaty [Black Flowers] 24, 70, 71, 87, 154, 221, 456

Czasy [Times] 123, 234

Czemu [Why] 87, 359, 404, 438, 471

Czemu nie w chórze [Why Not in Chorus] 341

Człowiek [A Human] 58, 74, 137, 148, 342

Czułość [Tenderness] 143, 210 
Czy podam się o amnestię? [Shall

I Request an Amnesty?] 98, 124, 548

Czy ten ptak kala gniazdo, co je kala [Does This Bird Sully the Nest which Sullies It] 401, 404

D

Daj mi wstążkę błękitną [Give Me a Blue Ribbon] 188

Dama w jasnej sukni [Lady in a Light Dress] 113

Dama w płaszczu i kapeluszu z szerokim rondem [Lady in a Coat and a Broad Brim Hat] 113

Dedykacja [A Dedication] 124, 136, 533

Deotymie. Odpowiedź [To Deotyma. A Reply] 404

Do Bronisława Z. [To Bronisław Z.] $108,200,404,427,457$, 496, 500

Do czytelnika [To the Reader] 56, 59, 403

Do Emira Abd el Kadera w Damaszku [To Emir Abd el Kader in Damascus] 58, 104, 195

Do L.K. [To L.K.] 144

Do mego brata Ludwika [To My Brother Ludwig] 130, 139, 190, 241, 337

Do Nikodema Biernackiego [To Nikodem Biernacki] 100, 278

Do obywatela Johna Brown [To Citizen John Brown] 104, 142, 189, 245

Do Pani na Korczewie [To the Lady of Korczew] 383

Do panny Józefy z Korczewa [To Miss Józefa de Korczew] 58

Do słynnej tancerki rosyjskiej, nieznanej zakonnicy [To a Famous
Russian Dancer, an Unknown Nun] 105, 454

Do spółczesnych. (Oda) [To my Contemporaries. (Ode)] 124, 181, 189,437

Do Stanisławy Hornowskiej [To Stanisława Hornowska] 135

Do Walentego Pomiana Z. [To Walenty Pomian Z.] 74, 89, 102, 134, 186, 405

Do Wielmożnej pani I. [To Her Ladyship I.] 387

Do władcy Rzymu [To the Ruler of Rome] 58, 123, 124

Do zeszłej... (na grobowym głazie) [To the Deceased... (on a Tombsotne)] 102, 142, 394, 529

Dobrzy ludzie [Good People] 264 Dookoła ziemi naszej [Around Our Land] 105, 395

Dumanie II [Meditation II] 138

Dwa guziki (z tyłu) [Two buttons (at the back)] 388, 404, 471, 493

Dwa męczeństwa [Two Martyrdoms] 58, 105, 143, 341, 344,390

Dwie aureole [Two Halos] 264

Dwie kobiety z dzieckiem [Two Women with a Child] 564

(Dziennik Warszawski [Warsaw Journal] 447

Dziewięć zaspokojonych pytań [Nine Satisfied Questions] 403

E

Emil na Gozdawiu [Emil in Gozdawie] 76, 86, 125 Encyklika Oblężonego. Oda [Encyclical of the Besieged. Ode] 59, 124

Epimenides 58, 72, 142, 246 Epos-nasza [Our Epic] 124, 449, 541 


\section{F}

Fabulizm Darwina [Darwin's Fabulism] 282

Fatum [Fate] 143, 222, 365, 435, 539, 543

Filoktet [Philoctetes] 264

Filozofia historii polskiej

[Philosophy of Polish

History] 293, 492

Filozofia wojny see La Philosophie de la guerre

Finis 38, 143, 391, 494

Fortepian Szopena [Chopin's Grand Piano] 18, 25, 75, 86, 96, 124, 179, 245, 314, 367, 381, 501

Fulminant. Rapsod [Fulminant. A Rhapsody] 58, 59, 75, 77, 233, 423, 519, 528

Fraszka [A Bagatelle] 49

Fraszka III [Epigram III] 196

\section{G}

Gadki [Gabs] 404

Garstka piasku. Legenda [A Handfull of Sand. A Legend] 57 Grzeczność [Politeness] 415, 157,457

\section{$\mathbf{H}$}

Harmonia [Harmony] 143
Historyk [Historian] 389
Hrabina Palmyra [Countess
Palmyra] 254

\section{I}

Idee i prawda [Ideas and Truth] 193 Improwizacja na zapytanie o wieści z Warszawy [Improvisation on a Request for News from Warsaw] 124

Ipse ipsum 53, 555

Ironia [Irony] 201
Irydion i Masynissa [Irydion and Masynissa] 115, 562 Izajasz [Isaiach] 562

\section{J}

Jak... [Just As...] 445

Jesień [Autumn] 433

Jeszcze Francja nie zginęła! [France

Has Not Yet Perished!] 124

Jeszcze słowo [A Word More] 55, 70, 107, 243

John Brown 58, 124, 351

K

Karykatura leonardowska [Leonardesque Caricature] 559

Klary Nagnioszewskiej samobójstwo [The Suicide of Klara Nagnioszewska] 250, 565

Klaskaniem mając obrzękłe prawice [Their Hands Swollen from Clapping] 180, 381, 418

Klątwy [Curses] 355

Kleopatra i Cezar [Cleopatra and Caesar] 24, 125, 158, 161, 166, 256, 500, 539, 540

Kolebka pieśni (Do spółczesnych ludowych pieśniarzy) [The Cradle of Songs (To Contemporary Folk Songsters)] 406, 449

Kółko [The Little Circle] 431, 462, 493

Krakus. Książę nieznany [Krakus. An Unknown Prince] 49, 58, 77, $125,126,159,163,247$

Królestwo [Kingdom] 143, 208, 273-275, 357, 407

Krytycy i artyści [Critics and Artists] 141

Krzyż i dziecko [The Cross and a Child] 221, 222, 363-366, 447,470 
L

La Philosophie de la guerre [The

Philosophy of War] 49, 251

Lapidaria 49, 308

Larwa [Larva] 184, 444

Laur dojrzały [Mature Laurel] 18, 124,356

Le Musicien inutile 50, 62, 552

Letters to:

- Artur Bartels dated 1 September 1875331

- Władysław Bentkowski from May 185712

- August Cieszkowski from May 1860465

- dated 1 March 1877155

- Seweryna Duchińska from 1879331

- Konstancja Górska from beginning of July 1866480

- from July-August 1866330

- from September 1881154

- Aleksander Jełowiecki from June 1871331

- Jan Koźmian of 1850 12, 307, 502

- Joanna Kuczyńska of 1862503 - from August 1867514

- Teofil Lenartowicz from June 186667

- from $188248,60,75,76$

- Józef Łussakowski from November 1854497

- Jadwiga Łuszczewska from October 1871331

- Ludwik Nabielak form February 187774

- around 5 December 1882314

- Eucja Rautenstrauch of 185971

- Jan Skrzynecki dated 15 April 1848305

- Marian Sokołowski dated 6 February 1864313

- from January 1865307
- ca.15 September 1875 322, 324, 331

- Maria Trębicka of 184665

- dated 20 October

$185365,71,72$

- 21-23 February 185452 ,

62,485

- dated May 1854 65, 72, 73, 483, 504

- dated 8 April 1856 52, 65, 71, 72

- dated 18 July 185652,65

- from October 1856 65, 72, 76

- Józef Bogdan Wagner of 187662 - of 1881109

- Antoni Zaleski dated 2 November 1844308

- Bronisław Zaleski from 1870496

- Józef Bohdan Zaleski dated 9 February 1848304 - dated 24 April 1848304

- dated 10 May 1851 301, 302

- dated 5 December 1882314

- Władysław Zamoyski from February 1864298

Lilie [Lilies] 58

Liryka i druk [Poetry and Print] 108, 354

List [Letter] 394

List do Walentego Pomiana Z. see Do Walentego Pomiana Z.

Listy o emigracji [Letters on Emigration] 285, 293, 294, 299, 300

Litania do NPM [Litany to the Blessed Virgin Mary] 498

M

Malarz z konieczności [Painter out of Necessity] 58, 141, 146, 221

Marionetki [Marionettes] 87, 141, 223, 367, 368 
Marmur-biały [White Marble] 132, 344, 404

Maryjo, Pani Aniołów!... [Mary, Lady of Angels!...] 379

Marzenie [A Dream] 145

Medalion Zygmunta Krasińskiego [Medallion of Zygmunt Krasiński] 111, 114, 118, 558

Memoriał o Młodej emigracji [Memorial on Young Emigration] 300, 302, 303

Milczenie [Silence] 35, 48, 75, 155, 220, 248, 265, 270, 271, 276, 278-281, 294, 296, 328, 343, 399, 401, 410, 412, 447, 505, 509

Miłość czysta u kąpieli morskich [Pure-Love at Sea Baths] 126, 222, 409

Mistycyzm [Mysticism] 209, 355, 356, 406

Modlitewnik dla Włodzimierza Łubieńskiego [A Prayer Book for Włodzimierz Łubieński] 262, 266

Moja ojczyzna [My

Country] 181, 388

Moja piosnka [My Song] 96, 108,382

Modlitwa [Prayer] 104, 132, 140

Mogił starych budowa [A Construction of Old Graves] 132

Moralność [Morality] 288, 471

Na posadzkę zapustnej sceny [Alone on the Floor] 161

Mój ostatni sonet [My Last Sonnet] 514

Mój psalm [My Psalm] 49

N

Na zapytanie czemu w konederatce odpowiedź [Response to the Question: Why Wear a
Four-pointed Confederate

Cup] 58, 124, 131, 404

Na zgon poezji [On the Death of Poetry] 97

Na zgon ś.p. Jana Gajewskiego

[On the Death of the Late Jan

Gajewski] 57, 520

Na zgon ś.p. Józefa Z. [On the Death of the Late Józef Z.] 149, 284, 389, 497

Narcyz [Narcissus] 101, 143, 221, 365,520

Naturalizm (spółczesny ekstrem). Do Antoniego Wagi [Naturalism (Modern Extremum). To Antoni Waga] 320, 331, 352

Neron [Nero] 563

Nerwy [Nerves] 87, 143, 221, 367,368

Niebo i ziemia [Heaven and Earth] 362, 363

Niewola [Enslavement] 55, 59, 77, 295, 303, 334, 399, 403, 487, 488, $493,515,520$

Noc tysiączna druga [The Thousandth and Second Night] 126, 137, 146, 246, 247

Notatki etno-filologiczne [Etno-Philological Notes] 270, 274, 278, 283, 325

Notatki z historii [Notes on History] 270, 271, 276, 286, 483

Notatki z mitologii [Notes on Mythology] 270, 287-291, 293

O

O historii [On History] 474

O idei interpretacji [On the Idea of Interpretation] 503

O Juliuszu Słowackim w sześciu publicznych posiedzeniach [ On Juliusz Słowacki. In Six Public 
Meetings] 58, 75, 77, 158, 272, 276, 283, 294, 296, 312, 316, 481, 486, 499, 504

O miłości ksiąg dwie [Two Books on Love] 264

O rzeźbiarzach florenckich (dziś żyjących) [Florentine Sculptors (Living Today)] 69

O sztuce (dla Polaków) [On Art (for Poles)] 62, 74, 98, 123, 154, 236, 311

Obyczaje [Customs] 221

Od rezultatów mylnego zamętu... [From results of mistaken confusion...] 350, 468, 469

Odpowiedź (III) [Reply (III)] 404

Odpowiedź do Włoch [A Response to Italy] 124

Odpowiedź krytykom „Listów o emigracji" [Reply to the Critics „Letter on Emigration”] 300, 493

Ogólniki [Generalities] 23, 99, 101, 200, 382

"Ołówkiem” na książeczce o Tunce ["In pencil" on the Booklet on Tunka] 351, 520

Opowiadanie [The Story] 565

Ostatni despotyzm [The Last Despotism] 221, 404, 418

Ostatnia $\mathrm{z}$ bajek [The Last of the Fables] 75, 85, 88, 248, 282, 317

$\mathbf{P}$

Pamięci Alberta Szeligi [In Memory of Albert Szeliga] 124

Patkul 125

Pielgrzym [Pilgrim] 143, 393, 447

Pierścień Wielkiej-Damy [The Noble Lady's Ring] 24, 90, 102, 108, 126, 134, 139, 141, 146, 147, 156, 171, 222, 223, 237, 247, 251, 263, 345, 373,498
Pierwszy list, co mnie doszedł z Europy [The First Letter I received from Europe] 71, 430, 462

Pieśni społecznej cztery stron [A Social Song in Four Pages] 55, 56, $67,107,243,303$

Pieśń od ziemi naszej [Song of Our Land] 96, 124, 125, 392

Pięć zarysów obyczajowych [Five Moral Sketches] 70

Piękno-czasu [The Beauty of Time] 529

Pijacy [Drunkards] 560

Pismo [Writings] 98, 136

Pióro [My Quill Pen] 57, 68, 136, 269, 399, 520

Plato i Archita [Plato and Archita] 59, 515

Plotki u wodopoju [Rumours at the Waterhole] 116, 563

Po balu [After the Ball] 367

Początek broszury politycznej

[Beginning of a Political

Pamphlet] 184, 298

Pokój [Peace] 344

Polka [A Polish Woman] 58, 123, 178, 221

Pompeja [Pompei] 48, 132, 139, 245

Post scriptum I 388

Powiedz im [Tell Them] 49

Powieść [Novel] 448

Pożegnanie [Farewell] 57, 67

Prac-czoło [Work in Brow's

Sweat] 284, 287, 386

Promethidion 21, 24, 29, 30, 34, $38,43,47,62,66,68,69,70,77$, $92,97,98,103,107,121,123,133$, $144,193,198,211,244,245,284$, 286, 287, 290, 302, 305, 309-314, $318,403,439,496,498,501,509$, $519,526,532,535,536$

Próby [Attempts] 58, 144, 145, 520 
Przeszłość [The Past] 127, 352, 356, 357

Psalm wigilii [Christmas Eve Psalm] 124, 358

Psalmów-psalm [The Psalm of Psalms] 98, 247, 481, 519, 520, 534

Purytanizm (z listu do M.S.)

[Puritanism (from the letter to M. S)] 393, 394, 404, 473

\section{Q}

Quidam 24, 35, 43, 58, 69, 74, 77, $100,125,126,132,136,137,139$, $144,145,235,246,349,373,481$, $482,498,545$

\section{$\mathbf{R}$}

Rozebrana [Disrobed] 96, 124, 132, $375,381,453,465,473-477$

Rozmowa umarłych [Dialogue of the Dead] 58, 130, 471

Ruiny [Ruins] 58, 132, 199

Rzecz o wolności słowa [On the Freedom of Speech] 24, 48, 88, $107,129,132,155-157,247,251$, $255,264,270,280-282,287$, 289-292, 294, 296, 312, 314, 316, 325-329, 399, 402, 498, 499, 501, 502, 508, 509, 517, 525, 531, 534

Rzeczywistość [Reality] 58

$S$

Salem. Do A.T. [Salem. To

A.T.] 107, 125, 129-131, 294, 295,482

Samotność [Loneliness] 394, 514

Sariusz [Sarius] 123

Saturnalia 208, 362

Sąsiedzi w Zakładzie św. Kazimierza w Paryżu [Neibours at the CEuvre de Saint-Casimir in Paris] 50, 553
Scherzo I 221, 394

Scherzo II 221

Sen [Dream] 348, 451

Sens-świata

[Sens-of-the-World] 345

Sfinks [The Sphinx] 143, 221, 254, 365,366

Sieroctwo [Orphanhood] 208, 346,406

Sieroty [Orphans] 145

Skowronek [Skylark] 57, 145

Sława [Fame] 136, 138, 139, 472

Słodycz. Tragedia w scenie jednej

[Sweetness. Tragedy in One

Act] 482

Słowianin [The Slav] 94, 213, 351,445

Słowo i słowo [A Word and the Word] 387, 388

Socjalizm [Socialism] 124, 282

Solo 77, 111, 558

Sonet do Marcelego Guyskiego

[Sonnet to Marceli Guyski] 178

Spartakus [Spartacus] 221, 388, 394

Specjalności [Specialities] 419, 422

Spowiedź [Confession] 221, 363, 365

Spółcześni [Contemporaries] 331

Stolica [Capital] 368

Stygmat [Stigma] 24, 31, 49, 67, 75, 85-87, 92, 94, 134, 248, 499

Sursum corda 59

Syberie [Two Syberias] 124, 184

Sybilla [Sibyl] 78

Szczesna. Powieść [Szczesna.

A Novel] 57, 77, 107, 134, 137, 142, 146, 245, 246

Sztuka w obliczu dziejów jak Syntetyki księga pierwsza [Art in the Face of History as Synthetics Part One] 254, 264, 311, 401, 506 
Śmierć [Death] 38, 102, 149, 384, 385,388

Śmierć, starzec i dziecko [Death, an Old Man and a Child] 564

Święty-pokój [Blessed Peace] 101, $124,143,351$

\section{$\mathbf{T}$}

Tajemnica lorda Singelworth [Lord Singelworth's Secret] 85, 248

Tancerka [Female Dancer] 75, 113, 559

Teofilowi [To Teofil] 148, 353

Tęcza [Rainbow] 100, 149

To rzecz ludzka!... [It is a Human

Matter!...] 123, 132, 233, 471

Toast [A Toast] 135

Trzy pytania [Three Questions] 403

Trzy strofki [Three

Stanzas] 438, 462

Ty mnie do pieśni pokornej nie wołaj [Do Not Summon Me to a Humble Song] 392

Tymczasem [Meanwhile] 124, 131,476

Tyrtej [Tyrtaeus] 125, 126, 146, 160, 163-165, 472, 509

U

Uwagi o „Pamiętniku pieśniarza” [Notes on „Diary of a Bard”] 495

V

Vade-mecum $13,17,20,24,27$, $32-36,41,42,48,49,75,78,99$, $127,143,147,149,225,248,256$, $259,260,264,265,270,273,277$, 282, 284, 287, 288, 298, 310, 314, $317,330,334,365,379,381,385$, 386, 392, 404, 405, 419, 421, 434, $440,463,493,494,509,510,515$, $517,518,536,543,545$
Vanitas vanitatis $99,147,355,383$, 394, 404

Vendôme 106, 488

W

W albumie [In an Album] 100

W albumie Juliana Dłużniewskiego [In Julian Dłużniewski's Album] 361

W pamiętniku [In an Album] 26, 160, 162, 185, 202, 224, 472

W pamiętniku L.A [In the Album of L.A.] $147,149,337$

W pracowni Guyskiego [In Guyski's Studio] 104, 197, 206

$\mathrm{W}$ tej powszedniości [In This Ordinariness] 135, 194, 195

W Weronie [In Verona] 96, 100, 132, 149, 206, 277, 280, 544

Waga [Scales] 320, 321, 324

Wakacje [Holiday] 404

Wanda, misterium [Wanda. A Mystery] 49, 70, 125, $146,159,160,163,165,171$, 247,251

Wczora-i-ja [Yesterday-and-I] 123, 124, 131, 471

Wesele. Powieść [Wedding. A Novel] 104, 134, 245, 454

Wędrowny sztukmistrz [Wandering Magician] 106

Widowiska w ogóle uważane [Spectacles in General] 154, 295

Wieczór w pustkach [An Evening in Wilderness] 57, 138, 145

Wielkie słowa [Big Words] 127, 404, 405, 418

Wielkość [Greatness] 58, 350, 388

Wierny-portret [An Accurate Portrait] 404

Wieś [Village] 183, 528

Wigilia [Christmas Eve] 70, 127 
Wita Stosa pamięci estetycznych zarysów siedem [In Memory of Veit Stoss - Seven Aestetic Sketches] 344, 482, 493, 494

Wspomnienie wioski [Memory of a Village] 57, 67, 145

Wtedy Ty, Matko [Then You, Mother] 450

Wzroki [Eyesights] 348

\section{Z}

Z Buonarrotiego [From

Buonarroti] 49, 453

$\mathrm{Z}$ listu. (Do Włodzimierza Łubieńskiego) [From a Letter. (To Włodzimierz Łubieński)] 429

Z pamiętnika [From the Diary] 101 Z pamiętnika (O zemście) [From an Album (On Revenge)] 486

Za kulisami [Backstage] 24, 75, 78, $126,140,160,163-165,178,191$, $217,223,236,248,264,502,525$

Zadaniem krytyki [The Task of Criticism] 109
Zagadka [Riddle] 404

Zapał [Fervour] 379

Zdjęcie z krzyża [The Descent from the Cross] 114, 560

Zebranie emigracyjne [Emigre meeting] 50, 553

Ziemia [Earth] 101, 104, 250

Złoty kubek [A Golden Mug] 51, 554

Złożenie do grobu [The Entombment] 116

Zmartwychwstanie historyczne [Historical Resurrection] 495, 503

Znicestwienie narodu [Annihilation of the Nation] 492

Znów legenda [A Legend Again] 341, 348, 450

Zoilus 115, 214, 561

Zwolon 24, 70, 77, 159, 160, 163, $235,244,410$

Żydowie polscy 1861 [Polish Jews 1861] 58, 104, 124, 129,188 



\section{Polish Studies - Transdisciplinary Perspectives}

Edited by Krzysztof Zajas and Jarosław Fazan

Vol. 1 Artur Płaczkiewicz: Miron Białoszewski: Radical Quest beyond Dualisms. 2012.

Vol. 2 Kinga Kosmala: Ryszard Kapuściński: Reportage and Ethics or Fading Tyranny of the Narrative. 2012.

Vol. 3 Michał Nowosielski: Polish Organisations in Germany. Their Present Status and Needs. 2012.

Vol. 4 Krzysztof Zajas: Absent Culture. The Case of Polish Livonia. 2013.

Vol. 5 Magdalena Sitarz: Literature as a Medium for Memory. The Universe of Sholem Asch's Novels. 2013.

Vol. 6 Barbara Przybyszewska-Jarmińska / Lech Sokół (eds.): Poland and Artistic Culture of Western Europe. 14th-20th Century. 2014.

Vol. 7 Katarzyna Fazan / Anna Róża Burzyńska / Marta Bryś (eds.): Tadeusz Kantor Today. Meta-morphoses of Death, Memory and Presence. Translated by Anda MacBride. 2014.

Vol. 8 Andrzej Hejmej: Music in Literature. Perspectives of Interdisciplinary Comparative Literature. Translated by Lindsay Davidson. 2014.

Vol. 9 Grzegorz Niziołek: Warlikowski: Extra Ecclesiam. Translated by Soren Gauger. 2015.

Vol. 10 Ryszard Koziołek: Sienkiewicz's Bodies. Studies of Gender and Violence. Translated by David Malcolm. 2015.

Vol. 11 Wojciech Tygielski: Italians in Early Modern Poland. The Lost Opportunity for Modernization? Translated by Katarzyna Popowicz. 2015.

Vol. 12 Dariusz Jarosz / Maria Pasztor: Polish-French Relations, 1944-1989. Translated by Alex Shannon. 2015.

Vol. 13 Urszula Augustyniak: History of the Polish -Lithuanian Commonwealth. State - Society Culture. 2015.

Vol. 14 Piotr Sobolczyk: Polish Queer Modernism. 2015.

Vol. 15 Jacek Soszyński / Agnieszka Chamera-Nowak (eds.): Book versus Power. Studies in the Relations between Politics and Culture in Polish History. Editorial assistance by Dan Embree. Translated by Jacek Soszyński 2015.

Vol. 16 Wojciech Kriegseisen: Between State and Church. Confessional Relations from Reformation to Enlightenment: Poland - Lithuania - Germany - Netherlands. Translated by Bartosz Wójcik and copy-edited by Alex Shannon. 2016.

Vol. 17 Urszula Sowina: Water, Towns and People. Polish Lands against a European Background until the Mid-16 ${ }^{\text {th }}$ Century. Translated by Justyna Woldańska. 2016.

Vol. 18 Grzegorz Krzywiec: Chauvinism, Polish Style. The Case of Roman Dmowski (Beginnings: 1886-1905). Translated by Jarosław Garliński. 2016.

Vol. 19 Andrzej Sakson: Von Memel bis Allenstein. Die heutigen Bewohner des ehemaligen Ostpreußens: Memelland, Kaliningrader Gebiet, Ermland und Masuren. Übersetzt von Marek Drewnowski. 2016.

Vol. 20 Antoni Mączak: Unequal Friendship. The Patron-Client Relationship in Historical Perspective. Translated by Alex Shannon. 2017.

Vol. 21 Olga Szmidt / Katarzyna Trzeciak (eds.): Face in Trouble - From Physiognomics to Facebook. Copy-edited by Soren Gauger. 2017. 
Vol. 22 Alina Cala: Jew. The Eternal Enemy? The History of Antisemitism in Poland. 2019.

Vol. 23 Agata Brajerska-Mazur / Edyta Chlebowska (eds.): Jew. On Cyprian Norwid. Studies and Essays. Vol. 1: Syntheses. 2019.

\section{www.peterlang.com}

